\begin{tabular}{|l|l|l|l|}
\hline Customer: & $\begin{array}{l}\text { The United States Department of Energy } \\
\text { National Energy Technology Laboratory }\end{array}$ & $\begin{array}{l}\text { Date of Issue: } \\
\text { 24 April 2003 }\end{array}$ & \\
\hline $\begin{array}{l}\text { Document } \\
\text { Title: }\end{array}$ & Master Document Register & $\begin{array}{l}\text { Version: } \\
\text { R2.0 }\end{array}$ & Page 1 of 7 \\
\hline
\end{tabular}

\title{
Examine and Evaluate a Process to use Salt Caverns to RECEIVE SHIP BORNe LIQUEFIEd NATURAL GAS
}

\author{
FinAL REPORT \\ StART DATE: OCTOBER 10, 2002 \\ END DATE: JUNE 10, 2003 \\ BY \\ Michael M. MCCALL \\ WILLIAM M. BISHOP \\ D. BRAXTON SCHERZ
}

ISSUE DATE: APRIL 24, 2003

DOE AWARD NUMBER:

DE-FC26-02NT41653

\section{SubMitTINg Organizations}

D. BRAXTON \& ASSOCIATES

2123 FM 1960 W \#108

Houston, TX 77090
CONVERSION GAS IMPORTS, L.L.C. 2929 BRIARPARK, STE 220

HOUSTON, TX 77042

RESPEC, INC

P.O. Box 725

RaPID CITY, SOUTH DaKOTA 57709
PROF. WILLIAM THOMPSON WASHINGTON STATE UNIVERSITY

Pullman, WAshington 


\begin{tabular}{|l|l|l|l|}
\hline Customer: & $\begin{array}{l}\text { The United States Department of Energy } \\
\text { National Energy Technology Laboratory }\end{array}$ & $\begin{array}{l}\text { Date of Issue: } \\
\mathbf{2 4} \text { April } 2003\end{array}$ & \\
\hline $\begin{array}{l}\text { Document } \\
\text { Title: }\end{array}$ & Master Document Register & $\begin{array}{l}\text { Version: } \\
\text { R2.0 }\end{array}$ & Page 2 of 7 \\
\hline
\end{tabular}

\section{DISCLAIMER}

"This report was prepared as an account of work sponsored by an agency of the United States Government. Neither the United States Government nor any agency thereof, nor any of their employees, makes any warranty, express or implied, or assumes any legal liability or responsibility for the accuracy, completeness, or usefulness of any information, apparatus, product, or process disclosed, or represents that its use would not infringe privately owned rights. Reference herein to any specific commercial product, process, or service by trade name, trademark, manufacturer, or otherwise does not necessarily constitute or imply its endorsement, recommendation, or favoring by the United States government or any agency thereof. The views and opinions of authors expressed herein do not necessarily state or reflect those of the United States Government or any agency thereof." 


\begin{tabular}{|l|l|l|l|}
\hline Customer: & $\begin{array}{l}\text { The United States Department of Energy } \\
\text { National Energy Technology Laboratory }\end{array}$ & $\begin{array}{l}\text { Date of Issue: } \\
\mathbf{2 4} \text { April 2003 }\end{array}$ & \\
\hline $\begin{array}{l}\text { Document } \\
\text { Title: }\end{array}$ & Master Document Register & $\begin{array}{l}\text { Version: } \\
\text { R2.0 }\end{array}$ & Page 3 of 7 \\
\hline
\end{tabular}

\begin{abstract}
The goal of the U.S. Department of Energy cooperative research project is to define, describe, and validate, a process to utilize salt caverns to receive and store the cargoes of LNG ships. The project defines the process as receiving LNG from a ship, pumping the LNG up to cavern injection pressures, warming it to cavern compatible temperatures, injecting the warmed vapor directly into salt caverns for storage, and distribution to the pipeline network. The performance of work under this agreement is based on U.S. Patent 5,511,905, and other U.S. and Foreign pending patent applications. The cost sharing participants in the research are The National Energy Technology Laboratory (U.S. Department of Energy), BP America Production Company, Bluewater Offshore Production Systems (U.S.A.), Inc., and HNG Storage, L.P.

Initial results indicate that a salt cavern based receiving terminal could be built at about half the capital cost, less than half the operating costs and would have significantly higher delivery capacity, shorter construction time, and be much more secure than a conventional liquid tank based terminal. There is a significant body of knowledge and practice concerning natural gas storage in salt caverns, and there is a considerable body of knowledge and practice in handling LNG, but there has never been any attempt to develop a process whereby the two technologies can be combined. Salt cavern storage is infinitely more secure than surface storage tanks, far less susceptible to accidents or terrorist acts, and much more acceptable to the community.

The project team developed conceptual designs of two salt cavern based LNG terminals, one with caverns located in Calcasieu Parish Louisiana, and the second in Vermilion block 179 about 50 miles offshore Louisiana. These conceptual designs were compared to conventional tank based LNG terminals and demonstrate superior security, economy and capacity. The potential for the development of LNG receiving terminals, utilizing salt caverns for storage and the existing comprehensive pipeline system has profound implications for the next generation of LNG terminals. LNG imports are expected to become an increasingly more important part of the U.S. energy supply and the capacities to receive LNG securely, safely, and economically must be expanded. Salt cavern LNG receiving terminals both in onshore and offshore locations can be quickly built and provide additional import capacity into the U.S. exceeding 6-10 Bcf/day in the aggregate.
\end{abstract}




\begin{tabular}{|l|l|l|l|}
\hline Customer: & $\begin{array}{l}\text { The United States Department of Energy } \\
\text { National Energy Technology Laboratory }\end{array}$ & $\begin{array}{l}\text { Date of Issue: } \\
\mathbf{2 4} \text { April } 2003\end{array}$ & \\
\hline $\begin{array}{l}\text { Document } \\
\text { Title: }\end{array}$ & Master Document Register & $\begin{array}{l}\text { Version: } \\
\text { R2.0 }\end{array}$ & Page 4 of 7 \\
\hline
\end{tabular}

\section{TABLE OF CONTENTS}

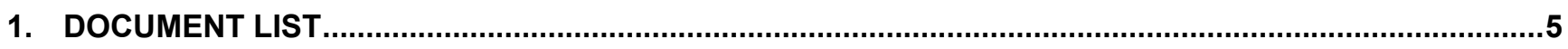

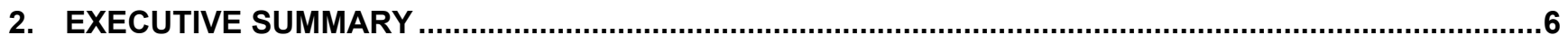




\begin{tabular}{|l|l|l|l|}
\hline Customer: & $\begin{array}{l}\text { The United States Department of Energy } \\
\text { National Energy Technology Laboratory }\end{array}$ & $\begin{array}{l}\text { Date of Issue: } \\
\mathbf{2 4} \text { April } 2003\end{array}$ & \\
\hline $\begin{array}{l}\text { Document } \\
\text { Title: }\end{array}$ & Master Document Register & $\begin{array}{l}\text { Version: } \\
\text { R2.0 }\end{array}$ & Page 5 of 7 \\
\hline
\end{tabular}

\section{DOCUMENT LIST}

\begin{tabular}{|c|c|}
\hline \multicolumn{2}{|c|}{ Task 1.0 Identify Critical Elements } \\
\hline CGI/DOE_Doc 01 & $\begin{array}{l}\text { Final Report I "Critical Elements in a Process to Utilize Salt Caverns in a } \\
\text { LNG Receiving Terminal" }\end{array}$ \\
\hline CGI/DOE_Doc 02 & $\begin{array}{l}\text { Subtask } 1.1 \text { Identify Potential Salt Formations Which Could be Used for } \\
\text { LNG Receiving }\end{array}$ \\
\hline CGI/DOE_Doc 03 & $\begin{array}{l}\text { Subtask } 1.2 \text { Identify Marine Mooring and Offloading Initiatives for LNG } \\
\text { Vessels }\end{array}$ \\
\hline CGI/DOE_Doc 04 & Subtask 1.3 Determine Major Equipment Requirements \\
\hline CGI/DOE_Doc 05 & Subtask 1.4 Determine Salt Cavern Requirements \\
\hline \multicolumn{2}{|c|}{ Task 2.0 Develop Conceptual Design of a Salt Cavern LNG Receiving Terminal } \\
\hline CGI/DOE_Doc 06 & $\begin{array}{l}\text { Final Report II "Conceptual Design of a Salt Cavern Based LNG } \\
\text { Receiving Terminal" } \\
\text { Design basis A: The LNG Onshore Terminal } \\
\text { Design Basis B: The Offshore Terminal }\end{array}$ \\
\hline \multicolumn{2}{|c|}{$\begin{array}{l}\text { Task 3.0 Comparison of LNG Terminals Conceptual Designs with Traditional LNG Receiving Terminals } \\
\text { and EI Paso's Energy Bridge }{ }^{\circledR}\end{array}$} \\
\hline CGI/DOE_Doc 07 & $\begin{array}{l}\text { Final Report III “Comparisons Between LNG Receiving Terminals: } \\
\text { Conventional, Salt Cavern Based, Offshore, and 'Energy Bridge'®” }\end{array}$ \\
\hline CGI/DOE_Doc 08 & Matrix for Comparison \\
\hline
\end{tabular}




\begin{tabular}{|l|l|l|l|}
\hline Customer: & $\begin{array}{l}\text { The United States Department of Energy } \\
\text { National Energy Technology Laboratory }\end{array}$ & $\begin{array}{l}\text { Date of Issue: } \\
\mathbf{2 4} \text { April } 2003\end{array}$ & \\
\hline $\begin{array}{l}\text { Document } \\
\text { Title: }\end{array}$ & Master Document Register & $\begin{array}{l}\text { Version: } \\
\text { R2.0 }\end{array}$ & Page 6 of 7 \\
\hline
\end{tabular}

\section{EXECUTIVE SUMMARY}

The goal of the U.S. Department of Energy cooperative research project is to define, describe, and validate, a process to utilize salt caverns to receive and store the cargoes of LNG ships. The project defines the process as receiving LNG from a ship, pumping the LNG up to cavern injection pressures, warming it to cavern compatible temperatures, injecting the warmed vapor directly into salt caverns for storage, and distribution to the pipeline network. The performance of work under this agreement is based on U.S. Patent $5,511,905$, and other U.S. and Foreign pending patent applications. The cost sharing participants in the research are The National Energy Technology Laboratory (U.S. Department of Energy), BP America Production Company, Bluewater Offshore Production Systems (U.S.A.), Inc., and HNG Storage, L.P.

Research reveals that LNG ship mooring and unloading at an onshore terminal could be done using conventional docks, jetties, loading arms, and other equipment used in LNG transfer service currently. There is no need for modifications to LNG ships currently in service and the unloading rates could approximate those achieved in conventional LNG tank based terminals. The offshore version of the conceptual design would need further development of loading techniques and equipment for LNG transfer at sea. There are multiple industry initiatives underway to develop offshore mooring and unloading equipment drawing on the significant experience of the oil and LPG industries where offshore product transfer operations take place in much of the world today. It is believed by those in the industry that within a year several solutions to offshore LNG transfer will be certified by the agencies that deal in marine technologies.

The major pump manufacturers have designed LNG pumps capable of developing cavern injection pressures, and the project team is advised that there are no technical difficulties in building and operating such pumps.

A high capacity, high efficiency, seawater warmed, pipe in pipe heat exchanger was studied in the research and conclusions have been drawn that the heat exchange at high rates is feasible. It is expected that a field test of the heat exchanger studied will be conducted to demonstrate its performance. This field test is expected to be the subject of a related cooperative research project

A salt cavern rock mechanics study was performed as a part of the project which confirmed that salt caverns can accept and discharge gas at high rates and at temperatures varying from 0 Degrees $F$ to 110 Degrees $F$. This enables unloading of ships at normal rates and provides very high deliverability into the natural gas pipeline grid. The conceptual design terminals have pipeline deliverability in excess of $3 \mathrm{Bcf} / \mathrm{Day}$, a rate that is as much as 6 times the rate of delivery that most tank based LNG terminals can achieve.

There are more than 1000 salt caverns in the U.S. and Canada in which hydrocarbon products are stored. All of the Strategic Petroleum Reserve's 600+ million barrels of crude oil are stored in salt caverns. In addition there are more than 600 million barrels of other products stored in salt caverns, including hydrogen, natural gas, ethylene, propylene, ethane, propane, butane, natural gasoline and refined products. Salt cavern storage facilities provide a logistical link between the natural gas, petrochemical and refining industries and are an integral part of the most comprehensive energy and processing industry infrastructure in the world found along the Gulf coast. Salt cavern operations occur largely unseen and unnoticed by the public because of their underground nature and trouble free operation.

More than two dozen potential sites were identified in the project combining salt formations suitable for storage, proximate multiple pipelines for large take away capacity and navigable water. The sites are about evenly split between onshore salt formation locations and offshore salt formation locations. Research reveals that because of the convergence of pipeline capacities and salt formations that a few very large capacity salt cavern based receiving terminals could provide all of the U.S.'s future LNG import needs. 


\begin{tabular}{|l|l|l|l|}
\hline Customer: & $\begin{array}{l}\text { The United States Department of Energy } \\
\text { National Energy Technology Laboratory }\end{array}$ & $\begin{array}{l}\text { Date of Issue: } \\
\mathbf{2 4} \text { April } 2003\end{array}$ & \\
\hline $\begin{array}{l}\text { Document } \\
\text { Title: }\end{array}$ & Master Document Register & $\begin{array}{l}\text { Version: } \\
\text { R2.0 }\end{array}$ & Page 7 of 7 \\
\hline
\end{tabular}

Initial results indicate that a salt cavern based receiving terminal could be built at about half the capital cost, less than half the operating costs and would have significantly higher delivery capacity, shorter construction time, and be much more secure than a conventional liquid tank based terminal. There is a significant body of knowledge and practice concerning natural gas storage in salt caverns, and there is a considerable body of knowledge and practice in handling LNG, but there has never been any attempt to develop a process whereby the two technologies can be combined. Salt cavern storage is infinitely more secure than surface storage tanks, far less susceptible to accidents or terrorist acts, and much more acceptable to the community.

The project team developed conceptual designs of two salt cavern based LNG terminals, one with caverns located in Calcasieu Parish Louisiana, and the second in Vermilion block 179 about 50 miles offshore Louisiana. These conceptual designs were compared to conventional tank based LNG terminals and demonstrate superior security, economy and capacity. The potential for the development of LNG receiving terminals, utilizing salt caverns for storage and the existing comprehensive pipeline system has profound implications for the next generation of LNG terminals. LNG imports are expected to become an increasingly more important part of the U.S. energy supply and the capacities to receive LNG securely, safely, and economically must be expanded. Salt cavern LNG receiving terminals both in onshore and offshore locations can be quickly built and provide additional import capacity into the U.S. exceeding 6-10 Bcf/day in the aggregate. 


\begin{tabular}{|l|l|l|l|}
\hline Customer: & $\begin{array}{l}\text { The United States Department of Energy } \\
\text { National Energy Technology Laboratory }\end{array}$ & $\begin{array}{l}\text { Date of Issue: } \\
24 \text { April } 2003\end{array}$ & \\
\hline $\begin{array}{l}\text { Document } \\
\text { Title: }\end{array}$ & $\begin{array}{l}\text { Report I: Critical Elements in a process to Utilize Salt Caverns in an LNG } \\
\text { Receiving Terminal }\end{array}$ & $\begin{array}{l}\text { Doc \# \& Version: } \\
\text { Doc } 01 \text { r1.0 }\end{array}$ & Page 1 of 11 \\
\hline
\end{tabular}

\title{
Critical Elements in a process to Utilize Salt Caverns IN AN LNG RECEIVING TERMINAL
}

\author{
BY \\ Michael M. McCaLl \\ WILLIAM M. BISHOP \\ D. BRAXTON SCHERZ
}

\begin{tabular}{||c|c||c|c|c|c|c|c|c||}
\hline \hline r 1.0 & For client review & $04 / 24 / 03$ & вS & мm & & & \\
\hline Version & Reason for Issue & $\begin{array}{c}\text { Issue } \\
\text { Date }\end{array}$ & $\begin{array}{c}\text { Orig. } \\
\text { Chk. Appr. } \\
\text { CGI }\end{array}$ & $\begin{array}{c}\text { Chk. } \\
\text { NETL }\end{array}$ & Appr. & Review \\
\hline \hline $\begin{array}{l}\text { Document Title: } \\
\text { Critical Elements in a process to Utilize Salt Caverns } \\
\text { in an LNG Receiving Terminal }\end{array}$ & \multicolumn{2}{|c||}{$\begin{array}{c}\text { Document No: } \\
\text { DE-FC26-02NT41653 }\end{array}$} \\
\hline
\end{tabular}


2. GLOSSARY OF TERMS

3. LNG FUNDAMENTALS.

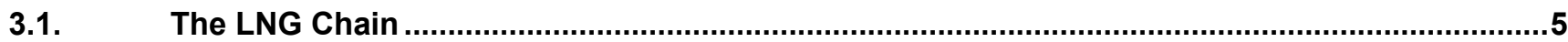

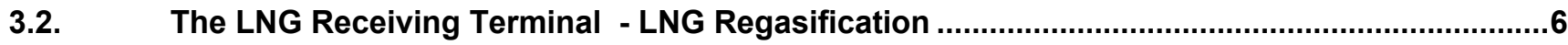

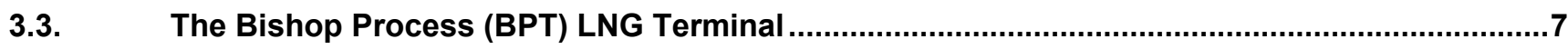

3.4. Fundamental Differences - Conventional and BPT LNG Terminal .........................................

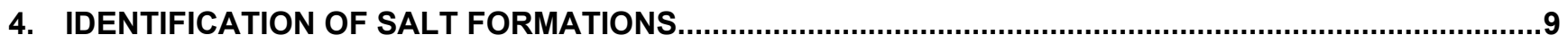

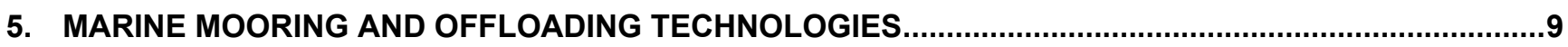

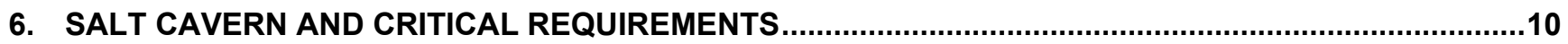

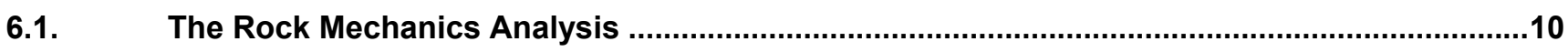

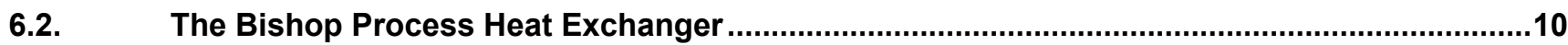

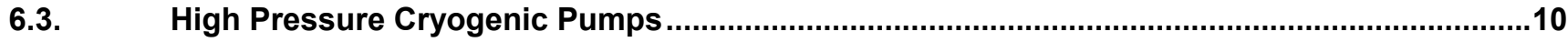




\begin{tabular}{|l|l|l|l|}
\hline Customer: & $\begin{array}{l}\text { The United States Department of Energy } \\
\text { National Energy Technology Laboratory }\end{array}$ & $\begin{array}{l}\text { Date of Issue: } \\
\mathbf{2 4} \text { April 2003 }\end{array}$ & \\
\hline $\begin{array}{l}\text { Document } \\
\text { Title: }\end{array}$ & $\begin{array}{l}\text { Report I: Critical Elements in a process to Utilize Salt Caverns in an LNG } \\
\text { Receiving Terminal }\end{array}$ & $\begin{array}{l}\text { Doc \# \& Version: } \\
\text { Doc 01 r1.0 }\end{array}$ & Page $\mathbf{3}$ of 11 \\
\hline
\end{tabular}

\section{EXECUTIVE SUMMARY}

Each element critical to the process of using salt caverns in the receipt of LNG have been identified and confirmed as feasible in the course of this research. Key elements examined were potential sites, salt cavern tolerances for gas injections at varying temperatures, LNG pumps capable of developing cavern injection pressures, predicted performance of a unique, high capacity, high efficiency heat exchanger, and offshore LNG ship mooring and unloading systems.

As a whole, the concept of using salt caverns in the receipt of ship borne LNG is foreign to the LNG industry and incorporates salt cavern storage technology with which most participants in the LNG industry have little familiarity. In the course of the research each element was examined in turn confirming the feasibility of the system as a whole. The major challenge for the implementation of a salt cavern alternative to the traditional tank based LNG receiving terminals lie in the perceived risks associated the technologies required to implement the projects, onshore somewhat, but offshore more so. A field test of the heat exchanger will most likely be necessary to provide confirmation to industry that that element is proven.

\section{GLOSSARY OF TERMS}

\section{AIR DRAFT}

The distance between the surface of navigable water, such as a channel, and the lowest point on some obstruction above it, a bridge for instance. A ship cannot use a waterway if it needs more vertical clearance than available. This consideration prevents certain tankers from reaching some terminals.

\section{ASSOCIATED AND NON-ASSOCIATED NATURAL GAS}

Natural gas is found in underground structures similar to those containing crude oil. There are three types of natural gas reservoir:

1. Structures from which only gas can be produced economically-called NON-ASSOCIATED GAS (or unassociated gas).

2. Condensate reservoirs which yield relatively large amounts of gas per barrel of light liquid hydro- carbons. Although many condensate reservoirs are produced primarily for gas, there are cases where gas is reinjected or "re-cycled" to improve liquid recovery, particularly if no gas market is yet available. This gas also is termed NON- ASSOCIATED.

3. Reservoirs where gas is found dissolved in crude oil (SO LUTION GAS) and in some cases also in contact with underlying gas saturated crude (GAS- CAP GAS). Both are called ASSOCIATED GAS. (Gas-cap gas is almost never produced until most of the economically recoverable oil has been yielded). In such fields, gas production rates will depend on oil output with the oil usually representing the major part in terms of energy equivalents.

\section{BACKHAUL}

A tanker's revenue-producing return voyage. Some ships shuttle between two tankers ports. They travel in one direction as dictated by normal oil flow patterns or refining system's needs. Often, they have no natural employment from when they discharge to their port of origin where another load awaits. They would like to find a cargo to pay their costs on this return trip. This is possible because oil tankers are capable of carrying many different products, e.g. a tanker carrying refined gasoline to a receiving terminal may have the opportunity to move to a nearby terminal to load "charge stock" and carry it back along a similar route to the refining terminal. Otherwise, the tanker must return in ballast. Charters often relet ships at bargain back haul rates for these voyages. They prefer some income to none.

While backhauls in the oil transportation industry are common, there are not yet enough LNG terminals worldwide to make backhauling feasible. However, LNG backhauls will be employed as the trade grows. 


\begin{tabular}{|l|l|l|l|}
\hline Customer: & $\begin{array}{l}\text { The United States Department of Energy } \\
\text { National Energy Technology Laboratory }\end{array}$ & $\begin{array}{l}\text { Date of Issue: } \\
24 \text { April 2003 }\end{array}$ & \\
\hline $\begin{array}{l}\text { Document } \\
\text { Title: }\end{array}$ & $\begin{array}{l}\text { Report I: Critical Elements in a process to Utilize Salt Caverns in an LNG } \\
\text { Receiving Terminal }\end{array}$ & $\begin{array}{l}\text { Doc \# \& Version: } \\
\text { Doc 01 r1.0 }\end{array}$ & Page 4 of 11 \\
\hline
\end{tabular}

\section{BOIL OFF GAS (BOG)}

During storage and transport, the vapor (almost pure methane) that escapes as LNG "boils" at atmospheric pressure and $-160^{\circ} \mathrm{C}$. This vapor boil off can be quite large and is captured and used as fuel for the facility or the LNG ship, or is compressed and sent out in the natural gas supply stream at the receiving terminal.

\section{CITY GATE}

A measuring station, which may also include pressure regulation, at which a distributing gas utility receives gas from a natural gas pipeline company or the transmission System.

\section{DAILY AVERAGE SEND-OUT}

The total volume of gas delivered during a period of time divided by number of days in the period.

\section{DAILY PEAK}

The maximum volume of gas delivered in any one day during a given period, usually a calendar year

\section{DISTRIBUTION COMPANY or GAS UTILITY}

A company which obtains the major portion of its gas operating revenues from the operation of a retail gas distribution system and which operates no transportation system other than incidental connections to a transportation system of another company. For purposes of American Gas Association (A.G.A.) statistics, a distribution company obtains at least 95 per cent of its gas operating revenue from the operation of its retail gas distribution system. (See also Transmission Company.)

\section{DISTRIBUTION SYSTEM}

Feeders, mains, services and equipment which carry or control the supply of gas from the point or points of local supply (usually the city gate station) to and including the consumer meters.

\section{FIXED MOORING}

An offshore facility (usually adjacent but not connected to shore) capable of safely securing an ocean going vessel through a system of anchors, chains, and buoys. The ship maintains a fixed heading after it is secured. An inexpensive offshore mooring solution but typically reserved for benign location or locations where wind and wave are unidirectional.

\section{INTERRUPTIBLE GAS}

Gas made available under agreements, which permit curtailment or cessation of delivery by the supplier.

\section{LINE PACK}

A method of peak-shaving by withdrawing gas from a section of a pipeline system in excess of the input into that section, i.e. normally the difference between the actual volume of gas in the pipeline at low flow (increased pressure) and that at normal flow.

\section{LIQUEFIED NATURAL GAS (LNG)}

Natural gas that has been liquefied by cooling to minus $258^{\circ} \mathrm{F}\left(-161^{\circ} \mathrm{C}\right)$ at atmospheric pressure.

\section{LIQUEFIED PETROLEUM GAS (LPG)}

Any hydrocarbon mixture in either the liquid or gaseous state the chief components of which consist of propane, propylene, butane, iso-butane, butylene or mixtures there- of in any ratio.

\section{LOAD FACTOR}

The ratio of the average load over a designated period to the peak load occurring in that period. Usually expressed as a percentage. 


\begin{tabular}{|l|l|l|l|}
\hline Customer: & $\begin{array}{l}\text { The United States Department of Energy } \\
\text { National Energy Technology Laboratory }\end{array}$ & $\begin{array}{l}\text { Date of Issue: } \\
24 \text { April } 2003\end{array}$ \\
\hline $\begin{array}{l}\text { Document } \\
\text { Title: }\end{array}$ & $\begin{array}{l}\text { Report I: Critical Elements in a process to Utilize Salt Caverns in an LNG } \\
\text { Receiving Terminal }\end{array}$ & $\begin{array}{l}\text { Doc \# \& Version: } \\
\text { Doc } 01 \text { r1.0 }\end{array}$ \\
\hline
\end{tabular}

\section{OFF-PEAK}

The period during a day, week, month or year when the load being delivered by a gas system is not at or near the maximum volume deliverable by that system.

\section{MOORING - ONSHORE}

Any facility connected to dry land providing a means to secure a ship

\section{MOORING - OFFSHORE}

A system of anchors, chains, and a buoy whereby a ship can securely fasten itself and remain on station in most weather conditions

\section{PEAK or PEAK LOAD}

The maximum load consumed or produced by a unit or group of units in a stated period of time.

\section{PEAK SHAVING}

The practice of augmenting the normal supply of gas during peak or emergency periods from another source where gas may have either been stored during periods of low demand, or manufactured specifically to meet the peak demand.

\section{SALT CAVERN}

A void within a salt formation solution mined usually for the purpose of hydrocarbon storage

\section{SALT FORMATION}

An underground geologic structure consisting of a highly monolithic substance consisting mainly of sodium chloride There are mainly tow types of formations embedded salt, and salt domes. Salt domes are highly pure and are well suited for cavern creation.

\section{SEND-OUT}

The quantity of gas delivered by a plant or system during a specified period of time.

\section{WEATHERVANE}

A ocean going vessel's reaction to the direction of the winds, waves and currents while berthed in an offshore mooring capable of $360^{\circ}$ rotation about its fixed mooring. Weathervaning moorings are robust and rather expensive but provide a safe offshore mooring in a variety of sea conditions.

\section{LNG FUNDAMENTALS}

\subsection{The LNG Chain}

The following Figure 3.1 is a graphical indication of the LNG Chain. In summary, natural gas is produced and transported to a liquefaction facility. The front end of the liquefaction facility dehydrates and removes mercury and $\mathrm{CO} 2$ from the gas stream. The gas stream is usually routed through a fractionation process where much of the Liquid Petroleum Gases (LPG's) are removed. However some liquefaction facilities remove very little LPGs. The lean gas stream, containing mainly methane and some ethane, is routed through a high capacity heat exchanger where it gives up its latent heat of vaporization and becomes a liquid at atmospheric pressures. At this point the Liquefied Natural Gas (LNG) is minus $160^{\circ} \mathrm{C}\left(-258^{\circ} \mathrm{F}\right)$ and must be kept cold throughout the storage and transportation process.

LNG is stored in large cryogenic tanks at pressures very slightly above atmospheric. To transport LNG to the buyer's receiving terminals, special liquid gas carriers are used. The ships are very large and are constructed with highly insulated tanks of varying designs and materials able to withstand cryogenic temperatures. 


\begin{tabular}{|l|l|l|l|}
\hline Customer: & $\begin{array}{l}\text { The United States Department of Energy } \\
\text { National Energy Technology Laboratory }\end{array}$ & $\begin{array}{l}\text { Date of Issue: } \\
\mathbf{2 4} \text { April } 2003\end{array}$ & \\
\hline $\begin{array}{l}\text { Document } \\
\text { Title: }\end{array}$ & $\begin{array}{l}\text { Report I: Critical Elements in a process to Utilize Salt Caverns in an LNG } \\
\text { Receiving Terminal }\end{array}$ & $\begin{array}{l}\text { Doc \# \& Version: } \\
\text { Doc } 01 \text { r1.0 }\end{array}$ & Page 6 of 11 \\
\hline
\end{tabular}

Upon arrival at the receiving terminal the LNG vessel pumps its cargo to cryogenic storage tanks of similar design and volume to those at the liquefaction terminal. The receiving terminal moves the LNG through a high pressure pumping system and into a vaporizer where the liquid is warmed and returned to natural gas. After vaporization, the gasified LNG flows into the existing pipeline infrastructure where it is delivered to the customer.

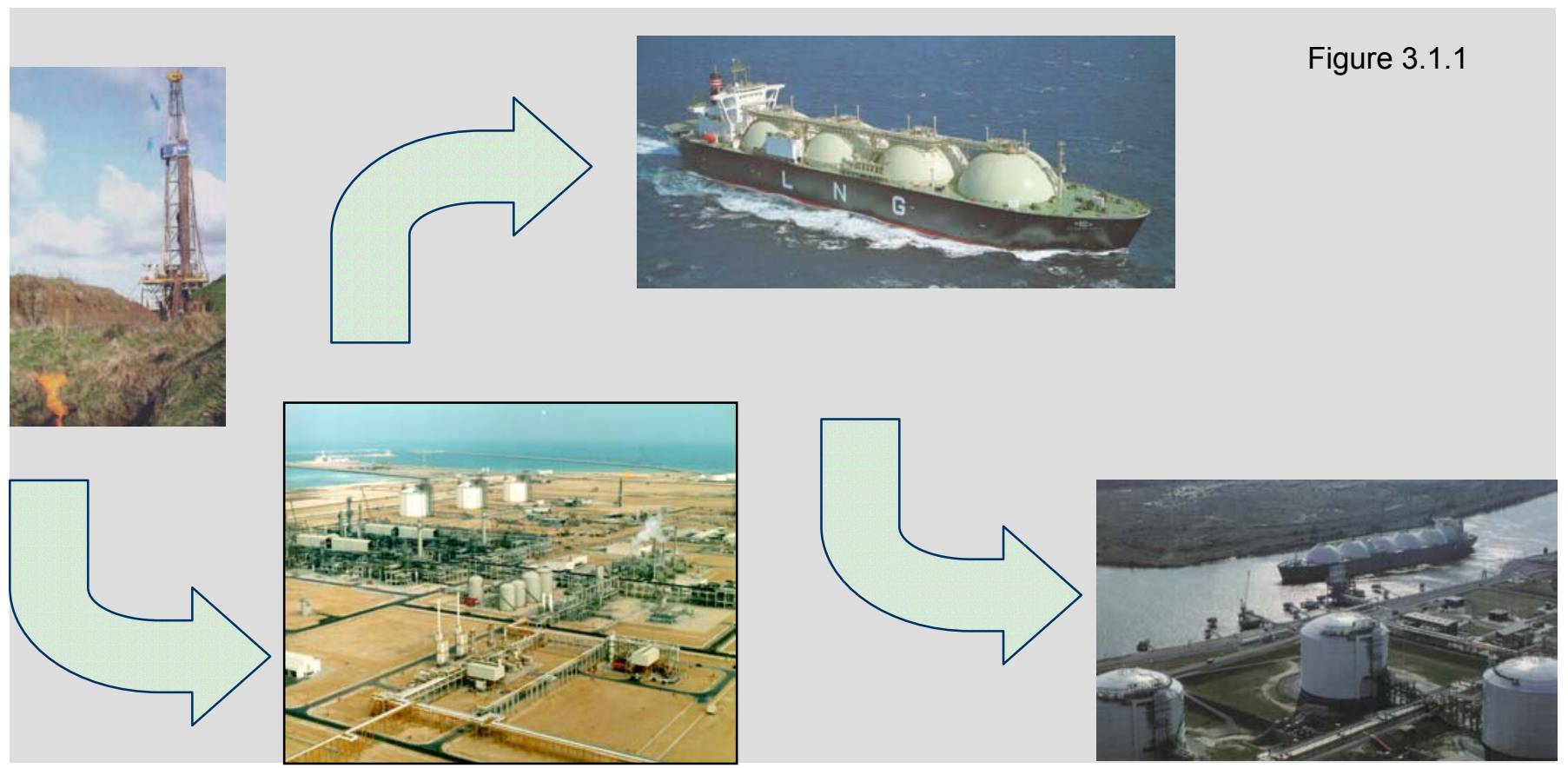

3.2. The LNG Receiving Terminal - LNG Regasification

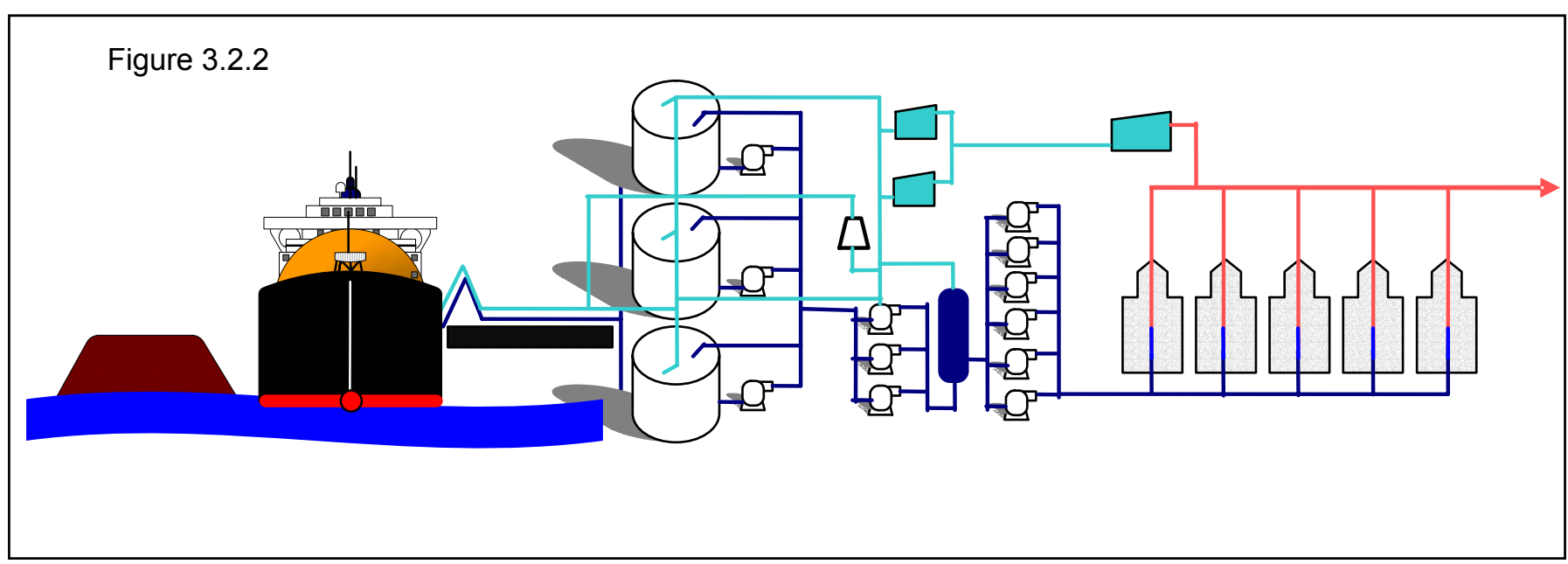

Figure 3.2.2 is a diagram showing the typical components of and LNG receiving terminal. The LNG carrier is moored along side a typical berth classified for gas carrier service. The ships pumps move the LNG off the 


\begin{tabular}{|l|l|l|l|}
\hline Customer: & $\begin{array}{l}\text { The United States Department of Energy } \\
\text { National Energy Technology Laboratory }\end{array}$ & $\begin{array}{l}\text { Date of Issue: } \\
24 \text { April 2003 }\end{array}$ & \\
\hline $\begin{array}{l}\text { Document } \\
\text { Title: }\end{array}$ & $\begin{array}{l}\text { Report I: Critical Elements in a process to Utilize Salt Caverns in an LNG } \\
\text { Receiving Terminal }\end{array}$ & $\begin{array}{l}\text { Doc \# \& Version: } \\
\text { Doc 01 r1.0 }\end{array}$ & Page 7 of 11 \\
\hline
\end{tabular}

vessel and into the storage tanks. The high pressure pumps pass LNG through the vaporizers and out to the pipeline infrastructure to market. The machinery required to recover Boil Off Gas (BOG) is clearly marked. During discharge, BOG is essential as it must be used to fill the evacuated volume of the ships tanks at rates equal to or slightly exceeding LNG pumping rates.

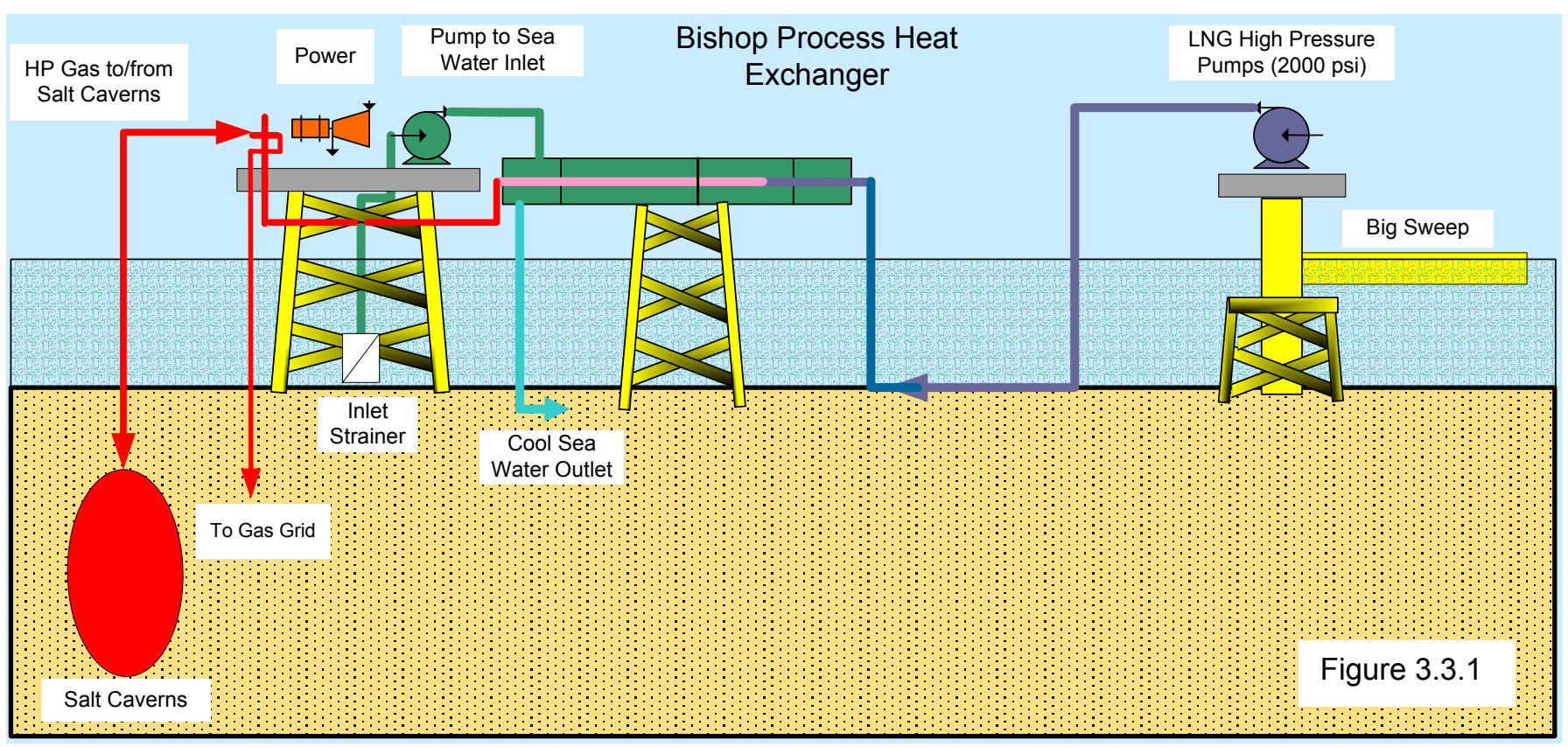

\subsection{The Bishop Process (BPT) LNG Terminal}

Figure 3.3.1 shows the major components of an offshore BPT LNG terminal. The operating principles are very similar between the onshore and offshore terminal. To summarize, the LNG carrier moors with the "Big Sweep" arm, a weathervaning structure that contains the offloading equipment. The high pressure pumps are located on the mooring platform. LNG is moved across the sea floor through cryogenic piping where it is warmed in the Bishop Process heat exchanger. The warmed gas flows through a well head located on the platform housing power generation, sea water circulating pumps, and the cavern solution mining/service equipment. The gasified LNG is directed to either the salt cavern or the existing pipeline infrastructure. A conceptual design with greater detail appears in Task 2.0.

\subsection{Fundamental Differences - Conventional and BPT LNG Terminal}

Although the two terminal designs share many common equipment items, there are some fundamental differences that are better illustrated in Figure 3.4.1 below. Existing terminals receive LNG at approximately $160 \mathrm{C}$ or $-250 \mathrm{~F}$. The LNG is pumped to a cryogenic storage tank until it is required for sendout. At that point the LNG is pumped to approximately 70 barg (1000 psi ) and warmed in vaporizers of various designs and capacities. Most U.S. receiving terminals have a send out capacity of 0.5 (existing) to 1.5 (projected) billion cubic feet per day Bcfd. 


\begin{tabular}{|l|l|l|l|}
\hline Customer: & $\begin{array}{l}\text { The United States Department of Energy } \\
\text { National Energy Technology Laboratory }\end{array}$ & $\begin{array}{l}\text { Date of Issue: } \\
\mathbf{2 4} \text { April } 2003\end{array}$ & \\
\hline $\begin{array}{l}\text { Document } \\
\text { Title: }\end{array}$ & $\begin{array}{l}\text { Report I: Critical Elements in a process to Utilize Salt Caverns in an LNG } \\
\text { Receiving Terminal }\end{array}$ & $\begin{array}{l}\text { Doc \# \& Version: } \\
\text { Doc 01 r1.0 }\end{array}$ & Page 8 of 11 \\
\hline
\end{tabular}

The terminal using salt caverns for storage and the BPT exchanger to warm LNG varies in its processing model only. For example, the BPT terminal receives cargoes from a standard LNG carrier in the conventional manner. However, the ships pumps supply LNG to the suction side of the high pressure pumps in the BPT terminal rather than passing the liquid directly to an LNG storage tank. The LNG is immediately pumped to 2000 psig, warmed in the BPT heat exchanger, and routed either to the natural gas grid, or to salt caverns for storage. The major fundamental difference between the two LNG terminals is the method for LNG storage. Conventional terminals store LNG in cryogenic tanks as a liquid, the BPT LNG terminal warms LNG for immediate storage as natural gas in salt caverns. Otherwise, the technologies, components, and principles vary little.

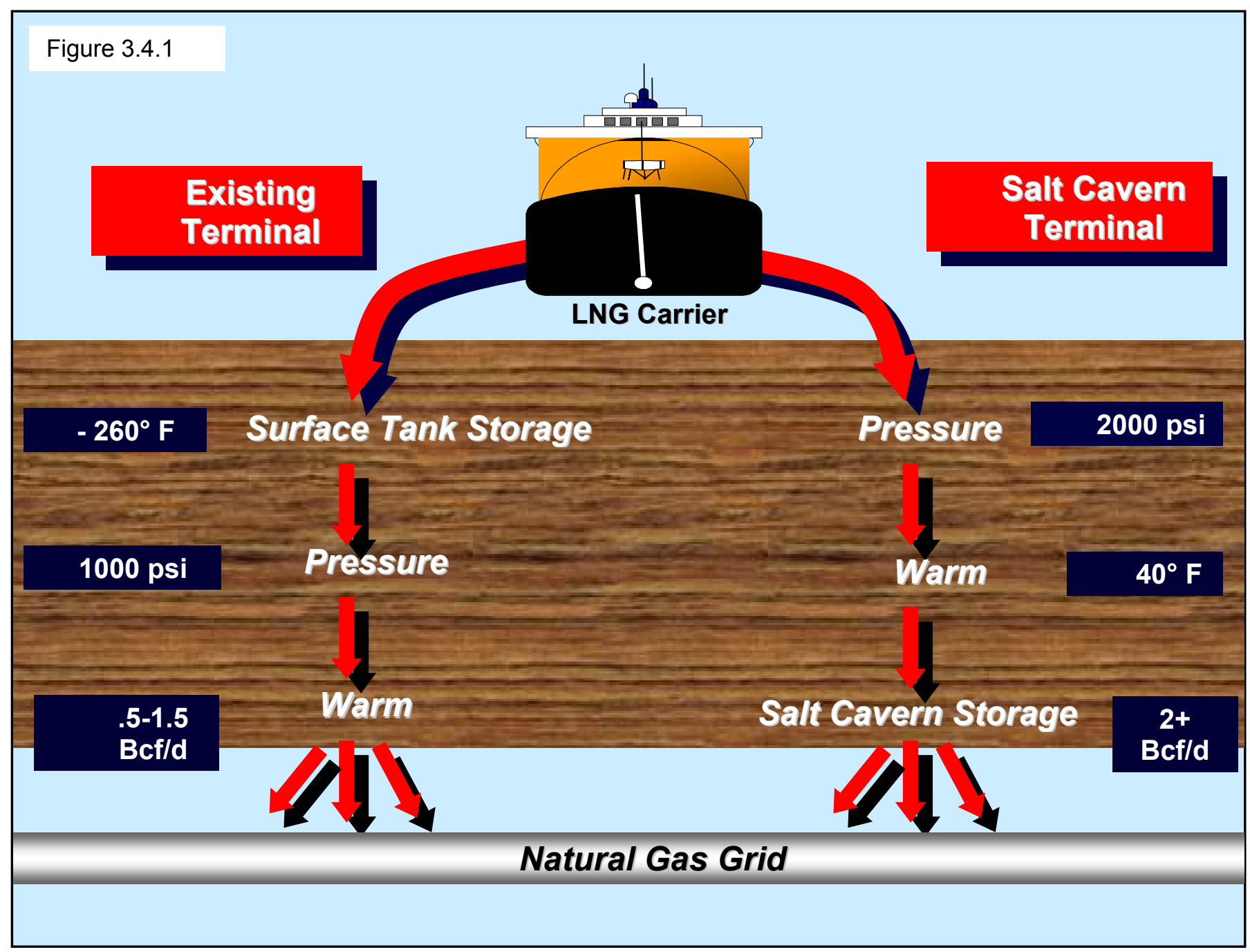




\begin{tabular}{|l|l|l|l|}
\hline Customer: & $\begin{array}{l}\text { The United States Department of Energy } \\
\text { National Energy Technology Laboratory }\end{array}$ & $\begin{array}{l}\text { Date of Issue: } \\
\mathbf{2 4} \text { April 2003 }\end{array}$ & \\
\hline $\begin{array}{l}\text { Document } \\
\text { Title: }\end{array}$ & $\begin{array}{l}\text { Report I: Critical Elements in a process to Utilize Salt Caverns in an LNG } \\
\text { Receiving Terminal }\end{array}$ & $\begin{array}{l}\text { Doc \# \& Version: } \\
\text { Doc 01 r1.0 }\end{array}$ & Page 9 of 11 \\
\hline
\end{tabular}

\section{IDENTIFICATION OF SALT FORMATIONS}

Subtask 1.1 of this document defines several sites suited for a Salt Storage LNG terminal both onshore and offshore. Dozens of potential locations have been identified in Texas, Louisiana, Mississippi and offshore areas adjacent to these states that have similar potential. Because of the close proximity of the existing natural gas grid, a series of LNG receiving facilities using the existing infrastructure in the Gulf of Mexico coastal area and contiguous salt caverns within the region could meet virtually any growth necessary in LNG imports required to replace declining production or meet growing natural gas demand.

There are salt formations suitable for the creation of salt caverns for storage purposes in most areas of the world except the Pacific Rim. Several contour maps describing the salt formations (salt domes in this case) are included as attachments. It is interesting to note that the Gulf of Mexico contains perhaps the most ideal salt formations anywhere in the world. That, coupled with approximately 10 Bcfd pipeline capacity in the GOM and coastal areas offer a unique opportunity to work with an underutilized natural resource to help meet the Nation's energy needs.

\section{MARINE MOORING AND OFFLOADING TECHNOLOGIES}

The solution to LNG transfer offshore lies in the technology and operational procedures that have been used in the offshore oil industry for over 30 years. Task 1.2 identifying marine mooring and offloading initiatives compares the existing and proposed LNG offshore transfer technologies, identifies the commonalities, and recognizes industry requirements and transfer preferences. Reduced NIMBY (not in my backyard) concerns and permitting requirements, siting flexibility, quicker construction times, and comparable CAPEX/OPEX are among the many advantages of transferring and handling LNG offshore.

Several offshore transfer challenges have been identified including the need to minimize the relative motion between LNG vessel and transfer facility, and the requirement to improve linking systems (transfer arms, hoses, subsea pipelines, etc.) for high availability.

Every major vendor with designs promoting the transfer of LNG offshore contributed to this study. Task 1.2 includes a matrix summarizing promising existing and conceptual designs. As of this writing, the only design nearing implementation is termed "Energy Bridge" developed by EI Paso Global LNG. Energy Bridge combines LNG shipping and regasification on a single ocean-going vessel and is technically quite feasible. The remaining designs are approximately 24 to 48 months away from fabrication.

The matrix indicates that oiil and natural gas producers considering LNG offshore transfer schemes prefer moorings that provide high availability. Weathervaning moorings (a mooring allows LNG vessel rotation around a vertical axis to assume a heading of minimum motion), facilitate maximum stability and good availability. Side by side cargo transfer is also essential (at least in the near term) as there are no existing or planned LNG carriers employing any other loading/unloading techniques.

Linking technologies (the apparatus and equipment required to safely interface between ship and shore) have improved rapidly over the last ten years, and there are plans to introduce an LNG hose capable of cryogenic liquid transfer sometime during 2004. The use of a hose in water without icing of the exterior surface could allow for tandem (e.g. vessel stern to vessel bow) LNG transfer similar to the standard procedure for transferring oil for ship to ship.

Currently all the technologies required for safe LNG transfer at sea exist, although not within the same company. There might be a possibility to consolidate LNG offshore engineering and design under the coordination of a recognized E\&C firm. The design firm would be tasked with conceiving and fabricating (with 


\begin{tabular}{|l|l|l|l|}
\hline Customer: & $\begin{array}{l}\text { The United States Department of Energy } \\
\text { National Energy Technology Laboratory }\end{array}$ & $\begin{array}{l}\text { Date of Issue: } \\
24 \text { April 2003 }\end{array}$ & \\
\hline $\begin{array}{l}\text { Document } \\
\text { Title: }\end{array}$ & $\begin{array}{l}\text { Report I: Critical Elements in a process to Utilize Salt Caverns in an LNG } \\
\text { Receiving Terminal }\end{array}$ & $\begin{array}{l}\text { Doc \# \& Version: } \\
\text { Doc } 01 \text { r1.0 }\end{array}$ & Page 10 of 11 \\
\hline
\end{tabular}

vendor support), a system capable of combining the heretofore proven LNG technologies into one universal package acceptable to the LNG industry.

\section{SALT CAVERN AND CRITICAL REQUIREMENTS}

\subsection{The Rock Mechanics Analysis}

The results of RESPEC's rock mechanic analysis confirm that salt caverns can be used in LNG receiving terminal applications. Gasified LNG at temperatures from $43.3^{\circ}\left(110^{\circ} \mathrm{F}\right)$ down to $-17.8^{\circ} \mathrm{C}\left(0^{\circ} \mathrm{F}\right)$ can be safely and reliably injected, stored, and withdrawn. Limits on cavern cycling and withdrawal rates are no different in LNG service than for conventional gas storage facilities, and are widely known in the industry. The report indicates that salt caverns can tolerate low temperatures. The results of the study also confirm that the use of salt caverns in LNG receiving is fundamentally no different than the widespread use of salt caverns for the natural gas pipeline industry.

\subsection{The Bishop Process Heat Exchanger}

The Bishop Process heat Exchanger (BPT), a critical component of the subject technology is a high capacity, pipe in pipe heat exchanger. These exchangers allow an LNG tanker to be offloaded at rates consistent with conventional LNG terminals but with resulting pressures suitable for injection of the gas directly into salt caverns without the use of compressors. Thus no significant amount of LNG is ever stored on the surface. In addition, because the exchangers use seawater or other waters as a warmant, the fuel operating costs are approximately $25 \%$ of gas fired exchangers.

Through numerical modeling performed under the present contract, proposed exchanger configurations, process design, and operational considerations have been successfully verified. HYSYS and MATLAB the process software used to design the exchanger, documented the location and thickness of the icing condition (a predicted consequence of using water to warm LNG). The warm water flow systems have been integrated into exchanger design to optimize BPT efficiencies and increase operational flexibility. The BPT exchanger inner annulus will be fabricated from stainless steel, a resilient material known to be resistant to cryogenic temperatures. The outer pipe can be fabricated with HDPE or coated carbon steel depending upon site conditions and specific application. The inner annulus will be centralized with a device designed to incorporate the effects of thermal expansion and contraction.

\subsection{High Pressure Cryogenic Pumps}

The major process differences in the BPT LNG receiving terminal and the traditional terminal are defined by the configuration of the High Pressure Pumping units called a "4-Pack" and the pipe-in-pipe configuration of the BPT. Each "4-Pack" is designed to pump 6,480 m3/day at 152 barg (2,200 psig) of LNG discharging immediately into the pipe-in-pipe Bishop Process heat Exchanger. Each pump with its own exchanger will gasify about $135 \mathrm{mmcfd}$. Each 4-pack and its associated BPT exchanger has the capacity of gasifying approximately $540 \mathrm{mmscfd}$. There are three major pump manufacturers in the world. Each manufacturer indicated that the pump and motor could be successfully fabricated using the technologies and processes currently available. The pump manufacturers advise that the pumps are not flow rate or pressure limited but rather horsepower limited. Therefore any pressure or pumping rate desired can be achieved with multiple units.

The major equipment items required for the BPT terminal have been identified. The pump manufactures confirm that the high pressure pumps required for the BPT process can be fabricated and pre-tested using 


\begin{tabular}{|l|l|l|l|}
\hline Customer: & $\begin{array}{l}\text { The United States Department of Energy } \\
\text { National Energy Technology Laboratory }\end{array}$ & $\begin{array}{l}\text { Date of Issue: } \\
\mathbf{2 4} \text { April } 2003\end{array}$ \\
\hline $\begin{array}{l}\text { Document } \\
\text { Title: }\end{array}$ & $\begin{array}{l}\text { Report I: Critical Elements in a process to Utilize Salt Caverns in an LNG } \\
\text { Receiving Terminal }\end{array}$ & $\begin{array}{l}\text { Doc \# \& Version: } \\
\text { Doc } 01 \text { r1.0 }\end{array}$ & Page 11 of 11 \\
\hline
\end{tabular}

existing materials, technology, and know-how. The BPT exchanger has been conceptually designed and a working model should be field tested to demonstrate its operating characteristics. 


\begin{tabular}{|l|l|l|l|}
\hline Customer: & $\begin{array}{l}\text { The United States Department of Energy } \\
\text { National Energy Technology Laboratory }\end{array}$ & $\begin{array}{l}\text { Date of Issue: } \\
\mathbf{2 4} \text { April } 2003\end{array}$ & \\
\hline $\begin{array}{l}\text { Document } \\
\text { Title: }\end{array}$ & $\begin{array}{l}\text { Subtask 1.1 Identify Potential Salt Formations Which Could be used for } \\
\text { LNG Receiving }\end{array}$ & $\begin{array}{l}\text { Doc \# \& Version: } \\
\text { Doc 02 r1.0 }\end{array}$ & Page 1 of 5 \\
\hline
\end{tabular}

\title{
Identify Potential Salt Formations Which Could be Used for LNG Receiving
}

\author{
BY \\ MichaEL M. MCCALL \\ WILLIAM M. BISHOP \\ D. BRAXTON SCHERZ
}

\begin{tabular}{|c|c||c|c|c|c|c|c|c||}
\hline r 1.0 & For client review & $04 / 15 / 03$ & вS & мм & & & \\
\hline Version & Reason for Issue & $\begin{array}{c}\text { Issue } \\
\text { Date }\end{array}$ & $\begin{array}{c}\text { Orig. } \\
\text { Chk. Appr. } \\
\text { CGI }\end{array}$ & $\begin{array}{c}\text { Chk. } \\
\text { NETL }\end{array}$ & Appr. & Review \\
\hline \hline $\begin{array}{l}\text { Document Title: } \\
\text { Identify Potential Salt Formations Which Could be } \\
\text { used for LNG Receiving }\end{array}$ & \multicolumn{7}{|c||}{$\begin{array}{c}\text { Document No: } \\
\text { DE-FC26-02NT41653 }\end{array}$} \\
\hline
\end{tabular}




\section{TABLE OF CONTENTS}

1. EXECUTIVE SUMMARY

2. TABLE OF SALT FORMATIONS SUITABLE (PARTIAL LIST) FOR DEVELOPMENT OF LNG RECEIVING FACILITIES.

3. CONTOUR MAPS 


\begin{tabular}{|l|l|l|l|}
\hline Customer: & $\begin{array}{l}\text { The United States Department of Energy } \\
\text { National Energy Technology Laboratory }\end{array}$ & $\begin{array}{l}\text { Date of Issue: } \\
24 \text { April } 2003\end{array}$ & \\
\hline $\begin{array}{l}\text { Document } \\
\text { Title: }\end{array}$ & $\begin{array}{l}\text { Subtask 1.1 Identify Potential Salt Formations Which Could be used for } \\
\text { LNG Receiving }\end{array}$ & $\begin{array}{l}\text { Doc \# \& Version: } \\
\text { Doc } 02 \text { r1.0 }\end{array}$ & Page 3 of 5 \\
\hline
\end{tabular}

\section{EXECUTIVE SUMMARY}

The U.S. coastal areas of the Gulf of Mexico have a convergence of multiple salt formations suitable for natural gas storage, major shipping fairways and harbor approaches capable of accommodating the largest LNG ships, and the most comprehensive natural gas pipeline infrastructure in the world. This section of the study defines several sites suited for a Salt Storage LNG terminal both onshore and offshore. A detailed conceptual design appearing later in this study describes two ideal locations that best exemplify this convergence, an onshore location in Calcasieu Parish, Louisiana, and an offshore site in Vermilion block 179. At these two sites LNG ships can easily access nearby salt formations, and nearby natural gas pipelines with take away capacity exceeding 2 Bcf/day are in close proximity.

Dozens of other potential locations have been identified in Texas, Louisiana, Mississippi and offshore areas adjacent to these states that have similar potential. A series of LNG receiving facilities using the existing infrastructure in the Gulf of Mexico coastal area and contiguous salt caverns within the region could meet virtually any growth necessary in LNG imports required to replace declining production or meet growing natural gas demand.

\section{TABLE OF SALT FORMATIONS SUITABLE (PARTIAL LIST) FOR DEVELOPMENT OF LNG RECEIVING FACILITIES}

\begin{tabular}{|l|l|l|}
\hline \multicolumn{1}{|c|}{ Site } & \multicolumn{1}{|c|}{ Location } & \multicolumn{1}{c|}{ County } \\
\hline \multicolumn{1}{|c|}{ Onshore Texas } & \multicolumn{1}{|c|}{ Pefferson } & DOE SPR Site \\
\hline Big Hill & Jefferson & \\
\hline Spindletop & Brazoria & DOE SPR Site \\
\hline Bryan Mound & Brazoria & \\
\hline Hoskins Mound & Brazoria & \\
\hline Stratton Ridge & \multicolumn{1}{|c|}{ Parish } \\
\hline \multicolumn{1}{|c|}{ Onshore Louisiana } & Cameron & \\
\hline Black Bayou & Cameron & DOE SPR Site \\
\hline West Hackberry & Calcasieu & This site was chosen for the conceptual facility \\
\hline Sulphur Mines & St. Mary & \\
\hline Cote Blanche Island & Iberia & \\
\hline Jefferson Island & Iberia & \\
\hline Vermilion Bay & Plaquemines & \\
\hline Venice & & Please reference the following contour maps \\
\hline & & \\
\hline \multicolumn{1}{|c|}{ Offshore Louisiana } & 115 & This site was chosen for the conceptual facility \\
\hline East Cameron & 73 & \\
\hline South Marsh Island & 179 & \\
\hline Vermilion & 16 & \\
\hline Grand Isle & 175 & \\
\hline Eugene Island & 178 & \\
\hline Eugene Island & 188 & \\
\hline Eugene Island & 205 & \\
\hline Eugene Island & 128 & \\
\hline Eugene Island & & \\
\hline
\end{tabular}




\begin{tabular}{|l|l|l|l|}
\hline Customer: & $\begin{array}{l}\text { The United States Department of Energy } \\
\text { National Energy Technology Laboratory }\end{array}$ & $\begin{array}{l}\text { Date of Issue: } \\
24 \text { April } 2003\end{array}$ & \\
\hline $\begin{array}{l}\text { Document } \\
\text { Title: }\end{array}$ & $\begin{array}{l}\text { Subtask 1.1 Identify Potential Salt Formations Which Could be used for } \\
\text { LNG Receiving }\end{array}$ & $\begin{array}{l}\text { Doc \# \& Version: } \\
\text { Doc } 02 \text { r1.0 }\end{array}$ & Page 4 of 5 \\
\hline
\end{tabular}

\begin{tabular}{|l|l|l|}
\hline Eugene Island & 126 & \\
\hline West Delta & 133 & \\
\hline Main Pass & 290 & \\
\hline Main Pass & 299 & \\
\hline & & \\
\hline
\end{tabular}

\section{SALT FORMATION LOCATIONS}

The red designations on the map below indicate the location of the formations mentioned above. Each of these locations are in close proximity with the GOM natural gas gathering systems capable of up to 10 Bcfd takeaway.

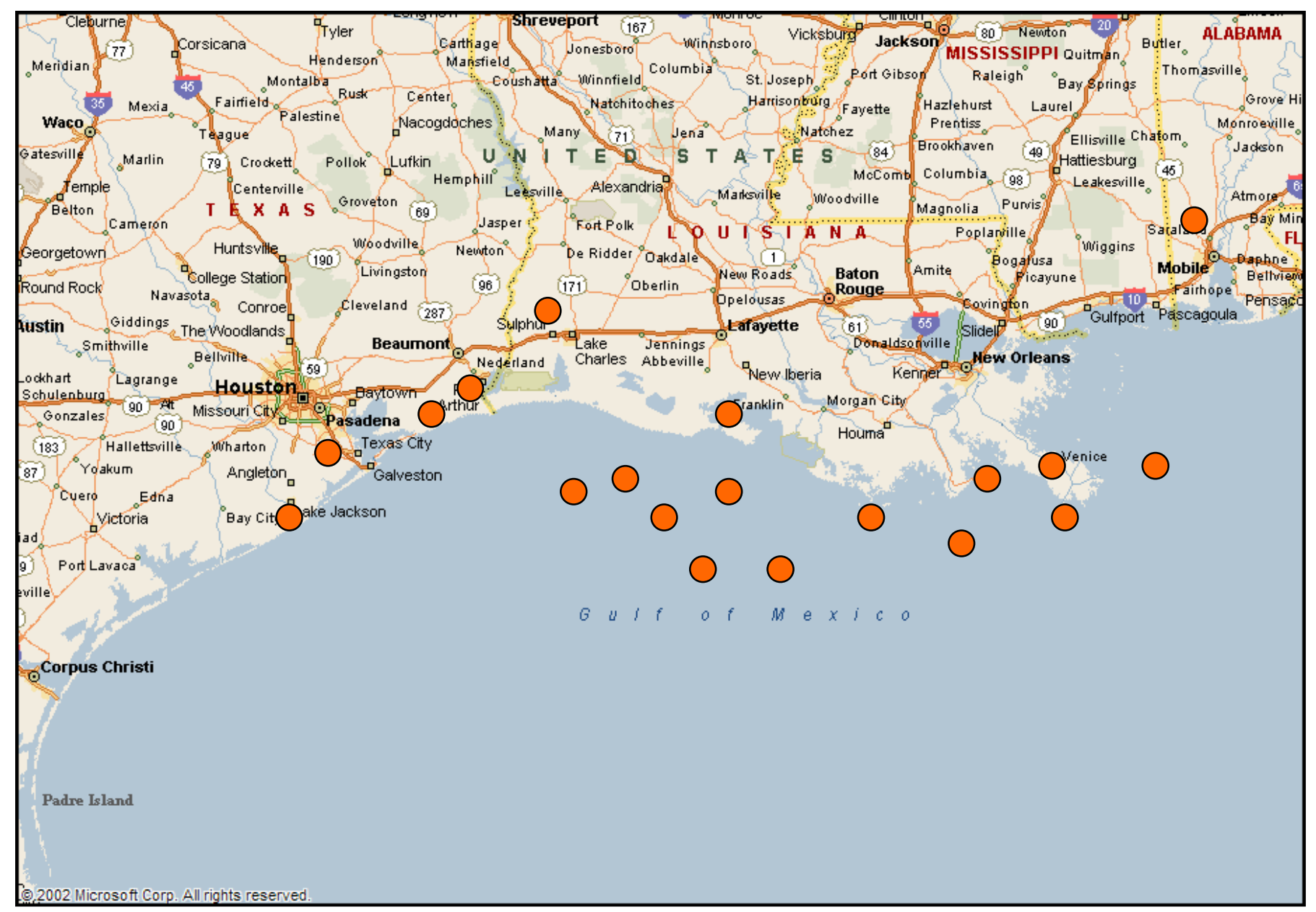

While $10 \mathrm{Bcf}$ or even greater of storage is a large amount of natural gas stored in one location, the actual size of the cavern compared to the salt formation is quite small, on the order of $1 / 100$ th to $1 / 1000$ th of the overall size of the domal formation. The attached contour maps indicate dome formations of sizes ranging from one to about four miles apart. The top of salt is ideally located about 1000 feet below the surface allowing for economical cavern creation at design pressures. The salt dome itself extends far below the surface, eventually joining with the basal 


\begin{tabular}{|l|l|l|l|}
\hline Customer: & $\begin{array}{l}\text { The United States Department of Energy } \\
\text { National Energy Technology Laboratory }\end{array}$ & $\begin{array}{l}\text { Date of Issue: } \\
\mathbf{2 4} \text { April } 2003\end{array}$ \\
\hline $\begin{array}{l}\text { Document } \\
\text { Title: }\end{array}$ & $\begin{array}{l}\text { Subtask 1.1 Identify Potential Salt Formations Which Could be used for } \\
\text { LNG Receiving }\end{array}$ & $\begin{array}{l}\text { Doc \# \& Version: } \\
\text { Doc } \mathbf{0 2} \text { r1.0 }\end{array}$ & Page 5 of 5 \\
\hline
\end{tabular}

formation. The salt caverns are washed in areas of the dome at prescribed distances from the edge and the top of salt formation to ensure the integrity of the storage cavity.

\section{CONTOUR MAPS}

The locations mapped on the following pages were selected because the salt formations are appropriately close to the seabed and in the midst of the extensive GOM gathering systems. Currently there is no hydrocarbon storage in any of these but each is ideal for development of cavern storage. 


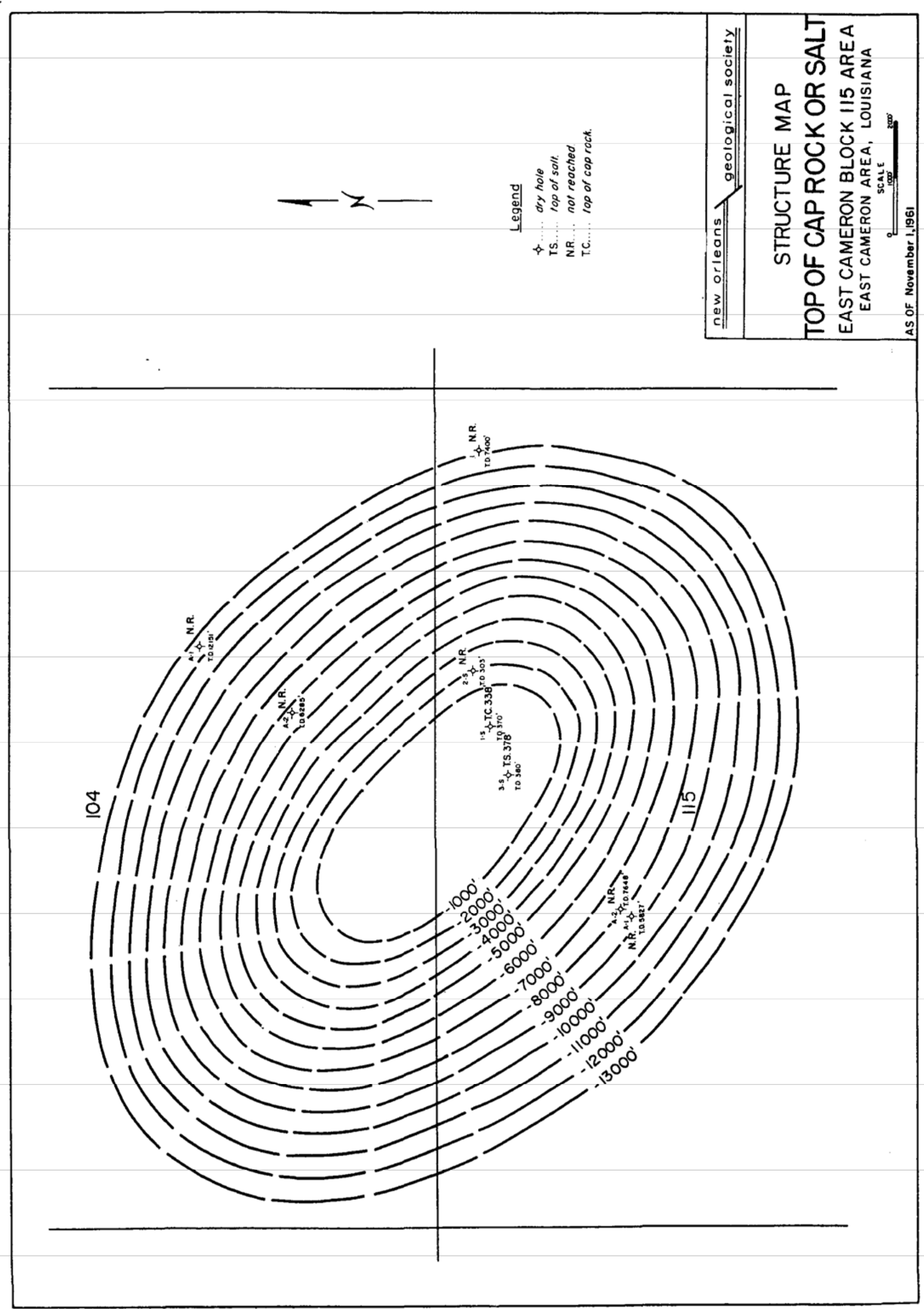




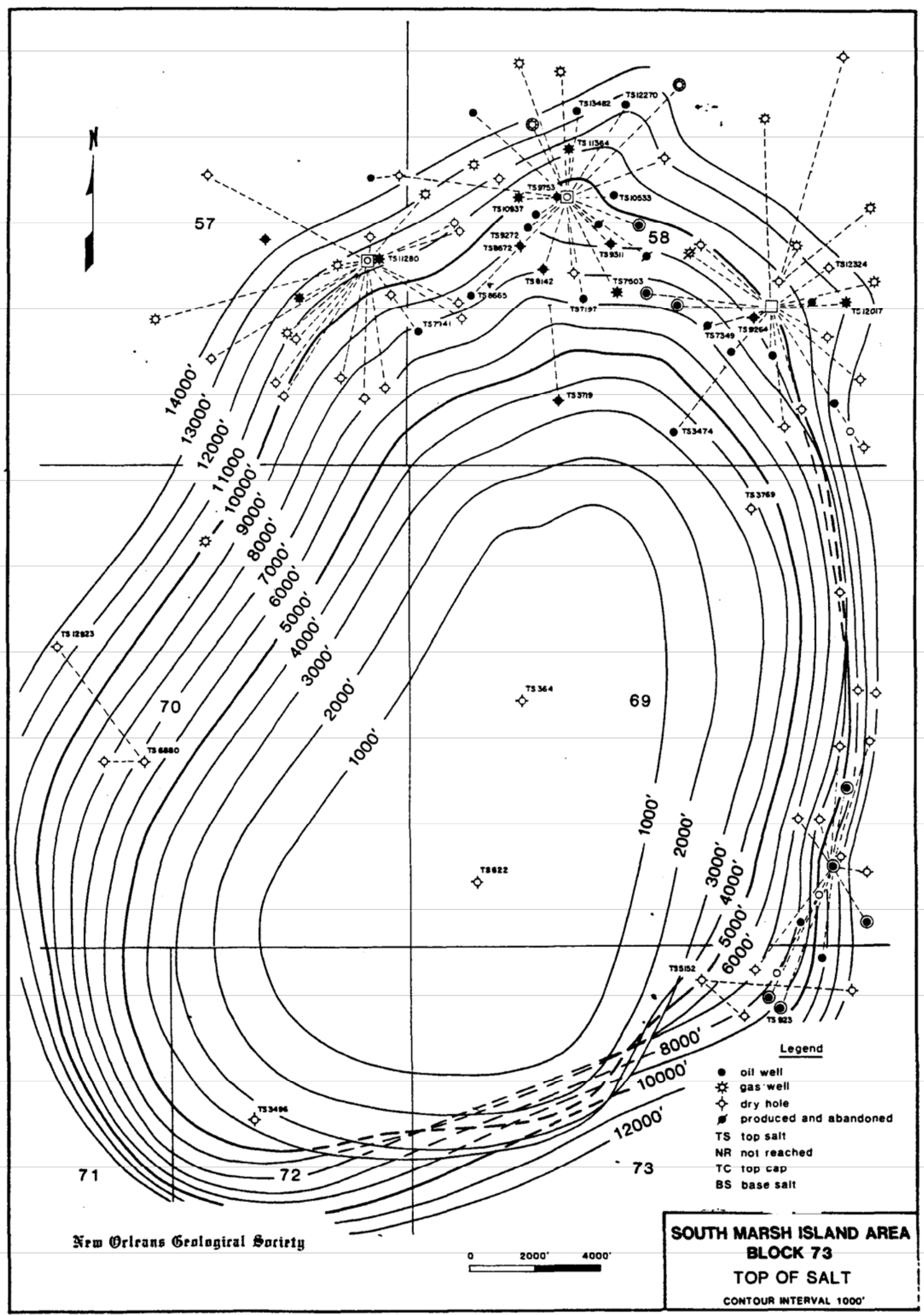




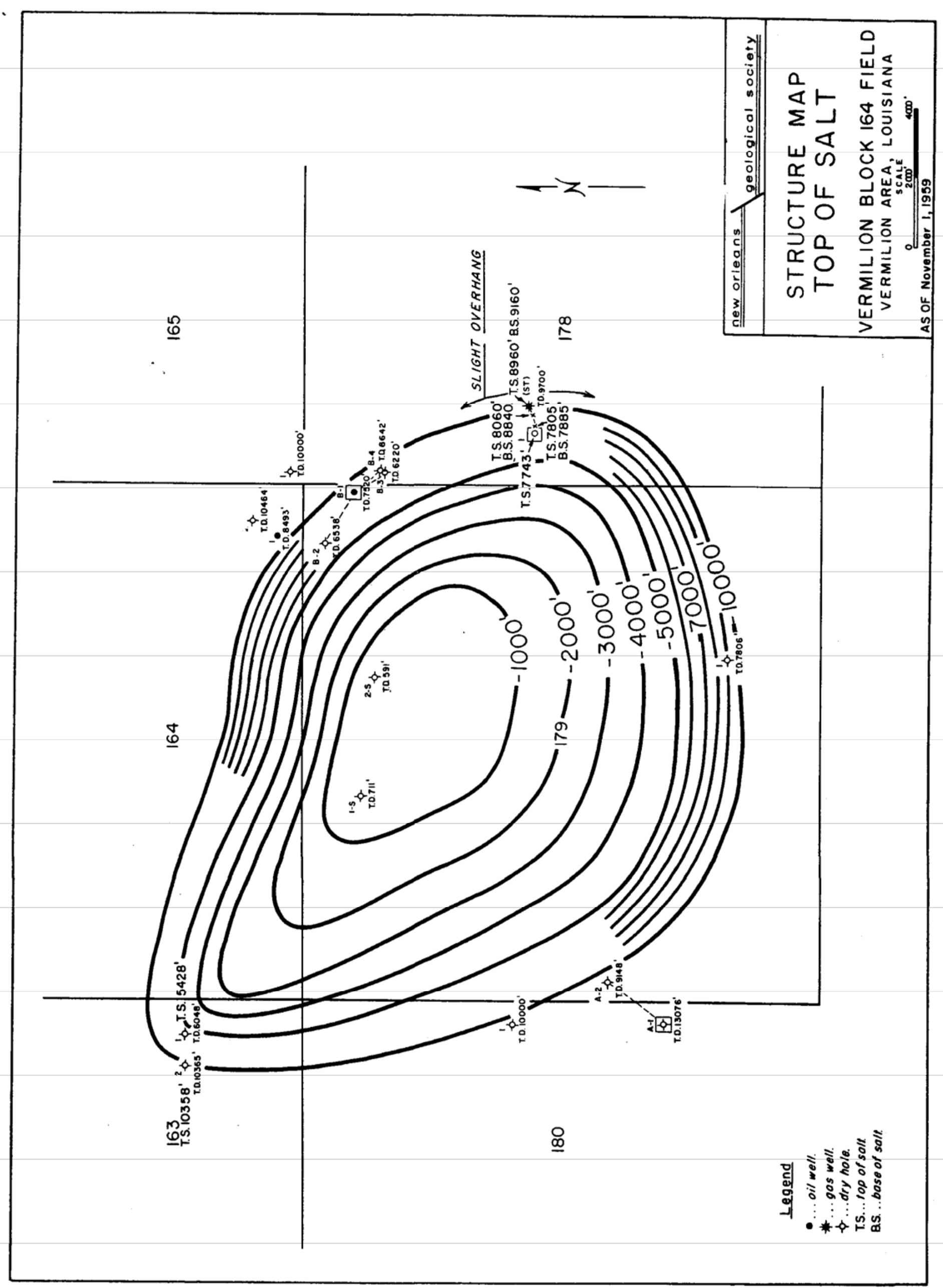




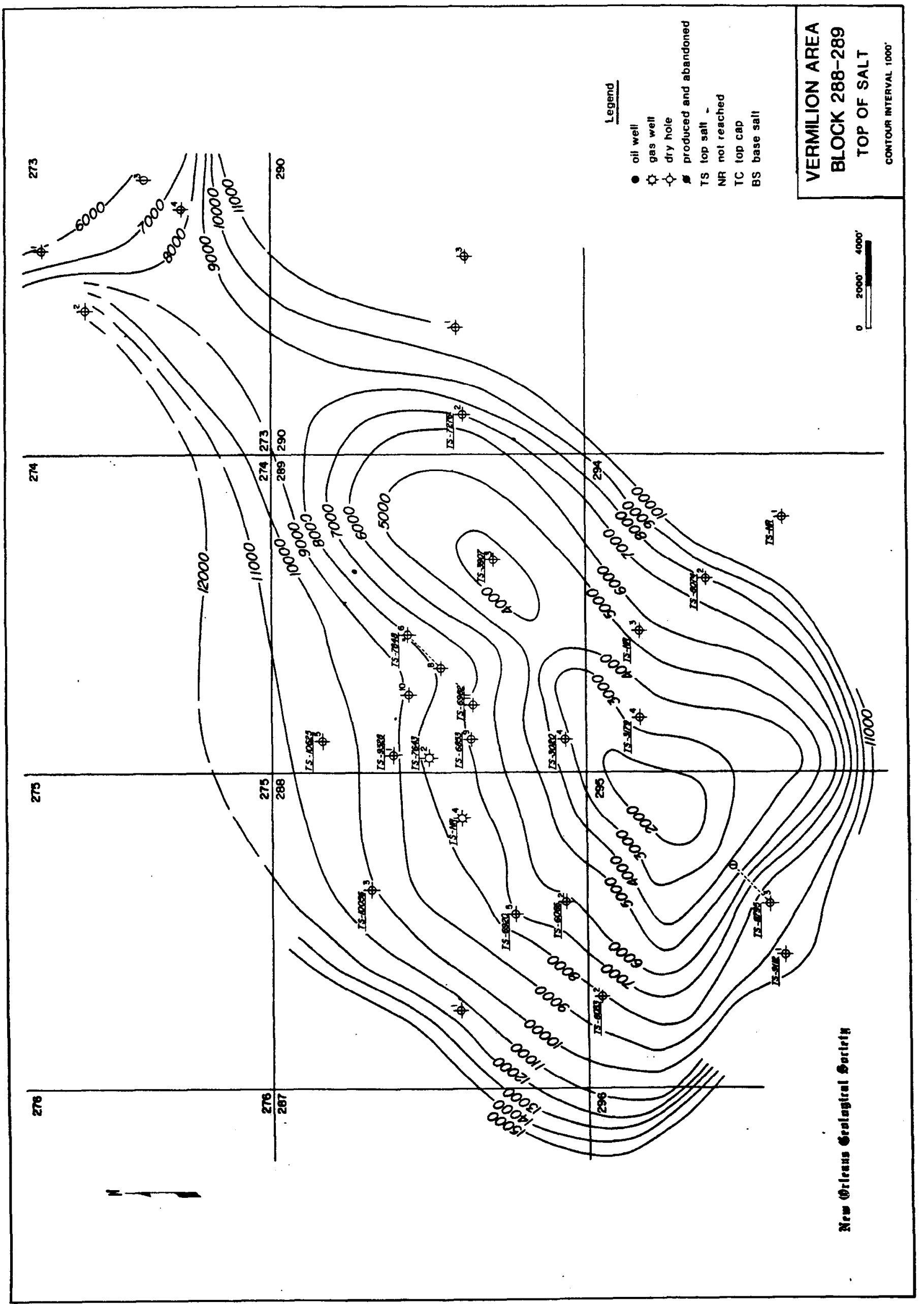




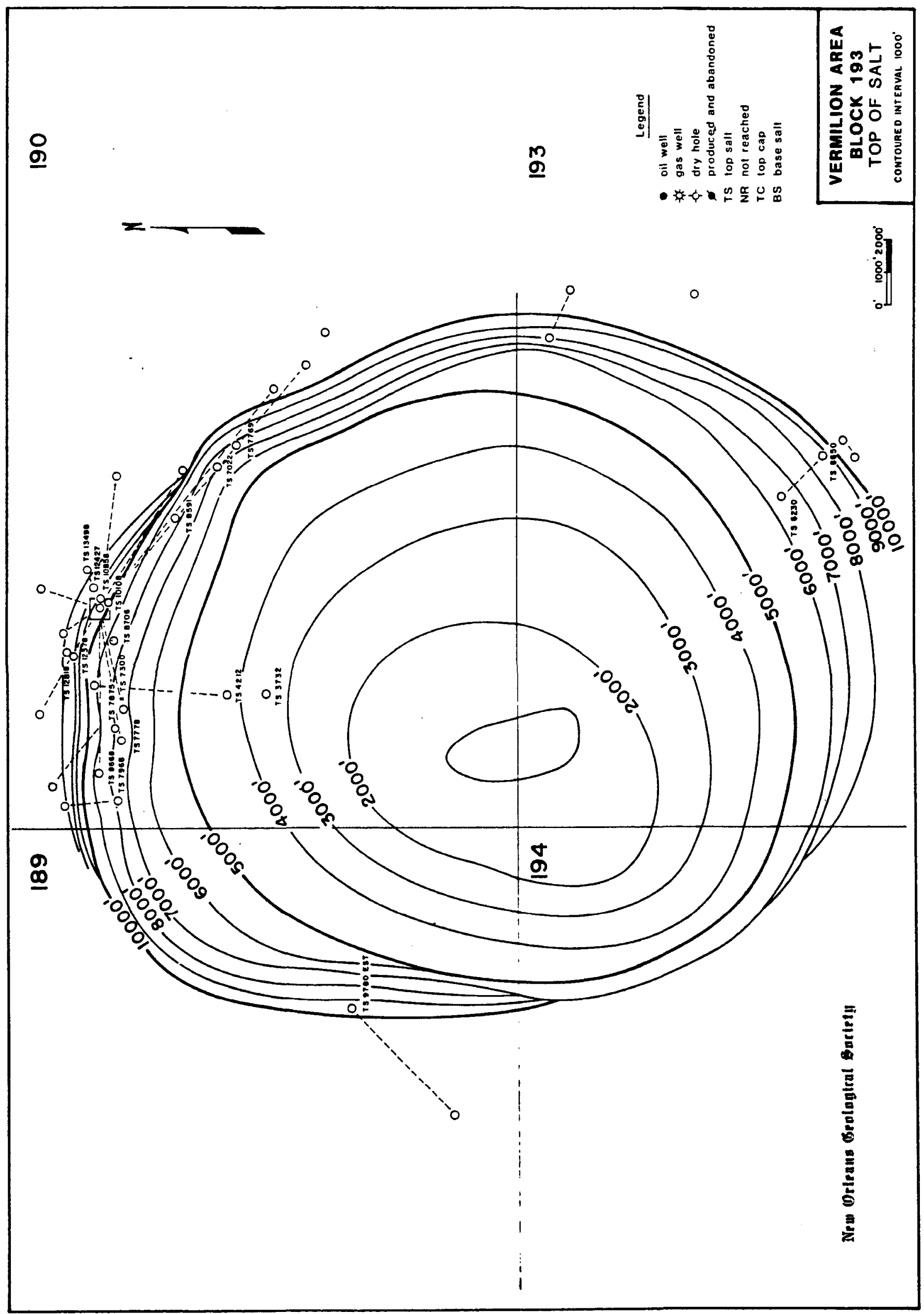




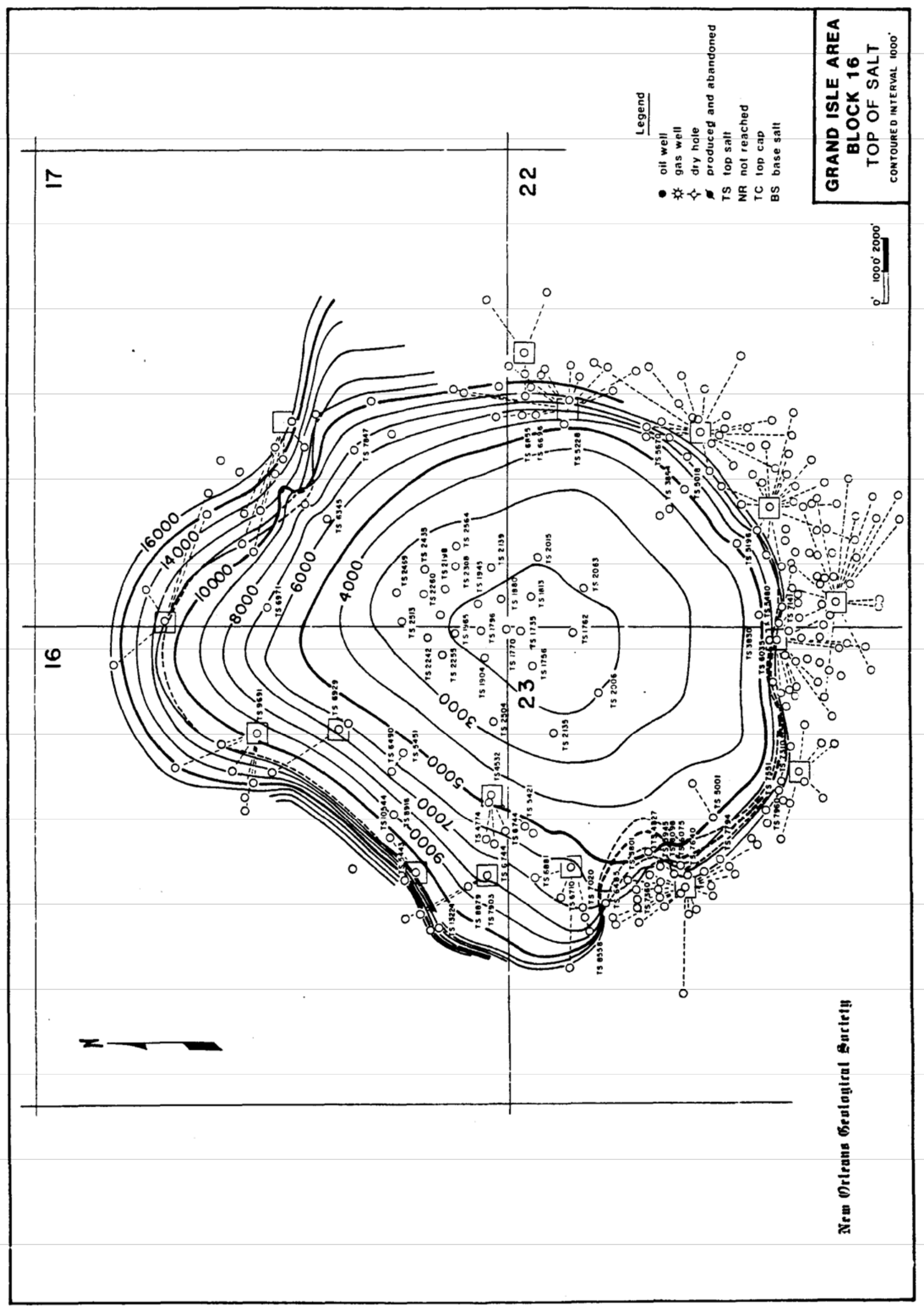




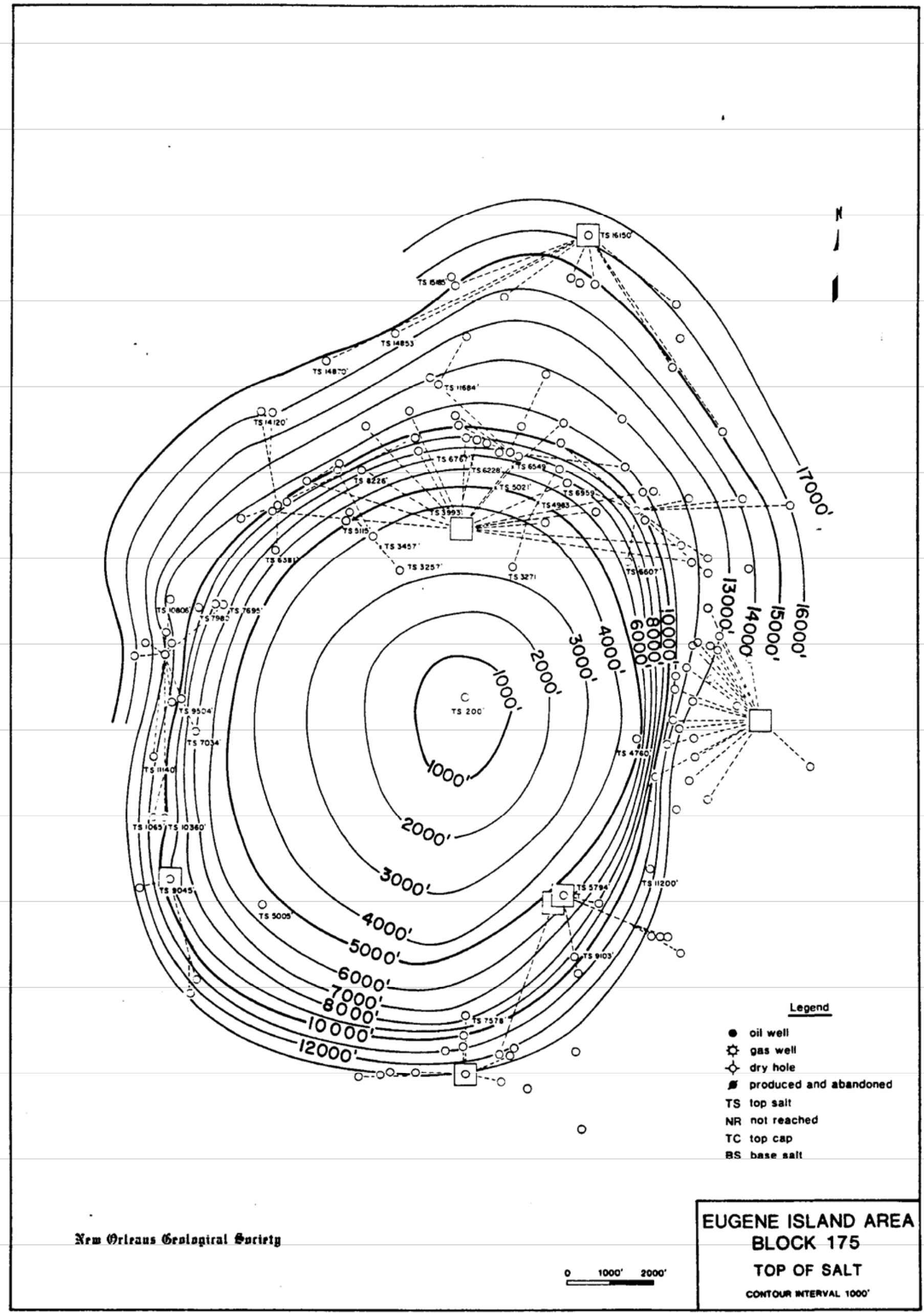




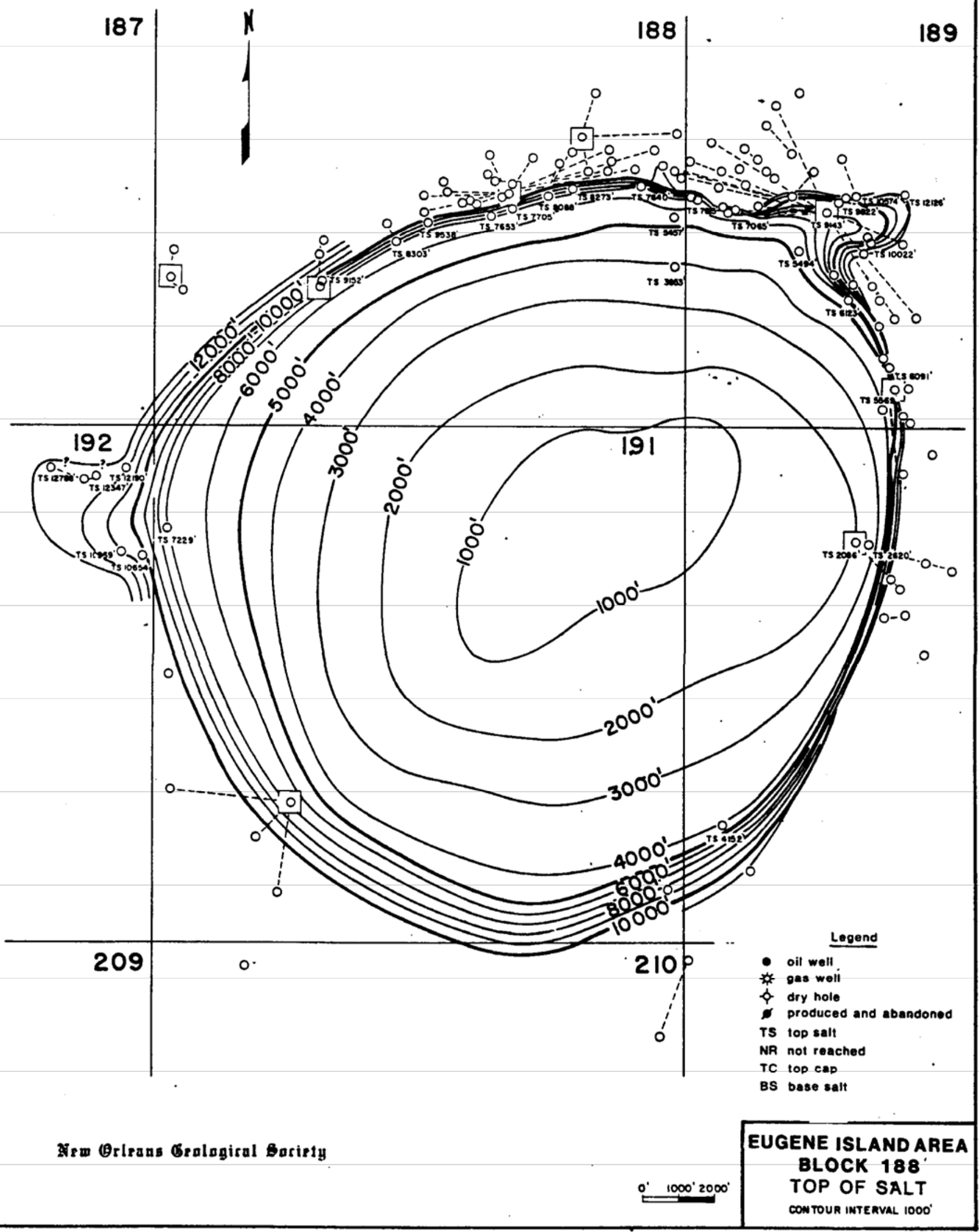




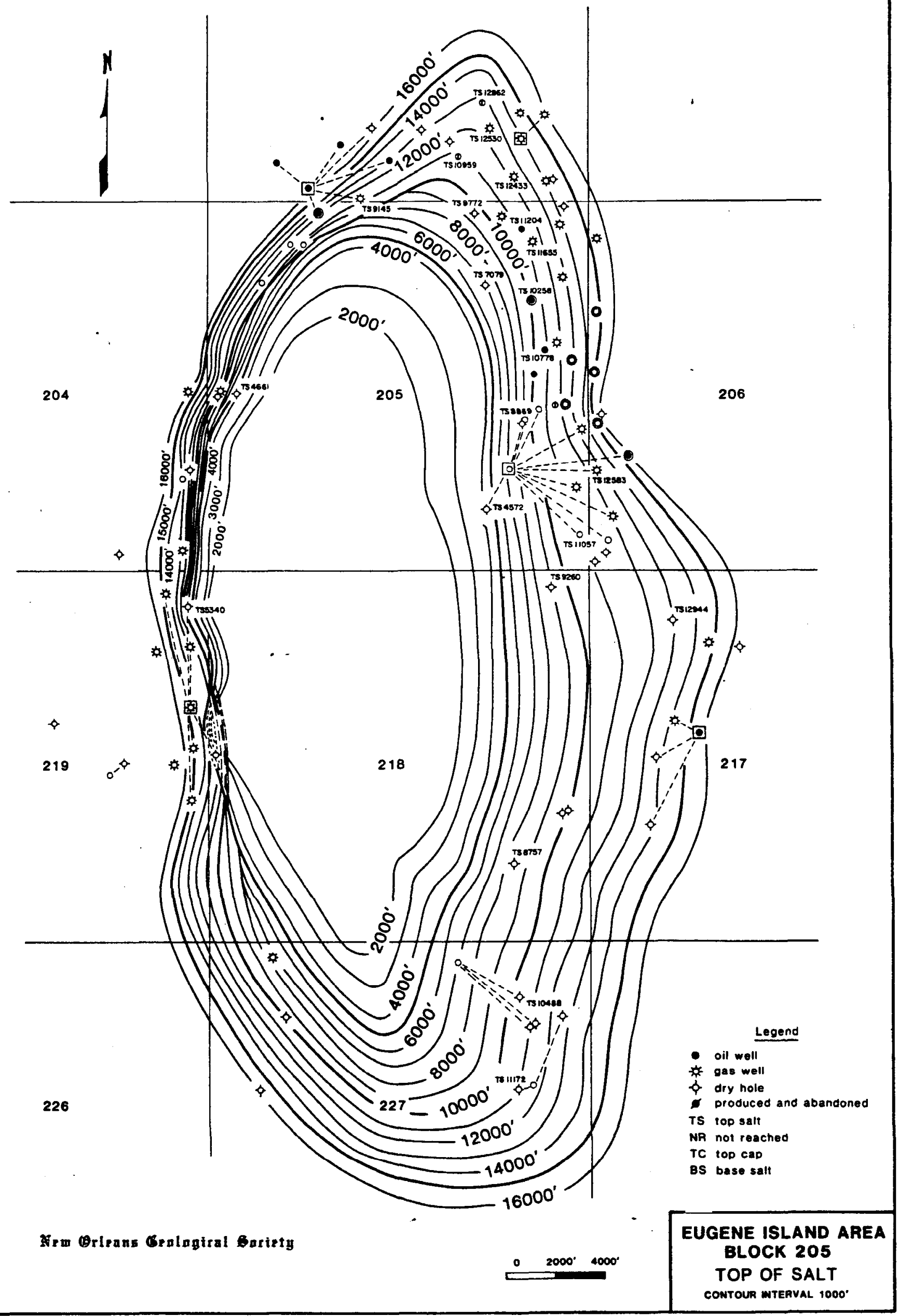




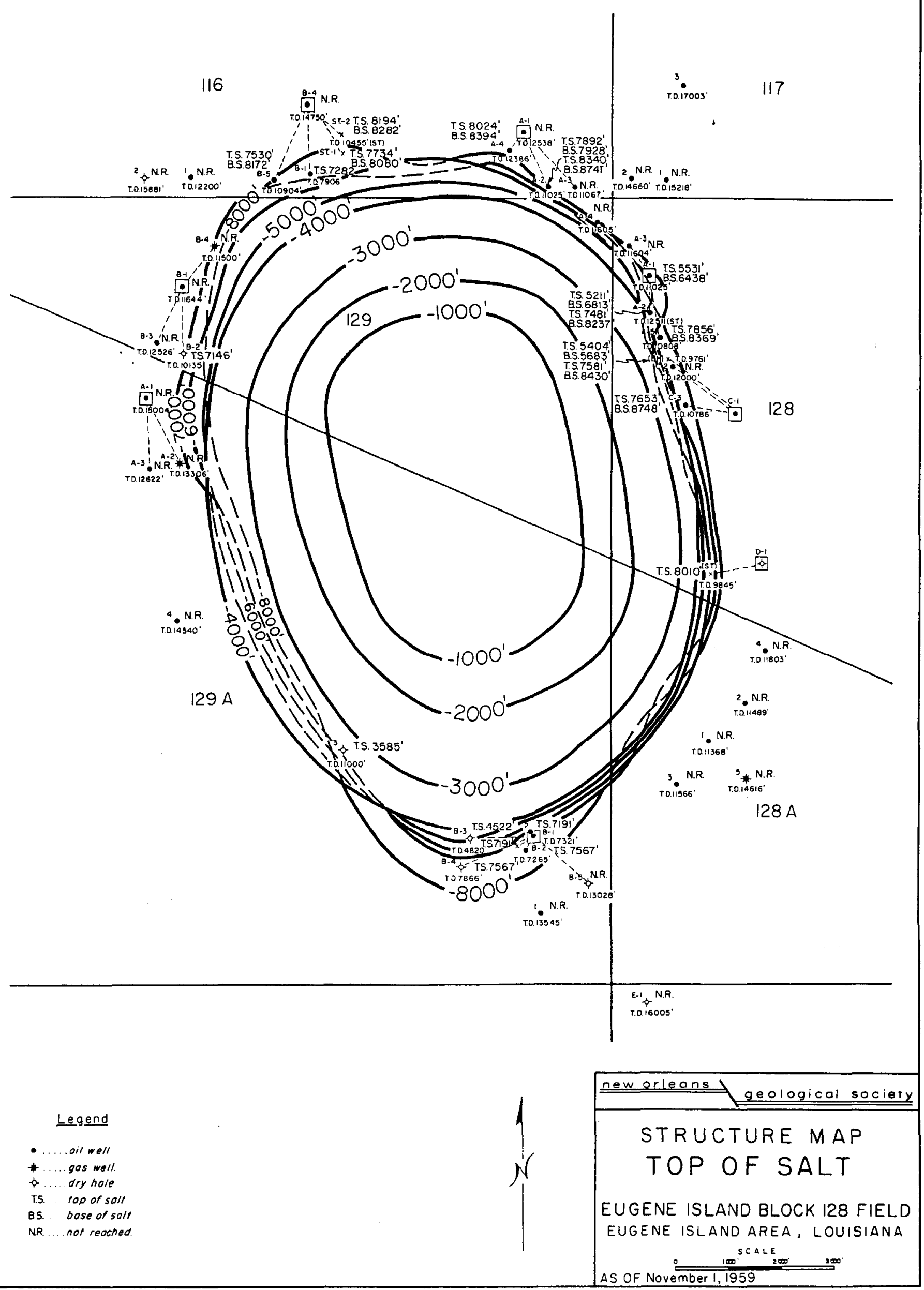




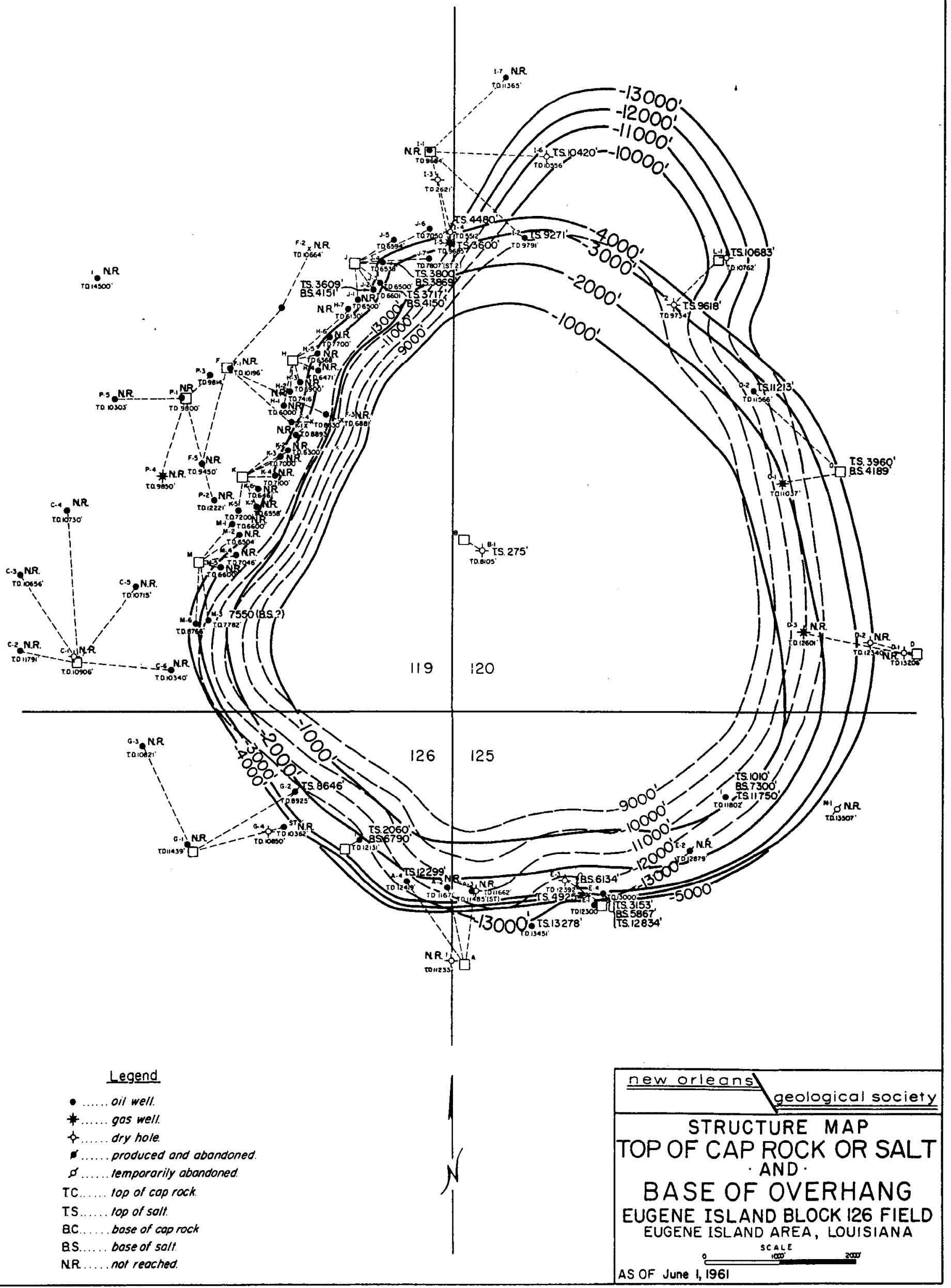




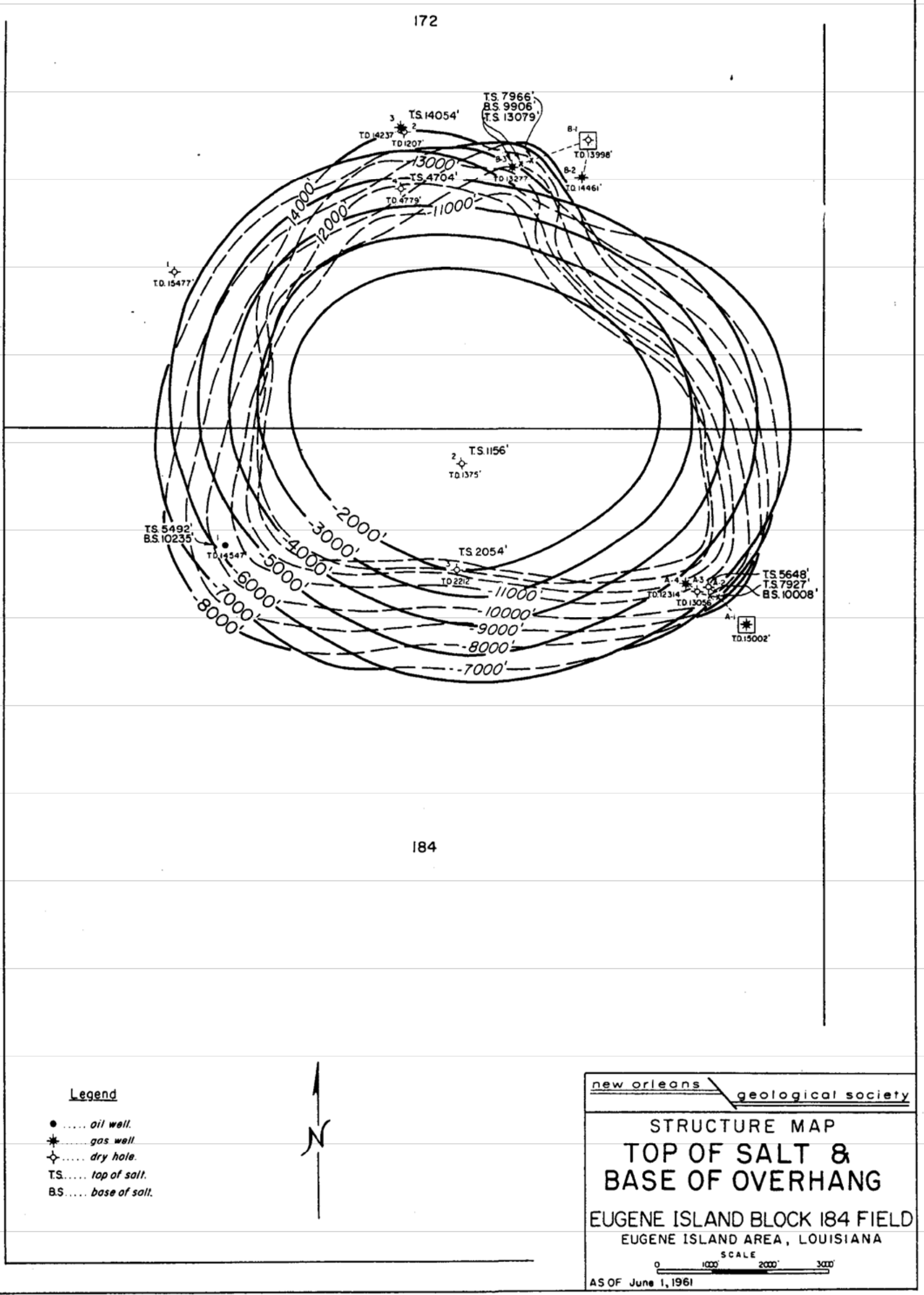




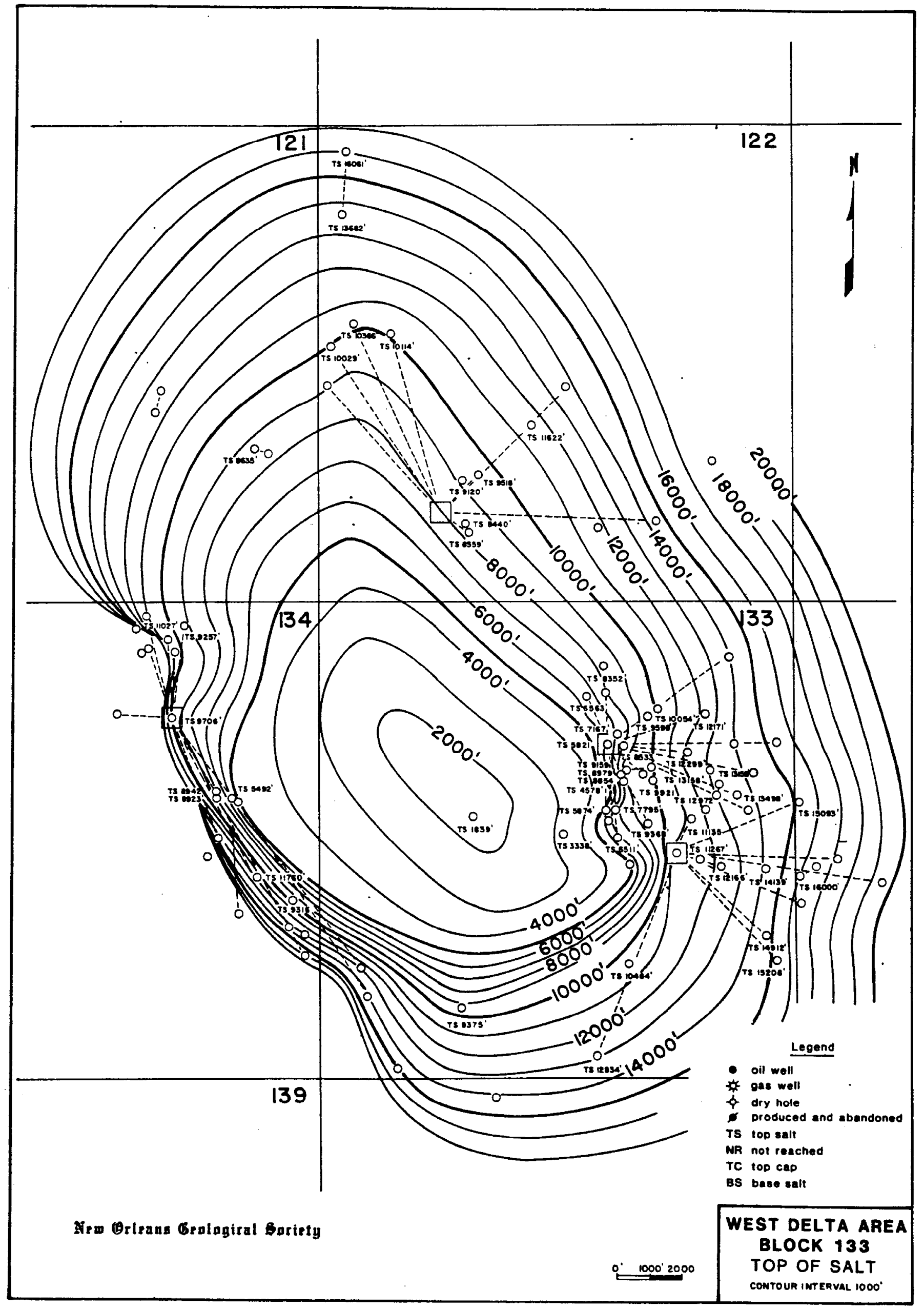




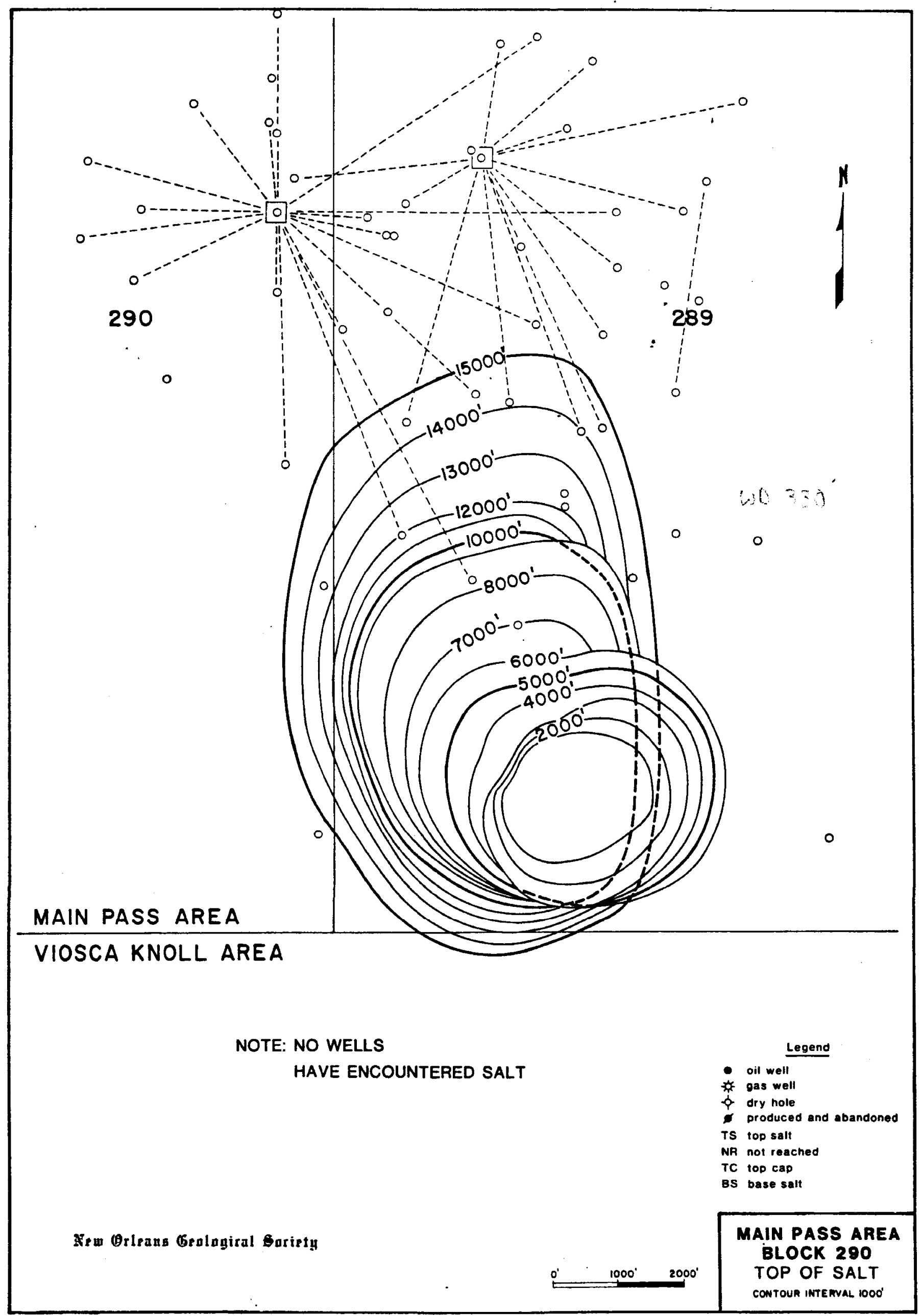




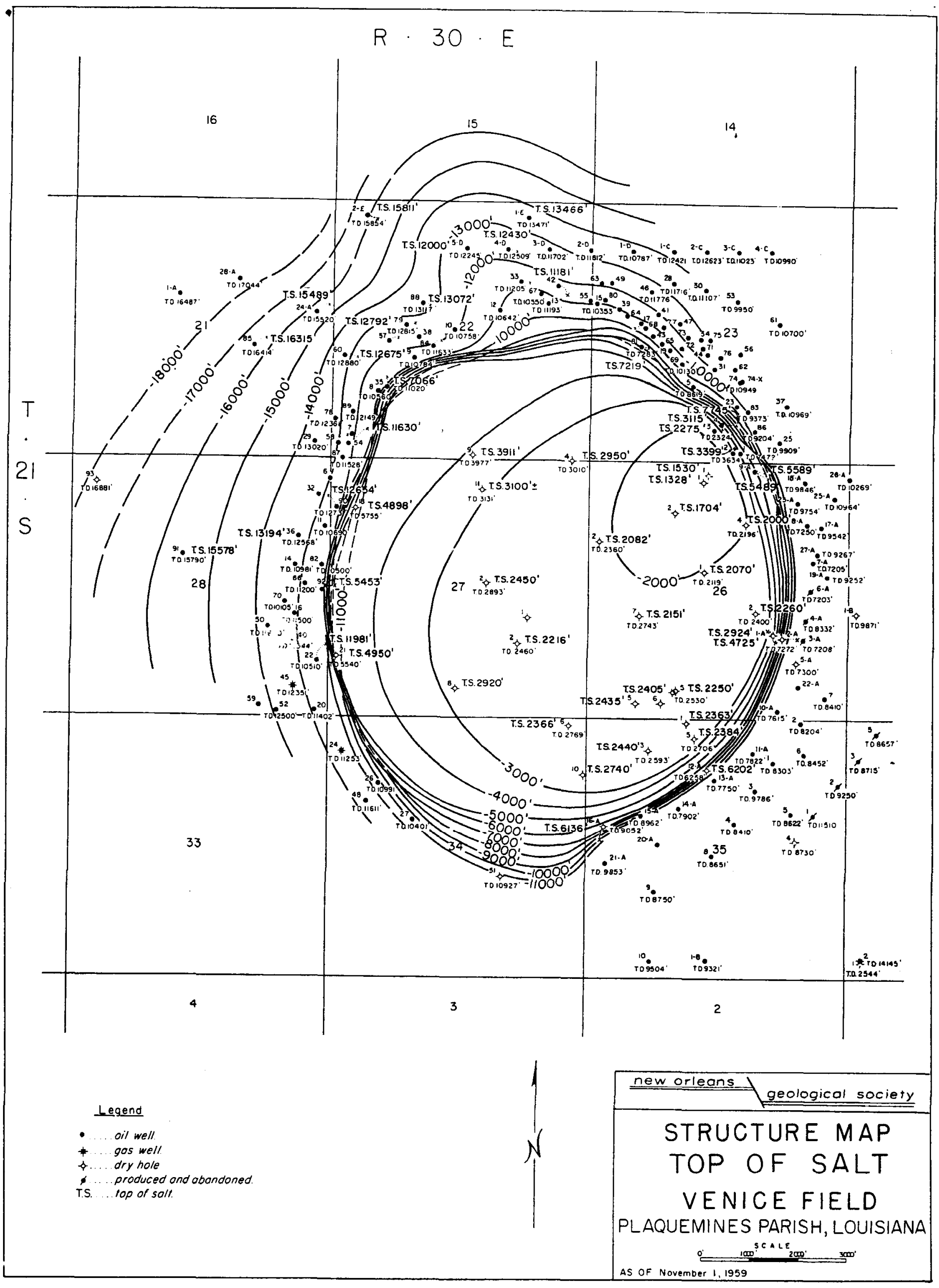




\begin{tabular}{|l|l|l|l|}
\hline Customer: & $\begin{array}{l}\text { The United States Department of Energy } \\
\text { National Energy Technology Laboratory }\end{array}$ & $\begin{array}{l}\text { Date of Issue: } \\
29 \text { April } 2003\end{array}$ & \\
\hline $\begin{array}{l}\text { Document } \\
\text { Title: }\end{array}$ & $\begin{array}{l}\text { Subtask 1.2 } \\
\text { Identify Marine Mooring and Offloading Initiatives for LNG Vessels }\end{array}$ & $\begin{array}{l}\text { Doc \# \& Version: } \\
\text { Doc } 003 \text { r4.0 }\end{array}$ & Page 1 of $\mathbf{4 0}$ \\
\hline
\end{tabular}

\section{Examine and Evaluate a Process to use Salt Caverns to Receive SHIP BORNE LIQUEFIED NATURAL GAS}

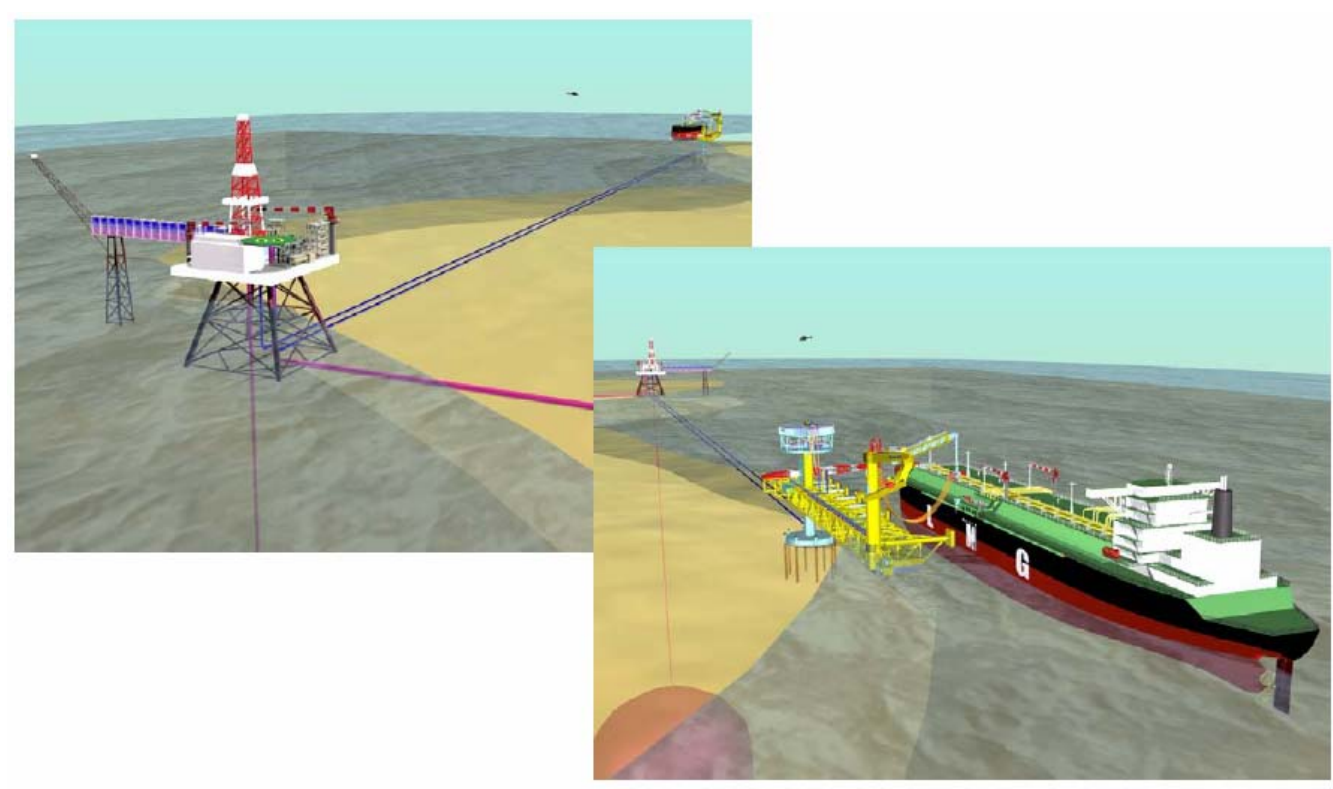

\section{BY}

MichaEL M. MCCALL

WILLIAM M. BISHOP

D. BRAXTON SCHERZ

\begin{tabular}{|c|c|c|c|c|c|c|c|c|}
\hline r 4.0 & For client review & $04 / 24 / 03$ & BS & MM & & & & \\
\hline Version & Reason for Issue & $\begin{array}{l}\text { Issue } \\
\text { Date }\end{array}$ & Orig. & $\begin{array}{l}\text { Chk. } \\
\text { CGI }\end{array}$ & Appr. & $\begin{array}{l}\text { Chk. } \\
\text { NE }\end{array}$ & $\begin{array}{l}\text { Appr. } \\
\text { TL }\end{array}$ & Review \\
\hline \multicolumn{2}{|c|}{$\begin{array}{l}\text { Document Title: } \\
\text { Subtask 1.2 Identify Marine Mooring and } \\
\text { Offloading Initiatives for LNG Vessels }\end{array}$} & \multicolumn{7}{|c|}{ Document No: } \\
\hline
\end{tabular}




\begin{tabular}{|l|l|l|l|}
\hline Customer: & $\begin{array}{l}\text { The United States Department of Energy } \\
\text { National Energy Technology Laboratory }\end{array}$ & $\begin{array}{l}\text { Date of Issue: } \\
29 \text { April } 2003\end{array}$ & \\
\hline $\begin{array}{l}\text { Document } \\
\text { Title: }\end{array}$ & $\begin{array}{l}\text { Subtask 1.2 } \\
\text { Identify Marine Mooring and Offloading Initiatives for LNG Vessels }\end{array}$ & $\begin{array}{l}\text { Doc\# \& Version: } \\
\text { Doc } 003 \text { r4.0 }\end{array}$ & Page 2 of $\mathbf{4 0}$ \\
\hline
\end{tabular}

\section{TABLE OF CONTENTS}

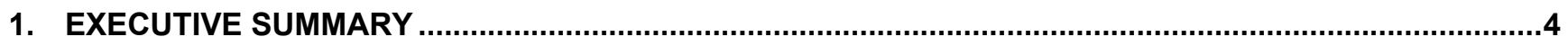

2. MOORING AND TRANSFER TECHNOLOGIES - THE OFFSHORE OIL INDUSTRY ..............................4

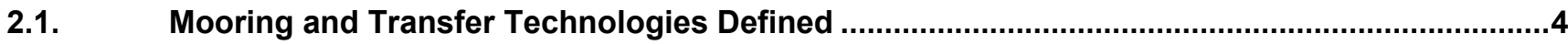

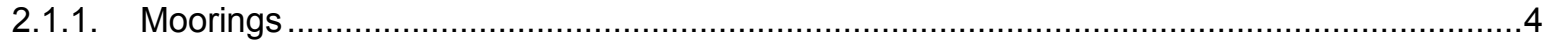

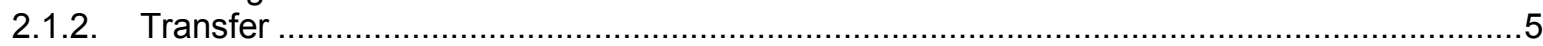

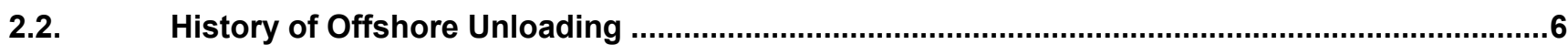

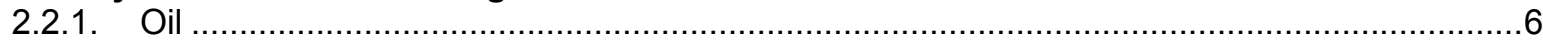

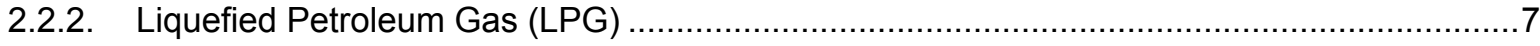

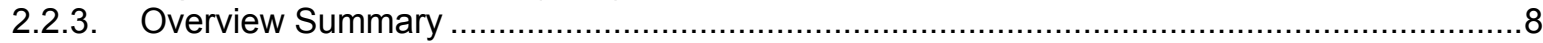

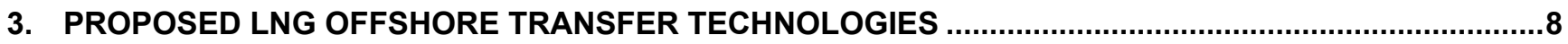

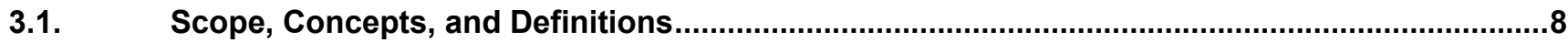

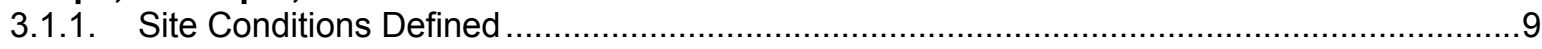

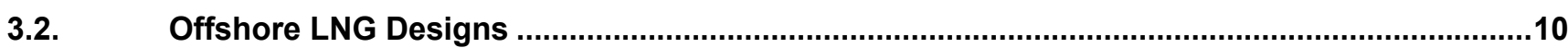

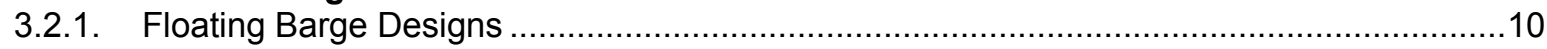

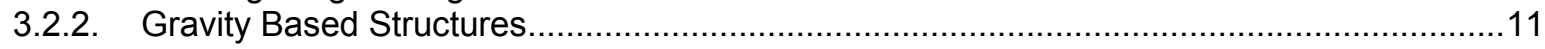

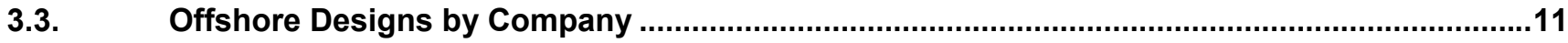

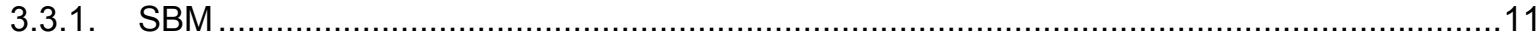

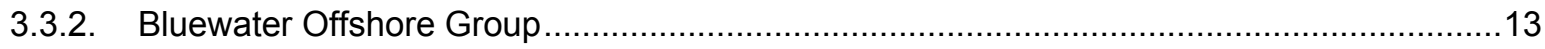

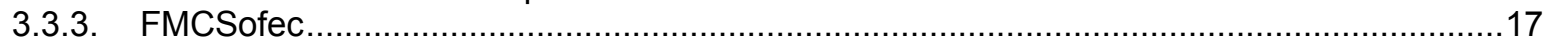

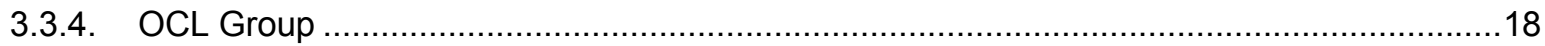

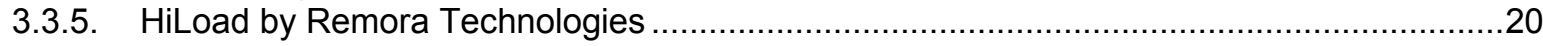

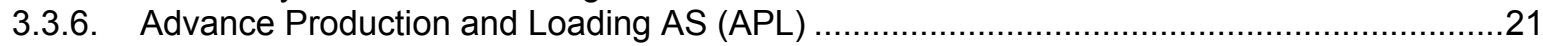

3.3.7. New Architectures of LNG Transfer by TFE, GdF, Eurodim, and ITP ..........................22

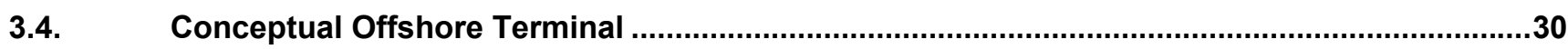

4. LINK TECHNOLOGIES TO FACILITATE LNG OFFSHORE TRANSFER ...........................................31

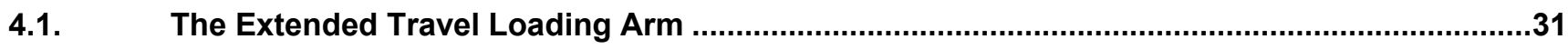

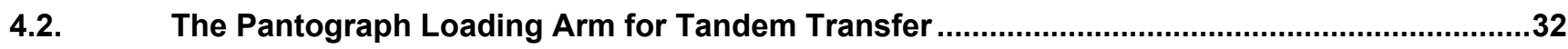

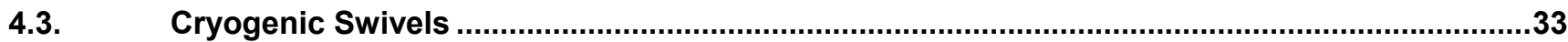

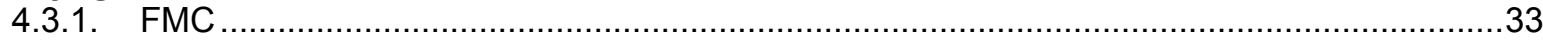

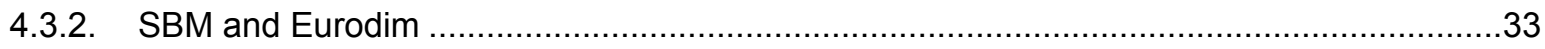

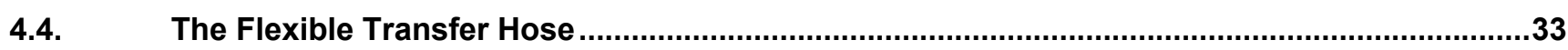

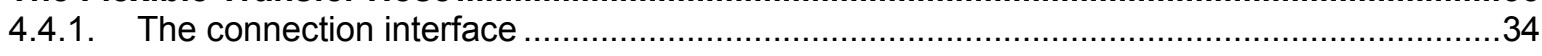




\begin{tabular}{|l|l|l|l|}
\hline Customer: & $\begin{array}{l}\text { The United States Department of Energy } \\
\text { National Energy Technology Laboratory }\end{array}$ & $\begin{array}{l}\text { Date of Issue: } \\
29 \text { April } 2003\end{array}$ \\
\hline $\begin{array}{l}\text { Document } \\
\text { Title: }\end{array}$ & $\begin{array}{l}\text { Subtask 1.2 } \\
\text { Identify Marine Mooring and Offloading Initiatives for LNG Vessels }\end{array}$ & $\begin{array}{l}\text { Doc \# \& Version: } \\
\text { Doc } 003 \text { r4.0 }\end{array}$ & Page 3 of 40 \\
\hline
\end{tabular}

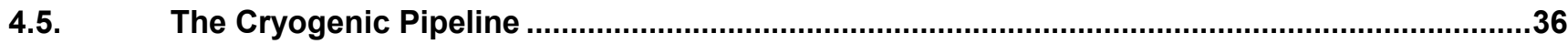

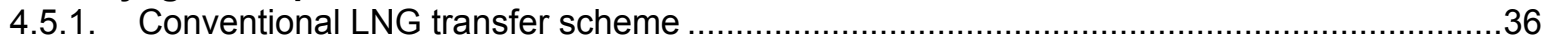

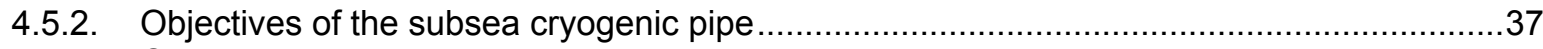

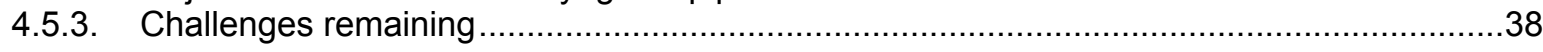

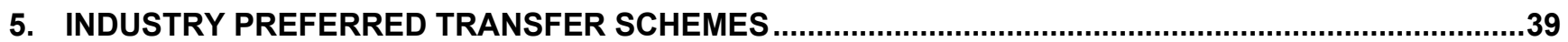

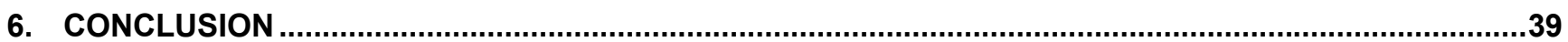




\begin{tabular}{|l|l|l|l|}
\hline Customer: & $\begin{array}{l}\text { The United States Department of Energy } \\
\text { National Energy Technology Laboratory }\end{array}$ & $\begin{array}{l}\text { Date of Issue: } \\
29 \text { April } 2003\end{array}$ & \\
\hline $\begin{array}{l}\text { Document } \\
\text { Title: }\end{array}$ & $\begin{array}{l}\text { Subtask 1.2 } \\
\text { Identify Marine Mooring and Offloading Initiatives for LNG Vessels }\end{array}$ & $\begin{array}{l}\text { Doc \# \& Version: } \\
\text { Doc } 003 \text { r4.0 }\end{array}$ & Page $\mathbf{4}$ of $\mathbf{4 0}$ \\
\hline
\end{tabular}

\section{EXECUTIVE SUMMARY}

This research confirms the feasibility of using offshore mooring facilities in a salt cavern based LNG receiving terminal. Task 1.2 identifying marine mooring and offloading initiatives compares the existing and proposed LNG offshore transfer technologies, identifies the commonalities, and recognizes industry requirements and transfer preferences. Reduced NIMBY (not in my backyard) concerns and permitting requirements, siting flexibility, quicker construction times, and lesser CAPEX/OPEX are among the many advantages of transferring and handling LNG offshore.

Producers considering LNG offshore transfer schemes prefer moorings that provide high availability. Weathervaning moorings (a mooring allows LNG vessel rotation around a vertical axis to assume a heading of minimum motion), facilitate maximum stability and good availability. Some producers have gone to gravity based structures that provide high availability in rough seas as they securely rest on the ocean floor. Also preferred are side by side cargo transfer schemes to accommodate current LNG ship cargo piping arrangements.

Several offshore transfer challenges have been identified including the need to minimize the relative motion between LNG vessel and transfer facility, and the requirement to improve linking systems (transfer arms, hoses, subsea pipelines, etc.) for high availability. Well designed marine berths capable of using the vessel's existing cargo manifolds could bring about the transfer LNG at sea in the very near future.

All the technologies required for safe LNG transfer at sea currently exist, although not within the same company. There is a possibility to consolidate LNG offshore engineering and design under the coordination of a recognized E\&C firm capable of combining the heretofore proven systems into one universal package acceptable to the LNG industry. This effort, coupled with the design work and testing necessary to complete the system is expected to take between 12 and 18 months to complete. The realization of an offshore LNG terminal using salt cavern storage is expected to take about 12 additional months for regulatory approval, and about 20 to 30 months to construct.

\section{MOORING AND TRANSFER TECHNOLOGIES - THE OFFSHORE OIL INDUSTRY}

The LNG trade offshore will follow in the footsteps of the proven technologies used in today's successful offshore oil industry. To appreciate the methods and systems to be employed by LNG offshore applications we must review the methodologies used to transfer oil at sea.

\subsection{Mooring and Transfer Technologies Defined}

\subsubsection{Moorings}

fig .2.1.1-1

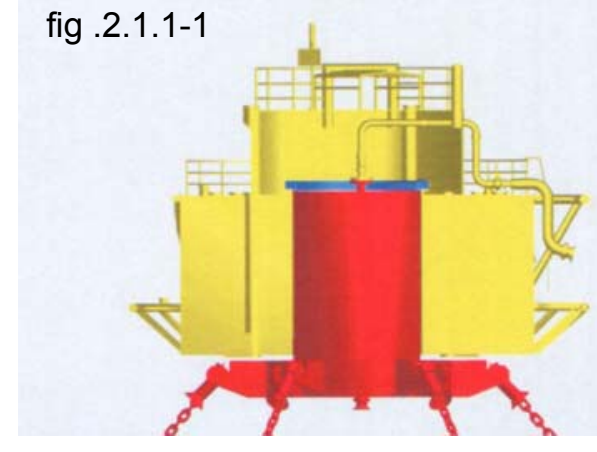




\begin{tabular}{|l|l|l|l|}
\hline Customer: & $\begin{array}{l}\text { The United States Department of Energy } \\
\text { National Energy Technology Laboratory }\end{array}$ & $\begin{array}{l}\text { Date of Issue: } \\
29 \text { April } 2003\end{array}$ & \\
\hline $\begin{array}{l}\text { Document } \\
\text { Title: }\end{array}$ & $\begin{array}{l}\text { Subtask 1.2 } \\
\text { Identify Marine Mooring and Offloading Initiatives for LNG Vessels }\end{array}$ & $\begin{array}{l}\text { Doc \# \& Version: } \\
\text { Doc } \mathbf{0 0 3} \mathbf{4 . 0}\end{array}$ & Page $\mathbf{5}$ of $\mathbf{4 0}$ \\
\hline
\end{tabular}

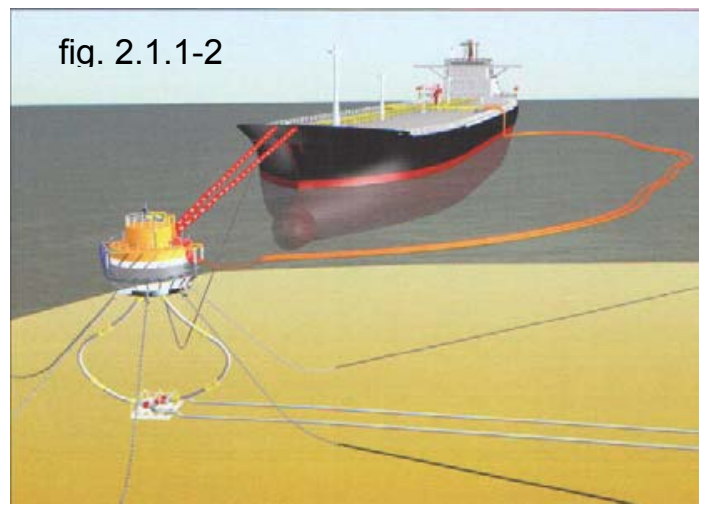

Vessels capable of transferring large quantities of oil at sea are classified as either Floating Storage Offshore (FSO) vessels used solely for storage and transfer, or Floating Storage and Production Offshore (FPSO) facilities which have the capability of processing the hydrocarbon stream into various petroleum products. These facilities whether spread moored, in a single, fixed orientation, or weathervaning (freely rotating with wind and current in a 360 degree motion around a fixed point) provide safe moorings for offshore oil transfer. Weathervaning moorings are used in more severe site conditions and provide greater availability in rough weather.

The Cantenary Anchored Leg Mooring (CALM) system (fig 2.1.1-1) also provides a popular, inexpensive option for product transfer. The CALM buoy consists of two main structural components; a turret structure (red) moored to the ocean floor, and a buoy body (yellow) that rotates with the ship. The product lines attach to the stationary structure and mate with rotating discharge piping through a fluid swivel. The ship approaches the CALM buoy, extends its hawser (large diameter polyester or nylon mooring line) through the bow, and connects to the rotating portion of the buoy. A floating cargo transfer hose is attached to the loading manifold of the receiving tanker, and the tanker weathervanes freely during the transfer operation. There are several weathervaning designs employing CALM buoys of many configurations. Some are fitted to the bow (fig. 2.1.1-2), or to the underside of the moored vessel. FPSO's and FSO's usually employ attached buoys for more permanent operation.

\subsubsection{Transfer}

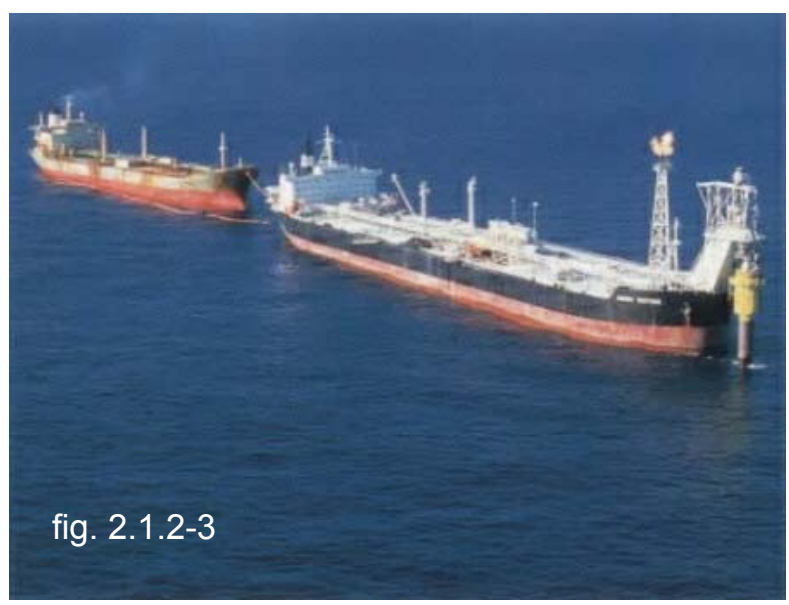

The transfer of oil from an offshore field and production facility employs several safe, reliable technologies that will be described in this section of the report. Understanding the methodologies used to transfer oil offshore is tantamount to the understanding of transferring LNG offshore. Many of the concepts and technology used to offload oil at sea could be applied to the transfer of LNG offshore. The following pictures and explanations will define the methods in current use beginning with the most popular option, tandem transfer (fig. 2.1.2-3).

Using the tandem transfer method, the receiving vessel approaches the stern of a moored storage vessel. A very strong hawser is attached to the stern of the moored tanker or storage facility while the approaching ship is still a safe distance away. A tugboat is then tied to the stern of the approaching vessel as the ships engines reverse thrust, pulling the two vessels apart. The hawser absorbs the strain and the vessels assume a relatively stable position in relation to each other. The ship's engine continuously pulling astern, maintains this relative position throughout the transfer operation.

The transfer of product from the mid-ship manifold of the offloading vessel to the mid-ship product manifold of the receiving tanker takes place through a large diameter floating hose capable of high oil transfer rates. After the receiving vessel is filled, air is used to blow back and purge the hose to the offloading tanker. The hose can then be disconnected and capped to prevent spillage.

The tug pulls the receiving vessel away for the offloading tanker as the hawser is loosened. The hawser is removed from the receiving vessel and the offloading vessel is made ready for the next receiving tanker. 


\begin{tabular}{|l|l|l|l|}
\hline Customer: & $\begin{array}{l}\text { The United States Department of Energy } \\
\text { National Energy Technology Laboratory }\end{array}$ & $\begin{array}{l}\text { Date of Issue: } \\
29 \text { April } 2003\end{array}$ & \\
\hline $\begin{array}{l}\text { Document } \\
\text { Title: }\end{array}$ & $\begin{array}{l}\text { Subtask 1.2 } \\
\text { Identify Marine Mooring and Offloading Initiatives for LNG Vessels }\end{array}$ & $\begin{array}{l}\text { Doc \# \& Version: } \\
\text { Doc } 003 \text { r4.0 }\end{array}$ & Page $\mathbf{6}$ of $\mathbf{4 0}$ \\
\hline
\end{tabular}

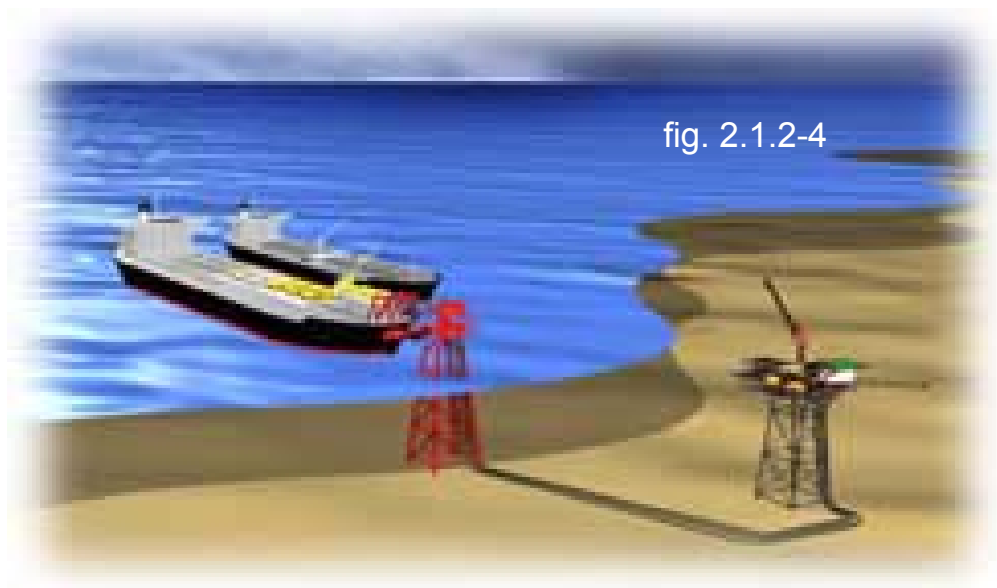

Its main advantages when compared to side-by-side offloading are: (1) Easier and safer berthing and mooring operation, (2) Higher availability, (3) Safer operation due to larger separation distance, (4) Quicker disconnection and sail-away, and (5) Robust mooring: no inadvertent breakaway risk

The side by side method of offloading is used from time to time in the offshore oil industry and is pictured in fig. 2.1.2-4. In this configuration, the receiving vessel approaches the side of the offloading tanker and is secured via polyester or nylon lines. A Yokohama fender, fig. 2.1.2-5, can be used to safely separate the two vessels. Cargo transfer takes place via loading arms, or more typically through flexible rubber hoses connecting the ships manifolds.

fig. 2.1.1-5

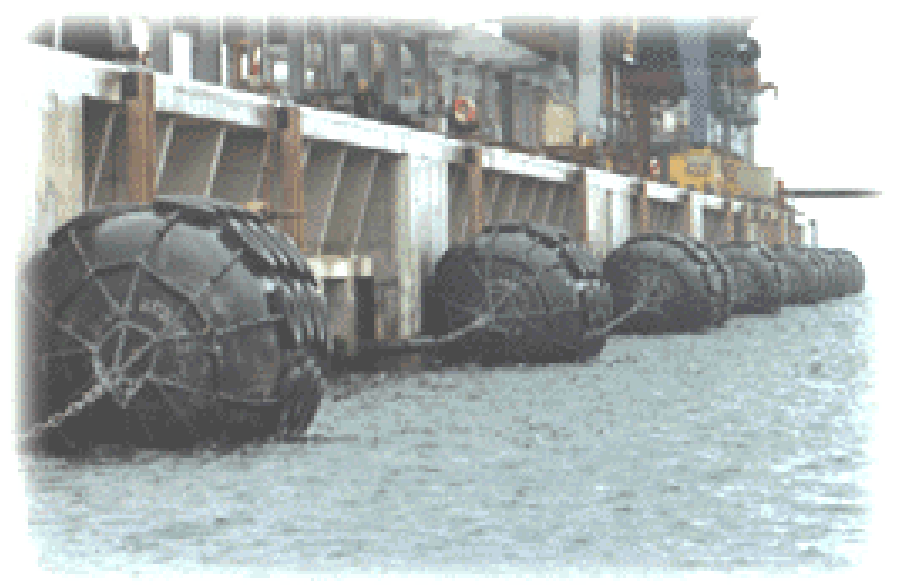

\subsection{History of Offshore Unloading}

\subsubsection{Oil}

FPSOs have been an integral part of the offshore oil industry since the late 1970's and have been used mainly in the North Sea, Brazil, Southeast Asia, and the China Sea. There are over 75 FPSO in current operation. Many are conversions (fig. 2.2.16 ) but, more and more, large scale offshore oil projects (e.g. Shell's Bonga Project with capacities of 200 thousand barrels of liquid per day) are specifying new-build FPSOs (fig. 2.2.1-7) for production at sea. The safety and reliability have been acceptable, and the technologies have been well proven over the years.

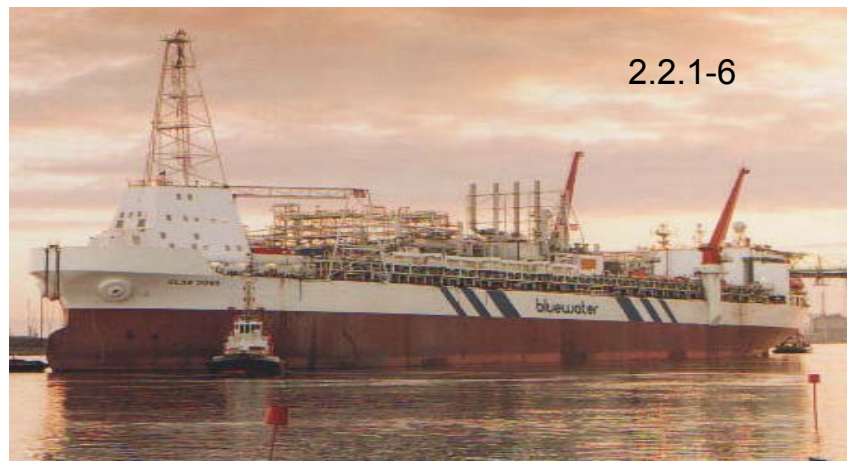




\begin{tabular}{|l|l|l|l|}
\hline Customer: & $\begin{array}{l}\text { The United States Department of Energy } \\
\text { National Energy Technology Laboratory }\end{array}$ & $\begin{array}{l}\text { Date of Issue: } \\
29 \text { April } 2003\end{array}$ & \\
\hline $\begin{array}{l}\text { Document } \\
\text { Title: }\end{array}$ & $\begin{array}{l}\text { Subtask 1.2 } \\
\text { Identify Marine Mooring and Offloading Initiatives for LNG Vessels }\end{array}$ & $\begin{array}{l}\text { Doc \# \& Version: } \\
\text { Doc } 003 \text { r4.0 }\end{array}$ & Page $\mathbf{7}$ of $\mathbf{4 0}$ \\
\hline
\end{tabular}

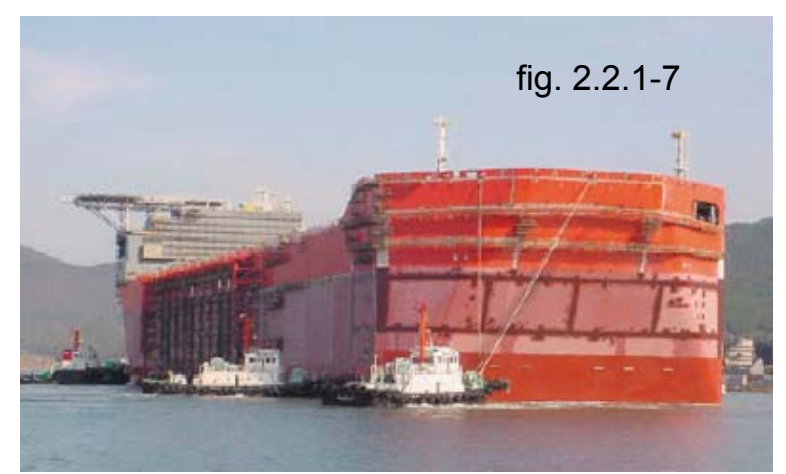

According to an INTEC Engineering study commissioned by DeepStar (a multiphase deepwater technology study currently funded by 16 oil companies and more than 40 contributing manufacturers, vendors, consulting organizations, classification organizations, and contractors), the largest spill from an FPSO occurred in the late 1990's approximately 3,900 barrels of oil were spilled from the Texaco Captain FPSO during startup at its field location.

The spill was attributed to human error during the start-up procedure; an overboard dump valve was inadvertently left open and hydrocarbons were released. Oil spills from all other FPSO operations have reportedly spilled less than 500 barrels of oil combined. FPSO's have been successfully operating for a cumulative 460 plus FPSOyears, processing an estimated 6.4 billion barrels of crude oil.

\subsubsection{Liquefied Petroleum Gas (LPG)}

Liquefied Petroleum Gases (e.g. propane and butane) are also transferred offshore. As of this time three dedicated LPG FSOs have been placed into service and another three are on order. Chevron Corporation built the first dedicated LPG FSO and placed it into service off the Nigerian coast in July of 1997. The Escravos (fig. 2.2.2-8) held 54,000 cubic meters of liquid and is 172 meters long. Quoting Mr. Dick Matzke of Chevron Overseas Petroleum, "The Escravos Gas Project is the boldest initiative to end gas flaring in Nigeria, and the NNPC embarked on this project because of its positive environmental ramifications as well as its economic benefits to Nigeria." (Author's note: the Nigerian Government has decided to end gas flaring by

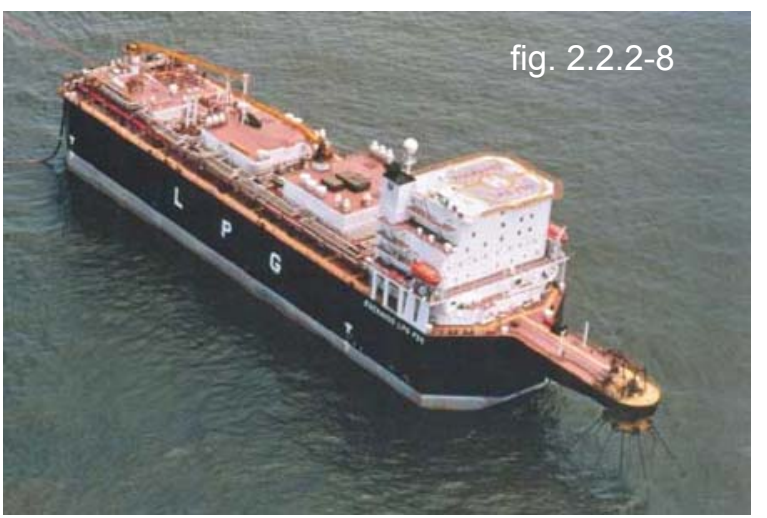
2005. This requirement will bring about an Atlantic Basin LNG supply "push." If the United States is ready with a sufficient number of LNG terminals and adequate storage, approximately 2 to 3 BCFD of the predicted 3 to 5 BCFD shortfall could be filled by this supply source.)

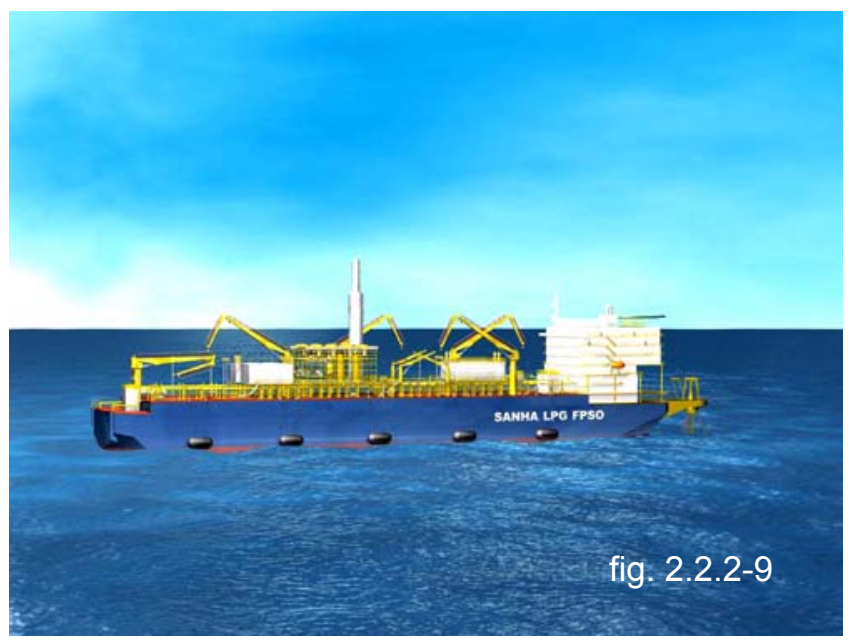

The American Bureau of Shipping (ABS) has played an active role in the qualification of LPG FSOs and the newly conceived LPG FPSO, the "Sanha." The "Sanha," slated for operation on the Sanha Field in Angola's Block 0 , is the world's first new-build LPG FPSO. The vessel, will have the largest hull of any LPG FPSO ever built and will have a production capacity of $211,880 \mathrm{cf} / \mathrm{d}$ and storage capacity of 4.7 million cf. The Sanha (fig. 2.2.2-9) will include LPG storage tanks and LPG production plants such as gas separators, gas refrigerators, and boil-off gas reliquefaction units on the upper deck or topsides.

Unlike LNG, which is primarily methane that must be stored at extremely low temperatures $\left(-260^{\circ} \mathrm{F}\right)$, LPG is primarily propane, which can be stored at a much 


\begin{tabular}{|l|l|l|l|}
\hline Customer: & $\begin{array}{l}\text { The United States Department of Energy } \\
\text { National Energy Technology Laboratory }\end{array}$ & $\begin{array}{l}\text { Date of Issue: } \\
29 \text { April } 2003\end{array}$ & \\
\hline $\begin{array}{l}\text { Document } \\
\text { Title: }\end{array}$ & $\begin{array}{l}\text { Subtask 1.2 } \\
\text { Identify Marine Mooring and Offloading Initiatives for LNG Vessels }\end{array}$ & $\begin{array}{l}\text { Doc \# \& Version: } \\
\text { Doc } 003 \text { r4.0 }\end{array}$ & Page $\mathbf{8}$ of $\mathbf{4 0}$ \\
\hline
\end{tabular}

higher or warmer temperature $\left(-56^{\circ} \mathrm{F}\right)$. Although the main gas compound is different, the key issues for safe storage and transportation for both gases in the liquefied form are storage temperature and the gas containment system. The ABS has been selected as the classification society of record, and no doubt plans to use the experience gained with the LPG FPSO to qualify offshore LNG units in the future.

In addition to the efforts of the classification societies to promote the safe transfer of liquefied gases from ship to ship, the International Chamber of Shipping (ICS), the Oil Companies International Marine Forum (OCIMF), and the Society of International Gas Tanker and Terminal Operators (SIGTTO) published the first "Ship to Ship Transfer Guide (Liquefied Gases)" in 1980. The guide covers ship to ship (STS) transfer operations of liquefied petroleum gases (LPG). Primarily, it is intended to familiarize masters and ship operators with the general principles involved.

Updated in 1995, the guide has become a reference for industry standard practice. Quoting from the opening section of the 1995 edition, "The STS (ship to ship) transfer of LPG cargoes has become a common practice. Experience gained from these regular operations has proved that STS transfer operations can be safe, given compliance with satisfactory procedures and suitable weather and sea conditions." The LNG industry is sure to follow.

\subsubsection{Overview Summary}

The above brief review of the storage and loading history of the offshore oil industry indicates that the technologies are successful, reliable, safe, and well understood. While LPG temperatures don't approach the process temperatures of LNG, the classification societies realize that the key issues involving safety and containment have already been solved by the tank and shipping vendors. The industry has reason to believe that the experience gained over the last 25 years can be applied to the offloading of LNG offshore described in the next section.

\section{PROPOSED LNG OFFSHORE TRANSFER TECHNOLOGIES}

\subsection{Scope, Concepts, and Definitions}

There are numerous offshore LNG transfer and receiving facility designs in various stages of development. This section will identify all known candidates as of the first quarter of 2003 . The designs will be categorized according to type, either weathervaning or fixed; side or tandem loading, and applicable operational sea states will be assigned. Each design will be pictured and briefly described in this section of the document. There will be no attempt to qualify the LNG transfer design based on LNG process (e.g. liquefaction or regasification) as the overriding emphasis of this study is concerned with the development of the transfer technology only. The attachment to this document will summarize all designs in a matrix lending itself to evaluation and quick reference.

Tandem and side by side cargo transfer have been discussed. The concept of spread mooring and weathervaning must now be addressed. The spread moored vessel (graphical representation fig. 3.3.1-18) is attached via its onboard mooring lines to a system of buoys securely buried in the sea floor in patterned arrangements designed to fit the ship. A massive chain (or chains) attached to each buoy is raised to the surface and connected to a large buoyant device for easy handling. As the vessel approaches the mooring location, the ships crew passes a mooing line to the line handlers who (in a small boat) attach the mooring line to each mooring chain. All mooring lines are attached in turn, each line winched aboard, and the vessel assumes its secure location in the middle of the mooring arrangement. 


\begin{tabular}{|l|l|l|l|}
\hline Customer: & $\begin{array}{l}\text { The United States Department of Energy } \\
\text { National Energy Technology Laboratory }\end{array}$ & $\begin{array}{l}\text { Date of Issue: } \\
29 \text { April } 2003\end{array}$ & \\
\hline $\begin{array}{l}\text { Document } \\
\text { Title: }\end{array}$ & $\begin{array}{l}\text { Subtask 1.2 } \\
\text { Identify Marine Mooring and Offloading Initiatives for LNG Vessels }\end{array}$ & $\begin{array}{l}\text { Doc \# \& Version: } \\
\text { Doc } 003 \text { r..0 }\end{array}$ & Page $\mathbf{9}$ of $\mathbf{4 0}$ \\
\hline
\end{tabular}

In principle, the ship's motions and the size of the mooring infrastructure will be minimized when the mooring allows the vessel to face into the environmental conditions, bow first, or "head-up" In calm or benign site conditions the vessel can be maintained head-up moored to a conventional loading dock, or spread moored as described above. Mooring the ship to a weathervaning offshore mooring sometimes known as a single point mooring or (SPM) as described in section 2.1.1 ensures that no matter what wind and current conditions exist, the ship always seeks a point of minimum motion. The following diagrams depict the various mooring motions that a weathervaning tanker might experience depending of course on the design of the mooring facility. In fig. 3.1-10, the ship rotates around a vertical axis ahead of the bow which tends to optimize mooring design.

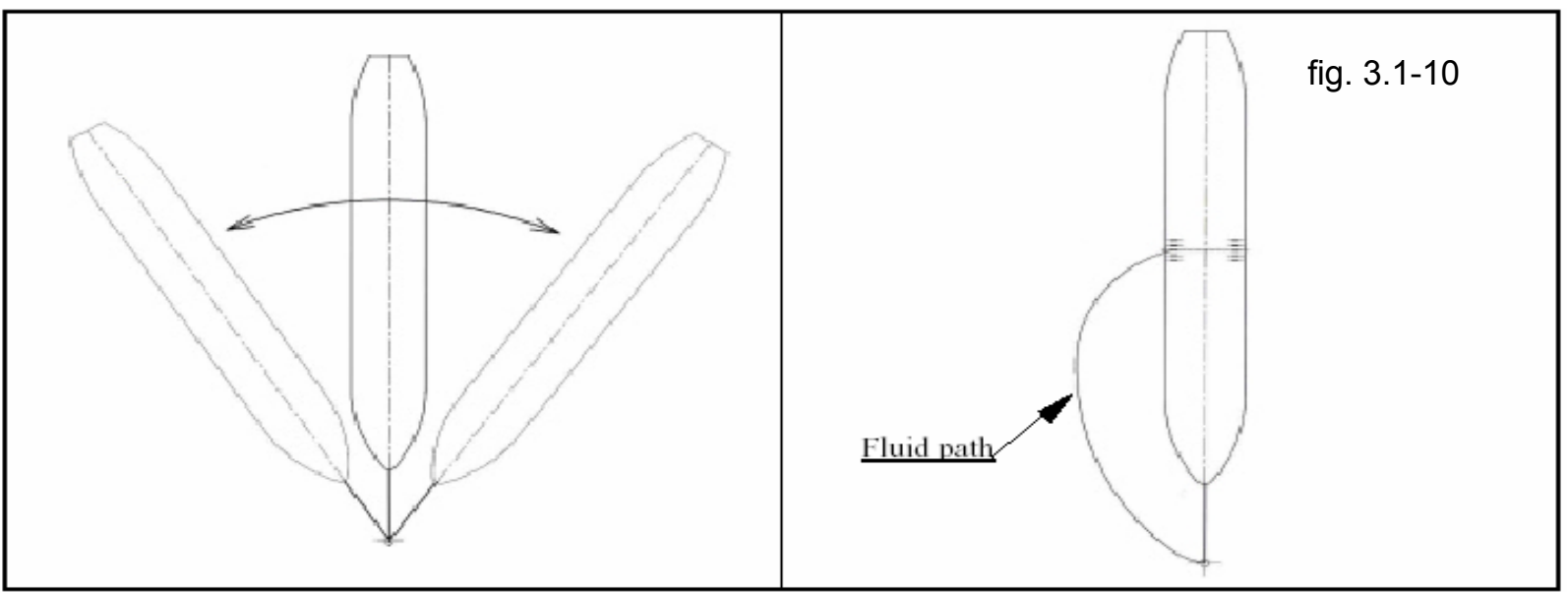

In figure 3.1-11, the rotation is close to the manifold which tends to optimize the transfer system piping and better accommodate side by side transfer.

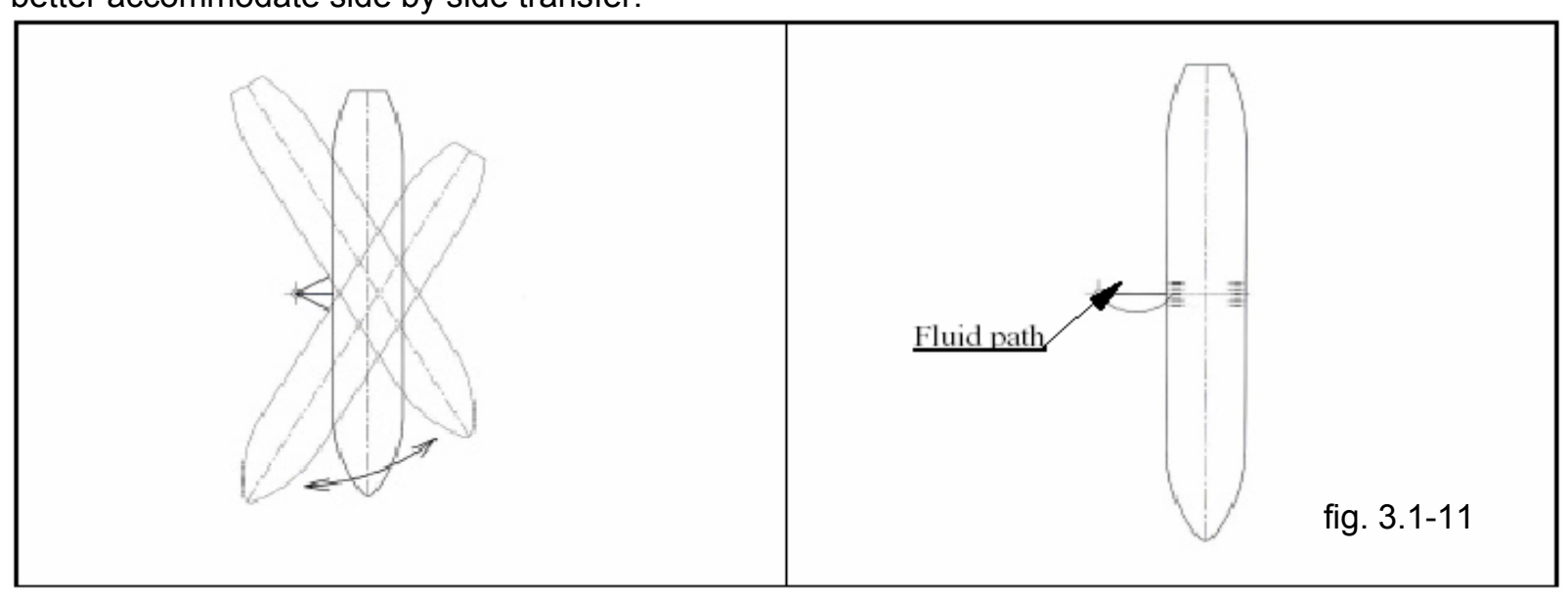

\subsubsection{Site Conditions Defined}

The following table defines site conditions in terms of severity and will be used throughout this report to quantify and rate the offshore mooring designs. 


\begin{tabular}{|l|l|l|l|}
\hline Customer: & $\begin{array}{l}\text { The United States Department of Energy } \\
\text { National Energy Technology Laboratory }\end{array}$ & $\begin{array}{l}\text { Date of Issue: } \\
29 \text { April } 2003\end{array}$ & \\
\hline $\begin{array}{l}\text { Document } \\
\text { Title: }\end{array}$ & $\begin{array}{l}\text { Subtask 1.2 } \\
\text { Identify Marine Mooring and Offloading Initiatives for LNG Vessels }\end{array}$ & $\begin{array}{l}\text { Doc \# \& Version: } \\
\text { Doc } 003 \text { r4.0 }\end{array}$ & Page $\mathbf{1 0}$ of $\mathbf{4 0}$ \\
\hline
\end{tabular}

\begin{tabular}{|c|c|c|c|}
\hline Design Description & $\begin{array}{c}\text { Wave } \\
\text { Hs }\end{array}$ & $\begin{array}{c}\text { Wind } \\
\text { Avg. speed / Peak speed }\end{array}$ & Current \\
\hline Benign & 1.5 to $2.0 \mathrm{~m}$ & $20 \mathrm{~m} / \mathrm{s} \mathrm{to} 30 \mathrm{~m} / \mathrm{s}$ & 0.5 to $1.5 \mathrm{knot}$ \\
\hline Moderate & 2.0 to $4.0 \mathrm{~m}$ & $30 \mathrm{~m} / \mathrm{s} / 36.5 \mathrm{~m} / \mathrm{s}$ & 1.5 to 2.0 \\
\hline Severe & over 4.0 & $30 \mathrm{~m} / \mathrm{s} 36.5 \mathrm{~m} / \mathrm{s}$ & 2.0 or over \\
\hline
\end{tabular}

Note: At approximately 2.0 to 2.5 meters $\mathrm{Hs}$, the mooring tug boats start to lose thrust and control as the propeller "breaks" the water during heavy swell.

\subsection{Offshore LNG Designs}

Traditional LNG import terminals all have a protected berthing environment for the LNG carriers, to enable them to berth and moor safely, and to minimize the motions during LNG offloading. The standard jetty LNG offloading arms have a limited reach, and are equipped with quick disconnect and emergency release couplers, to prevent damage of the ship's manifold or to the loading arms in case of an unexpected drifting of the LNG carrier, e.g. due to a broken mooring line. Depending on the local environmental conditions, the offloading jetties may require protection from rough seas by a breakwater. Sometimes dredging is necessary to allow the ships to berth and adds additional expense.

More and more, the industry is looking for alternative solutions, to keep the LNG carriers away from the shoreline, for various reasons: port authority concerns, permitting issues, public opposition, environmental and safety concerns, and recently also security concerns. Equally attractive is the possibility of an offshore LNG import terminal potentially saving money, if a long trestle, breakwater, and dredging could be avoided. These arguments also apply to LNG export terminals, although those locations are generally in more benign areas.

\subsubsection{Floating Barge Designs}

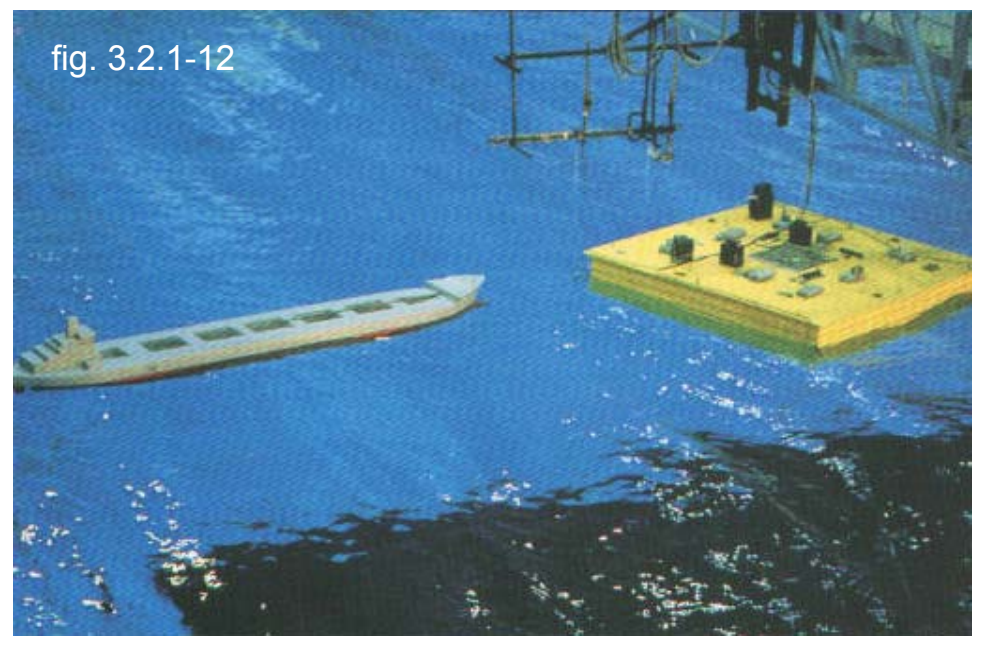

Several iterations of the floating barge have been conceptually designed over the years. The fig. 3.2.1-12 represents the former Mobil Oil venture into the LNG offshore liquefaction market. Most of the current designs are based on barges of ship shape design. These floating designs are capable of liquefaction or regasification and share the same mooring and transfer concerns with their counterparts mentioned later in this section. 


\begin{tabular}{|l|l|l|l|}
\hline Customer: & $\begin{array}{l}\text { The United States Department of Energy } \\
\text { National Energy Technology Laboratory }\end{array}$ & $\begin{array}{l}\text { Date of Issue: } \\
29 \text { April } 2003\end{array}$ & \\
\hline $\begin{array}{l}\text { Document } \\
\text { Title: }\end{array}$ & $\begin{array}{l}\text { Subtask 1.2 } \\
\text { Identify Marine Mooring and Offloading Initiatives for LNG Vessels }\end{array}$ & $\begin{array}{l}\text { Doc \# \& Version: } \\
\text { Doc } 003 \text { r. }\end{array}$ & Page 11 of 40 \\
\hline
\end{tabular}

\subsubsection{Gravity Based Structures}

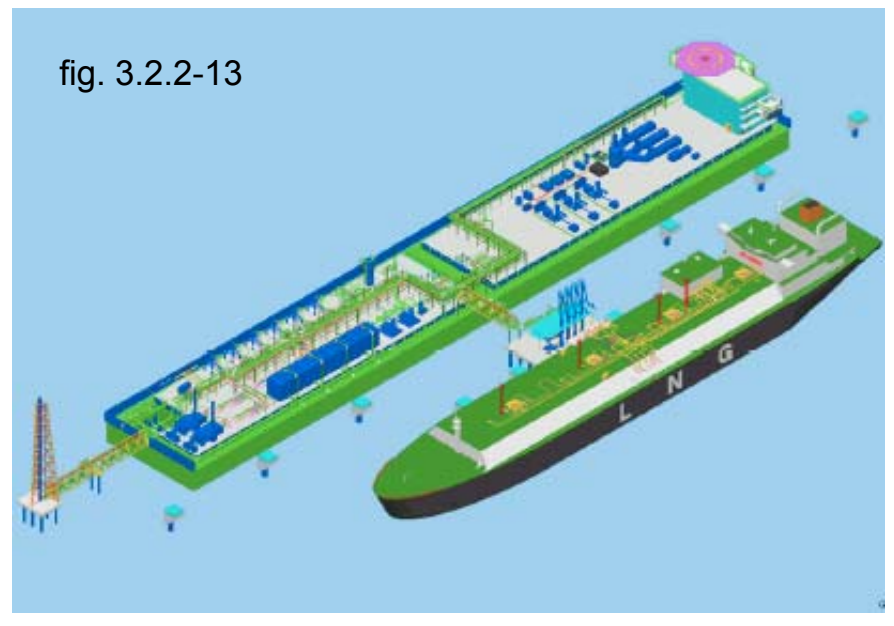

Gravity Based Structures (GBS) fig. 3.2.2-13 are gaining popularity due to storage capacity, space, ability to withstand wind/wave conditions, and protection for the moored LNG tanker. Gravity based structures differ from all other offshore designs in that they are not floating hulls. Rather the gravity based structure is an extremely large prestressed concrete hull that rests on the ocean floor. The bottom soil conditions and bathymetry must be

well known and suited to support the weight of the large structure without settling. Gravity based structures like their large floating counterparts include the LNG containment system in the lower hull, but due to costs and structural limits are restricted to water depths of about 75 meters or under. The process machinery is

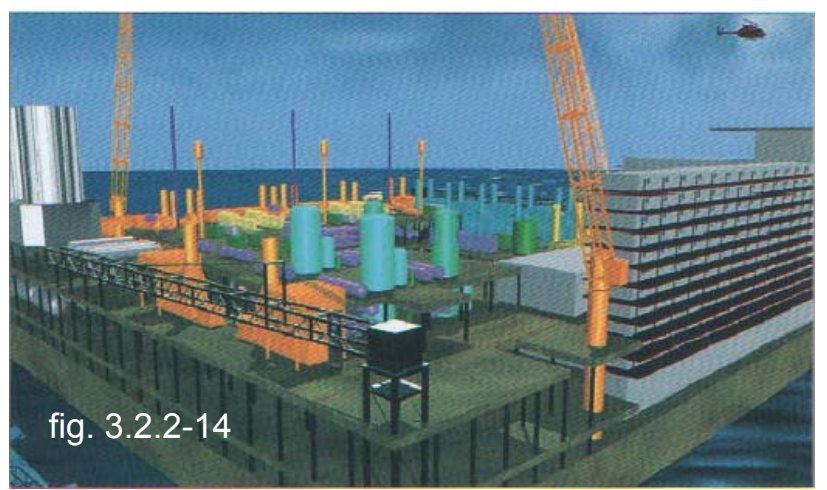
located on the upper deck as seen in figure 3.2.2-14.

\subsection{Offshore Designs by Company}

\subsubsection{SBM}

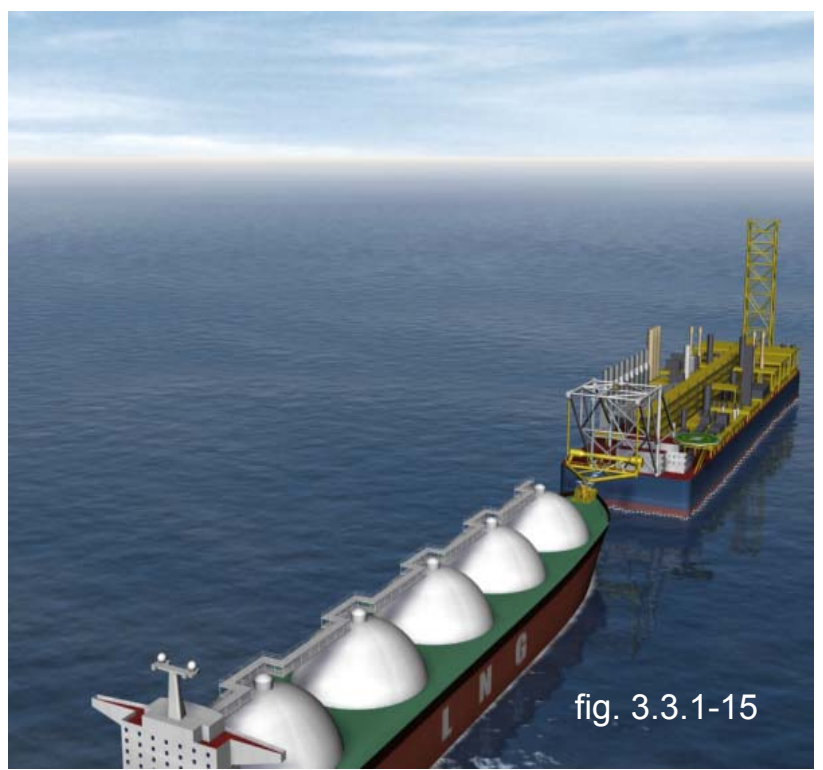

SBM, a leader for more than 40 years in the supply of offshore oil terminals, has more than 360 units installed worldwide as of today. In the more recent past SBM has developed several components namely a cryogenic swivel and offloading arm critical for the implementation of LNG transfer. Under the increasing demand from major oil companies involved in the "LNG Chain", such developments have been further advanced in the last few years in the form of engineering studies and proof of concept testing. The concepts submitted herewith integrate the result of these developments and engineering studies.

Industry requests prompted SBM to develop a singlepoint mooring (SPM) LNG Import/Export Terminal, that allows the transfer of LNG from/to LNG Carriers (LNGCs) in severe environmental conditions, i.e. in open sea, well away from the coast line fig. 3.3.1-15. The LNG can either be transferred to/from shore directly using a cryogenic LNG Subsea Pipeline, or in case of an Import terminal, it could be regasified on the 


\begin{tabular}{|l|l|l|l|}
\hline Customer: & $\begin{array}{l}\text { The United States Department of Energy } \\
\text { National Energy Technology Laboratory }\end{array}$ & $\begin{array}{l}\text { Date of Issue: } \\
29 \text { April } 2003\end{array}$ & \\
\hline $\begin{array}{l}\text { Document } \\
\text { Title: }\end{array}$ & $\begin{array}{l}\text { Subtask 1.2 } \\
\text { Identify Marine Mooring and Offloading Initiatives for LNG Vessels }\end{array}$ & $\begin{array}{l}\text { Doc \# \& Version: } \\
\text { Doc } 003 \text { r4.0 }\end{array}$ & Page $\mathbf{1 2}$ of $\mathbf{4 0}$ \\
\hline
\end{tabular}

SPM tower, and piped directly to a subsea gas pipeline network fig 3.3.1-16. SBM has also model tested a disconnectable RTM (riser turret moored) LNG vessel capable of 1.0 BCFD regasification onboard.

The SPM LNG Import/Export Terminal concept relies on the combination of conventional technologies, (1) mooring an LNGC to a fixed Jacket structure through a Soft Yoke. This station keeping concept has been applied successfully on six previous SBM installations, and (2) transferring the LNG fluid through hard piped LNG offloading arms with swivels and fluid connectors. Similar technology is used on conventional jetties for LNG offloading.

Figures 3.3.1-15 and 16 illustrate SBM's conceptual design. The vessel is moored using a special connection affixed to the bow, and the LNG transfer takes place in piping and swivels independent of the mooring loads. The system is design for rapid connection and disconnection in case an emergency departure is required. SBM states that the offshore

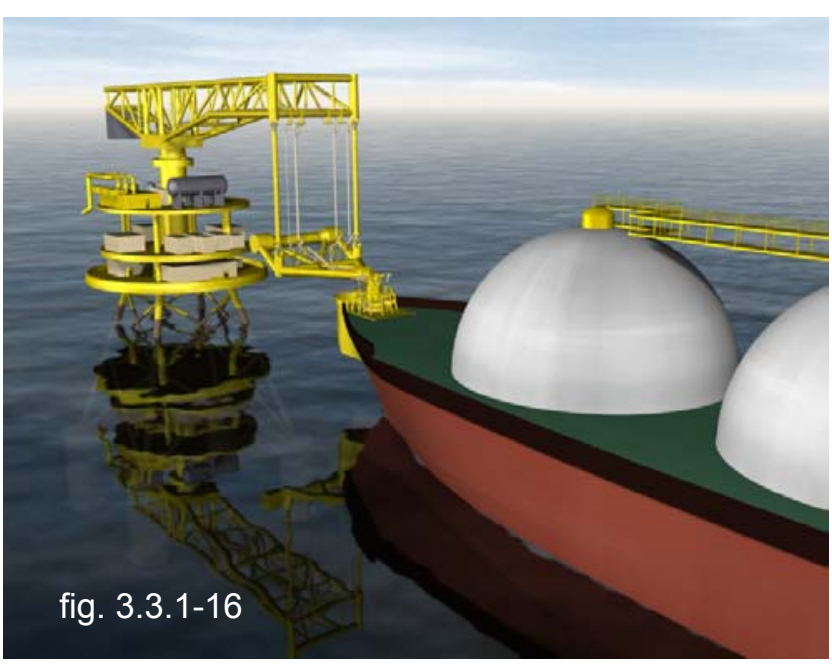
mooring system pictured can accommodate vessel connection in seas of 2.5 meters Hs with disconnection required in seas of 3.0 meters Hs or above. However, a more robust system can be designed for severe weather sites. The tandem connected, weathervaning system is capable of LNG transfer in severe weather conditions with seas exceeding 5 meters.

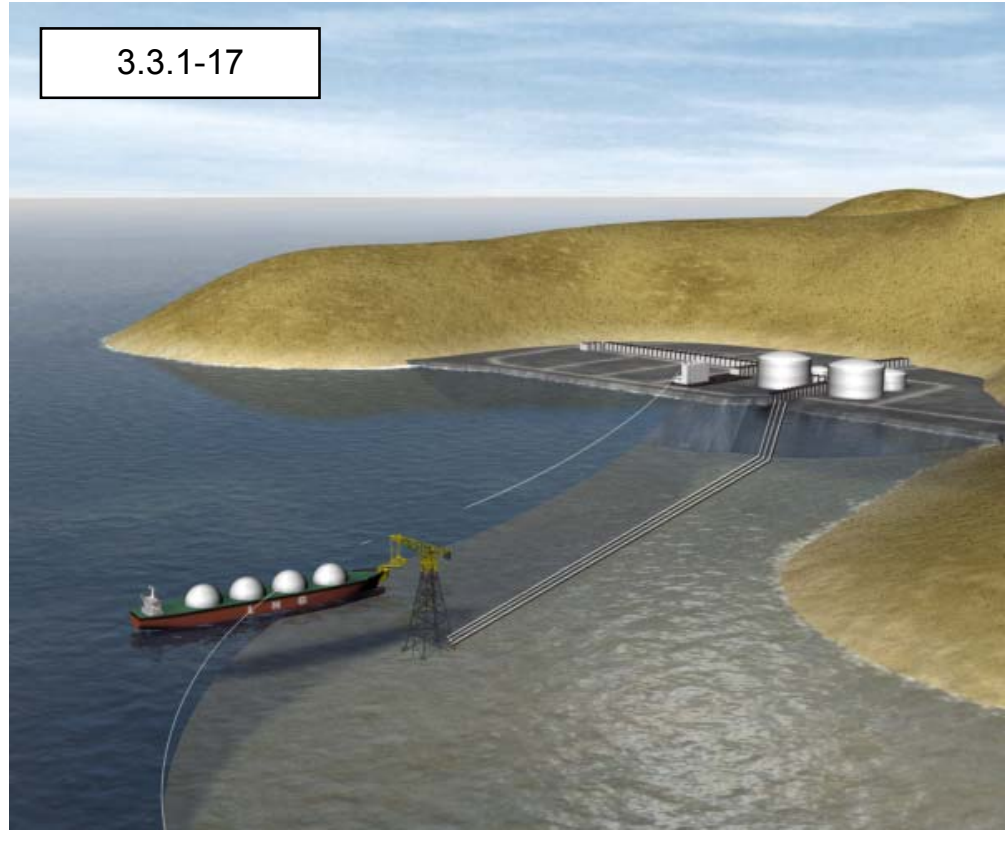

LNG Import/Export Terminal with Onshore LNG Storage

Awaiting the commercialization of cryogenic subsea pipelines, the offshore LNG loading terminal using the Single Yoke Mooring Offshore (SYMO) (fig. 3.3.117) could revolutionize LNG terminal operations the same way the Single Point Mooring (SPM) revolutionized crude oil loading operations. With a weathervaning LNG carrier moored to an SPM tower, LNG import or export terminals no longer need high-cost (port, breakwater) and maintenance intensive (dredging) marine facilities.

Conventional Buoy Mooring (CBM) with midship Loading Tower

In relatively benign conditions bow offloading may not be necessary, making it possible to use standard carriers. 


\begin{tabular}{|l|l|l|l|}
\hline Customer: & $\begin{array}{l}\text { The United States Department of Energy } \\
\text { National Energy Technology Laboratory }\end{array}$ & $\begin{array}{l}\text { Date of Issue: } \\
29 \text { April } 2003\end{array}$ & \\
\hline $\begin{array}{l}\text { Document } \\
\text { Title: }\end{array}$ & $\begin{array}{l}\text { Subtask 1.2 } \\
\text { Identify Marine Mooring and Offloading Initiatives for LNG Vessels }\end{array}$ & $\begin{array}{l}\text { Doc \# \& Version: } \\
\text { Doc } 003 \text { r4.0 }\end{array}$ & Page 13 of $\mathbf{4 0}$ \\
\hline
\end{tabular}

A solution is the use of a fixed tower with a rotating boom, which connects to a spread-moored carrier via the midship manifold, below.

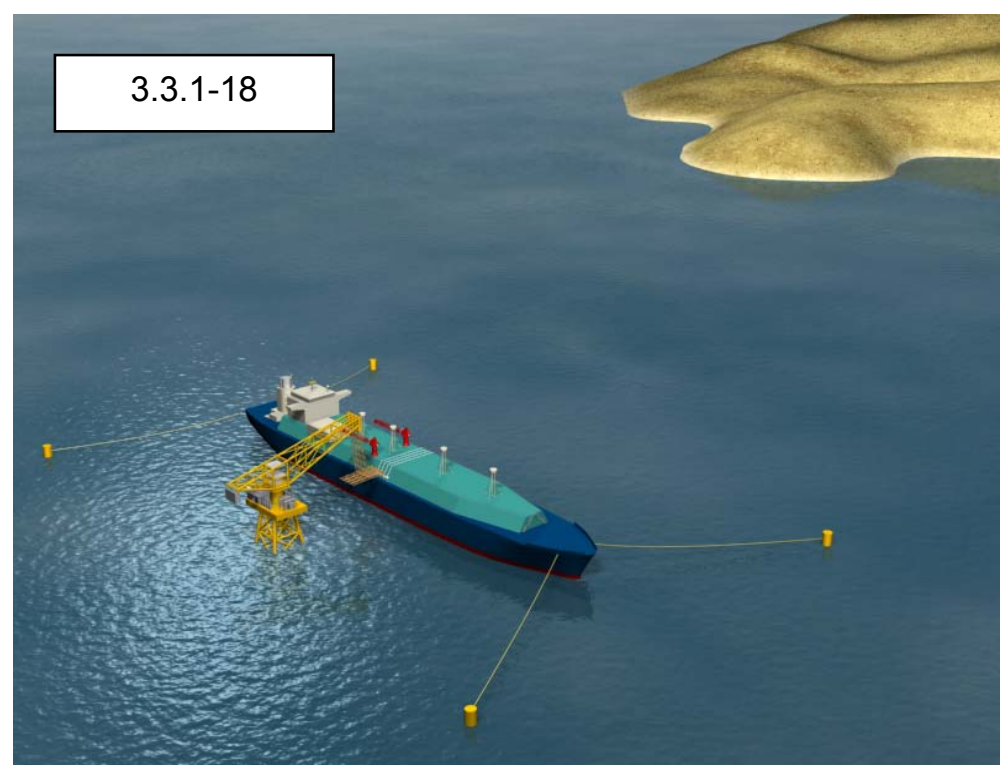

In benign environmental conditions, a Conventional Buoy Mooring (CBM) can be used to hold the carrier in position during the offloading operations.

\subsubsection{Bluewater Offshore Group}

Given that both production and import of LNG will move more and more offshore, Bluewater recognized a need for a safe, efficient and reliable transfer system. Since there is a wide variance in water depth and environmental conditions between the potential sites, a whole suite of concepts has been developed to serve each application's specifics (fig 3.3.2-19) on the following page.

All concepts share a common philosophy:

1. High System Availability. The investments made in the LNG production and transport chain are large, and so are the costs associated with downtime of LNG production and / or demurrage of the carriers. High system availability is achieved by using weathervaning mooring systems, and a robust flow path and a minimum number of cryogenic mechanical components. All concepts are based upon proven components.

2. Suitability for Non-Dedicated Vessels. The current market trend indicates that a spot market for LNG is developing. To allow flexible and efficient operation of the terminal facilities, it is essential that vessels of opportunity can be handled. Transfer of LNG in all systems takes place at the midship manifold and minimum adaptation of the LNG carrier is required.

The advantages of an LNG offshore terminal include:

- the lower costs for construction and operation

- the possibility to locate the terminal in deeper water thereby eliminating the need for dredging

- increased availability, safety and reduced voyage time as LNG carriers need not enter and maneuver in congested waters. 


\begin{tabular}{|l|l|l|l|}
\hline Customer: & $\begin{array}{l}\text { The United States Department of Energy } \\
\text { National Energy Technology Laboratory }\end{array}$ & $\begin{array}{l}\text { Date of Issue: } \\
29 \text { April } 2003\end{array}$ & \\
\hline $\begin{array}{l}\text { Document } \\
\text { Title: }\end{array}$ & $\begin{array}{l}\text { Subtask 1.2 } \\
\text { Identify Marine Mooring and Offloading Initiatives for LNG Vessels }\end{array}$ & $\begin{array}{l}\text { Doc \# \& Version: } \\
\text { Doc } 003 \text { r4.0 }\end{array}$ & Page 14 of 40 \\
\hline
\end{tabular}

fig. 3.3.2-19 LNG Transfer Offshore

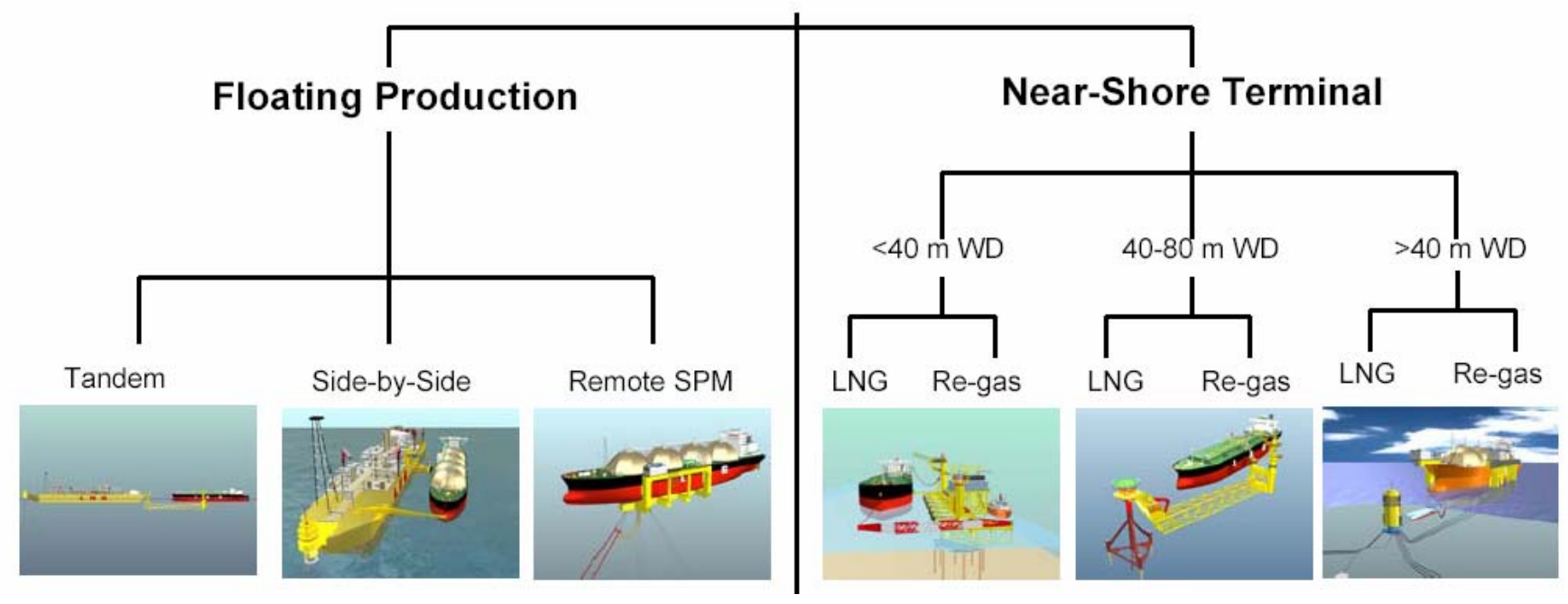

Bluewater Offshore Group has developed a series of concepts for LNG terminals based on the premise of safe transfer of LNG offshore to and from non-dedicated tankers in wave heights of up to $\mathrm{H}_{\mathrm{s}}=5.0 \mathrm{~m}$ and flow rates of up to $10,000 \mathrm{~m}_{3} / \mathrm{hr}$. Three near shore concepts were developed. The term near shore does not necessarily indicate a distance from the shore line, rather it refers to the shallower water depths closer to land. These near shore designs can be located in water depths from 15 up to 100 meters

Medium Waterdepth Terminal. This concept, dubbed 'Big Sweep' consists of three basic elements; see figure 3.3.2-20 on the following page.

- A jacket structure with turntable, anchored to the seabed

- A submerged rigid arm, hinged at one end to the jacket turntable and terminating at its other end with a buoyant column, and

- The LNG loading and transfer structure, located on top of the buoyant column.

To allow the vessel and arm to passively 'weathervane' into the most favourable direction with respect to the environment, the turntable is connected to the jacket structure by means of a bearing. This allows the turntable to rotate $360^{\circ}$ with respect to the jacket. The turntable supports the rigid arm hinges, the cryogenic fluid swivels and the hawser attachment point. 


\begin{tabular}{|l|l|l|l|}
\hline Customer: & $\begin{array}{l}\text { The United States Department of Energy } \\
\text { National Energy Technology Laboratory }\end{array}$ & $\begin{array}{l}\text { Date of Issue: } \\
29 \text { April } 2003\end{array}$ & \\
\hline $\begin{array}{l}\text { Document } \\
\text { Title: }\end{array}$ & $\begin{array}{l}\text { Subtask 1.2 } \\
\text { Identify Marine Mooring and Offloading Initiatives for LNG Vessels }\end{array}$ & $\begin{array}{l}\text { Doc \# \& Version: } \\
\text { Doc } 003 \text { r4.0 }\end{array}$ & Page 15 of 40 \\
\hline
\end{tabular}
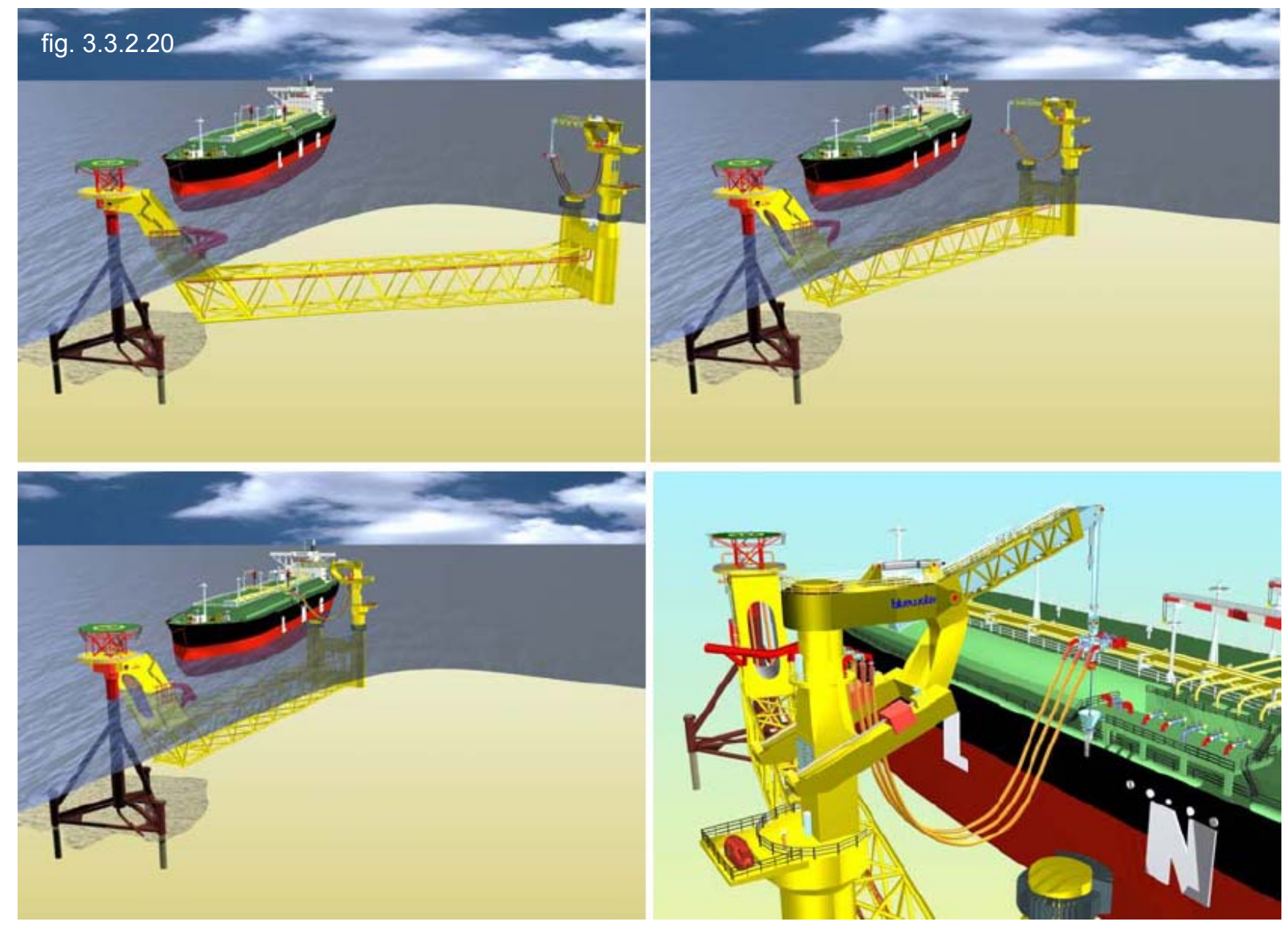

The overall length of the rigid arm is such that the buoyant column is positioned nominally near the midship cargo manifold of the LNG carrier. By adjusting the length of the mooring hawser the carrier's cargo manifold can be lined up to the offloading station for vessel sizes ranging from large to very large gas carriers.

The buoyant hull is equipped with a thruster system to swing the arm in a safe position during approach of the vessel and in-line with the vessel in the operational mode. A water ballast tank allows draft adjustment of the loading arm to match tanker size and / or drafts. The standard fluid transfer system consists essentially of 3 Pipe-in-Pipe (PIP) lines. Two lines are dedicated to LNG; either in full flow mode or re-circulation mode. The third line is dedicated for vapour return. The flow paths cross the weathervaning and pitch hinges between the jacket and the rigid arm. This is achieved with swivels and full metal jumpers which can be easily inspected and serviced.

The loading arm is normally trailing the jacket but can be temporarily 'parked' away from the LNG carrier line of approach, with its own propulsion. In this position the entire loading arm assembly cannot be damaged by a failed mooring approach of the export carrier tanker. Note that offshore tanker mooring to SPM systems is standard marine practice and that a failed approach run very rarely happens. Should the carrier 'brush' against the terminal, this will be a 'low energy' collision which can be accommodated by the cushioning fender system. 


\begin{tabular}{|l|l|l|l|}
\hline Customer: & $\begin{array}{l}\text { The United States Department of Energy } \\
\text { National Energy Technology Laboratory }\end{array}$ & $\begin{array}{l}\text { Date of Issue: } \\
29 \text { April } 2003\end{array}$ & \\
\hline $\begin{array}{l}\text { Document } \\
\text { Title: }\end{array}$ & $\begin{array}{l}\text { Subtask 1.2 } \\
\text { Identify Marine Mooring and Offloading Initiatives for LNG Vessels }\end{array}$ & $\begin{array}{l}\text { Doc \# \& Version: } \\
\text { Doc } 003 \text { r4.0 }\end{array}$ & Page 16 of 40 \\
\hline
\end{tabular}

The LNG carrier moors in tandem with the turntable and once it has secured itself safely and the overall alignment is stable, the loading arm will be deployed from its parked position toward the vessel's manifold. The hose deployment and loading operation may now be initiated. After completion of the transfer operations all of the steps discussed above are done in reverse order.

Shallow Water depth Terminal. Developed from the 'Big Sweep' system, this unit shown in fig. 3.3.2-21 is designed to operate in water depths below $40 \mathrm{~m}$. It allows direct offshore-to-shore transfer of LNG, at rates up to $10,000 \mathrm{~m} 3 / \mathrm{hr}$ from non-dedicated vessels.

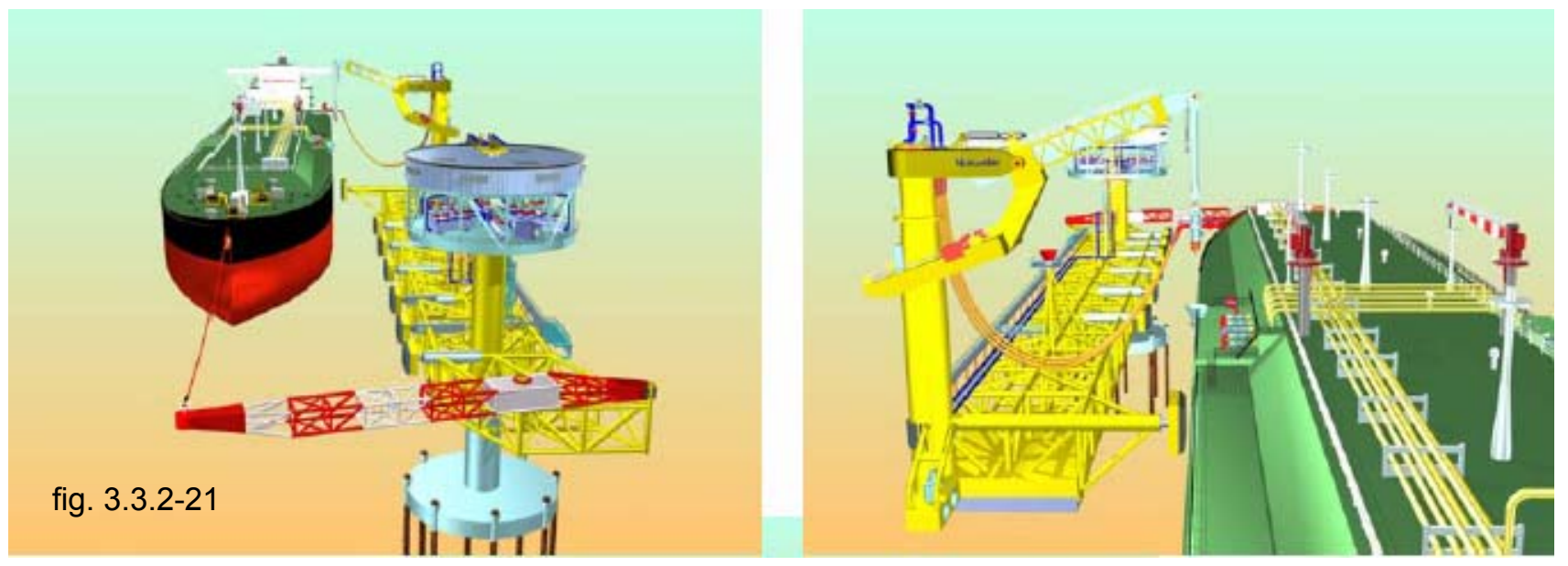

Motion characteristics are such that offloading can proceed up to significant wave heights of $3 \mathrm{~m}$, depending on the water depth, which may be as little as 15 metres. For extreme survival conditions such as in the Gulf of Mexico, the free-end of the unit is water-ballasted and set temporarily on the seabed. With dynamic positioning (DP) capability the unit would track the movement of the LNG carrier manifold when loading or unloading LNG. DP would also allow the unit to move out of the way when the LNG carrier is mooring itself to the turntable on the jacket, thereby avoiding marine hazards. Re-gasification equipment may be located on the unit for applications without LNG storage e.g. where gas is stored in salt caverns or delivered directly to the shore gas grid.

Offshore Re-Gasification Dock. The concept of a floating dock is not new, however in combination with a reduced displacement and connected to a Single Point Mooring (SPM) system, and also fitted with a simple but redundant Dynamic Positioning (DP) system, it becomes a powerful tool to:

- Berth standard LNG vessels offshore

- Enable unloading LNG through standard marine loading arms

- Allow transfer operation to continue in conditions up to $4 \mathrm{~m}$ significant wave height

- Provide a stable platform for a re-gasification plant

- Allow disconnection from its anchor legs for dry docking for campaign maintenance

The Offshore Regasification Dock also lends itself to remote deepwater locations where floating production and storage facilities may be required.

In essence the concept is based on mooring permanently a partly submerged dock, through an articulated rigid arm to a catenary anchor leg buoy, see figure 3.3.2-22. The articulated rigid arm has been selected because it allows the dock to take up a position of sway and yaw relative to the buoy, when seen from above. Since the concept is based on having transverse propulsion means integrated in the dock, it is quite clear that 


\begin{tabular}{|l|l|l|l|}
\hline Customer: & $\begin{array}{l}\text { The United States Department of Energy } \\
\text { National Energy Technology Laboratory }\end{array}$ & $\begin{array}{l}\text { Date of Issue: } \\
29 \text { April } 2003\end{array}$ & \\
\hline $\begin{array}{l}\text { Document } \\
\text { Title: }\end{array}$ & $\begin{array}{l}\text { Subtask 1.2 } \\
\text { Identify Marine Mooring and Offloading Initiatives for LNG Vessels }\end{array}$ & $\begin{array}{l}\text { Doc \# \& Version: } \\
\text { Doc } 003 \text { r4.0 }\end{array}$ & Page $\mathbf{1 7}$ of $\mathbf{4 0}$ \\
\hline
\end{tabular}

with an LNG vessel mooring on the hawser messenger wire of the SPM and inching itself up to the buoy, the dock is now able to fully track the path the LNG vessel will follow, including yaw and sway.
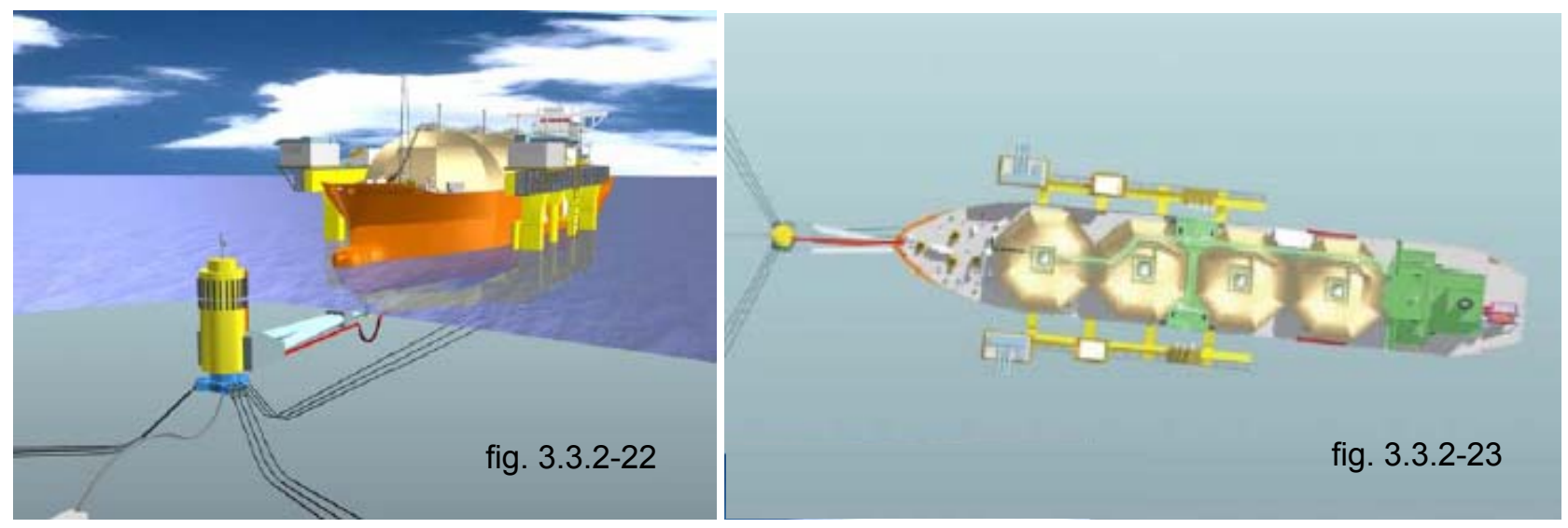

Hence the dock can simply maintain sideway clearance with the LNG vessel until it surfaces to contact the underside of the hull once it has completed its approach, see fig. 3.3.2-23.

The amount of contact force is a function of operating environmental parameters and will be of such

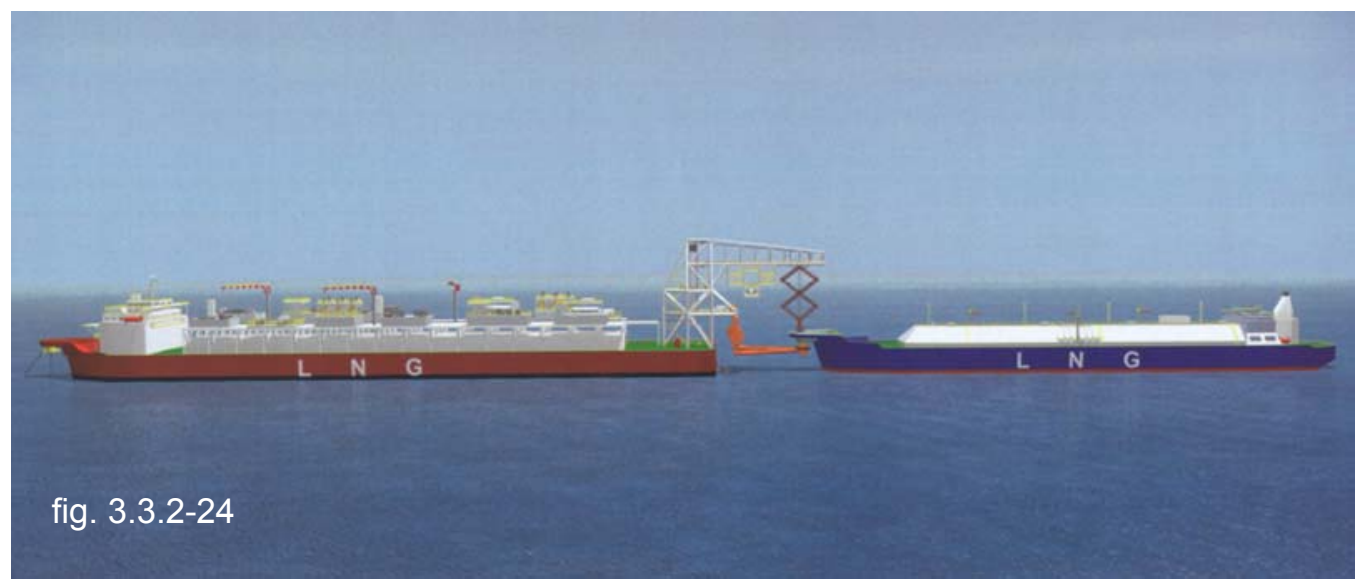
magnitude that no relative motions occur between vessel and dock. At all times contact forces are modest and can be easily accepted by the vessel. Effectively, the vessel is now fixed to the SPM through friction only. This design has major

the use of traditional loading arms is feasible over a wide range of weather conditions. advantages in that

\subsubsection{FMCSofec}

FMC the industry leader in the development and sales of cryogenic loading arms and swivels has established a new technology company with Sofec a manufacture of offshore terminal systems, to develop a generation of tandem LNG offshore offloading facilities. FMC Energy Systems has combined these two industry proven technologies to create a safe, reliable, tandem LNG loading/offloading system. The LNG Tandem Offloading System, which is capable of transferring LNG at a rate of $15,000 \mathrm{~m} 3 / \mathrm{hr}$, is comprised of two totally independent systems, the LNG transfer system and the mechanical mooring system (fig.3.3.3-24). 


\begin{tabular}{|l|l|l|l|}
\hline Customer: & $\begin{array}{l}\text { The United States Department of Energy } \\
\text { National Energy Technology Laboratory }\end{array}$ & $\begin{array}{l}\text { Date of Issue: } \\
29 \text { April } 2003\end{array}$ & \\
\hline $\begin{array}{l}\text { Document } \\
\text { Title: }\end{array}$ & $\begin{array}{l}\text { Subtask 1.2 } \\
\text { Identify Marine Mooring and Offloading Initiatives for LNG Vessels }\end{array}$ & $\begin{array}{l}\text { Doc \# \& Version: } \\
\text { Doc } 003 \text { r4.0 }\end{array}$ & Page 18 of 40 \\
\hline
\end{tabular}

The LNG transfer system utilizes industry proven LNG transfer technology from FMC Loading Systems in France. It provides simple LNG connection by vertically suspending the LNG Chiksan loading arms system, a double pantograph comprised of four sixteen-inch product lines, from a fixed outboard boom.

The mechanical mooring system uses a robust duplex yoke that minimizes the sway motions between vessels to maximize the FPSO's ability to offload in harsh weather conditions (fig. 3.3.3-25). This new concept in mooring yoke technology decouples lateral stiffness from fore and aft stiffness resulting in a dual or duplex action. This duplex yoke, made by FMC SOFEC Floating Systems,

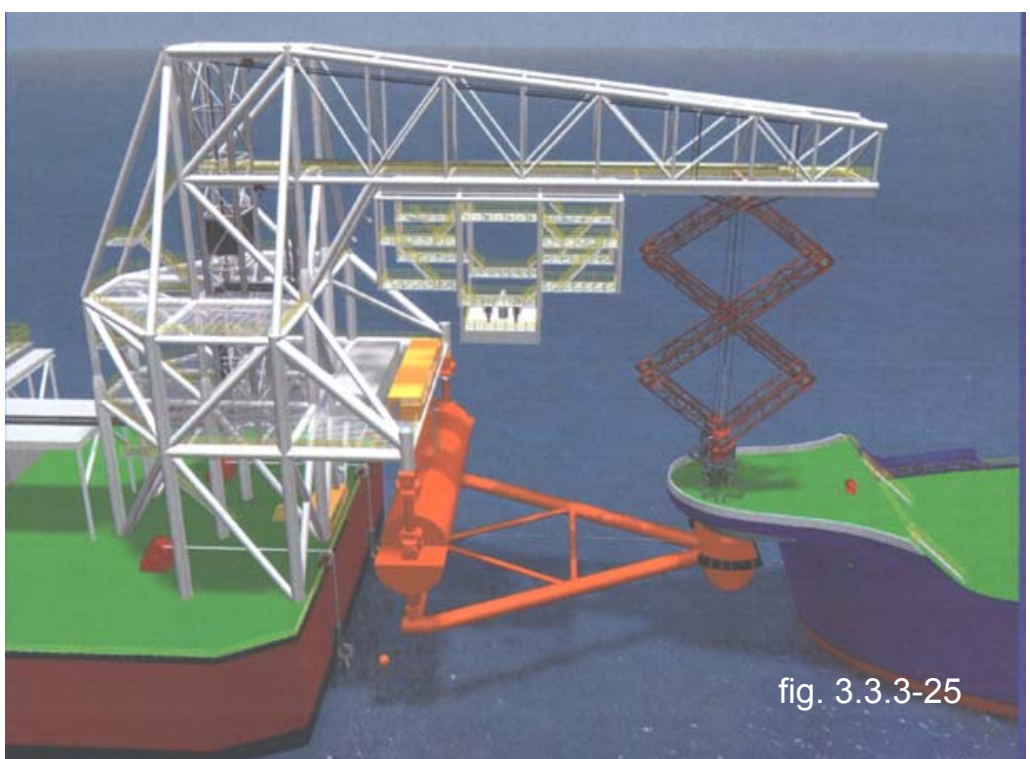
moors the vessels using a combination of industry proven yoke and high load connector technology. The mechanical mooring system is connected using a simple and safe procedure that minimizes assistance from auxiliary vessels. The duplex yoke has been very successful in wave basin model testing as well as extensive computer simulation. Fully integrated, these two systems have resulted in an excellent combination of proven technologies. The above figures illustrate the robust character of the Sofec yoke type mooring system coupled with the vertical, "Pantograph" LNG loading arm.

\subsubsection{OCL Group}

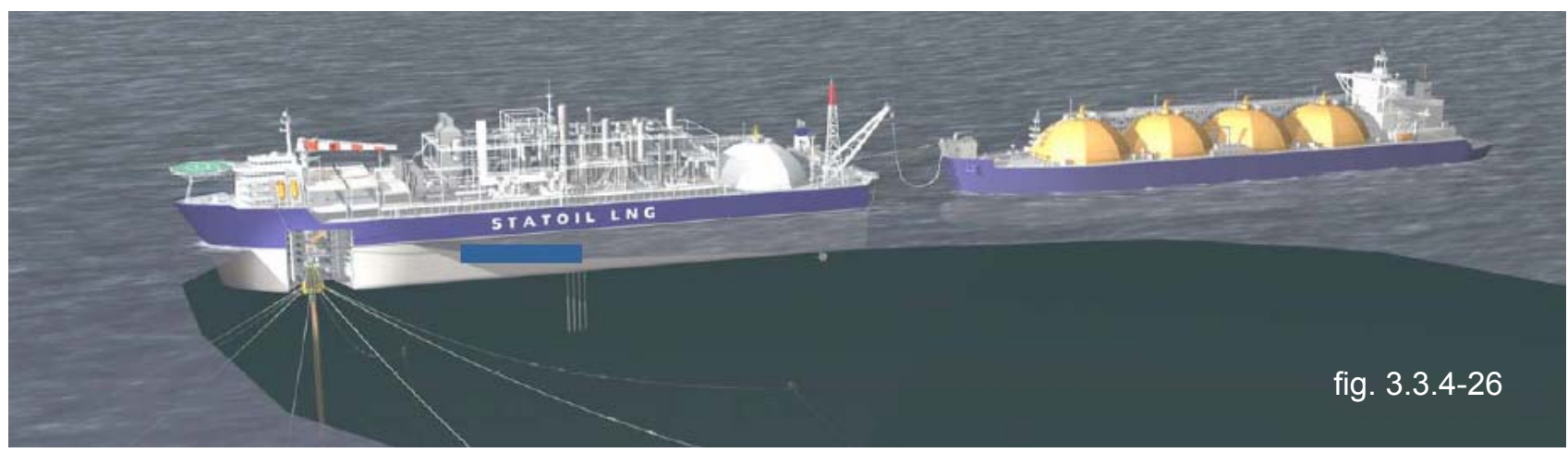

OCL Group a consortium of Statoil, Navion, APL, and Framo developed a novel system for offshore transfer of Liquefied natural gas based on a concept using a crane to suspend an array of flexible piping, from the tip of the crane to the LNG tanker (fig. 3.3.4-26. Although the system is based on the use of standard, proven components and procedures whenever possible, the actual transfer between the two vessels has not been performed. The project thru its step by step approach verified that the offshore loading system was technically feasible, but specific items such as loading regularity, connect/disconnect procedures, and safety were evaluated in general terms only. To fully develop the project, a computer model of the loading procedure and model test must be made. OCL in now in the process of verifying three important aspects in the current phase of development: 


\begin{tabular}{|l|l|l|l|}
\hline Customer: & $\begin{array}{l}\text { The United States Department of Energy } \\
\text { National Energy Technology Laboratory }\end{array}$ & $\begin{array}{l}\text { Date of Issue: } \\
29 \text { April } 2003\end{array}$ & \\
\hline $\begin{array}{l}\text { Document } \\
\text { Title: }\end{array}$ & $\begin{array}{l}\text { Subtask 1.2 } \\
\text { Identify Marine Mooring and Offloading Initiatives for LNG Vessels }\end{array}$ & $\begin{array}{l}\text { Doc \# \& Version: } \\
\text { Doc } 003 \text { r4.0 }\end{array}$ & Page 19 of $\mathbf{4 0}$ \\
\hline
\end{tabular}

- Behavior of the two tandemly moored vessels, especially the motions in the offloading area through scaled model testing

- Transfer of the flexible pipe and connection to the shuttle tanker

- Full scale testing of the actual flexible pipe configuration at actual temperature. The mechanical tension/compression and hydraulic testing have proven that transfer can be unproblematic with correct procedures.

The diagram below In fig 3.3.4-27 outlines the design conditions and distances between the offloading vessels.

- Relative movements +/- 6 meter (Design Maximum +/- 15 meter)

- Relative yaw +/- 15 degrees

(Design Maximum +/- 35 degrees)

- Relative roll +/- 10 degrees

(Design Maximum +/- 10 degrees)

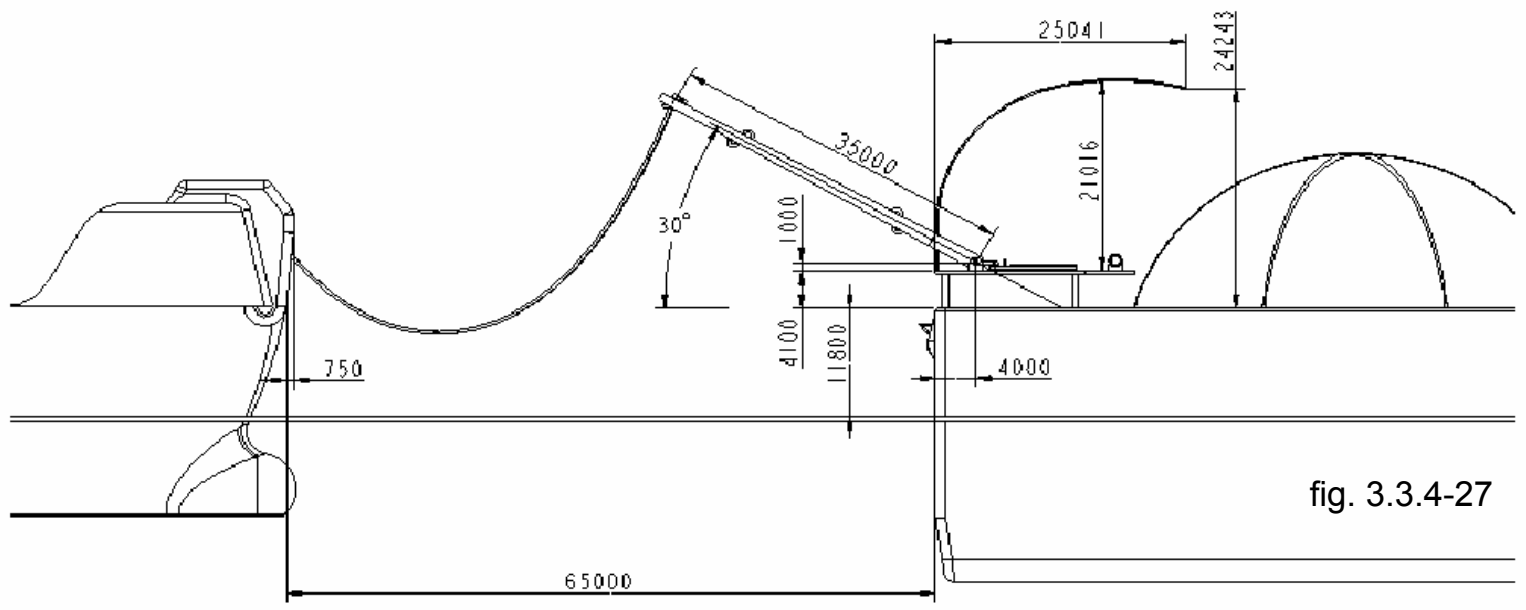




\begin{tabular}{|l|l|l|l|}
\hline Customer: & $\begin{array}{l}\text { The United States Department of Energy } \\
\text { National Energy Technology Laboratory }\end{array}$ & $\begin{array}{l}\text { Date of Issue: } \\
29 \text { April } 2003\end{array}$ & \\
\hline $\begin{array}{l}\text { Document } \\
\text { Title: }\end{array}$ & $\begin{array}{l}\text { Subtask 1.2 } \\
\text { Identify Marine Mooring and Offloading Initiatives for LNG Vessels }\end{array}$ & $\begin{array}{l}\text { Doc \# \& Version: } \\
\text { Doc } 003 \text { r. } 4\end{array}$ & Page $\mathbf{2 0}$ of $\mathbf{4 0}$ \\
\hline
\end{tabular}

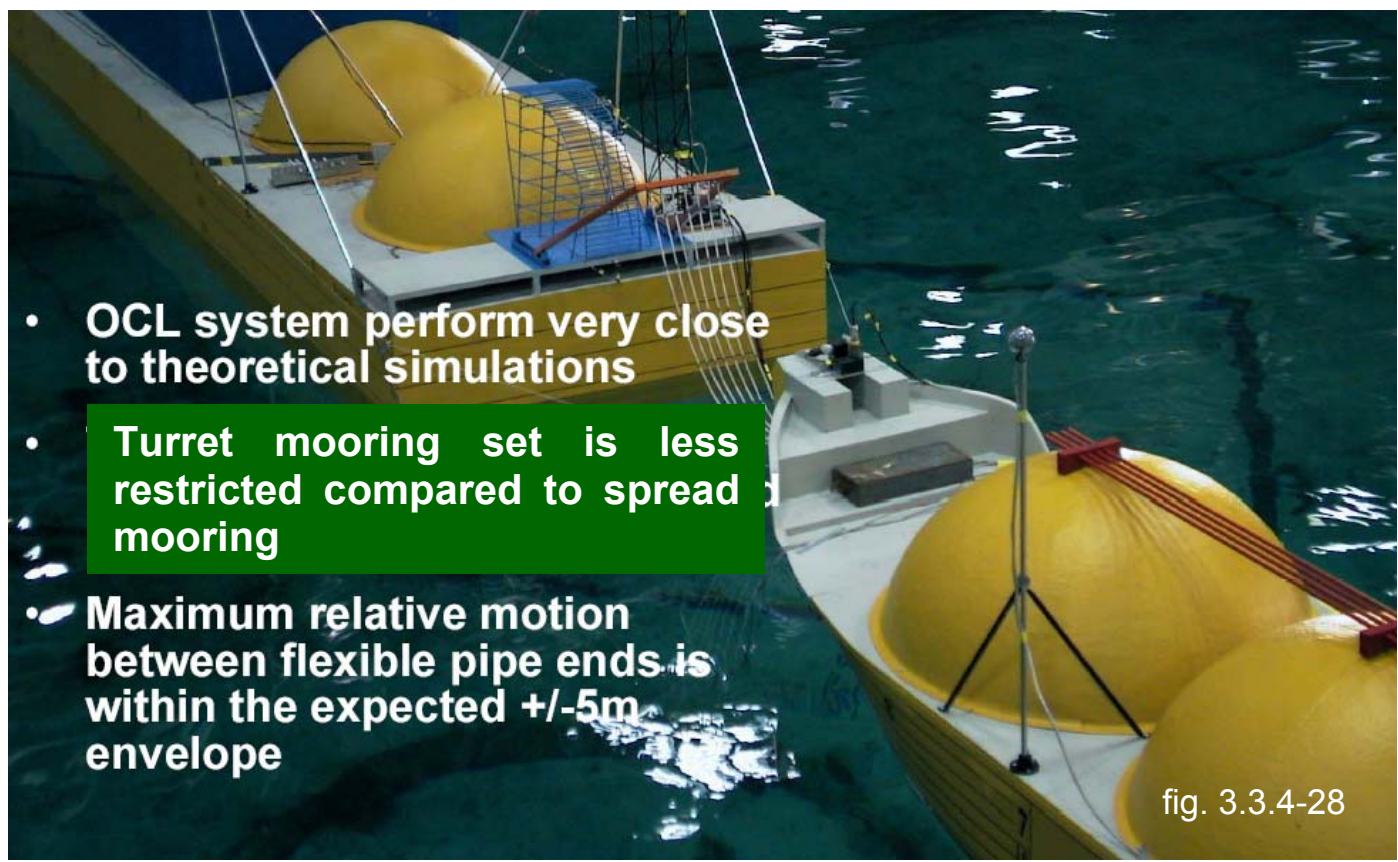

Figure 3.3.4-28 above summarizes the test results of the modeled offloading system. The hardware and the arrangement of the flexible piping connection can be readily seen in this photograph of the model.

\subsubsection{HiLoad by Remora Technologies}

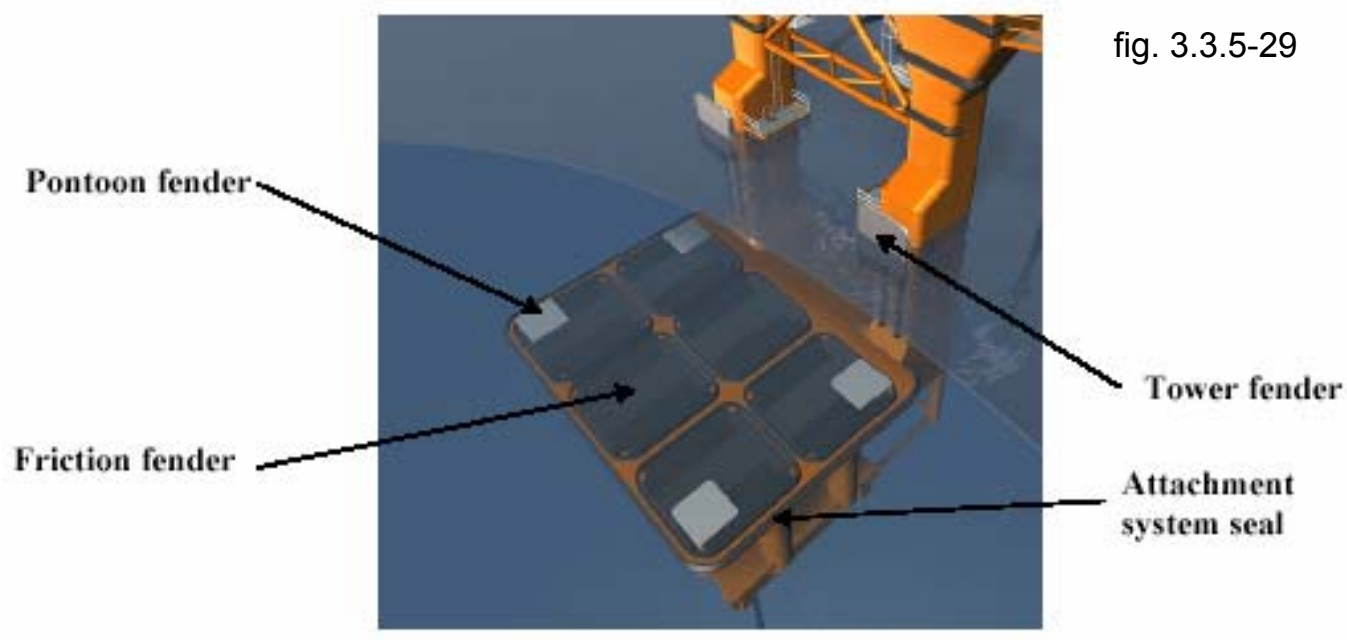

The HiLoad concept (fig 3.3.5-29) has been developed, engineered and model tested in cooperation with ConocoPhillips, and the application developed for the offshore oil industry is now ready for fabrication. The main purpose of the HiLoad development project has been to develop a mooring-less offshore loading system for deepwater fields in the US Gulf of Mexico. The remotely operated 


\begin{tabular}{|l|l|l|l|}
\hline Customer: & $\begin{array}{l}\text { The United States Department of Energy } \\
\text { National Energy Technology Laboratory }\end{array}$ & $\begin{array}{l}\text { Date of Issue: } \\
29 \text { April } 2003\end{array}$ & \\
\hline $\begin{array}{l}\text { Document } \\
\text { Title: }\end{array}$ & $\begin{array}{l}\text { Subtask 1.2 } \\
\text { Identify Marine Mooring and Offloading Initiatives for LNG Vessels }\end{array}$ & $\begin{array}{l}\text { Doc \# \& Version: } \\
\text { Doc } 003 \text { r. }\end{array}$ & Page 21 of 40 \\
\hline
\end{tabular}

HiLoad unit will dock onto any tanker in a similar way as a forklift picks up a pallet (fig 3.3.5-30) The HiLoad unit will connect to the forward part of the tanker, allowing the tanker to weathervane during operation kept in position by the HiLoad thrusters controlled by a Dynamic Positioning System. The tanker loading hose is stored onboard the HiLoad, and can simply be pulled along the tanker deck towards the midship manifold using one of the tanker's mooring winches.

During the development study it became clear that the HiLoad would have a number of other possible applications. It was therefore decided to also look at an LNG application whereby the device moors with the LNG tanker and safely positions the vessel for smooth operation with respect to tides and currents. Rather

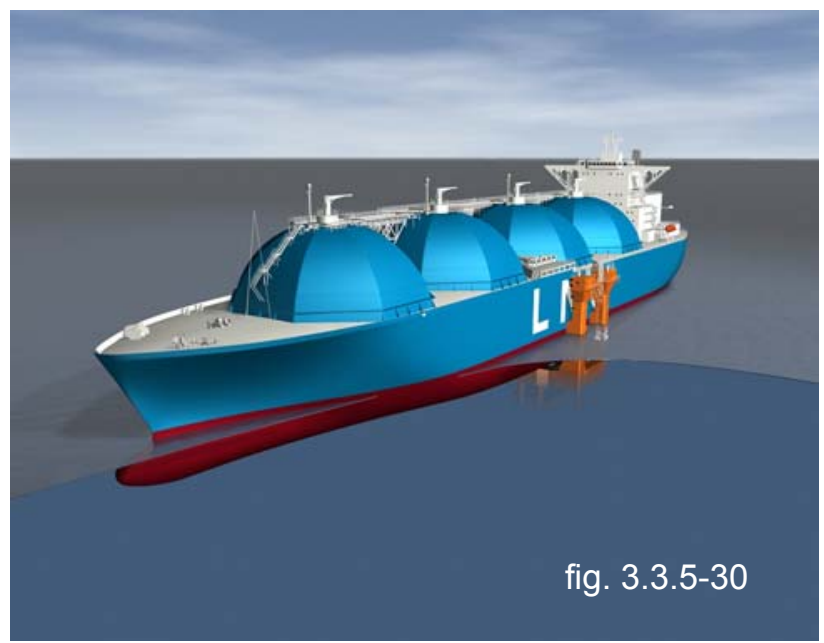
than employ a hose and reel device for the transfer of cargo, a cryogenic hose and boom arrangement could be used. In addition, Remora Technologies has proposed to construct a series of heat exchangers aboard the HiLoad unit to allow the vessel to discharge vaporized LNG through flexible risers and into an existing subsea gas gathering system. Although the LNG modifications have been conceptually designed, the actual HiLoad mooring system has been full scale tested and is ready for use.

\subsubsection{Advance Production and Loading AS (APL)}

fig. 3.3.6-31

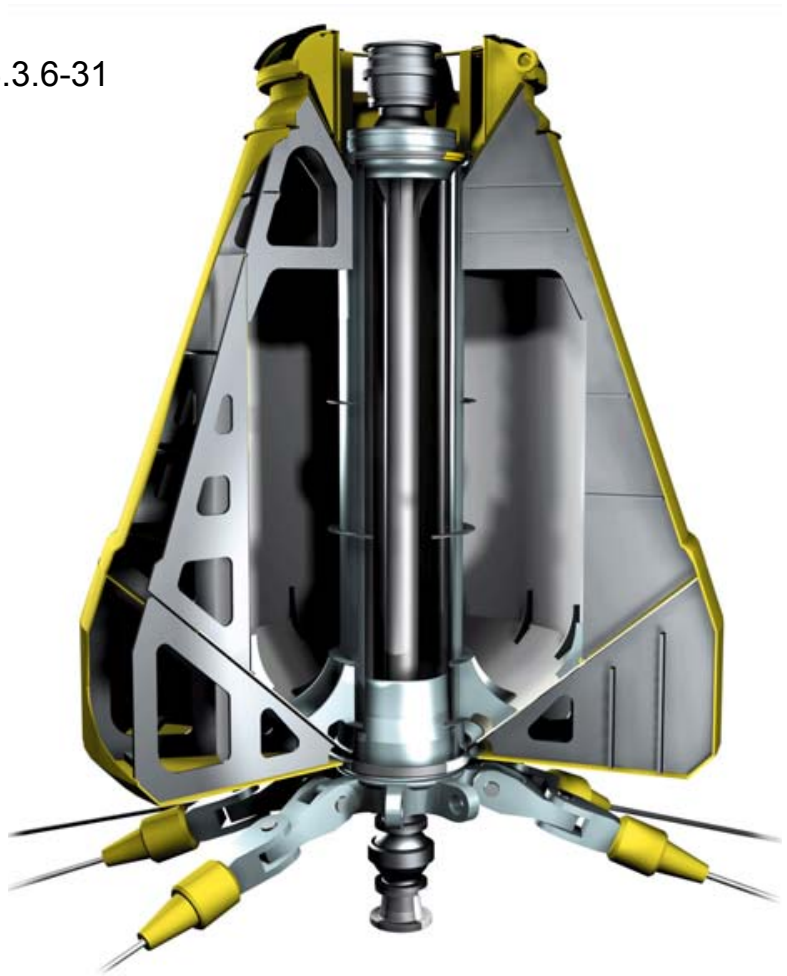

The submerged turret loading (STL) technology offers a flexible, safe and cost-effective solution for offshore loading of crude oil. First introduced in 1993, it is now recognised as the new standard in offshore loading. Per April 2000, 24 ships incorporated or were being fitted with the STL/STP mating cone which is an "internal" CALM buy of sorts (fig. 3.3.6-31).

STL systems currently in operation are installed in water depths from 85 to 350 metres, and have been designed for significant wave heights up to 16.4 metres. Tests in ocean basins have verified the feasibility of the STL/STP mooring systems for water depths from 40 to 900 metres. And mooring system analyses have demonstrated the suitability of these systems for water depths from 20 to more than 2000 metres. APL provides the mooring system and design for the offshore LNG regasification ("Energy Bridge") vessels built in Daewoo's shipyards by El Paso, Inc.

STL equipment is installed in a dedicated compartment (fig. 3.3.7-32) with an access trunk. Vessel modifications are restricted to standard steelwork, since all complicated bearing structures form part of the STL buoy. A buoy-locking mechanism, loading manifold and 


\begin{tabular}{|l|l|l|l|}
\hline Customer: & $\begin{array}{l}\text { The United States Department of Energy } \\
\text { National Energy Technology Laboratory }\end{array}$ & $\begin{array}{l}\text { Date of Issue: } \\
29 \text { April } 2003\end{array}$ & \\
\hline $\begin{array}{l}\text { Document } \\
\text { Title: }\end{array}$ & $\begin{array}{l}\text { Subtask 1.2 } \\
\text { Identify Marine Mooring and Offloading Initiatives for LNG Vessels }\end{array}$ & $\begin{array}{l}\text { Doc \# \& Version: } \\
\text { Doc } 003 \text { r. } 4\end{array}$ & Page 22 of $\mathbf{4 0}$ \\
\hline
\end{tabular}

guidance system are key components placed in the STL compartment. The pull-in winch and hydraulic power packs will be located on deck. A buoy moored to the seabed forms the basis for the STL system. Pulled into and secured in a mating cone, this unit connects the vessel to the mooring system.

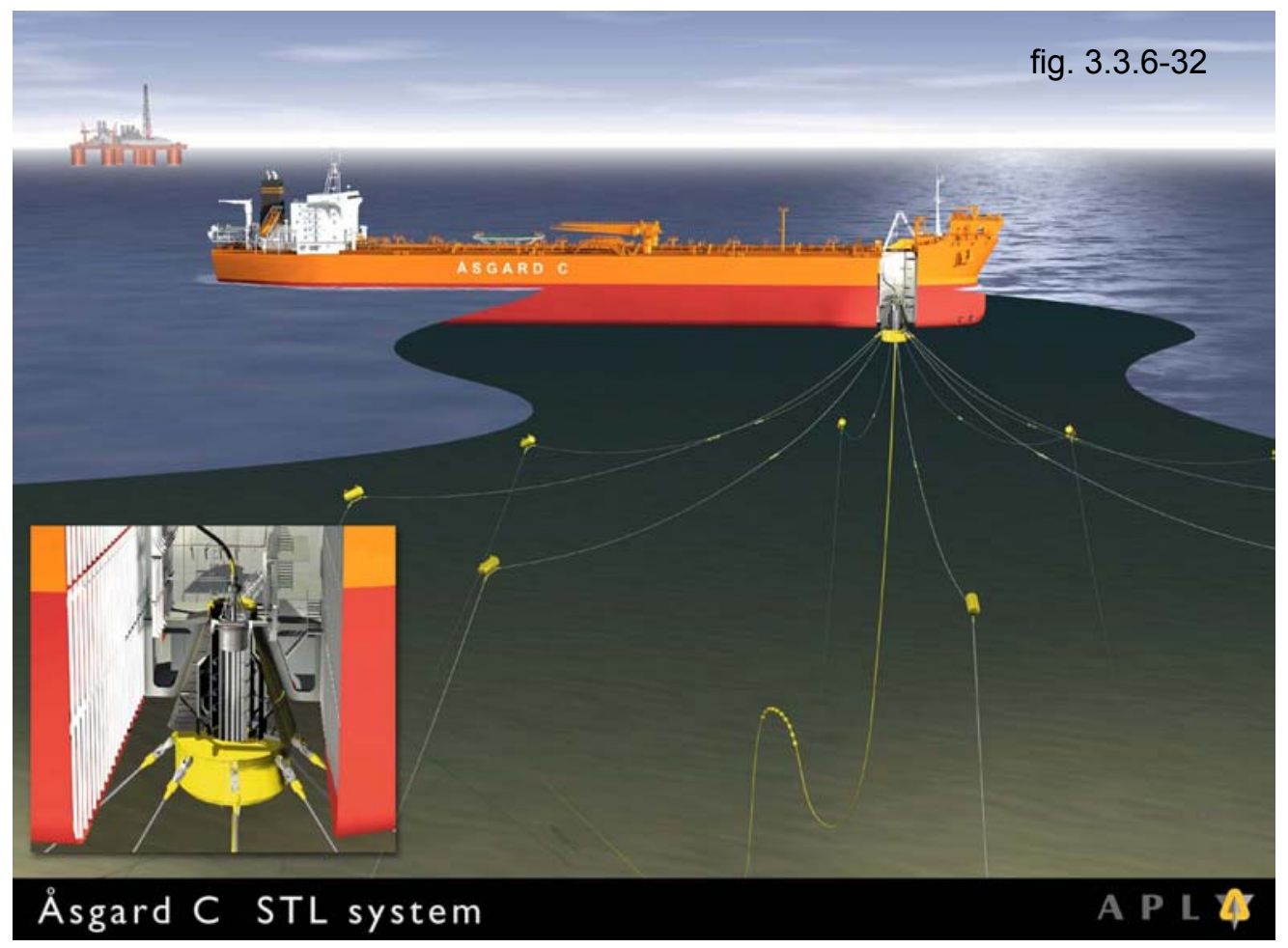

The buoy structure incorporates a turret connected to the mooring and a flexible riser. The outer hull rotates freely around the turret with the weathervaning vessel by means of internal bearings. The hydrocarbon stream is transferred through an in-line swivel and via the loading manifold to the vessel piping system. Or, in the case of Energy Bridge, the flow is reversed as the vaporized LNG moves through the in-line swivel and turret section, through the riser to the (pipeline end manifold) PLEM, and existing subsea gas grid. Figure 3.3.6-32 is an arrangement of a typical buoy and offshore production field. The riser through which the hydrocarbons flow is represented in yellow, and drops out of the center of the STL buoy.

APL's technology is the only offshore LNG mooring system certified and in the fabrication phase. Delivery of the first tanker and the sub sea infrastructure required for cargo transfer should be completed by late 2004 . El Paso has announced that the Gulf of Mexico will be the first site for an Energy Bridge application. Task 3.0 of this study includes a detailed review of El Paso's Energy Bridge concept using APL's technology.

\subsubsection{New Architectures of LNG Transfer by TFE, GdF, Eurodim, and ITP}

Eurodim, s.a. has over the last three years coordinated a consortium of the above the French companies to develop new architectures and components for the transfer of LNG offshore. The designs originating from this group are applicable to both the loading and receiving terminal. The first goal of the R\&D effort was to propose alternatives to traditional jetties (the dock and approach trestle), and to define the critical components of the designs that needed further study or testing. The consortium decided that the following conditions were to be met:

- To locate the mooring facility some distance from the coast to minimize navigational and siting problems

- To be able to load and unload non-dedicated vessels at $10,000 \mathrm{~m} 3 / \mathrm{hr}$ 


\begin{tabular}{|l|l|l|l|}
\hline Customer: & $\begin{array}{l}\text { The United States Department of Energy } \\
\text { National Energy Technology Laboratory }\end{array}$ & $\begin{array}{l}\text { Date of Issue: } \\
29 \text { April } 2003\end{array}$ & \\
\hline $\begin{array}{l}\text { Document } \\
\text { Title: }\end{array}$ & $\begin{array}{l}\text { Subtask 1.2 } \\
\text { Identify Marine Mooring and Offloading Initiatives for LNG Vessels }\end{array}$ & $\begin{array}{l}\text { Doc \# \& Version: } \\
\text { Doc } 003 \text { r4.0 }\end{array}$ & Page 23 of 40 \\
\hline
\end{tabular}

- To realize a significant CAPEX reduction by replacing the costly approach trestle and breakwater with subsea cryogenic pipelines and cryogenic hoses for cargo transfer

- To ensure a level of safety equal or above that which is realized for traditional jetties.

The following designs are weathervaning and are suited to severe weather sites.

\section{Rotating quay}

The consortium developed a system, which combined the advantages of:

- A traditional jetty noted for safety, reliability, with components using a proven technology, and able to accommodate non-dedicated ships.

- A single point mooring (SPM) that could be sited far from the coast, with cheaper cost, weathervaning capability to accommodate higher operating thresholds

This rotating quay, designed to replace the traditional jetty, was patented by TotalFinaElf in January 2000 (3.3.7-33). This revolving quay, which is mounted around a vertical axis on a fixed supporting structure, allows the moored vessel to weathervane with wind and current. The fixed structure is connected to the shore by subsea cryogenic lines.

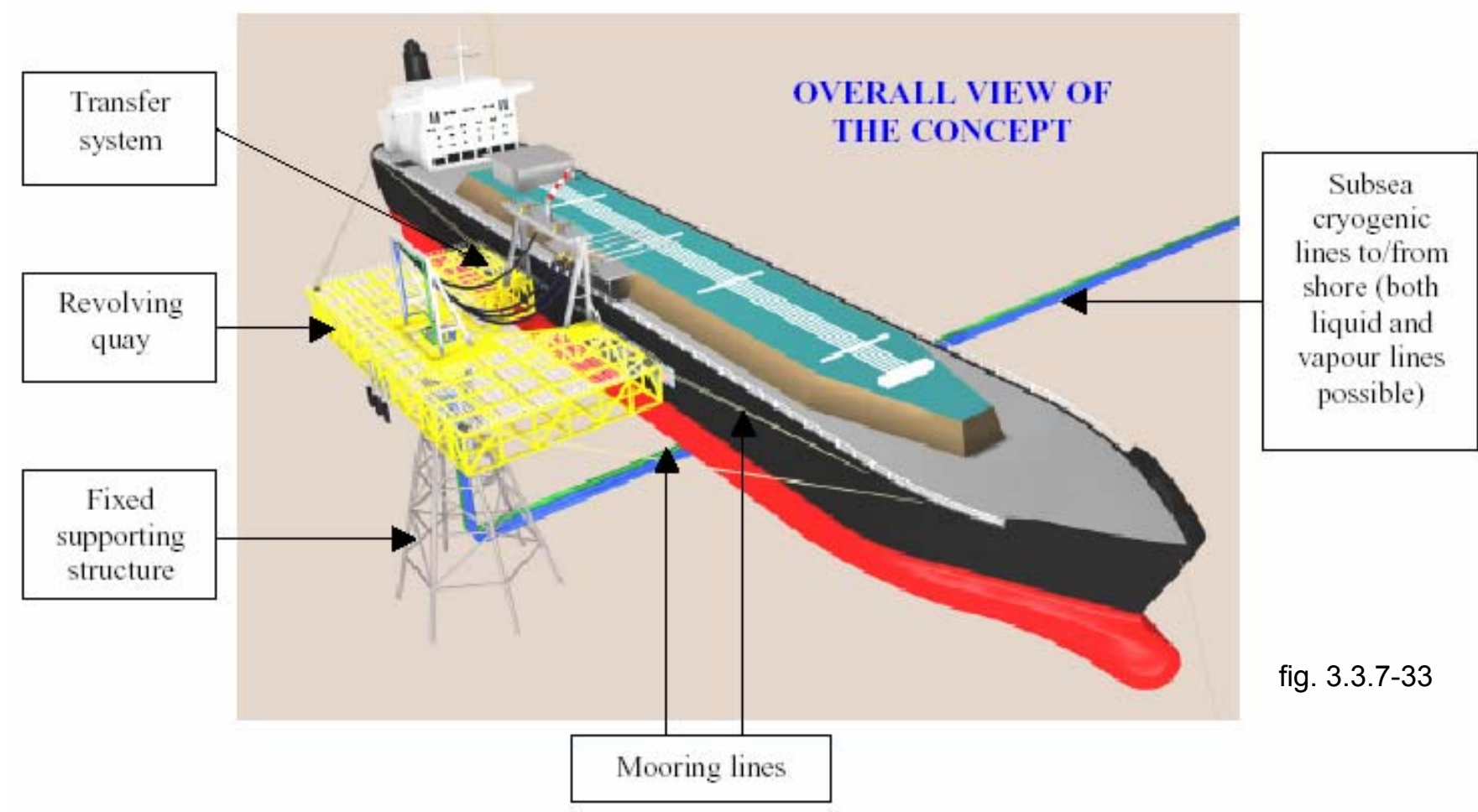

As the ship approaches the dock, the system allows a tug to position the quay parallel to the vessels parallel body for safe mooring. Soft hawsers, a simple and reliable system used in the offshore oil industry are used to provide the required flexibility fore and aft. After securing the vessel to the rotating quay, the movable structure maintains the optimum heading of the ship with reference to wind and waves. In case of emergency, 


\begin{tabular}{|l|l|l|l|}
\hline Customer: & $\begin{array}{l}\text { The United States Department of Energy } \\
\text { National Energy Technology Laboratory }\end{array}$ & $\begin{array}{l}\text { Date of Issue: } \\
29 \text { April } 2003\end{array}$ & \\
\hline $\begin{array}{l}\text { Document } \\
\text { Title: }\end{array}$ & $\begin{array}{l}\text { Subtask 1.2 } \\
\text { Identify Marine Mooring and Offloading Initiatives for LNG Vessels }\end{array}$ & $\begin{array}{l}\text { Doc \# \& Version: } \\
\text { Doc } 003 \text { r4.0 }\end{array}$ & Page 24 of 40 \\
\hline
\end{tabular}

a quick departure can be achieved with a very high level of safety and reliability. An illustration of the system is given on Figures 3.3.7-33 and 34 .

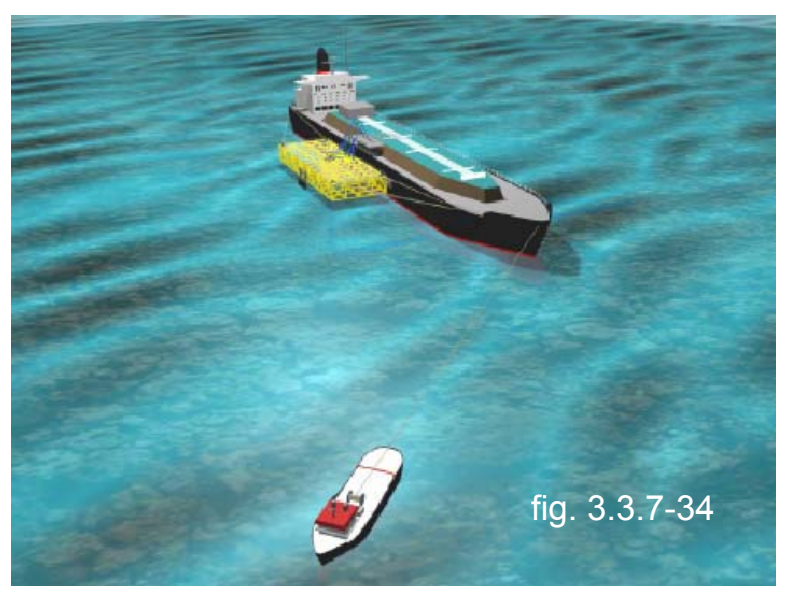

This concept meets the objectives set for all of the liquefied gas transfer architectures:

- Serving non-dedicated ships

- Applicable for both loading and discharging terminals

- Able to handle any type of liquefied gas.

- Flexibility with regard to depth.

- More compliant than a traditional berth with regard to weather operating thresholds.

- Reducing significantly the overall cost compared to traditional jetty design

- Eliminating the navigational, traffic and neighboring constraints by allowing the system to be at some distance from the coast.

In addition it presents several remarkable advantages:

- All components are standard and similar to the ones used on traditional jetties: mooring hooks, fenders, arms, gangway, etc.

- The system uses the same rules, standards and guidelines for design as used for traditional jetties e.g. OCIMF guidelines for mooring, PIANC (Permanent International Association of Navigation Congresses) or BSRA (British Ship Research Association) standards for fender selection, OCIMF specification for loading arms, all SIGTTO guidelines, etc.

- The rotating quay can support either hard arms or flexible hoses for the product transfer; the shape of the rotating quay can be adapted accordingly

Also, the supporting structure and the rotating quay have similar lattice structures (jacket and lattice beam) allowing a yard to build both structures at the same time. Transportation to the site can be made on two barges and installation is straightforward. Although this has not been estimated in detail, there is obviously an important reduction of the construction and installation time compared to a traditional jetty, which requires extensive civil work and piling.

Berthing and station keeping are also unique to this design in that the mooring facility actually tracks the parallel body of the ship while berthing. Traditional facilities require two to three $6,500 \mathrm{HP}$ tugboats to turn the vessel before docking. Once the ship is parallel to the berthing line tugs push the vessel toward the breasting dolphins at speeds no greater than 15 to $20 \mathrm{~cm} / \mathrm{sec}$. Berthing thresholds are limited to waves of 1.2 to 1.5 meters $\mathrm{Hs}$, and wind from 12 to $15 \mathrm{~m} / \mathrm{sec}$. Because the ship seldom if ever contacts the breasting dolphin fenders exactly parallel, each breasting dolphin must be

fig. 3.3.7-35

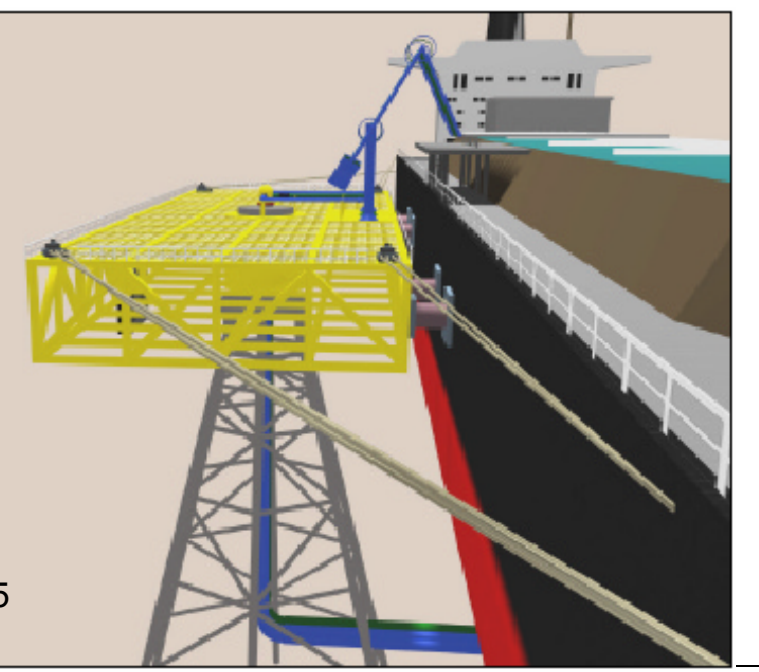

Filename: 41653R01 


\begin{tabular}{|l|l|l|l|}
\hline Customer: & $\begin{array}{l}\text { The United States Department of Energy } \\
\text { National Energy Technology Laboratory }\end{array}$ & $\begin{array}{l}\text { Date of Issue: } \\
29 \text { April } 2003\end{array}$ & \\
\hline $\begin{array}{l}\text { Document } \\
\text { Title: }\end{array}$ & $\begin{array}{l}\text { Subtask 1.2 } \\
\text { Identify Marine Mooring and Offloading Initiatives for LNG Vessels }\end{array}$ & $\begin{array}{l}\text { Doc \# \& Version: } \\
\text { Doc } 003 \text { r. } 4\end{array}$ & Page $\mathbf{2 5}$ of $\mathbf{4 0}$ \\
\hline
\end{tabular}

able to absorb all the berthing energy. Consequently, these structures are robust and expensive.

The rotating quay "self aligns" as its system of fenders come in contact with the vessel, fig. 3.3.7-35. For example as soon as the parallel body of the ship contacts the first breasting fender, the quay turns naturally to contact the remaining fenders immediately, thus sharing the berthing energy equally. Because the facility weathervanes and the ship rides the path of least resistance at the dock, mooring line stresses are reduced. Eight mooring lines rather than 12 to 16 are required to keep the ship secure, even in rough conditions

The cost savings are evident as the breasting dolphins can be made lighter, the mooring dolphins and accompanying catwalks eliminated, and the number of mooring hooks and lines reduced.

\section{Ariel Fluid Path SPM}

The Aerial Fluid Path (AFP) by TotalFinaElf and engineering by Eurodim is a side transfer weathervaning structure supporting a boom approximately 220 meters long. The boom is designed to rotate around the
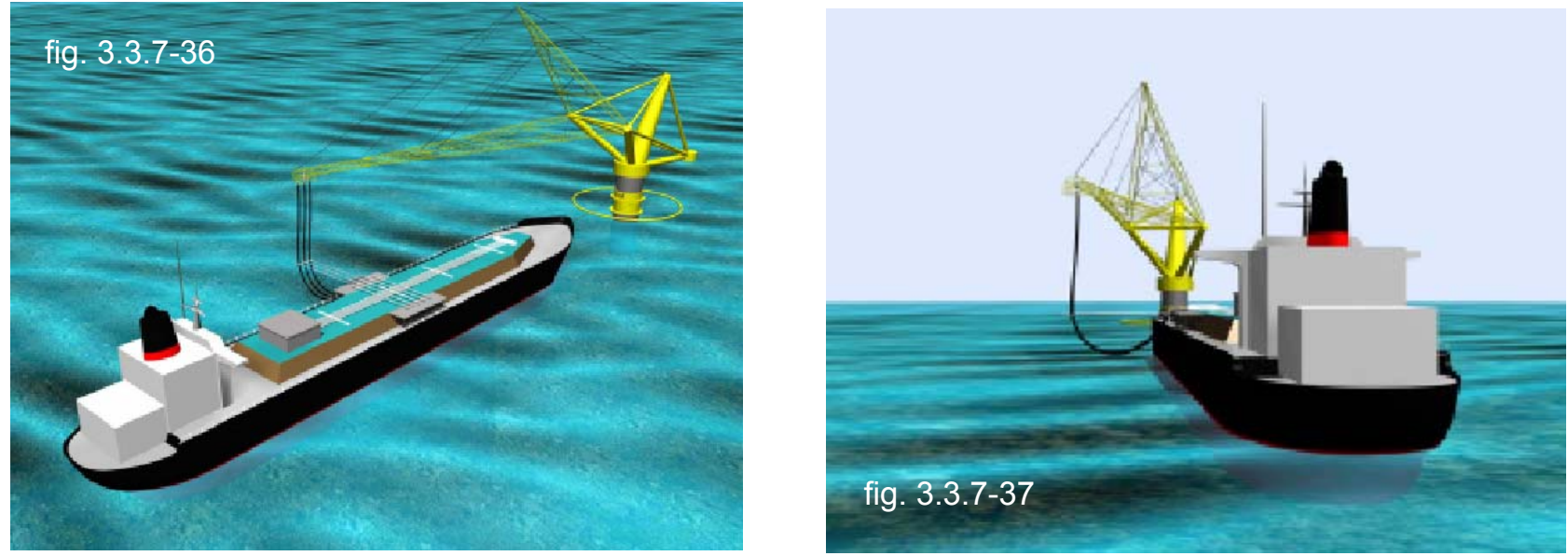

vertical axis of a fixed tower type single point mooring

(SPM). The boom is suspended about 50 meters above the water's surface to accommodate the largest LNG carriers, and the length is designed to reach the midship manifold as pictured above (figs. 3.3.7-36 \& 37)

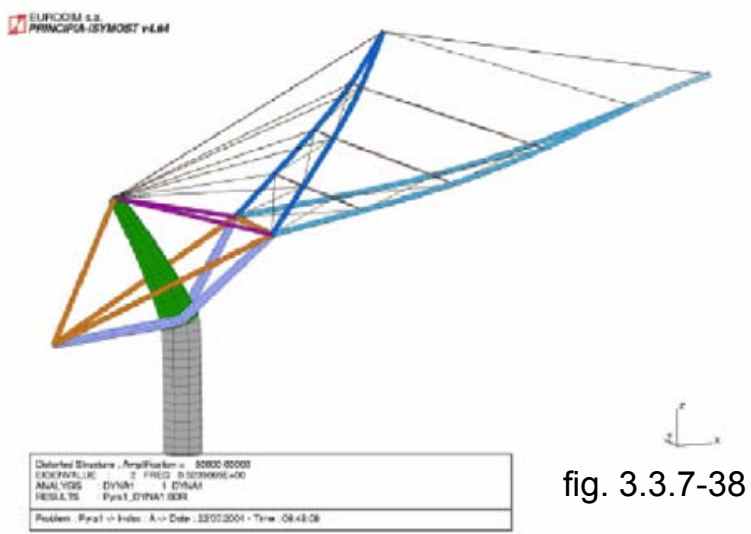

The boom carries the weight of the large diameter

flexible LNG hoses connected to the LNG tanker's manifold and is free to rotate with the ship. A patented beam and cable arrangement ensure that the hoses never exceed their designed bending radius. 


\begin{tabular}{|l|l|l|l|}
\hline Customer: & $\begin{array}{l}\text { The United States Department of Energy } \\
\text { National Energy Technology Laboratory }\end{array}$ & $\begin{array}{l}\text { Date of Issue: } \\
29 \text { April } 2003\end{array}$ & \\
\hline $\begin{array}{l}\text { Document } \\
\text { Title: }\end{array}$ & $\begin{array}{l}\text { Subtask 1.2 } \\
\text { Identify Marine Mooring and Offloading Initiatives for LNG Vessels }\end{array}$ & $\begin{array}{l}\text { Doc \# \& Version: } \\
\text { Doc } 003 \text { r. }\end{array}$ & Page 26 of $\mathbf{4 0}$ \\
\hline
\end{tabular}

The structure is self supporting and the boom and SPM structure has been modeled and designed to operate outside the natural frequencies that the waves and environment might impose. For this reason the standard industrial crane and boom proved unacceptable and the alternative (pictured) was employed. The diagram below is a graphical representation of the boom operating in its first (fig. 3.3.7-38) and second (fig. 3.3.7-39) natural frequency vibration modes without adverse effects. This AFP concept appears to provide good operating thresholds with maximum safety, minimum cost and construction times and reduction of underwater infrastructure and mooring equipment.

\section{Light Reel Tandem Offloading System}

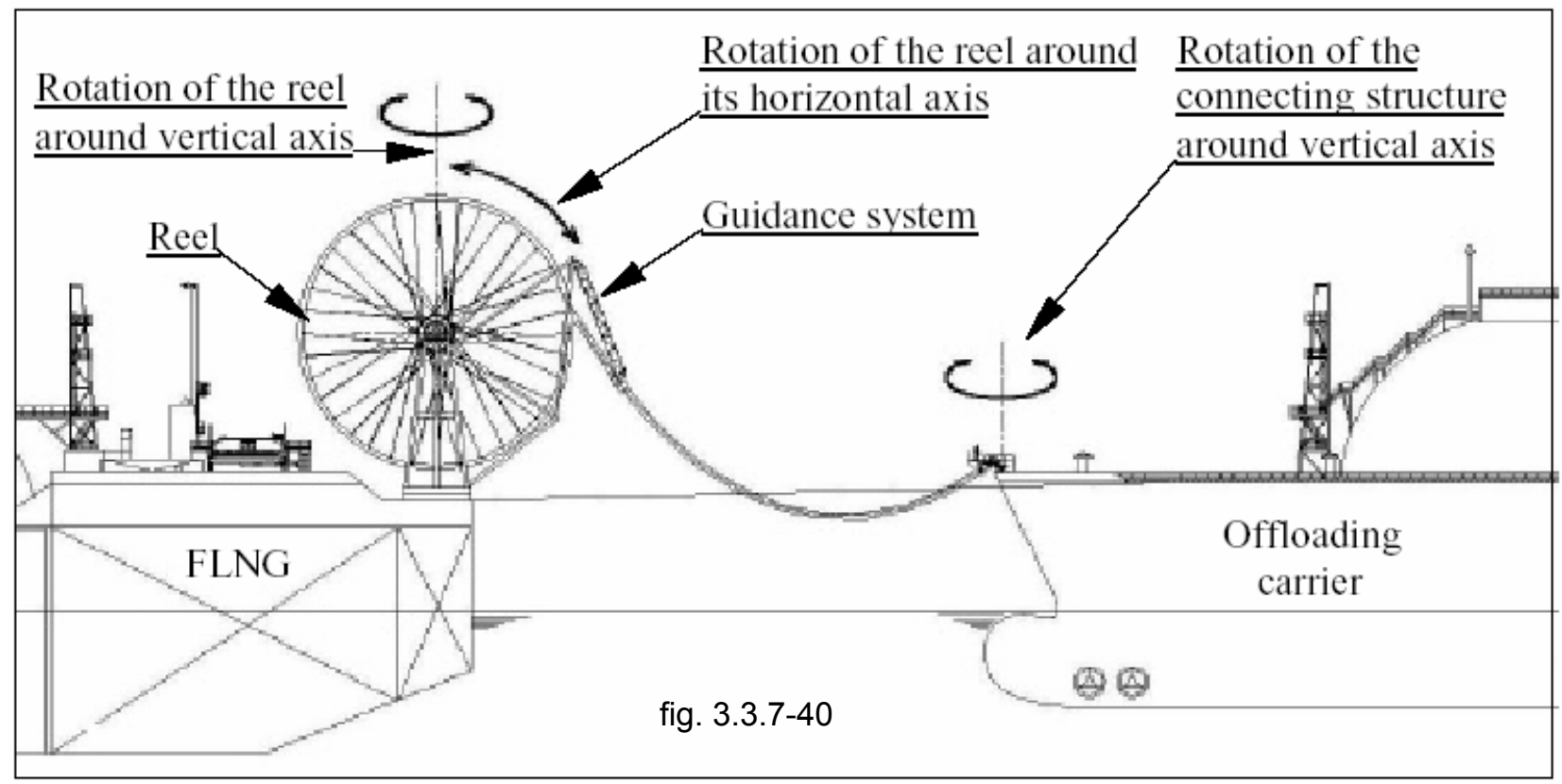

As previously established, the use of tandem transfer, weathervaning offshore units are required for safe use in the most severe siting conditions. The Light Reel system (fig. 3.3.7-40 \& 41) developed by Bluewater and Eurodim is an unusual departure from the designs listed above, but uses many familiar design concepts.

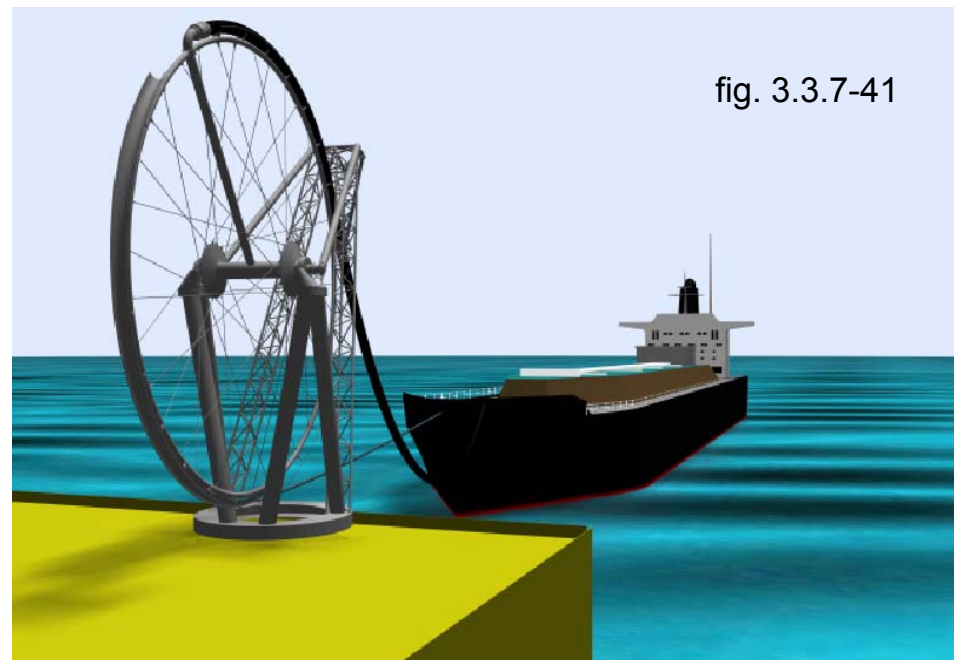

The Light Reel unit requires further study to evaluate the mechanical requirements for routine coupling with the offloading LNG vessel, and uncoupling under emergency conditions, however a brief description is provided below.

To summarize, a 16 meter reel containing the flexible LNG transfer hose is wound around the outside diameter for storage and use. One rotation of the reel can store about 100 meters of cryogenic hose. During LNG transfer the hose is connected to a structure on the bow of an LNG carrier, and clamped 


\begin{tabular}{|l|l|l|l|}
\hline Customer: & $\begin{array}{l}\text { The United States Department of Energy } \\
\text { National Energy Technology Laboratory }\end{array}$ & $\begin{array}{l}\text { Date of Issue: } \\
\mathbf{2 9} \text { April } 2003\end{array}$ & \\
\hline $\begin{array}{l}\text { Document } \\
\text { Title: }\end{array}$ & $\begin{array}{l}\text { Subtask 1.2 } \\
\text { Identify Marine Mooring and Offloading Initiatives for LNG Vessels }\end{array}$ & $\begin{array}{l}\text { Doc \# \& Version: } \\
\text { Doc } 003 \text { r4.0 }\end{array}$ & Page 27 of $\mathbf{4 0}$ \\
\hline
\end{tabular}

with a hydraulic connecting device. The swivels also serve to reduce the torque on the hoses ensuring reliability and long life. Two vertical swivels allow the joints to cope with large relative angles of motion between the two vessels, and the vessels are free to move as seen in fig. 3.3.7-42.

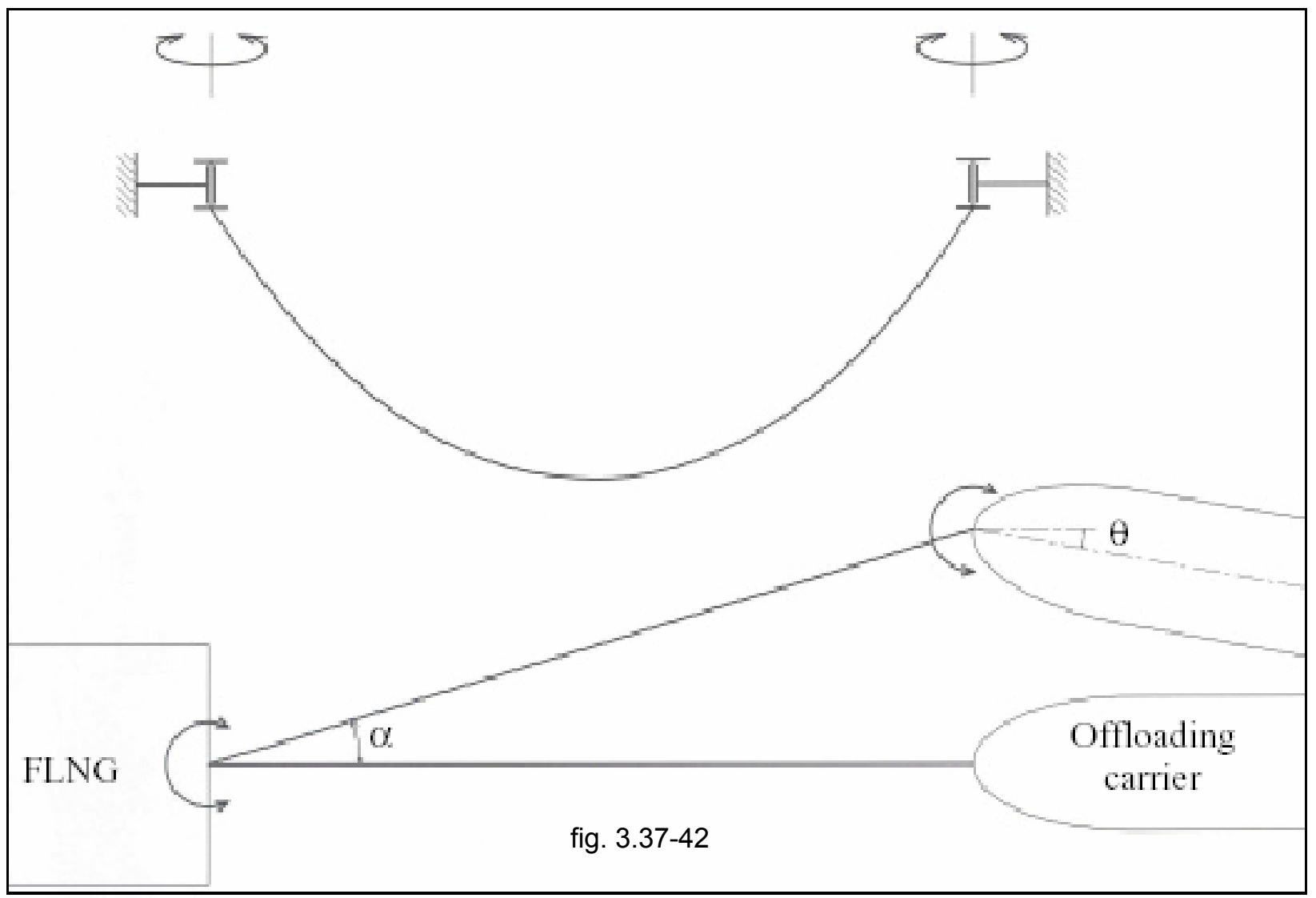

\section{Conventional Buoy Moorings}

Less severe sties with prevailing environmental conditions orientating the LNG carrier in one predominant direction can be served with a Conventional Buoy Mooring (CBM) system, sometimes called a "multi-buoy

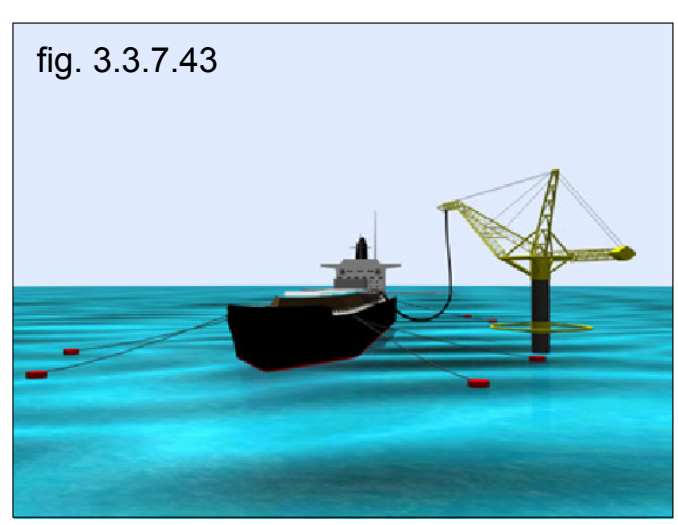
mooring." The mooring forces of the ship, instead of being transmitted to the jetty structure via the piles of the mooring and breasting dolphins, are transmitted by the ship mooring lines to the

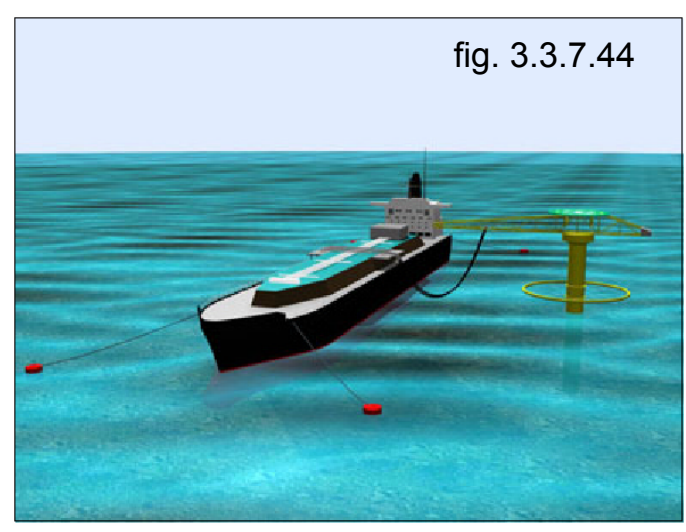




\begin{tabular}{|l|l|l|l|}
\hline Customer: & $\begin{array}{l}\text { The United States Department of Energy } \\
\text { National Energy Technology Laboratory }\end{array}$ & $\begin{array}{l}\text { Date of Issue: } \\
29 \text { April } 2003\end{array}$ & \\
\hline $\begin{array}{l}\text { Document } \\
\text { Title: }\end{array}$ & $\begin{array}{l}\text { Subtask 1.2 } \\
\text { Identify Marine Mooring and Offloading Initiatives for LNG Vessels }\end{array}$ & $\begin{array}{l}\text { Doc \# \& Version: } \\
\text { Doc } 003 \text { r. }\end{array}$ & Page 28 of $\mathbf{4 0}$ \\
\hline
\end{tabular}

chains of the multiple mooring buoys that are securely anchored to the seabed. From a structural stand point, this system carries the mooring loads in an optimised manner as no bending moment is generated in the structural link. This catenary structural link is in simple terms a massive "spring" that can be "tuned" during the engineering phase for the site conditions (wind, wave, and current) and calling vessels fig 3.3.7-43 $\& 44$.

A fixed tower riser (or support) linking sea bed/subsea cryogenic lines for LNG and vapor return line (or a trestle with aerial lines) could be used to transfer the cryogenic liquids. If flexible hoses were to be used with the CBM mooring concept, they could be supported in a catenary configuration between a cantilevered boom and a fixed tower. The boom would provide the overhead support required to position the transfer hose at the LNG carrier midship manifold.

Depending on the environmental conditions and the effect of wind and/or current, mooring stiffness, the location of the fixed tower, and boom orientation would be optimized. Optimized moorings range from that seen in (3.3.7-43) where the boom is perpendicular to the longitudinal axis of the moored LNG carrier, to an arrangement (3.3.7-44) where the boom is quite parallel to the longitudinal axis of the ship. This mooring arrangement would allow pivoting around a vertical axis with the hoses linking the boom tip to the midship manifold similar to the Aerial Fluid Path SPM concept. Anticipating the development of the required link technologies this mooring system could be used to transfer cryogenic liquids to the storage or processing

fig. 3.3.7.45
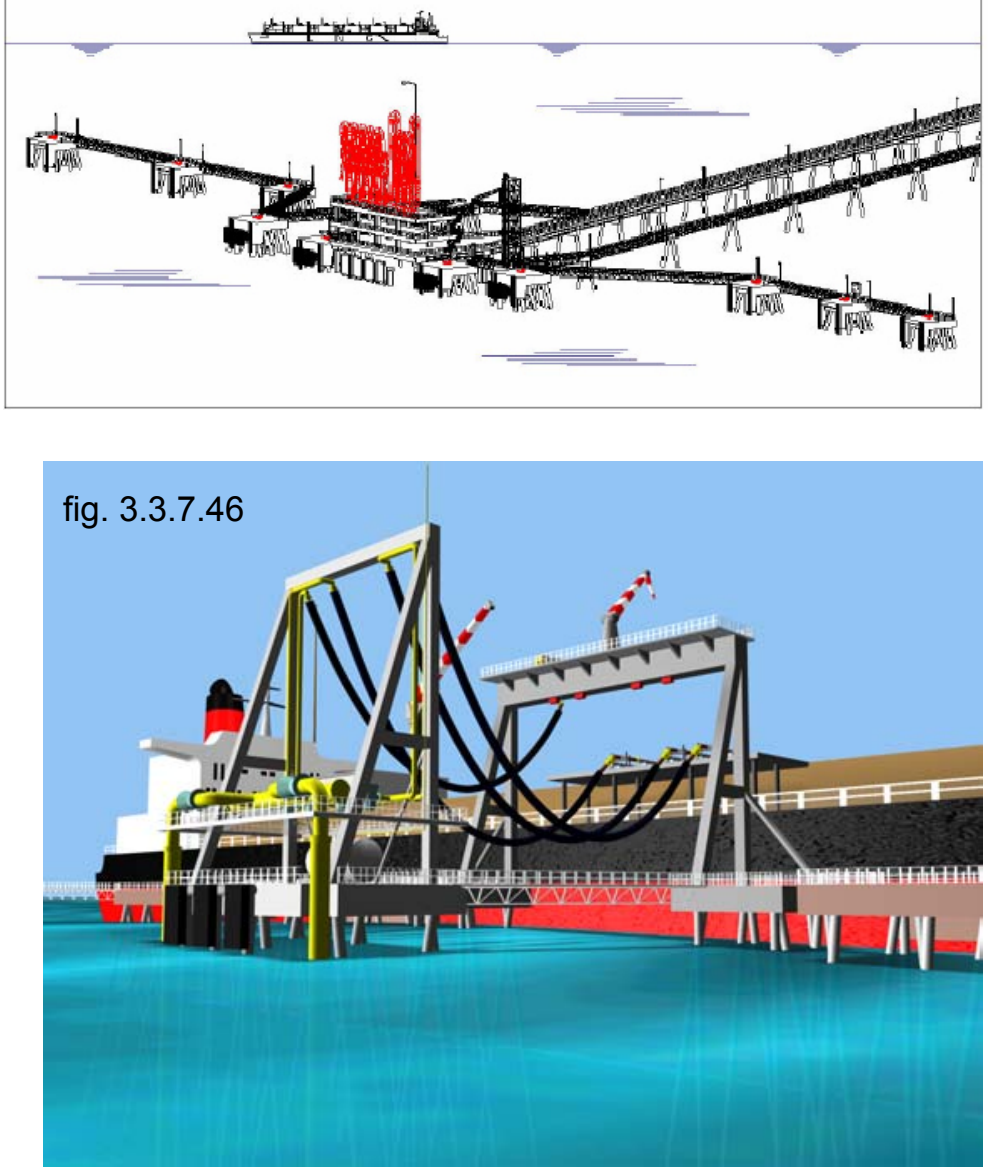
facility.

\section{Conventional Mooring Arrangements and} the "Gerris"

For benign site conditions, e.g. site with Hs ranging from 0.5 to 1.5 meters a conventional mooring jetty without a protective breakwater could be used to secure the LNG vessel. Cargoes could be transferred to shore via subsea cryogenic pipelines or conventional approach trestles. TFE and Eurodim have attempted to reduce conventional jetty cost with the following alternative to the standard OCIMFG/SIGTTO mooring jetty consisting of four breasting and four mooring dolphins fig 3.3.7.45.

The "Gerris," (fig. 3.3.7-46 \& 47) another concept by TFE and Eurodim was devised to determine the feasibility of offloading a nondedicated LNG ship at sea. À cost estimate for the "Gerris" jetty and an approach trestle of 2,500 and 5,000 meters comprised the based case of the project. TFE wanted to be able to, locate the facility some distance from the coast, load and unload dedicated tankers, and take advantage of the cryogenic hose for a more compliant and motion forgiving transfer system. 


\begin{tabular}{|l|l|l|l|}
\hline Customer: & $\begin{array}{l}\text { The United States Department of Energy } \\
\text { National Energy Technology Laboratory }\end{array}$ & $\begin{array}{l}\text { Date of Issue: } \\
29 \text { April } 2003\end{array}$ & \\
\hline $\begin{array}{l}\text { Document } \\
\text { Title: }\end{array}$ & $\begin{array}{l}\text { Subtask 1.2 } \\
\text { Identify Marine Mooring and Offloading Initiatives for LNG Vessels }\end{array}$ & $\begin{array}{l}\text { Doc \# \& Version: } \\
\text { Doc } 003 \text { r. }\end{array}$ & Page 29 of $\mathbf{4 0}$ \\
\hline
\end{tabular}

The hydrodynamic behavior and operating thresholds were assumed to be equal to a traditional jetty.

The study proved the feasibility of the "Gerrris" as an alternative to traditional designs subject to development of the linking technologies to be discussed in the next section.

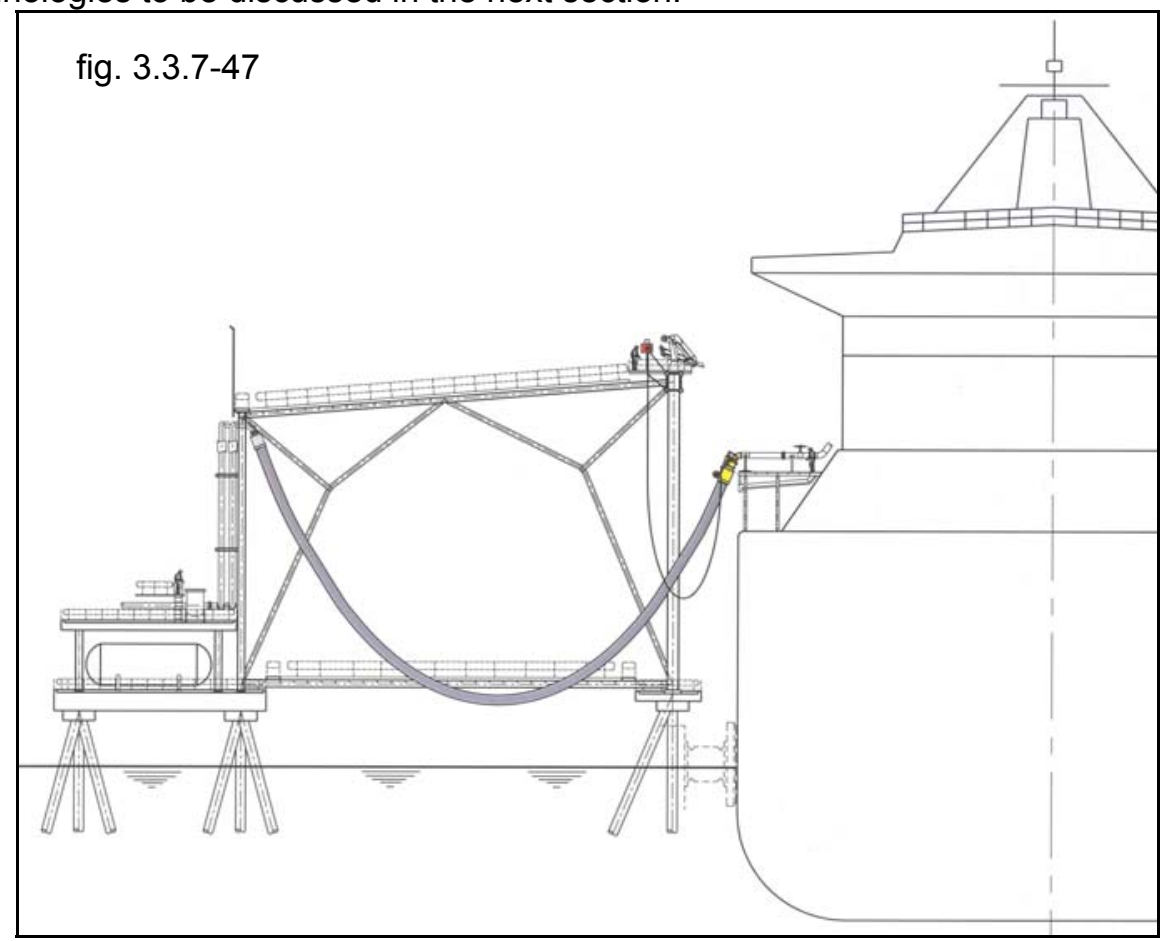




\begin{tabular}{|l|l|l|l|}
\hline Customer: & $\begin{array}{l}\text { The United States Department of Energy } \\
\text { National Energy Technology Laboratory }\end{array}$ & $\begin{array}{l}\text { Date of Issue: } \\
29 \text { April } 2003\end{array}$ & \\
\hline $\begin{array}{l}\text { Document } \\
\text { Title: }\end{array}$ & $\begin{array}{l}\text { Subtask 1.2 } \\
\text { Identify Marine Mooring and Offloading Initiatives for LNG Vessels }\end{array}$ & $\begin{array}{l}\text { Doc \# \& Version: } \\
\text { Doc } 003 \text { r4.0 }\end{array}$ & Page $\mathbf{3 0}$ of $\mathbf{4 0}$ \\
\hline
\end{tabular}

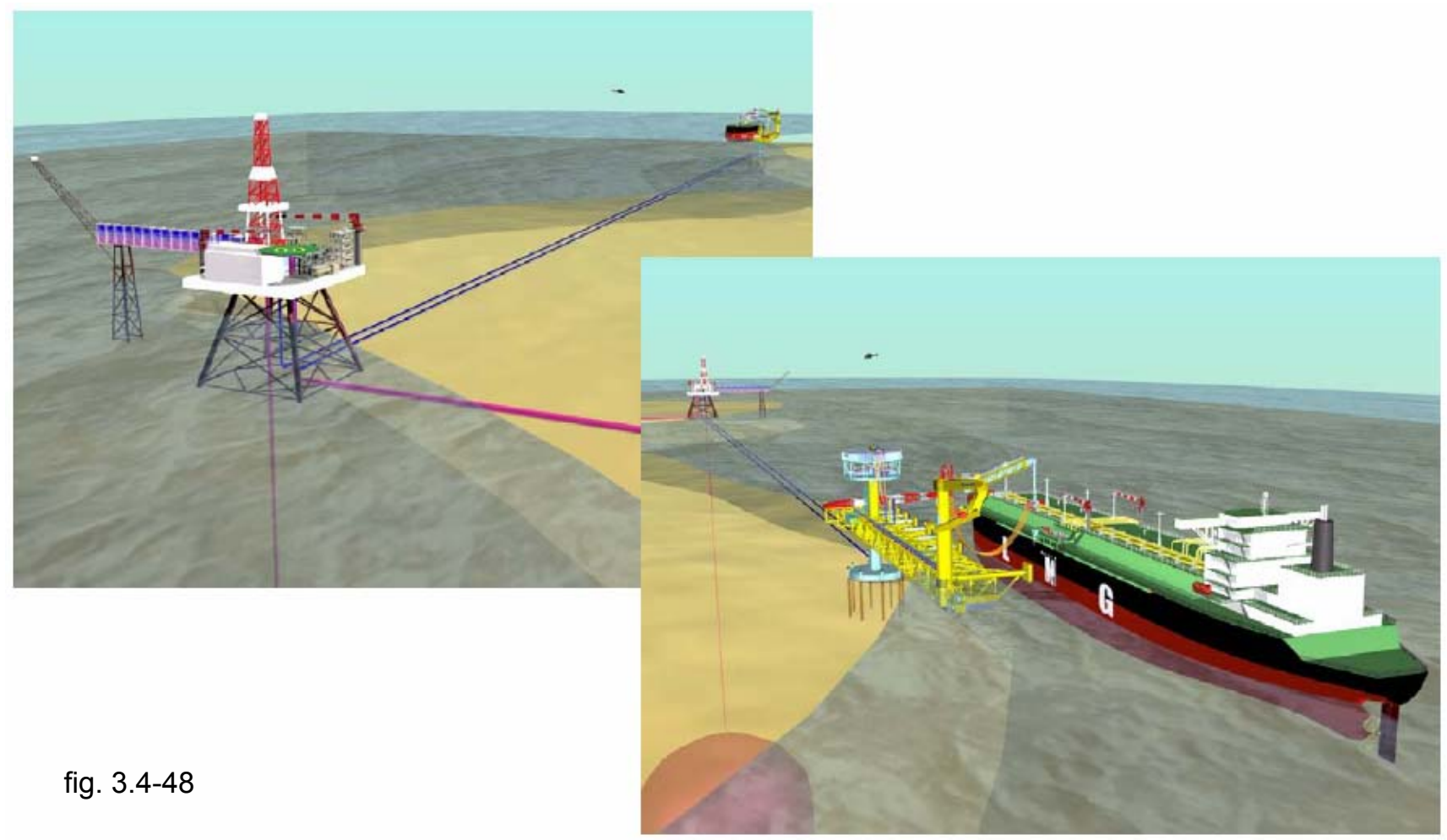

\subsection{Conceptual Offshore Terminal}

Bluewater Offshore Group, a contributor to this study, has proposed the below facility as an option for the receiving of LNG offshore for salt cavern storage (fig 3.4-48). This conceptual design could be located in water of from 60 to 200 feet, and addresses many of the offshore transfer concerns of the LNG producers. For additional details, please refer to Task 2.0 to further review the conceptual design of this offshore terminal concept. 


\begin{tabular}{|l|l|l|l|}
\hline Customer: & $\begin{array}{l}\text { The United States Department of Energy } \\
\text { National Energy Technology Laboratory }\end{array}$ & $\begin{array}{l}\text { Date of Issue: } \\
29 \text { April } 2003\end{array}$ & \\
\hline $\begin{array}{l}\text { Document } \\
\text { Title: }\end{array}$ & $\begin{array}{l}\text { Subtask 1.2 } \\
\text { Identify Marine Mooring and Offloading Initiatives for LNG Vessels }\end{array}$ & $\begin{array}{l}\text { Doc \# \& Version: } \\
\text { Doc } 003 \text { r4.0 }\end{array}$ & Page $\mathbf{3 1}$ of $\mathbf{4 0}$ \\
\hline
\end{tabular}

\section{LINK TECHNOLOGIES TO FACILITATE LNG OFFSHORE TRANSFER}

\subsection{The Extended Travel Loading Arm}

Offshore Ship to Ship LNG Arms with Hydraulic Coupler and Optional Targeting System

Application

Calm to Moderate Motion Offshore Ship to Ship Transfer

Guidelines for Motion Between Ships During Connection

- Max. Vertical Flange Displacement for Connection:

- Max. Horizontal Flange Displacement for Connection:

$+/-2.0 \mathrm{M}$

- Max. Flange Velocity for Connection:

- Max. Flange Acceleration for Connection

$+/-1.7 \mathrm{M}$

$+/-1.0 \mathrm{M} / \mathrm{Sec}$

$+/-0.5 \mathrm{M} / \mathrm{Sec} 2$

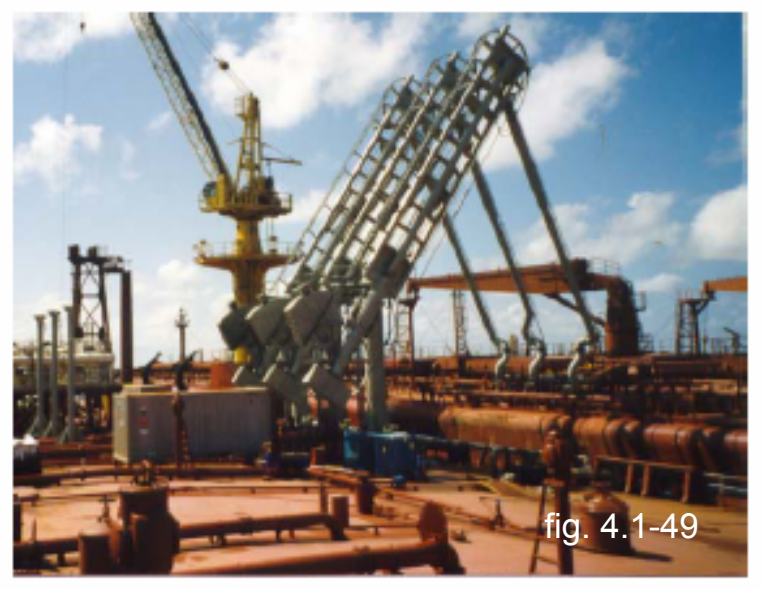

\section{Ship to Ship Offshore Chiksan LNG Loading Arms}

Key Advantages:

- Chiksan Proven LNG Constant Motion Swivel Joints to Eliminate

Excessive Wear Caused by Wave Action

- Removable Elbows \& Cartridge Swivel Joints for In Situ Maintenance

- Chiksan Emergency Release System (Meets OCIMF 1999)

- Position Monitoring System for Ultimate Loading Safety

- Chiksan LNG Hydraulic Coupler for Safe, Reliable Connection in an

Unstable (Moving) Environment with Patented Seal Protection System

(Meets OCIMF 1999)

- Optional Targeting System to Ensure Connection in Roughest

Environments 


\begin{tabular}{|l|l|l|l|}
\hline Customer: & $\begin{array}{l}\text { The United States Department of Energy } \\
\text { National Energy Technology Laboratory }\end{array}$ & $\begin{array}{l}\text { Date of Issue: } \\
29 \text { April } 2003\end{array}$ & \\
\hline $\begin{array}{l}\text { Document } \\
\text { Title: }\end{array}$ & $\begin{array}{l}\text { Subtask 1.2 } \\
\text { Identify Marine Mooring and Offloading Initiatives for LNG Vessels }\end{array}$ & $\begin{array}{l}\text { Doc \# \& Version: } \\
\text { Doc } 003 \text { r4.0 }\end{array}$ & Page $\mathbf{3 2}$ of $\mathbf{4 0}$ \\
\hline
\end{tabular}

The extended travel arms in figure 4.1-49 could be employed in benign environments for side by side LNG transfer with high availability. However, availability in moderate environments would suffer.

\subsection{The Pantograph Loading Arm for Tandem Transfer}

Application

Moderate to Severe Motion Offshore With Large Distance between Vessels

Guidelines for Motion between Vessels during Connection:

- Up to 5.0 M Significant Wave Heights

- Max. Heave

- Max. Flange Velocity for Connection

- Max. Flange Acceleration for Connection

$$
\begin{aligned}
& \text { +/- } 5.0 \mathrm{M} \\
& +/-2.5 \mathrm{M} / \mathrm{Sec} \\
& +/-2.5 \mathrm{M} / \mathrm{Sec} 2
\end{aligned}
$$

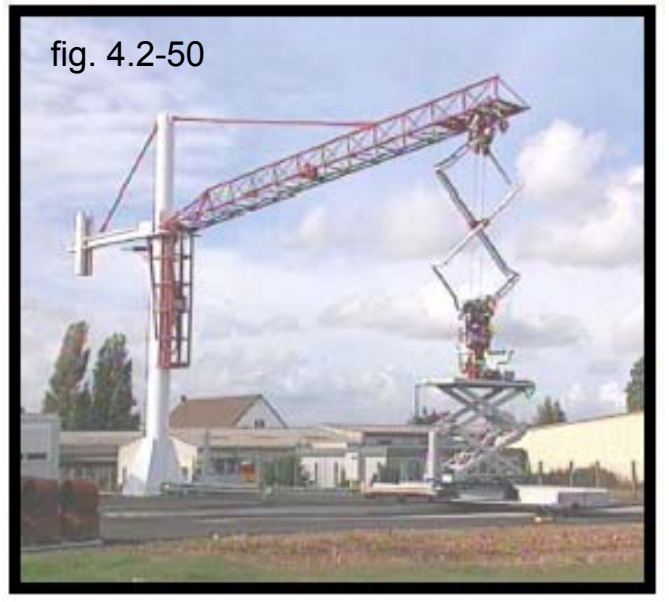

Key LNG Transfer Advantages:

- Chiksan Proven LNG Constant Motion Swivel Joints to Eliminate Excessive Wear Caused by Wave Action

- Removable Elbows \& Cartridge Swivel Joints for In Situ Maintenance

- Chiksan Emergency Release System (Meets OCIMF 1999)

- Position Monitoring System for Ultimate Loading Safety

- Chiksan LNG Hydraulic Coupler for Safe, Reliable Connection in an Unstable (Moving) Environment with Patented Seal Protection System (Meets OCIMF 1999)

- Targeting System to Ensure Connection in Roughest Environments

- Available with Double Pantograph System (1-24 "Liquid Line and 116"Vapor) or Twin type Double Pantograph System (3-16" Liquid Lines and 1-16" Vapor Line)

- 10,000 M3 Loading Rate with Double Pantograph System

FMC's Pantograph loading arm (fig. 4.2-50) is an important link technology that is currently being tested at FMC's facilities in France. With million of cycles and many more planned, the Pantograph loading arm is now ready for commercial use.

The Boom to Tanker Tethered Tandem Loading System (fig. 4.2-51) right uses FMC's pantograph loading shown in a tethered arrangement with a built for purpose crane and boom to facilitate hook-up. The industry has requested a more robust system for mooring purposes and the technology by FMCSofec in Section 3.3.3 is the result. Its articulated technology and proven swivel arrangement reduces transfer risk, but the tandem loading arrangement precludes all existing LNG tankers

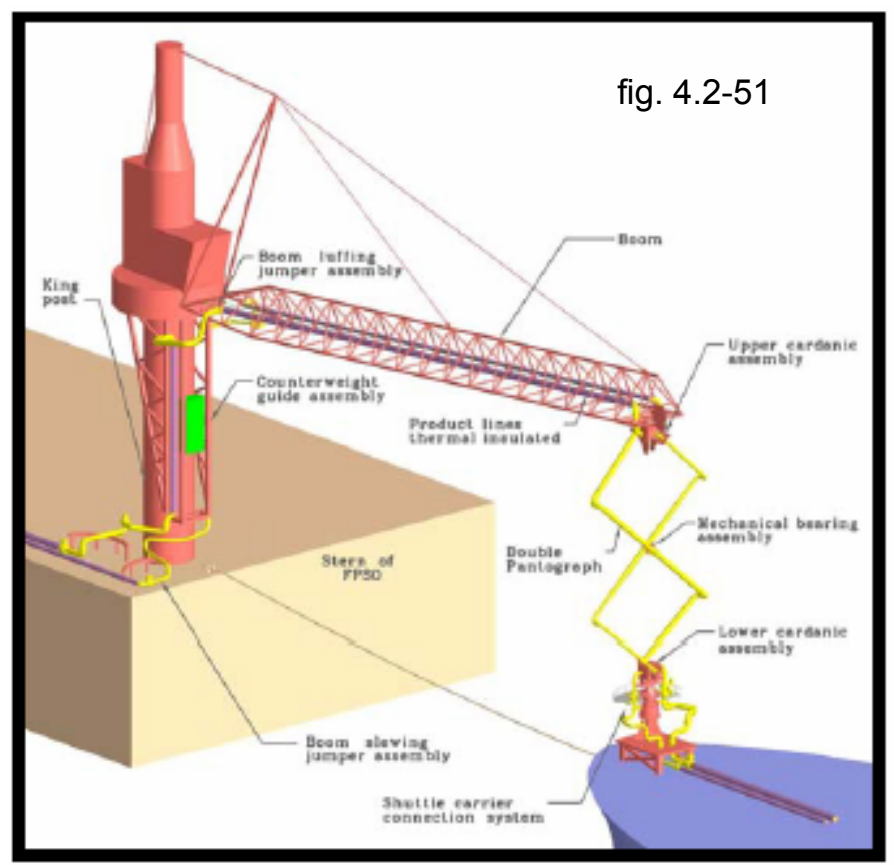




\begin{tabular}{|l|l|l|l|}
\hline Customer: & $\begin{array}{l}\text { The United States Department of Energy } \\
\text { National Energy Technology Laboratory }\end{array}$ & $\begin{array}{l}\text { Date of Issue: } \\
29 \text { April } 2003\end{array}$ & \\
\hline $\begin{array}{l}\text { Document } \\
\text { Title: }\end{array}$ & $\begin{array}{l}\text { Subtask 1.2 } \\
\text { Identify Marine Mooring and Offloading Initiatives for LNG Vessels }\end{array}$ & $\begin{array}{l}\text { Doc \# \& Version: } \\
\text { Doc } 003 \text { r..0 }\end{array}$ & Page $\mathbf{3 3}$ of $\mathbf{4 0}$ \\
\hline
\end{tabular}

\subsection{Cryogenic Swivels}

The cryogenic swivel is a key linking technology that must be employed in almost any offshore LNG terminal design. The liquid swivels must meet the following conditions:

Flow rate from 5,000 to $10,000 \mathrm{~m} 3 / \mathrm{hr}$

Diameters from 16 " to 24 "

Service temperature $-163^{\circ} \mathrm{C}$

Design Pressure 20 bar

The vapor swivels must meet the following conditions:

Service temperature $-120^{\circ} \mathrm{C}$

Design Pressure 6 bar absolute

\subsubsection{FMC}

FMC is the recognized leader in the manufacture and worldwide use of the cryogenic swivel. While several companies have swivel applications in LPG transfer systems, FMC has over 30 years of LNG swivel design, operation, and maintenance. The

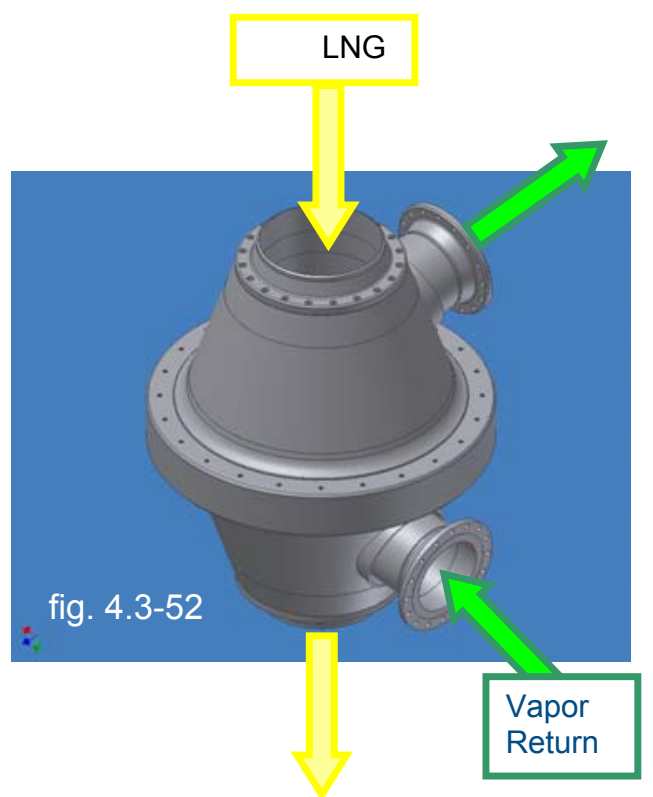
LNG industry maintains a strong confidence in the cryogenic swivels designed and built by FMC.

\subsubsection{SBM and Eurodim}

On a parallel path with FMC, SBM and Eurodim are also developing cryogenic swivels. SBM is currently testing a full scale model of its LNG swivel, and has operated the unit through many cycles. Neither company has certified its LNG swivels, but design is well past the conceptual phase.

\subsection{The Flexible Transfer Hose}

The flexible cryogenic transfer hose developed by Technip-Coflexip has already been built and tested for over 1.5 million cycles under cryogenic and warm conditions. Technip-Coflexip promoted the JIP for the development of the 16" cryogenic hose (description fig. 4.4-53 \& 54) to be used for LNG transfer offshore. Participants in this JIP were BP, BHP, Chevron, Gaz de France and Shell. The hose tested met all criteria, and Technip-Coflexip proved that lengths of up to $100 \mathrm{~m}$ of identical composition could be manufactured in their facilities in La Trait. However, production of the $100 \mathrm{~m}$ hose is approximately 12 months from realization.

Others not pictured yet very much involved in the design and fabrication of LNG cryogenic hoses

fig. $4.4-53$

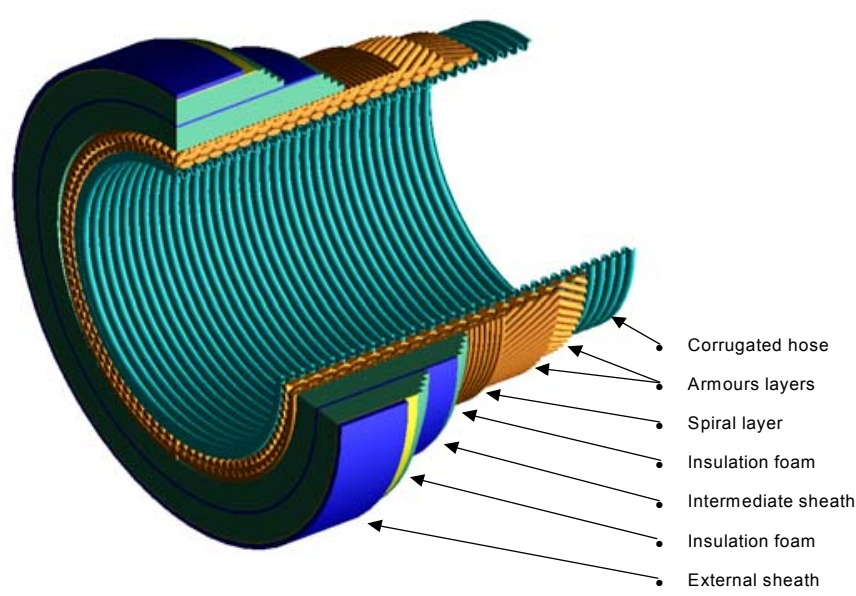




\begin{tabular}{|l|l|l|l|}
\hline Customer: & $\begin{array}{l}\text { The United States Department of Energy } \\
\text { National Energy Technology Laboratory }\end{array}$ & $\begin{array}{l}\text { Date of Issue: } \\
29 \text { April } 2003\end{array}$ & \\
\hline $\begin{array}{l}\text { Document } \\
\text { Title: }\end{array}$ & $\begin{array}{l}\text { Subtask 1.2 } \\
\text { Identify Marine Mooring and Offloading Initiatives for LNG Vessels }\end{array}$ & $\begin{array}{l}\text { Doc \# \& Version: } \\
\text { Doc } 003 \text { r4.0 }\end{array}$ & Page $\mathbf{3 4}$ of $\mathbf{4 0}$ \\
\hline
\end{tabular}

include the joint venture sponsored by ExxonMobil with SeriorFlexonics, and Alcatel Cryoflex ${ }^{\mathrm{TM}}$ Flexible Pipe a division of Nexans, A.S.

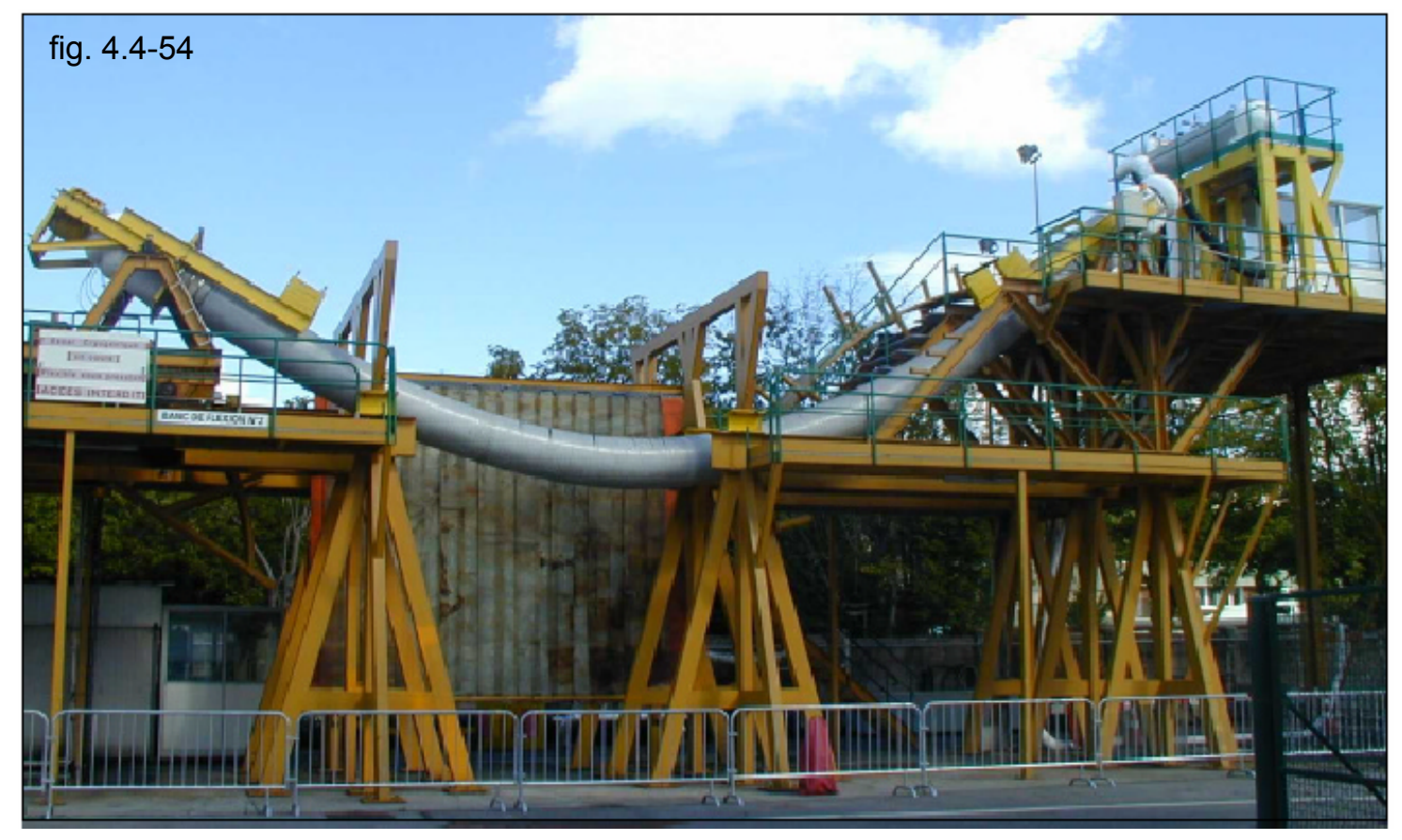

\subsubsection{The connection interface}

In conjunction with the hose test, Amri-KSB, Technip-Coflexip, and Eurodim formed a consortium to develop and test a connecting system compatible with a typical LNG ship manifold. The connection system was to have the means for automatic connection a t sea, and integrate all the necessary components including emergency shutdown and quick connect/disconnect couplers.

The connecting system has been developed with the following design philosophy:

- Safety is priority.

- Reliability is priority - avoid complexity and sophistication

- Respect of flexible hose integrity and behaviour predictability under all circumstances

- "Blind" connection and disconnection in dynamic conditions

- Safe and reliable emergency disconnection with very minimal spillage: "no spill"

- Minimal weight to maximize dynamic connection performances

- Outboard connection to avoid compatibility issues (fig. 4.4.1-55)

- Connection handling along the main acceleration axis (fig. 4.4.1-56) so that the mobile mass is simply hanging on the lifting cable which also serves also as a guiding cable ensuring that the pin and receiver cleanly mate. 


\begin{tabular}{|l|l|l|l|}
\hline Customer: & $\begin{array}{l}\text { The United States Department of Energy } \\
\text { National Energy Technology Laboratory }\end{array}$ & $\begin{array}{l}\text { Date of Issue: } \\
29 \text { April } 2003\end{array}$ & \\
\hline $\begin{array}{l}\text { Document } \\
\text { Title: }\end{array}$ & $\begin{array}{l}\text { Subtask 1.2 } \\
\text { Identify Marine Mooring and Offloading Initiatives for LNG Vessels }\end{array}$ & $\begin{array}{l}\text { Doc \# \& Version: } \\
\text { Doc } 003 \text { r4.0 }\end{array}$ & Page $\mathbf{3 5}$ of $\mathbf{4 0}$ \\
\hline
\end{tabular}

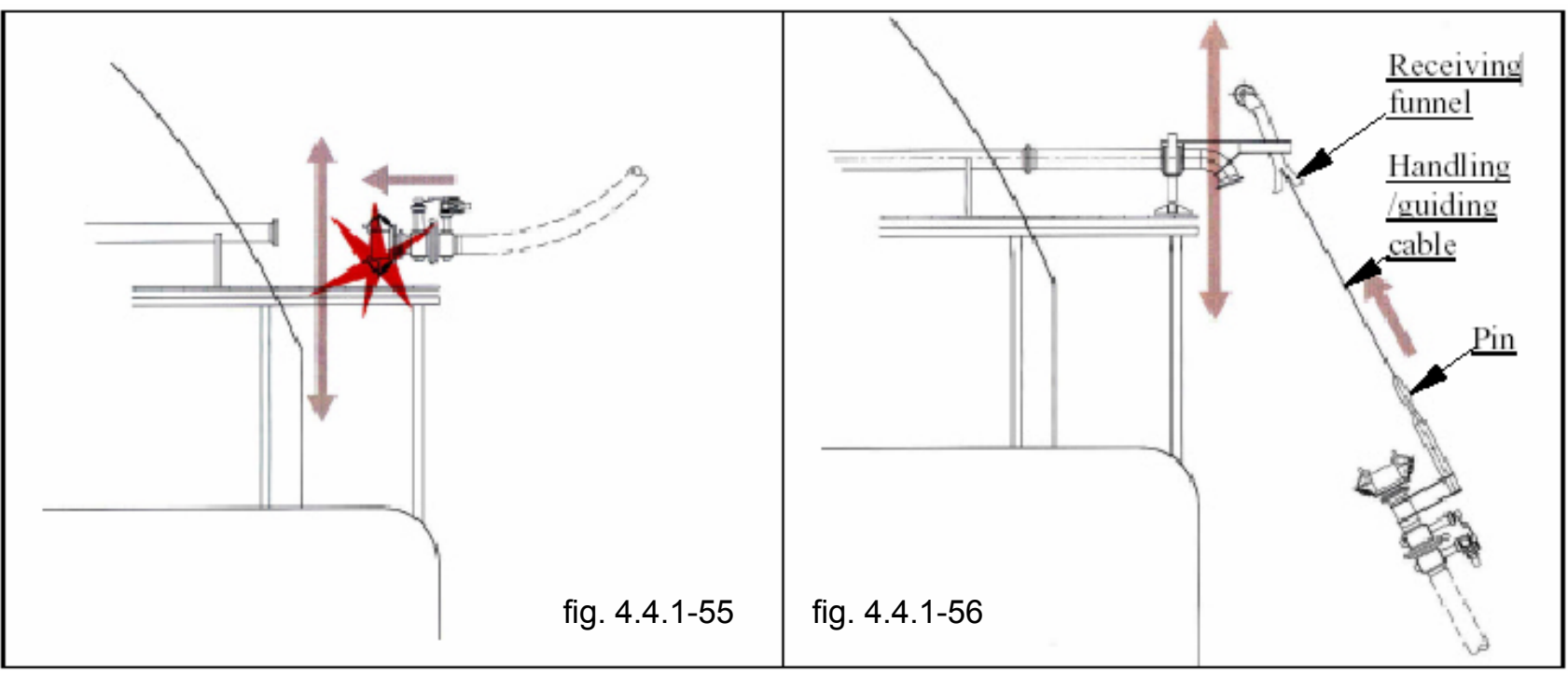

Figures 4.4.1-57 and 58 show the connecting system developed by the consortium this year.

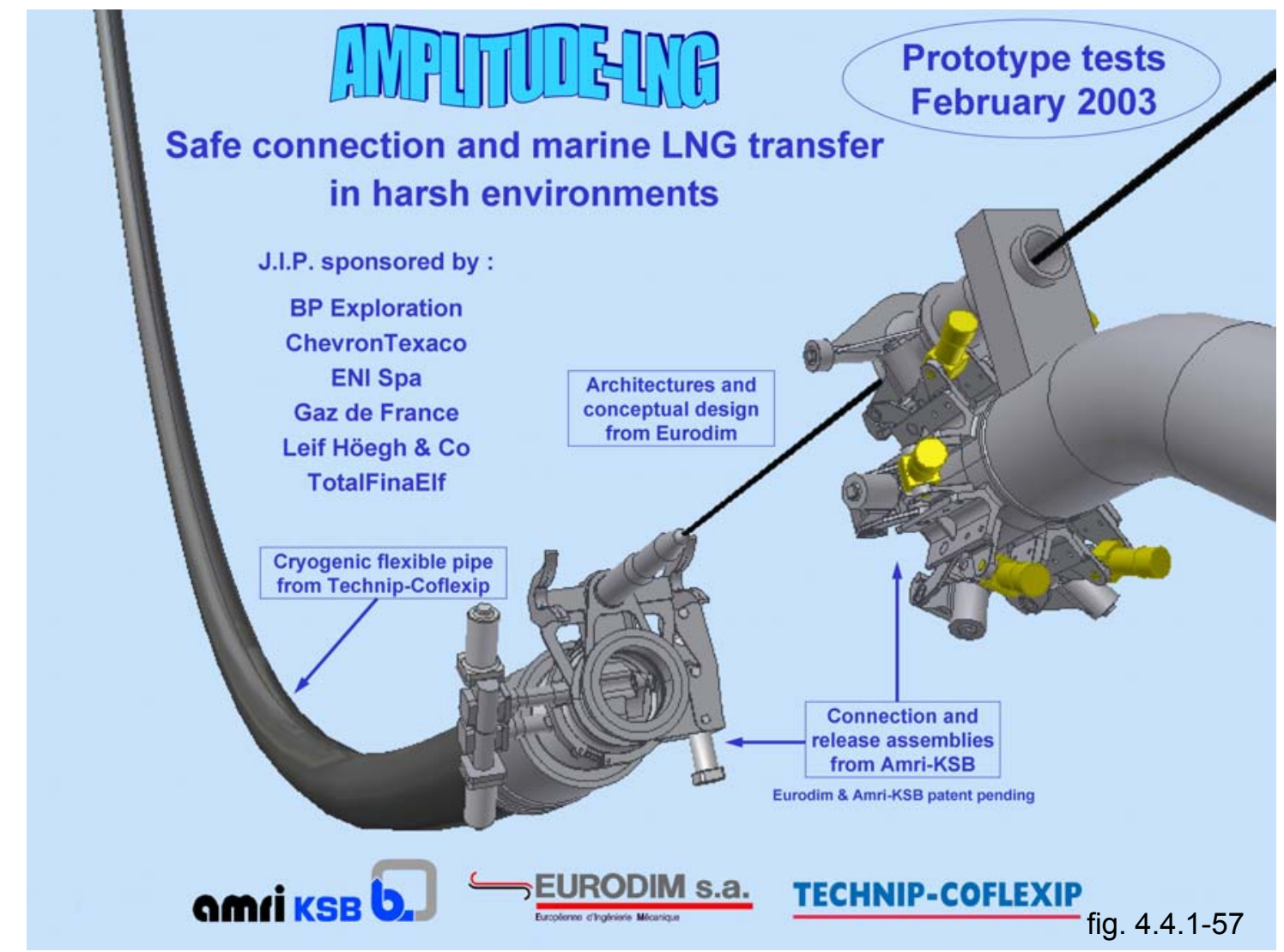




\begin{tabular}{|l|l|l|l|}
\hline Customer: & $\begin{array}{l}\text { The United States Department of Energy } \\
\text { National Energy Technology Laboratory }\end{array}$ & $\begin{array}{l}\text { Date of Issue: } \\
29 \text { April } 2003\end{array}$ & \\
\hline $\begin{array}{l}\text { Document } \\
\text { Title: }\end{array}$ & $\begin{array}{l}\text { Subtask 1.2 } \\
\text { Identify Marine Mooring and Offloading Initiatives for LNG Vessels }\end{array}$ & $\begin{array}{l}\text { Doc \# \& Version: } \\
\text { Doc } 003 \text { r. } 4\end{array}$ & Page $\mathbf{3 6}$ of $\mathbf{4 0}$ \\
\hline
\end{tabular}

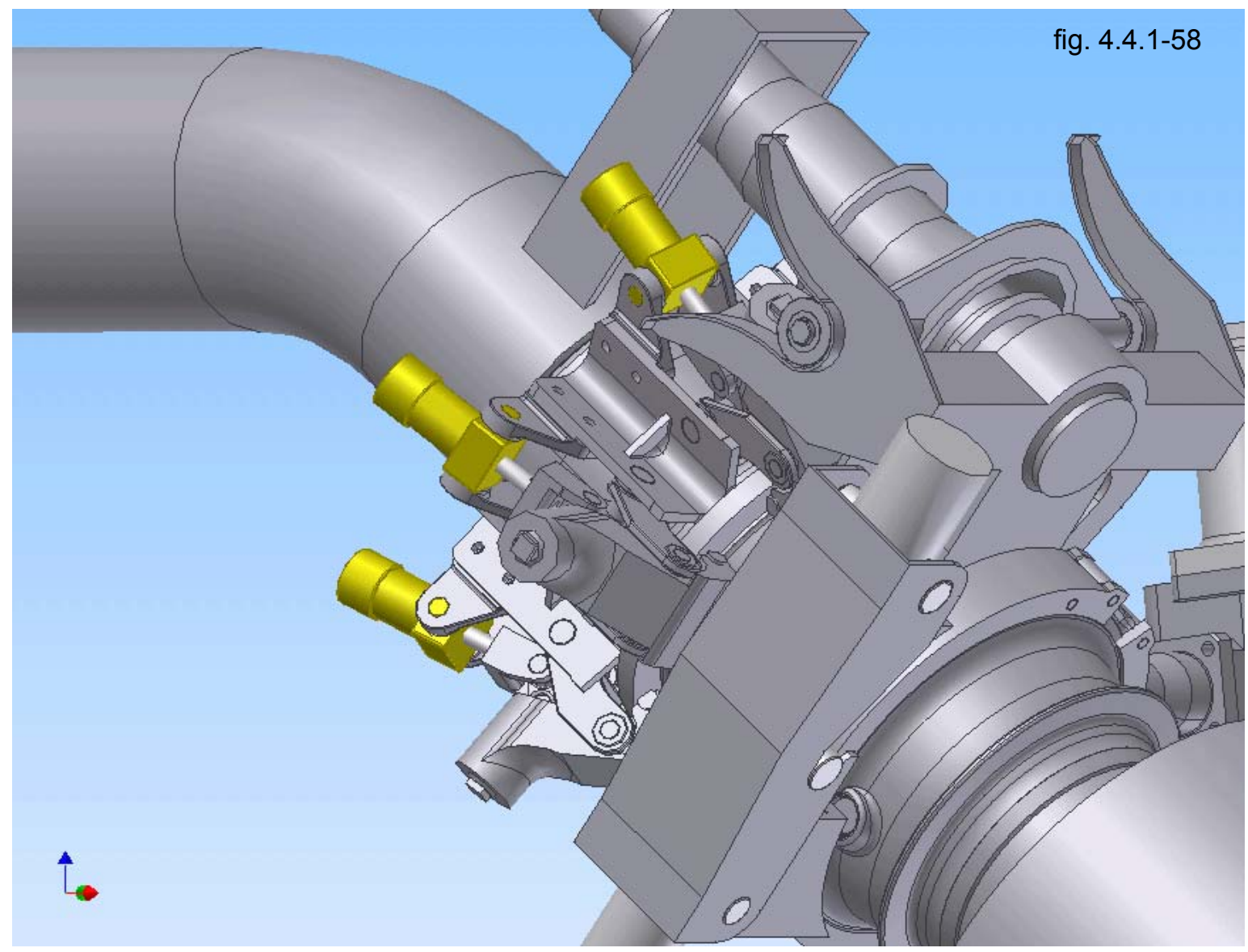

\subsection{The Cryogenic Pipeline}

\subsubsection{Conventional LNG transfer scheme}

The link between an LNG carrier and the onshore terminal storage area is defined by the transfer facilities, which typically feature:

a. A marine jetty head with berthing and mooring dolphins, connected to a platform, fitted with a gangway, loading arms, and some process related equipment

b. An approach trestle (or causeway), which supports the cryogenic pipelines. Typically two LNG pipelines in the diameter range of 20 to 40 inches, used in parallel during cargo transfer, and in series to keep the piping cold in stand-by mode. Utility piping, wiring and fiber optics for electrical and telecommunication, and a maintenance road atop the trestle for equipment access complete the design. The cold vapor return piping to and from the LNG storage tanks also services the dock via the approach trestle.

ITP's proposed subsea cryogenic pipeline could replace the expensive approach trestle (fig. 4.5.1-59) and reduce the construction and operation costs of LNG transfer facilities, as seen in the following photograph. 


\begin{tabular}{|l|l|l|l|}
\hline Customer: & $\begin{array}{l}\text { The United States Department of Energy } \\
\text { National Energy Technology Laboratory }\end{array}$ & $\begin{array}{l}\text { Date of Issue: } \\
29 \text { April } 2003\end{array}$ & \\
\hline $\begin{array}{l}\text { Document } \\
\text { Title: }\end{array}$ & $\begin{array}{l}\text { Subtask 1.2 } \\
\text { Identify Marine Mooring and Offloading Initiatives for LNG Vessels }\end{array}$ & $\begin{array}{l}\text { Doc \# \& Version: } \\
\text { Doc } 003 \text { r4.0 }\end{array}$ & Page $\mathbf{3 7}$ of $\mathbf{4 0}$ \\
\hline
\end{tabular}

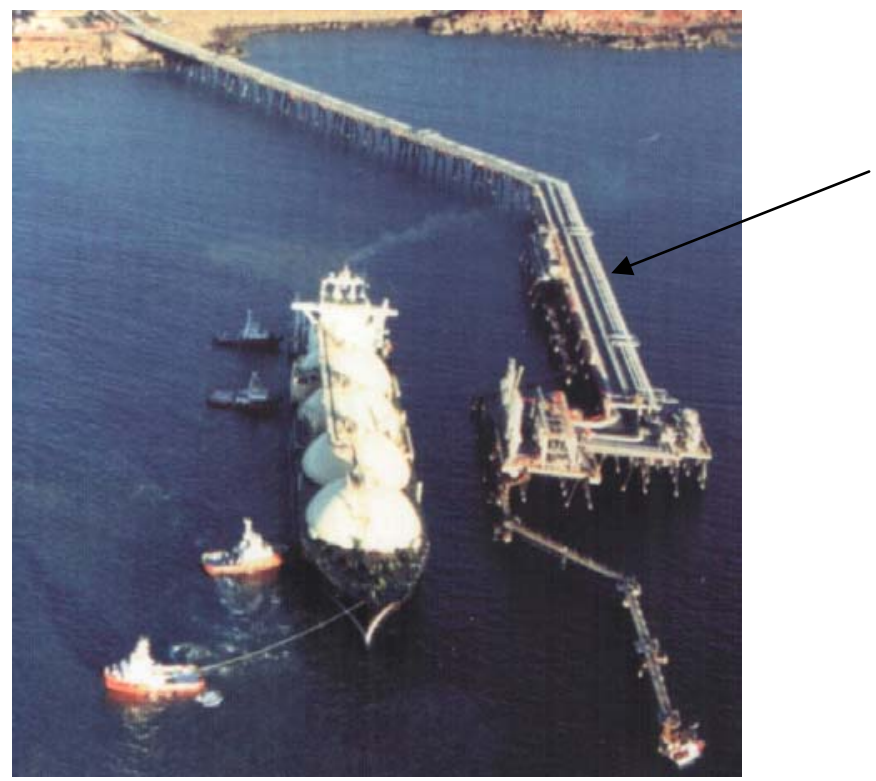

Typical LNG Jetty

Approach Trestle supporting $L N G$ pipelines, utilities, vapor return, and roadway

fig. 4.5.1-59

\subsubsection{Objectives of the subsea cryogenic pipe}

The subsea cryogenic pipeline provides the fluid connection between the offloading platform and the onshore storage facility.

The main criteria that led to the final design of the ITP subsea LNG pipe system are the following:

a. Cost reduction. Use of a cryogenic subsea pipeline is a major part of a larger industry focus to reduce the costs of the LNG chain. However, gas operators will consider purchasing this new architecture only if significant cost savings are achieved in comparison to conventional offloading technologies. By avoiding the civil work associated with the trestle, the cryogenic subsea pipeline can be built in less time and offers significant construction cost savings. TotalFinaElf estimated that overall costs could be reduced by 20 to 40 million USD, including the jetty head. Marine facility savings are further increased if the use of ITP's subsea pipeline technology precludes the construction of a large marine breakwater.

b. Environment: Two main environmental objectives are targeted :

- Visual impact. The near shore and shore side view is no longer impacted by a long artificial trestle, a source of great satisfaction to the local population.

- Normal local marine traffic can continue on course without being hindered by the trestle

c. Wider range of LNG terminal locations. The subsea cryogenic pipeline is capable of handling challenging marine conditions yet still allows erection of offshore LNG terminals in environments that heretofore were ill suited for LNG terminal use. By proposing a technique that offers the flexibility of locating the LNG transfer point far away from the coast, ITP gives the gas operators more choices for siting their LNG terminals (e.g. industrial area, coastal areas with shallow draught, etc.). 


\begin{tabular}{|l|l|l|l|}
\hline Customer: & $\begin{array}{l}\text { The United States Department of Energy } \\
\text { National Energy Technology Laboratory }\end{array}$ & $\begin{array}{l}\text { Date of Issue: } \\
29 \text { April } 2003\end{array}$ & \\
\hline $\begin{array}{l}\text { Document } \\
\text { Title: }\end{array}$ & $\begin{array}{l}\text { Subtask 1.2 } \\
\text { Identify Marine Mooring and Offloading Initiatives for LNG Vessels }\end{array}$ & $\begin{array}{l}\text { Doc \# \& Version: } \\
\text { Doc } 003 \text { r..0 }\end{array}$ & Page $\mathbf{3 8}$ of $\mathbf{4 0}$ \\
\hline
\end{tabular}

\subsubsection{Challenges remaining}

The main challenges associated with the subsea LNG pipeline are:

a. Cryogenic environment

- The materials of construction have to be resistant to low temperature.

- The shrinkage of the pipe has to be accommodated.

b. Simple and robust design The Operators participating in the ongoing development of the subsea cryogenic pipeline generally require that the selected design has to avoid the use of complex devices or high technology components which typically increase OPEX (maintenance cost) CAPEX, and the risk of system failure. On this basis, concepts such as those described previously (underwater tunnels or subsea expansion loops / expansion joints) could not be considered.

c. High thermal performance Due to the length of line envisioned (typically more than $1 \mathrm{~km}$ ), heat transfer between the LNG pipe and the sea environment has to be reduced as much as possible. Therefore the insulation system has to be highly thermally effective, water tight, and strong enough to permit handling and installation.

d. Reliability and safety The proposed system (fig. 4.5.3-60) has to be long lived and able to withstand the various stress/strain conditions both during installation and LNG transfer operations. If possible, the system should to be fail-safe, i.e. the pipeline should remain operational in case of local damage.

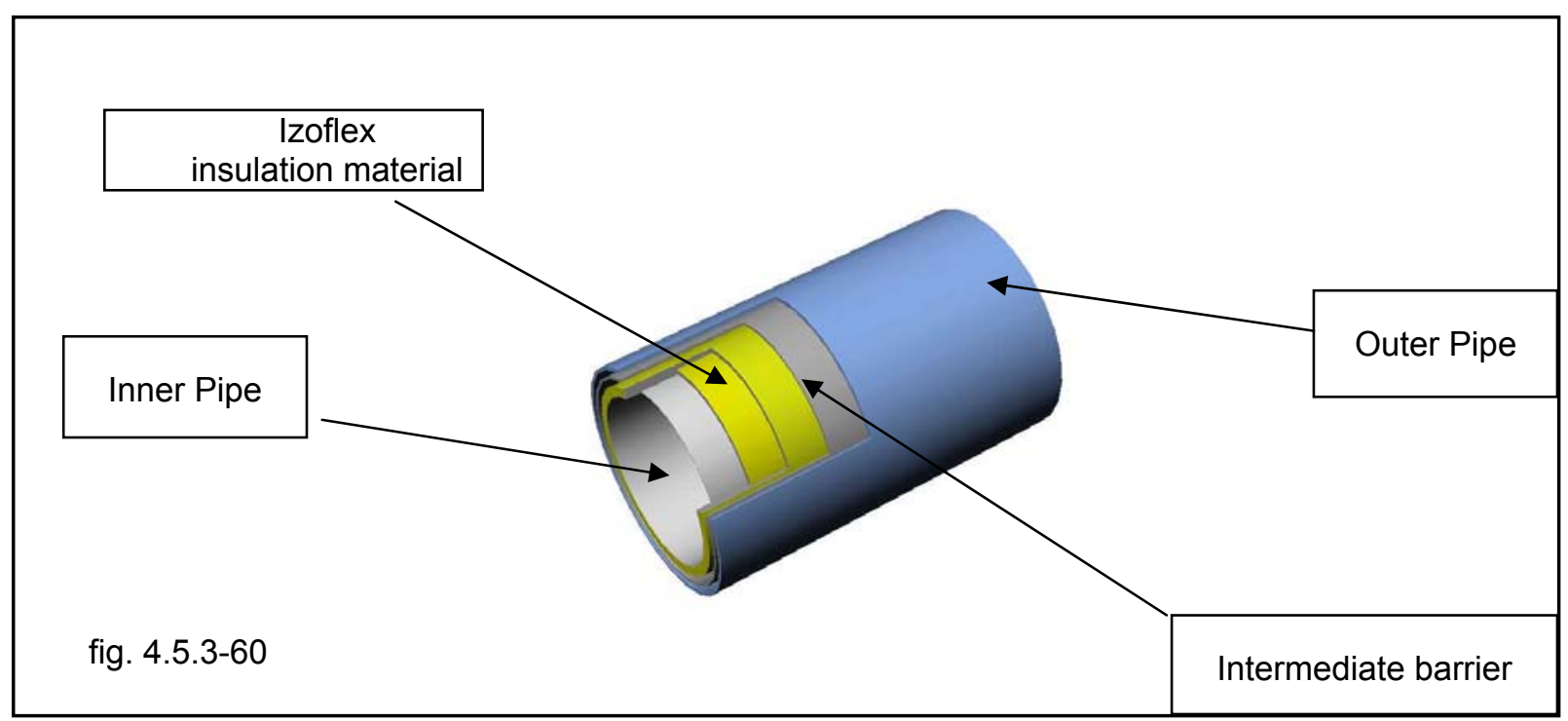




\begin{tabular}{|l|l|l|l|}
\hline Customer: & $\begin{array}{l}\text { The United States Department of Energy } \\
\text { National Energy Technology Laboratory }\end{array}$ & $\begin{array}{l}\text { Date of Issue: } \\
29 \text { April } 2003\end{array}$ & \\
\hline $\begin{array}{l}\text { Document } \\
\text { Title: }\end{array}$ & $\begin{array}{l}\text { Subtask 1.2 } \\
\text { Identify Marine Mooring and Offloading Initiatives for LNG Vessels }\end{array}$ & $\begin{array}{l}\text { Doc \# \& Version: } \\
\text { Doc } 003 \text { r4.0 }\end{array}$ & Page $\mathbf{3 9}$ of $\mathbf{4 0}$ \\
\hline
\end{tabular}

\section{INDUSTRY PREFERRED TRANSFER SCHEMES}

The most significant LNG offshore terminal designs have been presented in this section. The all important LNG links connecting the shore or process facility also have been outlined above. Many of these units already exist and are waiting for additional development, or the development of complimentary/enabling technologies.

Interviews over the course of this study with the major producers and potential importers of LNG indicated that the industry wants an offshore terminal capable of the following:

- High availability at $98 \%$ or above

- A site specific fit for purpose design with high reliability

- Side by side LNG transfer

- Rapid transfer rates at $10,000 \mathrm{~m} 3$ or above

- Risk's judged to be equivalent with traditional terminals

- Lower CAPEX and OPEX

\section{CONCLUSION}

The results of this industry survey are included in the attached matrix, however, for the convenieince of the reader, a summary of findings follows.

A thorough review of the technologies that are currently used in the transfer of hydrocarbons offshore indicate that many of the technologies and operational procedures can be employed by the LNG industry. For example, ship to ship transfer of oil and LPG has become a time tested, proven and reliable technology. The use of tugs, hawsers, and floating hoses, facilitates both side by side and tandem arrangements. Transferring petroleum products via Single Point Moorings (SPM's) and Catenary Anchored Leg Mooring (CALM) Buoys have provided additional savings and reliability. Floating Production Storage Offshore (FPSO's) have also grown in size and complexity and have been safely operated world wide.

Running in parallel with the technological advancements pursuant to the offshore oil industry, the LNG trade has accumulated extensive operational experience over the last 30 years. LNG on-shore facilities employ process technologies similar to the oil industry howbeit with upgraded metallurgies to accommodate the cryogenic temperatures (LNG is $-160^{\circ} \mathrm{C}$ ). The LNG trade has taken advantage of process modeling, FEA, CAD, and CAM resulting in rapid growth and excellent safety records for LNG manufacturing, storage, transportation, and regasification. Economies of scale, and lower equipment cost now make offshore LNG transfer possible. Among the many advantages:

- Reduced NIMBY concerns

- Reduced permitting requirements

- Quicker regulatory approval process

- $\quad$ Siting flexibility

- Reduced construction times

- Possibility for substantial reduction in CAPEX and OPEX

The study was awarded to CGI to prove the feasibility of developing a new LNG receiving and storage process. Task 1.2 identifying marine mooring and offloading initiatives compares the existing and proposed LNG offshore transfer technologies, identifies the commonalities, and recognizes industry requirements and transfer preferences. 


\begin{tabular}{|l|l|l|l|}
\hline Customer: & $\begin{array}{l}\text { The United States Department of Energy } \\
\text { National Energy Technology Laboratory }\end{array}$ & $\begin{array}{l}\text { Date of Issue: } \\
29 \text { April } 2003\end{array}$ & \\
\hline $\begin{array}{l}\text { Document } \\
\text { Title: }\end{array}$ & $\begin{array}{l}\text { Subtask 1.2 } \\
\text { Identify Marine Mooring and Offloading Initiatives for LNG Vessels }\end{array}$ & $\begin{array}{l}\text { Doc \# \& Version: } \\
\text { Doc } 003 \text { r..0 }\end{array}$ & Page $\mathbf{4 0}$ of $\mathbf{4 0}$ \\
\hline
\end{tabular}

Several offshore transfer challenges were identified including:

- The need for a secure mooring arrangement sufficient for cargo transfer

- The need to minimize the relative motion between LNG vessel and transfer facility

- The requirement to develop materials and technologies to safely facilitate LNG transfer and handling

- The ability to transfer LNG at sea using the LNG carrier's existing manifolds

- Reduced cost: New technology must be cheaper to mitigate risk weighting

In addition to the actual facility used to move the LNG between the terminal and the LNG vessel, specific links to offloading vessels and shore side facilities have to be employed to accommodate the siting of future offshore LNG terminals. These "link technologies" use clever adaptations of current technologies with upgraded materials and designs to accommodate the rigors of cryogenic service. There is a world wide effort to conceive, design, and test these link technologies with many new and innovative designs coming out of Europe, namely France and the Netherlands. These link technologies include:

- LNG subsea cryogenic pipelines to connect the land based facility with the offshore marine terminal

- Extended travel loading arms to accommodate relatively large ship to ship excursions along three axes

- Flexible loading lines to connect the transfer mechanism to the floating vessel

- Counter weighted yokes and cryogenic swivels to allow tandem ship to ship cargo transfer

- Extended ultra long floating cryogenic hoses and submersible flexible risers to facilitate LNG cargo movement through water without fractures due to freezing

The matrix attached to the end of Task 1.2 summarizes the offshore unloading initiatives included in this document. The matrix provides a convenient format to highlight trends, requirements, and technologies most desired by the LNG industry. Referencing the attached matrix, the LNG offshore industry seems to be moving in the direction described below:

- The offshore mooring should weathervane (rotation of the vessel around a vertical axis), to provide maximum availability, and facilitate maximum stability and minimum motion during LNG transfer operations (Note: Gravity Based Structures by design and installation provide protection from the elements without weathervaning and are exceptions),

- Offshore mooring facilities are expected to have high availability and remain operational, even in rough weather

- Side by side cargo transfer is preferred

- Ship/Shore link technologies are site specific, and development is crucial

- Decreased CAPEX and OPEX over conventional LNG terminals are expected 


\begin{tabular}{|c|c|c|c|c|c|c|c|c|c|c|c|c|}
\hline Description & $\begin{array}{l}\text { Company \& } \\
\text { Application }\end{array}$ & $\begin{array}{c}\text { Contact } \\
\text { Information }\end{array}$ & $\begin{array}{c}\text { Mooring } \\
\text { Design }\end{array}$ & $\begin{array}{c}\text { Transfer } \\
\text { Method \& } \\
\text { Flow Rate } \\
\text { (m3/hr) }\end{array}$ & $\begin{array}{l}\text { Water } \\
\text { Depth } \\
\text { Max/Min }\end{array}$ & $\begin{array}{c}\text { Sea }(\mathrm{Hs}) \\
\text { Condition } \\
\text { Docking }\end{array}$ & $\begin{array}{l}\text { Sea }(H s) \\
\text { Condition } \\
\text { Operating }\end{array}$ & $\begin{array}{c}\text { Site } \\
\text { Condition } \\
\text { Rating }\end{array}$ & Shore Link & $\begin{array}{c}\begin{array}{c}\text { Stage of } \\
\text { Development }\end{array}\end{array}$ & $\begin{array}{c}\text { Completion } \\
\text { Schedule }\end{array}$ & $\begin{array}{c}\text { Facility } \\
\text { Cost } \\
\text { mmUSD }\end{array}$ \\
\hline $\begin{array}{l}\text { SBM Offshore } \\
\text { Terminal }\end{array}$ & $\begin{array}{c}\text { Single Buoy } \\
\text { Moorings, Inc. } \\
\text { Soft Yoke Mooring } \\
\text { Tower } \\
\text { Loading/Unloading }\end{array}$ & $\begin{array}{l}\text { 5 Route de Fribourg } \\
\text { P. O. Box 152 } \\
\text { Marly, Switzerland, } \\
\text { CH-1723 } \\
\text { Tel. - } 37792051434\end{array}$ & Weathervaning & $\begin{array}{c}\text { Tandem } \\
\text { Bow Manifold } \\
\text { Liq. 12,000 }\end{array}$ & $\begin{array}{c}\text { No limit } \\
25 \mathrm{~m}\end{array}$ & 3.0 & $5.5 \mathrm{~m}$ & Severe & $\begin{array}{l}\text { Rec. Terminal: } \\
\text { Tandem un- } \\
\text { loading arm with } \\
\text { cryogenic swivel. } \\
\text { Transfer to shore } \\
\text { through cryogenic } \\
\text { subsea pipeline. }\end{array}$ & $\begin{array}{l}\text { Transfer system: } \\
\text { Arms and swivels } \\
\text { tested. } \\
\text { Class: Approved } \\
\text { in Principle. }\end{array}$ & $\begin{array}{l}\begin{array}{l}\text { Final design } \\
\text { phase to } \\
\text { completion }\end{array} \\
30 \text { mo. }\end{array}$ & \\
\hline & $\begin{array}{c}\text { Single Buoy } \\
\text { Moorings, Inc. } \\
\text { STMO Transfer } \\
\text { Loading/Unloading }\end{array}$ & $\begin{array}{l}5 \text { Route de Fribourg } \\
\text { P. O. Box 152 } \\
\text { Marly, Switzerland, } \\
\text { CH-1723 } \\
\text { Tel. - } 37792051434\end{array}$ & Weathervaning & $\begin{array}{c}\text { Tandem } \\
\text { Bow Manifold } \\
\text { Liq. 12,000 }\end{array}$ & $\begin{array}{c}\text { No limit } \\
40 \mathrm{~m}\end{array}$ & 3.0 & $5.0 \mathrm{~m}$ & Severe & $\begin{array}{l}\text { Liq. Terminal: } \\
\text { Tandem un- } \\
\text { loading arm with } \\
\text { cryogenic swivel. } \\
\text { No shore link } \\
\text { required. }\end{array}$ & $\begin{array}{l}\text { Transfer system: } \\
\text { Arms and swivels } \\
\text { tested. } \\
\text { Class: Approved } \\
\text { in Principle. }\end{array}$ & $\begin{array}{l}\begin{array}{l}\text { Final design } \\
\text { phase to } \\
\text { completion }\end{array} \\
30 \text { mo. }\end{array}$ & \\
\hline Riser Turret Mooring & $\begin{array}{c}\text { Single Buoy } \\
\text { Moorings, Inc. } \\
\text { Riser Turret } \\
\text { Mooring } \\
\text { Unloading }\end{array}$ & $\begin{array}{l}5 \text { Route de Fribourg } \\
\text { P. O. Box 152 } \\
\text { Marly, Switzerland, } \\
\text { CH-1723 } \\
\text { Tel. - } 37792051434\end{array}$ & Weathervaning & $\begin{array}{c}\text { Bow Turret } \\
\text { Disconnectable } \\
1 \text { BCFD }\end{array}$ & $\begin{array}{c}\text { No Limit } \\
50 \mathrm{~m}\end{array}$ & 4.5 & 10.0 & Severe & $\begin{array}{l}\text { Rec. Terminal } \\
\\
\text { Standard HP riser } \\
\text { and carbon steel } \\
\text { to existing gas } \\
\text { infrastructure }\end{array}$ & $\begin{array}{l}\text { Preliminary } \\
\text { Deign } \\
\text { Model tested }\end{array}$ & $\begin{array}{l}\text { Final design to } \\
\text { completion: } \\
24 \text { months }\end{array}$ & \\
\hline $\begin{array}{l}\text { Bluewater } \\
\text { "Big Sweep" } \\
\text { Liq. Terminal }\end{array}$ & $\begin{array}{l}\text { Bluewater Offshore } \\
\text { Production } \\
\text { Systems, Inc. } \\
\text { Loading only }\end{array}$ & $\begin{array}{l}8554 \text { Katy Freeway, } \\
\text { Suite } 327 \\
\text { Houston, TX } 77024 \\
\text { Tel } 7137228131\end{array}$ & Weathervaning & $\begin{array}{c}\text { Tandem } \\
\text { Liq. } 12,000\end{array}$ & $\begin{array}{c}\text { No limit } \\
100 \mathrm{~m}\end{array}$ & $3.0 \mathrm{~m}$ & 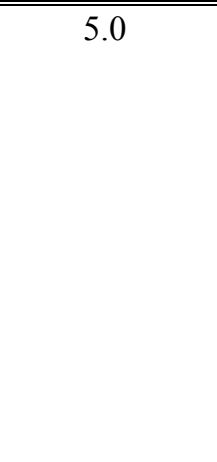 & Severe & $\begin{array}{l}\text { Liq. Terminal: } \\
\text { Tandem un- } \\
\text { loading thru } \\
\text { cryogenic swivel, } \\
\text { subsea cryogenic } \\
\text { pipeline to } \\
\text { "Manipulator" for } \\
\text { LNG vessel } \\
\text { loading }\end{array}$ & $\begin{array}{l}\text { Liq. Terminal: } \\
\text { Conceptual } \\
\text { design for LNG } \\
\text { delivery. "Big } \\
\text { Sweep" scaled } \\
\text { and physically } \\
\text { tested at Marin } \\
\text { "Manipulator" } \\
\text { scaled and } \\
\text { physically tested. }\end{array}$ & $\begin{array}{l}\text { Testing to } \\
\text { Construction } 30 \\
\text { mo. }\end{array}$ & \\
\hline $\begin{array}{c}\text { Bluewater } \\
\text { Deepwater Remote } \\
\text { SPM Dock }\end{array}$ & $\begin{array}{l}\text { Bluewater Offshore } \\
\text { Production } \\
\text { Systems, Inc. } \\
\text { Loading only }\end{array}$ & $\begin{array}{l}8554 \text { Katy Freeway, } \\
\text { Suite } 327 \\
\text { Houston, TX } 77024 \\
\text { Tel } 7137228131\end{array}$ & Weathervaning & $\begin{array}{c}\text { Tandem } \\
\text { Liq. } 12,000\end{array}$ & $\begin{array}{c}\text { No limit } \\
100 \mathrm{~m}\end{array}$ & 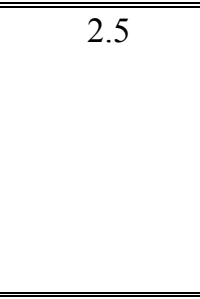 & $4.5 \mathrm{~m}$ & Severe & None & Conceptual & $\begin{array}{l}\text { Concept to } \\
\text { construction } 48 \\
\text { mo }\end{array}$ & \\
\hline
\end{tabular}




\begin{tabular}{|c|c|c|c|c|c|c|c|c|c|c|c|c|}
\hline Description & $\begin{array}{l}\text { Company \& } \\
\text { Application }\end{array}$ & $\begin{array}{c}\text { Contact } \\
\text { Information }\end{array}$ & $\begin{array}{c}\text { Mooring } \\
\text { Design }\end{array}$ & $\begin{array}{c}\text { Transfer } \\
\text { Method \& } \\
\text { Flow Rate } \\
\text { (m3/hr) }\end{array}$ & $\begin{array}{c}\text { Water } \\
\text { Depth } \\
\text { Max/Min }\end{array}$ & $\begin{array}{c}\text { Sea }(\mathrm{Hs}) \\
\text { Condition } \\
\text { Docking }\end{array}$ & $\begin{array}{c}\text { Sea }(\mathrm{Hs}) \\
\text { Condition } \\
\text { Operating }\end{array}$ & $\begin{array}{c}\text { Site } \\
\text { Condition } \\
\text { Rating }\end{array}$ & Shore Link & $\begin{array}{c}\text { Stage of } \\
\text { Development }\end{array}$ & $\begin{array}{c}\text { Completion } \\
\text { Schedule }\end{array}$ & $\begin{array}{c}\text { Facility } \\
\text { Cost } \\
\text { mmUSD }\end{array}$ \\
\hline
\end{tabular}

\begin{tabular}{|c|c|c|c|c|c|c|c|c|c|c|c|c|}
\hline $\begin{array}{l}\text { Bluewater } \\
\text { "Big Sweep" } \\
\text { Rec. Terminal }\end{array}$ & $\begin{array}{l}\text { Bluewater Offshore } \\
\text { Production } \\
\text { Systems, Inc. } \\
\text { Near Shore } \\
\text { Unloading }\end{array}$ & $\begin{array}{l}8554 \text { Katy Freeway, } \\
\text { Suite } 327 \\
\text { Houston, TX } 77024 \\
\text { Tel } 7137228131\end{array}$ & Weathervaning & $\begin{array}{l}\text { Side x Side } \\
\text { Liq } 12,000 \\
\text { Gas. } 8,000\end{array}$ & $\begin{array}{l}100 \mathrm{~m} \\
30 \mathrm{~m}\end{array}$ & $3.0 \mathrm{~m}$ & $9.0 \mathrm{~m}$ & Severe & $\begin{array}{l}\text { Rec Terminal: Liq } \\
\text {-"Manipulator" } \\
\text { LNG flexible via } \\
\text { cryogenic subsea } \\
\text { pipelines to shore } \\
\text { terminal } \\
\text { Gas: } \\
\text { "Manipulator" } \\
\text { LNG flexible } \\
\text { system to } \\
\text { vaporizers, } \\
\text { flexible riser to } \\
\text { gas grid or cavern } \\
\text { storage } \\
\end{array}$ & $\begin{array}{l}\text { Rec. Terminal: } \\
\text { Conceptual } \\
\text { design for gas } \\
\text { delivery. "Big } \\
\text { Sweep" scaled } \\
\text { and physically } \\
\text { tested at Marin } \\
\text { "Manipulator" } \\
\text { scaled and } \\
\text { physically tested. }\end{array}$ & $\begin{array}{l}\text { Testing to } \\
\text { Construction } 30 \\
\text { mo. }\end{array}$ & \\
\hline $\begin{array}{c}\text { Bunder } \\
\text { Bluewater } \\
\text { "Big Sweep" } \\
\text { Shallow Design }\end{array}$ & $\begin{array}{l}\text { Bluewater Offshore } \\
\text { Production } \\
\text { Systems, Inc. } \\
\text { Near Shore } \\
\text { Unloading }\end{array}$ & $\begin{array}{l}8554 \text { Katy Freeway, } \\
\text { Suite } 327 \\
\text { Houston, TX } 77024 \\
\text { Tel } 7137228131\end{array}$ & Weathervaning & $\begin{array}{l}\text { Side } x \text { Side } \\
\text { Liq. } 12,000 \\
\text { Gas. } 8,000\end{array}$ & $\begin{array}{l}40 \mathrm{~m} \\
15 \mathrm{~m}\end{array}$ & $2.5 \mathrm{~m}$ & $3.0 \mathrm{~m}$ & Moderate & $\begin{array}{l}\text { Rec Terminal: Liq } \\
\text { - "Manipulator" } \\
\text { LNG flexible via } \\
\text { cryogenic subsea } \\
\text { pipelines to shore } \\
\text { terminal } \\
\text { Gas: } \\
\text { "Manipulator" } \\
\text { LNG flexible } \\
\text { system to } \\
\text { vaporizers, } \\
\text { flexible riser to } \\
\text { gas grid or cavern } \\
\text { storage }\end{array}$ & $\begin{array}{l}\text { Rec. Terminal: } \\
\text { Conceptual } \\
\text { design for gas } \\
\text { delivery. "Big } \\
\text { Sweep" scaled } \\
\text { and physically } \\
\text { tested at Marin } \\
\text { "Manipulator" } \\
\text { scaled and } \\
\text { physically tested. }\end{array}$ & $\begin{array}{l}\text { Testing to } \\
\text { Construction } 30 \\
\text { mo. }\end{array}$ & \\
\hline 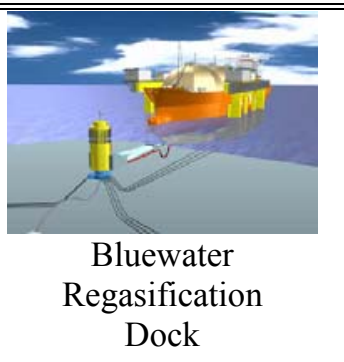 & $\begin{array}{l}\text { Bluewater Offshore } \\
\text { Production } \\
\text { Systems, Inc. } \\
\text { Unloading or } \\
\text { Regasification }\end{array}$ & $\begin{array}{l}8554 \text { Katy Freeway, } \\
\text { Suite } 327 \\
\text { Houston, TX } 77024 \\
\text { Tel } 7137228131\end{array}$ & Weathervaning & $\begin{array}{c}\text { Side x Side } \\
\text { Liq } 12,000 \\
\text { Gas } \\
\text { 3.0 BCFD }\end{array}$ & $\begin{array}{c}\text { No limit } \\
40 \mathrm{~m}\end{array}$ & $2.5 \mathrm{~m}$ & $4.0 \mathrm{~m}$ & Moderate & $\begin{array}{l}\text { Rec Terminal: } \\
\text { Fixed LNG } \\
\text { unloading arm to } \\
\text { either subsea } \\
\text { cryogenic pipe or } \\
\text { directly to on- } \\
\text { board vaporizers }\end{array}$ & Conceptual & $\begin{array}{l}\text { Concept to } \\
\text { construction } 36 \\
\text { months }\end{array}$ & \\
\hline$\pi+9,5$ & $\begin{array}{l}\text { Bluewater Offshore } \\
\text { Production } \\
\text { Systems, Inc. } \\
\text { Loading only }\end{array}$ & $\begin{array}{l}8554 \text { Katy Freeway, } \\
\text { Suite } 327 \\
\text { Houston, TX } 77024 \\
\text { Tel } 7137228131\end{array}$ & Weathervaning & $\begin{array}{l}\text { Side } \mathrm{x} \text { Side } \\
\text { Liq. } 12,000\end{array}$ & $\begin{array}{c}\text { No limit } \\
40 \mathrm{~m}\end{array}$ & $2.0 \mathrm{~m}$ & $3.5 \mathrm{~m}$ & Moderate & $\begin{array}{l}\text { Rec Terminal: } \\
\text { Fixed LNG } \\
\text { unloading arm to } \\
\text { either subsea } \\
\text { cryogenic pipe or } \\
\text { directly to on- } \\
\text { board vaporizers }\end{array}$ & Conceptual & $\begin{array}{l}\text { Concept to } \\
\text { construction } 24 \\
\text { months }\end{array}$ & \\
\hline 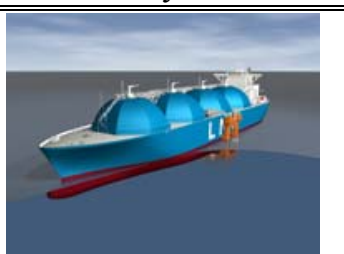 & $\begin{array}{c}\text { Remora } \\
\text { Technology } \\
\text { Unloading only }\end{array}$ & $\begin{array}{l}1400 \text { West Belt } \\
\text { North, Building B, } \\
\text { Houston, Texas, } \\
77043 \\
\text { tel. } 7134685550 \\
\text { cwo }\end{array}$ & Weathervaning & $\begin{array}{l}\text { Side } \mathrm{x} \text { side } \\
\text { Liq. } 12,000 \\
\text { Gas } 8,000\end{array}$ & $\begin{array}{c}\text { No limit } \\
40 \mathrm{~m}\end{array}$ & $2.5 \mathrm{~m}$ & $4.5 \mathrm{~m}$ & Severe & $\begin{array}{l}\text { Rec Terminal: } \\
\text { Liq: LNG } \\
\text { cryogenic flexible } \\
\text { riser } \\
\text { Gas: HiLoad }\end{array}$ & $\begin{array}{l}\text { Ready for } \\
\text { Manufacture: } \\
\text { HiLoad } \\
\text { mechanism. } \\
\text { Class: Approved } \\
\text { in Principle. }\end{array}$ & $\begin{array}{l}\text { Concept to } \\
\text { FEED } 4 \text { mo } \\
\text { FEED to proof } \\
\text { of concept } 16 \\
\text { mo }\end{array}$ & 50 \\
\hline
\end{tabular}




\begin{tabular}{|c|c|c|c|c|c|c|c|c|c|c|c|c|}
\hline Description & $\begin{array}{l}\text { Company \& } \\
\text { Application }\end{array}$ & $\begin{array}{c}\text { Contact } \\
\text { Information }\end{array}$ & $\begin{array}{l}\text { Mooring } \\
\text { Design }\end{array}$ & $\begin{array}{c}\text { Transfer } \\
\text { Method \& } \\
\text { Flow Rate } \\
(\mathrm{m} 3 / \mathrm{hr})\end{array}$ & $\begin{array}{l}\text { Water } \\
\text { Depth } \\
\text { Max/Min }\end{array}$ & $\begin{array}{c}\text { Sea }(H s) \\
\text { Condition } \\
\text { Docking }\end{array}$ & $\begin{array}{c}\text { Sea }(\mathrm{Hs}) \\
\text { Condition } \\
\text { Operating }\end{array}$ & $\begin{array}{c}\text { Site } \\
\text { Condition } \\
\text { Rating }\end{array}$ & Shore Link & $\begin{array}{c}\text { Stage of } \\
\text { Development }\end{array}$ & $\begin{array}{c}\text { Completion } \\
\text { Schedule }\end{array}$ & $\begin{array}{c}\text { Facility } \\
\text { Cost } \\
\text { mmUSD }\end{array}$ \\
\hline
\end{tabular}

\begin{tabular}{|c|c|c|c|c|c|c|c|c|c|c|c|c|}
\hline $\begin{array}{l}\text { Remora Technologies } \\
\text { HiLoad }\end{array}$ & & @ remoratech.com & & & & & & & $\begin{array}{l}\text { onboard } \\
\text { vaporizers via } \\
\text { high pressure } \\
\text { flexible riser }\end{array}$ & $\begin{array}{l}\text { Conceptual: } \\
\text { Transfer system: } \\
\text { Liq: long cryo } \\
\text { flexible hose } \\
\text { under } \\
\text { development. } \\
\text { Gas: proven HP } \\
\text { flexible riser from } \\
\text { vaporizer. }\end{array}$ & $\begin{array}{l}\text { Ready to build } 6 \\
\text { mo } \\
\\
\text { Construction for } \\
\text { first cargo } 18 \\
\text { mo }\end{array}$ & \\
\hline FMCSofec & $\begin{array}{l}\text { FMCSofec } \\
\text { Loading }\end{array}$ & $\begin{array}{l}\text { FMC Loading } \\
\text { Systems } \\
\text { FMC Technologies } \\
\text { Inc } \\
11997 \text { FM } 529 \\
\text { Houston TX } 77041 \\
\text { Phone } 2814053030\end{array}$ & Weathervaning & $\begin{array}{c}\text { Tandem } \\
10-12,000 \mathrm{M} / \mathrm{hr}\end{array}$ & $\begin{array}{l}\text { No Limit } \\
20 \text { meters }\end{array}$ & $5.0 \mathrm{~m}$ & $10.0 \mathrm{~m}$ & Severe & $\begin{array}{l}\text { Tandem Link by } \\
\text { FMC Pantograph } \\
\text { single or duplex } \\
\text { loading arm. } \\
\text { No shore link } \\
\text { required }\end{array}$ & $\begin{array}{l}\text { Design Phase } \\
\text { Class approved } \\
\text { swivels and } \\
\text { Pantograph } \\
\text { loading arm full } \\
\text { scale tested }\end{array}$ & $\begin{array}{l}\text { Detail design } \\
\text { Engineering to } \\
\text { completion } 24 \\
\text { mo }\end{array}$ & \\
\hline $\begin{array}{l}358 \\
\text { Shell FONG }\end{array}$ & $\begin{array}{l}\text { Shell Global } \\
\text { Solutions, Inc. } \\
\text { Loading only }\end{array}$ & $\begin{array}{l}\text { Westhollow } \\
\text { Technology Center, } \\
3333 \text { Highway } 6 \\
\text { South, Houston, TX } \\
\text { 77082-3101, USA } \\
\end{array}$ & Weathervaning & $\begin{array}{l}\text { Side } \mathrm{x} \text { side } \\
\text { Liq. } 12,000\end{array}$ & $\begin{array}{l}\text { No Limit } \\
30 \mathrm{~m}\end{array}$ & $2.0 \mathrm{~m}$ & $3.0 \mathrm{~m}$ & Moderate & $\begin{array}{l}\text { Liq Terminal: } \\
\text { Loading Arms }\end{array}$ & $\begin{array}{l}\text { Design modeled. } \\
\text { Class: Approved } \\
\text { in principle }\end{array}$ & $\begin{array}{l}\text { FEED through } \\
\text { construction } 48 \\
\text { mo }\end{array}$ & 750 \\
\hline MOSS Maritime & $\begin{array}{l}\text { Moss Maritime a.s } \\
\text { Unloading only }\end{array}$ & $\begin{array}{l}\text { P.O. Box } 120 \\
\text { N-1325 } \\
\text { Lysker, Norway } \\
4767526250\end{array}$ & Weathervaning & $\begin{array}{l}\text { Side x Side } \\
\text { Liq } 12,000\end{array}$ & $\begin{array}{l}\text { No limit } \\
30 \mathrm{~m}\end{array}$ & $2.5 \mathrm{~m}$ & $3.0 \mathrm{~m}$ & Moderate & $\begin{array}{l}\text { Rec Terminal } \\
\text { Liq Loading } \\
\text { Arms. } \\
\text { Vaporization to } \\
\text { Flexible riser }\end{array}$ & $\begin{array}{l}\text { Conceptual } \\
\text { Class: Approved } \\
\text { in principle }\end{array}$ & $\begin{array}{l}\text { FEED through } \\
\text { construction } 48 \\
\text { mo }\end{array}$ & 550 \\
\hline $\begin{array}{c}\text { EurodimTFE } \\
\text { Boom \& Hose } \\
\end{array}$ & $\begin{array}{l}\text { EURODIM, s.a. } \\
\text { Loading \& } \\
\text { Unloading }\end{array}$ & $\begin{array}{l}21 \text { avenue Edouard } \\
\text { Belin } \\
92566 \text { RUEIL } \\
\text { MALMAISON } \\
\text { CEDEX } \\
\text { France } \\
+33(47) 160586\end{array}$ & Weathervaning & $\begin{array}{l}\text { Side manifold } \\
\text { Liq } 12,000\end{array}$ & $\begin{array}{l}150 \mathrm{~m} \\
25 \mathrm{~m}\end{array}$ & $2.5 \mathrm{~m}$ & $4.5 \mathrm{~m}$ & Severe & $\begin{array}{l}\text { Cryogenic subsea } \\
\text { pipeline }\end{array}$ & Conceptual & $\begin{array}{l}\text { Concept to } \\
\text { construction } 36 \\
\text { mo }\end{array}$ & \\
\hline $\begin{array}{c}\text { g } \\
\text { EurodimTFE } \\
\text { Rotating Quay }\end{array}$ & $\begin{array}{l}\text { EURODIM, s.a. } \\
\text { Loading \& } \\
\text { Unloading }\end{array}$ & $\begin{array}{l}21 \text { avenue Edouard } \\
\text { Belin } \\
\text { 92566 RUEIL } \\
\text { MALMAISON } \\
\text { CEDEX } \\
\text { France } \\
+33(47) 160586 \\
\end{array}$ & Weathervaning & $\begin{array}{l}\text { Side manifold } \\
\text { Liq } 12,000\end{array}$ & $\begin{array}{l}150 \mathrm{~m} \\
25 \mathrm{~m}\end{array}$ & $2.5 \mathrm{~m}$ & $4.5 \mathrm{~m}$ & Severe & $\begin{array}{l}\text { Cryogenic subsea } \\
\text { pipeline }\end{array}$ & Conceptual & $\begin{array}{l}\text { Concept to } \\
\text { construction } 36 \\
\text { months }\end{array}$ & \\
\hline 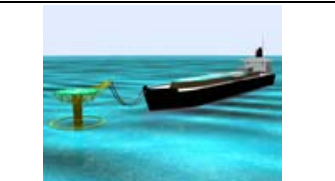 & $\begin{array}{l}\text { EURODIM, s.a. } \\
\text { Loading \& } \\
\text { Unloading }\end{array}$ & $\begin{array}{l}21 \text { avenue Edouard } \\
\text { Belin } \\
\text { 92566 RUEIL } \\
\text { MALMAISON }\end{array}$ & Weathervaning & $\begin{array}{l}\text { Side manifold } \\
\text { Liq } 12,000\end{array}$ & $\begin{array}{l}150 \mathrm{~m} \\
25 \mathrm{~m}\end{array}$ & $2.5 \mathrm{~m}$ & $4.5 \mathrm{~m}$ & Severe & $\begin{array}{l}\text { Cryogenic subsea } \\
\text { pipeline }\end{array}$ & Conceptual & $\begin{array}{l}\text { Concept to } \\
\text { construction } 36 \\
\text { mo. }\end{array}$ & \\
\hline
\end{tabular}




\begin{tabular}{|c|c|c|c|c|c|c|c|c|c|c|c|c|}
\hline Description & $\begin{array}{l}\text { Company \& } \\
\text { Application }\end{array}$ & $\begin{array}{c}\text { Contact } \\
\text { Information }\end{array}$ & $\begin{array}{l}\text { Mooring } \\
\text { Design }\end{array}$ & $\begin{array}{c}\text { Transfer } \\
\text { Method \& } \\
\text { Flow Rate } \\
(\mathrm{m} 3 / \mathrm{hr})\end{array}$ & $\begin{array}{l}\text { Water } \\
\text { Depth } \\
\text { Max/Min }\end{array}$ & $\begin{array}{c}\text { Sea }(\mathrm{Hs}) \\
\text { Condition } \\
\text { Docking }\end{array}$ & $\begin{array}{l}\text { Sea }(\mathrm{Hs}) \\
\text { Condition } \\
\text { Operating }\end{array}$ & $\begin{array}{c}\text { Site } \\
\text { Condition } \\
\text { Rating }\end{array}$ & Shore Link & $\begin{array}{c}\text { Stage of } \\
\text { Development }\end{array}$ & $\begin{array}{c}\text { Completion } \\
\text { Schedule }\end{array}$ & $\begin{array}{c}\text { Facility } \\
\text { Cost } \\
\text { mmUSD }\end{array}$ \\
\hline
\end{tabular}

\begin{tabular}{|c|c|c|c|c|c|c|c|c|c|c|c|c|}
\hline $\begin{array}{l}\text { EurodimTFE } \\
\text { Turret Moored }\end{array}$ & & $\begin{array}{l}\text { CEDEX } \\
\text { France } \\
+33(47) 160586 \\
\end{array}$ & & & & & & & & & & \\
\hline $\begin{array}{c}\text { El Paso } \\
\text { Energy Bridge }\end{array}$ & $\begin{array}{l}\text { El Paso Global } \\
\text { LNG } \\
\text { Unloading only }\end{array}$ & $\begin{array}{l}\text { P.O. Box } 2511 \\
\text { Houston, Texas } \\
77252-2511 \\
\text { (713) } 420-5161\end{array}$ & Weathervaning & $\begin{array}{l}\text { Bottom Turret } \\
\text { Gas } 1050 \\
\text { Side Manifold } \\
\text { Liq 12,000 }\end{array}$ & $\begin{array}{l}\text { No limit } \\
100 \mathrm{~m}\end{array}$ & $4.0 \mathrm{~m}$ & $12.0 \mathrm{~m}$ & Severe & $\begin{array}{l}\text { Regas Facility } \\
\text { Flexible riser } \\
\text { Can also } \\
\text { discharge LNG } \\
\text { thru side manifold }\end{array}$ & $\begin{array}{l}\text { Tested and in } \\
\text { Fabrication at } \\
\text { Daewoo shipyard } \\
\text { Korea } \\
\text { Class: Approved } \\
\text { in Principle. }\end{array}$ & $\begin{array}{l}\text { In fabrication to } \\
\text { construction } 24 \\
\text { mo. }\end{array}$ & 245 \\
\hline $\begin{array}{l}\text { ChevronTexaco } \\
\text { (ExxonMobil) } \\
\text { Gravity Based } \\
\text { Structure } \\
\end{array}$ & $\begin{array}{l}\text { ChevronTexaco } \\
\text { Loading \& } \\
\text { Unloading }\end{array}$ & $\begin{array}{l}\text { 6001 Bollinger } \\
\text { Canyon Rd., Room } \\
\text { L4032 } \\
\text { P.O. Box } 6045 \\
\text { San Ramon, CA } \\
\text { 94583-2324 }\end{array}$ & Fixed & $\begin{array}{l}\text { Side manifold } \\
\text { Liq 12,000 }\end{array}$ & $\begin{array}{l}75 \mathrm{~m} \\
50 \mathrm{~m}\end{array}$ & 1.5 & 3.0 & Moderate & $\begin{array}{l}\text { Liq Terminal } \\
\text { Loading Arms } \\
\text { Rec. Terminal } \\
\text { Loading arms to } \\
\text { pipeline to gas } \\
\text { grid }\end{array}$ & $\begin{array}{l}\text { Several in Service } \\
\text { Class Approved } \\
\text { in Principle }\end{array}$ & $\begin{array}{l}\text { FEED to } \\
\text { construction } 48 \\
\text { mo. }\end{array}$ & 750 \\
\hline Spread Moored & $\begin{array}{l}\text { EURODIM, s.a. } \\
\text { Loading \& } \\
\text { Unloading }\end{array}$ & $\begin{array}{l}21 \text { avenue Edouard } \\
\text { Belin } \\
\text { 92566 RUEIL } \\
\text { MALMAISON } \\
\text { CEDEX } \\
\text { France } \\
+33(47) 160586 \\
\end{array}$ & Fixed & $\begin{array}{l}\text { Side manifold } \\
\text { Side x side } \\
\text { Tandem } \\
\text { Liq 12,000 }\end{array}$ & $\begin{array}{c}\text { No Limit } \\
40 \mathrm{~m}\end{array}$ & $1.5 \mathrm{~m}$ & $2.5 \mathrm{~m}$ & Benign & $\begin{array}{l}\text { Cryogenic subsea } \\
\text { pipeline }\end{array}$ & $\begin{array}{l}\text { Many used on oil } \\
\text { offshore transfer } \\
\text { Class Approved } \\
\text { in Principle }\end{array}$ & $\begin{array}{l}\text { FEED to } \\
\text { Construction } 18 \\
\text { mo }\end{array}$ & $10-25$ \\
\hline Spread Moored & $\begin{array}{l}\text { Single Buoy } \\
\text { Moorings, Inc. } \\
\text { STMO Transfer } \\
\text { Loading/Unloading }\end{array}$ & $\begin{array}{l}5 \text { Route de Fribourg } \\
\text { P. O. Box 152 } \\
\text { Marly, Switzerland, } \\
\text { CH-1723 } \\
\text { Tel. - } 37792051434\end{array}$ & Fixed & $\begin{array}{l}\text { Side Manifold } \\
\text { Liq. } 12,000\end{array}$ & $\begin{array}{l}150 \mathrm{~m} / \\
20 \mathrm{~m}\end{array}$ & $1.5 \mathrm{~m}$ & $2.5 \mathrm{~m}$ & Benign & $\begin{array}{l}\text { Cryogenic } \\
\text { subsea pipeline }\end{array}$ & $\begin{array}{l}\text { Conceptual } \\
\text { design and } \\
\text { analysis }\end{array}$ & $\begin{array}{l}\text { Final design to } \\
\text { completion: } 30 \\
\text { months }\end{array}$ & \\
\hline Gerris & $\begin{array}{l}\text { EURODIM, s.a. } \\
\text { Loading \& } \\
\text { Unloading }\end{array}$ & $\begin{array}{l}21 \text { avenue Edouard } \\
\text { Belin } \\
\text { 92566 RUEIL } \\
\text { MALMAISON } \\
\text { CEDEX } \\
\text { France } \\
+33(47) 160586 \\
\end{array}$ & Fixed & $\begin{array}{l}\text { Side manifold } \\
\text { Liq 12,000 }\end{array}$ & $\begin{array}{c}\text { No Limit } \\
40 \mathrm{~m}\end{array}$ & $1.0 \mathrm{~m}$ & $2.5 \mathrm{~m}$ & Benign & $\begin{array}{l}\text { Cryogenic subsea } \\
\text { pipeline }\end{array}$ & Conceptual & $\begin{array}{l}\text { Concept to } \\
\text { construction } 30 \\
\text { mo }\end{array}$ & $20-40$ \\
\hline $\begin{array}{l}\text { Conventional } \\
\text { Jetty }\end{array}$ & $\begin{array}{l}\text { EURODIM, s.a. } \\
\text { Loading \& } \\
\text { Unloading }\end{array}$ & $\begin{array}{l}21 \text { avenue Edouard } \\
\text { Belin } \\
92566 \text { RUEIL } \\
\text { MALMAISON } \\
\text { CEDEX } \\
\text { France } \\
+33(47) 160586\end{array}$ & Fixed & $\begin{array}{l}\text { Side manifold } \\
\text { Liq } 12,000\end{array}$ & $\begin{array}{c}\text { No Limit } \\
40 \mathrm{~m}\end{array}$ & $1.0 \mathrm{~m}$ & $2.5 \mathrm{~m}$ & Benign & $\begin{array}{l}\text { Cryogenic subsea } \\
\text { pipeline }\end{array}$ & Conceptual & $\begin{array}{l}\text { Concept to } \\
\text { construction } 30 \\
\text { mo }\end{array}$ & $25-40$ \\
\hline
\end{tabular}




\begin{tabular}{|l|l|l|l|}
\hline Customer: & $\begin{array}{l}\text { The United States Department of Energy } \\
\text { National Energy Technology Laboratory }\end{array}$ & $\begin{array}{l}\text { Date of Issue: } \\
\text { 24 April 2003 }\end{array}$ & \\
\hline $\begin{array}{l}\text { Document } \\
\text { Title: }\end{array}$ & $\begin{array}{l}\text { Subtask 1.3 } \\
\text { Determine Major Equipment Requirements }\end{array}$ & $\begin{array}{l}\text { Doc \# \& Version: } \\
\text { Doc 04 r2.0 }\end{array}$ & Page 1 of 20 \\
\hline
\end{tabular}

\section{Examine and Evaluate a Process to use Salt Caverns to Receive SHIP BORNE LIQUEFIED NATURAL GAS}

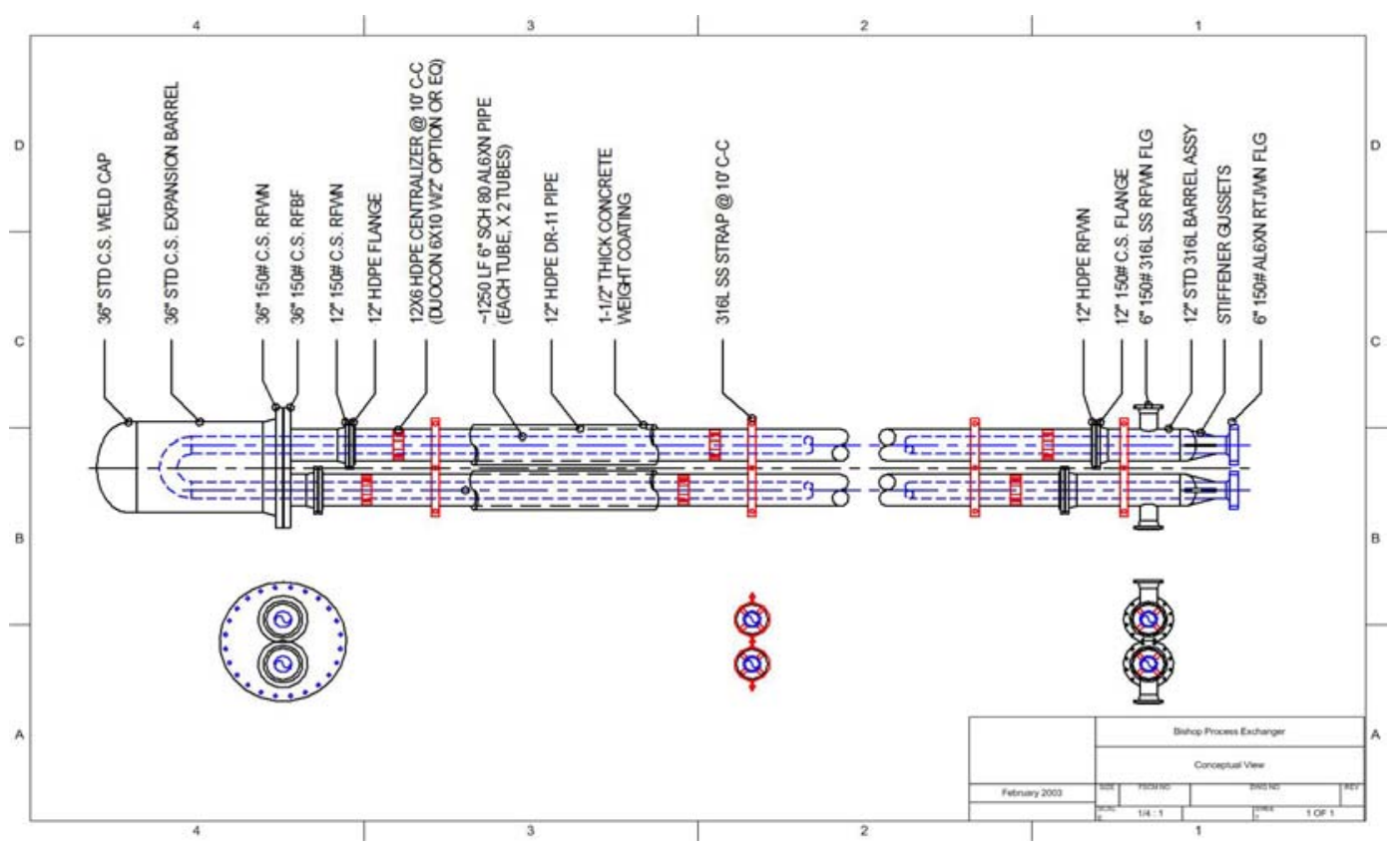

\section{BY \\ MiCHAEL M. MCCALL \\ WILLIAM M. BISHOP \\ D. BRAXTON SCHERZ}

\begin{tabular}{|c|c||c|c|c|c|c|c|c||}
\hline r 2.0 & For client review & O4/24/03 & вs & мм & & & \\
\hline Version & Reason for Issue & $\begin{array}{c}\text { Issue } \\
\text { Date }\end{array}$ & $\begin{array}{c}\text { Orig. } \\
\text { Chk. } \\
\text { CGI }\end{array}$ & $\begin{array}{c}\text { Appr. } \\
\text { Chk. } \\
\text { NETL Appr. }\end{array}$ & Review \\
\hline \hline $\begin{array}{l}\text { Document Title: } \\
\text { Subtask 1.3 Determine Major Equipment } \\
\text { Requirements }\end{array}$ & \multicolumn{7}{|c||}{$\begin{array}{c}\text { Document No: } \\
\text { DE-FC26-02NT41653 }\end{array}$} \\
\hline \hline
\end{tabular}




\begin{tabular}{|l|l|l|l|}
\hline Customer: & $\begin{array}{l}\text { The United States Department of Energy } \\
\text { National Energy Technology Laboratory }\end{array}$ & $\begin{array}{l}\text { Date of Issue: } \\
\text { 24 April 2003 }\end{array}$ & \\
\hline $\begin{array}{l}\text { Document } \\
\text { Title: }\end{array}$ & $\begin{array}{l}\text { Subtask 1.3 } \\
\text { Determine Major Equipment Requirements }\end{array}$ & $\begin{array}{l}\text { Doc \# \& Version: } \\
\text { Doc 04 r2.0 }\end{array}$ & Page 2 of 20 \\
\hline
\end{tabular}

\section{TABLE OF CONTENTS}

1. EXECUTIVE SUMMARY

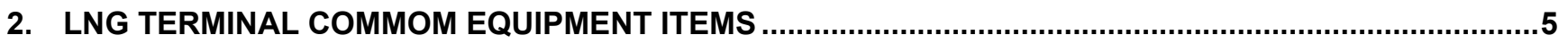

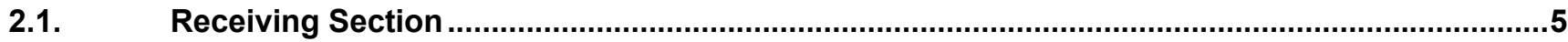

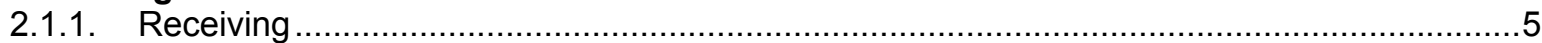

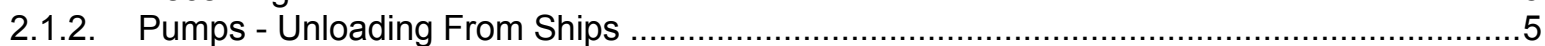

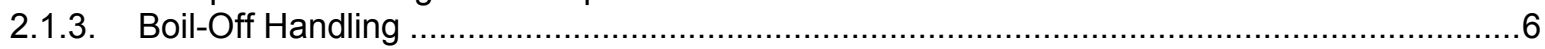

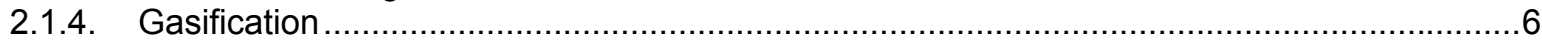

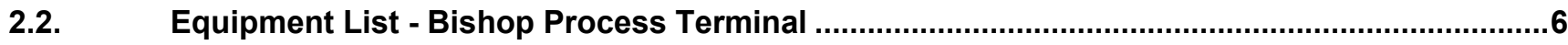

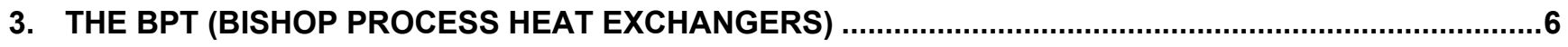

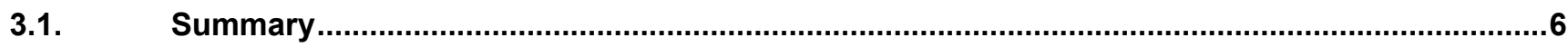

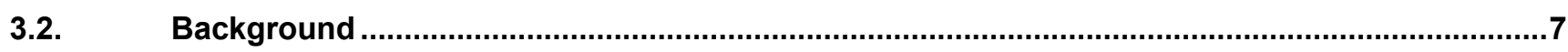

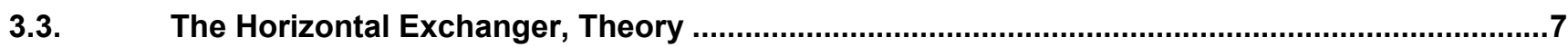

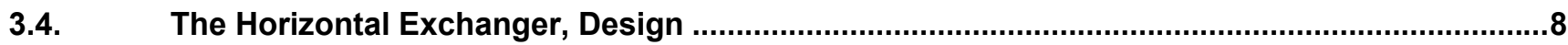

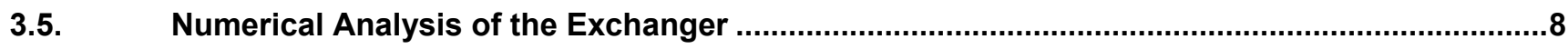

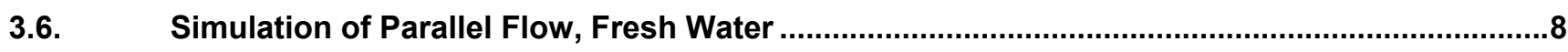

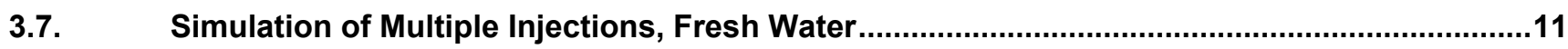

3.8. Simulation of a Counter-Flow Exchanger, Using Seawater ..............................................12

3.9. Simulation of a Combined Parallel and Counter-Flow Exchanger, with Two Warmant Injections (Mixed Injection). ...........................................................................................13

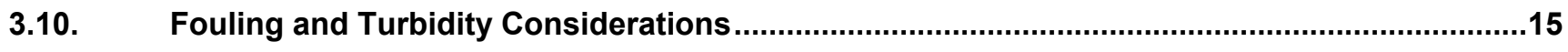

3.11. Simulation Using Finite Element Analysis ....................................................................16

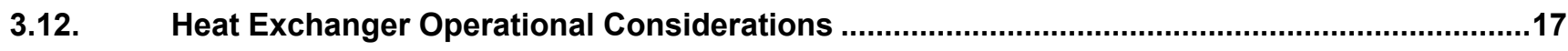

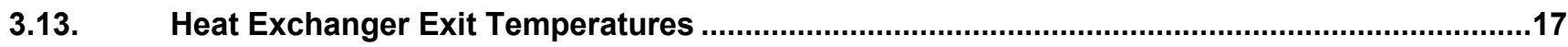

3.14. Using the Available Low Temperature to Process High Heating Value Gas ........................18

3.15. Bypassing Full Cavern Pressure to Feed a Base Load ......................................................18

3.16. Use of the Waste Heat from Power Generation ..................................................................18

3.17. Estimating Warmant Temperature Operational Range, Required Flow Ratio .........................19

3.18. Emergency Shut-in of the Exchangers, Shut-in Conditions ................................................19

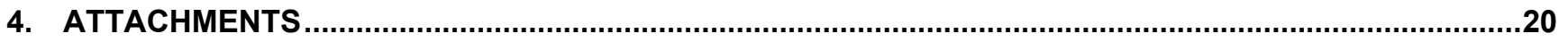




\begin{tabular}{|l|l|l|l|}
\hline Customer: & $\begin{array}{l}\text { The United States Department of Energy } \\
\text { National Energy Technology Laboratory }\end{array}$ & $\begin{array}{l}\text { Date of Issue: } \\
24 \text { April } 2003\end{array}$ \\
\hline $\begin{array}{l}\text { Document } \\
\text { Title: }\end{array}$ & $\begin{array}{l}\text { Subtask 1.3 } \\
\text { Determine Major Equipment Requirements }\end{array}$ & $\begin{array}{l}\text { Doc \# \& Version: } \\
\text { Doc 04 r2.0 }\end{array}$ & Page 3 of 20 \\
\hline
\end{tabular}

4.1. Attachment 1 - "4-Pack" - High Pressure LNG Pumping Unit .............................................20

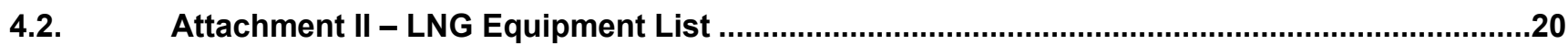

4.3. Attachment III - Numerical Analysis of BPT - Full Report ..................................................20 


\begin{tabular}{|l|l|l|l|}
\hline Customer: & $\begin{array}{l}\text { The United States Department of Energy } \\
\text { National Energy Technology Laboratory }\end{array}$ & $\begin{array}{l}\text { Date of Issue: } \\
\text { 24 April 2003 }\end{array}$ & \\
\hline $\begin{array}{l}\text { Document } \\
\text { Title: }\end{array}$ & $\begin{array}{l}\text { Subtask 1.3 } \\
\text { Determine Major Equipment Requirements }\end{array}$ & $\begin{array}{l}\text { Doc \# \& Version: } \\
\text { Doc 04 r2.0 }\end{array}$ & Page 4 of 20 \\
\hline
\end{tabular}

\section{EXECUTIVE SUMMARY}

The research confirms that a ships cargo can be unloaded and warmed to salt cavern compatible temperatures at normal ship discharge rates through the use of a high capacity, high efficiency heat exchanger. All large scaled LNG receiving terminals offload liquefied natural gas, pump it to pipeline pressures, and warm the high pressure liquid stream in heat exchangers of various designs. As the LNG approaches its pipeline compatible discharge temperature (about $5^{\circ} \mathrm{C}(40 \mathrm{~F})$ ) the density decreases and the stream enters the pipeline as a dense phase gas. A terminal using the Bishop Process heat Exchanger (BPT) employs all of the basic design parameters of the typical LNG receiving terminal

The entire LNG receiving terminal consists of three functional areas, LNG receiving, LNG regasification, and LNG storage. The regasification area includes the Bishop Process Heat (BPT) Exchangers and the warmant circulation equipment. LNG is unloaded by the ship's pumps at an average rate of about $7600 \mathrm{~m} 3 / \mathrm{hr}$. During ship unloading mode of operation, LNG is transferred from an LNG tanker into the salt caverns for storage and delivery. Because of the very small volumes of the surge vessel and the cylinders housing the LNG high pressure pumps, LNG boil-off is quite small compared to conventional terminals.

The major process differences in the BPT LNG receiving terminal and the traditional terminal are defined by the configuration of the High Pressure Pumping units called a "4-Pack" and the pipe-in-pipe configuration of the BPT. Each "4-Pack" is designed to pump 6,480 m3/day at 152 barg (2,200 psig) of LNG discharging immediately into the pipe-in-pipe Bishop Process heat Exchanger. Each pump with its own exchanger will gasify about $135 \mathrm{mmcfd}$. Each 4-pack and its associated BPT exchanger has the capacity of gasifying approximately $540 \mathrm{mmscfd}$. For the purposes of this study, a nominal 2,000 psi discharge pressure has been used.

The BPT, a critical component of the subject technology is a high capacity, pipe in pipe heat exchanger. These exchangers allow an LNG tanker to be offloaded at rates consistent with conventional LNG terminals but with resulting pressures suitable for injection of the gas directly into salt caverns without the use of compressors. Thus no significant amount of LNG is ever stored on the surface. In addition, because the exchangers use seawater or other waters as a warmant, the fuel operating costs are approximately $25 \%$ of gas fired exchangers.

Through numerical modeling performed under the present contract, proposed exchanger configurations, process design, and operational considerations have been successfully verified. HYSYS and MATLAB the process software used to design the exchanger, documented the location and thickness of the icing condition (a predicted consequence of using water to warm LNG). The warm water flow systems have been integrated into exchanger design to optimize BPT efficiencies and increase operational flexibility. The BPT exchanger inner annulus will be fabricated from stainless steel, a resilient material known to be resistant to cryogenic temperatures. The outer pipe can be fabricated with HDPE or coated carbon steel depending upon site conditions and specific application. The inner annulus will be centralized with a device designed to incorporate the effects of thermal expansion and contraction.

The major equipment items required for the BPT terminal have been identified. The pump manufactures confirm that the high pressure pumps required for the BPT process can be fabricated and pre-tested using existing materials, technology, and know-how. The BPT exchanger has been conceptually designed and a working model will be built to prove its operating characteristics. 


\begin{tabular}{|l|l|l|l|}
\hline Customer: & $\begin{array}{l}\text { The United States Department of Energy } \\
\text { National Energy Technology Laboratory }\end{array}$ & $\begin{array}{l}\text { Date of Issue: } \\
\text { 24 April 2003 }\end{array}$ & \\
\hline $\begin{array}{l}\text { Document } \\
\text { Title: }\end{array}$ & $\begin{array}{l}\text { Subtask 1.3 } \\
\text { Determine Major Equipment Requirements }\end{array}$ & $\begin{array}{l}\text { Doc \# \& Version: } \\
\text { Doc 04 r2.0 }\end{array}$ & Page 5 of 20 \\
\hline
\end{tabular}

\section{LNG TERMINAL COMMOM EQUIPMENT ITEMS}

The entire LNG receiving terminal consists of three functional areas, LNG receiving, LNG regasification, and LNG storage. The receiving area includes the marine facilities, surge vessel, high pressure pumps, and vapor handling system. The regasification area includes the Bishop Process Heat (BPT) Exchangers and the warmant circulation equipment. The storage area consists of the solution mined salt caverns either existing or created on or in conjunction with the unloading site.

\subsection{Receiving Section}

\subsubsection{Receiving}

LNG will be transported to the receiving terminal via tankers. LNG is unloaded by the ship's pumps at an average rate of about $7600 \mathrm{~m} 3 / \mathrm{hr}$. The high pressure pumping units are designed to unload the entire contents of a $138,000 \mathrm{~m} 3$ tanker within 18 hours. Because the entire contents of the LNG vessel are gasified and sent immediately to the caverns, the BPT LNG terminal is not limited by the send-out capacity of the vaporizer. Rather, the delivery from the salt caverns (at $3.0 \mathrm{Bcf}$ or more per day) and the number of ships capable of discharging over a given period of time determine terminal sendout capacity.

There are two distinct operating modes of the terminal: Ship Unloading and Stand-by. During ship unloading mode of operation, LNG is transferred from an LNG tanker into the salt caverns for storage and delivery. During the stand-by mode of operation (while no ship is unloading LNG), a portion of LNG is circulated around the unloading facilities in order to maintain cold temperatures. Because of the very small volumes of the surge vessel and the cylinders housing the LNG high pressure pumps, LNG boil-off is quite small compared to conventional terminals.

\subsubsection{Pumps - Unloading From Ships}

LNG is unloaded by the ship's pumps and passes through three 16" LNG Unloading Arms which are manifolded together. From the unloading arm manifold, LNG is delivered via two unloading pipelines to a single surge vessel with a working capacity of $520 \mathrm{~m} 3$. The surge vessel is kept at a constant level, slightly above atmospheric pressure to suppress boil-off and ensure flow. The LNG leaving the surge vessel is piped to the High Pressure Pump Reservoirs that house 4 large LNG pumps. These high pressure receiving units are called "4-packs" (Attachment 1). The pumps, a proven technology, will be among the largest capacity LNG send-out pumps manufactured, with an integral in-line motor rated at 2,600 horsepower. Built from aluminum to the latest codes and standards, each pump in the 4-pack has a capacity of $270 \mathrm{~m} 3 / \mathrm{hr}$, or $6480 \mathrm{~m} 3 /$ day. The 4-pack cylinder and pump arrangement will be skid mounted, and delivered from the factory ready for field installation.

The LNG is pressurized to 2,200 psig and passes out the discharge of the pump immediately into the pipe-inpipe Bishop Process Heat Exchanger. Each pump with its own exchanger will gasify about $135 \mathrm{mmcfd}$. Each 4pack has the capacity of gasifying approximately $540 \mathrm{mmscfd}$. Seven 4-packs have been specified for the Base Case with a total capacity of approximately $3.8 \mathrm{Bcfd}$. The discharge of each exchanger connects to a common header which forms the beginning of the pipeline routing the gasified LNG to the salt cavern storage facility.

During the standby mode, a portion of LNG from the surge vessel and each 4-pack is circulated through the unloading piping at the ship berthing area. It is returned by the recirculation line in order to keep the unloading equipment and piping at cryogenic temperature. This avoids excessive vapor generation at the initiation of ship unloading and speeds LNG tanker turnaround times. 


\begin{tabular}{|l|l|l|l|}
\hline Customer: & $\begin{array}{l}\text { The United States Department of Energy } \\
\text { National Energy Technology Laboratory }\end{array}$ & $\begin{array}{l}\text { Date of Issue: } \\
\text { 24 April 2003 }\end{array}$ & \\
\hline $\begin{array}{l}\text { Document } \\
\text { Title: }\end{array}$ & $\begin{array}{l}\text { Subtask 1.3 } \\
\text { Determine Major Equipment Requirements }\end{array}$ & $\begin{array}{l}\text { Doc \# \& Version: } \\
\text { Doc 04 r2.0 }\end{array}$ & Page 6 of 20 \\
\hline
\end{tabular}

\subsubsection{Boil-Off Handling}

During normal operation, vapors know as Boil-Off Gas (BOG) will be generated in the surge vessel, in the High Pressure Pump Reservoirs and through ambient heat leakage in the unloading line. A portion of the generated BOG equivalent to the unloading rate $(7600 \mathrm{~m} 3)$ must be returned to the ship via the vapor return line, the Ship Vapor Return Blower, and the LNG Vapor Return Arm to maintain pressure in the ship tanks. Additional requirements for BOG will be supplied from a low pressure reducing station supplied by the send-out stream.

During standby mode while no liquid is passing through the heat exchangers, the amount of BOG generated by heat leaks and pumping energy is reduced. However, the unloading BOG compressor will be sized to compress the entire content of BOG during standby also. If required, a small amount of LNG can be sprayed into a desuperheater installed at the suction of the Boil-Off Gas Suction Knock-Out Drum to maintain suitable low vapor temperature at the compressor suction.

\subsubsection{Gasification}

There are 28 pipe-in-pipe BPT vaporizers at 152 bar $(2,200$ psi) specified for the Base Case because the cavern operator requested a 200 psi discharge pressure increase to better suit the site described in Task 2.0. To accomplish this, 4 additional pumps were required. The heat exchanger calculations for this study are based on a nominal 138 bar $(2,000 \mathrm{psi}), 24$ pumps case. For the nominal case, all vaporizers are to operate at 138 barg. The slight increase in operating pressure is well within the capability of the equipment specified for the nominal case. The BPTs are sufficient for the entire regasification requirement without supplemental heat; however, waste heat from the gas turbines used for power generation during unloading could provide warmer water to the exchanger thus increasing efficiency.

The seawater loop consists of a Seawater Lift Pumping structure complete with pumps and rotary screen type strainer. The water circulates through multiple pass flow loops integral with the BPT exchanger. The seawater, flowing through the outer annulus of the pipe-in-pipe exchanger transfers the seawater heat content directly to the LNG stream within the inner pipe. The re-gasified LNG is sent to the Gas Metering Station for pipeline delivery. The temperature and pressure of the send-out gas from these units will be approximately $4^{\circ} \mathrm{C}$ and 151.5 barg, respectively. Part of the send-out gas may be used as fuel gas or vapor return to the tanks of the unloading vessel. A detailed review of the Bishop Process heat Exchanger follows this section.

\subsection{Equipment List - Bishop Process Terminal}

Attachment II references the equipment list required for a Bishop Process LNG terminal.

\section{THE BPT (BISHOP PROCESS HEAT EXCHANGERS)}

\subsection{Summary}

A critical component of the subject technology is the use of high capacity, pipe in pipe heat exchangers. These exchangers allow a LNG tanker to be offloaded at rates consistent with conventional LNG terminals but with resulting pressures suitable for injection of the gas directly into salt caverns without the use of compressors. Thus no significant amount of LNG is ever stored on the surface. In addition, because the exchangers use seawater or other waters as a warmant, the fuel operating costs are approximately $25 \%$ of gas fired 


\begin{tabular}{|l|l|l|l|}
\hline Customer: & $\begin{array}{l}\text { The United States Department of Energy } \\
\text { National Energy Technology Laboratory }\end{array}$ & $\begin{array}{l}\text { Date of Issue: } \\
\text { 24 April 2003 }\end{array}$ & \\
\hline $\begin{array}{l}\text { Document } \\
\text { Title: }\end{array}$ & $\begin{array}{l}\text { Subtask 1.3 } \\
\text { Determine Major Equipment Requirements }\end{array}$ & $\begin{array}{l}\text { Doc \# \& Version: } \\
\text { Doc 04 r2.0 }\end{array}$ & Page 7 of 20 \\
\hline
\end{tabular}

exchangers. The following sections discuss the development of these exchangers, the theory involved, the numerical modeling performed under the present contract, proposed exchanger configurations, and operational considerations.

\subsection{Background}

The original pipe in pipe heat exchangers were developed for salt cavern use when it was recognized that two hanging strings in a cavern well could form a counter flow heat exchanger. That is, the outer annulus would carry LNG into the cavern, forcing warm brine out of the cavern through the center tubing and warming the LNG in the process. Preliminary calculations showed the LNG would be warmed to temperatures compatible with the salt rock mechanics. This was followed by a finite element analysis (Ref. 1) that confirmed the preliminary results. The technology was then patented, U.S. Patent No. 5,511,905.

This in-cavern heat exchanger technology is expected to work well but it requires that the caverns in use be operated in a compensated manner, that is, brine is used as an operating medium, forcing it out when LNG is injected and pumping it back in when gas is withdrawn. This requires use of a surface brine pond, or some other brine storage medium, which is usually expensive. Because of this, no natural gas storage caverns are in compensated operation in this country at this time. This may change as the cost of gas rises for the necessary gas cushion that must be left in the cavern after drawdown. Higher value gaseous hydrocarbon products are stored using compensation. To allow uncompensated gas cavern operation to include LNG warming, the horizontal (surface) pipe in pipe exchanger was then developed.

\subsection{The Horizontal Exchanger, Theory}

The surface heat exchanger is freed from the use of cavern brine storage in that any warmant available on the surface may be used, such as seawater, process water, fresh water, etc. This warmant is not dependent on cavern brine return flow rates and thus may be pumped at any rate to achieve the desired LNG warming rate. Further, exchanger diameters can be chosen without affecting well size and number, which becomes very expensive as size is increased.

In designing a horizontal pipe in pipe heat exchanger of this type, it is important that no phase change be allowed to take place during the process. Phase change can disrupt the heat exchange mechanism as well as causing vapor lock, cavitation and other problems. Thus the exchanger is designed to operate above the cricondenbar of the fluid in question. This ensures that the fluid is always in the dense phase, that is, outside of the two-phase dome on a pressure-enthalpy chart. For methane this occurs at pressures above about 700 psi. For higher molecular weight natural gases, the cricondenbar is somewhat higher but usually well below the pressure required for injection into most salt caverns. A second concern is that density stratification be minimized. This can occur in single phase flow when density varies across the flow due to temperature or other changes and can degrade the exchanger performance. This type of stratification is governed by the Densimetric Froude Number given by:

$$
F=V\left(g D \frac{\Delta \gamma}{\gamma}\right)^{-\left(\frac{1}{2}\right)}
$$

Here $\mathrm{V}$ is fluid velocity, $\mathrm{g}$ is acceleration due to gravity, $\mathrm{D}$ is the pipe diameter, $\gamma$ is the fluid density and $\Delta \gamma$ is the change in fluid density. If $\gamma$ is large, the terms involving stratification in the governing equation of fluid motion drop out of the equation. As a practical example, two-phase flows in enclosed systems generally lose 


\begin{tabular}{|l|l|l|l|}
\hline Customer: & $\begin{array}{l}\text { The United States Department of Energy } \\
\text { National Energy Technology Laboratory }\end{array}$ & $\begin{array}{l}\text { Date of Issue: } \\
\text { 24 April 2003 }\end{array}$ & \\
\hline $\begin{array}{l}\text { Document } \\
\text { Title: }\end{array}$ & $\begin{array}{l}\text { Subtask 1.3 } \\
\text { Determine Major Equipment Requirements }\end{array}$ & $\begin{array}{l}\text { Doc \# \& Version: } \\
\text { Doc 04 r2.0 }\end{array}$ & Page 8 of 20 \\
\hline
\end{tabular}

all stratification when the Froude Number rises to a range of from 1 to 2 . In the present application, the value of the Froude Number ranges in the hundreds, which assures complete mixing of any density variations. These high values are determined by the fact that in dense phase flow, the term $\Delta \gamma / \gamma$ in the equation above is small. This is necessarily so since the change in density occurs over the length of the heat exchanger.

\subsection{The Horizontal Exchanger, Design}

In choosing diameters for the suspended strings in a cavern-installed heat exchanger, the outer diameter was constrained by the proposed well size which was limited by cost. At some point additional wells are cheaper than going with larger wells. From that point it was desirable to balance the pressure drop in the two paths while obtaining the desired heat transfer. In a surface exchanger, the diameters can be almost any size, so the selection was based on availability and workability of the cryogenic (inner) pipe. This resulted in the selection of $65 / 8$ " stainless, although other sizes are certainly feasible. Once the diameter is chosen, a limit on the flow velocity of the LNG is determined so as to limit pressure drop, and eventually determine the number of exchangers required to achieve a desired tanker offload rate. For the 6 5/8" pipe a maximum flow rate of 333 $\mathrm{m} 3 / \mathrm{hr}$ (velocity $=15.6 \mathrm{fps}, 4.75 \mathrm{~m} / \mathrm{sec}$ ) through 24 parallel exchangers will offload a 135,000metric ton tanker in $17 \mathrm{hrs}$ of constant rate $(8000 \mathrm{~m} 3 / \mathrm{hr})$ pumping. This is the nominal design point. Exchangers can be added or subtracted as needed to vary the rate. The stainless wall thickness has to be designed to accommodate the pressure required to reach and inject into the target salt cavern. In the nominal case, a 2000 psi pressure has been assumed, requiring a wall thickness of 0.432 " $(.011 \mathrm{~m})$ for the 316 stainless and 0.219 " $(0.0056 \mathrm{~m})$ for AL6XN. In the simulations which follow, only one was made using this latter thickness. Other materials may be suitable. For the warmant pipe, HDPE has been tentatively selected for its low roughness and resistance to corrosion. Other materials like coated steel are feasible, depending on the application. The cryogenic pipe is held in place inside the warmant pipe by centralizers. The numerical analysis, discussed below, was then used to approximately optimize the warmant pipe inside diameter and warmant flow rates.

\subsection{Numerical Analysis of the Exchanger}

The numerical analysis was performed by Prof. William Thomson, Chemical Engineering Department, Washington State University. The analysis took the natural gas properties for the specified gas and the heat transfer correlations from HYSYS and coupled this with MATLAB which is a computational code. The correlation used is the Dittus-Boelter equation. HYSYS is not set up to handle long pipe in pipe exchangers, nor can it calculate ice formation. This latter was done by iterating the solutions in MATLAB and making the wall surface conform to the warmant freeze point in the flow. The full report by Prof. Thomson is included in Attachment III. A range of variables was investigated. These included warmant pipe ID, warmant flow direction-parallel or counter flow, ratio of warmant flow to LNG flow, degree of fouling, cryo pipe wall thickness, warmant type-fresh or seawater, LNG and warmant inlet temperatures and the affect of sequential warmant injections. Note that the lowest temperature used for the LNG is $-250^{\circ} \mathrm{F}\left(117^{\circ} \mathrm{K}\right)$ since the high pressure cryogenic pumps add $10^{\circ} \mathrm{F}$ for the given flow rate, Ref 2 . The natural gas used in all calculations has a specific gravity of 0.62 and the composition in mole percent is: N2 1.55, C1 91.37, and C2 4.09. , C3 1.71, i-C4 0.35, n-C4 0.40, i-C5 0.16, n-C5 0.18, C6 0.19 . The thermal conductivity used for the 316 stainless was 6.8 Thermal conductivity for the AL6XN (one case) was $7.9 \mathrm{btu} / \mathrm{hr}-\mathrm{ft}-{ }^{\circ} \mathrm{F}$.

\subsection{Simulation of Parallel Flow, Fresh Water}




\begin{tabular}{|l|l|l|l|}
\hline Customer: & $\begin{array}{l}\text { The United States Department of Energy } \\
\text { National Energy Technology Laboratory }\end{array}$ & $\begin{array}{l}\text { Date of Issue: } \\
\text { 24 April 2003 }\end{array}$ & \\
\hline $\begin{array}{l}\text { Document } \\
\text { Title: }\end{array}$ & $\begin{array}{l}\text { Subtask 1.3 } \\
\text { Determine Major Equipment Requirements }\end{array}$ & $\begin{array}{l}\text { Doc \# \& Version: } \\
\text { Doc 04 r2.0 }\end{array}$ & Page 9 of 20 \\
\hline
\end{tabular}

In an attempt to minimize icing, the initial simulations were done for the parallel flow case, the rationale being that the higher warmant temperature at the inlet would inhibit icing. This is in fact the case, but at the downstream end of the exchanger, the warmant and LNG temperatures approached each other and thus extended the required exchanger length. Table 2.1 lists all of the parallel flow simulations.

Table 2.1 Simulation Results for Parallel Flow Heat Exchanger

CONDITIONS

RESULTS

\begin{tabular}{|c|c|c|c|c|c|c|c|c|c|c|c|c|c|c|c|}
\hline & Ratio & TH2O & TLNG & Tube & & nnulus & Fouling & Delta $P$ & Delta $P$ & T out & $L(0 F)$ & $L(40 F)$ & Qdot & ICE & Ice \\
\hline Case & H2O/LNG & INLET & INLET & D & Sch & D & & $\mathrm{H} 2 \mathrm{O}$ & LNG & $\mathrm{H} 2 \mathrm{O}$ & & $T @ 2500$ & $\mathrm{BTU} / \mathrm{s}$ & $\begin{array}{l}\text { Max } \\
\text { Thick }\end{array}$ & Length \\
\hline 1 & 2.25 & 80 & -250 & 6" & 80 & $11 "$ & 0.0000 & 277 & 106 & 32 & 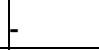 & -4 & 21570 & $0.23 "$ & $200-2500$ \\
\hline 2 & 2.25 & 80 & -250 & 6" & 80 & 14 & 0.0000 & 37 & 86 & 37 & - & -3 & 19494 & 0.15 & $0-2500$ \\
\hline 3 & 3.75 & 80 & -250 & 6" & 80 & 11 & 0.0000 & 667 & 128 & 48 & 1275 & 2500 & 25076 & & \\
\hline 4 & 3.75 & 80 & -200 & 6" & 80 & 11 & 0.0000 & 523 & 85 & 55 & 1025 & 1975 & 20629 & & \\
\hline 5 & 2.5 & 80 & -250 & 6" & 80 & 11 & 0.0000 & 304 & 117 & 34 & 1575 & 19 & 23414 & 0.025 & $900-2500$ \\
\hline 6 & 2.5 & 80 & -200 & 6" & 80 & 11 & 0.0000 & 300 & 110 & 41 & 1175 & 34 & 19611 & & \\
\hline 7 & 3.75 & 80 & -250 & 6" & 80 & 11 & 0.0035 & 670 & 97 & 51 & 2400 & 3 & 21861 & & \\
\hline 8 & 3.75 & 80 & -200 & 6" & 80 & 11 & 0.0035 & 672 & 92 & 57 & 1925 & 19 & 18338 & & \\
\hline 9 & 2.5 & 80 & -250 & 6" & 80 & 11 & 0.0035 & 300 & 93 & 39 & - & -7 & 20794 & & \\
\hline 10 & 2.5 & 80 & -200 & 6" & 80 & 11 & 0.0035 & 300 & 88 & 46 & 2150 & 9 & 17498 & & \\
\hline 11 & 3.75 & 80 & -250 & 6" & 80 & 14 & 0.0000 & 94 & 111 & 47 & 1450 & 33 & 24611 & 0.01 & $0-350$ \\
\hline 12 & 3.75 & 80 & -200 & 6" & 80 & 14 & 0.0000 & 84 & 98 & 53 & 1150 & 2250 & 20342 & & \\
\hline 13 & 2.5 & 80 & -250 & 6" & 80 & 14 & 0.0000 & 44 & 93 & 39 & - & -11 & 20415 & 0.07 & $0-2500$ \\
\hline 14 & 2.5 & 80 & -200 & $6 "$ & 80 & 14 & 0.0000 & 43 & 100 & 42 & 1525 & 28 & 10093 & 0.023 & $0-1175$ \\
\hline 15 & 3.75 & 80 & -250 & 6" & 80 & 14 & 0.0035 & 93 & 94 & 52 & - & -2 & 21350 & & \\
\hline 16 & 3.75 & 80 & -200 & 6" & 80 & 14 & 0.0035 & 93 & 109 & 56 & 2050 & 14 & 17943 & & \\
\hline 17 & 2.5 & 80 & -250 & 6" & 80 & 14 & 0.0035 & 43 & 90 & 40 & - & -15 & 20003 & & \\
\hline 18 & 2.5 & 80 & -200 & 6" & 80 & 14 & 0.0035 & 42 & 86 & 46 & 2350 & 4 & 17033 & & \\
\hline 19 & 3.75 & 80 & -250 & 6" & 80 & $11 "$ & 0.0017 & $891 / 3360 \mathrm{ft}$ & 169 & 49 & 1820 & 22 & 21848 & & \\
\hline 20 & 3.75 & 80 & -200 & 6" & 80 & $11 "$ & 0.0017 & 742 & 121 & 55 & 1470 & 2800 & 20104 & & \\
\hline $7^{\prime}$ & 3.75 & 80 & -250 & 6" & 80 & 11 & 0.0035 & $900 / 3395$ & 153 & 50 & 2400 & $24 / 3395$ & 23947 & & \\
\hline $8^{\prime}$ & 3.75 & 80 & -200 & 6" & 80 & 11 & 0.0035 & $900 / 3395$ & 143 & 56 & 1925 & $37 / 3395$ & 19897 & & \\
\hline $10^{\prime}$ & 2.5 & 80 & -200 & 6" & 80 & 11 & 0.0035 & $420 / 3500$ & 143 & 43 & 2170 & $26 / 3500$ & 19050 & & \\
\hline $11^{\prime}$ & 3.75 & 80 & -250 & 6" & 80 & 14 & 0.0000 & 123 & 177 & 46 & 1470 & 3255 & 25398 & 0.014 & $0-350$ \\
\hline $15^{\prime}$ & 3.75 & 80 & -250 & 6" & 80 & 14 & 0.0035 & $130 / 3500$ & 155 & 48 & 2555 & $21 / 3500$ & 23691 & & \\
\hline $16^{\prime}$ & 3.75 & 80 & -200 & 6" & 80 & 14 & 0.0035 & $130 / 3500$ & 146 & 54 & 2065 & $34 / 3500$ & 19700 & & \\
\hline $18^{\prime}$ & 2.5 & 80 & -200 & 6" & 80 & 14 & 0.0035 & $60 / 3500$ & 138 & 42 & 2345 & $22 / 3500$ & 18710 & & \\
\hline 21 & 2.5 & 80 & -200 & 6" & 80 & 12 & 0.0035 & $197 / 3500$ & 141 & 42 & 2205 & $24.5 / 3500$ & 018934 & & \\
\hline 22 & 3 & 80 & -250 & 6" & 80 & 12 & 0.0017 & $281 / 3500$ & 171 & 40 & 2030 & $28 / 3500$ & 24342 & & \\
\hline
\end{tabular}




\begin{tabular}{|l|l|l|l|}
\hline Customer: & $\begin{array}{l}\text { The United States Department of Energy } \\
\text { National Energy Technology Laboratory }\end{array}$ & $\begin{array}{l}\text { Date of Issue: } \\
\text { 24 April 2003 }\end{array}$ & \\
\hline $\begin{array}{l}\text { Document } \\
\text { Title: }\end{array}$ & $\begin{array}{l}\text { Subtask 1.3 } \\
\text { Determine Major Equipment Requirements }\end{array}$ & $\begin{array}{l}\text { Doc \# \& Version: } \\
\text { Doc 04 r2.0 }\end{array}$ & Page 10 of 20 \\
\hline
\end{tabular}

\begin{tabular}{|l|l|l|l|l|l|l|l|l|l|l|l|l|l|l|l|}
\hline 23 & 2.5 & 80 & -250 & $6^{\prime \prime}$ & 80 & 12 & 0.0035 & $197 / 3500$ & 149 & 35 & 2905 & $10 / 3500$ & 22692 & 0.0004 & $@ 3500$ \\
\hline 24 & 3 & 80 & -250 & $6^{\prime \prime}$ & 80 & 12 & 0.0035 & $280 / 3500$ & 154 & 42 & 2660 & $17 / 3500$ & 23304 & & \\
\hline 25 & 3.5 & 80 & -250 & $6^{\prime \prime}$ & 80 & 12 & 0.0035 & $378 / 3500$ & 157 & 47 & 2485 & $22 / 3500$ & 23760 & & \\
\hline 26 & 4 & 80 & -250 & $6^{\prime \prime}$ & 80 & 12 & 0.0035 & $491 / 3500$ & 159 & 51 & 2415 & $26 / 3500$ & 24114 & & \\
\hline 27 & 3.5 & 80 & -250 & $6^{\prime \prime}$ & 80 & 12 & 0.0017 & $378 / 3500$ & 176 & 45 & 1925 & $33 / 3500$ & 24828 & & \\
\hline 28 & 4 & 80 & -250 & $6^{\prime \prime}$ & 80 & 12 & 0.0017 & $491 / 3500$ & 179 & 38 & 1820 & $38 / 3500$ & 25206 & & \\
\hline 29 & 2.5 & 80 & -250 & $6 "$ & 80 & 12 & 0.0017 & $200 / 3500$ & 164 & 34 & 2240 & $34 / 3500$ & 23388 & 0.059 & $>3500$ \\
\hline 30 & 3 & 80 & -250 & $6 "$ & 80 & 13 & 0.0017 & $148 / 3500$ & 169 & 40 & 2100 & $27 / 3500$ & 24226 & & \\
\hline 31 & 3.5 & 80 & -250 & $6^{\prime \prime}$ & 80 & 13 & 0.0017 & $199 / 3500$ & 173 & 45 & 1960 & $32 / 3500$ & 24716 & & \\
\hline 32 & 4 & 80 & -250 & $6^{\prime \prime}$ & 80 & 13 & 0.0017 & $258 / 3500$ & 177 & 49 & 1890 & $36 / 3500$ & 25094 & & \\
\hline 33 & 3 & 80 & -250 & $6^{\prime \prime}$ & 80 & 13 & 0.0035 & $148 / 3500$ & 152 & 42 & 2730 & $15 / 3500$ & 23165 & & \\
\hline 34 & 3.5 & 80 & -250 & $6^{\prime \prime}$ & 80 & 13 & 0.0035 & $199 / 3500$ & 155 & 47 & 2555 & $20 / 3500$ & 23626 & & \\
\hline 35 & 4 & 80 & -250 & $6 "$ & 80 & 13 & 0.0035 & $258 / 3500$ & 158 & 51 & 2450 & $24 / 3500$ & 23983 & & \\
\hline 36 & 2.5 & 80 & -250 & $6 \prime$ & 80 & 13 & 0.0017 & $106 / 3500$ & 159 & 34 & 2555 & $12 / 3500$ & 22872 & 0.076 & $>3500$ \\
\hline
\end{tabular}

A study of the parallel flow results provides some immediate observations:

Warming is a strong function of the warmant flow velocity more so than the volumetric flow rate. Compare runs 5 and 13 which have the same flow rate but different warmant velocities due to different warmant diameters (11" vs. 14 "), where the final gas temperature is lower by 30 degrees for the smaller diameter pipe.

Very high flow rates in the same warmant diameter increase velocities and thus warming, but at the expense of high pressure drops. Compare cases 3 and 1. With a flow ratio of 3.75 and a pressure drop of 667 psi, case 3 reaches an LNG temperature of $40^{\circ} \mathrm{F}$ at $2500^{\prime}$, which was the original target length based on hand calculations. Preheating the LNG results in much less than a one for one improvement in the gas exit temperature.

Comparing case 5 with 6 and case 7 with 8 . In each case a 50 degree $F\left(28^{\circ} \mathrm{K}\right)$ warming of the LNG resulted in only about a 15 degree $\left(8^{\circ} \mathrm{K}\right)$ increase in the exit gas temperature at $2500^{\prime \prime}(762 \mathrm{~m})$.

High fouling factors make a significant difference, compare cases 5 and 9 . However these factors are probably too high, discussed below.

In the case of parallel flow, the formation of ice is pushed downstream from the entry point by the high heat rate delivered by the entering warmant. The ice starting point can be pushed downstream by increasing this rate, and can be eliminated entirely in this manner, see cases 3, 4, 7 and 8. Increasing the warmant diameter will lower the velocity and offset this effect, see case 11.

The effect of icing is to increase the pressure drop and local velocities, but it is difficult to separate these effects from other factors. Ice formation is self limiting, as expected, i. e. the thicknesses shown are stable. The increased velocities increase the heat transfer to the ice, while the increased insulating effect decreases heat transfer to the cryo wall. The simulation shows that the warmant bulk temperatures can approach the freezing point within at least $2^{\circ} \mathrm{F}\left(1^{\circ} \mathrm{K}\right)$ without causing excessive icing. This increases the delta $\mathrm{T}$ available from the warmant beyond what was assumed in early calculations. 


\begin{tabular}{|l|l|l|l|}
\hline Customer: & $\begin{array}{l}\text { The United States Department of Energy } \\
\text { National Energy Technology Laboratory }\end{array}$ & $\begin{array}{l}\text { Date of Issue: } \\
\text { 24 April 2003 }\end{array}$ & \\
\hline $\begin{array}{l}\text { Document } \\
\text { Title: }\end{array}$ & $\begin{array}{l}\text { Subtask 1.3 } \\
\text { Determine Major Equipment Requirements }\end{array}$ & $\begin{array}{l}\text { Doc \# \& Version: } \\
\text { Doc 04 r2.0 }\end{array}$ & Page 11 of 20 \\
\hline
\end{tabular}

Comparing the exit warmant temperatures with the exit LNG temperatures shows that the temperature difference between the two flows is becoming very small, thus extending the exchanger length. This dictated that the counter flow configuration should be examined.

\subsection{Simulation of Multiple Injections, Fresh Water}

Multiple injections of warmant can multiply the heat available as well as increasing the available temperature potential. Fig. 2.1 is an energy balance showing the flow ratio of warmant to LNG required to reach a given

Figure 2.1 Ratio of Warmant to LNG Flow Rate for Various LNG Exit Temperatures

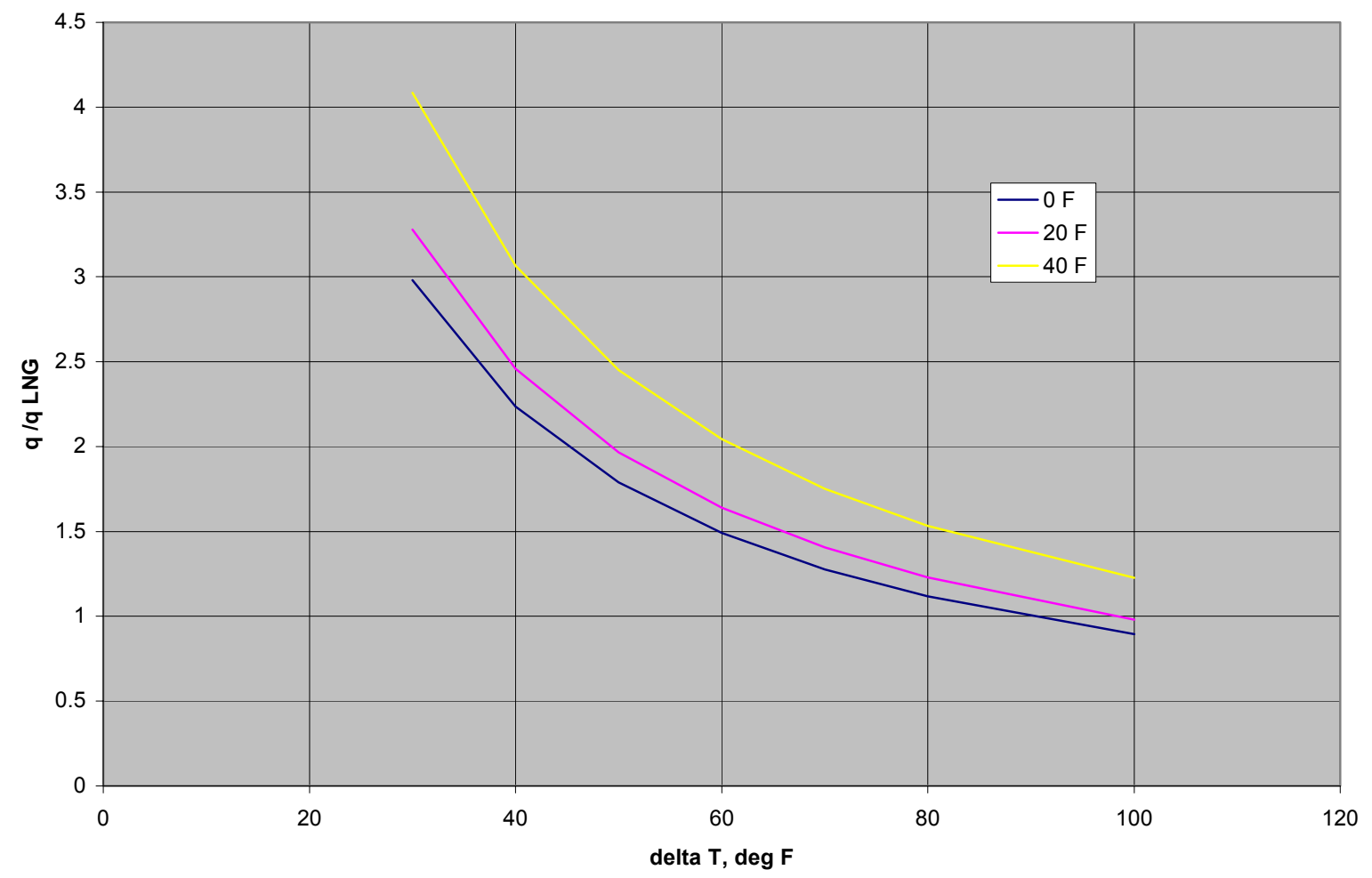

LNG exit temperature as a function of delta $\mathrm{T}$, the temperature available in the warmant above its freezing point. For instance, if the fresh water is at $72^{\circ} \mathrm{F}$ it has an available delta $\mathrm{T}$ of 40 degrees. Entering the figure at this temperature and requiring an exit temperature of $0^{\circ} \mathrm{F}$, shows that a flow ratio of about 2.25 is needed. If a second injection is used the energy available is doubled and the figure must be entered at a delta of 80 degrees. This produces a required flow ratio of only about 1.1. Again this is strictly an energy balance and says nothing about the length of the heat exchanger. However since the driving temperature difference is increased, the length will be shortened. This is illustrated in Table 2.2, where the base case for comparison is Case 1 in Table 2.1. There are two main issues investigated in this table. The first is without a 2 nd injection. It shows that a $20^{\circ} \mathrm{F}\left(11^{\circ} \mathrm{K}\right)$ rise in the warmant injection temperature to $100^{\circ} \mathrm{F}$ causes a $44^{\circ} \mathrm{F}\left(24^{\circ} \mathrm{K}\right)$ rise in the LNG at $2500^{\prime}$ as compared to the case where the warmant is injected at $80^{\circ} \mathrm{F}\left(44^{\circ} \mathrm{K}\right)$. Compare case 1 with case 2 in the table. This reflects the larger amount of energy stored in the warmant per degree of temperature increase as compared to warming the LNG. The second point, obtained from comparing cases 1 and 6 , shows that the intermediate injection allows the LNG to reach $40^{\circ} \mathrm{F}$ in just 2117 ', while without this injection, the LNG 


\begin{tabular}{|l|l|l|l|}
\hline Customer: & $\begin{array}{l}\text { The United States Department of Energy } \\
\text { National Energy Technology Laboratory }\end{array}$ & $\begin{array}{l}\text { Date of Issue: } \\
\text { 24 April 2003 }\end{array}$ & \\
\hline $\begin{array}{l}\text { Document } \\
\text { Title: }\end{array}$ & $\begin{array}{l}\text { Subtask 1.3 } \\
\text { Determine Major Equipment Requirements }\end{array}$ & $\begin{array}{l}\text { Doc \# \& Version: } \\
\text { Doc 04 r2.0 }\end{array}$ & Page 12 of 20 \\
\hline
\end{tabular}

is at only $-4^{\circ} \mathrm{F}$ at $2500^{\prime}$. This result has driven the optimization process to use of a second injection, but with some modification beyond this case.

TABLE 2.2 Effect of Inlet Warmant Temperature and 2nd Warmant Injection for the Base Case (No Fouling)

\begin{tabular}{|c|c|c|c|c|c|c|c|c|}
\hline & $\%$ Warmant & Warmant & Tout $\mathrm{H} 2 \mathrm{O}$ & L@ & L@ @ 40 F) & $\begin{array}{c}\text { Warmant } \\
\text { Delta } P\end{array}$ & ICE & Ice \\
\hline Case & Replaced1 & INLET & @2500ft & $O F$ & T @ 2500 & Psi & Max Thick & Length \\
\hline 1 & 0 & $80 \mathrm{~F}$ & $33 \mathrm{~F}$ & - & $-4 \mathrm{~F}$ & - & 0.2301 & $150->$ \\
\hline 2 & 0 & 100 & 44 & $1281 \mathrm{ft}$ & 40 & - & None & - \\
\hline 3 & $30 \%$ & 80 & 44 & 1500 & 30 & 135 & 0.009 & $750->1250$ \\
\hline 4 & $40 \%$ & 80 & 50 & 1477 & 36 & 145 & 0.009 & $750->1250$ \\
\hline 5 & $50 \%$ & 80 & 55 & 1463 & 2500 & 155 & 0.009 & $750->1250$ \\
\hline 6 & $100 \%$ & 80 & 66 & 1435 & 2117 & 244 & 0.009 & $750->1250$ \\
\hline
\end{tabular}

1 Warmant totally replaced at midpoint with various quantities of fresh warmant at $80 \mathrm{~F}$

2 For SI units: 80 OF $=300 \mathrm{~K}, 33 \mathrm{OF}=274 \mathrm{~K}, 135 \mathrm{psi}=0.93 \mathrm{Mpa}, 106 \mathrm{psi}=0.71 \mathrm{Mpa},,-40 \mathrm{~F}=253 \mathrm{~K}, 0.2301 \mathrm{in}=5.84$ $\mathrm{E}-03 \mathrm{~m}, 150 \mathrm{ft}=45.7 \mathrm{~m}$

\subsection{Simulation of a Counter-Flow Exchanger, Using Seawater}

Because of the long exchanger lengths required by the parallel flow approach, counter-flow exchangers were studied. In addition, seawater was incorporated into the model, partly to offset the increased icing that was expected and because seawater is a prime warmant candidate. The previous modeling had indicated that it was possible for the bulk temperature of the warmant to approach the freezing point without unduly increasing the icing problem. This increases the delta $T$ available, and needs to be checked with further detailed modeling and a physical test. Thus seawater should be good down to about $28^{\circ} \mathrm{F}$ as an exit temperature. The results of the counter-flow simulations are presented in Table 2.3. Of primary interest in this table is Case 8 , where $40^{\circ} \mathrm{F}$ is reached in approximately 2590'. Icing is somewhat of a problem in that it grows to $0.409 "$. This case, plus the previous parallel flow case with a second injection, Table 2.2, Case 6, indicated what should form the final and best configuration resulting from this series of simulations, namely a combined parallel and counter-flow exchanger. It will be discussed next. 


\begin{tabular}{|l|l|l|l|}
\hline Customer: & $\begin{array}{l}\text { The United States Department of Energy } \\
\text { National Energy Technology Laboratory }\end{array}$ & $\begin{array}{l}\text { Date of Issue: } \\
\text { 24 April 2003 }\end{array}$ & \\
\hline $\begin{array}{l}\text { Document } \\
\text { Title: }\end{array}$ & $\begin{array}{l}\text { Subtask 1.3 } \\
\text { Determine Major Equipment Requirements }\end{array}$ & $\begin{array}{l}\text { Doc \# \& Version: } \\
\text { Doc 04 r2.0 }\end{array}$ & Page 13 of 20 \\
\hline
\end{tabular}

Table 2.3 Counter-Flow Heat Exchanger: Effect of Parameters1 [Seawater, No Fouling]

\begin{tabular}{|c|c|c|c|c|c|c|c|c|c|c|}
\hline & Equiv. & Warmant & Warmant & LNG & L@ @ $40 \mathrm{~F}$ & L@0F & LNG2 & $\mathrm{H} 2 \mathrm{O} 2$ & ice $\max$ & icing \\
\hline Case & Flow ratio & Diameter & $\mathrm{T}$ & Inlet T & $(\mathrm{ft})$ & (ft) & $\Delta P(p s i)$ & $\Delta \mathrm{P}$ (psi) & thick (in) & $\begin{array}{c}\text { Interval } \\
\text { (ft) }\end{array}$ \\
\hline 1 & 2.25 & 11 in & $80 \mathrm{~F}$ & $-250 \mathrm{~F}$ & - & 2285 & 71 & 325 & 0.911 & $0->1435$ \\
\hline 2 & 2.25 & 12 & 80 & -250 & - & 2716 & 82 & 186 & 1.159 & $0->1925$ \\
\hline 3 & 2.25 & 12 & 70 & -250 & NOT Feasible & - & - & - & - & - \\
\hline 4 & 2.25 & 12 & 80 & -250 & - & 2716 & 82 & 186 & 1.159 & $0->1925$ \\
\hline 5 & 2.25 & 12 & 90 & -250 & 2681 & 2178 & 101 & 139 & 0.569 & $0->1365$ \\
\hline 6 & 2.25 & 12 & 80 & -250 & NOT Feasible & - & - & - & - & - \\
\hline 7 & 2.5 & 12 & 80 & -250 & 3317 & 2736 & 121 & 258 & 1.102 & $0->1925$ \\
\hline 8 & 2.75 & 12 & 80 & -250 & $\sim 2590$ & 2035 & 100 & 190 & 0.409 & $0->1190$ \\
\hline 9 & 2.25 & 12 & 80 & -250 & NOT Feasible & - & - & - & - & - \\
\hline 10 & 2.25 & 12 & 80 & -200 & 2328 & 1770 & 79 & 113 & 0.347 & $0->1050$ \\
\hline 11 & 2.75 & 12 & 80 & -250 & $\sim 2590$ & 2035 & 100 & 190 & 0.409 & $0->1190$ \\
\hline 12 & 2.75 & 13 & 80 & -250 & 2992 & 2395 & 114 & 118 & 0.539 & $0->1610$ \\
\hline 13 & 2.25 & 11 & 70 & -250 & NOT Feasible & - & - & - & - & - \\
\hline 14 & 2.25 & 11 & 90 & -250 & 2797 & 2285 & 104 & 371 & 0.913 & $0->1435$ \\
\hline
\end{tabular}

1 For SI units: $11 "=(0.028 \mathrm{~m}),-250 \mathrm{OF}=116 \mathrm{~K}, 33 \mathrm{OF}=274 \mathrm{~K}, 71 \mathrm{psi}=0.49 \mathrm{Mpa}, 325 \mathrm{psi}=2.24 \mathrm{Mpa}$, , 0.991 in $=0.025 \mathrm{~m}, 1435 \mathrm{ft}=437 \mathrm{~m}$

2 At the length required for the LNG to reach $40 \mathrm{OF}$, or $0 \mathrm{OF}$

\subsection{Simulation of a Combined Parallel and Counter-Flow Exchanger, with Two Warmant Injections (Mixed Injection).}

Based on the ability of the parallel flow configuration to minimize icing, the counter-flow configuration increased efficiency and the ability of a second injection to double the energy available, it was decided to combine these effects. The result is an exchanger which starts with parallel flow at the inlet, doubles back to the warmant source where it receives a second warmant injection, both flows being expelled at the midpoint, now the farthest end of the exchanger. A preliminary design of such an exchanger is shown in Figure 2.2. All pipes of the exchanger are fixed at the fluid injection end and the cryo pipe is free to expand into the capsule at the opposite end. Approximately 4.5' of expansion space has been allowed. 


\begin{tabular}{|l|l|l|l|}
\hline Customer: & $\begin{array}{l}\text { The United States Department of Energy } \\
\text { National Energy Technology Laboratory }\end{array}$ & $\begin{array}{l}\text { Date of Issue: } \\
\text { 24 April 2003 }\end{array}$ & \\
\hline $\begin{array}{l}\text { Document } \\
\text { Title: }\end{array}$ & $\begin{array}{l}\text { Subtask 1.3 } \\
\text { Determine Major Equipment Requirements }\end{array}$ & $\begin{array}{l}\text { Doc \# \& Version: } \\
\text { Doc 04 r2.0 }\end{array}$ & Page 14 of 20 \\
\hline
\end{tabular}

Figure 2.2 Prototype Bishop Process Heat Exchanger
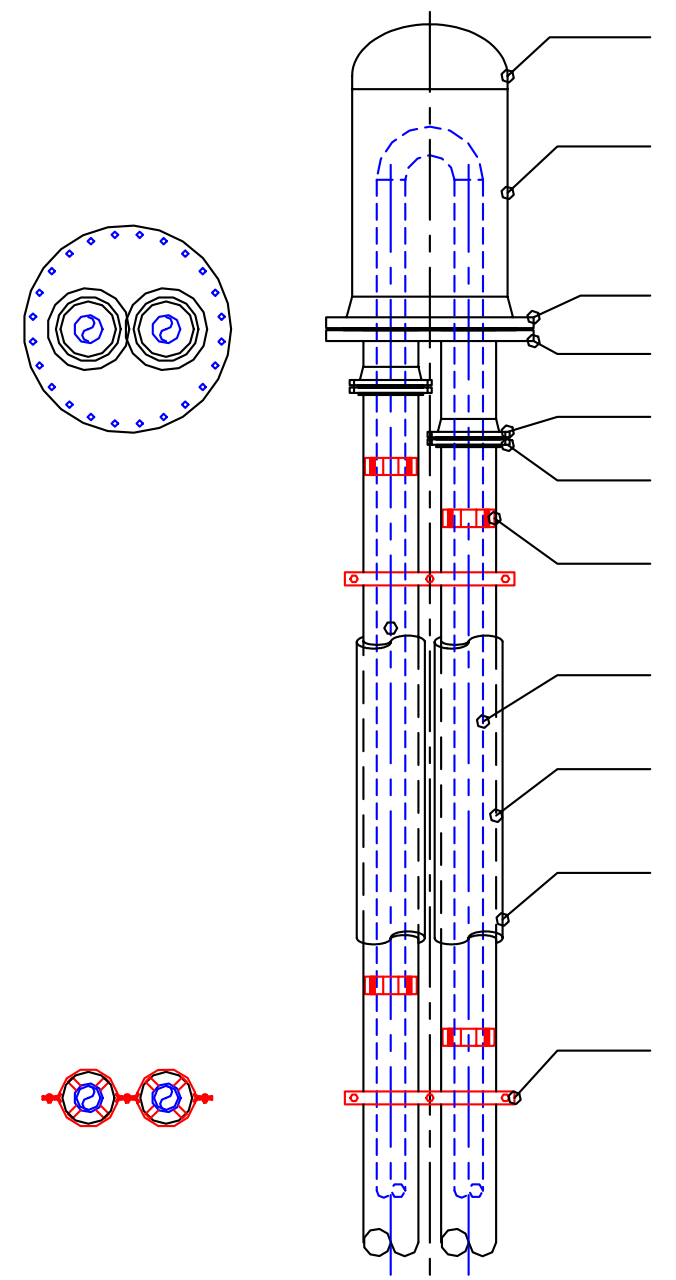

36" STD C.S. WELD CAP

36" STD C.S. EXPANSION BARREL

36" 150\# C.S. RFWN

36" 150\# C.S. RFBF

12" 150\# C.S. RFWN

12" HDPE FLANGE

12X6 HDPE CENTRALIZER @ 10' C-C (DUOCON 6X10 W/2" OPTION OR EQ)

1250 LF 6" SCH 80 AL6XN PIPE

(EACH TUBE, X 2 TUBES)

12" HDPE DR-11 PIPE

1-1/2" THICK CONCRETE

WEIGHT COATING
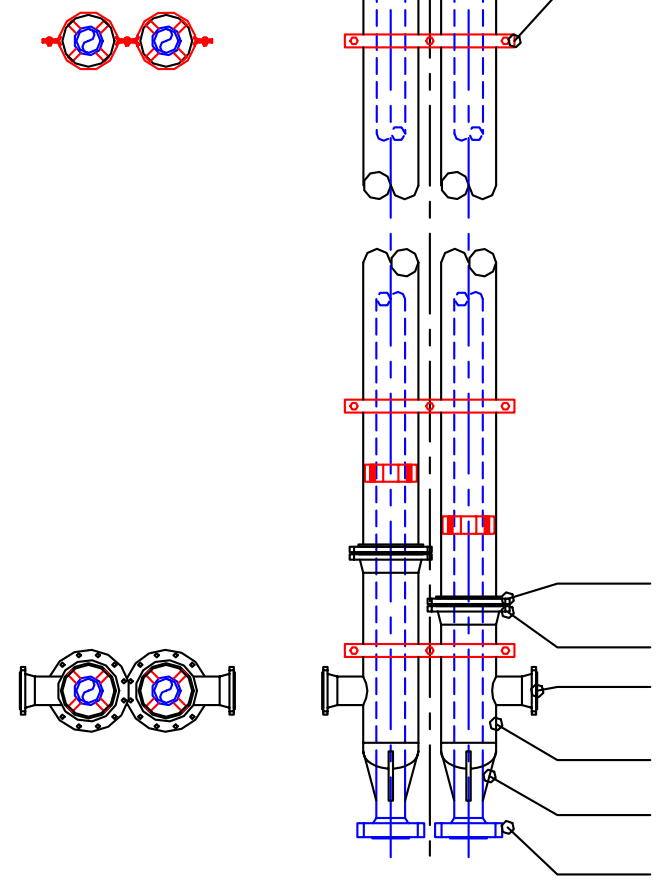

12" HDPE RFWN

12" 150\# C.S. FLANGE

6" 150\# 316L SS RFWN FLG

12" STD 316L BARREL ASSY

STIFFENER GUSSETS

6" 150\# AL6XN RTJWN FLG 


\begin{tabular}{|l|l|l|l|}
\hline Customer: & $\begin{array}{l}\text { The United States Department of Energy } \\
\text { National Energy Technology Laboratory }\end{array}$ & $\begin{array}{l}\text { Date of Issue: } \\
\text { 24 April 2003 }\end{array}$ & \\
\hline $\begin{array}{l}\text { Document } \\
\text { Title: }\end{array}$ & $\begin{array}{l}\text { Subtask 1.3 } \\
\text { Determine Major Equipment Requirements }\end{array}$ & $\begin{array}{l}\text { Doc \# \& Version: } \\
\text { Doc 04 r2.0 }\end{array}$ & Page 15 of 20 \\
\hline
\end{tabular}

This will vary depending on the cryo material. Simulation results for this exchanger are shown in Table 2.4.

TABLE 2.4 Effect of Mixed Injection Heat Transfer1

[Seawater, Flow ratio $=2.5,12 "(0.305 \mathrm{~m})$ Warmant Diameter]

\begin{tabular}{|c|c|c|c|c|c|c|c|}
\hline Case & Configuration & L (@ $\left.0^{\circ} \mathrm{F}\right)$ & $\begin{array}{c}\mathrm{L} @ 40^{\circ} \mathrm{F} \\
\mathrm{T} @ 3500 \mathrm{ft}\end{array}$ & $\begin{array}{c}\Delta \mathrm{P} H 2 \mathrm{O} \\
(\mathrm{psi})\end{array}$ & $\begin{array}{c}\triangle P \text { LNG } \\
(p s i)\end{array}$ & $\begin{array}{c}\text { ICE } \\
\text { Max Thick } \\
\text { (in) }\end{array}$ & $\begin{array}{l}\text { ICE } \\
\text { Length } \\
\text { (ft) }\end{array}$ \\
\hline 1 & $\begin{array}{l}\text { Mixed } \\
\text { Parallel }\end{array}$ & $1433 \mathrm{ft}$ & $2033 \mathrm{ft}$ & 1142 & 912 & None & - \\
\hline 2 & $\begin{array}{l}\text { Flow } \\
\text { Counter- }\end{array}$ & 2900 & $10 \mathrm{~F}$ & 2053 & 1723 & None & - \\
\hline 3 & Flow & 2736 & 3317 & 2584 & 1214 & 1.102 & $0->1925$ \\
\hline
\end{tabular}

1 For SI units: $0^{\circ} \mathrm{F}=255^{\circ} \mathrm{K}, 1433 \mathrm{ft}=437 \mathrm{~m}, 2033 \mathrm{ft}=620 \mathrm{~m}, 114 \mathrm{psi}=0.76 \mathrm{MPa}, 91 \mathrm{psi}=0.63 \mathrm{Mpa}$,

$1.102 \mathrm{in}=0.028 \mathrm{~m}, 1925 \mathrm{ft}=587 \mathrm{~m}$

2 At $2033 \mathrm{ft} \quad 3$ At $3500 \mathrm{ft} \quad 4$ At $3317 \mathrm{ft}$

This table compares pure parallel flow and counter-flow cases with the mixed configuration case. Each of the cases has a 2.5 warmant to LNG ratio with a thick walled cryo pipe, 0.432 " $(.0110 \mathrm{~m})$ and a 12 " $(0.305 \mathrm{~m})$ warmant pipe. The warmant is seawater at $80^{\circ} \mathrm{F}$. Parallel flow was maintained in the mixed exchanger up to 1250 ', where it met the counter-flow and both were expelled. The mixed flow case reaches $40^{\circ} \mathrm{F}\left(278^{\circ} \mathrm{K}\right)$ in 2033' $(620 \mathrm{~m})$. This is by far the best result of all of the simulations. It is not yet fully optimized, that is thin wall pipe could be used, flow ratio could be varied, the warmant or LNG could be preheated, etc. However it appears that the final design will be close to this configuration. Note that at $1250^{\prime}(381 \mathrm{~m})$, where the flow changes from parallel to counter, the temperature has reached $-16^{\circ} \mathrm{F}\left(246^{\circ} \mathrm{K}\right)$ and the pressure drop was $70 \mathrm{psi}(0.48 \mathrm{Mpa})$. As shown in the table, total pressure drop for both fluids was significantly lower than for the comparison cases. This is due both to the shorter length and to the lower viscosities in the warmer fluids. The lower pressure requirements represent a significant operational savings. In cases where it is feasible to warm the gas just to $0^{\circ} \mathrm{F}$, for instance, the required total length is reduced to less than 1433'. Note that this is far from being optimized since the first 1250' is the parallel flow heat exchanger, followed by a short counter-flow exchanger. Making the sections of equal length will reduce overall length even more. The option of going to $0^{\circ} \mathrm{F}$ is discussed in a following section.

\subsection{Fouling and Turbidity Considerations}

A comparison of simulations for fouling factors of 0.0017 and $0.0035 \mathrm{hr}-{ }^{\circ} \mathrm{F}-\mathrm{ft} 2 / \mathrm{btu}$ is shown in Figure 2.3. For the fouling factors considered, length of exchanger increases about $40 \%$ over the zero fouling case. Unfortunately, the factors simulated are large for seawater exchangers, which are typically in the range of $0.0005 \mathrm{hr}-{ }^{\circ} \mathrm{F}-\mathrm{ft} 2 / \mathrm{btu}$ at ambient temperatures. For the colder environment of the present exchangers and for the metals used, actual factors may be lower. Also, fouling factor effect will be combined with wall thickness and the pipe thermal conductivity effects, which will all combine to affect exchanger length and have not been optimized in this study.

The fouling factor of $0.0005 \mathrm{hr}-\mathrm{F}$-ft2/btu quoted in this report is for long term operating conditions and thus represents true operating conditions. This effect will to a great extent be masked in the exchanger by variation in wall thickness and the steel conductivity which have not yet been optimized. It is anticipated that with higher water velocities and colder temperatures in the Bishop Process exchangers (as compared to overhead rack types for instance) less fouling will be developed. 


\begin{tabular}{|l|l|l|l|}
\hline Customer: & $\begin{array}{l}\text { The United States Department of Energy } \\
\text { National Energy Technology Laboratory }\end{array}$ & $\begin{array}{l}\text { Date of Issue: } \\
\text { 24 April 2003 }\end{array}$ & \\
\hline $\begin{array}{l}\text { Document } \\
\text { Title: }\end{array}$ & $\begin{array}{l}\text { Subtask 1.3 } \\
\text { Determine Major Equipment Requirements }\end{array}$ & $\begin{array}{l}\text { Doc \# \& Version: } \\
\text { Doc 04 r2.0 }\end{array}$ & Page 16 of 20 \\
\hline
\end{tabular}

However, in the event that fouling becomes a bigger problem than indicated by the 0.0005 value, there are at least two remedies. 1) Because of the configuration of the exchangers and their intermittent operation, it is possible to drain and flush each exchanger between tanker arrivals. This flush could be for chemical fouling as well as a biocide. The flush liquid could be recovered after each use and finally disposed of when spent. 2) In the extreme case the warmant pipe is designed as a sleeve over the cryo pipe and its centralizers. This sleeve could be removed from each exchanger and then both the cryo and warmant pipes cleaned as needed. This could be done one exchanger at a time so as to minimize disruption.

All ambient exchangers have some problem with fouling. It is believed that the Bishop Process exchanger would be least effected. These will be investigated in detail before performing a field test. Fouling data from existing LNG/seawater exchangers should be incorporated.

In addition, turbidity in the warmant is considered to be a problem in some exchangers. However, in the present case, the velocities in the warmant pipe are much higher than they would be in any source body, and thus settling of particles in this pipe should not be a problem. Typical turbidity is primarily composed of soft clay particles which do not present an erosion problem. Harder minerals like quartz, if incorporated into the flow could cause erosion, but this effect should be confined to the bottom center-line of the warmant pipe.

Figure 2.3 Exchanger Length vs. Flow Ratio for Various Fouling Factors

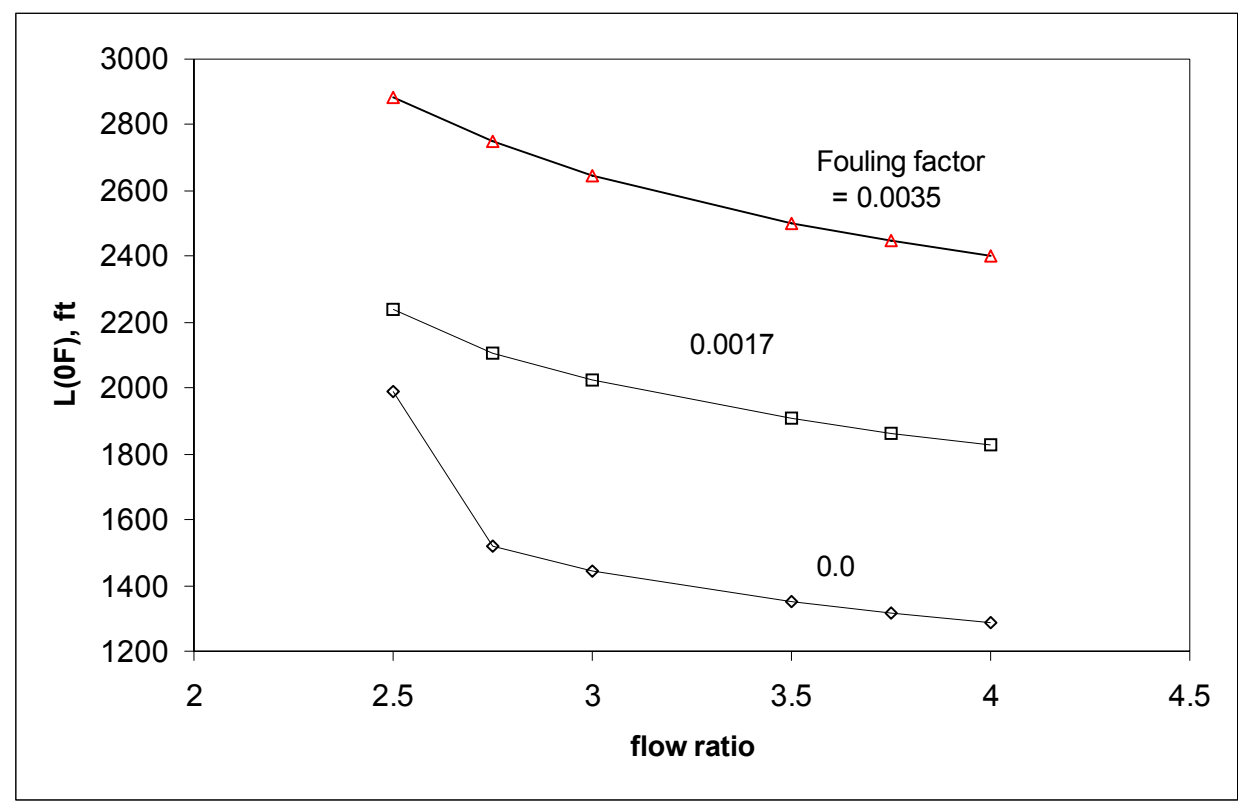

\subsection{Simulation Using Finite Element Analysis}

A computational fluid dynamics code, CFD-ACE, was used to attempt a preliminary confirmation of the foregoing simulations, which are based on correlations. Remaining funding permitted only a coarse grid modeling. The results of this modeling predicted a $2^{\circ} \mathrm{F}\left(1^{\circ} \mathrm{K}\right)$ less of a drop in the warmant temperature over the first $165^{\prime}(50 \mathrm{~m})$ of the parallel flow. Since this is the region where the gradients are steepest, this may not represent a significant discrepancy. Additionally, the higher warmant temperature would cause higher heat 


\begin{tabular}{|l|l|l|l|}
\hline Customer: & $\begin{array}{l}\text { The United States Department of Energy } \\
\text { National Energy Technology Laboratory }\end{array}$ & $\begin{array}{l}\text { Date of Issue: } \\
\text { 24 April 2003 }\end{array}$ & \\
\hline $\begin{array}{l}\text { Document } \\
\text { Title: }\end{array}$ & $\begin{array}{l}\text { Subtask 1.3 } \\
\text { Determine Major Equipment Requirements }\end{array}$ & $\begin{array}{l}\text { Doc \# \& Version: } \\
\text { Doc 04 r2.0 }\end{array}$ & Page 17 of 20 \\
\hline
\end{tabular}

transfer downstream. This degree of agreement appears to be sufficient for this stage of the technology. Ultimate refining of the prediction capability will await the field test results.

\subsection{Heat Exchanger Operational Considerations}

Fig. 3.12-1 is a schematic of an LNG receiving terminal (offshore version) using a Bishop heat exchanger. The tanker pumps offload the LNG to the terminal high pressure pumps. These raise the LNG pressure such that it matches the pipeline and cavern requirements. This will normally put the pressure well above the cricondenbar of the LNG being pumped, which assures that the gas stays in the dense phase. Referencing the nominal design case for this study, LNG moves from the high pressure pumps, and will pass directly to the heat exchangers at $8000 \mathrm{~m} 3 / \mathrm{hr}$ and 2000psi. Nominally, twenty-four pumps are required to meet these process conditions. The cryogenic pumps are restricted to about 2,600 horsepower but not in pressure within reasonable limits. Higher discharge pressures (e.g. the 2,200 psi 28 pump case) require more pumps at lower flow rates per pump to maintain horsepower restraints.

Figure 3.12-1

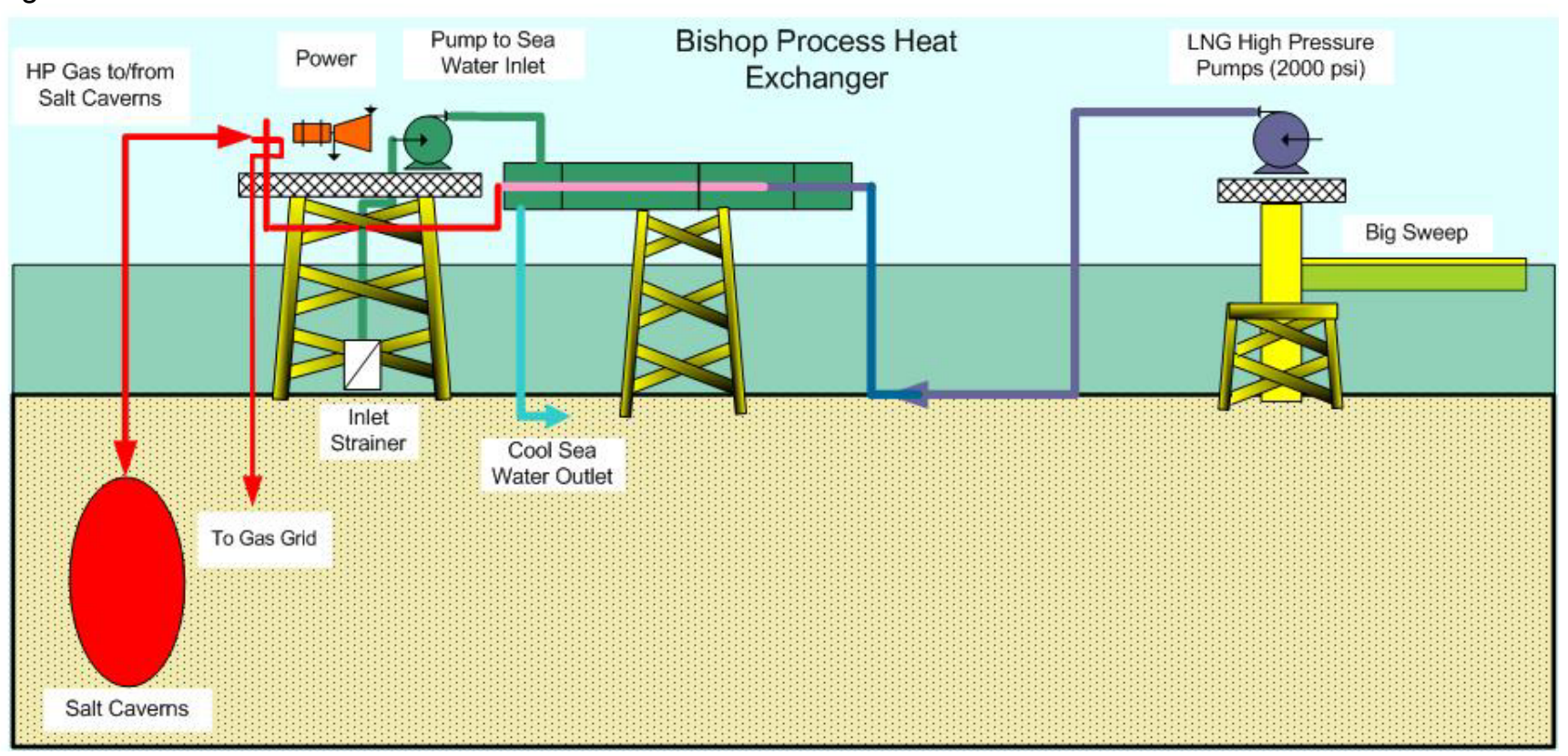

\subsection{Heat Exchanger Exit Temperatures}

The first pass through the exchangers will take the dense phase gas to the temperature desired for the cavern. The RESPEC rock mechanics study, discussed in a later section, shows that at least down to $0^{\circ} \mathrm{F}$, and probably lower, the temperature does not have a negative effect on the cavern. This provides some leeway in determining the exchanger exit temperature. To make the exchangers shorter and less expensive, gas could be allowed to enter the cavern at $0^{\circ} \mathrm{F}$ and then make a return pass through the exchangers on the way out. This final pass could also be used to offset cooling caused by the pressure drop down to pipeline conditions. Final desired temperature would depend on the specific pipeline and the amount of mixing expected. Generally speaking moderately low temperatures are desirable in a pipeline to increase throughput. If the cavern is 


\begin{tabular}{|l|l|l|l|}
\hline Customer: & $\begin{array}{l}\text { The United States Department of Energy } \\
\text { National Energy Technology Laboratory }\end{array}$ & $\begin{array}{l}\text { Date of Issue: } \\
\text { 24 April 2003 }\end{array}$ & \\
\hline $\begin{array}{l}\text { Document } \\
\text { Title: }\end{array}$ & $\begin{array}{l}\text { Subtask 1.3 } \\
\text { Determine Major Equipment Requirements }\end{array}$ & $\begin{array}{l}\text { Doc \# \& Version: } \\
\text { Doc 04 r2.0 }\end{array}$ & Page 18 of 20 \\
\hline
\end{tabular}

distant from the storage caverns, a second, exit pass through the exchangers is not possible. This is the case for the Liberty Project, discussed later, where the caverns are 35 miles from the proposed terminals. Here the exchangers are limited to whatever the connecting pipeline can be reasonably designed for. A benefit of a remotely located cavern, such as for Liberty, is that the gas will warm to ambient temperature during the trip.

Making use of the cavern tolerance for low temperatures does not mean that the well casing can tolerate the same temperatures. It is important that this casing be protected. The temperature range over which a cemented casing can operate can be improved by using some of the advanced cements now available. However a failsafe technique is to provide a hanging string and to shunt a warm stream of gas down the annulus. Calculations would have to be performed to determine the rate and temperature required. The same operation would be performed for both entry and exit of the cooled gas.

\subsection{Using the Available Low Temperature to Process High Heating Value Gas}

Much of the LNG available world wide has heating values above that which is allowable in the domestic pipelines that transport it. This often requires consideration of removal of liquid petroleum gasses at or near the receiving terminal or mixing with other gas if that is possible. It would appear to this writer that it would be much preferable to remove the heavier gases at the source and ship them separately if necessary, rather than ship them in the relatively high cost LNG mode. Nevertheless, it is possible to remove a portion of these by using the temperature and pressure drop as the gas exits the cavern. Assuming a typical gas with a gravity of 0.705 and a heating value of $1250 \mathrm{btu} / \mathrm{mcf}$ is injected at $40^{\circ} \mathrm{F}$, dropping it from $2000 \mathrm{psi}$ in the cavern to $1000 \mathrm{psi}$ for the pipeline drops the gas gravity to 0.625 and the heating value to $1140 \mathrm{btu} / \mathrm{mcf}$. Dropping the same gas from $0^{\circ} \mathrm{F}$ and $2000 \mathrm{psi}$ to $1000 \mathrm{psi}$ drops the gravity to 0.61 and the heating value to $1100 \mathrm{btu} / \mathrm{mcf}$. These are much more acceptable heating values. Of course the liquids have to be separated and collected. The cavern will drop in pressure as it is drawn down and the pressure drop at the valve will be reduced. However at the same time the temperature in the cavern will be dropping, offsetting the reduced temperature drop at the valve. Whether this type of operation is worth doing will of course depend on the project specifics and marketing considerations.

\subsection{Bypassing Full Cavern Pressure to Feed a Base Load}

If, as might be expected, a proposed LNG terminal is feeding a fairly constant base load, it is not necessary to bring all of the delivered LNG to cavern pressure. The cavern can be bypassed with pipeline pressure only. For instance, the Liberty project analyzed in this study, proposes as one option to bring in 1.7 BCFD on average. This is done with a terminal that operates at approximately $4.1 \mathrm{BCFD}$ when offloading. If the true base load is 1.7 BCFD, 1.7 of the 4.1 BCFD only needs to be pumped to pipeline pressure, say 900 psi. This requires two smaller pipelines, one high pressure, one low pressure, rather than one high pressure. In the Liberty case these would be 35 miles long. However $41 \%$ of the gas would only go to 900 psi rather than 2,200 psi that the caverns require. This would be a significant energy saving as well as reducing the number of required pumps. For projects where the dock, exchangers and caverns are co-located, the main receiving pipeline would only be taking low pressure gas downstream of the cavern and the shunt pipeline would be a simple cavern bypass.

\subsection{Use of the Waste Heat from Power Generation}




\begin{tabular}{|l|l|l|l|}
\hline Customer: & $\begin{array}{l}\text { The United States Department of Energy } \\
\text { National Energy Technology Laboratory }\end{array}$ & $\begin{array}{l}\text { Date of Issue: } \\
\text { 24 April 2003 }\end{array}$ & \\
\hline $\begin{array}{l}\text { Document } \\
\text { Title: }\end{array}$ & $\begin{array}{l}\text { Subtask 1.3 } \\
\text { Determine Major Equipment Requirements }\end{array}$ & $\begin{array}{l}\text { Doc \# \& Version: } \\
\text { Doc 04 r2.0 }\end{array}$ & Page 19 of 20 \\
\hline
\end{tabular}

Referencing the nominal case in this study, a terminal processing $8000 \mathrm{~m} 3 / \mathrm{hr}$ of LNG to 2000psi, approximately $80,000 \mathrm{hp}(60,000 \mathrm{kw})$ of power is required for the LNG and warmant pumps together. Assuming a warmant to LNG flow ratio of 2.5 , and a power generation efficiency of 0.37 , approximately $15^{\circ} \mathrm{F}$ $\left(8^{\circ} \mathrm{K}\right)$ can be added to the ambient warmant temperature by installing suitable heat exchangers. Conversely, if the heat is added to the LNG, which may be more efficient, the inlet temperature of the LNG can be raised by about $45^{\circ} \mathrm{F}\left(25^{\circ} \mathrm{K}\right)$. In cases where the available warmant temperature is low, use of the waste heat should be considered in order to reduce heat exchanger length. For U.S. Gulf of Mexico coastal waters, summer surface temperatures average around $85^{\circ} \mathrm{F}\left(29^{\circ} \mathrm{C}\right)$ and winter temperatures around $65^{\circ} \mathrm{F}\left(18^{\circ} \mathrm{C}\right)$. Addition of the $15^{\circ} \mathrm{F}$ $\left(8^{\circ} \mathrm{K}\right)$ to the winter warmant temperature would bring it to $85^{\circ} \mathrm{F}\left(29^{\circ} \mathrm{C}\right)$. In cases where the warmant drops to unusually low temperatures not contemplated in the exchanger design, this can be overcome by offloading at a lower rate, thus increasing the warmant to LNG flow ratio. Obviously warmant temperature histories need to be studied to determine final design operating ranges. If relatively extreme temperature lows are anticipated, it may be necessary to provide supplementary gas-fired heating of either the warmant or the LNG. Another option is simply to lower the target exchanger exit temperature. Most of these considerations go away if multiple injections are used as was discussed under the simulation in section 2.4.4. A discussion of the feasible range of ambient warmant temperatures follows in the next section.

In addition to using the waste heat as a pre heater for the LNG or the warmant, the LNG can be used to precool the air intake for the power generation turbines. This will pre-warm the LNG by some small amount.

\subsection{Estimating Warmant Temperature Operational Range, Required Flow Ratio}

Using a simple energy balance as was done in preparing Figure 2.1 it is possible to write an equation for the required flow ratio for a given available warmant temperature:

$$
\Delta \mathrm{T} \text { qw/qlng }=132
$$

Here $\Delta T$ refers to the warmant temperature less the warmant minimum temperature. For seawater this minimum would be about $30^{\circ} \mathrm{F}$. This equation is valid for bringing the gas to $40^{\circ} \mathrm{F}$. If we assume seawater at $50^{\circ} \mathrm{F}$, available delta $\mathrm{T}$ becomes 20 degrees. Using the equation this would require a flow ratio of 6.6, which is unacceptably high. However if a second injection is made to double the energy available, delta T becomes 40 and the resultant flow ratio is 3.3 , which is not too bad. If additionally the LNG is preheated by waste heat from the power source, delta T remains at 40 but the right hand side of the above equation becomes 115 instead of 132. Then with two warmant injections the required flow ratio becomes 2.9. This is an acceptable flow ratio. It can be reduced even further by lowering the gas exit temperature if downstream conditions permit. Of course the above calculation says nothing about the heat exchanger specifications. Referring back to the discussion on "mixed" flow exchangers in section 2.4.4, it is probable that the exchanger length even in this example can be held to acceptable dimensions. It would even be feasible to double the exchanger back to the warmant source twice rather than once and obtain four injections of the lower temperature warmant, two parallel and two counter-flows. Note that above calculations are for pure methane. Results for typical natural gases would vary.

\subsection{Emergency Shut-in of the Exchangers, Shut-in Conditions}

If in the case of an emergency, loss of power for instance, both the warmant flow and the LNG flow are stopped, the warmant, seawater or fresh water, will not freeze. This is due to the high volume of warmant contained in a section of exchanger compared to that for the LNG. If both flows are stopped the approximate 


\begin{tabular}{|l|l|l|l|}
\hline Customer: & The United States Department of Energy & Date of Issue: \\
& National Energy Technology Laboratory & 24 April 2003 \\
\hline $\begin{array}{l}\text { Document } \\
\text { Title: }\end{array}$ & Subtask 1.3 & Doc \# \& Version: & Doc 04 r2.0 \\
& Determine Major Equipment Requirements & Page 20 of 20 \\
\hline
\end{tabular}

equilibrium temperature is $35^{\circ} \mathrm{F}\left(1.5^{\circ} \mathrm{C}\right)$. This is far removed from freezing since the heat of fusion of the warmant is extremely high, $143 \mathrm{btu} / \mathrm{lb}$ for water. If the LNG is stopped and the warmant flow continues, there is of course no problem. If the LNG is stopped and the warmant is drained, say from a pipe failure, the LNG will simply warm over time at cavern or pipeline pressure, depending on the destination to which it is connected. The small amount of LNG in the exchangers is not capable of changing these pressures.

When the exchangers are not in use it is proposed that they "ride" on cavern or pipeline pressure. That is that they remain open to their destination. This minimizes pressure cycling of the exchanger pipe and provides a back pressure for the cryogenic pumps at startup.

\section{ATTACHMENTS}

\subsection{Attachment 1 - "4-Pack" - High Pressure LNG Pumping Unit}

\subsection{Attachment II - LNG Equipment List}

\subsection{Attachment III - Numerical Analysis of BPT - Full Report}




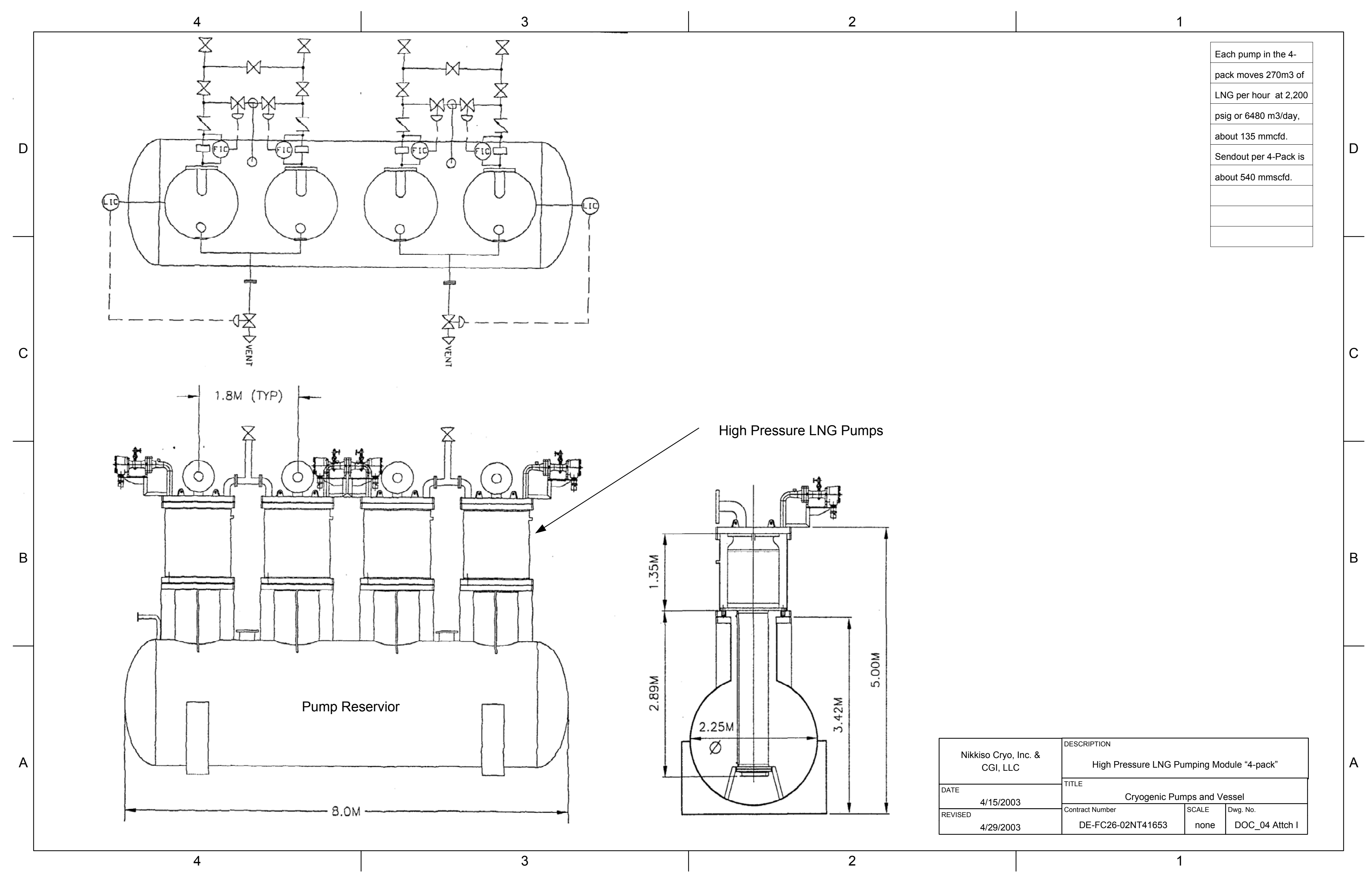




\begin{tabular}{|c|c|}
\hline \multicolumn{2}{|c|}{ Attachment II Major Equipment List } \\
\hline Description & Details \\
\hline $\begin{array}{l}\text { STORAGE TANKS/PROCESS VESSELS } \\
\text { Salt Storage Caverns } \\
\text { Recondenser } \\
\text { BOG Compressor Knock Out Drum } \\
\text { HP Fuel Gas Knock Out Drum } \\
\text { HP Flare Knock Out Drum, } \\
\text { Service Water Storage Tank } \\
\text { Diesel Storage Tank } \\
\text { Surge Vessel } \\
\text { Foam Tank }\end{array}$ & $\begin{array}{l}6 \text { ea total 18BCF } \\
9 ' I D \times 45^{\prime}, 304 \text { SS } \\
70 \mathrm{~m} 3 \\
3 \mathrm{~m} 3 \\
50 \mathrm{m3} \\
20 \mathrm{~m} 3 \\
50 \mathrm{~m} 3 \\
540 \mathrm{~m} 3 \\
4 \mathrm{~m} 3 \\
\end{array}$ \\
\hline $\begin{array}{l}\qquad \text { VAPORIZERS/HEAT EXCHANGERS } \\
\text { Bishop Process heat exchanger } \\
\text { HP knockout drum heater } 20 \mathrm{~kW} \\
\text { Gaseous N2 Vaporizer } 35 \mathrm{~kW} \\
\text { Gaseous N2 Vaporizer (Spare) } 35 \mathrm{~kW} \\
\text { Liquid N2 Pressurization vaporizer } 35 \mathrm{~kW} \\
\text { Turbogenerator Heat Recovery LNG Exchanger } \\
\text { Turbogenerator Inlet Air Chiller } \\
\text { Liquid N2 Vaporizer } 35 \mathrm{~kW}\end{array}$ & $\begin{array}{l}28 @ 270 \text { tons } / \mathrm{hr} .(7,560 \mathrm{~m} 3 / \mathrm{hr}) \\
20 \mathrm{~kW} \\
35 \mathrm{~kW} \\
35 \mathrm{~kW} \\
35 \mathrm{~kW} \\
\\
35 \mathrm{~kW} \\
\end{array}$ \\
\hline $\begin{array}{l}\text { PUMPS } \\
\text { Second stage sendout pump } \\
\text { Seawater pump } \\
\text { Process Area Sump Pump } \\
\text { Service Water Pump }\end{array}$ & $\begin{array}{l}28 @ 270 \mathrm{~m} 3 / \mathrm{hr} \\
2187 \mathrm{~m} 3 / \mathrm{hr} \\
10 \mathrm{hp}, 5 \mathrm{~m} 3 / \mathrm{hr} \\
5 \mathrm{hp}, 57 \mathrm{~m} 3 / \mathrm{hr}\end{array}$ \\
\hline $\begin{array}{l}\text { COMPRESSORS } \\
\text { Ship unloading compressor, 59 MMSCFD } \\
\text { Ship vapor return blower } \\
\text { Instrument air compressor and drier }\end{array}$ & $\begin{array}{l}59 \mathrm{MMSCFD} \\
4.0 \mathrm{mmMm} 3 / \mathrm{hr} \\
100 \mathrm{scfm}\end{array}$ \\
\hline $\begin{array}{l}\text { SEAWATER STRUCTURE } \\
\text { Seawater Intake Structure } \\
\text { Seawater Outfall Structure } \\
\text { Seawater Intake Screens } \\
\text { Seawater Rotary Screens }\end{array}$ & $\begin{array}{l}12,000 \mathrm{~m} 3 / \mathrm{hr} \text { each } \\
12,000 \mathrm{~m} 3 / \mathrm{hr} \text { each } \\
12,000 \mathrm{~m} 3 / \mathrm{hr} \text { each } \\
12,000 \mathrm{~m} 3 / \mathrm{hr} \text { each }\end{array}$ \\
\hline $\begin{array}{l}\text { UTILITIES } \\
\text { Flares } \\
\text { HP Flare } \\
\\
\text { N2 Dewar for Terminal, Vac. insul. tank, } 42 \mathrm{~m} 3 \\
\text { Electrochlorination Unit, } 12,000 \mathrm{~m} 3 / \mathrm{hr}\end{array}$ & $415,000 \mathrm{~kg} / \mathrm{hr}$ \\
\hline $\begin{array}{l}\qquad \text { Firewater Protection } \\
\text { Firewater Protection System } \\
\text { includes distribution piping, hydrant system, AFFF foam system } \\
\text { and water tanks for fire fighting systems, incl. dry powder (jetty) } \\
\text { Electric Firewater Pump } \\
\text { Diesel Driven Firewater Pump } \\
\text { Firewater Jockey Pump }\end{array}$ & $\begin{array}{l}2500 \mathrm{gpm} \\
2500 \mathrm{gpm} \\
200 \mathrm{gpm}\end{array}$ \\
\hline $\begin{array}{l}\text { Emergency Generator } \\
\text { Gas Turbine Generator }\end{array}$ & $\begin{array}{l}\text { Diesel Driven, } 1050 \mathrm{~kW} \\
2 \text { ea., 32MW, GE LM 2500+ }\end{array}$ \\
\hline $\begin{array}{l}\text { BUILDINGS } \\
\text { Administration Office/Control Center } \\
\text { Compressor Building } \\
\text { Warehouse/Maintenance Building }\end{array}$ & $10,000 \mathrm{ft} 2$ \\
\hline $\begin{array}{l}\text { MARINE FACILITY } \\
\text { Traditional Jetty } \\
\text { Platform and Topworks } \\
\text { Berth, walkways and dolphins } \\
\text { LNG Unloading Arms } \\
\text { Vapor Ret. Unloading Arm }\end{array}$ & $\begin{array}{l}320 \text { meter ship accommodation } \\
3 \text { ea. } 16 " \text { Dia } \\
10,500 \mathrm{~m} 3 / \mathrm{hr}, 16 " \mathrm{D}\end{array}$ \\
\hline
\end{tabular}




\title{
FINAL REPORT
}

\section{Thermal Analyses of LNG Heat Exchangers}

\author{
Report submitted to CGI
}

By

William J. Thomson

Chemical Engineering Consultant

February 28, 2003

\section{SUMMARY}

The operation of a double pipe heat exchanger to heat high pressure LNG prior to storage in a salt dome, has been simulated using an "in-house computer code in combination with the Peng-Robinson Equation of State for prediction of the dense gas LNG properties. The robustness of the code was compared to the predictions of a Computational Fluid Dynamics code (CFD-ACE) and it was found to adequately corroborate the in-house simulation code. However, the question of the uncertainty in the heat transfer coefficient correlation still remains. The simulation was used to conduct a parametric study of the effects of various system parameters; specifically,

Flow ratio of Warmant/LNG: $2.25-3.75, \mathrm{~m}^{3} / \mathrm{m}^{3}$

Warmant inside pipe diameter: [0.279-0.356 m (11"-14")]

Fouling factor: $0-6.17 \mathrm{E}-4 \mathrm{~m}^{2}-\mathrm{K} / \mathrm{W}\left(0.0035 \mathrm{ft}^{2}-\mathrm{h}-\mathrm{F} / \mathrm{BTU}\right)$

Inlet LNG temperature: $116 \mathrm{~K}-172 \mathrm{~K}\left(-250{ }^{0} \mathrm{~F},-150{ }^{0} \mathrm{~F}\right)$

Warmant inlet temperature: $294 \mathrm{~K}-311 \mathrm{~K}\left(70^{\circ} \mathrm{F}-100\right)$

The parametric study assumed a stainless steel pipe with an inside diameter of $0.168 \mathrm{~m}$ (6"schedule 80 pipe). In addition to the parametric study, a separate evaluation was also conducted for the effects of pipe wall thickness, co-current versus counter current flow, seawater versus fresh water and multiple injections.

While the design of the heat exchange system has not been optimized, the results of the parametric study have succeeded in narrowing the design parameters. For example, it was found that: (1) flow ratios between 2.5 and 3.0 are necessary to be able to heat the LNG to $255 \mathrm{~K}\left(0^{\circ} \mathrm{F}\right)$ or above, in a pipe length of $762 \mathrm{~m}(2500 \mathrm{ft}),(2)$ a thinner walled pipe halves the length of pipe necessary to reach $255 \mathrm{~K}$, (3) due to increased ice formation, counter-current flow has only a small advantage over co-current flow, (4) multiple injections of fresh warmant are advantageous, with $50 \%$ replacement at mid-length resulting in the heating of the LNG to $277 \mathrm{~K}$ in a pipe length of $762 \mathrm{~m}(2500 \mathrm{ft})$, and (5) a mixed, co-current/counter current midpoint injection is able to heat the LNG to $277 \mathrm{~K}$ in a pipe length of $50.9 \mathrm{~m}(2003 \mathrm{ft})$. 
Under these flow conditions it has been determined that conduction through the pipe wall and/or through a fouling deposit or ice layer is the controlling heat transfer resistance. Thus, maximum heat transfer efficiency will be obtained by employing clean pipes, avoiding significant ice formation and utilizing the thinnest pipe walls that are compatible with the expected fluid pressures. Consequently, seawater as the warmant has an advantage over fresh water in that it is less prone to ice formation. Because of the need for flow ratios of 2.5 or greater, the avoidance of excessive pressure drops on the warmant side of the exchanger, will require warmant pipe diameters of at least $0.305 \mathrm{~m}$ (12").

\section{RESULTS}

\section{$\underline{\text { Simulation Approach }}$}

Because the HYSYS simulation code is not set up for double pipe heat exchanger configurations of the type employed in this application, we have developed a "stand alone" computer code, running on MatLab, in order to calculate the heat transfer and pressure losses in a co-current or counter-current, double pipe heat exchanger. The code employs LNG properties derived from the HYSYS software package, which are based on the Peng-Robinson equation of state. The code is iterative, since it accounts for ice formation, variable fluid properties and counter-current flow. While the energy balances predicted by this code can be closed to within $99.9 \%$, the calculations are based on the Dittus-Boelter heat transfer coefficient correlation, which is the same correlation used in HYSYS. However, the Reynolds numbers of the flows used here extend beyond those upon which the original correlation was based. Consequently, we have compared the heat transfer predictions of our code with that predicted by the CFD-ACE computational fluid dynamics code. In a preliminary simulation, using a very coarse finite volume grid, it was found that the CFD code consistently under-predicted the heat transfer rates calculated by the in-house code. For example, the warmant temperature drop over the first $50 \mathrm{~m}$ of the pipe was calculated to be about $1 \mathrm{~K}$, less than that predicted by the in-house code. Unfortunately, there was not sufficient time in this phase of the project to do a complete CFD simulation, which would require a much finer grid in order to obtain an accurate simulation. Figure 1 shows the radial temperature profile predicted by the CFD code at a point 10 meters downstream of the exit. In this figure, the y-axis values up to $0.0841 \mathrm{~m}$ are in the LNG and the values above $0.0951 \mathrm{~m}$ are in the warmant. As can be seen, the profile is very flat across the two fluids, as would be expected for turbulent flow, and there is a large gradient across the pipe wall.

\section{$\underline{\text { Parametric Study }}$}

Figures 2 and 3 show selective properties (bulk temperatures, pressures, and ice thickness) as a function of the exchanger length for the "base case" run, which is defined as: 


\section{Base Case}

Inlet LNG temperature $=116 \mathrm{k}(-250 \mathrm{~F})$, Inlet water temperature $=300 \mathrm{k}(80 \mathrm{~F})$, volumetric flow ratio $=2.25$, fouling $=0.0000$ Warmant inside diameter $=11 \mathrm{in}(0.279 \mathrm{~m})$, LNG inside pipe diameter $=0.168 \mathrm{~m}$ ( 6 " schedule 80 ) stainless with wall thickness $=.011 \mathrm{~m}(0.432$ in)

As can be seen, the LNG temperature barely reaches $0{ }^{\circ} \mathrm{F}(255 \mathrm{~K})$ at a length of $3000 \mathrm{ft}$. (914 $\mathrm{m})$. This is due to the continuous build-up of ice on the outer diameter of the inner tube. In addition, with the inlet pressure arbitrarily fixed at $1000 \mathrm{psi}(6.89 \mathrm{Mpa})$, the pressure drop on the water-side of the exchanger is about 340 psi ( $2.34 \mathrm{MPa})$.

Figures 3-7 show the results of the parametric study, providing the length required for the LNG to reach $0{ }^{\circ} \mathrm{F}(255 \mathrm{~K})$ and the warmant side pressure drop as a function of flow ratio and fouling factor. Of course the pressure drop is independent of fouling, since the fouling thickness would be much less than the pipe diameter. For purposes of presenting the parametric results, the exit LNG temperature was chosen to be $0{ }^{\circ} \mathrm{F}(255 \mathrm{~K})$, since it was not possible to reach $40{ }^{\circ} \mathrm{F}(277 \mathrm{~K})$ in many of the cases. As noted above, the warmant pressure drops are large for a warmant pipe diameter of $11 "(0.279 \mathrm{~m})$ and it appears that a $12 "(0.305 \mathrm{~m})$ diameter may provide a trade-off between heat transfer (pipe length required) and pressure drop. Another factor of interest in these plots is the influence of the resistance to heat transfer exerted by the inner pipe wall in combination with fouling. This can be seen in the dependence of length on flow ratio as the warmant pipe diameter and fouling factor increases. For example, at low flow ratios in the 14" $(0.356 \mathrm{~m})$ warmant pipe diameter, there is little difference in the dependence of length required to reach $0{ }^{\circ} \mathrm{F}(255 \mathrm{~K})$ on the fouling factor. This is because the convective resistance to heat transfer becomes the dominant resistance under these conditions.

The effect of flow ratio and warmant pipe diameter on length (to reach $0{ }^{\circ} \mathrm{F}$ ) and warmant pressure drop, can be more clearly seen in the cross-plots of Figures 8 and 9. These plots can be used to determine the optimum trade-off between heat transfer (length required) and pressure drop.

\section{Effect of Inlet LNG Temperature}

Table 1 shows the effect of the inlet LNG temperature for the base case. As can be seen, the length to reach $0{ }^{\circ} \mathrm{F}(255 \mathrm{~K})$ is a strong function of the inlet LNG temperature. In fact, $0{ }^{\circ} \mathrm{F}$ cannot be reached for the base case (inlet LNG temperature $=-250{ }^{\circ} \mathrm{F}, 116 \mathrm{~K}$ ), but the required length drops by a factor of two, if the inlet LNG temperature is increased by $50{ }^{\circ} \mathrm{F}(27.8 \mathrm{~K})$. In addition, an increase of $90{ }^{\circ} \mathrm{F}(50 \mathrm{~K})$ in the inlet temperature, allows the $\mathrm{LNG}$ to reach $40^{\circ} \mathrm{F}(274 \mathrm{~K})$ in a $2500 \mathrm{ft}(762 \mathrm{~m})$ long pipe.

\section{Effect of Warmant Freezing Temperature}

Figure 10 shows the effect of using seawater (freezing point $=271 \mathrm{~K}, 28{ }^{\circ} \mathrm{F}$ ) versus fresh water (freezing point $=273 \mathrm{~K}, 32{ }^{\circ} \mathrm{F}$ ) on the LNG temperature and ice thickness versus pipe length. As can be seen, the LNG temperature at a $2500 \mathrm{ft}$ (762 m) length reaches -4 ${ }^{\circ} \mathrm{F}(253 \mathrm{~K})$ when using fresh water, but reaches $13{ }^{\circ} \mathrm{F}(262 \mathrm{~K})$ when seawater is used as 
the warmant. The primary reason for this is that ice formation in the case of seawater occurs $500 \mathrm{ft}(152 \mathrm{~m})$ further down the pipe and reaches a thickness of only 0.05 " $(0.0013 \mathrm{~m})$, whereas it reaches a thickness of $0.225 "(0.0057 \mathrm{~m})$ in the case of fresh water.

TABLE 1

Effect of Inlet LNG Temperature for Base Case ${ }^{1}$ [Fresh water, no fouling]

\begin{tabular}{|c|c|c|c|c|c|c|c|c|}
\hline Case & $\begin{array}{c}\text { TLNG } \\
\text { INLET } \\
\left({ }^{0} \mathrm{~F}\right)\end{array}$ & $\begin{array}{c}\triangle \mathrm{P} H 2 \mathrm{H} \\
@ 2500 \mathrm{ft} \\
(\mathrm{psi})\end{array}$ & $\begin{array}{c}\triangle P \text { LNG } \\
@ 2500 \mathrm{ft} \\
\text { (psi) }\end{array}$ & $\begin{array}{c}\text { Tout } \mathrm{H} 2 \mathrm{O} \\
@ 2500 \mathrm{ft} \\
\left({ }^{0} \mathrm{~F}\right)\end{array}$ & $\left(\begin{array}{c}\mathrm{L} \\
\left(0^{0} \mathrm{~F}\right)\end{array}\right.$ & $\begin{array}{c}\mathrm{L} \\
\left(@ 40{ }^{0} \mathrm{~F}\right) \\
T @ 2500 \\
\end{array}$ & $\begin{array}{c}\text { ICE } \\
\text { Max Thick } \\
\text { (in) }\end{array}$ & $\begin{array}{c}\text { Ice } \\
\text { Length @ } \\
(\mathrm{ft})\end{array}$ \\
\hline 1 & -250 & 268 & 106 & 33 & - & -4 & 0.2301 & $150->$ \\
\hline 2 & -240 & 259 & 108 & 33 & 1988 & 6 & 0.1499 & $425->$ \\
\hline 3 & -235 & 255 & 109 & 34 & 1750 & 11 & 0.1084 & $500->$ \\
\hline 4 & -230 & 251 & 110 & 34 & 1581 & 16 & 0.0644 & 625-> \\
\hline 5 & -225 & 248 & 111 & 34 & 1455 & 21 & 0.0241 & $800->$ \\
\hline 6 & -220 & 245 & 112 & 34 & 1379 & 25 & & \\
\hline 7 & -200 & 245 & 108 & 38 & 1234 & 30 & & \\
\hline 8 & -180 & 245 & 105 & 41 & 1099 & 35 & & \\
\hline 9 & -160 & 244 & 100 & 45 & 972 & 40 & & \\
\hline 10 & -150 & 244 & 98 & 47 & 911 & 42 & & \\
\hline
\end{tabular}

${ }^{1}$ For SI units: $-250^{\circ} \mathrm{F}=116 \mathrm{~K}, 260 \mathrm{psi}=1.79 \mathrm{Mpa}, 106 \mathrm{psi}=0.71 \mathrm{Mpa}, 33^{\circ} \mathrm{F}=274 \mathrm{~K},-4^{0} \mathrm{~F}=$ $253 \mathrm{~K}, 0.2301 \mathrm{in}=5.84 \mathrm{E}-03 \mathrm{~m}, 150 \mathrm{ft}=45.7 \mathrm{~m}$

\section{The Effect of Multiple Injections - Co-Current Flow}

The effect of warmant inlet temperature and one additional warmant injection (at the midpoint) is shown in Table 2, using seawater as the warmant. The table lists the results in the co-current heat exchanger, showing the effect of warmant inlet temperature (100 ${ }^{\circ} \mathrm{F}, 311 \mathrm{~K}$ vs. $80{ }^{\circ} \mathrm{F}, 300 \mathrm{~K}$ ) and of a second injection at the mid-point. Four separate cases are shown for the latter; with the injected quantity of warmant expressed as a percentage of the inlet warmant flow, with values from $30-100 \%$. Case 1 is the seawater base case run and, as can be seen, preheating the warmant to $100{ }^{\circ} \mathrm{F}$, allows the LNG to reach $40{ }^{\circ} \mathrm{F}(277 \mathrm{~K})$ at a length of $2500 \mathrm{ft}(762 \mathrm{~m})$. This seems like a very advantageous way to go, since it is a big improvement over the case with freshwater inlet at $80^{\circ} \mathrm{F}$. Notice that there is no ice formation when the warmant is preheated. In the case of a second injection, replacing the warmant with $50 \%$ of the original flow allows the LNG to reach $40{ }^{\circ} \mathrm{F}$ at a length of $2500 \mathrm{ft}$. It also reduces the warmant pressure drop from $244 \mathrm{psi}$ (1.68 Mpa), for $100 \%$ injection to $155 \mathrm{psi}(1.07 \mathrm{Mpa})$.

TABLE 2 


\section{Effect of Inlet Warmant Temperature and Warmant Injection for Base Case}

[Sea Water, No Fouling] ${ }^{2}$

\begin{tabular}{|c|c|c|c|c|c|c|c|c|}
\hline Case & $\begin{array}{l}\% \text { Warmant } \\
\text { Replaced }^{1}\end{array}$ & $\begin{array}{c}\text { Warmant } \\
\text { INLET }\end{array}$ & $\begin{array}{l}\text { Tout H2O } \\
@ 2500 f t\end{array}$ & $\begin{array}{l}\mathrm{L} @ \\
0{ }^{\circ} \mathrm{F}\end{array}$ & $\begin{array}{r}\left.\mathrm{L} @ 40^{\circ} \mathrm{F}\right) \\
T @ 2500\end{array}$ & $\begin{array}{c}\text { Warman } \\
\text { Delta P } \\
\text { Psi }\end{array}$ & $\begin{array}{c}\text { ICE } \\
\text { Max Thick }\end{array}$ & $\begin{array}{c}\text { Ice } \\
\text { Length }\end{array}$ \\
\hline 1 & 0 & $80^{\circ} \mathrm{F}$ & $33^{\circ} \mathrm{F}$ & - & $-4^{\circ} \mathrm{F}$ & - & $0.2301^{\prime \prime}$ & $150->$ \\
\hline 2 & 0 & 100 & 44 & $1281 \mathrm{ft}$ & 40 & - & None & - \\
\hline 3 & $30 \%$ & 80 & 44 & 1500 & 30 & 135 & 0.009 & $750->1250$ \\
\hline 4 & $40 \%$ & 80 & 50 & 1477 & 36 & 145 & 0.009 & $750->1250$ \\
\hline 5 & $50 \%$ & 80 & 55 & 1463 & 2500 & 155 & 0.009 & $750->1250$ \\
\hline 6 & $100 \%$ & 80 & 66 & 1435 & 2117 & 244 & 0.009 & $750->1250$ \\
\hline
\end{tabular}

1 Warmant totally replaced at midpoint with various quantities of fresh warmant at $80 \mathrm{~F}$

2 For SI units: $80^{\circ} \mathrm{F}=300 \mathrm{~K}, 33^{\circ} \mathrm{F}=274 \mathrm{~K}, 135 \mathrm{psi}=0.93 \mathrm{Mpa}, 106 \mathrm{psi}=0.71 \mathrm{Mpa},,-4{ }^{0} \mathrm{~F}=$ $253 \mathrm{~K}, 0.2301 \mathrm{in}=5.84 \mathrm{E}-03 \mathrm{~m}, 150 \mathrm{ft}=45.7 \mathrm{~m}$

\section{Counter-Current Heat Exchange}

A separate analysis was also conducted for counter-current heat exchange, using seawater as the warmant. Since the simulation program for the counter-current case employs an explicit algorithm, it is first necessary to estimate the warmant exit temperature (cold end of the exchanger). This is done by assuming the exit LNG temperature reaches $40{ }^{\circ} \mathrm{F}(274$ $\mathrm{K})$, and then calculating an overall energy balance to estimate the exit warmant temperature. The calculations then start at that end and proceed until the specified inlet warmant temperature is reached. Because enthalpies are also a function of pressure, and a particular set of input parameters may not lead to a feasible solution, this process is iterative. At that point, the exit warmant temperature is reset and the calculations are repeated.

The results of the simulation for 10 separate cases are shown below in Table 3 . The cases where a particular input parameter was varied, are identified in color. In a number of cases, it is not possible to reach even $0^{0} \mathrm{~F}(255 \mathrm{~K})$, within $3500 \mathrm{ft}(1,069 \mathrm{~m})$, and these are listed in the table as being "not feasible". The pressure drops are listed for the length required to attain either $40{ }^{\circ} \mathrm{F}$ or $0{ }^{0} \mathrm{~F}(274 \mathrm{~K}$ or $255 \mathrm{~K})$. The only available direct comparison between the co-current and counter-current exchanger with seawater is for the base case. In the case of the base case for the co-current exchanger, the LNG could only reach $-4{ }^{0} \mathrm{~F}(253 \mathrm{~K})$ at a length of $2500 \mathrm{ft}(762 \mathrm{~m})$. However, as can be seen from the first case in Table $1,0{ }^{0} \mathrm{~F}$ can be reached at a length of $2285 \mathrm{ft}(696 \mathrm{~m})$ in the countercurrent configuration. It should be noted, that in comparison to the co-current operation, ice formation is present in every counter-current run, persisting over most of the exchanger and reaching thicknesses as large as $1.1 "(0.00279 \mathrm{~m})$. This is a consequence of low warmant temperatures at the cold end of the exchanger. It should also be kept in mind that all the calculations in Table 3, assume no fouling on the warmant side of the inner pipe. Whereas the inlet warmant temperature has a very large effect in co-current operation, preheating the LNG to $-200{ }^{\circ} \mathrm{F}(144 \mathrm{~K})$ had the biggest advantage in the 
counter-current operation, requiring only $2328 \mathrm{ft}(71 \mathrm{~m})$ to reach $\left.40{ }^{0} \mathrm{~F} 274 \mathrm{~K}\right)$. Note that this run resulted in the least ice formation of all the runs listed in Table 3.

TABLE 3

\section{Counter-current Heat Exchanger: Effect of Parameters ${ }^{1}$ [Seawater, No Fouling]}

\begin{tabular}{|c|c|c|c|c|c|c|c|c|c|}
\hline \multicolumn{4}{|c|}{ INPUT } & \multicolumn{6}{|c|}{ RESULTS } \\
\hline $\begin{array}{c}\text { Equiv. } \\
\text { Flowratio }\end{array}$ & $\begin{array}{l}\text { Warmant } \\
\text { Diameter }\end{array}$ & $\begin{array}{c}\text { Warmant } \\
\mathbf{T} \\
\end{array}$ & $\begin{array}{c}\text { LNG } \\
\text { Inlet T } \\
\end{array}$ & $\begin{array}{c}\mathrm{L} @ 40^{\circ} \mathrm{F} \\
(\mathrm{ft})\end{array}$ & $\begin{array}{c}\mathbf{Q} @ 0^{\circ} \mathrm{F} \\
(\mathrm{ft})\end{array}$ & $\begin{array}{c}\text { LNG }^{2} \\
\Delta \mathbf{P}(\mathrm{psi})\end{array}$ & $\begin{array}{c}\mathrm{H}^{2} \mathrm{O}^{2} \\
\Delta \mathrm{P}(\mathrm{psi})\end{array}$ & $\begin{array}{c}\text { ice max } \\
\text { thick (in) }\end{array}$ & $\begin{array}{c}\text { icing } \\
\text { Interval (ft) }\end{array}$ \\
\hline 2.25 & 11 in & $80^{\circ} \mathrm{F}$ & $-250^{\circ} \mathrm{F}$ & - & 2285 & 71 & 325 & 0.911 & $0->1435$ \\
\hline 2.25 & 12 & 80 & -250 & - & 2716 & 82 & 186 & 1.159 & $0->1925$ \\
\hline 2.25 & 12 & 70 & -250 & NOT Feasible & - & - & - & - & - \\
\hline 2.25 & 12 & 80 & -250 & - & 2716 & 82 & 186 & 1.159 & $0->1925$ \\
\hline 2.25 & 12 & 90 & -250 & 2681 & 2178 & 101 & 139 & 0.569 & $0->1365$ \\
\hline 2.25 & 12 & 80 & -250 & NOT Feasible & - & - & - & - & - \\
\hline 2.5 & 12 & 80 & -250 & 3317 & 2736 & 121 & 258 & 1.102 & $0->1925$ \\
\hline 2.75 & 12 & 80 & -250 & $\sim 2590$ & 2035 & 100 & 190 & 0.409 & $0->1190$ \\
\hline 2.25 & 12 & 80 & -250 & NOT Feasible & - & - & - & - & - \\
\hline 2.25 & 12 & 80 & -200 & 2328 & 1770 & 79 & 113 & 0.347 & $0->1050$ \\
\hline 2.75 & 12 & 80 & -250 & $\sim 2590$ & 2035 & 100 & 190 & 0.409 & $0->1190$ \\
\hline 2.75 & 13 & 80 & -250 & 2992 & 2395 & 114 & 118 & 0.539 & $0->1610$ \\
\hline 2.25 & 11 & 70 & -250 & NOT Feasible & - & - & - & - & - \\
\hline 2.25 & 11 & 90 & -250 & 2797 & 2285 & 104 & 371 & 0.913 & $0->1435$ \\
\hline
\end{tabular}

1 For SI units: $11^{\prime \prime}=(0.028 \mathrm{~m}),-250^{\circ} \mathrm{F}=116 \mathrm{~K}, 33^{\circ} \mathrm{F}=274 \mathrm{~K}, 71 \mathrm{psi}=0.49 \mathrm{Mpa}, 325 \mathrm{psi}$ $=2.24 \mathrm{Mpa}, 0.991 \mathrm{in}=0.025 \mathrm{~m}, 1435 \mathrm{ft}=437 \mathrm{~m}$

${ }^{2}$ At the length required for the LNG to reach $40{ }^{0} \mathrm{~F}$, or $0{ }^{0} \mathrm{~F}$

Thus, on the basis of these calculations, it appears that while counter-current operation is advantageous due to the higher overall temperature driving force for heat transfer, the low temperatures for both warmant and LNG at the cold end of a counter-current exchanger is a distinct disadvantage, due to the relatively large formation of ice over much of the exchanger length. The net trade-off between these two factors appears to be positive. That is, counter-current lengths are somewhat less than co-current lengths, but the effect is not very large. However, ice would be less of a problem if the warmant side of the inner pipe became fouled.

Effect of Pipe Wall Thickness 
The effect of the pipe wall thickness was evaluated by comparing the results for a AL6XN pipe, with a wall thickness of $0.0056 \mathrm{~m}(0.219$ ") versus the 6 " schedule 80 stainless steel pipe with a thickness of $0.011 \mathrm{~m}(0.432$ "), utilizing seawater under base case conditions, but with a flow ratio of 2.5 and a warmant pipe diameter of 12 ". These results are shown below in Table 4 along with a comparison of the same conditions with the thicker walled pipe. As can be seen, the thinner pipe wall reaches $0{ }^{\circ} \mathrm{F}(255 \mathrm{~K})$ in about half the distance required for the thicker pipe wall, although neither pipe is able to reach $40{ }^{\circ} \mathrm{F}(277 \mathrm{~K})$ in a length of $3500 \mathrm{ft}(1067 \mathrm{~m})$.

TABLE 4

Effect of Pipe Wall Thickness ${ }^{1}$

[Base Case with Seawater, Flow ratio $=2.5,12$ " $(0.305 \mathrm{~m})$ Warmant Diameter]

\begin{tabular}{|c|c|c|c|c|c|c|c|c|}
\hline Case & $\begin{array}{l}\text { Pipe Wall } \\
\text { Thickness } \\
\text { (in) }\end{array}$ & $\left(\stackrel{\mathrm{L}}{\left.0^{0} \mathrm{~F}\right)}\right.$ & $T @ 3500 \mathrm{ft}$ & $\begin{array}{c}\Delta \mathrm{P} \mathrm{H} 2 \mathrm{O} \\
@ 0^{\circ} \\
(\mathrm{psi})\end{array}$ & $\begin{array}{c}\Delta \mathrm{P} \mathrm{H} 2 \mathrm{O} \\
@ 3500 \mathrm{ft} \\
(\mathrm{psi})\end{array}$ & $\begin{array}{c}\text { Tout } \mathrm{H} 2 \mathrm{O} \\
@ 3500 \mathrm{ft} \\
\left({ }^{0} \mathrm{~F}\right)\end{array}$ & $\begin{array}{c}\text { ICE } \\
\text { Max Thick } \\
\text { (in) }\end{array}$ & $\begin{array}{c}\text { Ice } \\
\text { Length } @ \\
\text { (ft) }\end{array}$ \\
\hline 1 & 0.432 & $2900 \mathrm{ft}$ & $10^{\circ} \mathrm{F}$ & 112 & 205 & 33.2 & 0.02 & $0->1500$ \\
\hline 2 & 0.219 & 1505 & $30^{\circ} \mathrm{F}$ & 98 & 200 & 31.6 & None & - \\
\hline
\end{tabular}

$1^{1}$ For SI units: $0.432 "=(0.011 \mathrm{~m}), 2900 \mathrm{ft}=884 \mathrm{~m}, 10^{\circ} \mathrm{F}=261 \mathrm{~K}, 112 \mathrm{psi}=0.77 \mathrm{MPa}, 205 \mathrm{psi}$ $=1.41 \mathrm{Mpa}, 33.2^{\circ} \mathrm{F}=273.7 \mathrm{~K}, 0.02 \mathrm{in}=5.1 \mathrm{E}-4 \mathrm{~m}, 1500 \mathrm{ft}=457 \mathrm{~m}$

\section{Effect of Mixed Injection}

Given the fact that relatively large quantities of ice tend to form at the cold end of a counter-current exchanger but not in the co-current exchanger, a "mixed" injection scheme was evaluated. In this configuration, co-current flow was maintained up to a pipe length of $1250 \mathrm{ft}(38.1 \mathrm{~m})$ at which point, the configuration was changed to a countercurrent flow with fresh warmant. Table 5 compares these results for the thick walled pipe under base case conditions but at a flow ratio of 2.5 and a 12 " $(0.305 \mathrm{~m})$ warmant pipe diameter, with both co-current flow and counter-current flow. At the point where the configuration was changed from co-current flow to counter current flow (1250 ft, $381 \mathrm{~m})$, the LNG temperature had reached $-16^{\circ} \mathrm{F}(246 \mathrm{~K})$ and the warmant pressure drop was 70 psi $(0.48 \mathrm{Mpa})$. As can be seen from Table 5 , the mixed injection case is far superior; the LNG is heated to $40{ }^{\circ} \mathrm{F}(274 \mathrm{~K})$ in a length of $2033 \mathrm{ft}(620 \mathrm{~m})$, whereas the countercurrent case requires a length of $3317 \mathrm{ft}(1011 \mathrm{~m})$ and the co-current case is not able to reach $40{ }^{\circ} \mathrm{F}(274 \mathrm{~K})$ in a length of $3500 \mathrm{ft} .(1218 \mathrm{~m})$ In addition, the total warmant pressure drop is significantly lower in the mixed injection configuration, at $114 \mathrm{psi}(0.76$ $\mathrm{MPa})$, versus $258 \mathrm{psi}(1.78 \mathrm{MPa})$ in the counter-current configuration.

TABLE 5 


\section{Effect of Mixed Injection Heat Transfer ${ }^{1}$ \\ [Base Case with Seawater, Flow ratio $=2.5,12$ " $(0.305 \mathrm{~m})$ Warmant Diameter]}

\begin{tabular}{cccccccc} 
Case & Configuration & $\left(\begin{array}{c}\mathrm{L} \\
\left(0^{0} \mathrm{~F}\right)\end{array}\right.$ & $\begin{array}{c}\mathrm{T} @ 3500 \mathrm{ft} \\
4{ }^{\circ} \mathrm{F}\end{array}$ & $\begin{array}{c}\Delta \mathrm{P} H 2 \mathrm{H} \\
(\mathrm{psi})\end{array}$ & $\begin{array}{c}\Delta \mathrm{P} \text { LNG } \\
(\mathrm{psi})\end{array}$ & $\begin{array}{c}\text { Max Thick } \\
(\mathrm{in})\end{array}$ & $\begin{array}{c}\text { Icength } @ \\
(\mathrm{ft})\end{array}$ \\
\hline 1 & Mixed & $1433 \mathrm{ft}$ & $2033 \mathrm{ft}$ & $114^{2}$ & $91^{2}$ & None & - \\
2 & Co-current & 2900 & $10^{\circ} \mathrm{F}$ & $205^{3}$ & $172^{3}$ & None & - \\
3 & Counter-Current & 2736 & 3317 & $258^{4}$ & $121^{4}$ & 1.102 & $0->1925$
\end{tabular}

1 For SI units: $0{ }^{0} \mathrm{~F}=255 \mathrm{~K}, 1433 \mathrm{ft}=437 \mathrm{~m}, 2033 \mathrm{ft}=620 \mathrm{~m}, 114 \mathrm{psi}=0.76 \mathrm{MPa}, 91 \mathrm{psi}=$ $0.63 \mathrm{Mpa}$, , $1.102 \mathrm{in}=0.028 \mathrm{~m}, 1925 \mathrm{ft}=587 \mathrm{~m}$

2 At $2033 \mathrm{ft}$

3

At $3500 \mathrm{ft}$

4 At $3317 \mathrm{ft}$

\section{Conclusions and Recommendations}

No attempt was made in this study to optimize the heat exchanger design for heating the LNG to $0{ }^{\circ} \mathrm{F}$ or $40{ }^{\circ} \mathrm{F}$. Nevertheless, a number of preliminary design guidelines have emerged.

- Counter-current heat exchange, while providing for a larger temperature driving force over the total length of the exchanger, is prone to large ice depositions, which somewhat mitigates the effect of the larger temperature driving force.

- A inlet volumetric flow ratio (warmant/LNG) of at least 2.5 will be necessary to achieve the desired goals of heating the LNG to $40{ }^{\circ} \mathrm{F}$.

- The heat transfer resistance of the pipe wall is dominant, therefore the utilization of the thinnest pipe wall which is compatible with pressure considerations is advantageous.

- In order to avoid unacceptable pressure drops on the warmant-side of the exchanger, the warmant pipe diameter will have to be at least $12 "(0.305 \mathrm{~m})$.

- A mixed co/counter - current exchanger with warmant replacement at the switch point, appears to be desirable, avoiding ice formation at the cold end and providing for larger temperature driving forces at the hot end.

Once the economics have been clearly defined, the heat exchanger design should be optimized, allowing for uncertainties in the input parameters (fouling, heat transfer coefficients). The accuracy of the heat transfer coefficients should be ascertained, by 
optimizing the finite volume element grid in the CFD code so that it more accurately calculates transport conditions in the vicinity of the wall. 


\section{FIGURES}

FIGURE 1

Temperature profile predicted by CFD across a radial section of the exchanger at $10 \mathrm{~m}$ downstream from pipe entrance entrance.

(Temperature in $\mathrm{K}$; Y-Axis coordinate in $\mathrm{m}$; wall between 0.0841 and $0.0951 \mathrm{~m}$ )

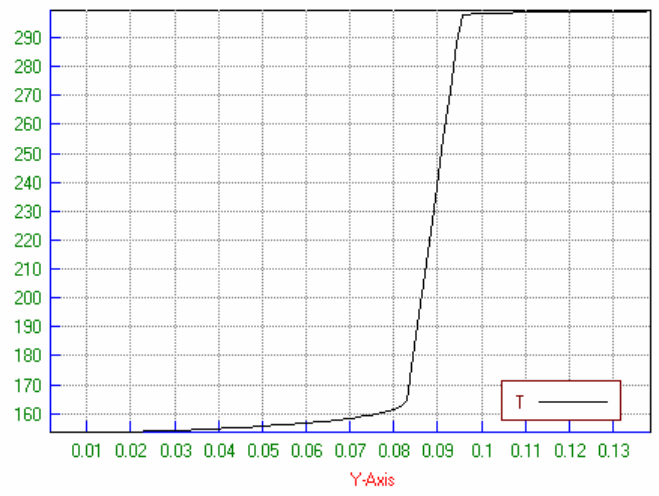

FIGURE 2

Axial Temperature and Pressure Gradients for "Base" Case
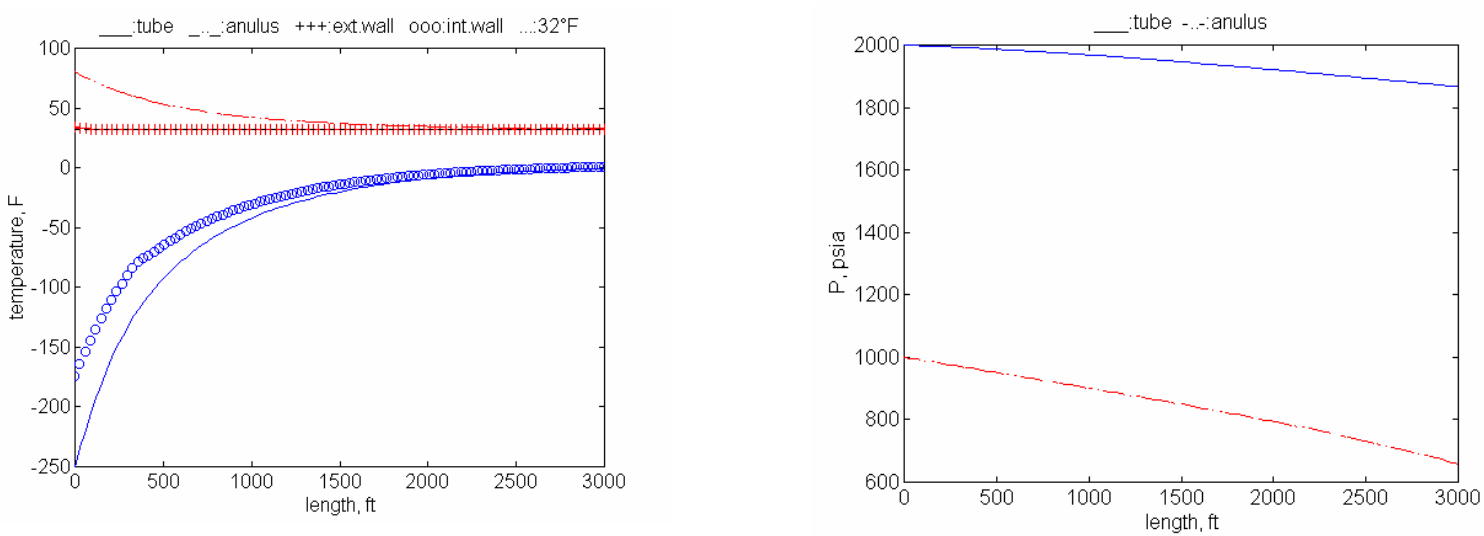

FIGURE 3

Ice Thickness versus Pipe Length for "Base" Case

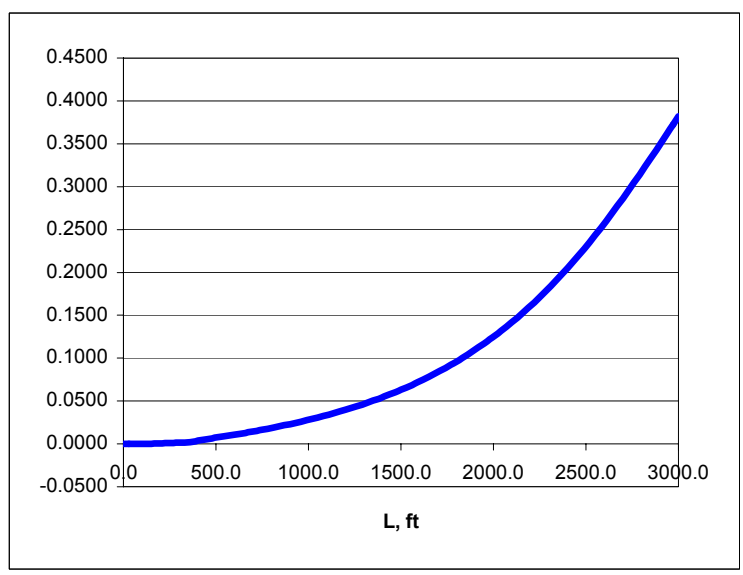


FIGURE 4

Length (to reach $0{ }^{\circ} \mathrm{F}$ ) and Warmant Pressure Drop vs, Flow Ratio

[Warmant Pipe Diameter $=11$ "]
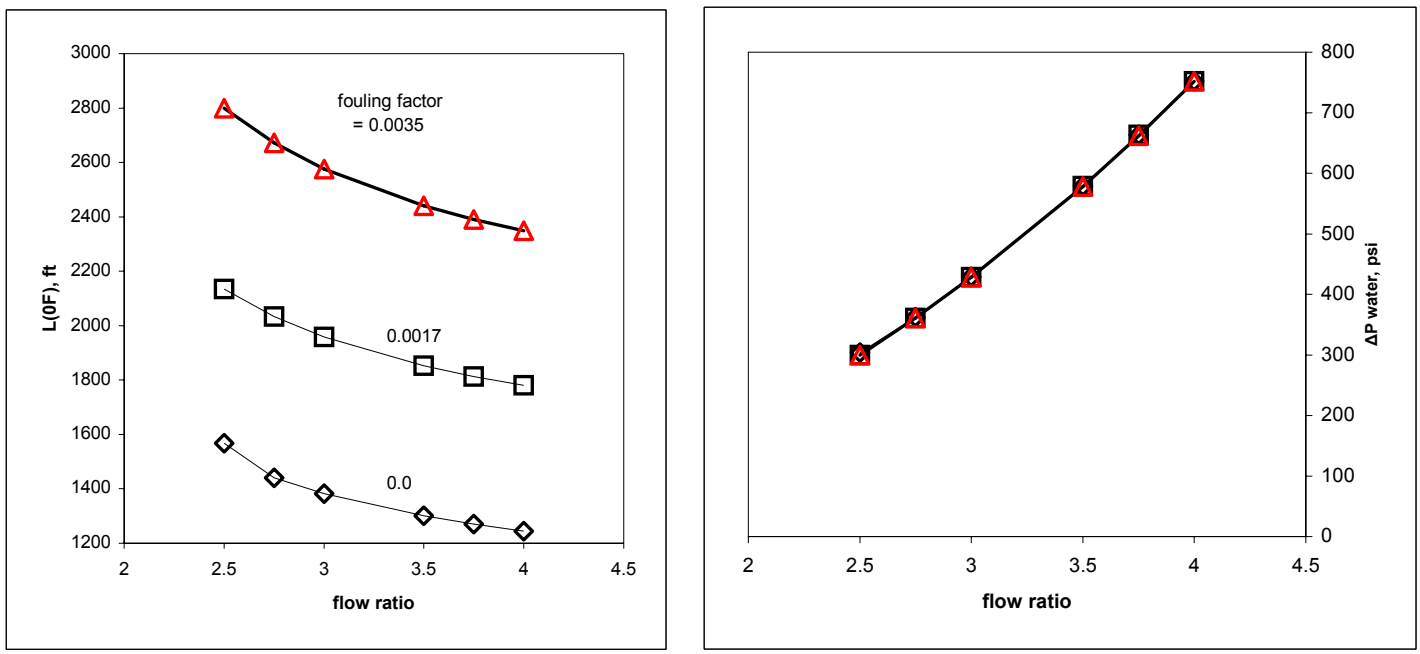

FIGURE 5

Length (to reach $0{ }^{\circ} \mathrm{F}$ ) and Warmant Pressure Drop vs, Flow Ratio

[Warmant Pipe Diameter = 12"]
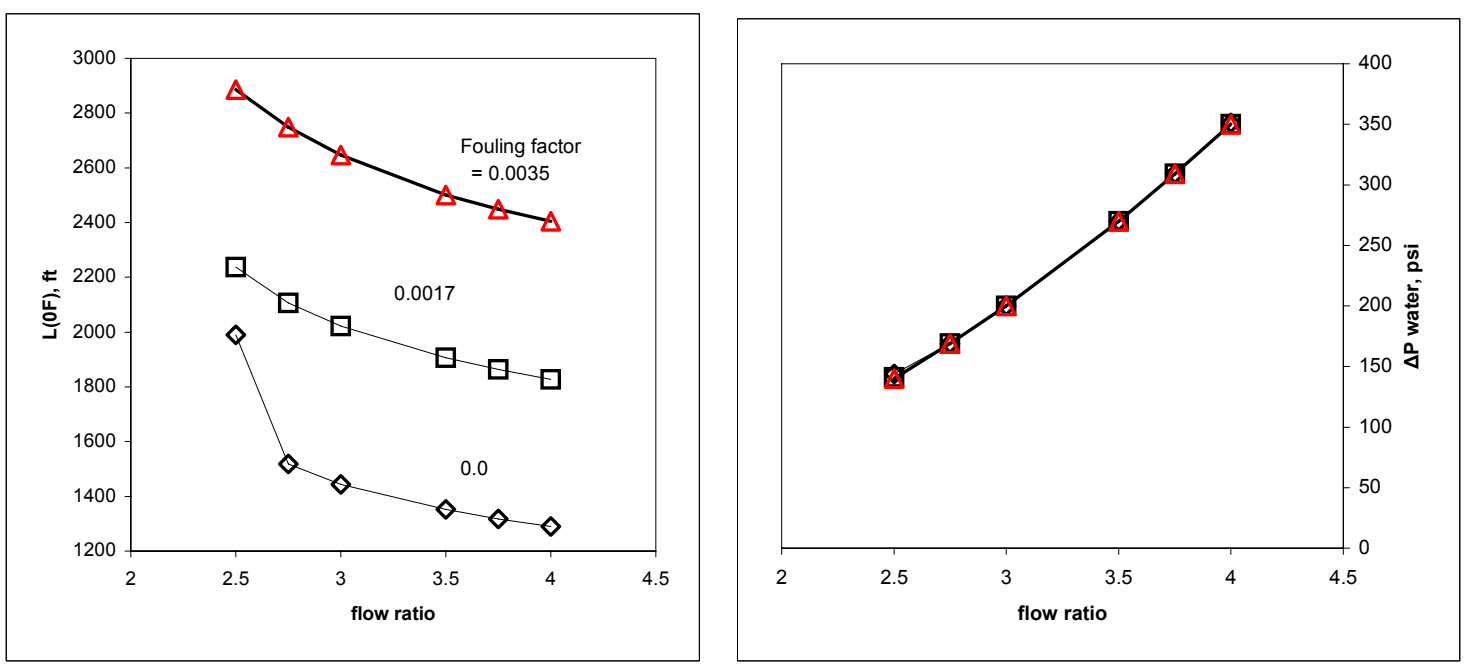
FIGURE 6

Length (to reach $0{ }^{\circ} \mathrm{F}$ ) and Warmant Pressure Drop vs, Flow Ratio

[Warmant Pipe Diameter $=13$ "]
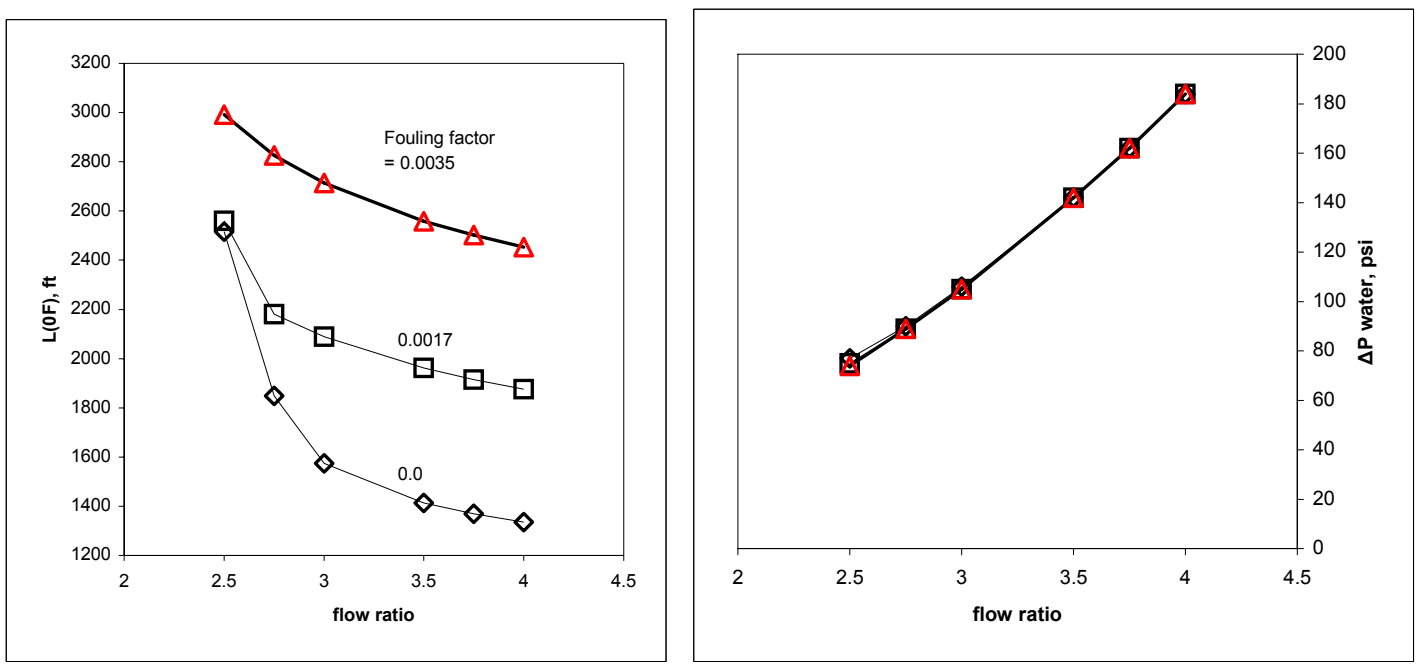

FIGURE 7

Length (to reach $0{ }^{\circ} \mathrm{F}$ ) and Warmant Pressure Drop vs, Flow Ratio

[Warmant Pipe Diameter $=14$ "]
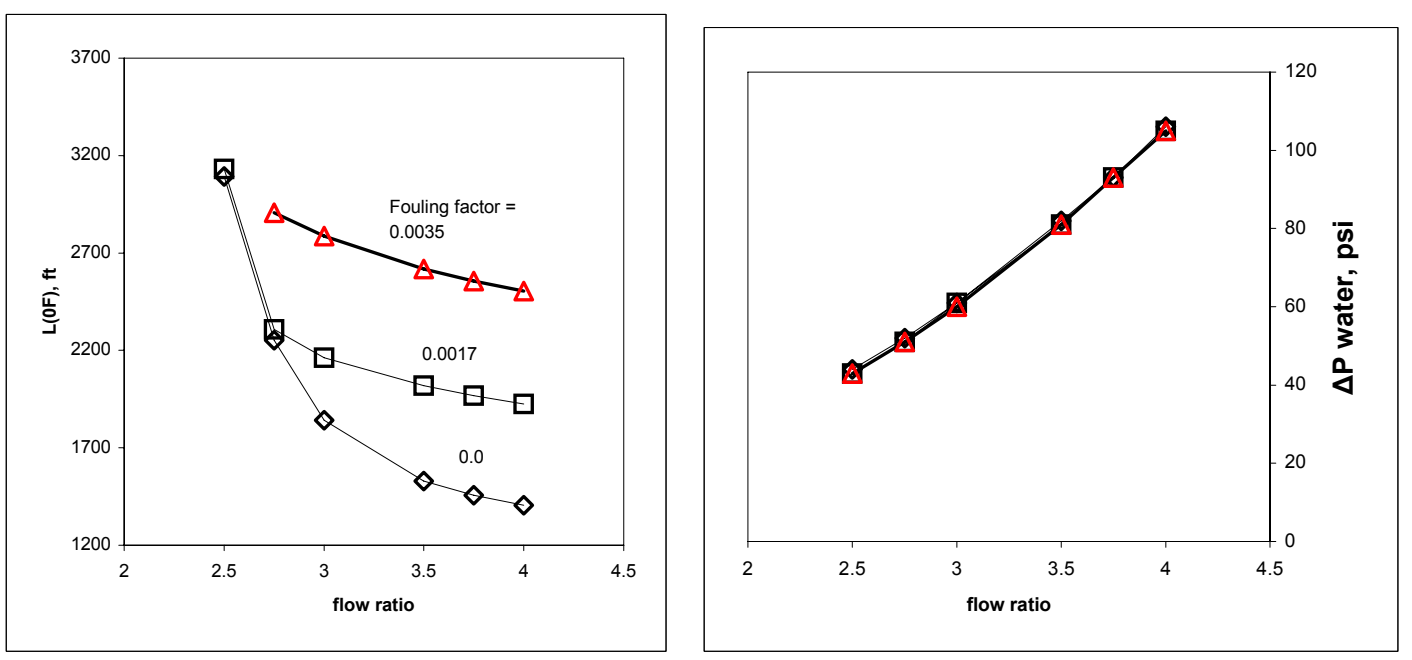
FIGURE 8

Effect of Warmant Diameter and Flow Ratio on Length

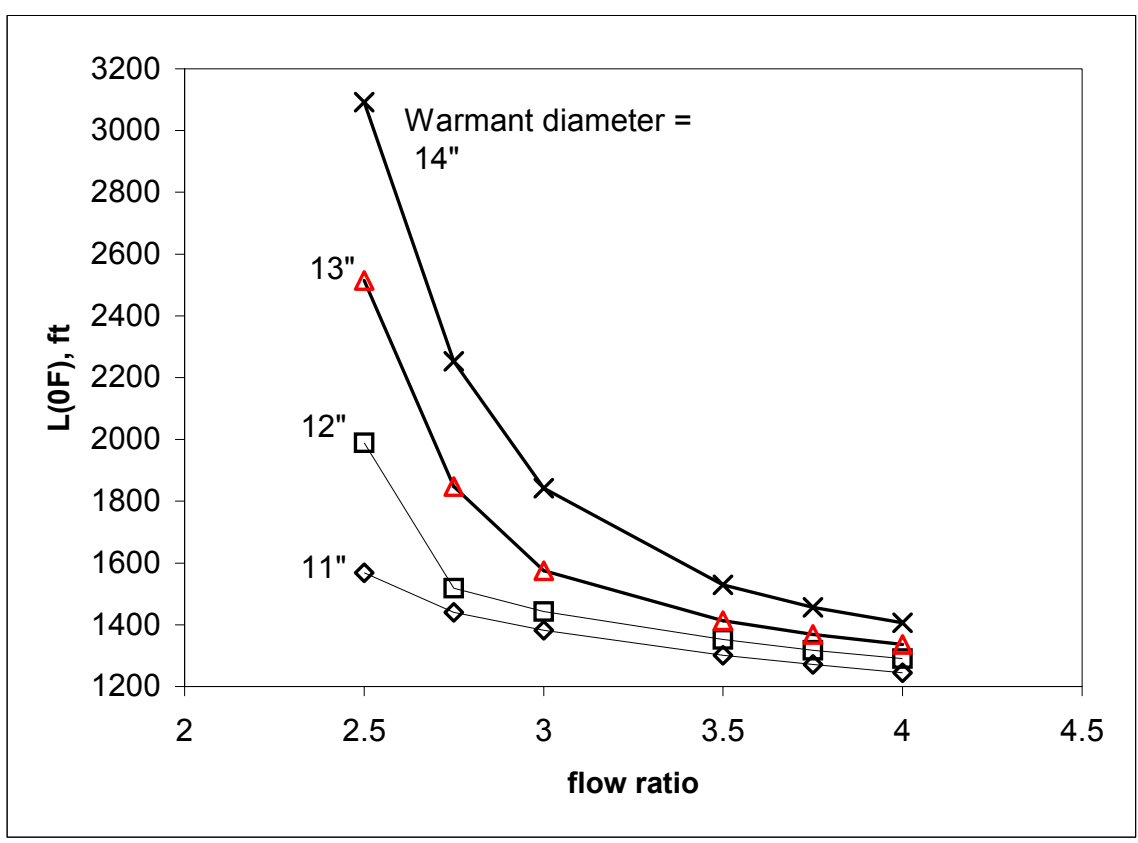

FIGURE 9

Effect of Warmant Diameter and Flow Ratio on Pressure Drop

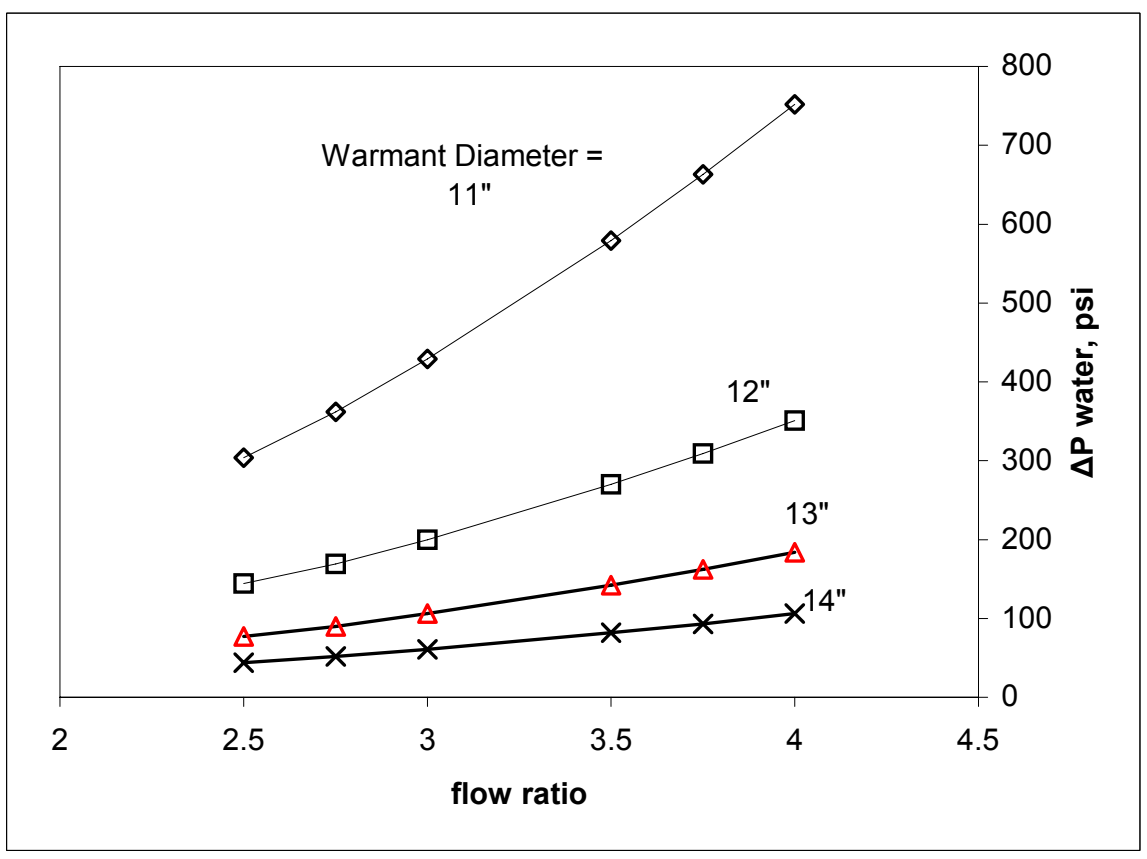


FIGURE 10

Effect of Sea Water on LNG Temperature and Ice Thickness

[Base Case Conditions]
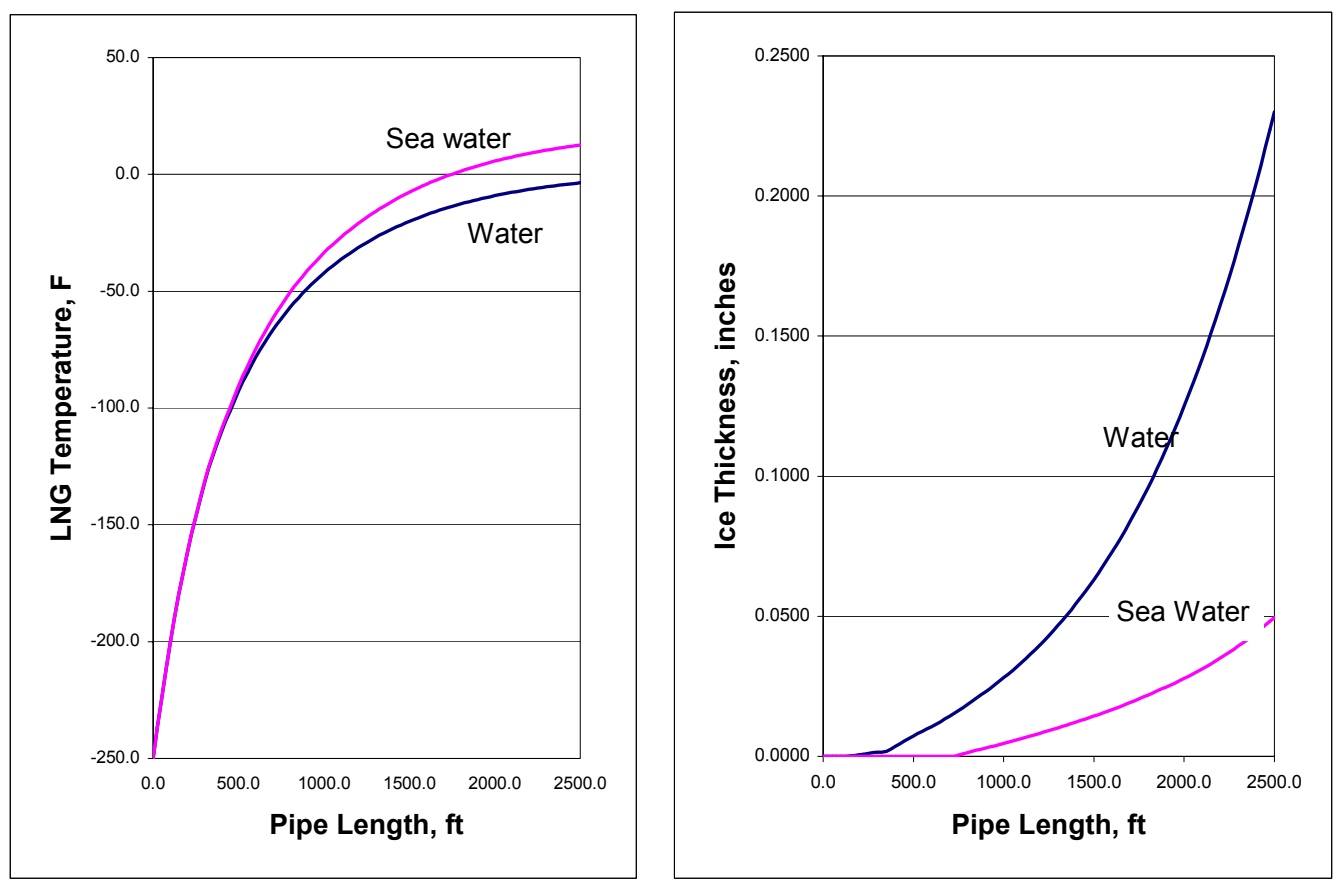


\begin{tabular}{|l|l|l|l|}
\hline Customer: & $\begin{array}{l}\text { The United States Department of Energy } \\
\text { National Energy Technology Laboratory }\end{array}$ & $\begin{array}{l}\text { Date of Issue: } \\
24 \text { April } 2003\end{array}$ & \\
\hline $\begin{array}{l}\text { Document } \\
\text { Title: }\end{array}$ & Subtask 1.4 Determine Salt Cavern Requirements & $\begin{array}{l}\text { Doc \# \& Version: } \\
\text { Doc } 05 \text { r1.0 }\end{array}$ & Page 2 of 4 \\
\hline
\end{tabular}

\section{TABLE OF CONTENTS}

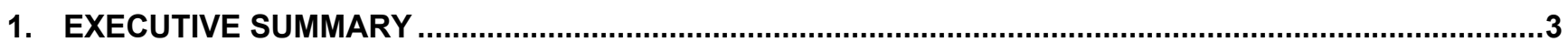

2. THE EFFECT OF LOW TEMPERATURE GAS INJECTION ON SALT CAVERN STABILITY .....................3

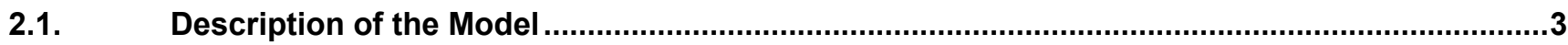

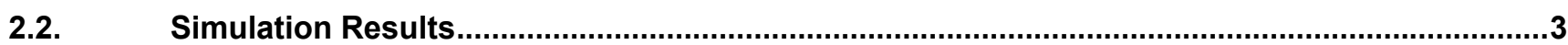




\begin{tabular}{|l|l|l|l|}
\hline Customer: & $\begin{array}{l}\text { The United States Department of Energy } \\
\text { National Energy Technology Laboratory }\end{array}$ & $\begin{array}{l}\text { Date of Issue: } \\
24 \text { April } 2003\end{array}$ & \\
\hline $\begin{array}{l}\text { Document } \\
\text { Title: }\end{array}$ & Subtask 1.4 Determine Salt Cavern Requirements & $\begin{array}{l}\text { Doc \# \& Version: } \\
\text { Doc } 05 \mathrm{r} 1.0\end{array}$ & Page 1 of 4 \\
\hline
\end{tabular}

\title{
Determine Salt Cavern Requirements
}

\author{
BY \\ MiChAEL M. MCCALL \\ WILLIAM M. BISHOP \\ D. BRAXTON SCHERZ
}

\begin{tabular}{|c|c||c|c|c|c|c|c|c||}
\hline r 1.0 & For client review & $02 / 09 / 03$ & вs & мм & & & \\
\hline Version & Reason for Issue & $\begin{array}{c}\text { Issue } \\
\text { Date }\end{array}$ & $\begin{array}{c}\text { Orig. } \\
\text { Chk. Appr. } \\
\text { CGI }\end{array}$ & $\begin{array}{c}\text { Chk. } \\
\text { NETL }\end{array}$ & Appr. & Review \\
\hline Document Title: & \multicolumn{2}{|c||}{$\begin{array}{c}\text { Document No: } \\
\text { CGI/DOE_DOC 05 } \\
\text { DE-FC26-02NT41653 }\end{array}$} \\
\hline
\end{tabular}




\begin{tabular}{|l|l|l|l|}
\hline Customer: & $\begin{array}{l}\text { The United States Department of Energy } \\
\text { National Energy Technology Laboratory }\end{array}$ & $\begin{array}{l}\text { Date of Issue: } \\
24 \text { April } 2003\end{array}$ & \\
\hline $\begin{array}{l}\text { Document } \\
\text { Title: }\end{array}$ & Subtask 1.4 Determine Salt Cavern Requirements & $\begin{array}{l}\text { Doc \# \& Version: } \\
\text { Doc } 05 \text { r1.0 }\end{array}$ & Page 3 of 4 \\
\hline
\end{tabular}

\section{EXECUTIVE SUMMARY}

The results of RESPEC's rock mechanic analysis confirm that salt caverns can be used in LNG receiving terminal applications. Gasified LNG at temperatures from $43.3^{\circ} \mathrm{C}\left(110^{\circ} \mathrm{F}\right)$ down to $-17.8^{\circ} \mathrm{C}\left(0^{\circ} \mathrm{F}\right)$ can safely and reliably be injected, stored, and withdrawn. Limits on cavern cycling and withdrawal rates are no different in LNG service than for conventional gas storage facilities, and are widely known in the industry. The report indicates that salt caverns can tolerate low temperatures. The results of the study also confirm that the use of salt caverns in LNG receiving is fundamentally no different than the widespread use of salt caverns for the natural gas pipeline industry..

\section{THE EFFECT OF LOW TEMPERATURE GAS INJECTION ON SALT CAVERN STABILITY}

This analysis was performed by Joel D. Nieland of RESPEC, Rapid City, South Dakota. RESPEC is a firm that specializes in rock mechanics including testing and modeling. They have extensive experience with salt. Their complete report is included as Attachment I. The purpose of the study was to determine what effect, if any, the injection of colder than normal gas would have on cavern stability. Since any lowering of the allowable injection temperature could decrease heat exchanger requirements, it was also desired to explore the lower limits on injection temperature. The injection temperatures studied were

- $0^{\circ} \mathrm{F}\left(-18^{\circ} \mathrm{K}\right)$

- $40^{\circ} \mathrm{F}\left(4.4^{\circ} \mathrm{K}\right)$

- $110^{\circ} \mathrm{F}\left(44^{\circ} \mathrm{K}\right)$ for comparison temperatures more typical of normal cavern operations.

\subsection{Description of the Model}

The salt cavern modeled was based on a conceptual offshore Gulf of Mexico receiving terminal consisting of six identical caverns at what would be their initial service volumes, i.e. a relatively small volume of $2.2 \mathrm{MMB}$ $(350,000 \mathrm{~m} 3)$. The intent would be to expand these as time and demand allowed. The fill and drawdown rates were made high so as to assess what the cavern limits might be as well as to examine a maximum terminal use. The facility was assumed to receive and deliver gas in two scenarios:

1. Receive one tanker of 3BCF ( $140,000 \mathrm{~m} 3 \mathrm{LNG})$ in 18 hours ( 0.75 days) and discharge it in 3 days. Pressure at the casing seat fluctuates between 2000psi and 1350 psi. Injected gas temperatures were $0^{\circ} \mathrm{F}$ and $40^{\circ} \mathrm{F}$. Simulation continued for five years in each case.

2. Receive two tankers of 6 BCF total over 36 hours ( 1.5 days) and discharge it also in 3 days. The pressure fluctuates at the casing seat between 2000psi and 705psi. Injected gas temperatures were $0^{\circ} \mathrm{F}, 40^{\circ} \mathrm{F}$ and $110^{\circ} \mathrm{F}$. Simulation continued for five years in each case.

\subsection{Simulation Results}

The most significant unknown before the completion of this study was the effect that wide ranges of temperatures would have upon cavern structure. Modeling for temperature ranges from $-17.8^{\circ} \mathrm{C}\left(0^{\circ} \mathrm{F}\right)$ to $43.3^{\circ}$ $\left(110^{\circ} \mathrm{F}\right)$, the simulations showed that the temperature effect is virtually neutral. Some of the reasons for this are: 


\begin{tabular}{|l|l|l|l|}
\hline Customer: & $\begin{array}{l}\text { The United States Department of Energy } \\
\text { National Energy Technology Laboratory }\end{array}$ & $\begin{array}{l}\text { Date of Issue: } \\
24 \text { April } 2003\end{array}$ & \\
\hline $\begin{array}{l}\text { Document } \\
\text { Title: }\end{array}$ & Subtask 1.4 Determine Salt Cavern Requirements & $\begin{array}{l}\text { Doc \# \& Version: } \\
\text { Doc } 05 \mathrm{r} 1.0\end{array}$ & Page 4 of 4 \\
\hline
\end{tabular}

1. The salt properties of importance remain constant or improve with decreasing temperature. The coefficient of thermal expansion is approximately constant over the temperature range covered, and thermal conductivity increases at low temperatures thus decreasing thermal stresses. Also the thermal contraction at lower temperatures reduces the stress in the tangential and vertical directions. This is a plus. However creep rate is slowed, slowing the response to these lowered stresses and thus stresses are slower to be relieved. This is a negative. The net effect is very small.

2. The temperature change for a given change in pressure is less when the compression or expansion starts at a lower temperature. This can be seen from a pressure-enthalpy chart. It is also seen in Fig 4.8 of the RESPEC report where the temperature swings for the $110^{\circ} \mathrm{F}$ injections are larger than those for the $0^{\circ} \mathrm{F}$ injections.

3. As time passes, the cavern wall temperature cycling takes place about a fairly steady average temperature. This also can be seen from Fig 4.8. For the $110^{\circ}$ injections, wall temperature cycles about an average of about $104^{\circ}$, the $40^{\circ}$ injections about $44^{\circ}$ and the $0^{\circ}$ injections about $3^{\circ} \mathrm{F}$. Thus in the vicinity of the wall, a new temperature base is established to which the salt has adapted structurally over time, except for the variations about the mean.

The RESPEC report does point out that over long periods of continuous and intense cycling as simulated in these cases, tensile fracturing is predicted to occur on the cavern periphery. These are fractures perpendicular to the wall and could eventually cause sloughing off of the wall and roof and reduce the life of the cavern. This concern would be the same for any cavern under this type of pressure cycling. This type of failure would not be catastrophic and indeed the failure anticipated by the simulation has not, according to RESPEC, been corroborated by observation of actual caverns.

Nevertheless, several guidelines exist that proscribe against rapid cyclic depressurization, and operators need to be aware of a potential problem. The high pressure fluctuations observed in the present model can of course be overcome by simply making the cavern larger so that the pressure drop with withdrawal of one or two cargoes is not of concern.

As was discussed earlier in this section, these studies do not include the effect of temperature on the last cemented casing. Depending on the gas injection temperature, this casing may need to be protected by using a suitable cement or by slipstreaming warm gas in an outer annulus provided by a hanging string. A temperature of $40^{\circ} \mathrm{F}$ should not pose a problem since many brine wells are operated at this temperature. The literature may reveal data on operating at colder temperatures. 


\section{FEASIBILITY OF OFF-LOADING CHILLED NATURAL GAS IN SALT CAVERNS: GEOMECHANICAL ASSESSMENT}

Topical Report RSI-1712

prepared for

Conversion Gas Imports

2929 Briarpark, Suite 220

Houston, Texas 77042

April 2003 


\title{
FEASIBILITY OF OFF-LOADING CHILLED NATURAL GAS IN SALT CAVERNS: GEOMECHANICAL ASSESSMENT
}

Topical Report RSI-1712

\author{
by \\ Joel D. Nieland \\ RESPEC \\ P.O. Box 725 \\ Rapid City, South Dakota 57709
}

prepared for

Conversion Gas Imports

2929 Briarpark, Suite 220

Houston, Texas 77042

April 2003 


\section{TABLE OF CONTENTS}

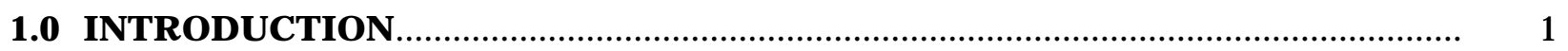

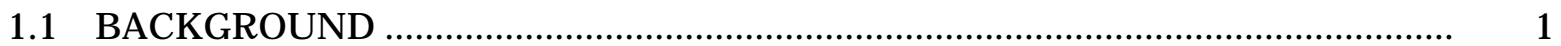

1.2 OBJ ECTIVE OF THE GEOMECHANICAL EVALUATION ................................ 1

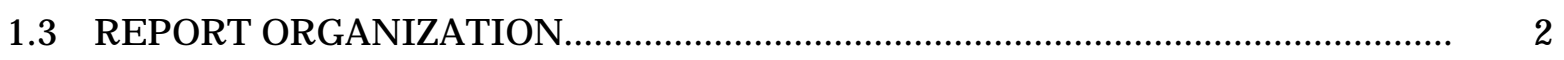

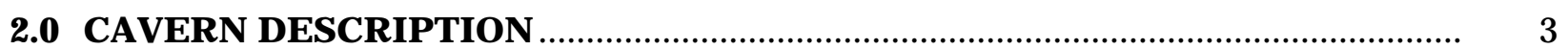

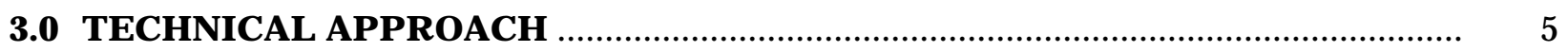

3.1 NUMERICAL MODELING .......................................................................... 5

3.1.1 Cavern Thermodynamics Program ...................................................... 5

3.1.2 Heat Transfer Finite Element Program ................................................. 5

3.1.3 Thermomechanical Finite Element Program............................................. 6

3.1.4 Constitutive Model for Salt.................................................................. 6

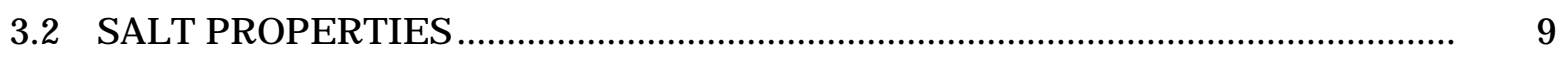

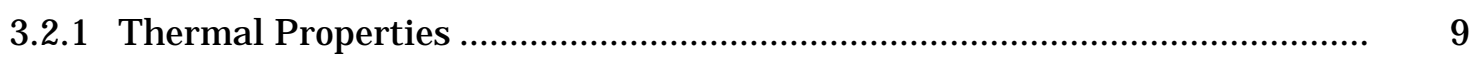

3.2.2 Elastic Properties ............................................................................ 9

3.2.3 Creep Properties.................................................................................... 10

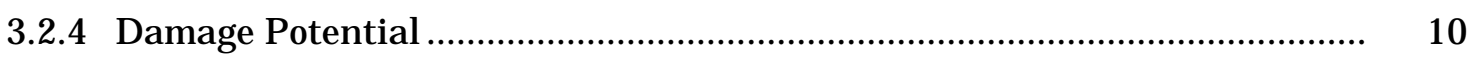

3.2.5 Tensile Strength ................................................................................. 11

3.3 PROPERTIES OF CAVERN FLUIDS ........................................................... 11

3.3.1 Natural Gas Characteristics............................................................. 12

3.3.2 Brine Characteristics .................................................................... 12

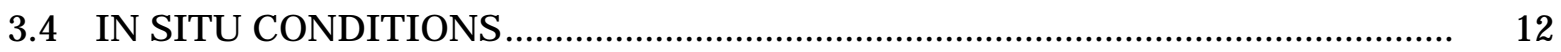

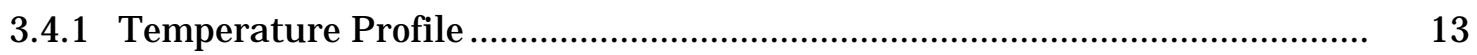

3.4.2 Stress Distribution ............................................................................. 13

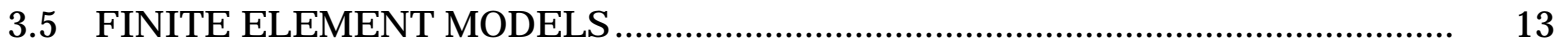

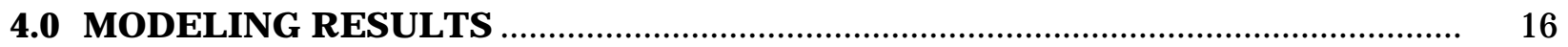

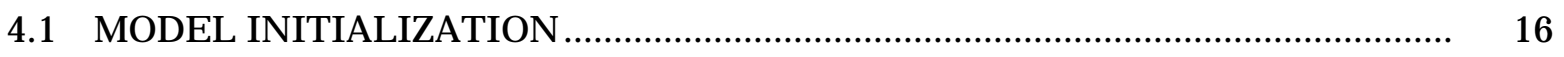

4.2 TEMPERATURE CHANGES DURING GAS STORAGE .................................. 18

4.3 CAVERN STABILITY DURING GAS STORAGE SCENARIOS ......................... 18

4.4 EVALUATION OF GAS WITHDRAWAL RATE ............................................... 35

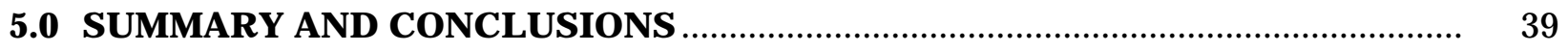

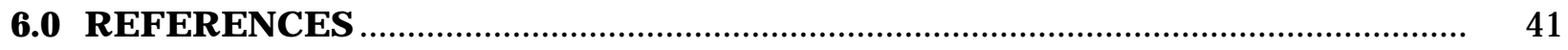




\section{LIST OF TABLES}

TABLE

PAGE

3-1 Estimates of Munson-Dawson Creep Parameters for Avery I sland Salt ................ 11

3-2 Gas Composition................................................................................... 12 


\section{LIST OF FIGURES}

FIGURE

PAGE

2-1 Schematic of Modeled Cavern ........................................................................ 4

3-1 Axisymmetric Finite Element Model Used to Represent LNG Receiving Terminal Caverns.

4-1 Model ed Gas Storage Cycles.

4-2 Temperature Distributions in Salt for Single-Tanker Scenario With $-17.8^{\circ} \mathrm{C}\left(0^{\circ} \mathrm{F}\right)$ Gas I njection Temperature .

4-3 Temperature Distributions in Salt for Single-Tanker Scenario With $4.4^{\circ} \mathrm{C}\left(40^{\circ} \mathrm{F}\right)$ Gas Injection Temperature......

4-4 Temperature Distributions in Salt for Double-Tanker Scenario With $-17.8^{\circ} \mathrm{C}$ $\left(0^{\circ} \mathrm{F}\right)$ Gas I njection Temperature.

4-5 Temperature Distributions in Salt for Double-Tanker Scenario With $4.4^{\circ} \mathrm{C}\left(40^{\circ} \mathrm{F}\right)$ Gas Injection Temperature....

4-6 Temperature Distributions in Salt for Double-Tanker Scenario With $43.3^{\circ} \mathrm{C}$ $\left(110^{\circ} \mathrm{F}\right)$ Gas I njection Temperature.

4-7 Temperature Distributions Around Top of Cavern During First Withdrawal in Double-Tanker Scenarios

4-8 Cavern Wall Temperature Versus Time for Various Gas Storage Scenarios 25

4-9 Damage Potential Contours Around Top of Cavern During First Withdrawal for Double-Tanker Scenarios

4-10 Maximum Principal Stress Contours Around Top of Cavern During First 3-Day Withdrawal of Single-Tanker Simulations

4-11 Maximum Principal Stress Contours Around Top of Cavern During First 3-Day Withdrawal of Double-Tanker Simulations.

4-12 Maximum Principal Stress Contours Around Top of Cavern During 3-Day Withdrawal of Single-Tanker Simulation With $-17.8^{\circ} \mathrm{C}\left(0^{\circ} \mathrm{F}\right)$ Injection Temperature After Cycling for 5 Years......

4-13 Maximum Principal Stress Contours Around Top of Cavern During 3-Day Withdrawal of Single-Tanker Simulation With $4.4^{\circ} \mathrm{C}\left(40^{\circ} \mathrm{F}\right)$ Injection Temperature After Cycling for 5 Years.

4-14 Maximum Principal Stress Contours Around Top of Cavern During 3-Day Withdrawal of Double-Tanker Simulations With $-17.8^{\circ} \mathrm{C}\left(0^{\circ} \mathrm{F}\right)$ Injection Temperature After Cycling for 5 Years

4-15 Maximum Principal Stress Contours Around Top of Cavern During 3-Day Withdrawal of Double-Tanker Simulation With $4.4^{\circ} \mathrm{C}\left(40^{\circ} \mathrm{F}\right)$ Injection Temperature After Cycling for 5 Years 


\section{LIST OF FIGURES \\ (Continued)}

4-16 Maximum Principal Stress Contours Around Top of Cavern During 3-Day Withdrawal of Double-Tanker Simulation With $43.3^{\circ} \mathrm{C}\left(110^{\circ} \mathrm{F}\right)$ Injection Temperature After Cycling for 5 Y ears.....

4-17 Maximum Principal Stress Contours Around Top of Cavern During 10-Day Double-Tanker Withdrawal

4-18 Maximum Principal Stress Contours Around Top of Cavern During 20-Day Double-Tanker Withdrawal

4-19 Maximum Principal Stress Contours Around Top of Cavern During 30-Day Double-Tanker Withdrawal 


\subsection{INTRODUCTION}

\subsection{BACKGROUND}

Conversion Gas Imports, LLC (CGI) was awarded a contract in September 2002 by the National Energy Technology Laboratory to examine an innovative process to off-load natural gas from liquefied natural gas (LNG) tankers directly into an offshore salt storage cavern or into a pipeline for injection into an onshore cavern. The process involves warming and pressurizing the gas by means of a heat exchanger to temperatures that can be safely accepted by salt storage caverns. RESPEC was engaged by CGI to evaluate salt cavern stability for such a facility.

Salt cavern storage of natural gas is a proven technology. The gas injected into conventional salt storage caverns is generally injected at temperatures greater than $37.8^{\circ} \mathrm{C}\left(100^{\circ} \mathrm{F}\right)$. However, LNG tankers store LNG at a temperature of about $-157^{\circ} \mathrm{C}\left(-250^{\circ} \mathrm{F}\right)$. Thus in order to off-load directly into a salt storage cavern, the LNG must be converted from a liquid to a gas and be heated to a temperature that can be safely accepted by salt storage caverns. The economic viability of this process is dependent on the minimum gas temperature that can be safely accepted by a salt storage cavern.

The structural integrity of a solution-mined cavern in a salt dome is dependent upon the state of stress in the salt surrounding the cavern. The stress state around a cavern is used to determine the structural stability of the cavern roof and walls and to evaluate the potential for connectivity with other caverns or connectivity with geologic strata outside of the salt dome. The stress state in the salt around the cavern is dependent on (1) the original in situ state of stress, (2) the gas pressure in the cavern, (3) cavern geometry, (4) salt creep, and (5) temperature changes in the salt. Because salt has a relatively high coefficient of thermal expansion, temperature changes from the original in situ temperature can have a significant effect on stresses surrounding the cavern.

\subsection{OBJECTIVE OF THE GEOMECHANICAL EVALUATION}

The objective of this geomechanics evaluation is to evaluate the stability of a generic cavern for various gas injection temperatures. The cavern stability will be evaluated in terms of the stability of the cavern roof and walls. This objective is addressed in this evaluation using (1) salt properties available in the open literature and (2) numerical modeling of the generic cavern design using software developed by RESPEC specifically for modeling excavations in salt. The assumptions associated with in situ conditions, geometric approximations, and salt characterization are described throughout the report. 


\subsection{REPORT ORGANIZATION}

A description of the generic cavern and its setting is given in Chapter 2.0, and the technical approach to the geomechanics modeling is described in Chapter 3.0. Chapter 4.0 presents the geomechanics modeling results, and Chapter 5.0 gives a summary of the modeling results and the study condusions. Cited references are provided at the end of the report. 


\subsection{CAVERN DESCRIPTION}

The cavern model used in this investigation is a cylindrically shaped cavern typical of those used for conventional natural gas storage in the Gulf Coast region. The cavern is assumed to be in located in a salt dome and an all-salt stratigraphy is assumed. The modeled cavern has a roof depth of 730 meters (2,400 feet), a total depth of 960 meters (3,150 feet), and a radius of 22 meters ( 72 feet). The total volume of the cavern is $350,000 \mathrm{~m}^{3}$ ( 2.2 million barrels ( $M$ M bbls)). The casing seat is at a depth of 716 meters (2,350 feet). The maximum casing seat pressure is assumed to be $13.8 \mathrm{MPa}(2,000 \mathrm{psi})$ or $0.019 \mathrm{MPa}$ per meter of depth $(0.85 \mathrm{psi} / \mathrm{foot})$. The minimum pressure evaluated at the casing seat is $4.9 \mathrm{MPa}$ (700 psi) or $0.0067 \mathrm{MPa}$ per meter of depth ( $0.30 \mathrm{psi} / \mathrm{foot})$. The cavern size is based on a facility with six caverns having the working gas capacity of two LNG tankers (about $1.9 \times 10^{8} \mathrm{Nm}^{3}$ (7 billion cubic feet (Bcf))). ${ }^{1}$ Figure 2shows a schematic of the cavern modeled in this study. The model assumes an in situ temperature in situ temperature of $33^{\circ} \mathrm{C}\left(92^{\circ} \mathrm{F}\right)$ at the cavern midheight.

${ }^{1}$ Natural gas quantities are expressed in terms of normal cubic meters $\left(\mathrm{Nm}^{3}\right)$ with reference conditions of $0^{\circ} \mathrm{C}$ and $0.101325 \mathrm{MPa}$ and in terms of standard cubic feet (scf) with reference conditions of $60^{\circ} \mathrm{F}$ and $14.696 \mathrm{psi}$. 
RSI-1399-03-001

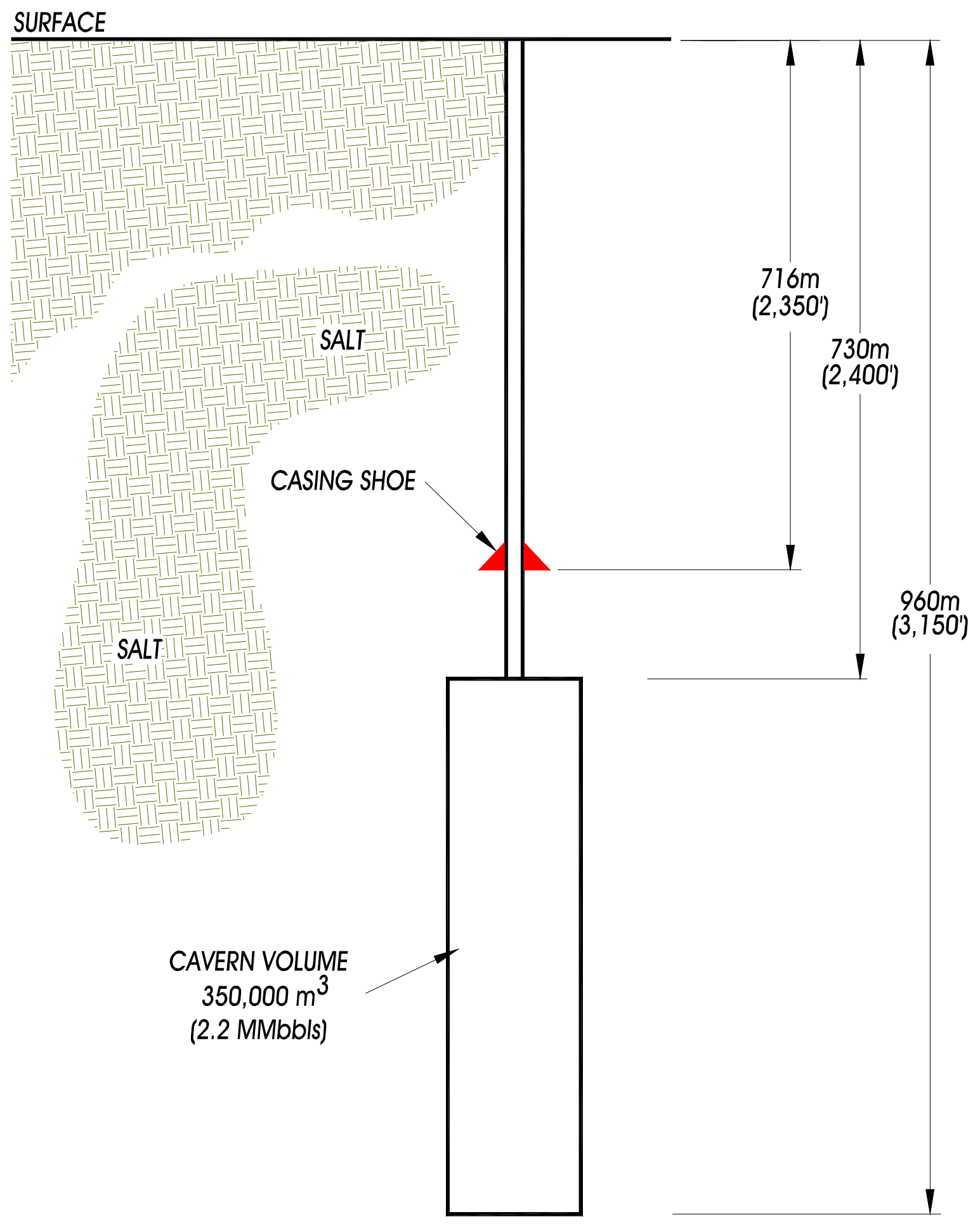

Figure 2-1. Schematic of Modeled Cavern. 


\subsection{TECHNICAL APPROACH}

Cavern stability for the LNG receiving terminal was based on the following performance criterion: the injection of chilled gas must not result in extensive areas of tensile stress or salt damage (microfracturing). Extensive areas of tensile stress or salt damage could lead to spalling of the roof and/or walls of the cavern and subsequent damage to the casing seat, well, and/or hanging string. This criterion was evaluated using numerical models of the cavern described in Chapter 2.0. The following sections describe the numerical modeling methods, material and cavern fluids properties, in situ conditions, and the finite el ement model used.

\subsection{NUMERICAL MODELING}

Numerical modeling software was used to model the thermodynamics in the caverns, the heat transfer in the salt surrounding the caverns, and the mechanical behavior of the salt surrounding the caverns. These specialized computer programs and the constitutive model used to define the viscoplastic deformation of the salt are described in the following subsections.

\subsubsection{Cavern Thermodynamics Program}

The Salt Cavern Thermal Simulator (SCTS) [Nieland, 2002] is a program for simulating the thermodynamics and heat transfer related to the storage of natural gas in underground salt caverns. It accounts for the thermal effects associated with gas compression and expansion; the mass transfer during injection and withdrawal; and the heat transfer between the gas and its surroundings, both in the wellbore and in the cavern.

SCTS was used to determine cavern wall temperatures throughout the simulated LNG receiving terminal gas cycle. SCTS calculates a single bulk cavern temperature and a single cavern wall temperature. The cavern wall temperature as a function of time, determined from SCTS, was applied as a boundary condition to the thermal finite element model to estimate the temperature of the salt surrounding the cavern as a function of time.

\subsubsection{Heat Transfer Finite Element Program}

SPECTROM-41 [Svalstad, 1989] is a finite element heat transfer analysis program that has been developed by RESPEC to analyze thermal problems in geologic formations. The primary transport process modeled by SPECTROM-41 is conductive heat transfer. SPECTROM-41 has the capability to model complex material properties (including temperature-dependent thermal conductivity) and boundary conditions. SPECTROM-41 was used in this study to simulate the heat transfer between the cavern and the surrounding salt. The results of these calculations were 
then integrated into the thermomechanical analyses to account for the thermal stresses and strains that are a result of the temperature changes in the salt surrounding the cavern.

\subsubsection{Thermomechanical Finite Element Program}

SPECTROM-32 [Callahan et al., 1989] is a thermomechanical, finite element program that has been developed by RESPEC for the solution of rock mechanics problems. It was designed specifically for the simulation of underground openings and structures. SPECTROM-32 not only has the capability to model the elastic-plastic response that is commonly associated with brittle rock types, but it also has the capability to simulate the viscoplastic behavior that is observed in rock salt. The features and capabilities of SPECTROM-32 that were required specifically for this investigation include:

- Option for axisymmetric geometries

- Kinematic and traction boundary conditions

- Munson-Dawson multimechanism constitutive model for viscoplastic behavior of salt

- Capability to represent arbitrary in situ stress and temperature fields

- Capability to simulate excavation operations.

\subsubsection{Constitutive Model for Salt}

The deformation rate of salt can be decomposed into thermal expansion, elastic deformation, and inelastic deformation. The inelastic deformation is stress-, temperature, and ratedependent. It is comprised of both viscoplastic and brittle components, with the viscoplastic component usually dominating in the range of stress and temperature expected in the salt surrounding natural gas storage caverns. Considerable research has been performed to determine a satisfactory constitutive law that characterizes the viscoplastic behavior of rock salt. The Munson-Dawson multimechanism constitutive model has been found to perform reasonably well in fitting data from laboratory constant-stress tests and in predicting the response of laboratory, field, and bench-scale tests performed on salt from Avery Island [DeVries, 1988]. Two differential rate equations comprise the Munson-Dawson model: (1) the strain-rate equations which give the viscoplastic strain rates (Equation 3-1) and (2) the evolutionary equation which gives the rate of change of an internal variable (Equation 3-2). The three-dimensional form of the Munson-Dawson model is given bel ow.

$$
\begin{gathered}
\dot{\varepsilon}_{\mathrm{ij}}^{\mathrm{vp}}=\frac{\partial \sigma_{\mathrm{e}}}{\partial \sigma_{\mathrm{ij}}} \mathrm{F} \dot{\varepsilon}_{\mathrm{s}} \\
\dot{\zeta}=(\mathrm{F}-1) \dot{\varepsilon}_{\mathrm{s}}
\end{gathered}
$$


where:

$$
\begin{aligned}
& \dot{\varepsilon}_{\mathrm{s}}=\sum_{\mathrm{i}=1}^{3} \dot{\varepsilon}_{\mathrm{s}} \\
& \dot{\varepsilon}_{\mathrm{s}_{1}}=\text { steady-state strain rate for mechanism i } \\
& \dot{\varepsilon}_{\mathrm{s}_{1}}=\mathrm{A}_{1} \exp \left(-\mathrm{Q}_{1} / \mathrm{RT}\right)\left(\sigma_{\mathrm{e}} / \mu\right)^{\mathrm{n}_{1}} \\
& \dot{\varepsilon}_{\mathrm{s}_{2}}=\mathrm{A}_{2} \exp \left(-\mathrm{Q}_{2} / \mathrm{RT}\right)\left(\sigma_{\mathrm{e}} / \mu\right)^{\mathrm{n}_{2}} \\
& \dot{\varepsilon}_{\mathrm{s}_{3}}=\left[\mathrm{B}_{1} \exp \left(-\mathrm{Q}_{1} / \mathrm{RT}\right)+\mathrm{B}_{2} \exp \left(-\mathrm{Q}_{2} / \mathrm{RT}\right)\right] \cdot \sinh \left[\mathrm{q}\left(\sigma_{\mathrm{e}}-\sigma_{\mathrm{o}}\right) / \mu\right] \mathrm{H}\left(\sigma_{\mathrm{e}}-\sigma_{\mathrm{o}}\right) \\
& F= \begin{cases}\exp \left[\Delta\left(1-\frac{\varsigma}{\varepsilon_{t}^{*}}\right)^{2}\right] & \text { for } \varsigma<\varepsilon_{t}^{*} \\
1 & \text { for } \varsigma=\varepsilon_{t}^{*} \\
\exp \left[-\delta\left(1-\frac{\varsigma}{\varepsilon_{t}^{*}}\right)^{2}\right] & \text { for } \varsigma>\varepsilon_{t}^{*}\end{cases} \\
& \varepsilon_{\mathrm{t}}^{*}=\mathrm{K}_{\mathrm{o}} \exp (\mathrm{cT})\left(\sigma_{\mathrm{e}} / \mu\right)^{\mathrm{m}} \\
& \Delta=\alpha+\beta \log \left(\sigma_{\mathrm{e}} / \mu\right)
\end{aligned}
$$

and

$$
\begin{aligned}
\dot{\mathrm{e}}_{\mathrm{ij}}^{\mathrm{vp}} & =\text { viscoplastic strain-rate tensor } \\
\sigma_{\mathrm{e}} & =\sqrt{3 \mathrm{~J}_{2}} \text { (effective stress) } \\
\mathrm{J}_{2} & =\frac{1}{2} \mathrm{~s}_{\mathrm{ij}} \mathrm{s}_{\mathrm{ji}} \\
\mathrm{s}_{\mathrm{ij}} & =\sigma_{\mathrm{ij}}-\delta_{\mathrm{ij}} \sigma_{\mathrm{m}} \text { (deviatoric stress tensor) } \\
\sigma_{\mathrm{m}} & =\frac{1}{3} \sigma_{\mathrm{kk}} \text { (mean stress) }
\end{aligned}
$$




$$
\begin{aligned}
\sigma_{\mathrm{ij}} & =\text { stress tensor } \\
\delta_{\mathrm{ij}} & =\text { Kronecker delta } \\
\varsigma & =\text { internal variable } \\
\mathrm{T} & =\text { absolute temperature } \\
\mathrm{H}(\mathrm{x}) & =\text { Heaviside function } \\
\mu & =1.395\left(10^{6}\right) \text { psi (a constant) } \\
\mathrm{Q}_{1} / \mathrm{R} & =22,732 \mathrm{R} \text { (a constant) } \\
\mathrm{n}_{1} & =5.5 \text { (a constant) }
\end{aligned}
$$

$A_{1}, A_{2}, B_{1}, B_{2}, Q_{2}, n_{2}$, $q, \sigma_{0}, \delta, K_{0}, c, m, \alpha, \beta=$ experimentally determined parameters.

As indicated by Equation 3-3, the steady-state creep rate $\left(\dot{\varepsilon}_{\mathrm{s}}\right)$ based on the Munson-Dawson model is composed of three terms. Each term is associated with a different creep mechanism. The first and third mechanisms $\left(\dot{\varepsilon}_{s_{1}}\right.$ and $\left.\dot{\varepsilon}_{s_{3}}\right)$ are dislocation climb and dislocation glide, respectively, and the second mechanism $\left(\dot{\varepsilon}_{s_{2}}\right)$ is referred to as the undefined mechanism. The relative contribution of each mechanism to the steady-state creep rate strongly depends on the effective stress and temperature.

When pressure conditions in a storage cavern are changed, the transient nature of the Munson-Dawson model can be an important factor in the response of the cavern. According to Equation 3-1, the steady-state creep rate is multiplied by a transient factor (F) to obtain the viscoplastic strain rate. The value of the transient factor depends on whether the internal variable $(\varsigma)$ is less than, equal to, or greater than the transient strain limit $\left(\varepsilon_{\mathrm{t}}^{*}\right)$, which is a function of the effective stress and temperature. When $\varsigma<\varepsilon_{\mathrm{t}}^{*}$, the viscoplastic strain rate is greater than the steady-state creep rate $(F>1)$. This is the work-hardening branch of the Munson-Dawson model. The work-hardening branch is commonly associated with an increase in loading, such as when a cavern is excavated or when the cavern pressure is decreased. When $\varsigma>\varepsilon_{t}^{*}$, the viscoplastic strain rate is less than the steady-state creep rate $(F<1)$. This is the recovery branch of the Munson-Dawson law. This branch is commonly associated with a decrease in loading, such as when the cavern pressure is increased. Through the evolutionary equation, the value of the internal variable is al ways approaching the transient strain limit. In turn, the viscoplastic strain rate is always approaching the steady-state creep rate (i.e., $F$ approaches unity as $\varsigma$ approaches $\varepsilon_{\mathrm{t}}^{*}$ ). 
The Munson-Dawson model has 14 parameters that must be determined experimentally or estimated empirically. The parameter values used to represent the salt are presented in Section 3.2.3.

\subsection{SALT PROPERTIES}

The following sections describe the material properties that were used to simulate the salt surrounding the LNG receiving terminal cavern in this analysis.

\subsubsection{Thermal Properties}

The specific heat of salt was assumed to be $840 \mathrm{~J} / \mathrm{kg}-\mathrm{K}(0.20 \mathrm{Btu} / \mathrm{lbm})$, based on measurements by Dahlstrom [1988], and the density of salt was assigned a typical value of $2,160 \mathrm{~kg} / \mathrm{m}^{3}\left(135 \mathrm{lbm} / \mathrm{ft}^{3}\right)$. The thermal conductivity of salt changes significantly with temperature. In the SPECTROM-41 simulations, the thermal conductivity of salt as a function of temperature is based on recent measurements made on rock salt from the Michigan Basin [Nieland et al., 2001] and is described by:

$$
K=a\left(\frac{T}{T_{0}}\right)^{b}
$$

where:

$$
\begin{aligned}
\mathrm{K}= & \text { thermal conductivity } \\
\mathrm{a}= & 6.678 \mathrm{~W} / \mathrm{m}-\mathrm{K} \\
\mathrm{T}= & \text { absolute temperature }(\mathrm{K}) \\
\mathrm{T}_{0}= & \text { absolute temperature which water freezes } \\
& \text { at } 1 \text { atm pressure }(\text { e.g., } 273.15 \mathrm{~K}) \\
\mathrm{b}= & -1.793 .
\end{aligned}
$$

A constant value of $5.4 \mathrm{~W} / \mathrm{m}-\mathrm{K}$ (3.1 Btu/hr-ft- $\left.{ }^{\circ} \mathrm{F}\right)$ was used in scTs to make the thermodynamic calculations to estimate the cavern wall temperature as a function of time. This value was determined using Equation 3-11 and the assumed original in situ temperature of $33^{\circ} \mathrm{C}\left(92^{\circ} \mathrm{F}\right)$ at the cavern midheight.

\subsubsection{Elastic Properties}

The Young's modulus (E) and Poisson's ratio ( $v$ ) used for the salt in this study are based on laboratory testing of Avery Island salt [Hansen and Carter, 1984]. The average values of Young's modulus and Poisson's reported are $30.6 \mathrm{GPa}\left(4.44 \times 10^{6} \mathrm{psi}\right)$ and 0.38 , respectively. 
The coefficient of linear thermal expansion for salt only varies slightly throughout the temperature range expected around the caverns. A constant value of $3.9 \times 10^{-5} \mathrm{~K}^{-1}\left(2.2 \times 10^{-5}\right.$

$\mathrm{R}^{-1}$ ) was used to model the salt in this study and is calculated from a temperature-dependent equation given by Senseny et al. [1992] at the assumed cavern midheight temperature of $33^{\circ} \mathrm{C}$ $\left(92^{\circ} \mathrm{F}\right)$.

\subsubsection{Creep Properties}

Because Avery Island salt was extensively tested for the nuclear waste program, its creep properties are available in the open literature. Avery Island salt creep properties were used to represent the salt hosting the caverns of the LNG receiving terminal evaluated here. The Munson-Dawson creep parameters for Avery Island salt are shown in Table 3-1 [DeVries, 1988].

\subsubsection{Damage Potential}

The criterion used to evaluate whether or not damage (micro- or macrofracturing that causes porosity and permeability increases) occurs in the salt is based on the stress state. Two stress measures are used in defining the damage criteria: the first invariant of the stress tensor, $I_{1}$, and the second invariant of the deviatoric stress tensor, $\mathrm{J}_{2}$. These two stress measures are defined as follows:

$$
\begin{gathered}
\mathrm{I}_{1}=\sigma_{1}+\sigma_{2}+\sigma_{3} \\
\mathrm{~J}_{2}=\frac{1}{6}\left[\left(\sigma_{1}-\sigma_{2}\right)^{2}+\left(\sigma_{1}-\sigma_{3}\right)^{2}+\left(\sigma_{2}-\sigma_{3}\right)^{2}\right]
\end{gathered}
$$

where:

$$
\sigma_{1}, \sigma_{2}, \sigma_{3}=\text { principal stresses. }
$$

A damage limit has been established that is based on dilation observed in an extensive database of creep tests of WIPP and Avery I sland salt [Van Sambeek et al., 1993]. The dilation limit can be expressed mathematically in terms of the stress invariants as:

$$
\sqrt{J_{2}} \leq 0.27 I_{1}
$$

The term "damage potential" is defined as the ratio of $\sqrt{I_{2}}$ to $I_{1}$. Thus regions of salt exhibiting a damage potential value of 0.27 or larger are expected to experience damage. Damage is expected to increase with increasing damage potential values. 
Table 3-1. Estimates of Munson-Dawson Creep Parameters for Avery Island Salt (After DeVries [1988])

\begin{tabular}{|c|c|c||}
\hline Parameters & Units & Estimators \\
\hline \hline $\mathrm{A}_{1}$ & day $^{-1}$ & $2.09\left(10^{26}\right)$ \\
\hline $\mathrm{A}_{2}$ & day $^{-1}$ & $1.13\left(10^{14}\right)$ \\
\hline $\mathrm{B}_{1}$ & day $^{-1}$ & $5.94\left(10^{10}\right)$ \\
\hline $\mathrm{B}_{2}$ & day $^{-1}$ & $1.89\left(10^{3}\right)$ \\
\hline $\mathrm{K}_{\circ}$ & - & $2.52\left(10^{4}\right)$ \\
\hline $\mathrm{m}$ & - & 2.54 \\
\hline$\alpha$ & - & -8.83 \\
\hline$\beta$ & - & -5.05 \\
\hline $\mathrm{q}$ & - & 3,330 \\
\hline $\mathrm{Q}_{2} / \mathrm{R}$ & $\mathrm{K}$ & 6,520 \\
\hline $\mathrm{n}_{2}$ & - & 3.14 \\
\hline$\sigma_{0}$ & $\mathrm{MPa}$ & 8.82 \\
\hline $\mathrm{C}$ & $\mathrm{K}^{-1}$ & $9.20\left(10^{-3}\right)$ \\
\hline$\delta$ & - & 0.242 \\
\hline
\end{tabular}

\subsubsection{Tensile Strength}

The tensile strength of Gulf Coast dome salts, based on indirect tensile tests on salt from 11 Gulf Coast salt domes [Pfeifle et al., 1995], is generally less than $2 \mathrm{MPa}$ (300 psi). However, as a conservative measure in this study, we assume a tensile strength of zero.

\subsection{PROPERTIES OF CAVERN FLUIDS}

The mechanical response of a storage cavern depends not only on the material properties of the salt surrounding the cavern but also on the material properties of the fluids inside the cavern. In the simulations, cavern fluids were represented by their pressures applied as normal tractions to the surfaces of the cavern walls. The fluids were assumed to be essentially stagnant, and at a given depth, the vertical pressure gradient was assumed to be equal to the fluid's density at that depth. The following two subsections describe how the vertical pressure gradients for natural gas and saturated brine were derived. 


\subsubsection{Natural Gas Characteristics}

Natural gas is modeled in SCTS as a real gas using the American Gas Association's Detail Characterization Method as described by Starling and Savidge [1994]. The gas composition used to model the gas off-loaded from tankers is described in Table 3-2 [Bishop, 2002].

Table 3-2. Gas Composition

\begin{tabular}{||c|c||}
\hline Gas Component & Mole Percent \\
\hline \hline Methane & 91.37 \\
\hline Nitrogen & 1.55 \\
\hline Ethane & 4.09 \\
\hline Propane & 1.71 \\
\hline i-Butane & 0.35 \\
\hline n-Butane & 0.40 \\
\hline i-Pentane & 0.16 \\
\hline n-Pentane & 0.18 \\
\hline n-Hexane & 0.19 \\
\hline
\end{tabular}

Gas pressure is applied in the finite element model with tractions on the cavern surface. A linear pressure gradient was assumed for the gas in the cavern and is based on the bulk cavern gas density estimated by SCTS.

\subsubsection{Brine Characteristics}

Brine was represented in the cavern model during simulation of the leaching and dewatering processes. Because of the very small compressibility of brine (approximately $2.8 \times$ $\left.10^{-4} / \mathrm{MPa}\left(1.9 \times 10^{-6} / \mathrm{psi}\right)\right)$, the increase in brine density associated with the hydrostatic pressure increase over the height of a cavern is negligible (about 0.1 percent change per 305 meters (1,000 feet)). Consequently, the brine density was assumed to remain a constant $1,201 \mathrm{~kg} / \mathrm{m}^{3}$ $\left(75 \mathrm{lb} / \mathrm{foot}^{3}\right)$, resulting in a vertical pressure gradient of $0.0011 \mathrm{MPa} / \mathrm{meter}(0.52 \mathrm{psi} / \mathrm{foot})$.

\subsection{IN SITU CONDITIONS}

Since the creep rate of salt is dependent on temperature and stress, it is important to model temperatures and stresses which are representative of those in the vicinity of the cavern. The following two subsections describe the in situ temperature and stress distributions assumed in this analysis. 


\subsubsection{Temperature Profile}

The undisturbed temperature profile in the salt dome was chosen to be representative of an offshore facility and is described by:

$$
\mathrm{T}=10+0.00254 \mathrm{z}
$$

where $\mathrm{T}$ is the temperature in degrees Centigrade and $\mathrm{z}$ is the depth in meters. This results in an undisturbed in situ temperature of $33^{\circ} \mathrm{C}\left(92^{\circ} \mathrm{F}\right)$ at the cavern midheight.

\subsubsection{Stress Distribution}

The undisturbed in situ stress distribution was assumed to be isotropic and equal to the weight of the overburden. The weight of the overburden is based on the typical rock salt density of $2,160 \mathrm{~kg} / \mathrm{m}^{3}\left(135 \mathrm{lbm} / \mathrm{ft}^{3}\right)$. At the cavern midheight depth, the vertical stress is estimated to be about $18.0 \mathrm{MPa}(2,610 \mathrm{psi})$.

\subsection{FINITE ELEMENT MODELS}

Because of axial symmetry, the LNG receiving terminal caverns are modeled using an axisymmetric model. It is assumed that the caverns for such a facility would be sufficiently separated (e.g. web-to-diameter ratios greater than 3) that cavern interactions can be neglected.

Figure 3-1 shows the axisymmetric cavern model used. The region immediately outside the walls of the caverns is very finely subdivided. This extremely fine subdivision was used to accurately represent the high stress and temperature gradients that were anticipated near the cavern periphery. The extents of the models were sel ected to isol ate the response of the caverns from the influences of the radial and bottom boundaries which are artificial truncations of the actual horizontal and vertical extents of the salt.

The kinematic boundary conditions specified along the sides of the axisymmetric models were:

- No radial displacement along the centerline

- No radial displacement along the outer radius

- No vertical displacement al ong the bottom surface.

The upper surface of the models is free to move in the vertical direction. 
RSI-1399-03-002

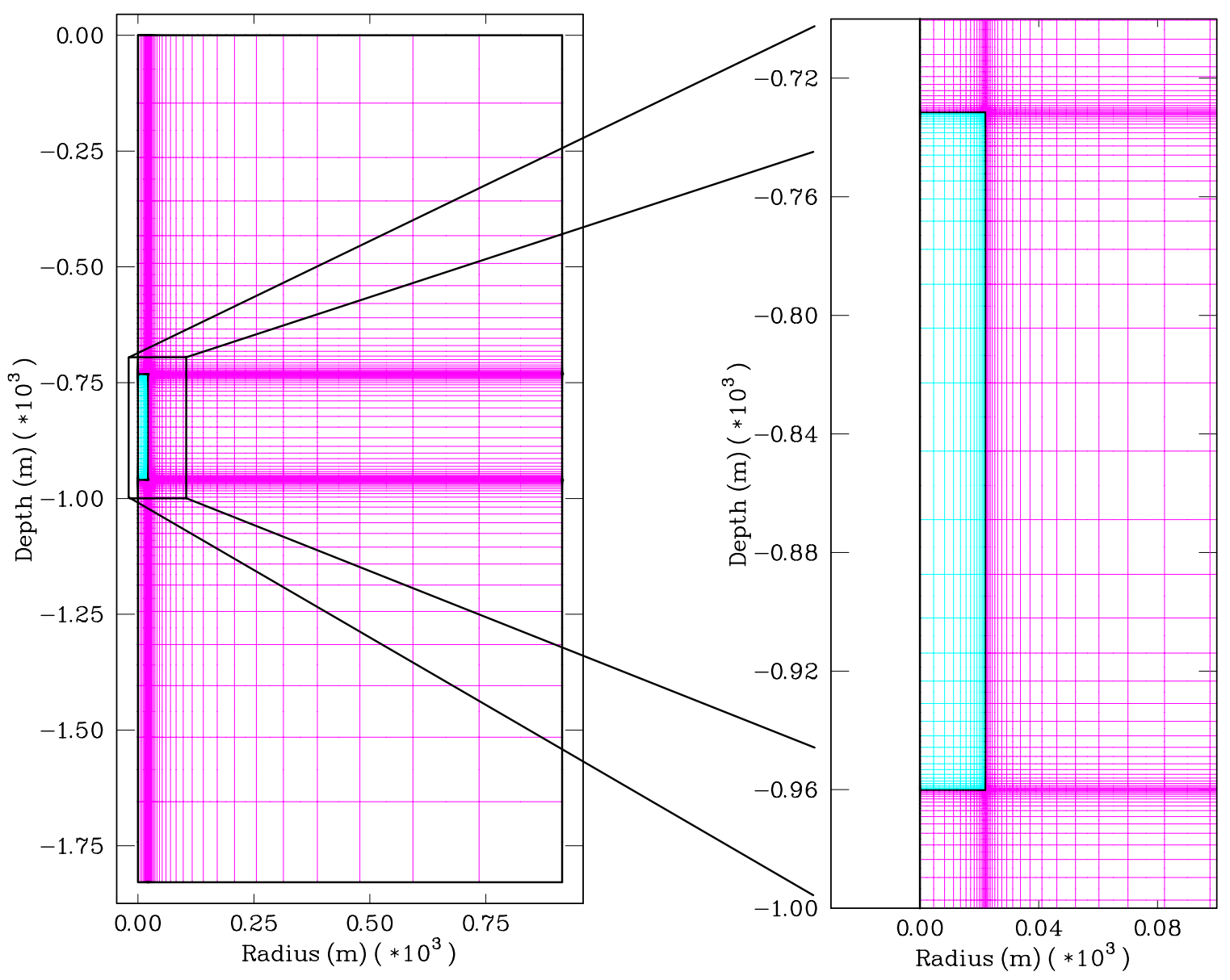

Figure 3-1. Axisymmetric Finite Element Model Used to Represent LNG Receiving Terminal Caverns. 
After excavation of the salt, normal tractions are specified al ong the surfaces of the cavern to simulate the fluid pressure inside the cavern. The magnitudes of these tractions are equal to the hydrostatic pressure based on the density of brine during the solution mining portion of the simulation and based on the respective wellhead pressure and gas density during the natural gas storage portion of the simulated history. The cavern is modeled between the depths of 730 meters and 960 meters (2,400 feet and 3,150 feet). There are 13,623 nodes and 4,444 8-noded finite elements in this model. 


\subsection{MODELING RESULTS}

Cavern stability is evaluated in terms of damage potential and the development of tensile stresses. Salt that has a damage potential greater than the 0.27 limit does not indicate immediate failure of the salt, only that the salt is in a stress state that will result in microfracturing of the salt that could eventually lead to spalling. Tensile failure, however, will occur immediately if the tensile strength of the salt is exceeded. The tensile strength of salt is low (1-2 MPa (150-300 psi)) and we conservatively assume no tensile strength in this study. The maximum principal stresses are examined to determine tensile regions in the salt. The sign convention used here assumes compression is negative and thus the maximum principal stress is the least compressive (or most tensile) of the three principal stresses.

CGI proposed two 5-year gas storage scenarios to be used in the evaluation of the LNG receiving terminal. As described in Chapter 2.0, the hypothetical terminal was designed to have a working gas capacity approximately equal to that contained in two LNG tankers. The first scenario consists of continuous cycles of withdrawing and injecting a single LNG tanker load of gas. In this scenario, the casing seat pressure is reduced from $13.8 \mathrm{MPa}(2,000 \mathrm{psi})$ to 9.3 $\mathrm{MPa}(1,350 \mathrm{psi})$ to represent the removal of a single LNG tanker load of gas (about 50 percent of the working gas) over a 3-day period, followed by repressurization to $13.8 \mathrm{MPa}$ (2,000 psi) over a 0.75 -day period to represent the gas injection from a single LNG tanker. The second storage scenario consists of withdrawing and injecting the gas from two LNG tankers. In this scenario, the casing seat pressure is reduced from 13.8 $\mathrm{MPa}(2,000 \mathrm{psi})$ to $4.9 \mathrm{MPa}$ (705 psi) to represent the removal of the double-tanker load of gas (the entire working gas) over a 3-day period, followed by repressurization to $13.8 \mathrm{MPa}(2,000 \mathrm{psi})$ over a 1.5-day period to represent the gas injection from two LNG tankers. The pressure cycles for the two gas-storage scenarios are shown in Figure 4-1. The single-tanker scenario was evaluated for gas injection temperatures of $-17.8^{\circ} \mathrm{C}\left(0^{\circ} \mathrm{F}\right)$ and $4.4^{\circ} \mathrm{C}\left(40^{\circ} \mathrm{F}\right)$. The double-tanker scenario was evaluated for gas temperatures of $-17.8^{\circ} \mathrm{C}\left(0^{\circ} \mathrm{F}\right), 4.4^{\circ} \mathrm{C}\left(40^{\circ} \mathrm{F}\right)$, and $43.3^{\circ} \mathrm{C}\left(110^{\circ} \mathrm{F}\right)$.

\subsection{MODEL INITIALIZATION}

The stress and temperature history of the salt surrounding the caverns prior to gas storage was estimated by modeling the leaching and dewatering of the cavern. In the leaching simulation, the cavern was leached for a period of 500 days, assuming a $21^{\circ} \mathrm{C}\left(70^{\circ} \mathrm{F}\right)$ freshwater injection temperature. This was followed by dewatering of the cavern over a period of 100 days using $4.4^{\circ} \mathrm{C}\left(40^{\circ} \mathrm{F}\right)$ gas at a pressure of $10.3 \mathrm{MPa}(1,500 \mathrm{psi})$. The cavern was then filled with $4.4^{\circ} \mathrm{C}\left(40^{\circ} \mathrm{F}\right)$ gas to a pressure of $13.8 \mathrm{MPa}(2,000 \mathrm{psi})$ over a 10 -day period. The stress and temperature distribution at this point was then used as the starting point for all of the modeled storage scenarios. 


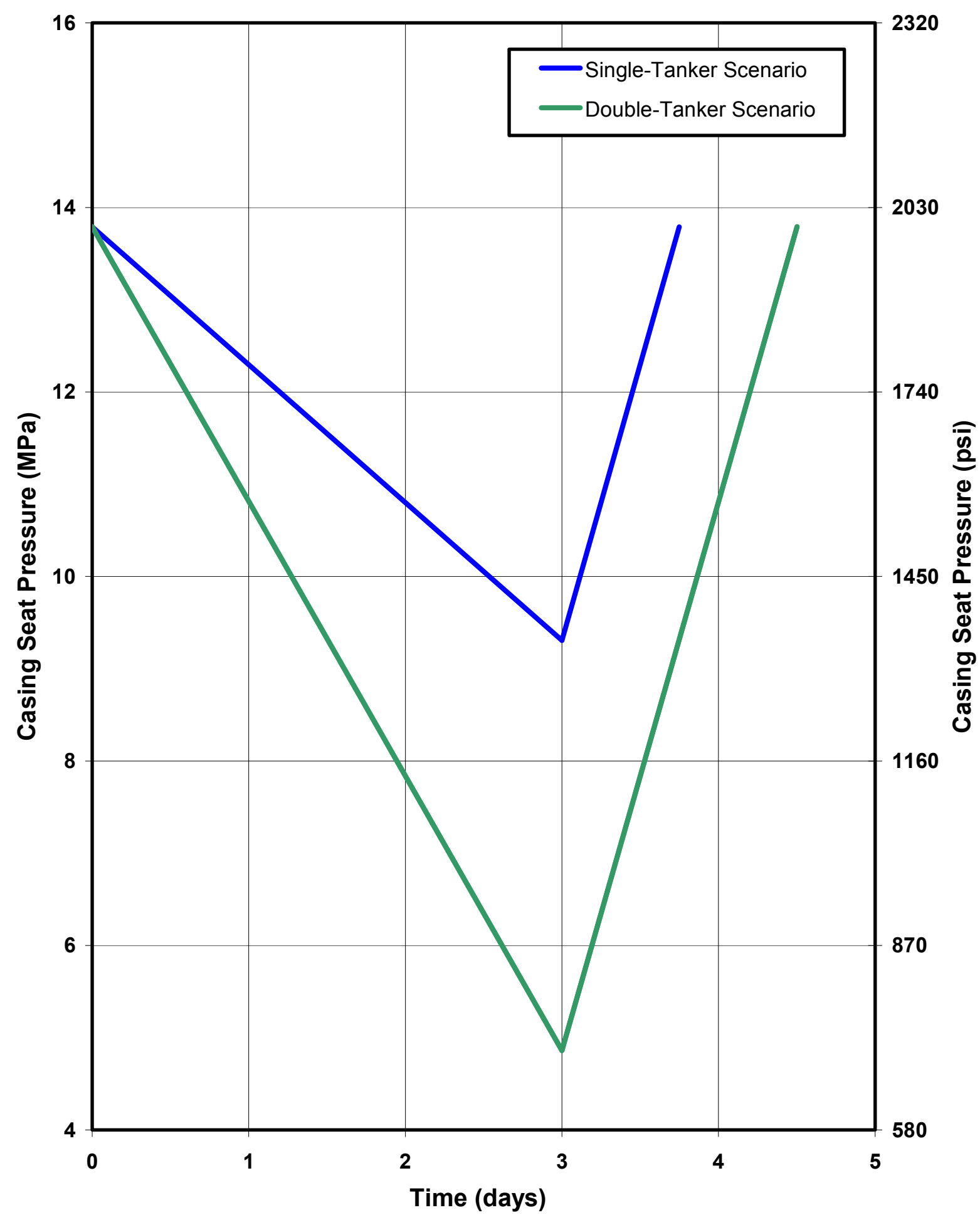

Figure 4-1. M Modeled Gas Storage Cycles. 


\subsection{TEMPERATURE CHANGES DURING GAS STORAGE}

The temperature changes that occur in the salt can have a significant effect on cavern stability. Salt has a very high coefficient of thermal expansion (5-10 times higher than most rock) and thus temperature changes result in stress changes due to the thermal expansion or contraction that occurs. The creep rate of salt is also highly temperature dependent. Since the stress state in the salt is redistributed as it creeps, temperature changes in the salt will affect this stress redistribution process. Because the gas temperature in a cavern changes significantly as it is compressed and decompressed, the simulated gas storage cycles result in both short-term and long-term temperature changes in the salt. The short-term temperature changes in the salt that are the result of gas injection and withdrawal only affect the first couple of meters of salt surrounding the cavern. The long-term temperature changes, that affect a much larger region, are much more gradual.

Figures 4-2 through 4-6 show the predicted temperature distribution in the salt surrounding the cavern at various times for each of the simulated cycles. These figures indicate the longterm temperature changes that occur gradually. For the $-17.8^{\circ} \mathrm{C}$ and $4.4^{\circ} \mathrm{C}\left(0^{\circ} \mathrm{F}\right.$ and $\left.40^{\circ} \mathrm{F}\right)$ gas injection temperatures (both the single-tanker and double-tanker simulations), the salt around the cavern is cooled during the 5-year simulations. In the simulations with a $-17.8^{\circ} \mathrm{C}\left(0^{\circ} \mathrm{F}\right)$ injection temperature, the salt is cooled significantly more than in the simulations with the $4.4^{\circ} \mathrm{C}\left(40^{\circ} \mathrm{F}\right)$ injection temperature. The double-tanker scenario cools the salt only slightly more than the singletanker scenario with the same injection temperature. In the doubletanker simulation with a gas injection temperature of $43.3^{\circ} \mathrm{C}\left(110^{\circ} \mathrm{F}\right)$, the salt around the cavern is heated during the 5-year simulation.

Figure 4-7 shows the temperature distribution around the upper portion of the cavern during the first gas withdrawal in the double-tanker scenarios. This figure indicates the shortterm temperature changes that occur during gas withdrawal. The temperature change at the cavern surface is about $50^{\circ} \mathrm{C}\left(90^{\circ} \mathrm{F}\right)$. Note that the over this 3-day withdrawal period, only a couple of meters of salt around the cavern have a significant change in temperature. Figure 4-8 shows the cavern wall temperature predicted by SCTS for the first 90 days for each of the 5-year simulations. The temperature changes during injection and withdrawal for the singletanker simulations are less than half of those for the double-tanker simulations.

\subsection{CAVERN STABILITY DURING GAS STORAGE SCENARIOS}

In all of the simulations, the least stable conditions occur at the end of gas withdrawal. Thus only results during gas withdrawal are presented in this section. Because the initial stress and temperature conditions are the same for all of the simulations, the results for first withdrawal are exactly the same for both of the single-tanker simulations. Likewise, the results for the first withdrawal of all the double-tanker simulations are exactly the same. 


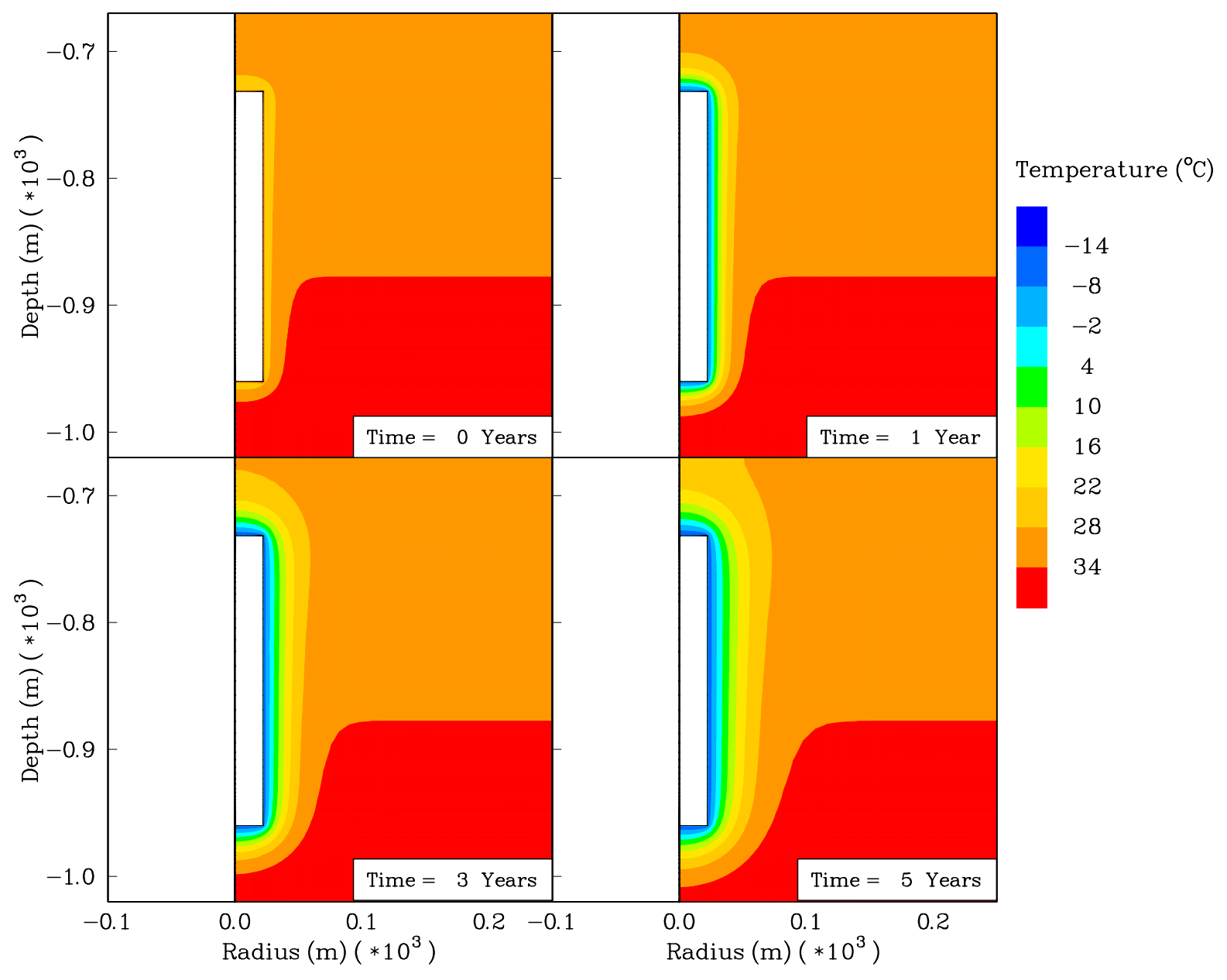

Figure 4-2. Temperature Distributions in Salt for Single-Tanker Scenario With $-17.8^{\circ} \mathrm{C}\left(0^{\circ} \mathrm{F}\right)$ Gas Injection Temperature. 


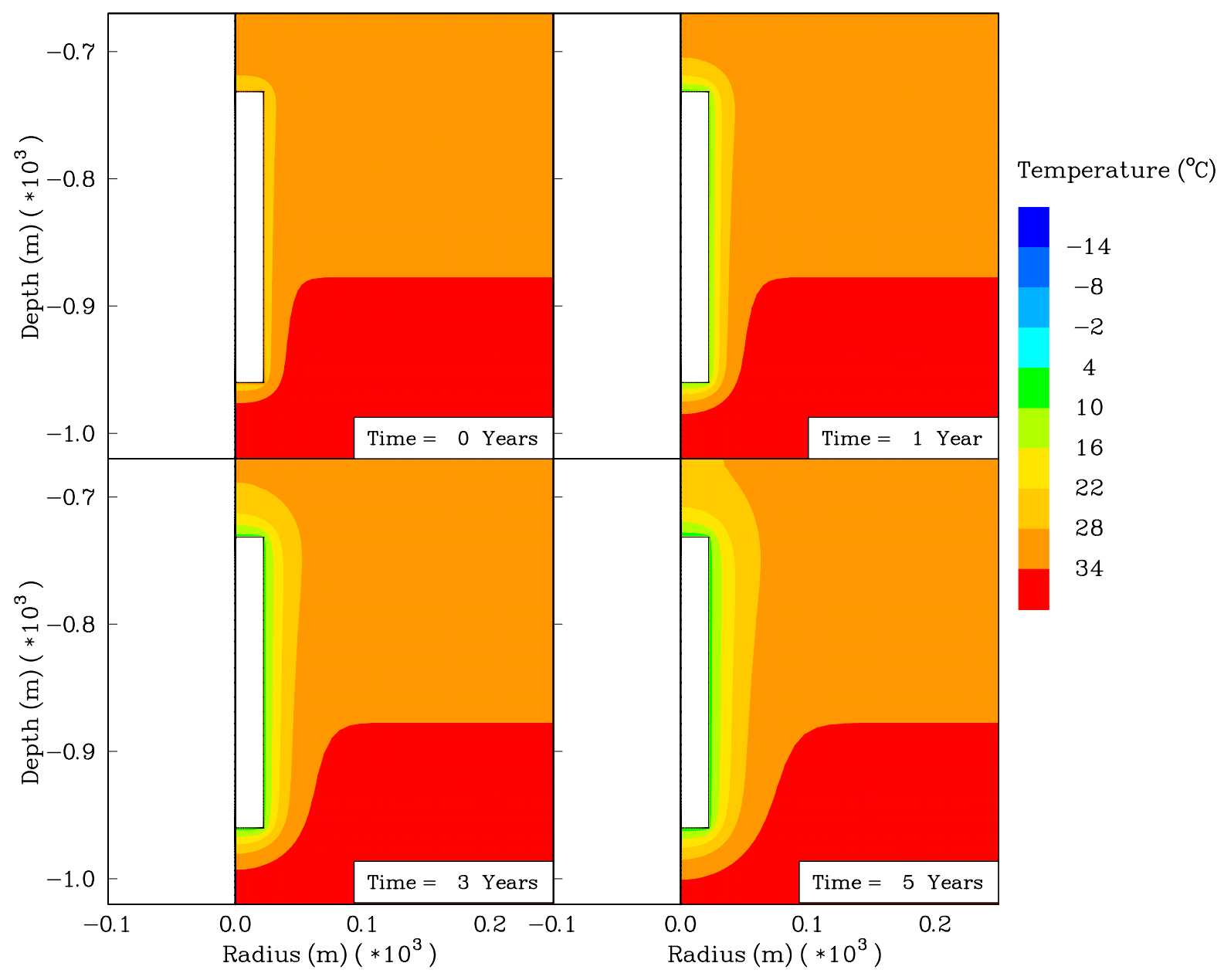

Figure 4-3. Temperature Distributions in Salt for Single-Tanker Scenario With $4.4^{\circ} \mathrm{C}\left(40^{\circ} \mathrm{F}\right)$ Gas Injection Temperature. 


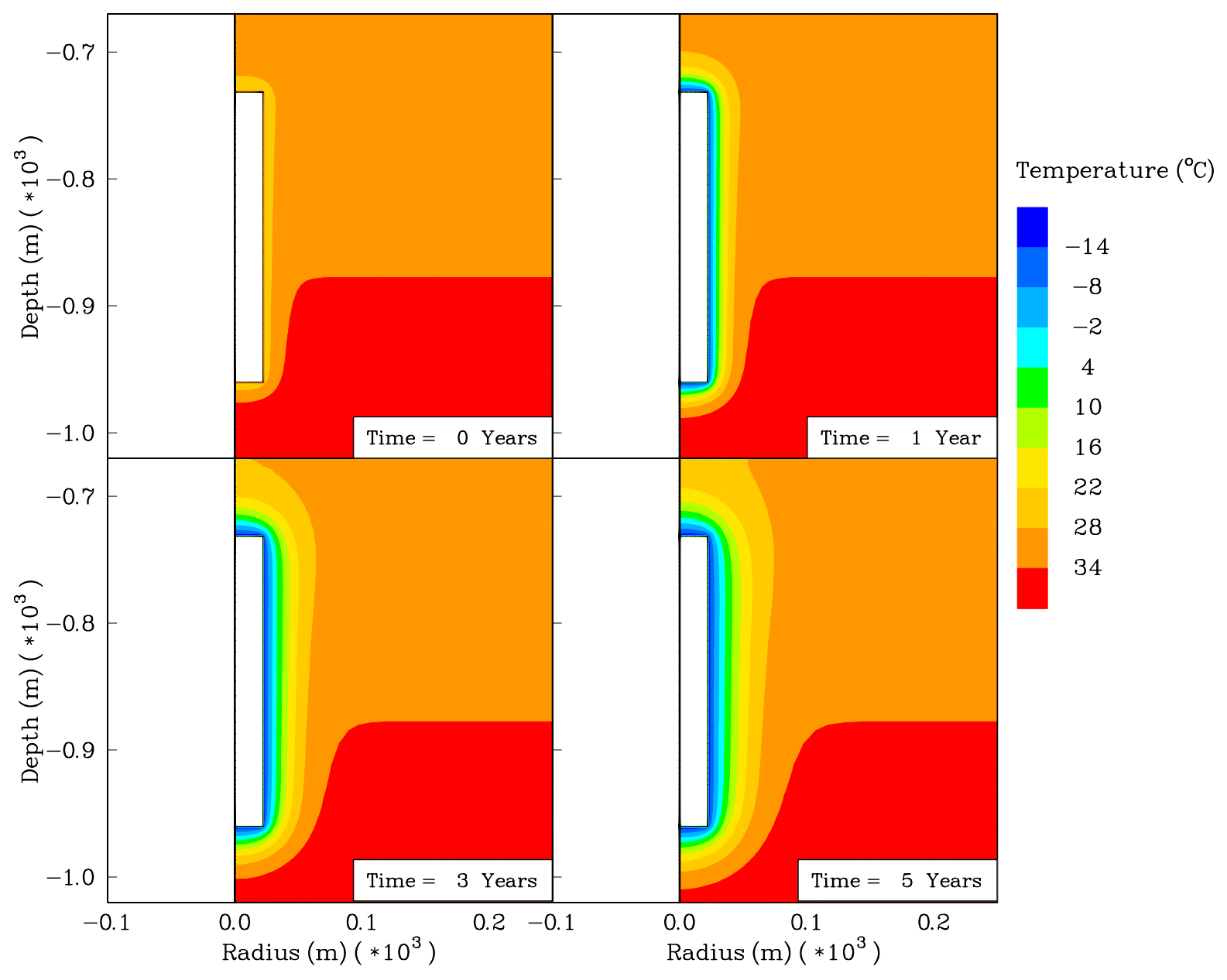

Figure 4-4. Temperature Distributions in Salt for Double-Tanker Scenario With $-17.8^{\circ} \mathrm{C}\left(0^{\circ} \mathrm{F}\right)$ Gas Injection Temperature. 


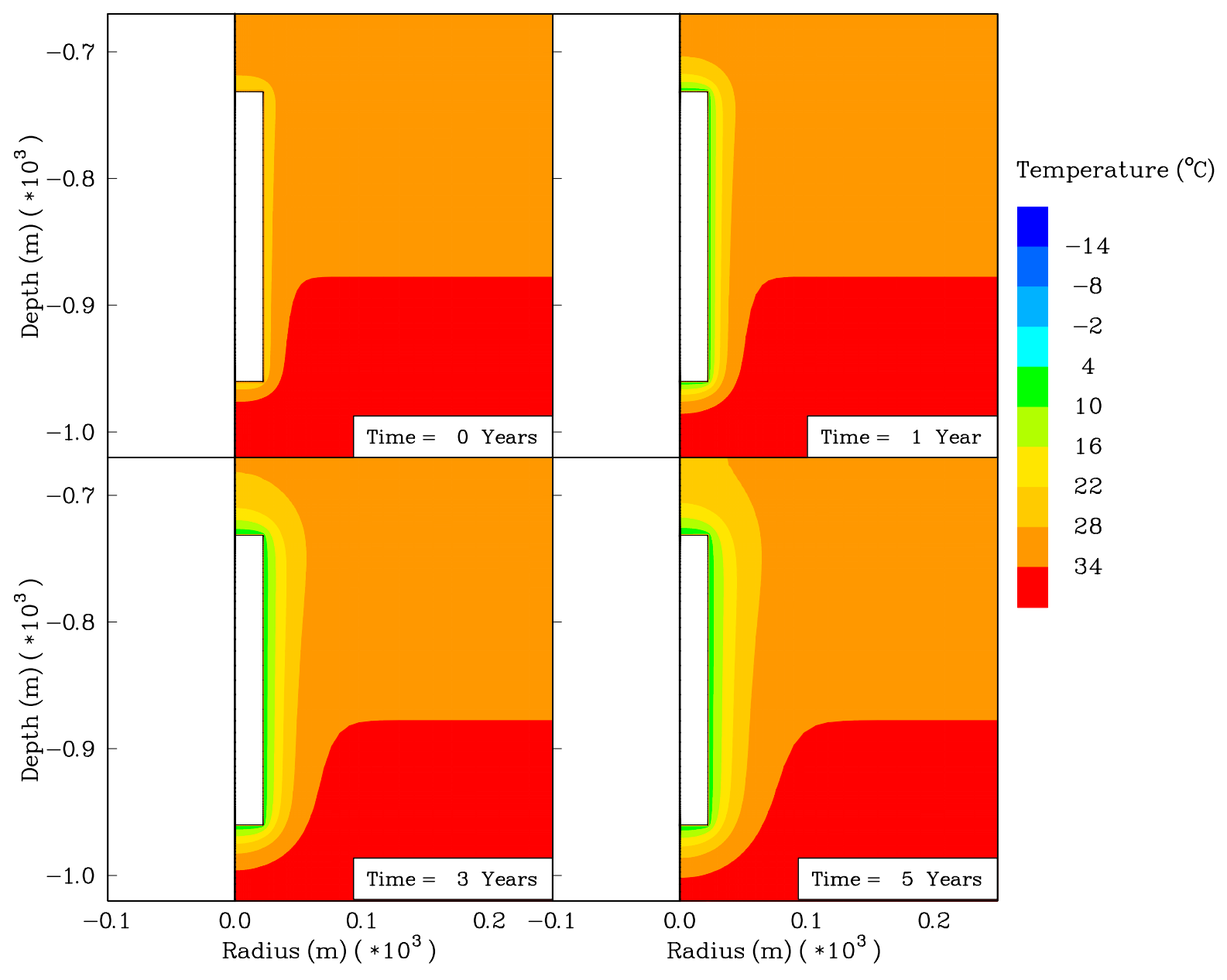

Figure 4-5. Temperature Distributions in Salt for Double-Tanker Scenario With $4.4^{\circ} \mathrm{C}\left(40^{\circ} \mathrm{F}\right)$ Gas Injection Temperature. 


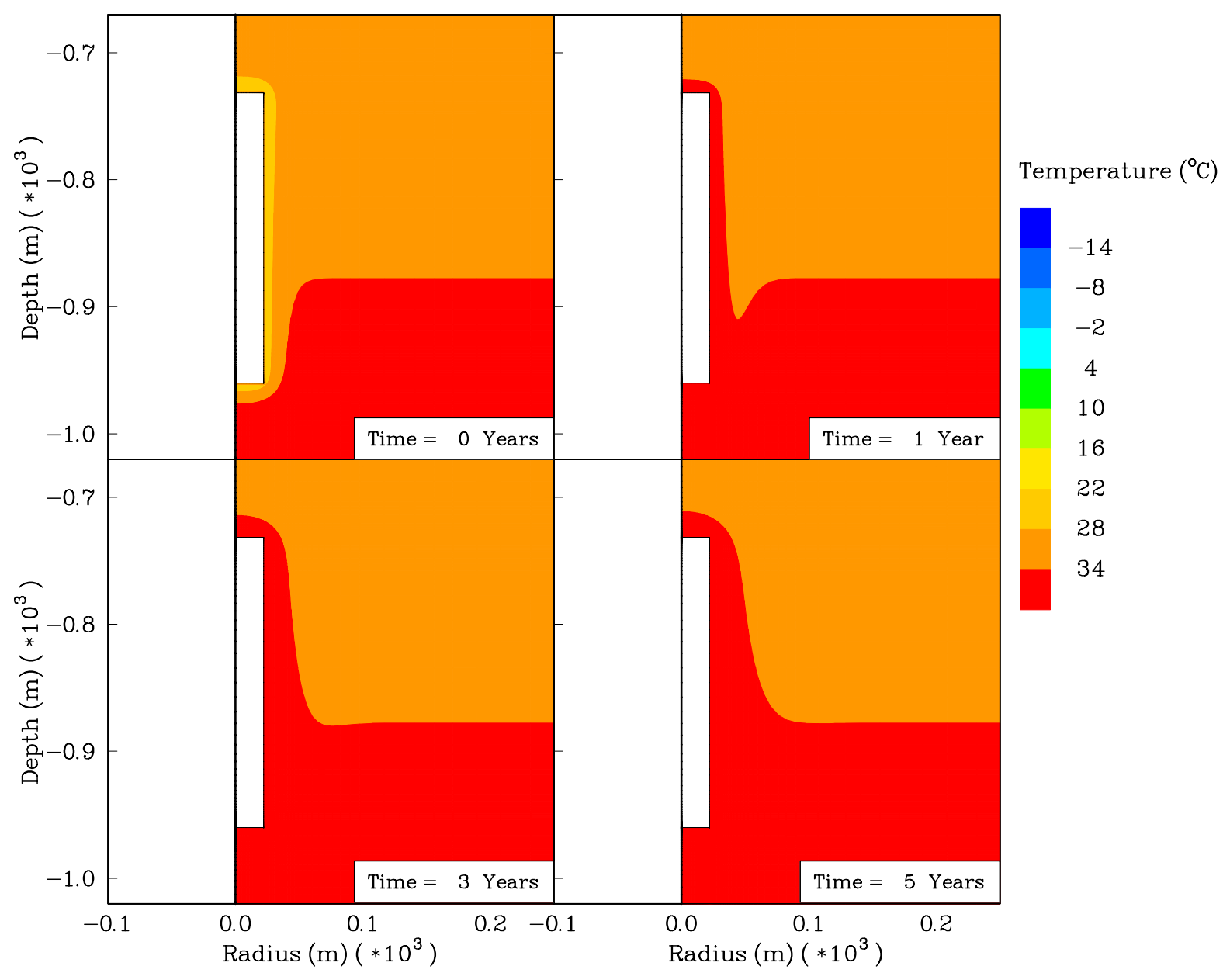

Figure 4-6. Temperature Distributions in Salt for Double-Tanker Scenario With $43.3^{\circ} \mathrm{C}$ $\left(110^{\circ} \mathrm{F}\right)$ Gas Injection Temperature. 
RSI-1399-03-009

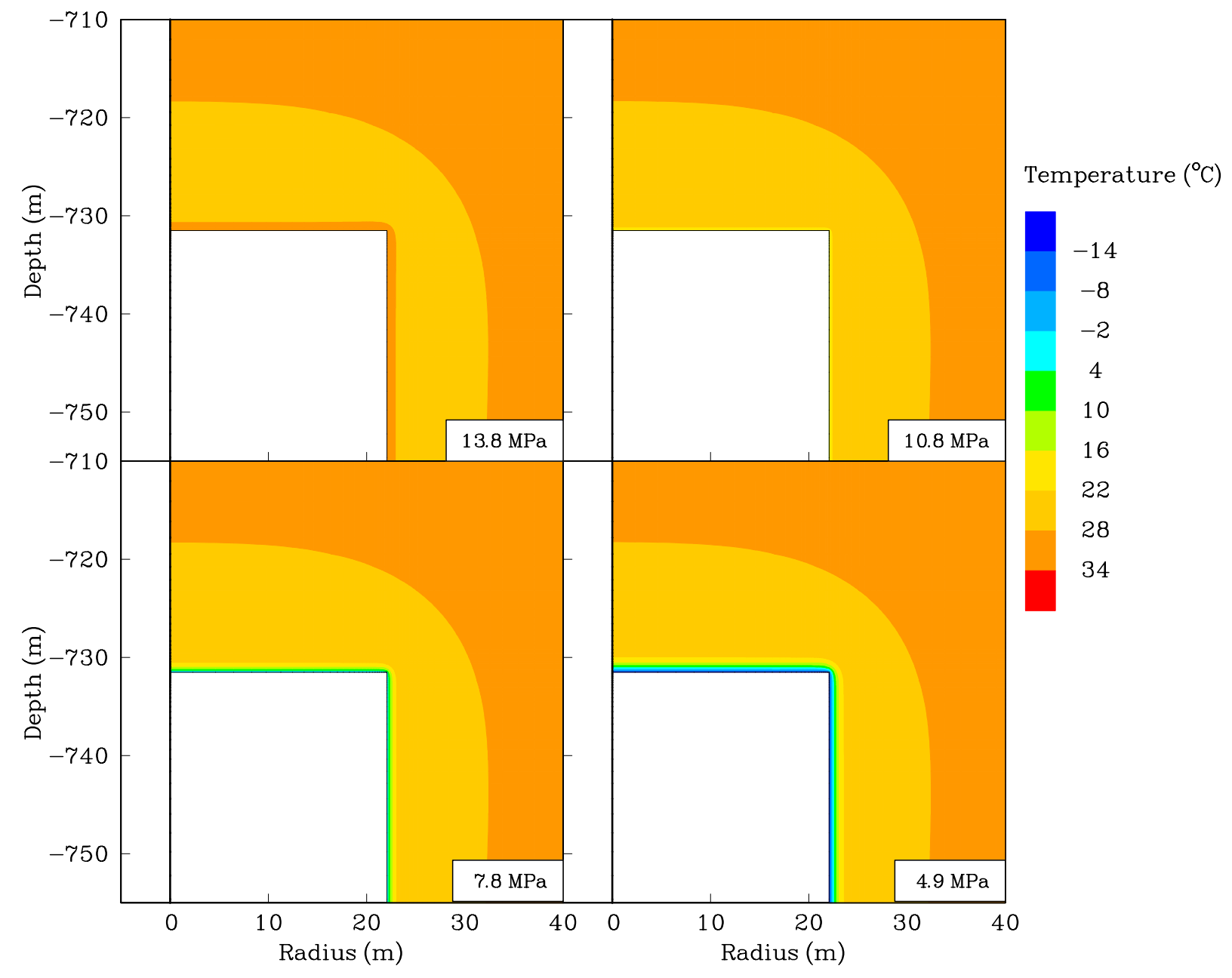

Figure 4-7. Temperature Distributions Around Top of Cavern During First Withdrawal in Double-Tanker Scenarios. 


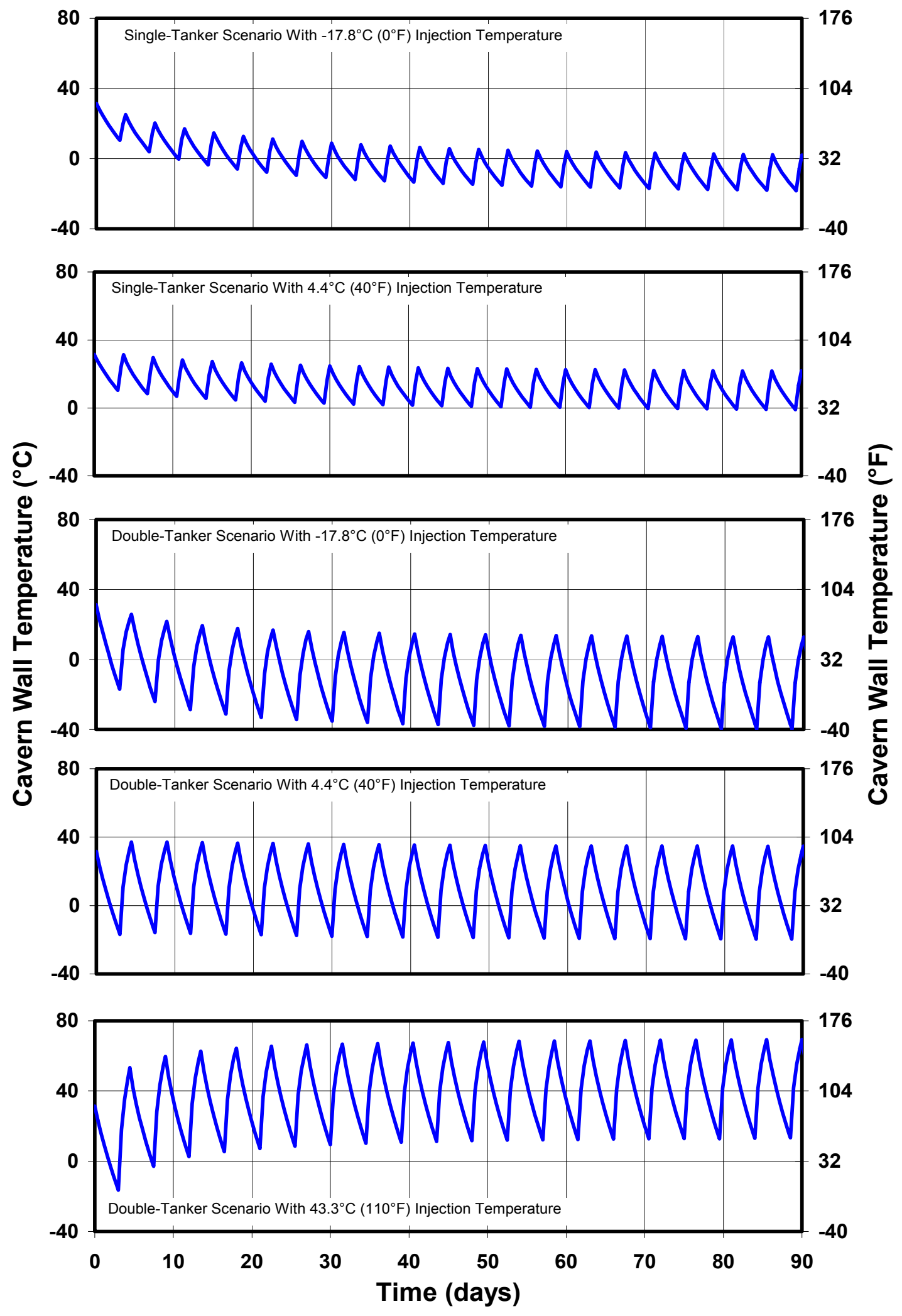

Figure 4-8. Cavern Wall Temperature Versus Time for Various Gas Storage Scenarios. 
Figure 4-9 shows damage potential contours in the salt around the upper portion of the cavern during the first withdrawal for the doubletanker simulations. As shown in this figure, the values of damage potential in the salt increase as the cavern pressure decreases. However, with the exception of the sharp corner between the roof and walls (which is an artifact of the simplified cavern geometry), damage potential values remain significantly below the 0.27 limit. Damage potential contours are not shown in regions that are in tension (note the "uncontoured" region around the cavern periphery at lower pressures) because the damage potential is not meaningful in tensile regions. Throughout all of the 5-year simulations, the damage potential values in the salt remain low.

Figure 4-10 shows maximum principal stress contours in the salt during the first withdrawal for the singletanker simulations. In this case, tensile stresses just start to develop near the end of the 3-day withdrawal. At the end of the 3-day withdrawal, the tensile zone extends about 0.3 meter ( 1 foot) into the salt. Figure 4-11 shows maximum principal stress contours in the salt during the first withdrawal for the double-tanker simulations. In this case, tensile stresses start to devel op in the first day of the 3-day withdrawal period, and by the end of the withdrawal period, the tensile zone extends about 1.5 meters ( 5 feet) into the salt.

Figures 4-12 and 4-13 show maximum principal stress contours in the salt around the top of the cavern during withdrawal after 5 years of cycling for single-tanker simulations with injection temperatures of $-17.8^{\circ} \mathrm{C}\left(0^{\circ} \mathrm{F}\right)$ and $4.4^{\circ} \mathrm{C}\left(40^{\circ} \mathrm{F}\right)$, respectively. Small regions of tensile stresses develop by the end of withdrawal in both cases. Thus the results for both cases after 5 years are very similar to those during the first gas withdrawal.

Figures 4-14, 4-15, and 4-16 show maximum principal stress contours in the salt around the top of the cavern during withdrawal after 5 years of cycling for double-tanker simulations with injection temperatures of $-17.8^{\circ} \mathrm{C}\left(0^{\circ} \mathrm{F}\right), 4.4^{\circ} \mathrm{C}\left(40^{\circ} \mathrm{F}\right)$, and $43.3^{\circ} \mathrm{C}\left(110^{\circ} \mathrm{F}\right)$, respectively. Again, very little difference is seen between the initial withdrawal results (Figure 4-11) and the results after 5 years. Also, the results for the three different injection temperatures are very similar.

All of the simulations indicate that tensile fractures will develop around the cavern periphery. The orientation of the tensile stresses is tangential to the cavern surface and will result in fractures oriented perpendicular to the cavern surface. Since these tensile zones occur only near the cavern surface and are surrounded by highly compressive zones, it is unlikely that fractures would result in catastrophic failure of the cavern nor are they likely to form connections to other caverns or the edge of the salt dome. However, repeated fracturing of the cavern periphery by continuously cycling the gas will result in salt on the roof and sidewalls progressively sloughing off, reducing the life of the cavern. 
RSI-1399-03-011

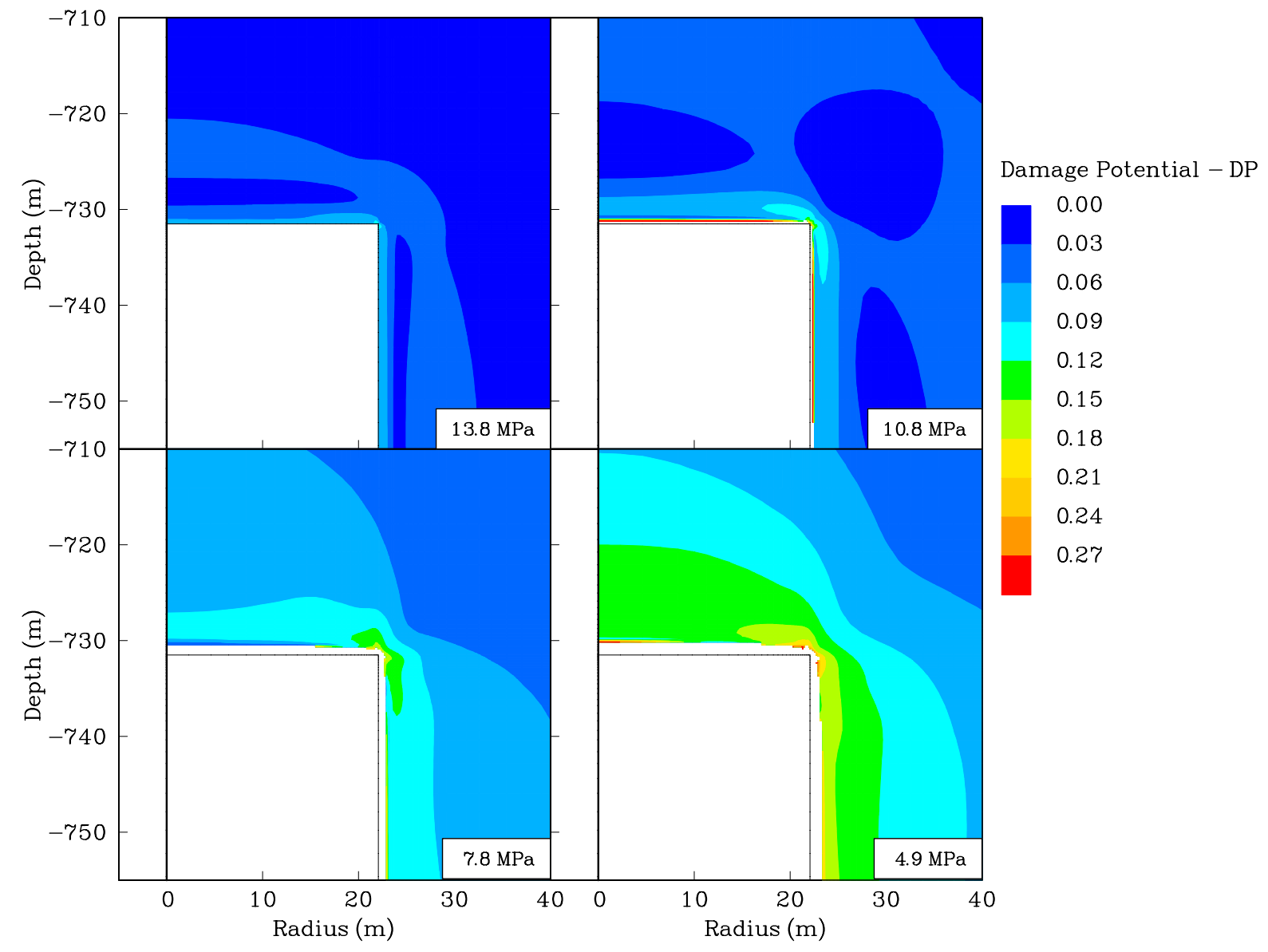

Figure 4-9. Damage Potential Contours Around Top of Cavern During First Withdrawal for Double-Tanker Scenarios. 
RSI-1399-03-012

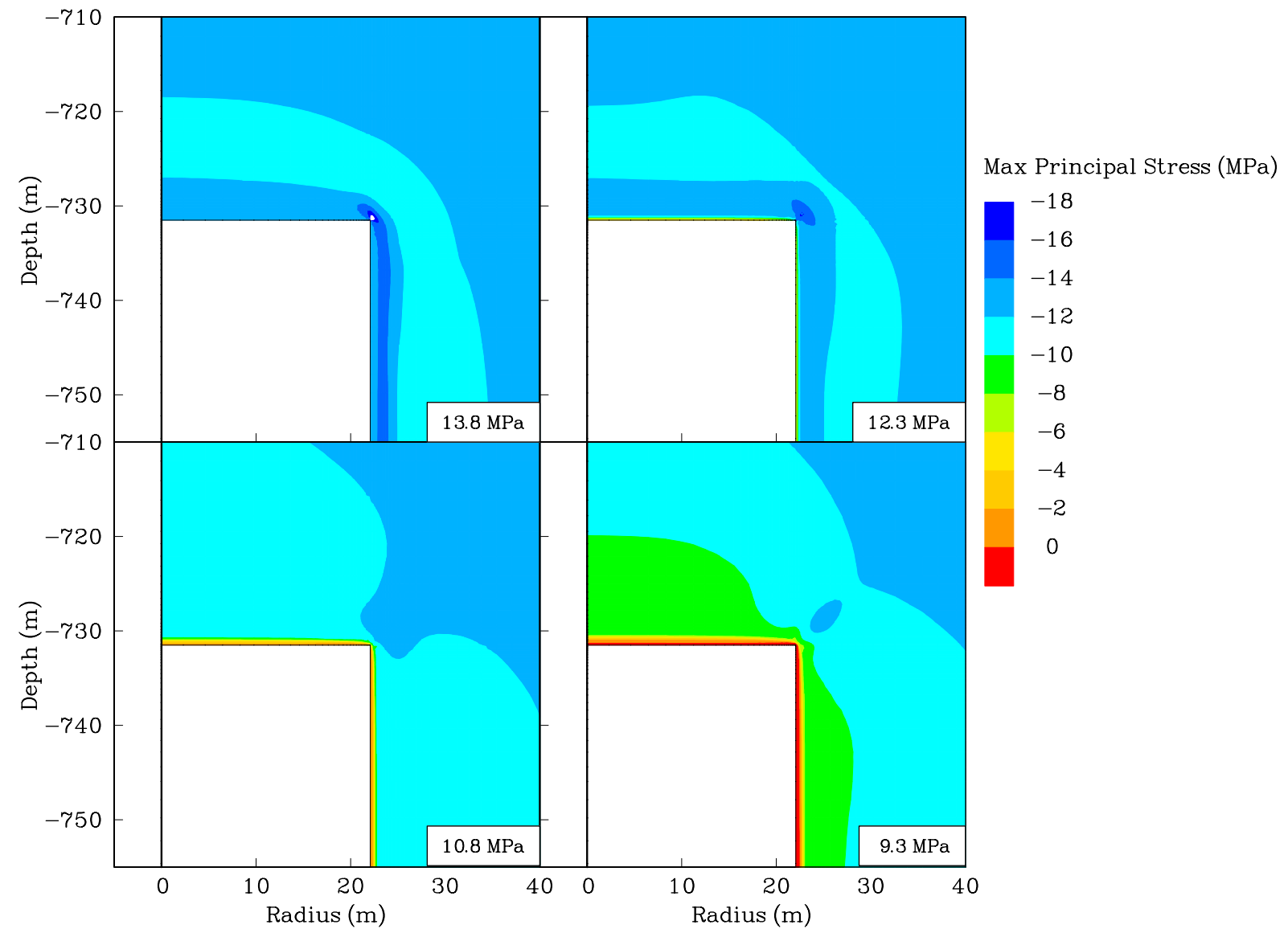

Figure 4-10. Maximum Principal Stress Contours Around Top of Cavern During First 3-Day Withdrawal of Single-Tanker Simulations. 
RSI-1399-03-013

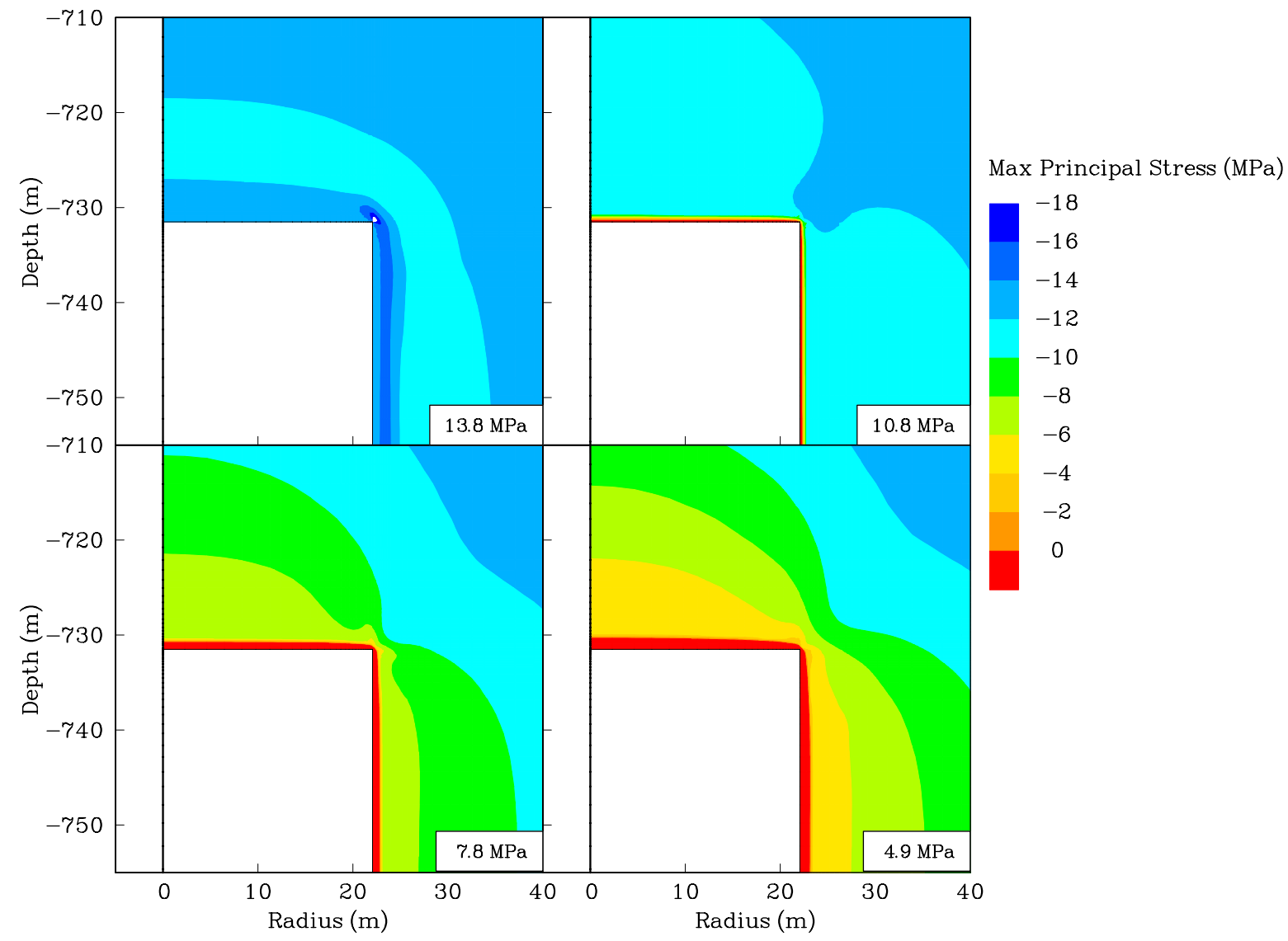

Figure 4-11. Maximum Principal Stress Contours Around Top of Cavern During First 3-Day Withdrawal of Double-Tanker Simulations. 
RSI-1399-03-014

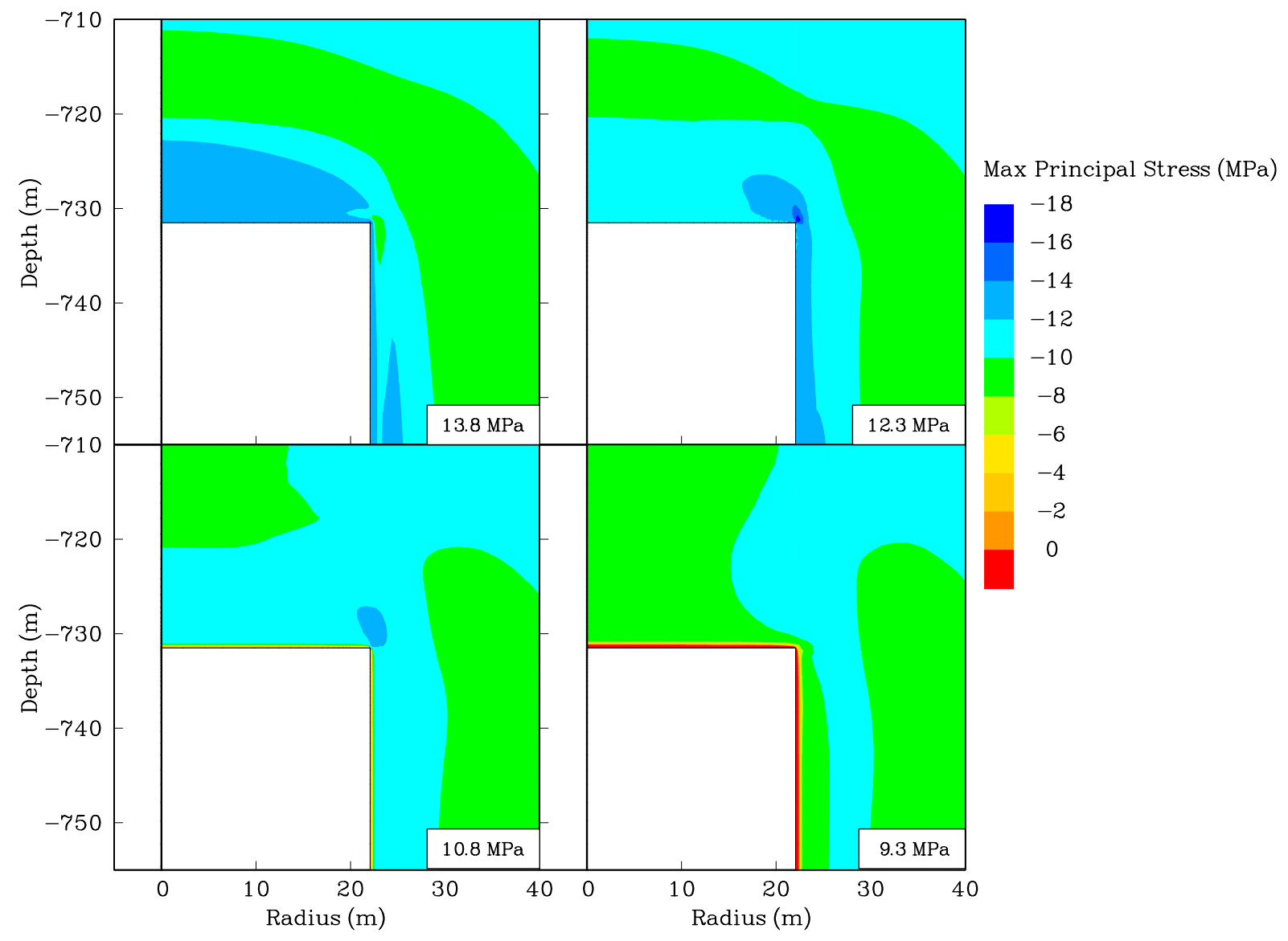

Figure 4-12. Maximum Principal Stress Contours Around Top of Cavern During 3-Day Withdrawal of Single-Tanker Simulation With $-17.8^{\circ} \mathrm{C}\left(0^{\circ} \mathrm{F}\right)$ Injection Temperature After Cycling for 5 Years. 
RSI-1399-03-015

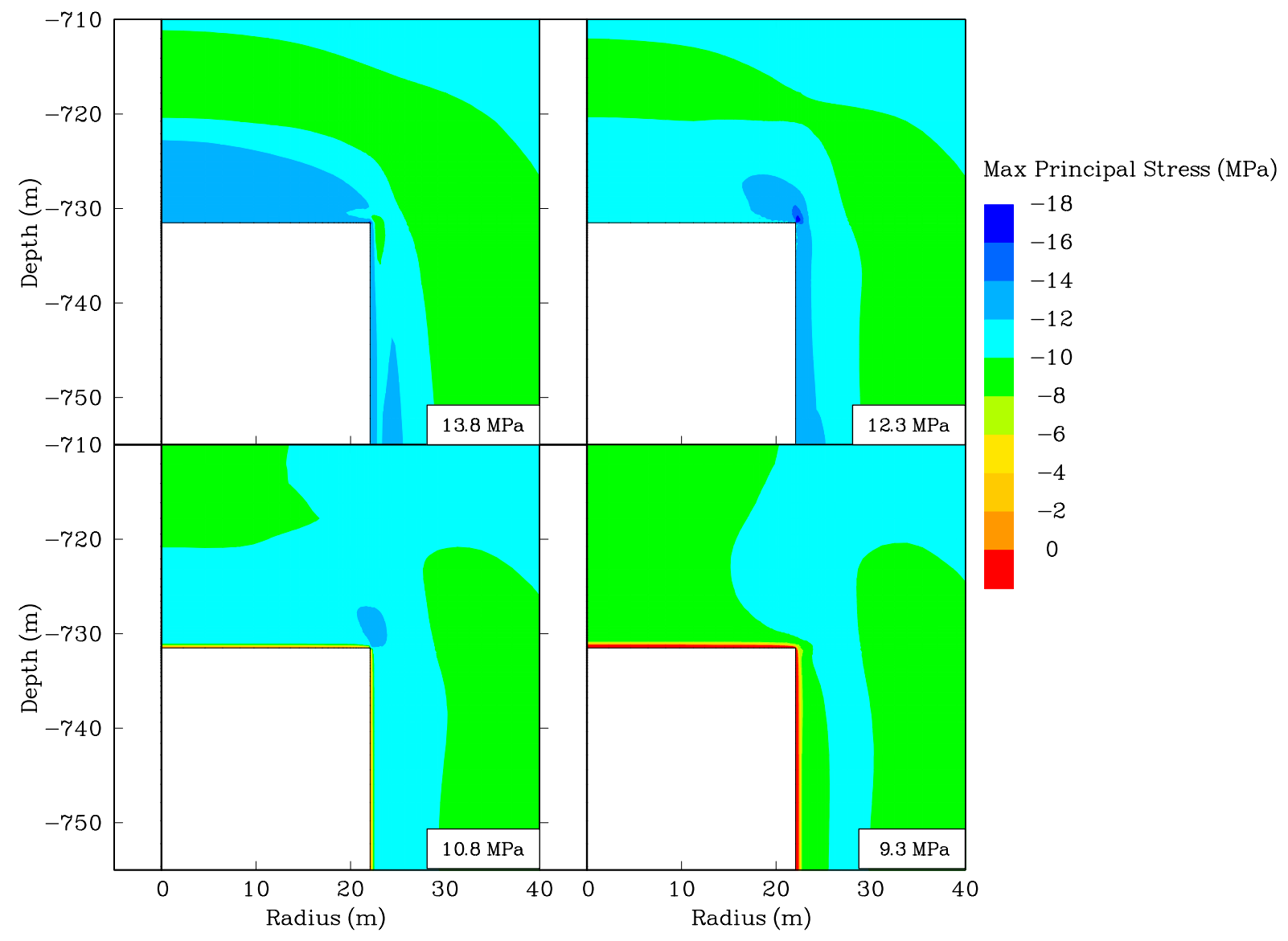

Figure 4-13. Maximum Principal Stress Contours Around Top of Cavern During 3-Day Withdrawal of Single-Tanker Simulation With $4.4^{\circ} \mathrm{C}\left(40^{\circ} \mathrm{F}\right)$ Injection Temperature After Cycling for 5 Years. 


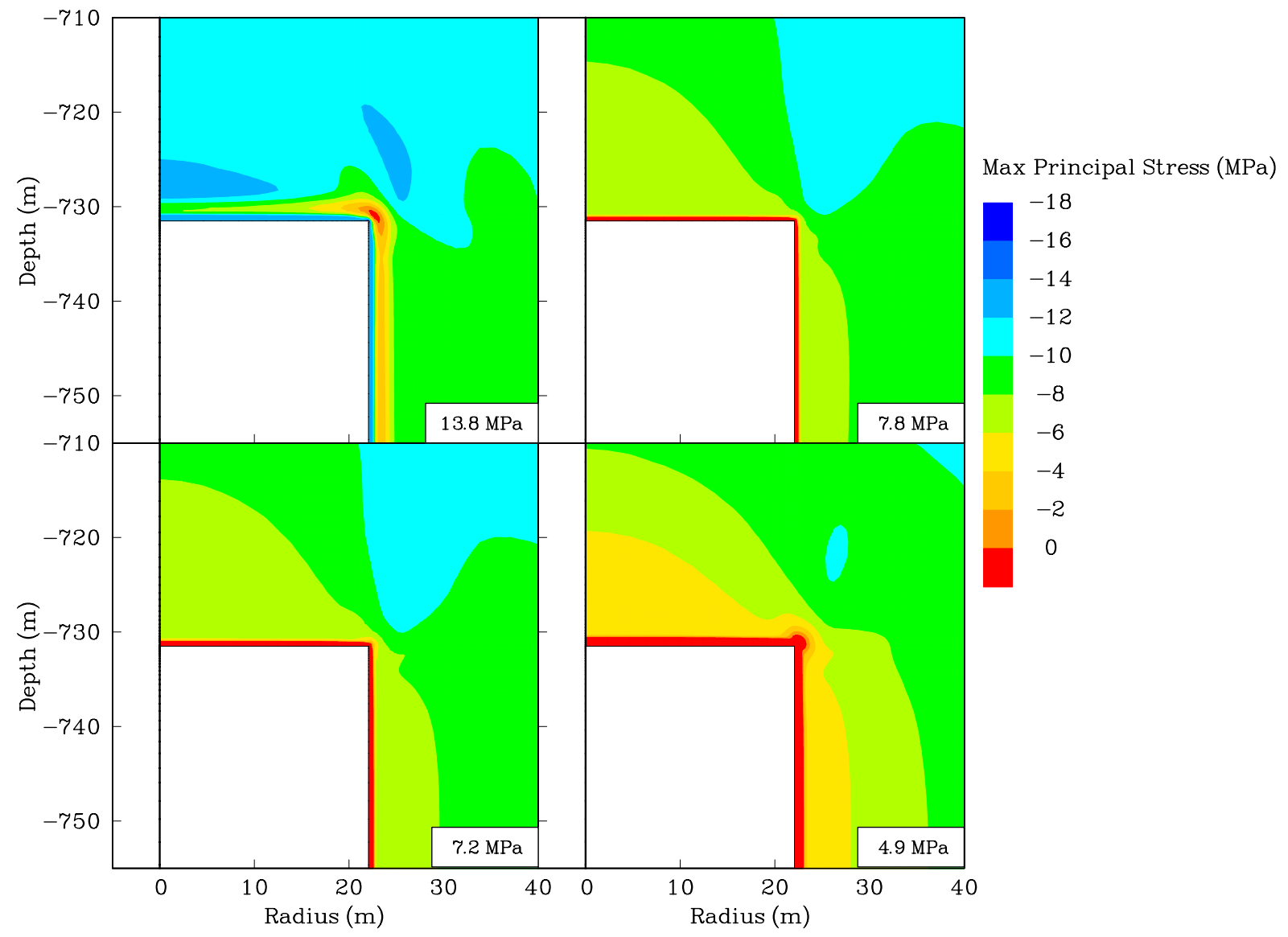

Figure 4-14. Maximum Principal Stress Contours Around Top of Cavern During 3-Day Withdrawal of Double-Tanker Simulations With $-17.8^{\circ} \mathrm{C}\left(0^{\circ} \mathrm{F}\right)$ I njection Temperature After Cycling for 5 Years. 


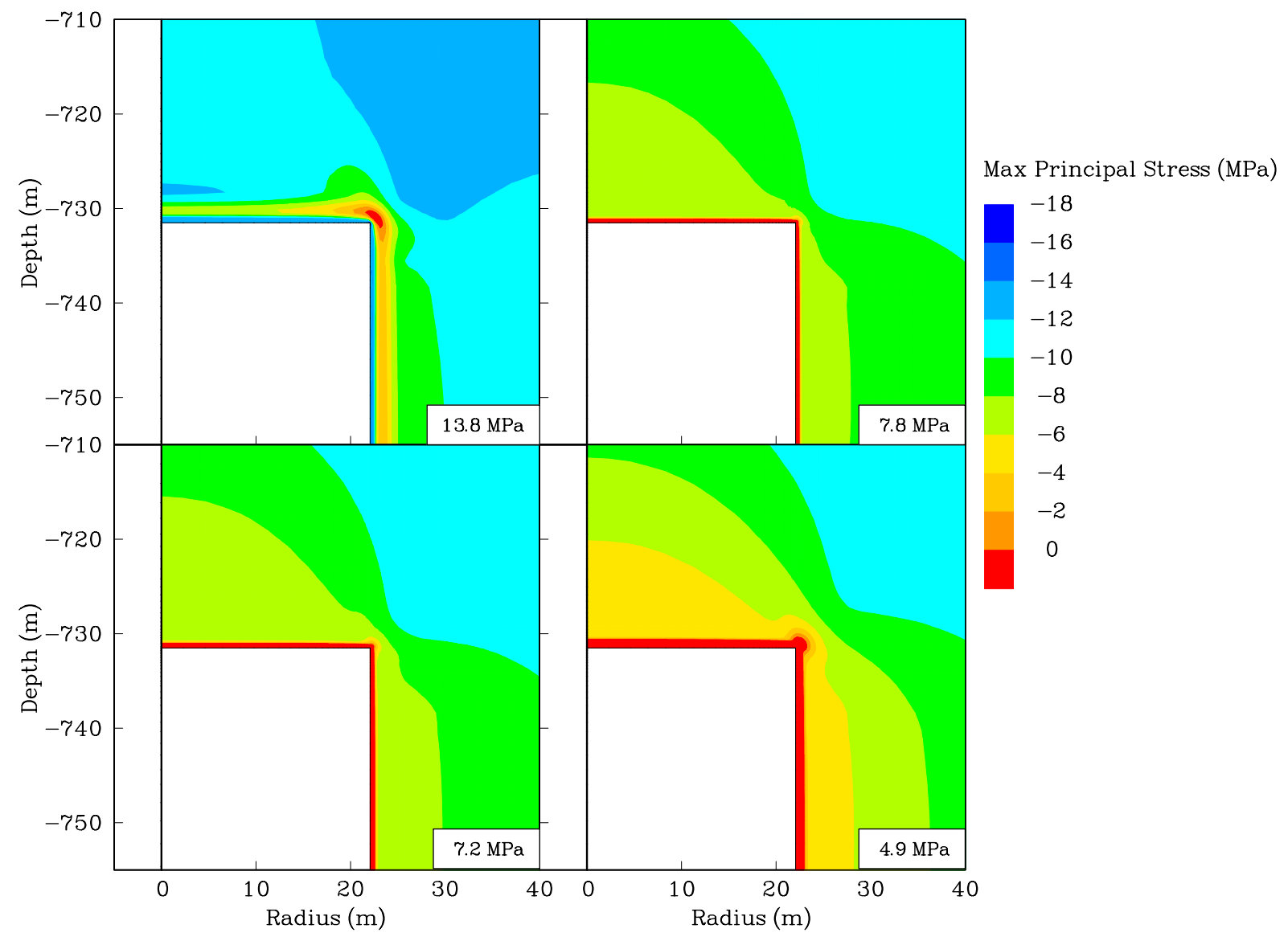

Figure 4-15. Maximum Principal Stress Contours Around Top of Cavern During 3-Day Withdrawal of Double-Tanker Simulation With $4.4^{\circ} \mathrm{C}\left(40^{\circ} \mathrm{F}\right)$ Injection Temperature After Cycling for 5 Years. 


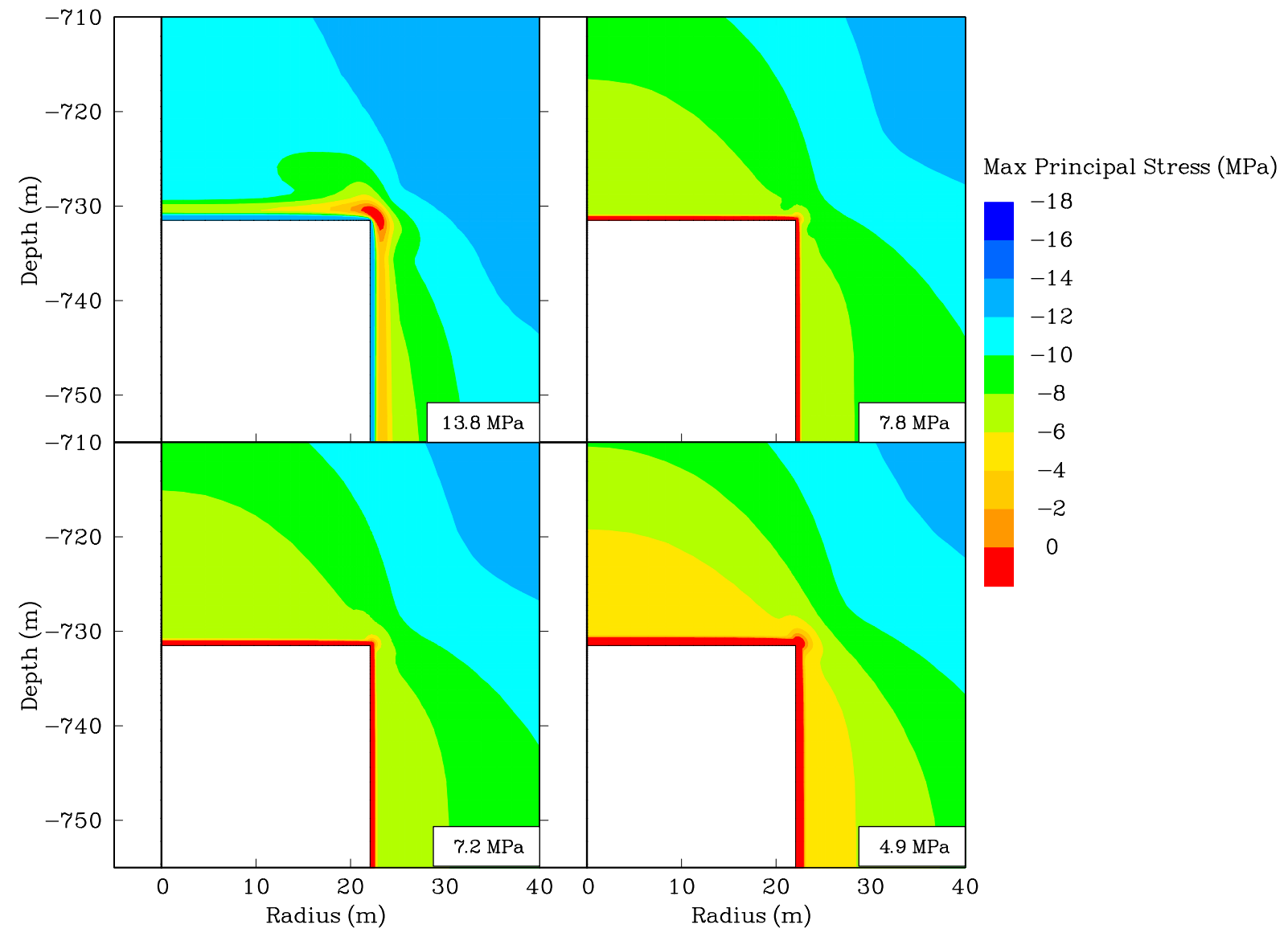

Figure 4-16. Maximum Principal Stress Contours Around Top of Cavern During 3-Day Withdrawal of Double-Tanker Simulation With $43.3^{\circ} \mathrm{C}\left(110^{\circ} \mathrm{F}\right)$ Injection Temperature After Cycling for 5 Years. 


\subsection{EVALUATION OF GAS WITHDRAWAL RATE}

Three simulations were made to investigate the effect of the withdrawal rate on cavern stability. Similar to the double-tanker scenarios, the entire working gas was withdrawn from the cavern. Rather than withdrawing the gas in a 3-day period, 10-day, 20-day, and 30-day withdrawals were simulated. These simulations used the same initial conditions as the previous simulations. Contours of the maximum principal stress around the top of the cavern for these three simulations are shown in Figures 4-17 through 4-19. There is not much difference between the results of the 10-day withdrawal and the original 3-day withdrawal (Figure 4-11). However, during the 20-day withdrawal, the region of tensile stresses that develops is somewhat smaller. Increasing the withdrawal time to 30 days reduces the size of the tensile zone even more. Reducing the withdrawal rate allows more time for heat transfer to take place between the gas and the salt, reducing the thermal gradients that result in thermal contraction in the salt. Also, salt creep has more time to redistribute the stresses in the salt to counteract the thermal contraction that occurs. 
RSI-1399-03-019

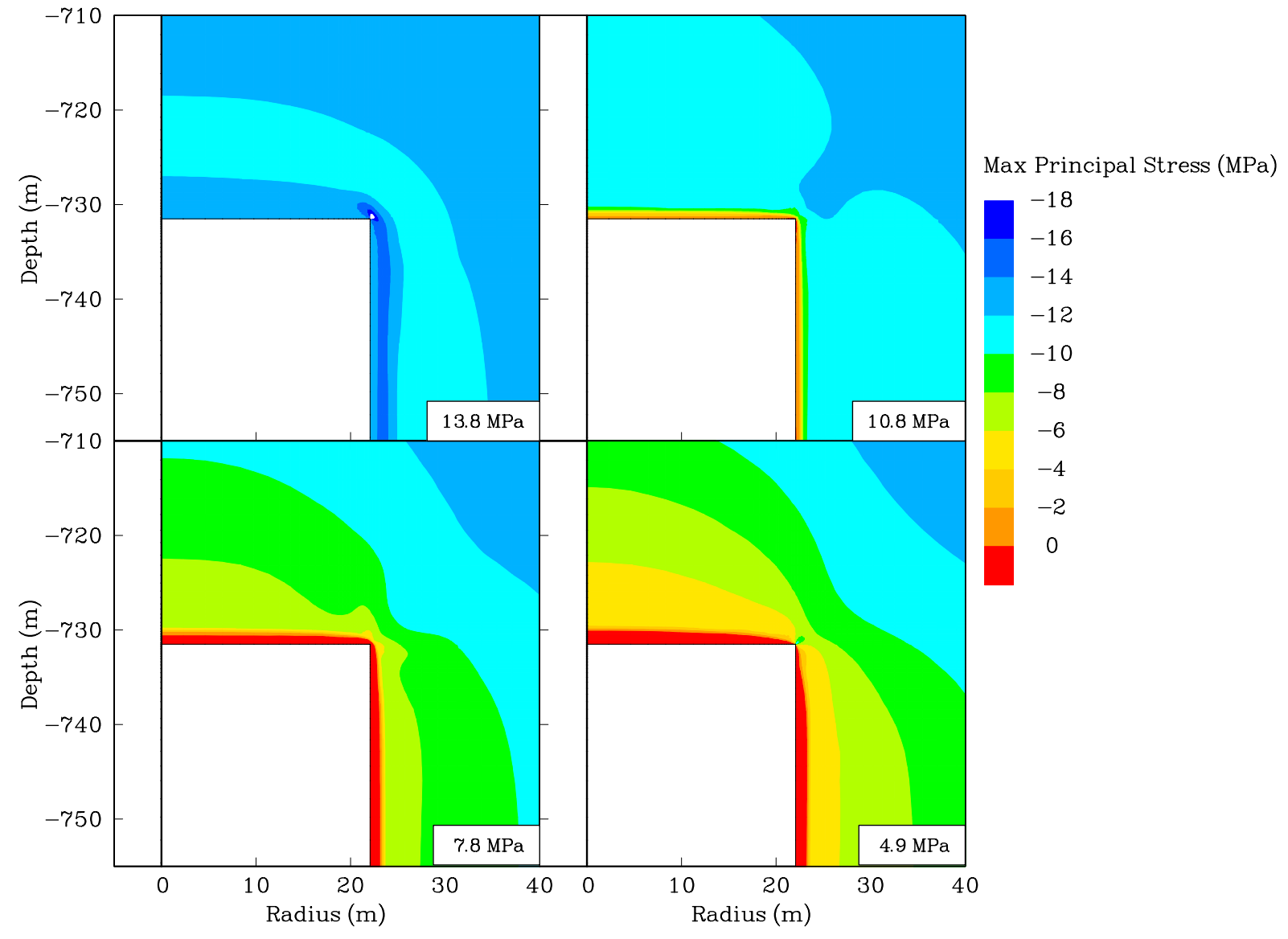

Figure 4-17. Maximum Principal Stress Contours Around Top of Cavern During 10-Day Double-Tanker Withdrawal. 
RSI-1399-03-020

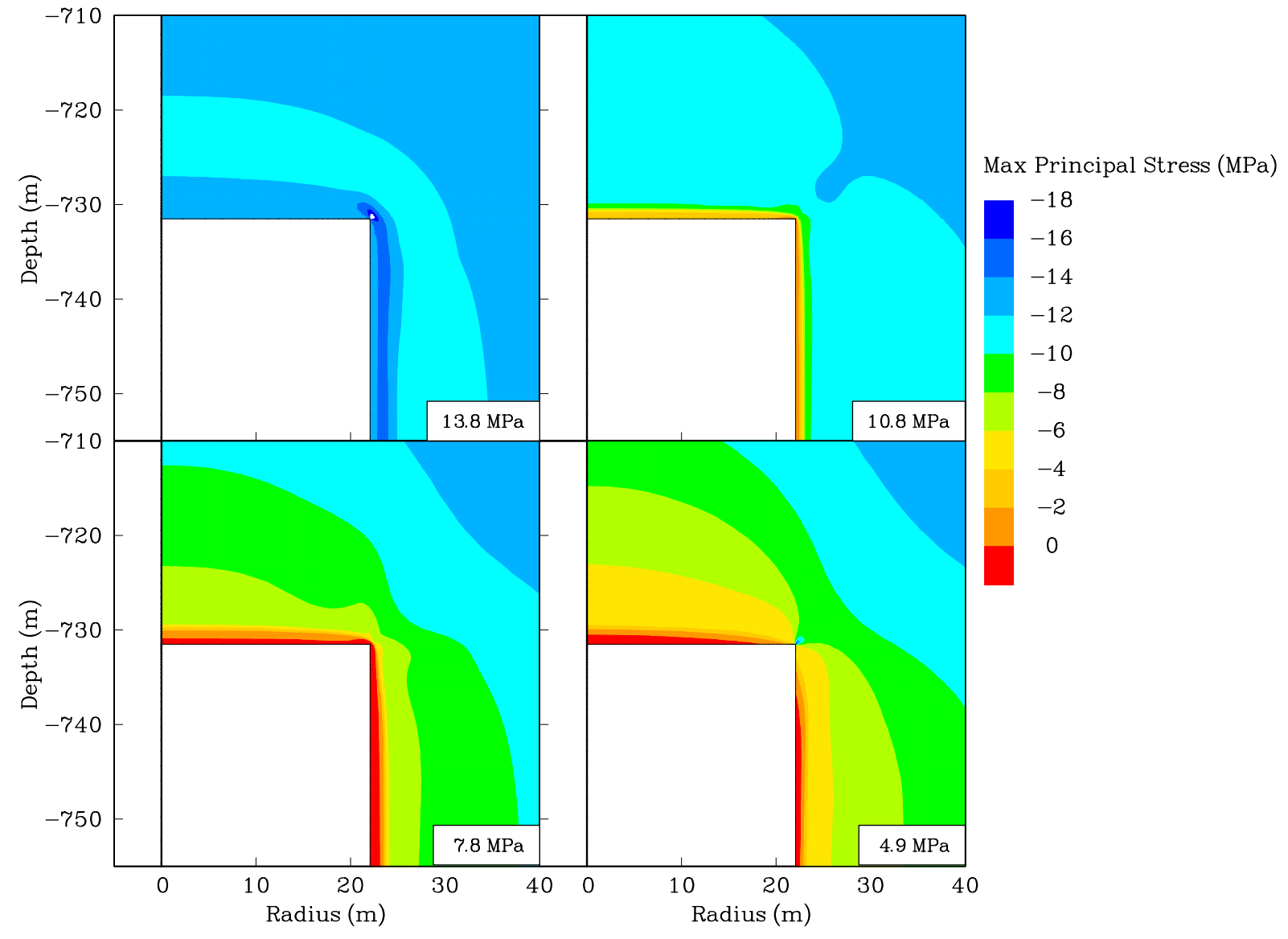

Figure 4-18. Maximum Principal Stress Contours Around Top of Cavern During 20-Day Double-Tanker Withdrawal. 
RSI-1399-03-021

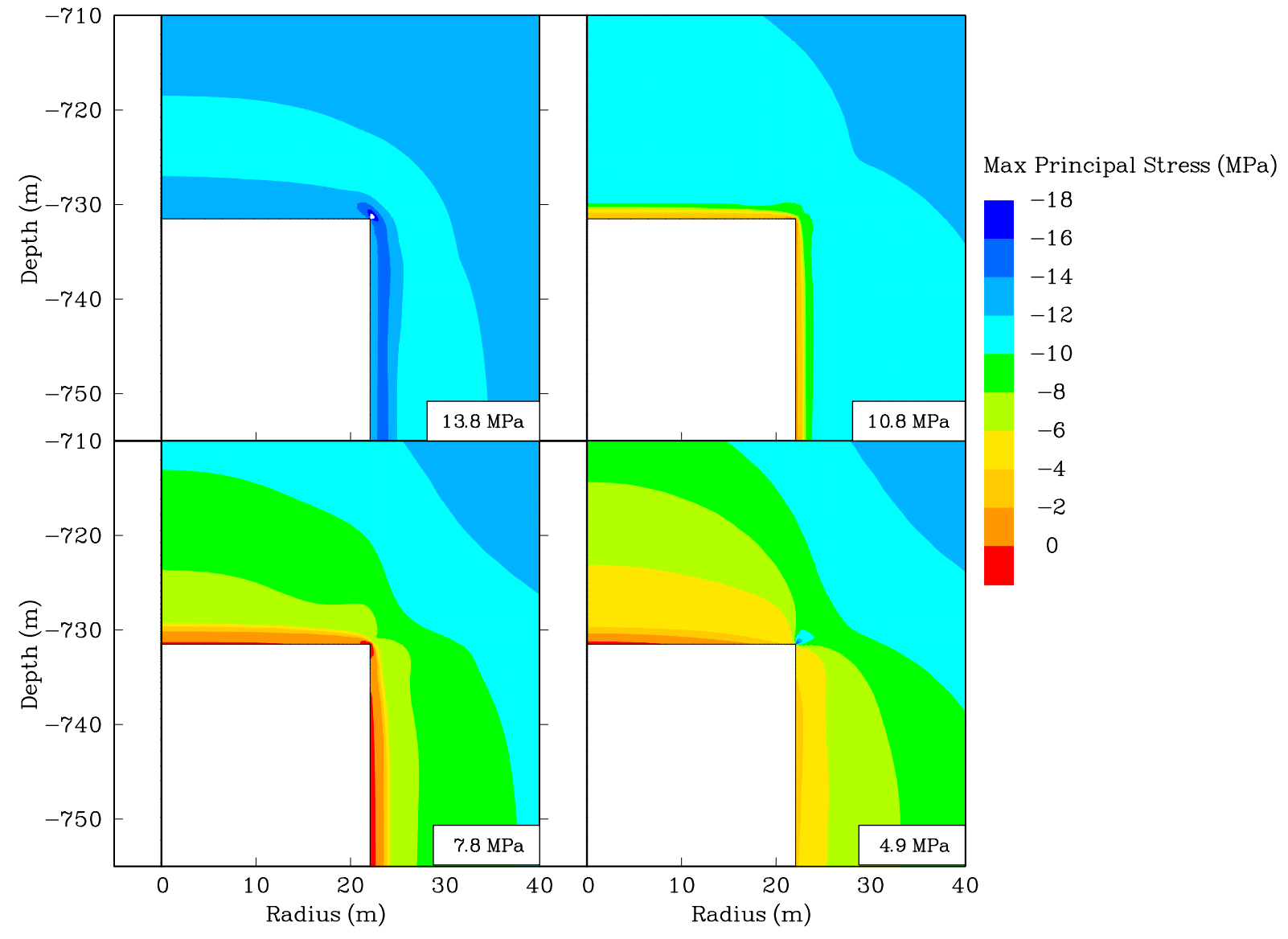

Figure 4-19. Maximum Principal Stress Contours Around Top of Cavern During 30-Day Double-Tanker Withdrawal. 


\subsection{SUMMARY AND CONCLUSIONS}

A geomechanical study was performed to investigate the feasibility of off-loading natural gas from liquefied natural gas (LNG) tankers directly into a salt storage cavern. Because the economics of this process depend on the temperature to which the natural gas must be heated to be safely injected into a storage cavern, several cavern injection temperatures were investigated. The study investigated chilled gas injection temperatures of $-17.8^{\circ} \mathrm{C}\left(0^{\circ} \mathrm{F}\right)$ and $4.4^{\circ} \mathrm{C}\left(40^{\circ} \mathrm{F}\right)$ and also a more conventional gas injection temperature of $43.3^{\circ} \mathrm{C}\left(110^{\circ} \mathrm{F}\right)$.

The six-cavern facility that was investigated was sized to accommodate approximately two LNG tankers of working gas (about $1.9 \times 10^{8} \mathrm{Nm}^{3}$ (7 B ff)). Only one cavern in the facility was modeled. It was assumed that the caverns at the facility would be sufficiently separated so that cavern interactions can be neglected. The study considered a cylindrical cavern located in a salt dome which is typical of conventional natural gas storage caverns. The cavern had a typical working gas pressure range, with a minimum pressure of $0.007 \mathrm{MPa}$ per meter of depth $(0.30$ psi/foot) at the casing shoe and a maximum pressure of $0.019 \mathrm{MPa}$ per meter of depth $(0.85$ psi/foot) at the casing shoe. A casing shoe depth of 716 meters (2,350 feet) was assumed, resulting in a minimum pressure of about $4.9 \mathrm{MPa}$ (705 psi) at the casing shoe and a maximum pressure of about $13.8 \mathrm{MPa}(2,000 \mathrm{psi})$ at the casing shoe. All of the gas storage simulations started at the end of a 20-month cavern development simulation.

The gas storage scenarios evaluated for the LNG off-loading facility cycle the working gas more rapidly than conventional natural gas storage caverns. The single-tanker scenario consists of continuous 3.75-day cycles of approximately 50 percent of the working gas. In each cycle, 50 percent of the working gas was withdrawn over a 3-day period followed by reinjection over a 0.75-day period. This storage scenario was evaluated for gas injection temperatures of $-17.8^{\circ} \mathrm{C}$ $\left(0^{\circ} \mathrm{F}\right)$ and $4.4^{\circ} \mathrm{C}\left(40^{\circ} \mathrm{F}\right)$. The double-tanker scenario consists of continuous 4.5-day cycles of the entire working gas. In each of these cycles, the complete working gas was withdrawn over a 3-day period, followed by reinjection over a period of 1.5 days. This storage scenario was evaluated for gas injection temperatures of $-17.8^{\circ} \mathrm{C}\left(0^{\circ} \mathrm{F}\right), 4.4^{\circ} \mathrm{C}\left(40^{\circ} \mathrm{F}\right)$, and $43.3^{\circ} \mathrm{C}\left(110^{\circ} \mathrm{F}\right)$.

The simulations indicate that the gas injection temperature has very little impact on cavern stability. Over the 5-year storage simulations, the salt around the cavern was cool ed significantly below the initial midheight temperature of $33.1^{\circ} \mathrm{C}\left(91.6^{\circ} \mathrm{F}\right)$ for injection temperatures of $-17.8^{\circ} \mathrm{C}$ $\left(0^{\circ} \mathrm{F}\right)$ and $4.4^{\circ} \mathrm{C}\left(40^{\circ} \mathrm{F}\right)$ and heated slightly above the initial temperature with an injection temperature of $43.3^{\circ} \mathrm{C}\left(110^{\circ} \mathrm{F}\right)$. However, cavern stability after 5 years of storage was similar for all three injection temperatures. This demonstrates the ability of the creep of salt to effectively counteract the thermal stresses that are generated due to the gradual cooling (or heating) of the salt surrounding the cavern. 
High withdrawal rates will result in tensilefracturing of thecavern periphery. Although this is not likely to result in catastrophic failure of the cavern, it will result in salt on the roof and sidewalls progressively sloughing off, reducing the life of the cavern. Tensile zones developed during withdrawal for the simulations with chilled gas injection temperatures, as well as the simulation with the more conventional gas injection temperature of $43.3^{\circ} \mathrm{C}\left(110^{\circ} \mathrm{F}\right)$, because of the large temperature drop that occurs during gas withdrawal. For the single-tanker scenario where 50 percent of the working gas is cycled, the temperature drop in the cavern during 3-day withdrawal was predicted to be about $21^{\circ} \mathrm{C}\left(38^{\circ} \mathrm{F}\right)$. For the doubletanker scenario where 100 percent of the working gas is cycled, the temperature drop in the cavern during 3-day withdrawal was predicted to be about $48^{\circ} \mathrm{C}\left(87^{\circ} \mathrm{F}\right)$.

The extent of tensile fracturing can be alleviated by two methods. First, decreasing the ratio of gas withdrawn to the total working gas was shown to significantly reduce the amount of salt around the cavern that experiences tensile stresses. Secondly, decreasing the withdrawal rate reduces the temperature swings by all owing more time for heat transfer to take place between the cavern and surrounding salt and also allows more time for salt creep to counteract the thermal stresses that do occur. This was demonstrated by the 10-, 20-, and 30-day withdrawal simulations.

The off-loading of chilled natural gas directly into salt cavern appears to be feasible. However, the development of tensile fracturing is generally not permitted in the design of conventional storage caverns. If tensile fracturing is to be permitted, its implications with respect to cavern life must be investigated further. Also, the evaluated storage scenarios repeatedly cycle the cavern over its operating pressure range at a very high frequency (81 times per year for the double-tanker storage scenario). This cycling frequency also is not typical in conventional natural gas storage caverns and warrants an investigation of salt fatigue.

Although this study indicates that the off-loading of chilled natural gas is feasible, the study is generic and actual gas storage facilities would require site and design-specific analyses. Salt properties, including creep, damage, and in situ temperatures, are known to vary significantly from site to site. Cavern design parameters, such as geometry and depth, also vary significantly among storage facilities. 


\subsection{REFERENCES}

Bishop W., 2002. Personal electronic communication between J . D. Nieland, RESPEC, Rapid City, SD, and W. Bishop, Conversion Gas I mports, Houston, TX, November 7.

Callahan, G. D., A. F. Fossum, and D. K. Svalstad, 1989. Documentation of SPECTROM32: A Finite Element Thermomechanical Stress Analysis Program, DOE/CH/10378-2, prepared by RE/SPEC Inc., Rapid City, SD, for the U. S. Department of Energy, Chicago Operations Office, Argonne, IL, Vol. I and II.

Dahlstrom, D. J ., 1988. Thermal Properties Measurements of Avery I sland Salt Core, RSI-0334, prepared by RE/SPEC Inc., Rapid City, SD, for Stone \& Webster Engineering Corporation, Boston, MA.

DeVries, K. L., 1988. Viscoplastic Laws for Avery I sland Salt, RSI-0333, prepared by RE/SPEC Inc., Rapid City, SD, for Stone \& Webster Engineering Corporation, Boston, MA.

Hansen, F. D. and N. L. Carter, 1984. "Creep of Avery I sland Rock Salt," Proceedings of the First Conference on the Mechanical Behavior of Salt, University Park, Pennsylvania, November 1981, pp. 71-83.

Nieland, J . D., 2002. Salt Cavern Thermal Simulator Version 1.5 User's Manual, Revision 1, RSI-1650, prepared by RESPEC, Rapid City, SD, for Gas Technology Institute, Chicago, IL.

Nieland, J . D., K. D. Mellegard, R. S. Schalge, and H. D. Kaiser, 2001. Storage of Chilled Natural Gas in Bedded Salt Storage Caverns, Revision I, RSI-1354, prepared by RESPEC, Rapid City, SD; Sofregaz US Inc., Houston, TX; and IDS Engineering, Houston, TX; for the United States Department of Energy, National Energy Technology Laboratory, Morgantown, WV.

Pfeifle, T. W., T. J . Vogt, and G. A. Brekken, 1995. Correlation of Chemical, Mineralogic, and Physical Characteristics of Gulf Coast Dome Salt to Deformation and Strength Properties, Research Project Report No. 94-0004-S, prepared by RE/SPEC Inc., Rapid City, SD, for the Solution Mining Research Institute Inc., Woodstock, I L.

Senseny, P. E., F. D. Hansen, J . E. Russell, N. L. Carter, and J . W. Handin, 1992. "Mechanical Behaviour of Rock Salt: Phenomenology and Micromechanisms," International J ournal of Rock Mechanics and Mining Sciences \& Geomechanics Abstracts, Vol. 29, No. 4, pp. 363-378. 
Starling, K. E. and J . L. Savidge, 1994. Compressibility of Natural Gas and Other Related Hydrocarbon Gases, Report No. 8, $2^{\text {nd }}$ Edition, Catalog No. XQ9212, prepared for American Gas Association.

Svalstad, D. K., 1989. Documentation of SPECTROM-41: A Finite Element Heat Transfer Analysis Program, DOE/CH/10378-1, prepared by RE/SPEC Inc., Rapid City, SD, for the U.S. Department of Energy, Chicago Operations Office, Argonne, IL.

Van Sambeek, L. L., J . L. Ratigan, and F. D. Hansen, 1993. "Dilatancy of Rock Salt in Laboratory Tests," Proceedings, 34th U.S. Symposium on Rock Mechanics, University of Wisconsin-Madison, Madison, WI, J une 27-30, B. C. Haimson (ed.), International J ournal of Rock Mechanics and Mining Sciences \& Geomechanics Abstracts, Pergamon Press, Vol. 30, No. 7, pp. 735-738. 


\begin{tabular}{|l|l|l|l|}
\hline Customer: & $\begin{array}{l}\text { The United States Department of Energy } \\
\text { National Energy Technology Laboratory }\end{array}$ & $\begin{array}{l}\text { Date of Issue: } \\
24 \text { April } 2003\end{array}$ & \\
\hline $\begin{array}{l}\text { Document } \\
\text { Title: }\end{array}$ & Report II: “Conceptual Design of a Salt Cavern Based LNG Terminal” & $\begin{array}{l}\text { Doc \# \& Version: } \\
\text { Doc } 06 \text { r1.0 }\end{array}$ & Page 1 of 13 \\
\hline
\end{tabular}

\title{
Conceptual Design of a Salt Cavern Based lng Terminal
}

\author{
BY \\ Michael M. McCaLl \\ WiLliam M. BISHOP \\ D. BRAXTON SCHERZ
}

\begin{tabular}{|c|c|c|c|c|c|c|c|c|}
\hline r 1.0 & For client review & $24 / 04 / 03$ & BS & MM & & & & \\
\hline Version & Reason for Issue & $\begin{array}{l}\text { Issue } \\
\text { Date }\end{array}$ & Orig. & $\begin{array}{l}\text { Chk. } \\
\text { CGI }\end{array}$ & Appr. & $\begin{array}{l}\text { Chk. } \\
\text { NE }\end{array}$ & $\begin{array}{l}\text { Appr. } \\
\text { TL }\end{array}$ & Review \\
\hline \multicolumn{2}{|c|}{$\begin{array}{l}\text { Document Title: } \\
\text { Conceptual Design of a Salt Cavern LNG } \\
\text { Terminal }\end{array}$} & \multicolumn{7}{|c|}{ Document No: } \\
\hline
\end{tabular}




\begin{tabular}{|l|l|l|l|}
\hline Customer: & $\begin{array}{l}\text { The United States Department of Energy } \\
\text { National Energy Technology Laboratory }\end{array}$ & $\begin{array}{l}\text { Date of Issue: } \\
24 \text { April } 2003\end{array}$ & \\
\hline $\begin{array}{l}\text { Document } \\
\text { Title: }\end{array}$ & Report II: “Conceptual Design of a Salt Cavern Based LNG Terminal” & $\begin{array}{l}\text { Doc \# \& Version: } \\
\text { Doc 06 r1.0 }\end{array}$ & Page 2 of 13 \\
\hline
\end{tabular}

\section{TABLE OF CONTENTS}

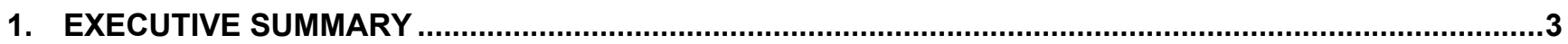

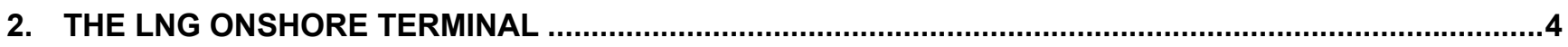

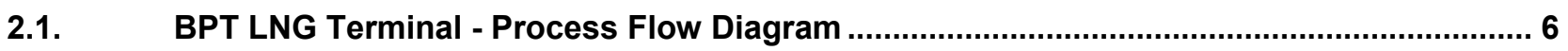

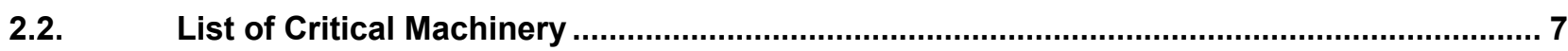

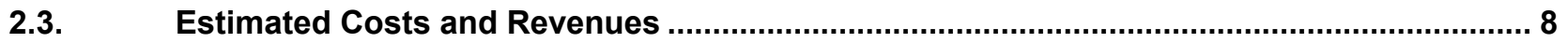

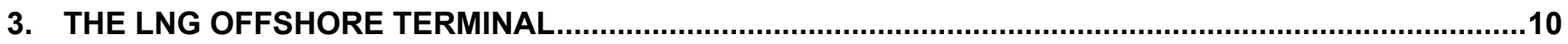

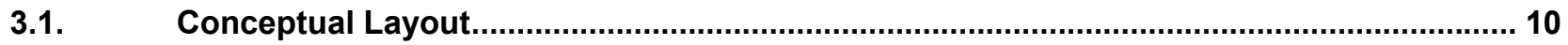

3.2. Offshore Terminal - Estimated Cost and Revenue ......................................................... 12 


\begin{tabular}{|l|l|l|l|}
\hline Customer: & $\begin{array}{l}\text { The United States Department of Energy } \\
\text { National Energy Technology Laboratory }\end{array}$ & $\begin{array}{l}\text { Date of Issue: } \\
\mathbf{2 4} \text { April } 2003\end{array}$ & \\
\hline $\begin{array}{l}\text { Document } \\
\text { Title: }\end{array}$ & Report II: “Conceptual Design of a Salt Cavern Based LNG Terminal” & $\begin{array}{l}\text { Doc \# \& Version: } \\
\text { Doc 06 r1.0 }\end{array}$ & Page 3 of 13 \\
\hline
\end{tabular}

\section{EXECUTIVE SUMMARY}

Numerical modeling, finite element analysis, and reviews by experts specialized in pipe-in-pipe technology confirmed the feasibility of the using salt cavern in the receipt of LNG. The study team used the critical elements referenced in Task 1.0 to conceptually design two LNG receiving terminals, (1) an onshore terminal capable of economic, safe, and reliable LNG transfer and regasification, and (2) an offshore terminal using the identified elements required to transfer and regasify LNG safely, reliably, and economically.

A specific site was identified for both terminals. The onshore terminal is located at the mouth of the Calcasieu River, in Cameron Parrish, Louisiana. The offshore terminal is located in the Gulf of Mexico over Vermillion Block 179, about 50 miles south of Interstate City, Louisiana. Each of the following conceptual LNG receiving terminal are designed according to the known environmental surroundings of the sites. Both terminals employ the BPT exchanger, associated pumping equipment, and utilize salt caverns for storage. All cost estimates are site specific and are accurate to within $\pm 35 \%$.

The Onshore Terminal uses proven technology. Other than the pumping and regasification process already discussed, the marine unloading facility represents little departure from typical LNG receiving terminal. The marine berth and Ship to Shore interface are quite familiar to the industry, and docking/undocking methods are accepted world wide. Because the LNG industry is familiar with the critical components, the BPT onshore terminal will most likely be the first terminal constructed.

Based on a throughput cost of service of $\$ 0.096$ per mmBtu, the conceptual "Liberty" land based terminal has an internal rate of return of $15.0 \%$.

LNG offshore is coming, and coming quickly. The concept of moving LNG offshore is at least 30 years old, and the methodologies of LNG at-sea transfer will be almost identical to the procedures developed for the offshore oil industry. Design firms, E\&C companies, and experts having a thorough insight of the transfer of oil and LPG offshore, realize that the technologies to handle cryogenic materials will have to be further developed and refined. All imminently workable LNG offshore solutions in various stages of testing or fabrication are based on this understanding.

This section of the study reveals that the proposed conceptual offshore terminal is competitive in terms of total installed cost, operation and maintenance. The throughput fee and rate of return are similar to the onshore design, and both are advantageous compared to conventional LNG terminals with similar capacities. Based on the same pro forma economic evaluation, the conceptual offshore terminal generates a $15 \%$ internal rate of return on a throughput cost of service of $\$ 0.095 \mathrm{mmBtu}$.

Additional study and development of the key components (cryogenic swivels, flexible transfer systems, and cryogenic subsea piping), further wave tank modeling, and industry willingness to "risk" moving LNG offshore are required before an LNG at-sea can become a reality. However, if the total install cost for the terminal can be kept within the reasonable estimates of this study, an LNG offshore terminal could be built by 2006. 


\begin{tabular}{|l|l|l|l|}
\hline Customer: & $\begin{array}{l}\text { The United States Department of Energy } \\
\text { National Energy Technology Laboratory }\end{array}$ & $\begin{array}{l}\text { Date of Issue: } \\
24 \text { April } 2003\end{array}$ & \\
\hline $\begin{array}{l}\text { Document } \\
\text { Title: }\end{array}$ & Report II: “Conceptual Design of a Salt Cavern Based LNG Terminal” & $\begin{array}{l}\text { Doc \# \& Version: } \\
\text { Doc } 06 \text { r1.0 }\end{array}$ & Page 4 of 13 \\
\hline
\end{tabular}

\section{THE LNG ONSHORE TERMINAL}

By design the BPT LNG receiving terminal is capable of sending out as much as 3.0 Bcfd from the salt storage caverns. The process itself is capable of regasifying as much as $3.8 \mathrm{Bcfd}$. To provide the large volumes of LNG necessary to help mitigate the natural gas shortfall projected by the EIA, CERA, and others, the LNG terminal must be located near a pipeline infrastructure capable of sufficient capacity to take advantage of the BPT terminal's substantial send-out capability. Knowing that some of the nation's largest pipelines pass through an area in South Louisiana known as "Henry Hub," the Study Team assembled various maps and charts of the Louisiana Gulf
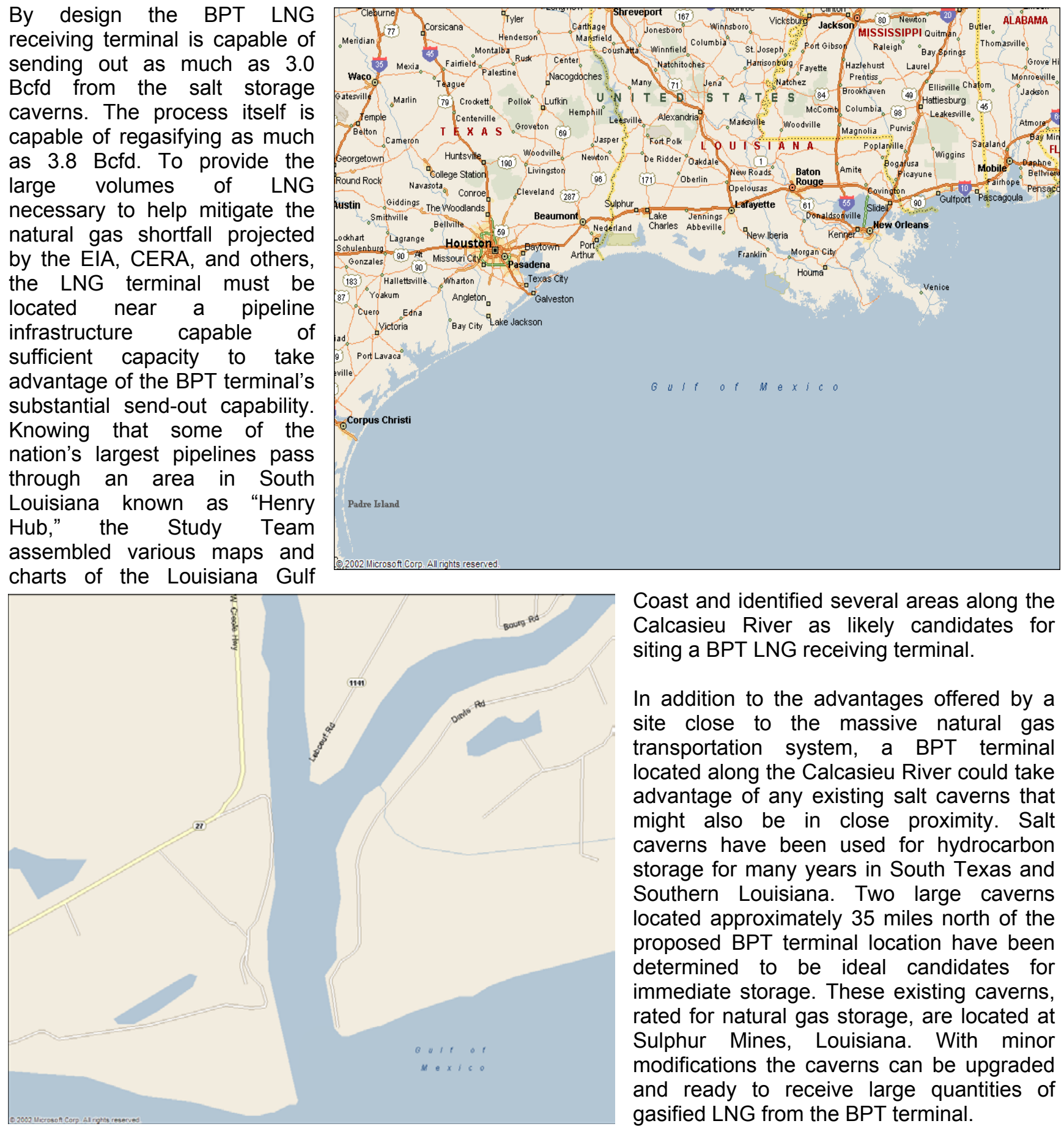

Coast and identified several areas along the Calcasieu River as likely candidates for siting a BPT LNG receiving terminal.

In addition to the advantages offered by a site close to the massive natural gas transportation system, a BPT terminal located along the Calcasieu River could take advantage of any existing salt caverns that might also be in close proximity. Salt caverns have been used for hydrocarbon storage for many years in South Texas and Southern Louisiana. Two large caverns located approximately 35 miles north of the proposed BPT terminal location have been determined to be ideal candidates for immediate storage. These existing caverns, rated for natural gas storage, are located at Sulphur Mines, Louisiana. With minor modifications the caverns can be upgraded and ready to receive large quantities of gasified LNG from the BPT terminal. 


\begin{tabular}{|l|l|l|l|}
\hline Customer: & $\begin{array}{l}\text { The United States Department of Energy } \\
\text { National Energy Technology Laboratory }\end{array}$ & $\begin{array}{l}\text { Date of Issue: } \\
24 \text { April } 2003\end{array}$ & \\
\hline $\begin{array}{l}\text { Document } \\
\text { Title: }\end{array}$ & Report II: “Conceptual Design of a Salt Cavern Based LNG Terminal” & $\begin{array}{l}\text { Doc \# \& Version: } \\
\text { Doc } 06 \text { r1.0 }\end{array}$ & Page 5 of 13 \\
\hline
\end{tabular}

A visit to the Cameron Chamber of commerce and local courthouse yielded several very detailed maps indicating that an area west of the river, and at the mouth of the river just past the channel entrance could provide an ideal location for the marine facility, high pressure LNG pumps, and BPT exchangers (see Attachment I). An investigation of the site revealed that the land was marshy, uninhabited, and fairly remote. The Sabine National Wildlife Area lies well to the north of the proposed location.

While no natural harbor exists along the Calcasieu River capable of berthing a large ocean going vessel, there appears to be ample space to dredge a slip on the western bank, and expand a small area just inside the mouth of the river. To facilitate

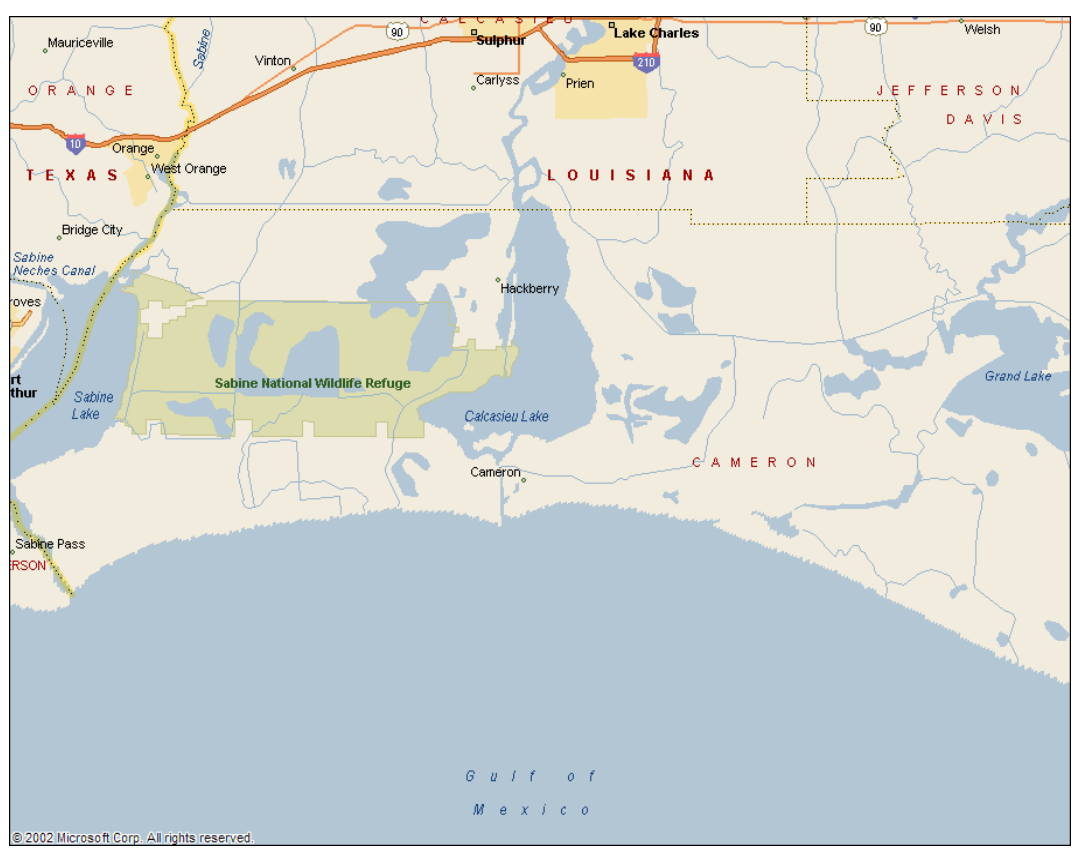
LNG tanker maneuvering a turning basin will also have to be created at the mouth of the river (Attachment II Plan View - Onshore LNG Terminal).

The turning basin located at the mouth of the river offers no additional restrictions to navigation or vessel traffic. The USCG requires that all vessels in the vicinity of an LNG tanker entering a navigable waterway observe a Restricted Navigational Area (RNA). The RNA is defined as a clear space two miles ahead and one mile behind the LNG vessel until it is safely berthed. The turning basin at the mouth of the river will actually decrease traffic delays, as the LNG tanker will be quickly docked and off the river almost immediately after entering the river channel. Attachment II indicates the location of the proposed slip and turning basin.

Also identified in Attachment II are:

1. The loading and transfer arms

2. Surge cylinder

3. LNG pump house

4. Vapor generator (required for forced vaporization)

5. Water warmant intake and pumping structure

6. Water warmant outfall structure

7. Bishop Process Heat Exchangers

8. Office, control room, and machine shop

9. Power generation station

All components in the Plan View are drawn to scale and the dock reflects the capability of the BPT terminal to accept LNG carriers up to $250,000 \mathrm{~m} 3$. Although tankers of this size may never be built, the BPT LNG terminal with its massive sendout capability would be a likely offloading destination for LNG carriers of this size.

The gasified LNG discharged from the terminal via the proposed 42" diameter high pressure pipeline is clearly marked. The pipeline connects the marine receiving terminal to the salt cavern storage facility located 35 miles away at Sulphur, Louisiana. The BPT LNG process does not require that LNG storage be located at or near the marine terminal, a major siting and security advantage. 


\begin{tabular}{|l|l|l|l|}
\hline Customer: & $\begin{array}{l}\text { The United States Department of Energy } \\
\text { National Energy Technology Laboratory }\end{array}$ & $\begin{array}{l}\text { Date of Issue: } \\
24 \text { April } 2003\end{array}$ & \\
\hline $\begin{array}{l}\text { Document } \\
\text { Title: }\end{array}$ & Report II: “Conceptual Design of a Salt Cavern Based LNG Terminal” & $\begin{array}{l}\text { Doc \# \& Version: } \\
\text { Doc } 06 \text { r1.0 }\end{array}$ & Page 6 of 13 \\
\hline
\end{tabular}

\subsection{BPT LNG Terminal - Process Flow Diagram}

A Process Flow Diagram (PFD) of the BPT LNG terminal is illustrated in Attachment III. Although the mechanical elements differ between the BPT onshore and offshore terminal, the same basic process principles apply. Much of the machinery required to receive, regasify, and sendout out LNG to salt storage is identical. Therefore, the PFD depicted in Attachment III will be conceptually applicable to both terminals.

Referencing Attachment III, the LNG vessel arrives and is secured at the berth. The four High Pressure Pumps (G-1 through G-4) housed in Pump Reservoir (C-2) are kept cold via recirculation of LNG with the Standby Mode Circulating Pump (G5) discharging into the LNG unloading line, through the surge vessel, and returning to the High Pressure Pump Reservoir(C-1). Recirculating LNG is allowed to flood the pump and motor housing and reenter the suction side of Circulating Pump G5. The vapor generated by the recirculation process is reliquefied in a Reliquefaction Packaged Compressor Unit K-2.

Just prior to discharge, one pump from a single 4-pack, is placed in the recirculation mode with its discharge valve to the BPT exchanger cracked. The loading and vapor arms are connected and the LNG tanker begins to discharge its cargo. The LNG from the ship's cargo pumps, pressurized at about 45 to 60 psig, begins to fill the surge vessel. The suction and discharge valves from the 4-pack are opened in increasing fashion to accommodate increasing volumes of LNG received from the ship's cargo pumps until an equilibrium is achieved. As the ship brings more and more cargo pumps online, the 4-packs are started accordingly until full pumping rates are achieved.

During the full rate pumping mode, all LNG is circulated through the Bishop Process Heat Exchangers (BPT) shown in the drawing as E-1 through E-4. Warming water is provided from a source with pump G6. The exchangers are designed with two separate inlets that circulate the warming water in opposite directions and provide a way to "refresh" the heat transfer capability. Multiple circulation modes ensure that the proper heat transfer takes place even with colder warmant temperatures.

After leaving the exchanger, the regasified LNG now in the dense phase (for a detailed discussion, reference Subtask 1.3), passes through the 42" diameter pipeline and into the salt cavern storage facility.

Boil Off Gas (BOG), is required to fill the ships tanks during discharge, and must be returned to the ship at the equivalent unloading rate. BOG is usually supplied via vapor generated by agitation in the LNG storage tanks during unloading. While discharging at the BPT LNG terminal, a reducing station supplied from the outlet of the BPT exchanger, and a blower (K-3) will provide the prescribed amount of vapor.

Rate down and return to standby mode is accomplished by reversing the above procedure. 


\begin{tabular}{|l|l|l|l|}
\hline Customer: & $\begin{array}{l}\text { The United States Department of Energy } \\
\text { National Energy Technology Laboratory }\end{array}$ & $\begin{array}{l}\text { Date of Issue: } \\
\mathbf{2 4} \text { April } 2003\end{array}$ & \\
\hline $\begin{array}{l}\text { Document } \\
\text { Title: }\end{array}$ & Report II: “Conceptual Design of a Salt Cavern Based LNG Terminal” & $\begin{array}{l}\text { Doc \# \& Version: } \\
\text { Doc 06 r1.0 }\end{array}$ & Page 7 of 13 \\
\hline
\end{tabular}

2.2. List of Critical Machinery

\title{
Liberty LNG Terminal to Existing Salt Cavern Storage
}

\author{
Description \\ UPGRADES TO EXISTING STORAGE CAVERNS (Sulphur Mines, La) \\ PROCESS VESSELS \\ Recondenser, 9'ID x 45', 304 SS \\ BOG Compressor Knock Out Drum 35 m3 \\ HP Fuel Gas Knock Out Drum, 3 m3 \\ HP Flare Knock Out Drum, $50 \mathrm{~m} 3$ \\ Service Water Storage Tank, $20 \mathrm{~m} 3$ \\ Diesel Storage Tank, $50 \mathrm{~m} 3$ \\ Foam Tank, $4 \mathrm{~m} 3$ \\ Surge Vessels \\ VAPORIZERS \\ Submerged Combustion Vap., $205 \mathrm{mmcfd} / 433 \mathrm{~m} 3 / \mathrm{hr}$ \\ CPP Shell and Tube $150 \mathrm{mmcfd} / 317 \mathrm{m3} / \mathrm{hr}$ \\ Bishop Process $128 \mathrm{mmcfd} / 270 \mathrm{~m} 3 / \mathrm{hr}$ \\ HEAT EXCHANGERS \\ Standby glycol/fuel gas heater $127 \mathrm{~kW}$ \\ HP knockout drum heater $20 \mathrm{~kW}$ \\ Gaseous N2 Vaporizer 35 kW \\ Gaseous N2 Vaporizer (Spare) $35 \mathrm{~kW}$ \\ Liquid N2 Pressurization vaporizer $35 \mathrm{~kW}$ \\ Liquid N2 Vaporizer $35 \mathrm{~kW}$ \\ Waste Heat recovery from turbo-generator exhaust \\ PUMPS \\ High Pressure sendout pump, 2,200 psi @ 270 m3/hr \\ Process Area Sump Pump, 10 hp, 5 m3/hr \\ Service Water Pump, 5 hp, 57 m3/hr \\ Firewater Pumps \\ COMPRESSORS \\ BOG compressor, 0.5 MMSCFD \\ Ship Vapor Return Blower \\ Ship Unloading Compressor \\ SEAWATER INTAKE/OUTFALL (Incl Electrochlorination) \\ Seawater pump (warmant), $3150 \mathrm{~m} 3 / \mathrm{hr}$ \\ Electrochlorination Unit, $19,000 \mathrm{~m} 3 / \mathrm{hr}$ \\ Seawater Intake Structure $(19,000 \mathrm{~m} 3 / \mathrm{hr}$ each) \\ Seawater Outfall Structure $(19,000 \mathrm{~m} 3 / \mathrm{hr}$ each)
}




\begin{tabular}{|l|l|l|l|}
\hline Customer: & $\begin{array}{l}\text { The United States Department of Energy } \\
\text { National Energy Technology Laboratory }\end{array}$ & $\begin{array}{l}\text { Date of Issue: } \\
24 \text { April } 2003\end{array}$ & \\
\hline $\begin{array}{l}\text { Document } \\
\text { Title: }\end{array}$ & Report II: “Conceptual Design of a Salt Cavern Based LNG Terminal” & $\begin{array}{l}\text { Doc \# \& Version: } \\
\text { Doc } 06 \text { r1.0 }\end{array}$ & Page 8 of 13 \\
\hline
\end{tabular}

Seawater Intake Screens $(20,000 \mathrm{~m} 3 / \mathrm{hr}$ each)

Seawater Rotary Screens $(20,000 \mathrm{~m} 3 / \mathrm{hr}$ each)

\title{
UTILITIES
}

HP Flare, $415,000 \mathrm{~kg} / \mathrm{hr}$

Electrical Switchgear \& Power Distrib (5\% of FC)

Emergency Generator - Diesel Driven, $500 \mathrm{~kW}$

Lighting Generator - Diesel Driven, $750 \mathrm{~kW}$

GE LM 2500+ with chiller and DLE low emissions package

Instrument air compressor and drier, $100 \mathrm{scfm}$

N2 Dewar for Terminal, Vac. insul. tank, $42 \mathrm{~m} 3$

Firewater Protection System (Foam Sys, dry powder, tanks)

MARINE FACILITIES - JETTY

Platforms and walkways

Cryogenic Piping (I/E, piping w/ insulation)

Berth (Mooring, Breasting Dolphins)

Dredging

MARINE FACILITIES - UNLOADING

Unloading Arms

\section{NAVIGATIONAL AIDS (lighting and buoys)}

BUILDINGS

Administration Office/Control Center

Building for Sendout Pumps

Warehouse/Maintenance Building, 10,000 sf

\author{
SITE PREPARATION \\ BULKS \\ Piping (exclud. trestle) \\ Piling \\ Insulation and Paint \\ Instrumentation and metering skids
}

\section{REAL ESTATE}

PIPELINE TO SULPHUR MINES

TIE IN TO MAJOR FOUR PIPELINES

\subsection{Estimated Costs and Revenues}

There are three major elements contributing to the overall total installed cost (TIC) of the LNG onshore terminal, the LNG terminal at the mouth of the Calcasieu River, the upgrades and pipeline interconnects required for the existing salt cavern facilities, and the 35 mile pipeline required to connect the offloading terminal to the storage caverns. The cost estimates for the financial model (Attachment IV) were developed using a factored cost estimating program specific to the industry. Budget estimates for upgrading the existing salt cavern facilities are based on actual operating experience and direct quotations. Pipeline estimates were sourced from the contractors. 


\begin{tabular}{|l|l|l|l|}
\hline Customer: & $\begin{array}{l}\text { The United States Department of Energy } \\
\text { National Energy Technology Laboratory }\end{array}$ & $\begin{array}{l}\text { Date of Issue: } \\
24 \text { April } 2003\end{array}$ & \\
\hline $\begin{array}{l}\text { Document } \\
\text { Title: }\end{array}$ & Report II: “Conceptual Design of a Salt Cavern Based LNG Terminal” & $\begin{array}{l}\text { Doc \# \& Version: } \\
\text { Doc } 06 \text { r1.0 }\end{array}$ & Page $\mathbf{9}$ of 13 \\
\hline
\end{tabular}

The financial model applied is based on a long-established standard model for gas storage. Necessary modifications were made to reflect the key economic and financial aspects of the onshore LNG Terminal modeled after the actual project mentioned throughout the above sections, especially in the area of terminal energy use fees and actual terminal energy use requirements.

The major elements of the terminal TIC and $O \& M$ budget are included on the second and third page of Attachment IV. The major elements of the economic/financial model and its results are shown on the "Summary" page, e.g. Attachment IV pg. 1.

Most of the items on the "Summary Facility Assumptions" page are self explanatory. Notable items, parameters, and assumptions for the Onshore LNG terminal are described below.

The facility sizing basis is shown in the section of the "Summary" page labeled "Facility Basis" and "LNG Terminal Project Metrics." The reference assumption is 225 cargos per year and this corresponds to 1.7 Bcf per day average daily import and grid dispatch quantity. Note that 16 Bcf figure for "Storage Working Gas Volume" is an off-line technical result regarding total storage capacity of the salt caverns and the economic model makes no assumptions regarding the amount of storage capacity required for the LNG terminal operations.

"Pricing" is the next section of the "Summary" page. The "Throughput Fee" is assumed as a \$ amount per mmBtu. This assumption can be varied to determine the IRR associated with the assumed fee to satisfy a certain IRR target or "hurdle rate." The "Other Revenue" line allows for other revenue that might be generated as a percentage of LNG throughput. In fact, the storage terminal with multiple connections may be able to realize fees from services in addition to LNG import terminal operations (such as gas storage or hub services). These fees may or may not relate to the percentage of revenue from LNG terminal throughput fees. For a reference case focused on only LNG terminal operations, both of the "other revenue" assumptions have been set to zero. The "Pricing" section also includes pricing parameters for the "Terminal Energy Use Charge" expressed as a percentage of throughput retained by the terminal as a fuel charge. In the financial projections, this amount is inflated with the general inflation rate and the amount is modeled as a Henry Hub index price.

The "Other Assumptions" section of the "Summary" page includes a number of important parameters that affect the economics/financial results. The section labeled "Others" is reflects fees for "Technology Rights" and is intentionally left blank to better compare the onshore and offshore options.

The next major section of the "Summary Facility Assumptions" block of the "Summary" page shows the capital cost for various major components of the terminal. These are largely self-explanatory. The "Project Metrics" summarizes some commonly applied quantity references for the LNG terminal business.

The "Tax Rates" section shows the assumptions for tax rates applicable for a Louisiana project. The calculation of "terminal value" for cash flow purposes assumes sale of the facility on an EBITDA multiple basis with the resulting proceeds realizing capital gains treatment for federal tax purposes and ordinary rates for state tax purposes.

The "Depreciation" section allows different assumptions to be made that affect primarily the after-tax cash flows to the ownership. In order to provide for a more conservative (i.e. higher required fee or reduced IRR depiction) assessment, the reference assumption is for straight-line depreciation over 20 years.

"Financial Assumptions" are shown in the block on the upper right hand side. A 50-50 debt equity structure is assumed with debt costs at prime plus $2 \%$ which corresponds to $6.75 \%$ for a reference case. The time period for repaying debt has a strong effect on equity cash flows, debt service coverages, and equity returns. Given the long term nature of the related investments for LNG production and transport, a 20 year amortization period is assumed.

The "Financial Results" block shows model outputs generally from the cash flow calculation. The cost of capital is a straightforward calculation based on the input assumptions for costs and amounts of debt and equity. The "Project Economics" section reflect results for the project without any debt. This is essentially an "all equity" approach to project NPV and IRR. Estimated EBTIDA amounts are expressed in thousands of 


\begin{tabular}{|l|l|l|l|}
\hline Customer: & $\begin{array}{l}\text { The United States Department of Energy } \\
\text { National Energy Technology Laboratory }\end{array}$ & $\begin{array}{l}\text { Date of Issue: } \\
24 \text { April } 2003\end{array}$ & \\
\hline $\begin{array}{l}\text { Document } \\
\text { Title: }\end{array}$ & Report II: “Conceptual Design of a Salt Cavern Based LNG Terminal” & $\begin{array}{l}\text { Doc \# \& Version: } \\
\text { Doc 06 r1.0 }\end{array}$ & Page 10 of 13 \\
\hline
\end{tabular}

dollars per year. Equity returns as NPV and IRR are shown on an after tax basis for cash-on-cash expected flows. Minimum debt service coverages are demonstrated on a pre-tax basis as shown. Based on a throughput fee of $\$ 0.096 \mathrm{mmBtu}$, the conceptual land based terminal in years one through five averaged an EBITDA of $\$ 45,129,000$ USD based on a through-put of 225 cargoes per year. On a $16.4 \%$ after tax equity IRR the projected equity return was $\$ 21,377,000$ USD.

The same financial model is used for the offshore terminal with modifications to Project Budget and $O$ \& $M$ expenses only.

\section{THE LNG OFFSHORE TERMINAL}

\subsection{Conceptual Layout}

The offshore LNG terminal using the BPT exchangers and salt caverns as storage is pictured in Attachment V. The Process Flow Diagram varies little from the onshore terminal, therefore more attention will be focused on offshore layout. The illustration clearly shows the swing arm mechanism "Big Sweep" designed to safely berth the LNG carrier and an adjacent platform with the major process machinery. The mooring platform houses the high pressure LNG pumps that pressurize the LNG to 2,200 psig. The pressurized liquid is routed to the regasification platform via a subsea pipeline rated for cryogenic service. LNG passes through the BPT exchanger and moves directly into the offshore gas gathering system, or to the salt caverns for storage. The following explanation is excerpted from section 1.2 for the reader's convenience.

The 'Big Sweep' concept consists of three basic elements, see figure 3.1-1 on the following page.

- A jacket structure with turntable, anchored to the seabed

- A submerged rigid arm, hinged at one end to the jacket turntable and terminating at its other end with a buoyant column, and

- The LNG loading and transfer structure, located on top of the buoyant column.

To allow the vessel and arm to passively 'weathervane' into the most favourable direction with respect to the environment, the turntable is connected to the jacket structure by means of a bearing. This allows the turntable to rotate $360^{\circ}$ with respect to the jacket. The turntable supports the rigid arm hinges, the cryogenic fluid swivels and the hawser attachment point.

The overall length of the rigid arm is such that the buoyant column is positioned nominally near the midship cargo manifold of the LNG carrier. By adjusting the length of the mooring hawser the carrier's cargo manifold can be lined up to the offloading station for vessel sizes ranging from large to very large gas carriers.

The buoyant hull is equipped with a thruster system to swing the arm in a safe position during approach of the vessel and in-line with the vessel in the operational mode. A water ballast tank allows draft adjustment of the loading arm to match tanker size and / or drafts. The standard fluid transfer system consists essentially of 3 Pipe-in-Pipe (PIP) lines. Two lines are dedicated to LNG; either in full flow mode or re-circulation mode. The third line is dedicated for vapour return. The flow paths cross the weathervaning and pitch hinges between the jacket and the rigid arm. This is achieved with swivels and full metal jumpers which can be easily inspected and serviced.

The loading arm is normally trailing the jacket but can be temporarily 'parked' away from the LNG carrier line of approach, with its own propulsion. In this position the entire loading arm assembly cannot be damaged by a failed mooring approach of the export carrier tanker. Note that offshore tanker mooring to SPM systems is standard marine practice and that a failed approach run very rarely happens. Should the carrier 'brush' against the terminal, this will be a 'low energy' collision which can be accommodated by the cushioning fender system. 


\begin{tabular}{|l|l|l|l|}
\hline Customer: & $\begin{array}{l}\text { The United States Department of Energy } \\
\text { National Energy Technology Laboratory }\end{array}$ & $\begin{array}{l}\text { Date of Issue: } \\
24 \text { April } 2003\end{array}$ & \\
\hline $\begin{array}{l}\text { Document } \\
\text { Title: }\end{array}$ & Report II: “Conceptual Design of a Salt Cavern Based LNG Terminal” & $\begin{array}{l}\text { Doc \# \& Version: } \\
\text { Doc } 06 \text { r1.0 }\end{array}$ & Page 11 of 13 \\
\hline
\end{tabular}

The LNG carrier moors in tandem with the turntable and once it has secured itself safely and the overall alignment is stable, the loading arm will be deployed from its parked position toward the vessel's manifold. The hose deployment and loading operation may now be initiated. After completion of the transfer operations all of the steps discussed above are done in reverse order.
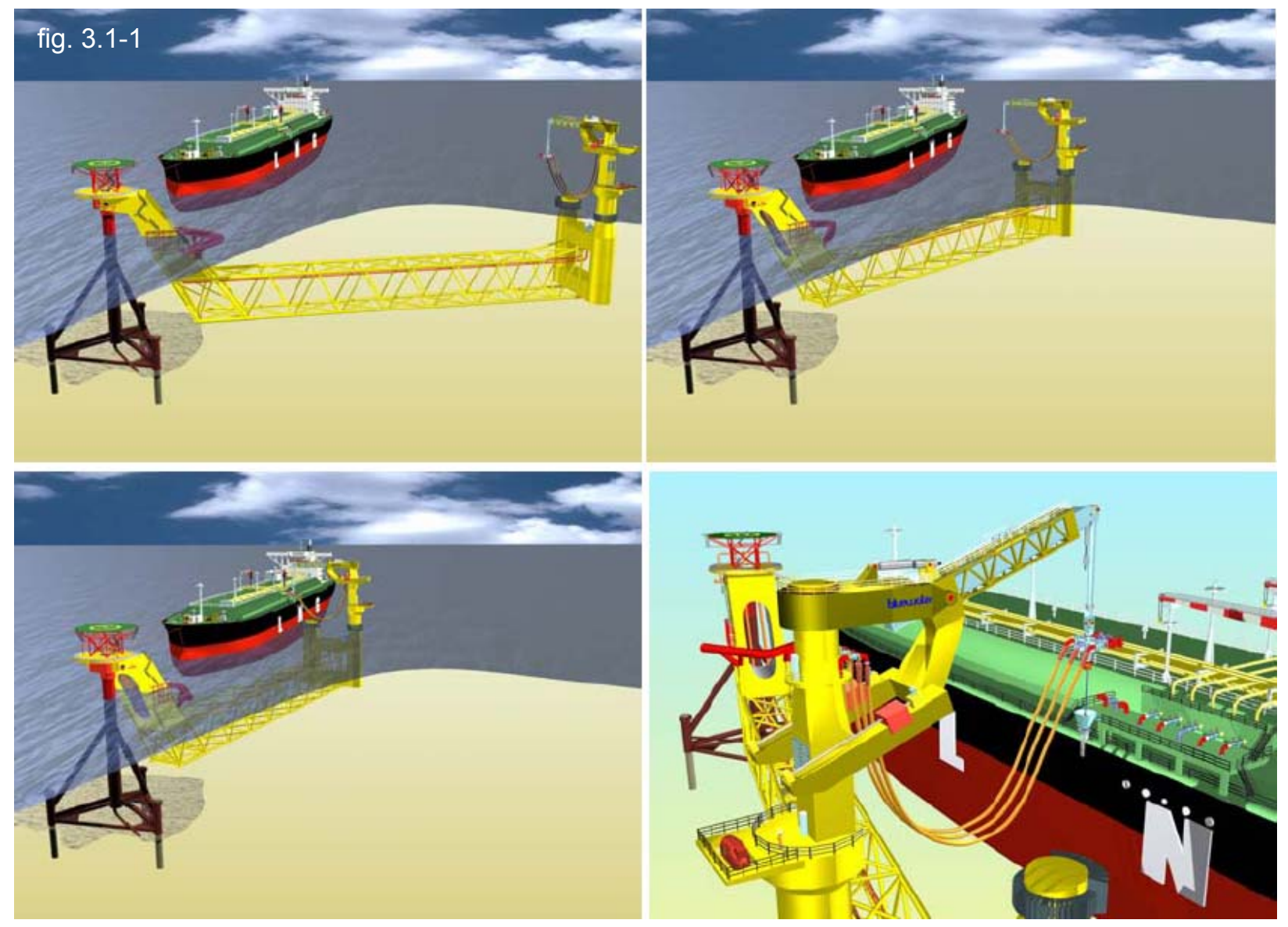

Shallow Water depth Terminal. Developed from the 'Big Sweep' system, this unit shown in fig. 3.1-2 is designed to operate in water depths below $40 \mathrm{~m}$, It allows direct offshore-to-shore transfer of LNG, at rates up to $10,000 \mathrm{~m} 3 / \mathrm{hr}$ from non-dedicated vessels.

Motion characteristics are such that offloading can proceed up to significant wave heights of $3 \mathrm{~m}$, depending on the water depth, which may be as little as 15 meters. With dynamic positioning (DP) capability the unit would track the movement of the LNG carrier manifold when loading or unloading LNG. DP would also allow the unit to move out of the way when the LNG carrier is mooring itself to the turntable on the jacket, thereby avoiding marine hazards. For extreme survival conditions e.g. the Gulf of Mexico, the free-end of the unit is waterballasted and set temporarily on the seabed. 


\begin{tabular}{|l|l|l|l|}
\hline Customer: & $\begin{array}{l}\text { The United States Department of Energy } \\
\text { National Energy Technology Laboratory }\end{array}$ & $\begin{array}{l}\text { Date of Issue: } \\
24 \text { April } 2003\end{array}$ & \\
\hline $\begin{array}{l}\text { Document } \\
\text { Title: }\end{array}$ & Report II: “Conceptual Design of a Salt Cavern Based LNG Terminal” & $\begin{array}{l}\text { Doc \# \& Version: } \\
\text { Doc } 06 \text { r1.0 }\end{array}$ & Page 12 of 13 \\
\hline
\end{tabular}

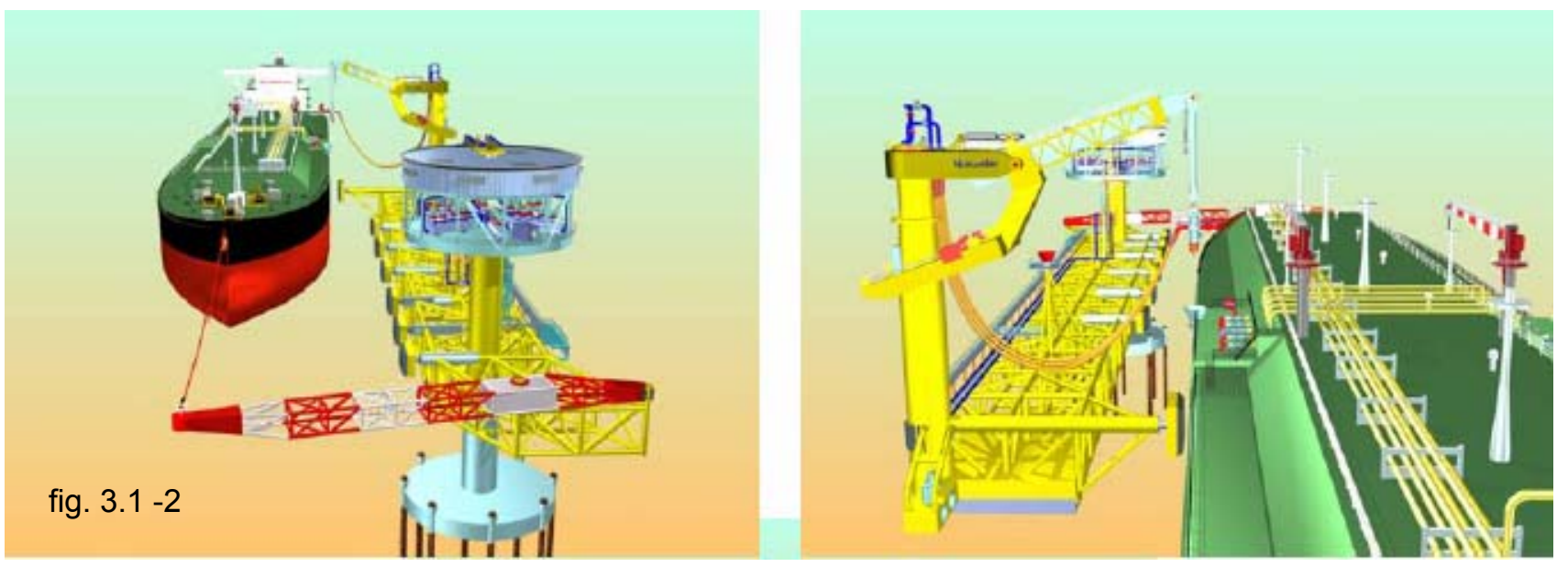

Re-gasification equipment may be located on the unit for applications without LNG storage e.g. where gas is stored in salt caverns or delivered directly to the shore gas grid.

Attachment $\mathrm{VI}$ is a plan view if the facility to scale. The platforms are approximately 1800 meters apart to allow for ample maneuvering distance. Although the plan view indicates that four caverns will be used for storage, the number and size of the caverns are for the most part subject to customer requirements as most salt formations can accommodate any number of caverns. Attachment VII has been included to better illustrate the major components of the offshore LNG terminal.

\subsection{Offshore Terminal - Estimated Cost and Revenue}

There are three major elements contributing to the overall total installed cost (TIC) of the LNG offshore terminal, (1) platforms and weathervaning mooring facilities, (2) the cryogenic pipeline required to connect the mooring facility to the cavern platform, and (3) the newly designed solution mined salt storage caverns. The cost estimates for the financial model (Attachment VIII) were developed using a factored cost estimating program specific to the industry. Budget estimates for the offshore mooring facilities are based on actual operating experience and direct quotations. Cryogenic pipeline estimates were sourced from the contractors.

The financial model applied is based on a long-established standard model for gas storage. Necessary modifications were made to reflect the key economic and financial aspects of the offshore LNG Terminal based on the designers best estimates, especially in the area of terminal energy use fees and actual terminal energy use requirements.

The major elements of the terminal TIC and $O \& M$ budget are included on the second and third page of Attachment VIII. The major elements of the economic/financial model and its results are shown on the "Summary" page, e.g. Attachment VIII pg. 1.

Most of the items on the "Summary Facility Assumptions" page are self explanatory. Please refer to section 2.3 of this report for additional details of notable items, parameters, and assumptions for the Offshore LNG terminal.

The "Financial Results" block shows model outputs generally from the cash flow calculation. The cost of capital is a straightforward calculation based on the input assumptions for costs and amounts of debt and equity. The 


\begin{tabular}{|l|l|l|l|}
\hline Customer: & $\begin{array}{l}\text { The United States Department of Energy } \\
\text { National Energy Technology Laboratory }\end{array}$ & $\begin{array}{l}\text { Date of Issue: } \\
24 \text { April } 2003\end{array}$ & \\
\hline $\begin{array}{l}\text { Document } \\
\text { Title: }\end{array}$ & Report II: “Conceptual Design of a Salt Cavern Based LNG Terminal” & $\begin{array}{l}\text { Doc \# \& Version: } \\
\text { Doc } 06 \text { r1.0 }\end{array}$ & Page 13 of 13 \\
\hline
\end{tabular}

"Project Economics" section reflects results for the project without any debt. This is essentially an "all equity" approach to project NPV and IRR. Estimated EBTIDA amounts are expressed in thousands of dollars per year. Equity returns as NPV and IRR are shown on an after tax basis for cash-on-cash expected flows. Minimum debt service coverages are shown on a pre-tax basis as shown. Based on a throughput fee of $\$ 0.095 \mathrm{mmBtu}$, the conceptual offshore terminal in years one through five averaged an EBITDA of $\$ 42,698,000$ USD based on a through-put of 230 cargoes per year. On a $16.4 \%$ after tax equity IRR the projected equity return was $\$ 20,493,000$ USD. 


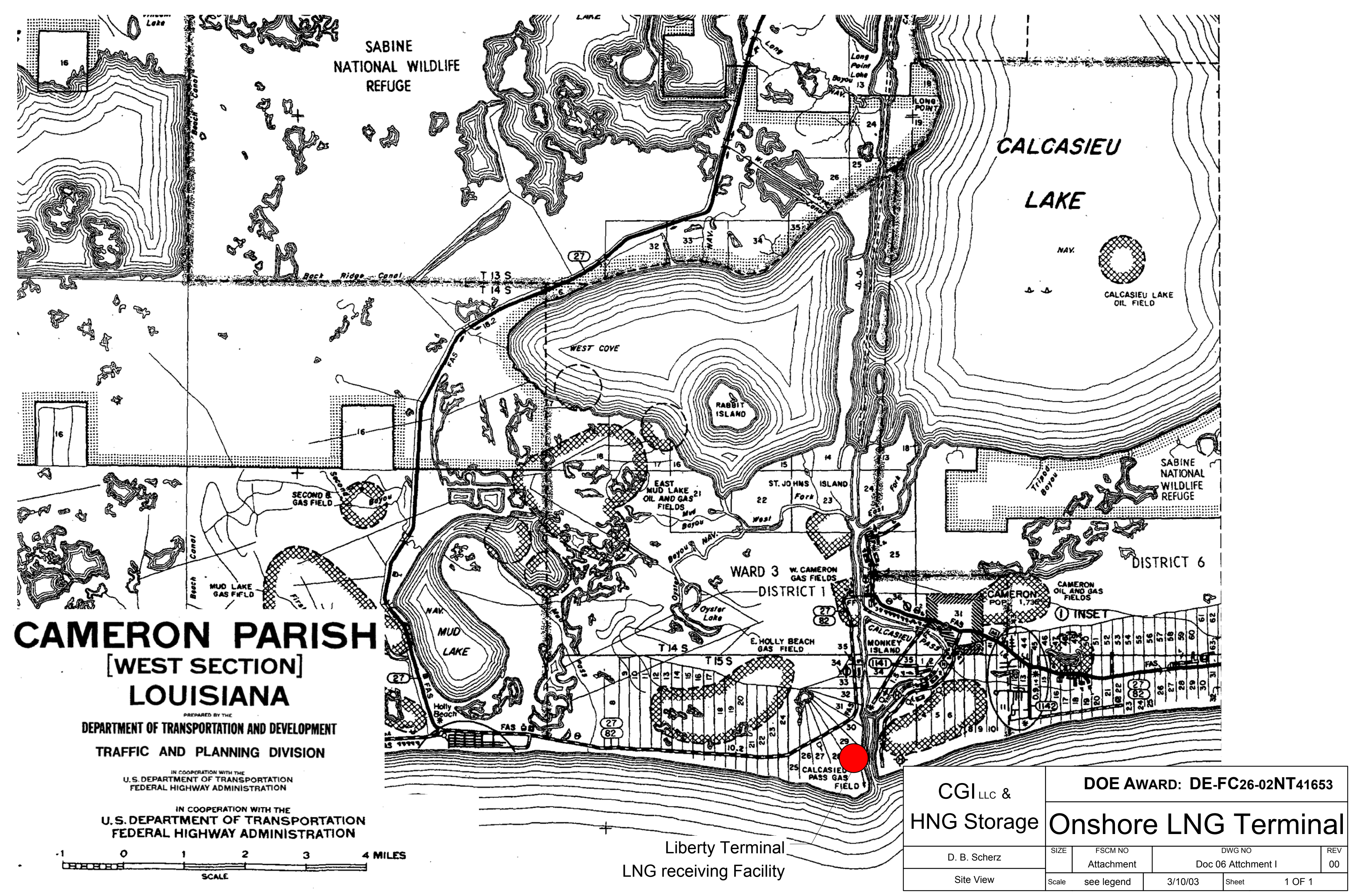




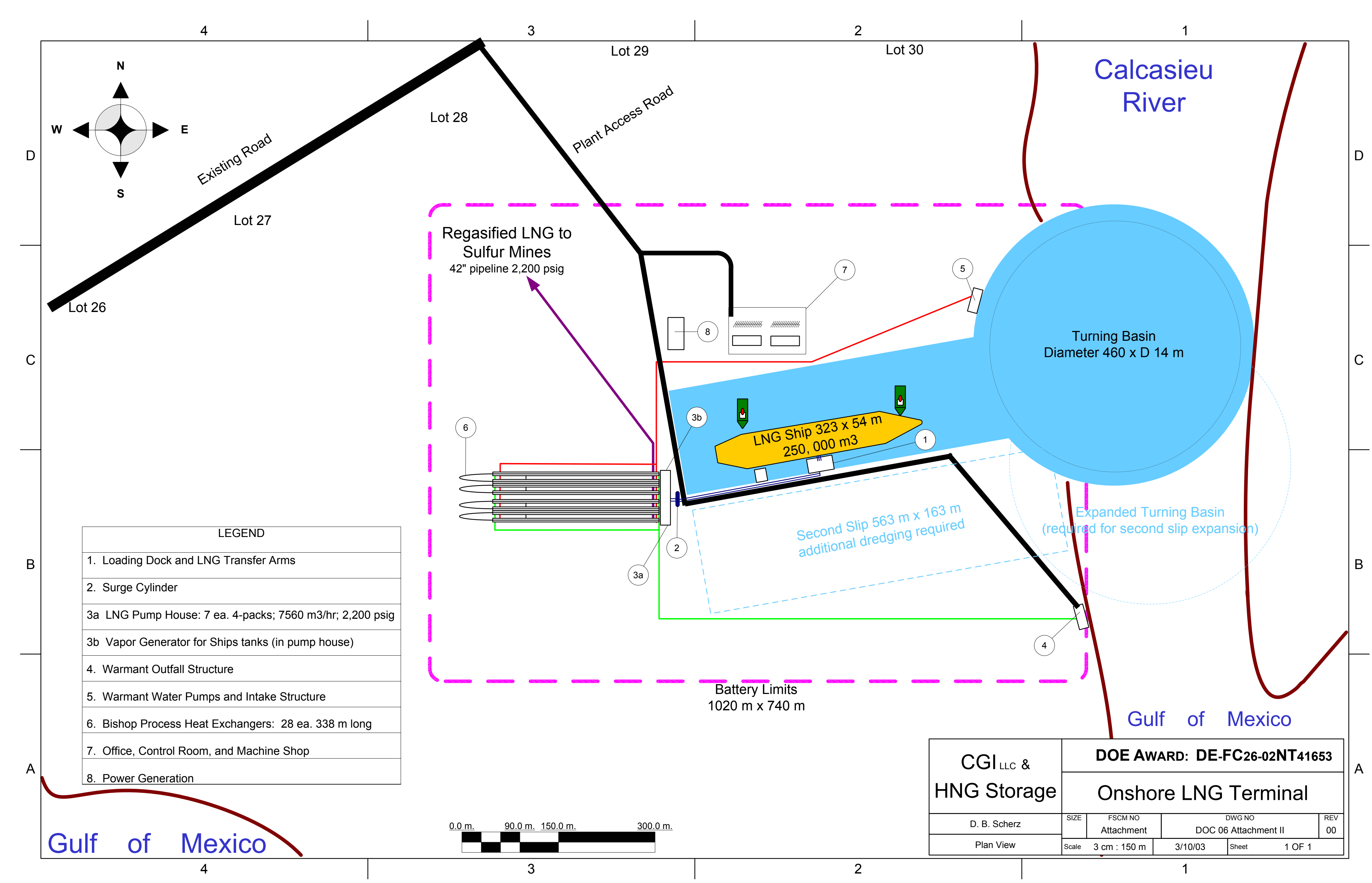




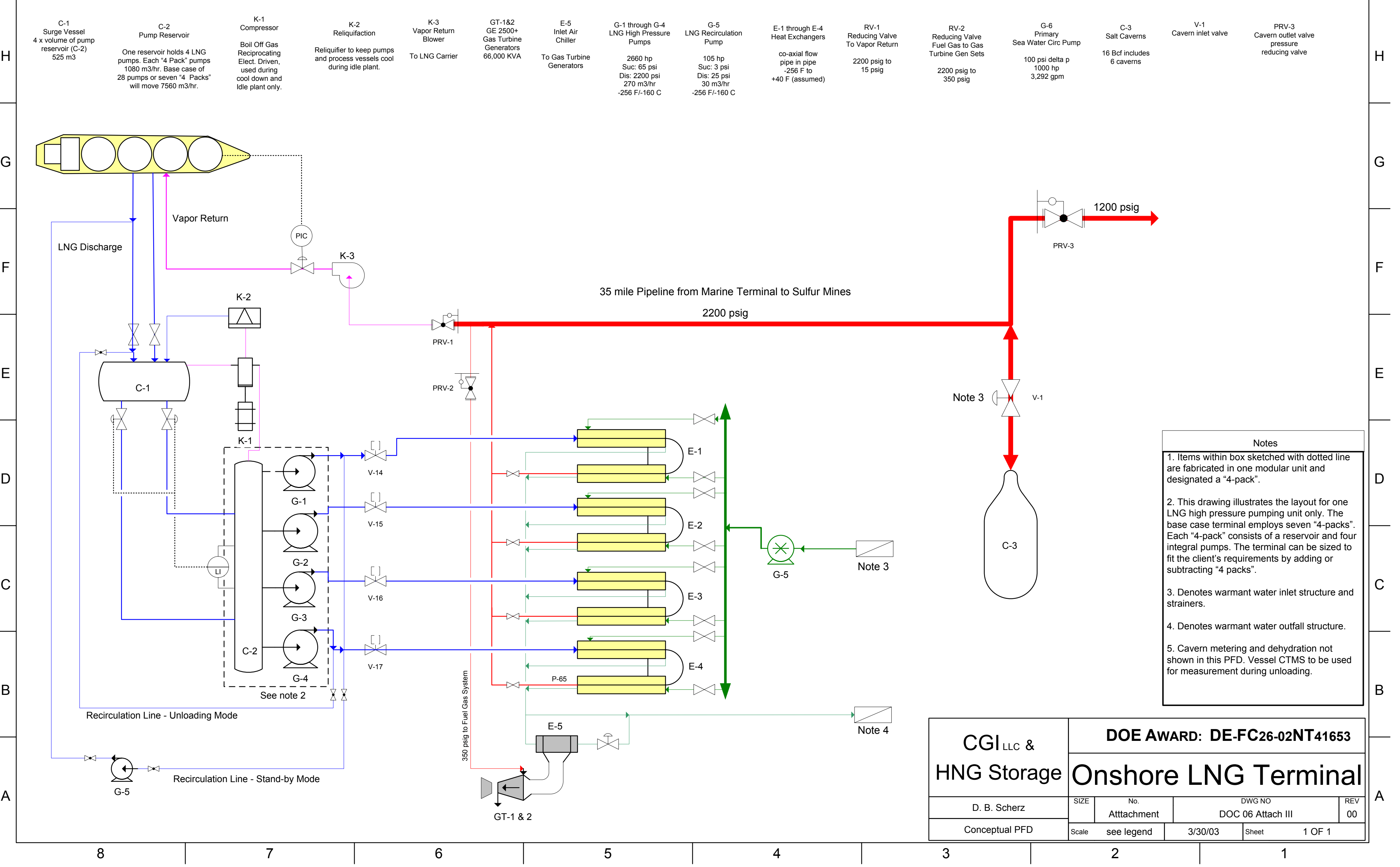




\section{LIBERTY LNG TERMINAL \\ PROFORMA ECONOMICS \\ Doc 06 Attachment IV pg 1}

\section{SUMMARY FACILITY ASSUMPTIONS}

\section{FINANCIAL ASSUMPTIONS}

\section{Facility Basis - Firm Service}

Cargos per Year

LNG Discharge per Ship, cubic meters LNG

LNG Btu content, Btu/scf

Storage Working Gas Volume, Bcf

Storage Base Gas Volume, Bcf

Pricing

Throughput Fee, $\$ / \mathrm{MmBtu}$

Facility Costs, $\$$

\begin{tabular}{rlr} 
& Facility Costs, $\$$ & \\
\cline { 2 - 3 } 225 & Marine Port Facilities & $56,733,600$ \\
138,000 & LNG Process \& HP Pipeline & $136,310,776$ \\
1067 & Terminal Utility System & $28,188,700$ \\
16.00 & Storage Surface Facility & $17,363,650$ \\
7.30 & Storage Construction & $18,358,100$ \\
& Header Pipeline & $14,397,250$ \\
& Engineering \& Const. Mgmt. & $14,925,225$ \\
& Project Acquisition \& Tech. Rights & $1,920,000$ \\
0.096 & Owner Costs, Permits, Misc. & $7,361,958$ \\
$0.0 \%$ & Financing Fees & $16,281,125$ \\
$0.00 \%$ & Contingency & $43,784,595$ \\
$\$ 3.50$ & Total Facility Cost & $\mathbf{3 5 5 , 6 2 4 , 9 7 9}$
\end{tabular}

Assumed Henry Hub Index for initial year

Gas Storage Net Revenue Realized \$MM/year

$\$ 0.0$

\section{Other Assumptions}

(Delivered), $\$ / \mathrm{Mcf}$

Base Gas Source ("Lease" or "Buy")

Total Operations Cost, \$M/Year

- Labor \& Maintenance, $\$ \mathrm{M} / \mathrm{Yr}$

- Electrical Demand Charge, \$M/Yr

Management Overhead, \$M/Year

Property Taxes (assumed amount), \$M/Yr

Storage Site Lease Fee, \$M/yr

$\%$ Revenue Stream to Inflation Protect, \%/yr

General Inflation Rate

Inflation applied to certain annual costs, $\% / \mathrm{yr}$

Energy Use for Terminal ops., \% of throughput

Full storage cavern compression charge rate

$\%$ of throughput requiring compression at cavern

Project \& Technology Rights

Running Royalty, as \% of Henry Hub index

Project \& License Upfront Payment, \$MM

\section{LNG Terminal Project Metrics}

Load Factor (based on 240 cargos/yr max)

Reference Annual throughput, mcf/yr

Annual LNG Offloaded, BCF/yr

Reference throughput, million mmBtu/yr $\quad 653,086,4$

Daily equivalent amount (mcf/day)

\section{Tax Rates}

Federal, $\% / \mathrm{YR}$

State, \%/YR

Blended Rate, \%/Yr

Property, \%/YR, initial year/capital cost

Capital Gain Rate for Terminal Value

Depreciation

Depreciation (Straight-Line or Accel) Straight-Line

Depreciable Life, Years

Project Life, Years
Financial Structure

Sr. Debt Percent of Capital

Jr. Debt Percent of Capital

Equity Percent of Capital

Senior Debt Term

Junior Debt Term

Base Gas Lease Carrying Cost, \%/YR

FINANCIAL RESULTS

\begin{tabular}{|lr|}
\hline & \\
Cost of Capital & $\mathbf{1 0 . 8 8 \%}$ \\
\hline Pretax WACC & $\mathbf{9 . 6 0 \%}$ \\
WACC & $\mathbf{1 5 . 0 \%}$ \\
Equity Return (assumed from above) & \\
& \\
Project Economics & $\mathbf{1 4 7 , 5 7 9}$ \\
\hline Project NPV@Pretax WACC, \$M & $\mathbf{1 5 . 1 \%}$ \\
Project Pretax IRR & $\mathbf{9 3 , 8 3 5}$ \\
NPV @ WACC (tax-effected), \$M & $\mathbf{1 2 . 1 \%}$ \\
Project IRR (tax-effected) & $\mathbf{\$ 4 2 , 1 3 9}$ \\
Yr. 1 EBITDA \$M/year & $\mathbf{\$ 4 5 , 1 2 9}$ \\
Avg. EBITDA, Yrs 1-5, \$M/year & \\
Equity Returns, AFTER-Tax & $\mathbf{2 1 , 3 7 7}$ \\
\hline Equity NPV@ Assumed Equity Return, \$M & $\mathbf{1 6 . 4 \%}$ \\
Equity IRR (calculated) & \\
& Pre-tax \\
Debt Coverage & $\mathbf{3 . 5}$ \\
\hline Minimum EBITDA/Interest Coverage & $\mathbf{2 . 6}$ \\
\hline Minimum EBITDA/Debt Service &
\end{tabular}

$0.00 \%$ based on mmBtu throughput
Rate

$50.0 \% \quad 6.75 \%$

$0.0 \%$

$15.0 \%$ 
LIBERTY LNG TERMINAL

PROFORMA ECONOMICS

Doc 06 Attachment IV pg 2

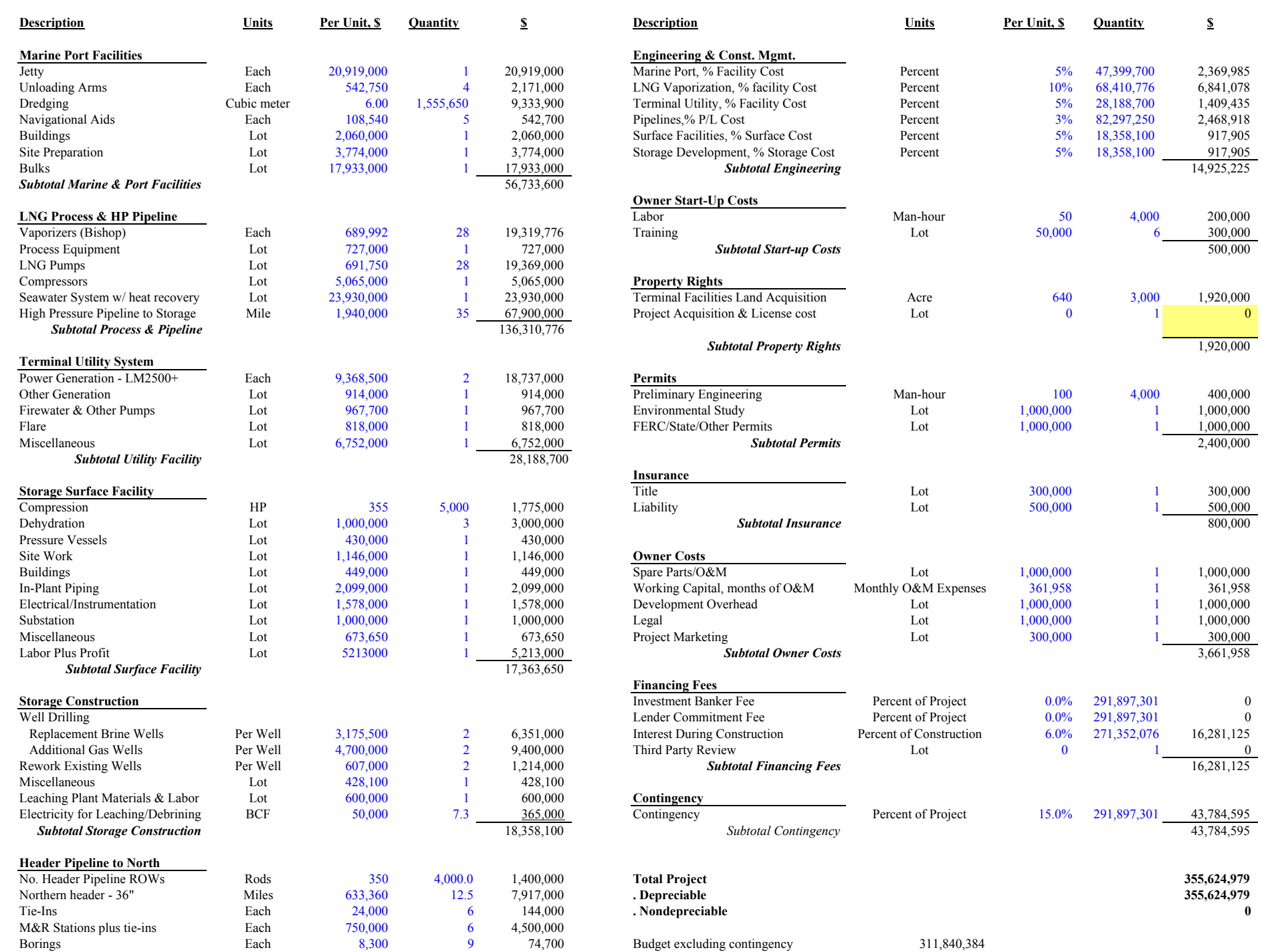


LIBERTY LNG TERMINAL

PROFORMA ECONOMICS

Doc 06 Attachment IV pg 3

Operations \& Maintenance Expenses - Year 1

\begin{tabular}{|c|c|c|c|c|}
\hline$\underline{\text { Description }}$ & $\underline{\text { Units }}$ & $\underline{\text { Per Unit }}$ & Quantity & $\underline{\text { Total Cost }}$ \\
\hline Managers & Each & 100,000 & 3 & 300,000 \\
\hline Administrative & Each & 40,000 & 2 & 80,000 \\
\hline Field Operators \& Technicians & Each & 45,000 & 14 & 630,000 \\
\hline Benefits & $\%$ of Payroll & $35 \%$ & $1,010,000$ & 353,500 \\
\hline Subtotal Labor & & & & $1,363,500$ \\
\hline Subcontractor Services & & & & \\
\hline Contract Repairs & Lot & 240,000 & 1 & 240,000 \\
\hline Contract Services & Lot & 600,000 & 1 & 600,000 \\
\hline Equipment Rental & Lot & 120,000 & 1 & 120,000 \\
\hline Computer Services & Lot & 10,000 & 1 & 10,000 \\
\hline Subtotal Subcontractor Services & & & & 970,000 \\
\hline Material \& Supplies & & & & \\
\hline Spare Parts & Lot & 160,000 & 1 & 160,000 \\
\hline Chemicals & Lot & 100,000 & 1 & 100,000 \\
\hline Plant Supplies & Lot & 140,000 & 1 & 260,000 \\
\hline Subtotal Material \& Supplies & & & & 260,000 \\
\hline
\end{tabular}

Direct Operating \& Maintenance

\begin{tabular}{ll} 
Expenses & \\
\hline Major item replacement & Lot \\
Recruiting \& Training & Lot \\
Insurance & Lot \\
Auto \& Truck Rental & Lot \\
Tools \& Equipment & Lot \\
Travel & Lot \\
Miscellaneous & Lot \\
\multicolumn{1}{c}{ Subtotal Direct Opereration \& Misc. Exp. } &
\end{tabular}

200,000
20,000
$1,300,000$
40,000
80,000
10,000
100,000

Project O\&M Total

\begin{tabular}{lr}
1 & 200,000 \\
1 & 20,000 \\
1 & $1,300,000$ \\
1 & 40,000 \\
1 & 80,000 \\
1 & 10,000 \\
1 & 100,000 \\
\cline { 2 - 2 } & $1,750,000$ \\
& \\
& $\mathbf{4 , 3 4 3 , 5 0 0}$
\end{tabular}




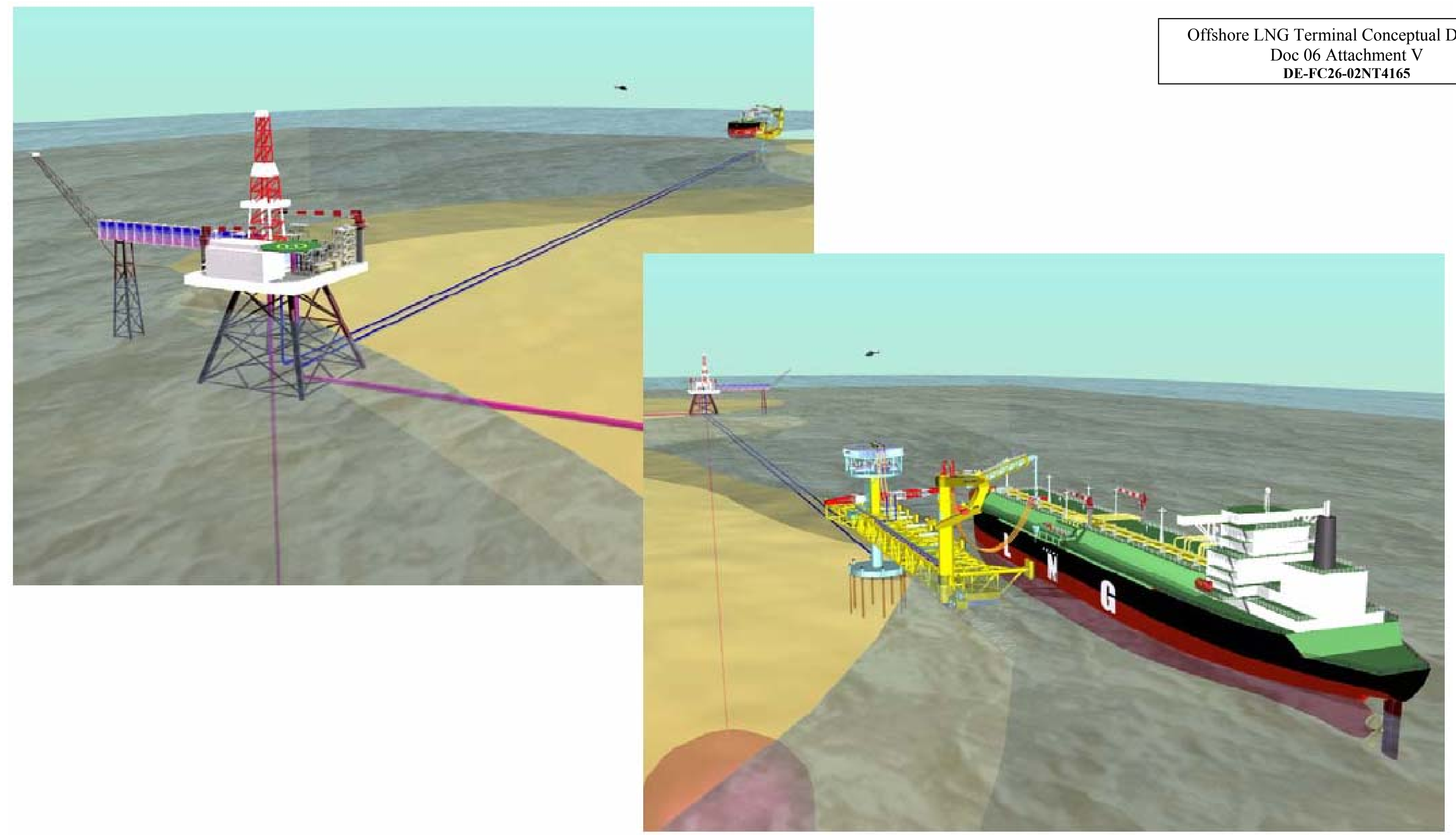

Field Lay-out for LNG Import Terminal with Salt Cavern Storage 


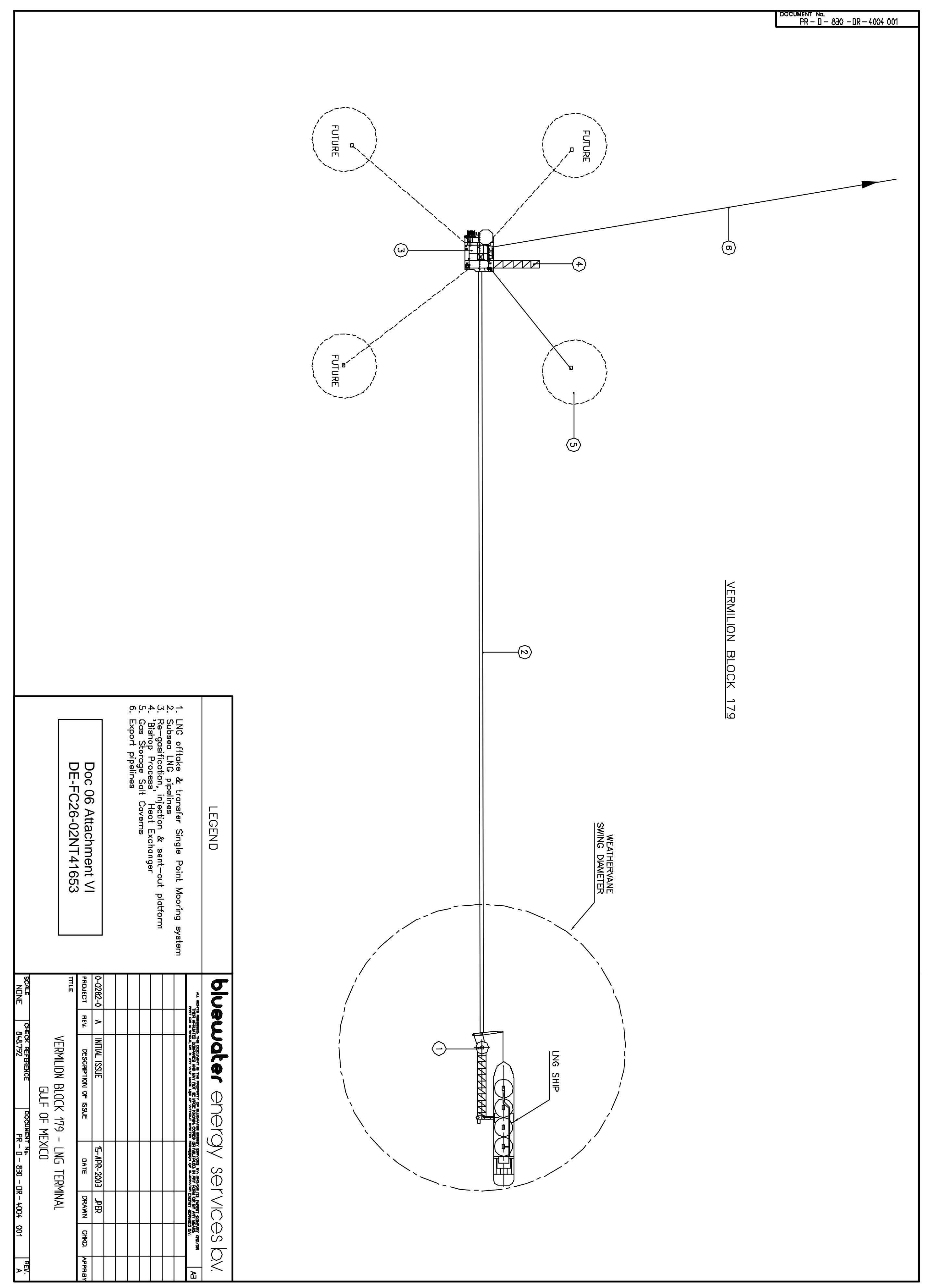




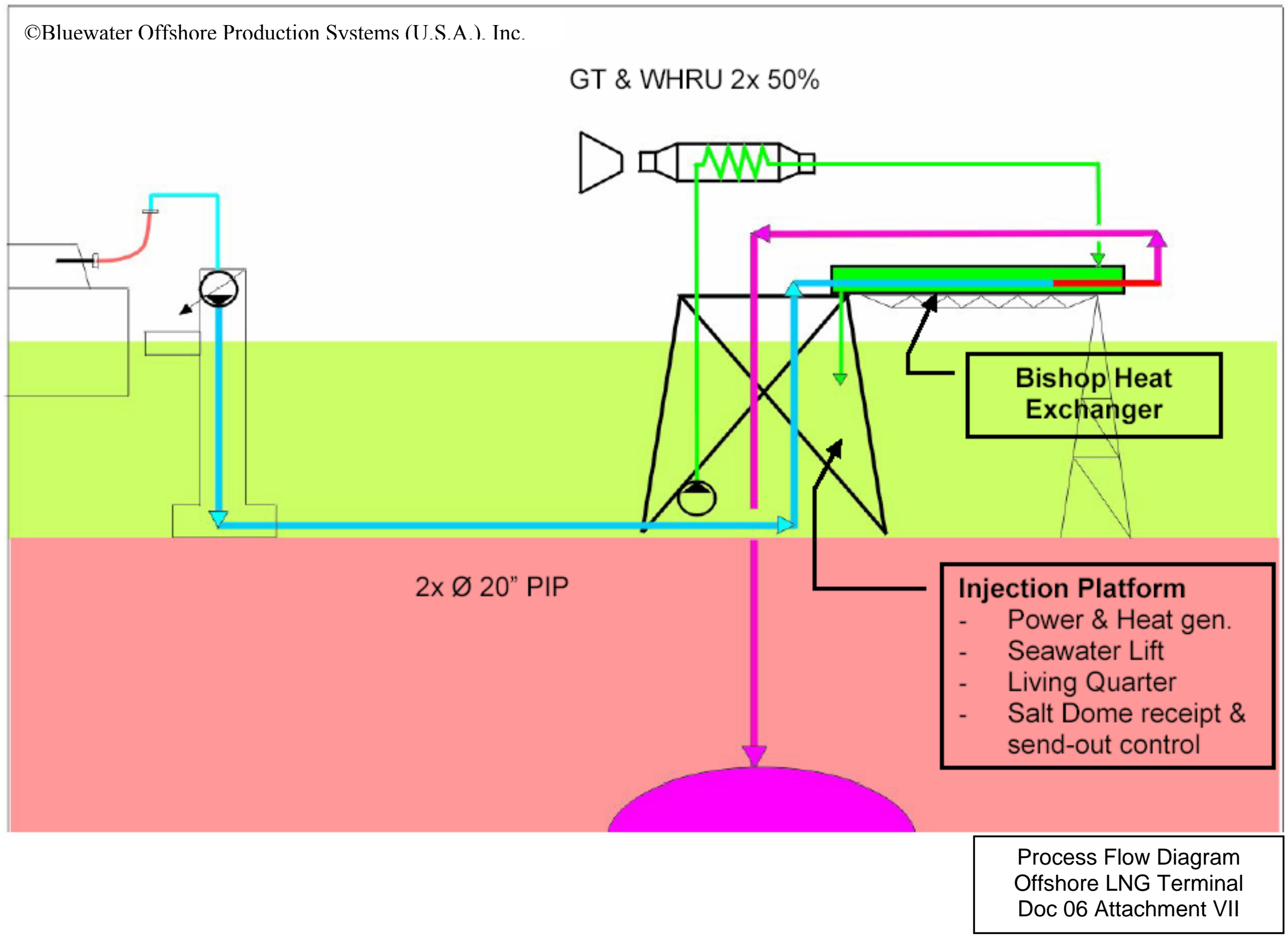




\section{BLUEWATER LNG TERMINAL \\ PROJECT SUMMARY}

Doc 06 Attachment VIII pg 1

\section{SUMMARY FACILITY ASSUMPTIONS}

\section{Facility Basis - Firm Service}

Cargos per Year

LNG Discharge per Ship, cubic meters LNG

LNG Btu content, Btu/scf

Storage Working Gas Volume, Bcf

Storage Base Gas Volume, Bcf

\section{Pricing}

\section{Throughput Fee, \$/MmBtu}

Other Revenue - \% of Terminal Throughput Rev. Terminal Energy Use Charge, \% of throughput

Assumed Henry Hub Index for initial year

Gas Storage Net Revenue Realized \$MM/year

\section{Other Assumptions}

Base Gas Price (Delivered), \$/Mcf

Base Gas Source ("Lease" or "Buy")

Total Operations Cost, \$M/Year

- Labor \& Maintenance, $\$ M / Y r$

- Electrical Demand Charge, $\$ M / Y r$

Management Overhead, \$M/Year

Property Taxes (assumed amount), \$M/Yr

Storage Site Lease Fee, $\$ M / y r$

$\%$ Revenue Stream to Inflation Protect, \%/yr

General Inflation Rate

Inflation applied to certain annual costs, \%/yr

Energy Use for Terminal ops., \% of throughput

Full storage cavern compression charge rate

$\%$ of throughput requiring compression at cavern

Project \& Technology Rights

Running Royalty, as \% of Henry Hub index

Project \& License Upfront Payment, \$MM

$0.00 \%$ based on mmBtu throughput

\section{Facility Costs, \$}

Marine Port Facilities

Terminal Utility System $\quad 28,188,700$

Storage Surface Facility $\quad 25,055,650$

Storage Construction $\quad 43,996,100$

Header Pipeline

Engineering \& Const. Mgmt.

Project Acquisition \& Tech. Rights

Owner Costs, Permits, Misc.
Financing Fees

$0.0 \%$

$0.00 \%$

$\$ 3.50$

$\$ 0.0$

Contingency

Total Facility Cost

$18,698,900$

$15,433,327$

10,000

$8,595,792$

$15,341,511$

$41,375,277$

$\mathbf{3 3 6 , 4 4 7 , 7 5 6}$

LNG Terminal Project Metrics

Load Factor (based on 240 cargos/yr max)

Reference Annual throughput, $\mathrm{mcf} / \mathrm{yr}$

Annual LNG Offloaded, BCF/yr

$96 \%$

3.50

lease

7,350

7,150

200

360

4,000

500

$100 \%$

$3.0 \%$

$1.5 \%$

$0.35 \%$

$1.25 \%$

$5 \%$

626

Daily equivalent amount (mcf/day) $\quad 1,737,997$

Tax Rates

Federal, \%/YR

$35.0 \%$

State, $\% / Y R \quad 4.50 \%$

Blended Rate, \%/Yr. $\quad 37.93 \%$

Property, \%/YR, initial year/capital cost $\quad 1.19 \%$

Capital Gain Rate for Terminal Value $\quad 20 \%$

Depreciation

Depreciation (Straight-Line or Accel) Straight-Line

Depreciable Life, Years

Project Life, Years

20
20

\section{FINANCIAL ASSUMPTIONS}

Financial Structure \% Capital

Sr. Debt Percent of Capital

$50.0 \%$

$\underline{\text { Rate }}$

Jr. Debt Percent of Capital

Equity Percent of Capital

$50.0 \%$

$0.0 \%$

Senior Debt Term

Junior Debt Term

Base Gas Lease Carrying Cost, \%/YR

FINANCIAL RESULTS

Cost of Capital

Pretax WACC

WACC

Equity Return (assumed from above)

$9.60 \%$

$15.0 \%$

Project Economics

Project NPV@Pretax WACC, \$M

140,265

Project Pretax IRR

NPV@ WACC (tax-effected), \$M

$15.1 \%$

Project IRR (tax-effected)

Yr. 1 EBITDA \$M/year

Avg. EBITDA, Yrs 1-5, \$M/year

$\$ 39,849$

$\$ 42,698$

Equity Returns, AFTER-Tax

Equity NPV@ Assumed Equity Return, \$M

Equity IRR (calculated)

Debt Coverage

Minimum EBITD

Pre-tax 
BLUEWATER LNG TERMINAL

PROJECT BUDGET

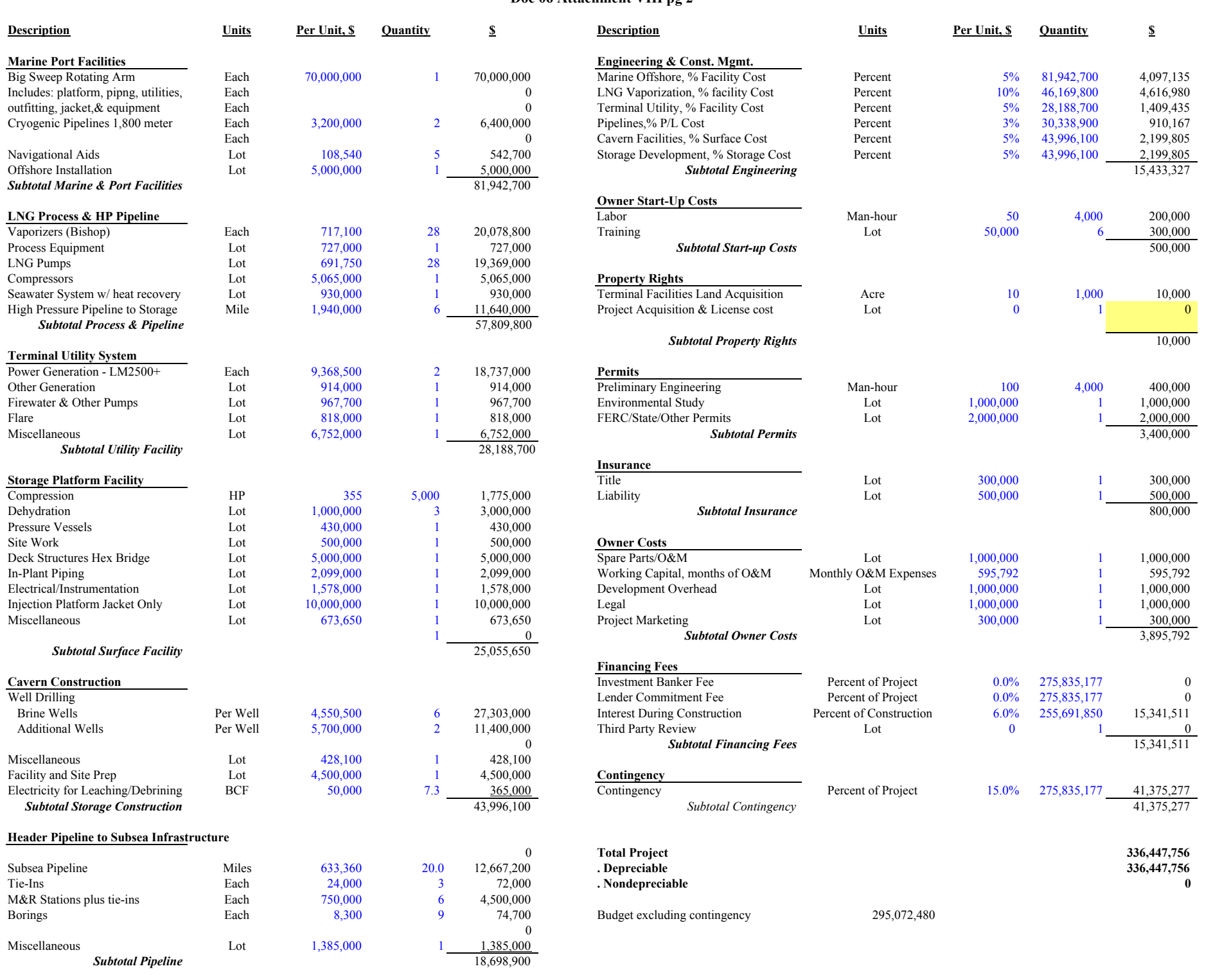




\section{BLUEWATER LNG TERMINAL \\ OPERATIONS AND MAINTENANCE EXPENSES \\ Doc 06 Attachment VIII pg 3 \\ Operations \& Maintenance Expenses - Year 1}

\begin{tabular}{|c|c|c|c|c|}
\hline$\underline{\text { Description }}$ & $\underline{\text { Units }}$ & $\underline{\text { Per Unit }}$ & Quantity & Total Cost \\
\hline Managers & Each & 100,000 & 6 & 600,00 \\
\hline Administrative & Each & 40,000 & 4 & 160,000 \\
\hline Field Operators \& Technicians & Each & 45,000 & 18 & 810,000 \\
\hline Benefits & $\%$ of Payroll & $35 \%$ & $1,570,000$ & 549,500 \\
\hline
\end{tabular}

Subcontractor Services

\begin{tabular}{ll}
\hline Contract Repairs & Lot \\
Contract Services & Lot \\
Equipment Rental & Lot \\
Computer Services & Lot
\end{tabular}

Subtotal Subcontractor Services

10,000

Material \& Supplies

\begin{tabular}{ll}
\hline Spare Parts & Lot \\
Chemicals & Lot \\
Plant Supplies & Lot
\end{tabular}

Direct Operating \& Maintenance Expenses

$\begin{array}{ll}\text { Major item replacement } & \text { Lot } \\ \text { Recruiting \& Training } & \text { Lot } \\ \text { Insurance } & \text { Lot } \\ \text { Transport Rental } & \text { Lot } \\ \text { Tools \& Equipment } & \text { Lot } \\ \text { Travel } & \text { Lot } \\ \text { Miscellaneous } & \text { Lot }\end{array}$

Miscellaneous

$\begin{array}{lc}\text { Lot } & 200,000 \\ \text { Lot } & 50,000 \\ \text { Lot } & 1,300,000 \\ \text { Lot } & 500,000 \\ \text { Lot } & 80,000 \\ \text { Lot } & 250,000 \\ \text { Lot } & 100,000\end{array}$

Subtotal Direct Opereration \& Misc. Exp.

Project O\&M Total

\section{.}




\begin{tabular}{|l|l|l|l|}
\hline Customer: & $\begin{array}{l}\text { The United States Department of Energy } \\
\text { National Energy Technology Laboratory }\end{array}$ & $\begin{array}{l}\text { Date of Issue: } \\
\text { 24 April 2003 }\end{array}$ & \\
\hline $\begin{array}{l}\text { Document } \\
\text { Title: }\end{array}$ & $\begin{array}{l}\text { Report III: Comparisons Between LNG Receiving Terminals: } \\
\text { Conventional, Salt cavern Based, and "Energy Bridge®” }\end{array}$ & $\begin{array}{l}\text { Doc \# \& Version: } \\
\text { Doc 07 r2.0 }\end{array}$ & Page 1 of 7 \\
\hline
\end{tabular}

\title{
Comparisons between LNG Receiving Terminals: Conventional, Salt cavern Based, and "Energy Bridge ${ }^{\circledR}$ "
}

\author{
BY \\ MiCHAEL M. MCCALL \\ WILLIAM M. BISHOP \\ D. BRAXTON SCHERZ
}

\begin{tabular}{|c|c|c|c|c|c|c|c|c|}
\hline r 1.0 & For client review & 02/09/03 & BS & мм & & & & \\
\hline Version & Reason for Issue & $\begin{array}{l}\text { Issue } \\
\text { Date }\end{array}$ & Orig. & $\begin{array}{l}\text { Chk. } \\
\text { CGI }\end{array}$ & Appr. & $\begin{array}{l}\text { Chk. } \\
\text { NE }\end{array}$ & $\begin{array}{l}\text { Appr. } \\
\text { TL }\end{array}$ & Review \\
\hline \multicolumn{2}{|c|}{$\begin{array}{l}\text { Document Title: } \\
\text { Comparisons Between LNG Receiving Terminals: } \\
\text { Conventional, Salt cavern Based, and "Energy } \\
\text { Bridge }{ }^{\circledR} \text { " }\end{array}$} & \multicolumn{7}{|c|}{ Document No: } \\
\hline
\end{tabular}




\section{TABLE OF CONTENTS}

1. EXECUTIVE SUMMARY ......

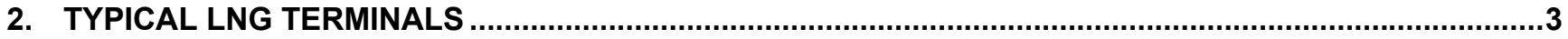

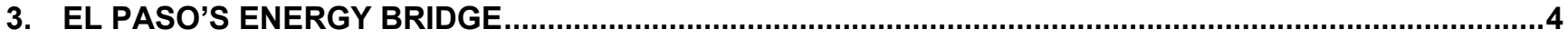

4. SUMMARY OF ESTIMATED CAPITAL, OPERATION, AND FUEL COSTS .........................................6 


\begin{tabular}{|l|l|l|l|}
\hline Customer: & $\begin{array}{l}\text { The United States Department of Energy } \\
\text { National Energy Technology Laboratory }\end{array}$ & $\begin{array}{l}\text { Date of Issue: } \\
24 \text { April 2003 }\end{array}$ & \\
\hline $\begin{array}{l}\text { Document } \\
\text { Title: }\end{array}$ & $\begin{array}{l}\text { Report III: Comparisons Between LNG Receiving Terminals: } \\
\text { Conventional, Salt cavern Based, and “Energy Bridge®” }\end{array}$ & $\begin{array}{l}\text { Doc \# \& Version: } \\
\text { Doc } 07 \text { r2.0 }\end{array}$ & Page 3 of 7 \\
\hline
\end{tabular}

\section{EXECUTIVE SUMMARY}

The technologies in the LNG industry have remained essentially unchanged over the years. "Energy Bridge," a notable exception developed by El Paso Global LNG Co., combines LNG shipping and regasification on a single ocean-going vessel. Energy Bridge because of its mobility, "zero footprint", and offloading flexibility may have advantages in markets where spot trades command higher prices. The LNG spot market continues to grow, but long term baseload LNG sales contracts have yet to be eclipsed. Whether or not Energy Bridge realizes its true competitive advantage has yet to be confirmed.

Five representative LNG terminals were evaluated to determine an indicative cost of service required to achieve a $15 \%$ IRR on each project. A summary review of the findings (Table 4.1) prepared for this Document 07, indicates that the Bishop Process Exchanger LNG terminals generate the lowest terminal fees required to achieve the $15 \%$ IRR condition. This is attributable to competitive CAPEX costs, very high sendout rates, excellent fuel efficiencies, and lower operating costs.

\section{LNG TERMINALS - FIVE CASES}

Five generally defined LNG terminals were selected for the basis of this study. There were no attempts to "equalize" the terminals by establishing a base line capacity, or any other common element that might skew the results of the matrix. Rather, each terminal is based upon an actual or proposed LNG project. The Bishop Process Onshore and Offshore terminals in this section are representative also and are not to be confused with the onshore and offshore terminals in Task 2.0. Terminals in Task 2.0 are site specific and estimated costs reflect each terminal location. Terminal send-out is a product of design, and the results of the comparisons have been based on a $100 \%$ load factor for each project and unitized on a BTU basis. Regarding El Paso's Energy Bridge ${ }^{\circledR}$, there are no provisions for a land based receiving terminal. For cost comparison purposes the estimate for an LNG vessel of $138,000 \mathrm{~m} 3$ of membrane tank design was used.

An LNG specific cost estimating model using factored analysis was chosen as a basis of the calculated results. LNG receiving terminals have many machinery items in common and the costs for these items remain common throughout the comparison. There are of course major differences in the methods used to store LNG, the design of the marine facility, and the methods used to vaporize LNG. These major differences are reflected in capital costs, fuel cost, and personnel required to staff the terminals.

For the first case, an LNG terminal located on the Pacific Coast of the Americas (North or South) was selected. Pacific coast LNG sites typically share several major design similarities including, (1) the requirement for a breakwater and a long approach trestle to protect and access the LNG berth, and (2) large LNG storage tanks to allow for adequate reserve due to the long distances from LNG supplier (Asia in most cases) to the receiving terminal. These requirements generally increase the cost of the terminal as indicated in the following tables.

An estimate of an LNG terminal located on the Atlantic coast of North America forms the basis of the second case. This terminal will serve as a baseload LNG receiving facility, and benefits from a good location directly adjacent to deep water. For this reason a short approach trestle connects the dock with the shore facility, and no breakwater is required. Storage can be optimized because there are several LNG supply terminals located within reasonable shipping distances from the receiving facility.

Cases three and four reflect LNG receiving terminals based on the use of the Bishop Process Heat Exchanger (BPT) and use salt caverns for storage. A detailed discussion of the Onshore and Offshore BPT terminal is included in Task 2.0 of this study. El Paso's Energy Bridge ${ }^{\circledR}$ concept represents the fifth case. 


\begin{tabular}{|l|l|l|l|}
\hline Customer: & $\begin{array}{l}\text { The United States Department of Energy } \\
\text { National Energy Technology Laboratory }\end{array}$ & $\begin{array}{l}\text { Date of Issue: } \\
\text { 24 April 2003 }\end{array}$ & \\
\hline $\begin{array}{l}\text { Document } \\
\text { Title: }\end{array}$ & $\begin{array}{l}\text { Report III: Comparisons Between LNG Receiving Terminals: } \\
\text { Conventional, Salt cavern Based, and "Energy Bridge }{ }^{\circledR} \text { ” }\end{array}$ & $\begin{array}{l}\text { Doc \# \& Version: } \\
\text { Doc 07 r2.0 }\end{array}$ & Page 4 of 7 \\
\hline
\end{tabular}

\section{EL PASO - ENERGY BRIDGE®}

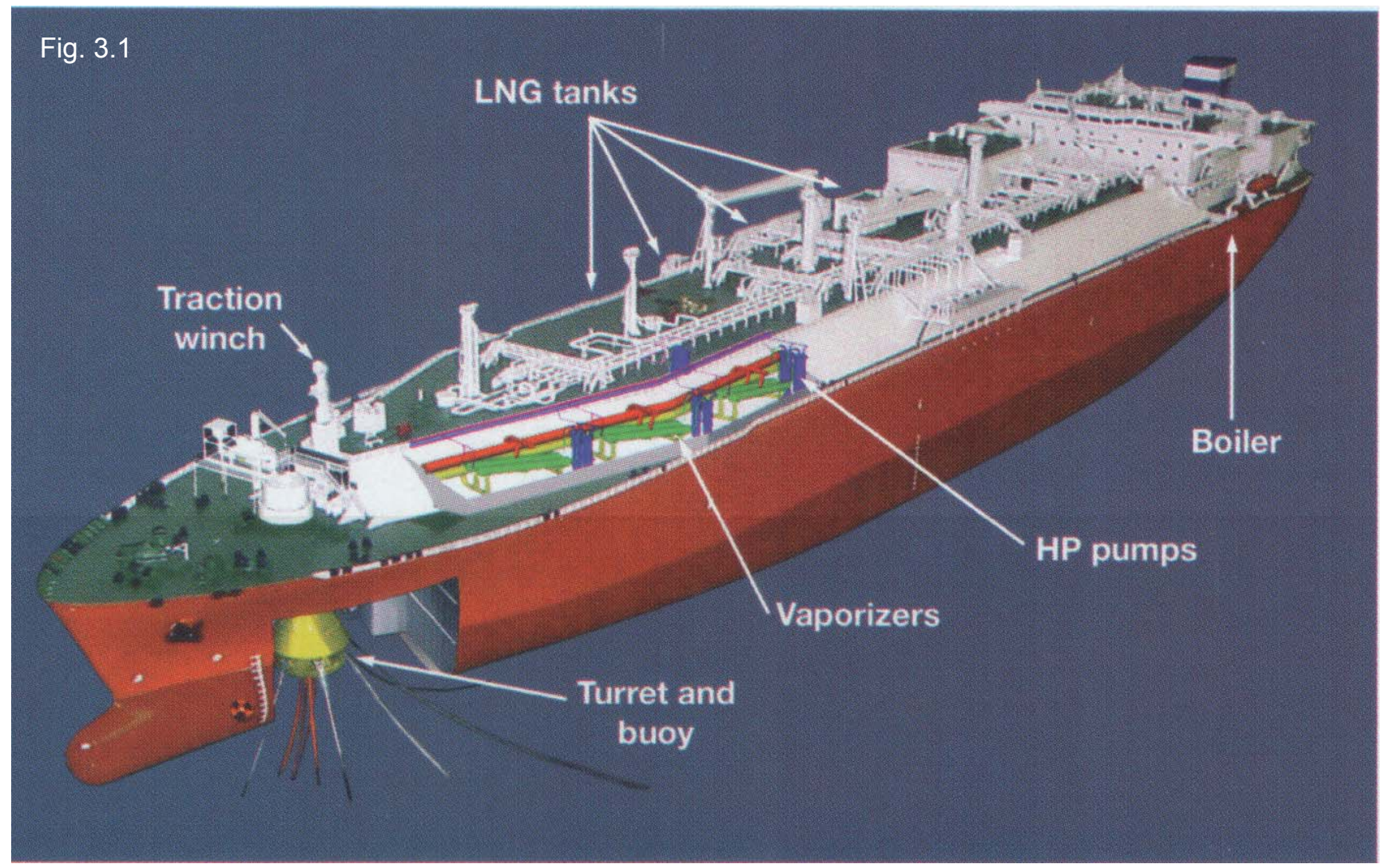

The fifth LNG terminal used in the comparison is based on El Paso's Energy Bridge concept. EL PASO'S ENERGY BRIDGE developed by EI Paso Global LNG Co., combines LNG shipping and regasification on a single ocean-going vessel. Proven technologies are employed by Energy Bridge allowing natural gas to be delivered directly to coastal markets. With this new system, scheduled gas delivery from remote regions could take place on a baseload or seasonal basis, using highly reliable offshore moorings and subsea pipelines to shore.

Figure 3.1 above is an artist's rendering of what an EPEB vessel might look like. A new ship design is not required, simply modification of an existing LNG carrier. Shown are some of the major components, such as onboard vaporizers and a view of the turret with the docking buoy attached to the receiving housing.

The EPEB inter-connection design uses the APL Submerged Turret Loading (APL) system, with a docking buoy that provides a single-point mooring system with high reliability for offshore LNG-vessel unloading. The APL system has been proven in actual conditions and under very severe conditions in the North Sea off the coast of Norway.

Connections with the APL buoy have been made in seastates over 5 meters and operational loading has taken place on seastates over 13 meters. There are currently 19 APL buoys in service, used for traditional oil and gas 


\begin{tabular}{|l|l|l|l|}
\hline Customer: & $\begin{array}{l}\text { The United States Department of Energy } \\
\text { National Energy Technology Laboratory }\end{array}$ & $\begin{array}{l}\text { Date of Issue: } \\
\text { 24 April 2003 }\end{array}$ & \\
\hline $\begin{array}{l}\text { Document } \\
\text { Title: }\end{array}$ & $\begin{array}{l}\text { Report III: Comparisons Between LNG Receiving Terminals: } \\
\text { Conventional, Salt cavern Based, and "Energy Bridge®” }\end{array}$ & $\begin{array}{l}\text { Doc \# \& Version: } \\
\text { Doc 07 r2.0 }\end{array}$ & Page 5 of 7 \\
\hline
\end{tabular}

production operation. Over 1,000 connections have been made to date in the North Sea with a $100 \%$ success rate.

EI Paso envisions a fleet of specially equipped EPEB vessels bringing LNG to market. Figure 3.2 shows the general system layout. Upon arrival in the terminal area, the EPEB ship connects to a submerged offloading system which moors the vessel and connects it to an offload pipeline. This takes place well offshore and

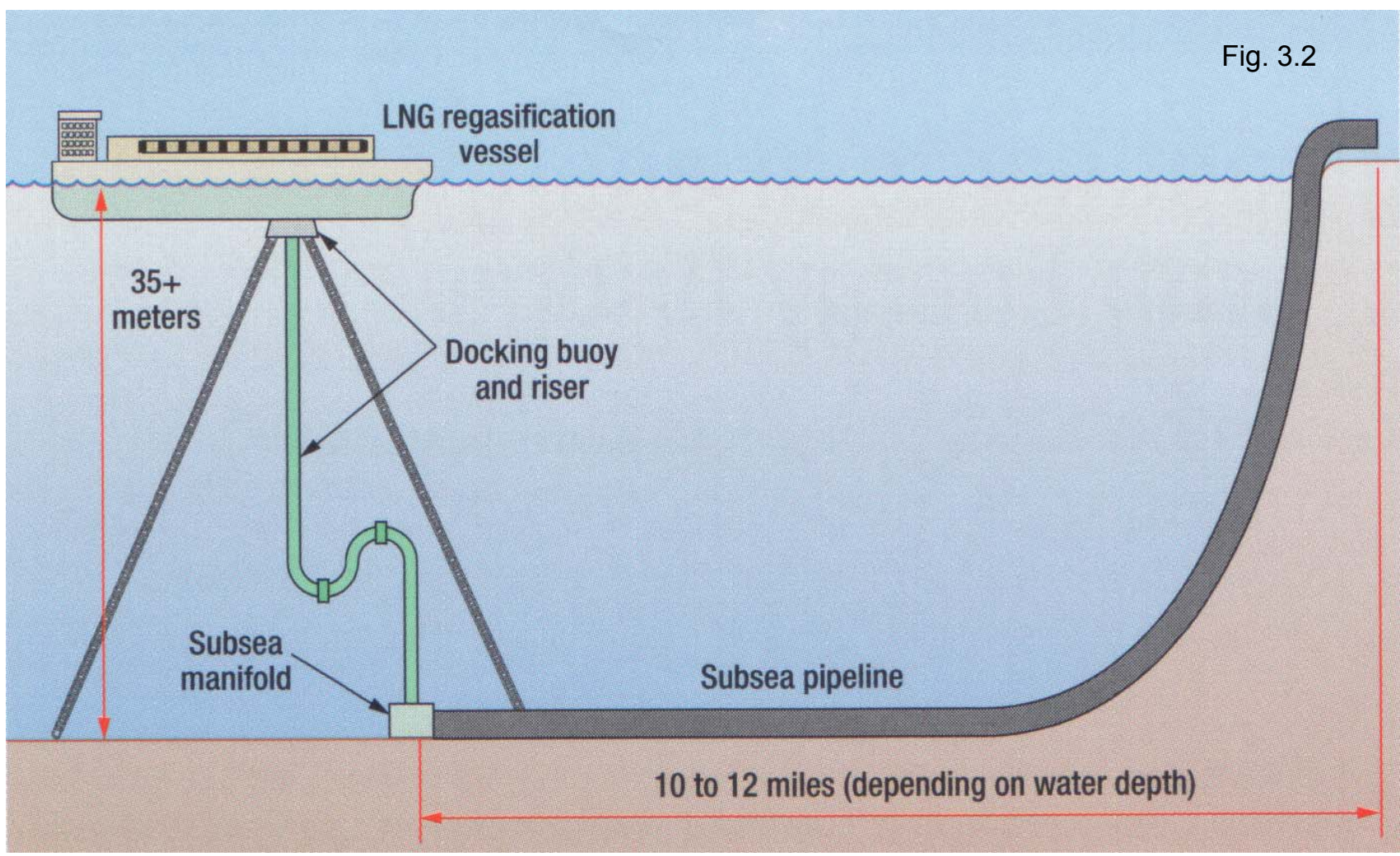

typically over the horizon. Once connected to the offload pipeline, the ship begins onboard regasification to provide safe LNG conversion to vaporous natural gas at pressures up to 1,400 psi.

Referring to Figure 3.2, the gas is sent through the offloading system and riser to a seabed pipeline that leads to an onshore customer's facility, or a nearby as transmission pipeline. At conclusion of the transfer the ship releases the offloading system to its idle position safely beneath the ocean's surface where it remains until the next ship arrives. Each 138,000 m3 tanker carries about 3 Bcf of gas and will typically off load in 7 to 10 days. At $100 \%$ load factor the vessel can discharge its cargo in about 5.5 days.

Figure 3.3 shows how the system will look when gas is being offloaded. The APL system is suitable for water depths of 35 meters to well over 100 meters. Once the ship is connected to the mooring buoy, it freely weathervanes with the wind and the current, thus mitigating much of the stress on the mooring lines and anchors. Once connected send-out to shore can occur in seas of 10 to $11 \mathrm{~m}$, providing for high reliability. The typical offshore gas installation have two offloading buoys and risers to accommodate simultaneous docking and undocking assuring continuous flow. 


\begin{tabular}{|l|l|l|l|}
\hline Customer: & $\begin{array}{l}\text { The United States Department of Energy } \\
\text { National Energy Technology Laboratory }\end{array}$ & $\begin{array}{l}\text { Date of Issue: } \\
\text { 24 April 2003 }\end{array}$ & \\
\hline $\begin{array}{l}\text { Document } \\
\text { Title: }\end{array}$ & $\begin{array}{l}\text { Report III: Comparisons Between LNG Receiving Terminals: } \\
\text { Conventional, Salt cavern Based, and "Energy Bridge }{ }^{\circledR} \text { ” }\end{array}$ & $\begin{array}{l}\text { Doc \# \& Version: } \\
\text { Doc 07 r2.0 }\end{array}$ & Page 6 of 7 \\
\hline
\end{tabular}

A detailed review of the marketing aspects of this innovative design is beyond the scope of this study. However, general reactions to Energy Bridge and its comparison to the other four LNG terminal options will be assessed in the matrix of Doc 08 of this study Task.

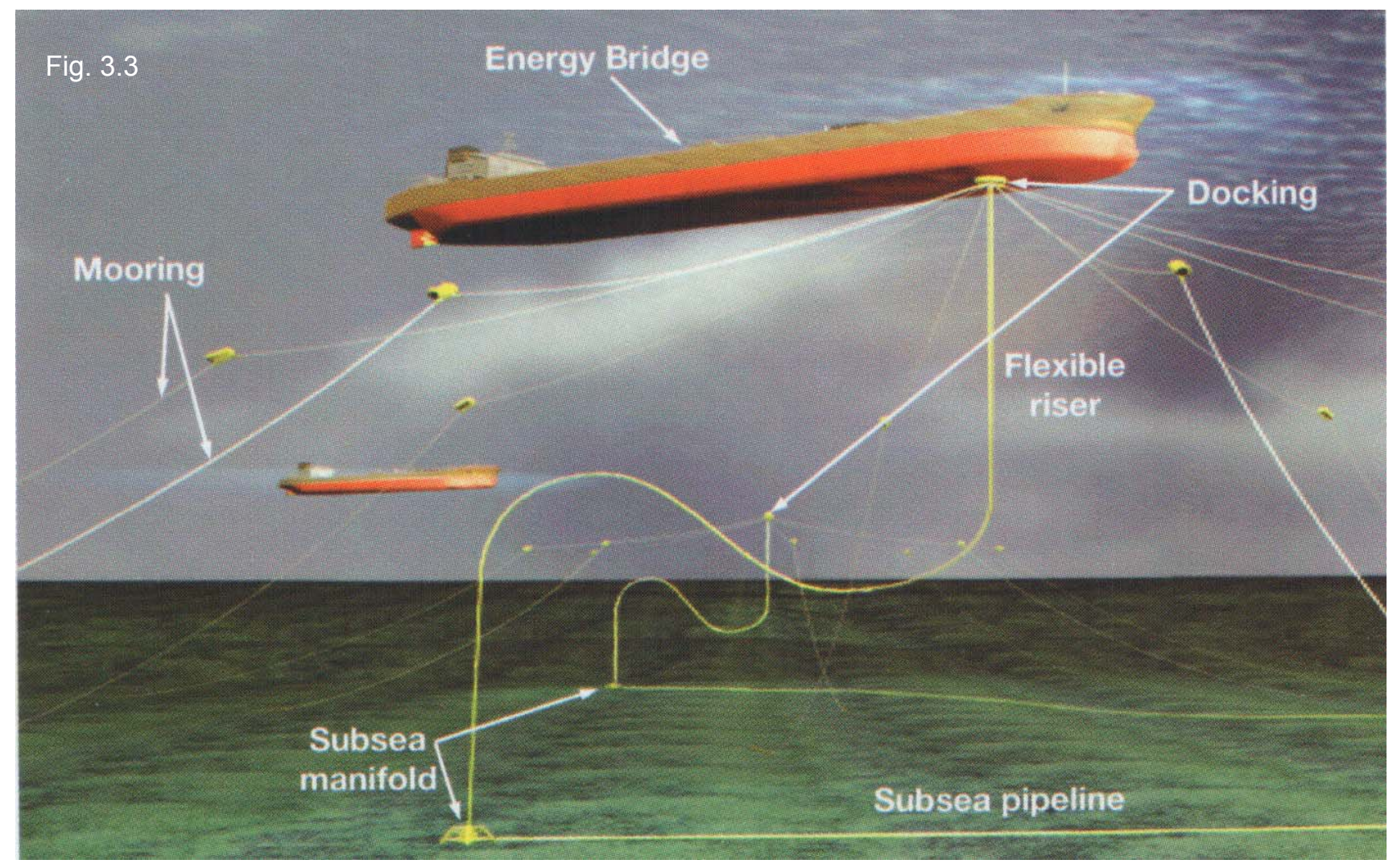

\section{SUMMARY OF LNG TERMINAL ESTIMATED CAPITAL, OPERATION, AND FUEL COSTS}

LNG terminal estimated Operating and Maintenance costs are based on historical LNG operation and maintenance data. The major engineering firms estimate OPEX costs at $1.5 \%$ of the TIC capital cost of the terminal for the first year of operation and $1 \%$ thereafter. For the purposes of this study, CGI will use that assumption for all five terminal examples and average costs over a 20 year period. The O\&M costs do not include fuel gas or imported power. The estimated fuel consumption of each terminal and fuel efficiencies have been derived from engineering studies listing the power requirements, or from fuel requirements published in existing tariffs. Table 4.1 includes a summary of all critical elements involved in the analysis, and it is understood that the results are indicative rather than actual.

As the table indicates, the BPT LNG terminals due to competitive CAPEX costs, excellent fuel efficiencies, and lower operating costs generate the lowest terminal fees required to achieve the $15 \%$ IRR condition. The equipment list used to generate the factored analysis and the summary sheet of the financial model for each terminal is included in Doc 07 Attachment I. The following document (Doc 08) includes the matrix used to summarize the advantages and disadvantages of each LNG terminal design. 


\begin{tabular}{|l|l|l|l|}
\hline Customer: & $\begin{array}{l}\text { The United States Department of Energy } \\
\text { National Energy Technology Laboratory }\end{array}$ & $\begin{array}{l}\text { Date of Issue: } \\
\text { 24 April 2003 }\end{array}$ & \\
\hline $\begin{array}{l}\text { Document } \\
\text { Title: }\end{array}$ & $\begin{array}{l}\text { Report III: Comparisons Between LNG Receiving Terminals: } \\
\text { Conventional, Salt cavern Based, and "Energy Bridge®” }\end{array}$ & $\begin{array}{l}\text { Doc \# \& Version: } \\
\text { Doc 07 r2.0 }\end{array}$ & Page 7 of 7 \\
\hline
\end{tabular}

Table 4.1 - LNG Terminal Cost Comparison

\begin{tabular}{|c|c|c|c|c|c|c|c|c|c|c|}
\hline 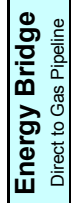 & 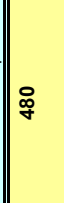 & 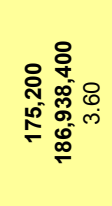 & ఫे & 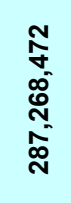 & مُ & 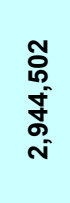 & $\begin{array}{l}8 \\
8 \\
8 \\
0 \\
\text { i. }\end{array}$ & \begin{tabular}{l}
0 \\
\multirow{0}{0}{} \\
0
\end{tabular} & ○े & ণึ \\
\hline 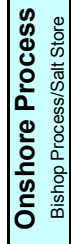 & 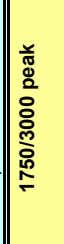 & 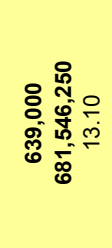 & $\stackrel{\sim}{\sim}$ & 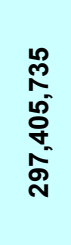 & $\underset{0}{J}$ & $\begin{array}{l}8 \\
\dot{9} \\
0 \\
0+ \\
0 \\
0 \\
0\end{array}$ & $\begin{array}{l}8 \\
0 \\
8 \\
0 \\
\infty\end{array}$ & $\stackrel{0}{0}$ & 今े & 옹 \\
\hline 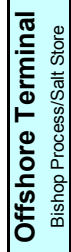 & 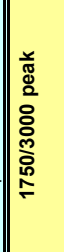 & 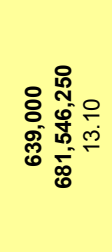 & $\stackrel{\mathscr{\sim}}{\sim}$ & 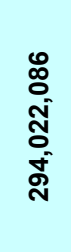 & $\stackrel{?}{0}$ & $\begin{array}{l}\stackrel{0}{N} \\
\text { m } \\
\vdots \\
\text { m }\end{array}$ & $\begin{array}{l}8 \\
8 \\
80 \\
0 \\
\infty \\
\infty\end{array}$ & $\stackrel{\hat{o}}{0}$ & 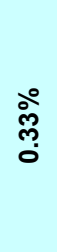 & $\begin{array}{l}\text { ¿े } \\
\text { Oे }\end{array}$ \\
\hline 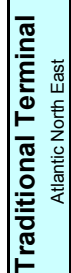 & 适 & 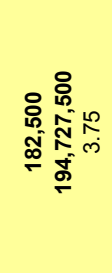 & $\hat{0}$ & 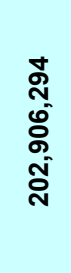 & $\stackrel{\text { ț }}{r}$ & $\begin{array}{l}\stackrel{8}{\circ} \\
o \\
0 \\
0 \\
i\end{array}$ & $\begin{array}{l}0 \\
0 \\
0 \\
0 \\
0 \\
0\end{array}$ & $\begin{array}{l}\text { \&o } \\
0\end{array}$ & 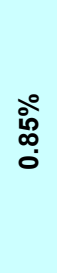 & స్ํํ \\
\hline 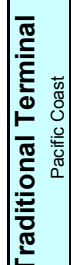 & ఃి & 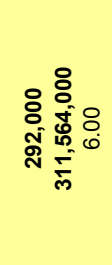 & 응 & 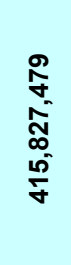 & $\stackrel{m}{\stackrel{m}{\longrightarrow}}$ & 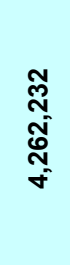 & $\begin{array}{l}\text { ठे } \\
\text { ¿ें } \\
\text { F }\end{array}$ & $\begin{array}{l}\text { டூ } \\
\text { O̊ }\end{array}$ & 今ั & 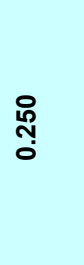 \\
\hline 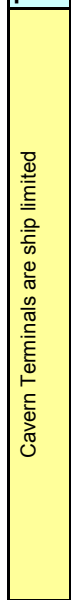 & 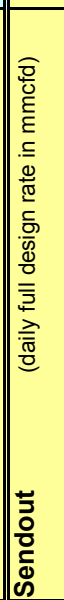 & 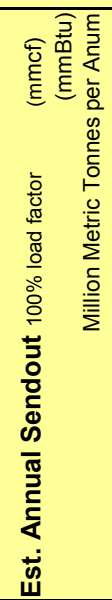 & 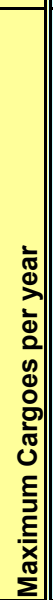 & 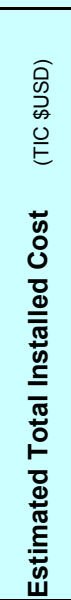 & 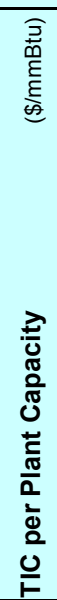 & 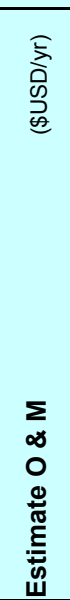 & 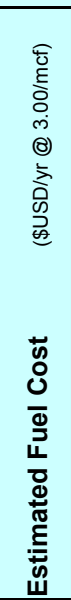 & 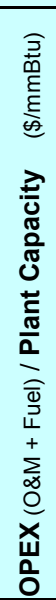 & 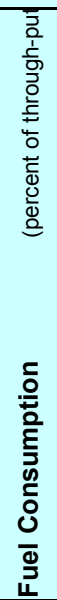 & 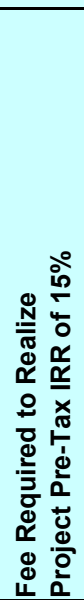 \\
\hline
\end{tabular}

Note: Table 4.1 references LNG terminals representative of geographic locations and as such do not refer specifically to the Pro-Forma estimates for the LNG Onshore and Offshore terminals presented in Task 2.0 


\section{PACIFIC COAST LNG TERMINAL \\ PROFORMA ECONOMICS}

Project Summary

\section{SUMMARY FACILITY ASSUMPTIONS}

\section{FINANCIAL ASSUMPTIONS}

\section{Facility Basis - Firm Service}

Cargos per Year

LNG Btu content, Btu/scf

Storage Working Gas Volume, Bcf

Storage Base Gas Volume, Bcf

Pricing

Throughput Fee, $\$ / \mathrm{MmBtu}$

Other Revenue - \% of Terminal Throughput Rev Terminal Energy Use Charge, \% of throughput Assumed Henry Hub Index for initial year

Gas Storage Net Revenue Realized \$MM/year

Other Assumptions

Base Gas Price (Delivered), \$/Mc

Base Gas Source ("Lease" or "Buy")

Total Operations Cost, \$M/Year

- Labor \& Maintenance, $\$ M / Y r$

- Electrical Demand Charge, $\$ \mathrm{M} / \mathrm{Yr}$

Management Overhead, \$M/Year

Property Taxes (assumed amount), \$M/Yr

Storage Site Lease Fee, \$M/yr

$\%$ Revenue Stream to Inflation Protect, \%/yr

General Inflation Rate

Inflation applied to certain annual costs, $\% / y r$

Energy Use for Terminal ops., \% of throughput

Full storage cavern compression charge rate

$\%$ of throughput requiring compression at cavern

Project \& Technology Rights

Running Royalty, as \% of Henry Hub index

Project \& License Upfront Payment, \$MM

\section{Facility Costs, $\$$}

$50,910,255$

LNG Vaporization \& Process

$74,108,000$

Terminal Utility System

Storage Surface Facility

Site Specific Misc

Header Pipeline

Engineering \& Const. Mgmt.

Project Acquisition \& Tech. Rights

Owner Costs, Permits, Misc.

Financing Fees

Contingency

Total Facility Cost

$28,288,700$

$166,070,000$

$31,423,797$

$19,674,248$

50,000

$7,191,583$

$21,048,045$

$\begin{array}{rlr}0.0 \% & \text { Financing } & 21,048,045 \\ 0.00 \% & \text { Contingency } & 56,133,750\end{array}$

$\$ 3.50$

$\$ 0.0$

\section{LNG Terminal Project Metrics}

Load Factor (based on 240 cargos/yr max) $\quad 100 \%$

Reference Annual throughput, mcf/yr 291,076,745

Annual LNG Offloaded, BCF/yr 291

Reference throughput, million mmBtu/yr $\quad 310,578,887$

Daily equivalent amount (mcf/day) 808,547

Tax Rates

Federal, \%/YR $\quad 35.0 \%$

State, $\% / Y R \quad 4.50 \%$

Blended Rate, \%/Yr. $\quad 37.93 \%$

Property, \%/YR, initial year/capital cost $\quad 0.88 \%$

Capital Gain Rate for Terminal Value $\quad 20 \%$

Depreciation

Depreciation (Straight-Line or Accel) Straight-Line

Depreciable Life, Years

Project Life, Years

20

$0.00 \%$

$00 \%$ based on mmBtu throughput 0
Financial Structure

Sr. Debt Percent of Capital

Jr. Debt Percent of Capital

Equity Percent of Capital

\% Capita

$\underline{\text { Rate }}$

Senior Debt Term

Junior Debt Term

Base Gas Lease Carrying Cost, \%/YR

$6.75 \%$
$0.0 \%$

$50.0 \% \quad 15.0 \%$

FINANCIAL RESULTS

\begin{tabular}{|lr|}
\hline & \\
Cost of Capital & \\
\hline Pretax WACC & $\mathbf{1 0 . 8 8 \%}$ \\
WACC & $\mathbf{9 . 6 0 \%}$ \\
Equity Return (assumed from above) & $\mathbf{1 5 . 0 \%}$ \\
& \\
Project Economics & $\mathbf{2 1 8 , 6 6 0}$ \\
\hline Project NPV@Pretax WACC, \$M & $\mathbf{1 5 . 7 \%}$ \\
Project Pretax IRR & $\mathbf{1 4 2 , 1 7 4}$ \\
NPV @ WACC (tax-effected), \$M & $\mathbf{1 2 . 5 \%}$ \\
Project IRR (tax-effected) & \\
& $\mathbf{\$ 5 7 , 2 4 1}$ \\
Yr. 1 EBITDA \$M/year & $\mathbf{\$ 6 1 , 0 5 9}$ \\
Avg. EBITDA, Yrs 1-5, \$M/year & \\
Equity Returns, AFTER-Tax & $\mathbf{4 1 , 8 1 6}$ \\
\hline Equity NPV@ Assumed Equity Return, \$M & $\mathbf{1 7 . 1 \%}$ \\
Equity IRR (calculated) & \\
\hline & Pre-tax \\
Debt Coverage & $\mathbf{3 . 7}$ \\
\hline Minimum EBITDA/Interest Coverage & $\mathbf{2 . 7}$ \\
\hline Minimum EBITDA/Debt Service &
\end{tabular}




\begin{tabular}{|c|c|c|c|c|c|c|c|}
\hline \multicolumn{8}{|c|}{ LNG Terminals Cost Comparison Equipment Summary Sheet } \\
\hline $\begin{array}{l}\text { Traditional Land Based Terminal } \\
\text { West Coast w/Breakwater } \\
\text { Capacity - } 0.8 \text { Bcfd } \quad \text { Description }\end{array}$ & $\begin{array}{c}\text { Bare } \\
\text { Equipment } \\
\text { Cost }(\$ M)\end{array}$ & $\begin{array}{l}\text { Steel } \\
\text { Concrete } \\
\text { I/E \& Piping } \\
\text { Cost (\$M) }\end{array}$ & $\begin{array}{l}\text { Installed } \\
\text { Direct \& } \\
\text { Indirect } \\
\text { Cost (\$M) }\end{array}$ & $\begin{array}{l}\text { Freight } \\
\text { Spares } \\
\text { Other } \\
\text { Cost }(\$ M)\end{array}$ & $\begin{array}{l}\text { Taxes } \\
\text { Duties } \\
\text { Insurance } \\
\text { Cost }(\$ M)\end{array}$ & $\begin{array}{l}\text { Contract } \\
\text { Engineering } \\
(12 \%) \\
\text { Cost }(\$ M)\end{array}$ & $\begin{array}{l}\text { Total } \\
\text { Cost } \\
\text { Cost (\$M) }\end{array}$ \\
\hline $\begin{array}{l}\text { LNG STORAGE TANK } 2 \times(160,000 \mathrm{~m} 3) 6.4 \text { Bcf } \\
\text { LNG Storage Tank Subtotal }\end{array}$ & $62,000.0$ & $\begin{array}{r}27,280.0 \\
27280\end{array}$ & $\begin{array}{r}54,684.0 \\
54684\end{array}$ & $\begin{array}{r}1,364.0 \\
1364\end{array}$ & $\begin{array}{r}1639.3 \\
1639.28\end{array}$ & $\begin{array}{r}9835.7 \\
9835.68\end{array}$ & $\begin{array}{l}94,803 \\
94,803\end{array}$ \\
\hline \multicolumn{8}{|l|}{ PROCESS VESSELS } \\
\hline Recondenser, 9'ID x 45', 304 SS & 142.0 & 85.9 & 172.2 & 15.7 & 8.1 & 48.0 & 472 \\
\hline BOG Compressor Knock Out Drum 70 m3 & 35.6 & 25.5 & 51.0 & 4.1 & 2.3 & 13.4 & 132 \\
\hline HP Fuel Gas Knock Out Drum, 3 m3 & 10.5 & 7.5 & 15.0 & 1.2 & 0.7 & 4.0 & 39 \\
\hline HP Flare Knock Out Drum, 50 m3 & 28.8 & 20.6 & 41.3 & 3.3 & 1.8 & 10.9 & 107 \\
\hline Service Water Storage Tank, $20 \mathrm{~m} 3$ & 12.2 & 8.1 & 16.1 & 1.4 & 0.7 & 4.4 & 43 \\
\hline Diesel Storage Tank, $50 \mathrm{~m} 3$ & 16.8 & 11.1 & 22.2 & 1.9 & 1.0 & 6.0 & 59 \\
\hline Foam Tank, $4 \mathrm{~m} 3$ & 6.5 & 4.3 & 8.6 & 0.7 & 0.4 & 2.3 & 23 \\
\hline Process Vessels Subtotal & 252.4 & 162.9 & 326.5 & 28.3 & 15.0 & 89.0 & 874.2 \\
\hline \multicolumn{8}{|l|}{ VAPORIZERS } \\
\hline Open Rack Vaporizers, 170 ton/hr (3 each) & 5,940 & 4,574 & 9,168 & 703.9 & 397.2 & 2361.9 & 23,145 \\
\hline Submerged Combustion Vaporizers, 170 Tons/hr (2 each) & 1,736 & 1,337 & 2,680 & 205.7 & 116.1 & 690.3 & 6,764 \\
\hline Shell \& Tube & 0 & 0 & 0 & 0.0 & 0.0 & 0.0 & 0 \\
\hline Vaporizers Subtotal & 7,676 & 5,911 & 11,848 & 910 & 513 & 3,052 & 29,909 \\
\hline \multicolumn{8}{|l|}{ HEAT EXCHANGERS } \\
\hline Standby glycol/fuel gas heater $127 \mathrm{~kW}$ & 6.1 & 4.03 & 8.07 & 0.7 & 0.4 & 2.2 & 21 \\
\hline HP knockout drum heater $20 \mathrm{~kW}$ & 0.8 & 0.53 & 1.06 & 0.1 & 0.0 & 0.3 & 3 \\
\hline Gaseous N2 Vaporizer 35 kW & 0.66 & 0.74 & 1.48 & 0.1 & 0.1 & 0.3 & 3 \\
\hline Gaseous N2 Vaporizer (Spare) 35 kW & 0.66 & 0.74 & 1.48 & 0.1 & 0.1 & 0.3 & 3 \\
\hline Liquid N2 Pressurization vaporizer 35 kW & 0.66 & 0.74 & 1.48 & 0.1 & 0.1 & 0.3 & 3 \\
\hline Liquid N2 Vaporizer $35 \mathrm{~kW}$ & 0.66 & 0.74 & 1.48 & 0.1 & 0.1 & 0.3 & 3 \\
\hline Heat Exchangers Subtotal & 9.5 & 7.5 & 15.0 & 1.1 & 0.6 & 3.8 & 37.7 \\
\hline \multicolumn{8}{|l|}{ WASTE HEAT RECOVERY } \\
\hline Waste Heat Recovery Subtotal & 0 & 0 & 0 & 0 & 0 & 0 & 0 \\
\hline \multicolumn{8}{|l|}{ PUMPS } \\
\hline First stage sendout pump, 416 m3/hr (intank) & $\$ 640$ & 668.8 & 1340.6 & 84.6 & 53.4 & 317.9 & 3,105 \\
\hline Second stage sendout pump, $325 \mathrm{~m} 3 / \mathrm{hr}$ & $\$ 825$ & 862.1 & 1728.2 & 109.1 & 68.8 & 409.8 & 4,003 \\
\hline Seawater pump, $2187 \mathrm{~m} 3 / \mathrm{hr}$ & $\$ 452$ & 472.3 & 946.8 & 59.8 & 37.7 & 224.5 & 2,193 \\
\hline Sub combustion Vap. Overflow pump, $5 \mathrm{hp}$ & 15.00 & 21.5 & 43.0 & 2.3 & 1.6 & 9.5 & 93 \\
\hline Process Area Sump Pump, $10 \mathrm{hp}, 5 \mathrm{~m} 3 / \mathrm{hr}$ & 7.10 & 10.2 & 20.4 & 1.1 & 0.8 & 4.5 & 44 \\
\hline Service Water Pump, 5 hp, $57 \mathrm{m3} / \mathrm{hr}$ & 17.40 & 24.9 & 49.9 & 2.6 & 1.9 & 11.1 & 108 \\
\hline Firewater Pumps & 203.70 & 213 & 426.7 & 26.9 & 17.0 & 101.2 & 988 \\
\hline Pumps Subtotal & $2,160.20$ & 2,273 & 4,556 & 286 & 181 & 1,079 & 10,534 \\
\hline \multicolumn{8}{|l|}{ COMPRESSORS } \\
\hline BOG Compressors & 800.00 & 440 & 882 & 86.0 & 42.9 & 254.6 & 2,506 \\
\hline Ship Vapor Return Blower & $1,000.00$ & 550 & 1102.5 & 107.5 & 53.7 & 318.3 & 3,132 \\
\hline Ship Unloading Compressor & $2,200.00$ & 1155 & 2315.3 & 233.8 & 114.7 & 680.4 & 6,699 \\
\hline Compressors Subtotal & $4,000.00$ & 2,145 & 4,300 & 427 & 211 & 1,253 & 12,337 \\
\hline \multicolumn{8}{|l|}{ SEAWATER INTAKE SYSTEM (Incl Electrochlorination) } \\
\hline Electrochlorination Unit, $12,000 \mathrm{~m} 3 / \mathrm{hr}$ & 20 & 29 & 57.33 & 3.0 & 2.1 & 12.7 & 124 \\
\hline Seawater Intake Structure $(12,000 \mathrm{~m} 3 / \mathrm{hr}$ each $)$ & 1,100 & 1150 & 2304 & 145.5 & 91.7 & 546.4 & 5,337 \\
\hline Seawater Outfall Structure $(12,000 \mathrm{~m} 3 / \mathrm{hr}$ each $)$ & 1,100 & 1755 & 3517 & 175.7 & 128.1 & 764.6 & 7,440 \\
\hline Seawater Intake Screens $(13,200 \mathrm{~m} 3 / \mathrm{hr}$ each $)$ & 400 & 858 & 1720 & 74.9 & 59.8 & 357.3 & 3,470 \\
\hline Seawater Rotary Screens $(13,200 \mathrm{~m} 3 / \mathrm{hr}$ each $)$ & 400 & 1078 & 882 & 85.9 & 47.4 & 283.2 & 2,777 \\
\hline Seawater Intake System Subtotal & 3,020 & 4,869 & 8,480 & 485 & 329 & 1,964 & 19,148 \\
\hline \multicolumn{8}{|l|}{ UTILITIES } \\
\hline HP Flare, $415,000 \mathrm{~kg} / \mathrm{hr}$ & 507 & 84 & 167.6 & 44.7 & 15.5 & 90.9 & 909 \\
\hline Electrical Switchgear \& Power Distrib ( $5 \%$ of FC) & & 2,850 & & 142.5 & 57.0 & 342.1 & 3,392 \\
\hline Emergency Generator - Diesel Driven, 500 kW & 230.0 & 63.3 & 126.8 & 21.6 & 8.5 & 50.4 & 501 \\
\hline Gas Turbine Generator, $4 \mathrm{MW}$, Centaur 50 & $4,500.0$ & 990.0 & $1,984.5$ & 409.5 & 152.2 & 896.9 & 8,933 \\
\hline Instrument air compressor and drier, $100 \mathrm{scfm}$ & 299.8 & 165.1 & 331.0 & 32.2 & 16.1 & 95.5 & 940 \\
\hline N2 Dewar for Terminal, Vac. insul. tank, $42 \mathrm{~m} 3$ & 78.0 & 60.1 & 120.4 & 9.2 & 5.2 & 31.0 & 304 \\
\hline Firewater Protection System (Foam Sys, dry powder, tanks) & 300.0 & 198.0 & 396.9 & 33.9 & 18.1 & 107.4 & 1,054 \\
\hline Utilities Subtotal & $5,914.4$ & $4,410.5$ & $3,127.1$ & 693.7 & 272.6 & $1,614.2$ & $16,032.5$ \\
\hline \multicolumn{8}{|l|}{ MARINE FACILITIES - JETTY } \\
\hline Topworks (Road/750 meter Trestle/Pipeway) & & 9,000 & 0 & 450.0 & 180.0 & 1080.0 & 10,710 \\
\hline Cryogenic Piping (I/E, piping $w /$ insulation) & & 17,050 & 0 & 0.0 & 341.0 & 2046.0 & 19,437 \\
\hline Berth (Mooring, Breasting Dolphins) & & 24,000 & 0 & $1,200.0$ & 480.0 & 2880.0 & 28,560 \\
\hline Dredging & & - & 0 & 0.0 & 0.0 & 0.0 & 0 \\
\hline Marine Facilities - Jetty Subtotal & & 50,050 & 0 & 1650 & 1001 & 6006 & 58707 \\
\hline
\end{tabular}




\begin{tabular}{|c|c|c|c|c|c|c|c|}
\hline \multicolumn{8}{|l|}{ MARINE FACILITIES - UNLOADING } \\
\hline Unloading Arms & 8,650 & 963 & 1930.6 & 740.2 & 236.1 & 1385.2 & 13,905 \\
\hline Marine Facilities - Unloading Subtotal & 8,650 & 963 & 1,931 & 740 & 236 & 1,385 & 13,905 \\
\hline BREAKWATER & 0 & 60,000 & 0 & 3,000 & 1,200 & 7,200 & 71,400 \\
\hline Breakwater Subtotal & 0 & 60,000 & 0 & 3,000 & 1,200 & 7,200 & 71,400 \\
\hline \multicolumn{8}{|l|}{ NAVIGATIONAL AIDS (lighting and buoys) } \\
\hline \multicolumn{8}{|l|}{ Navigational Aids Subtotal } \\
\hline \multicolumn{8}{|l|}{ BUILDINGS } \\
\hline Administration Office/Control Center & & 1400 & & 70.0 & 28.0 & 168.0 & 1,666 \\
\hline Compressor Building (Included in cost of compressors) & & 350 & & 17.5 & 7.0 & 42.0 & 417 \\
\hline Warehouse/Maintenance Building, 10,000 ft2 & & 525 & & 26.3 & 10.5 & 63.0 & 625 \\
\hline Buildings Subtotal & & 2275 & & 113.75 & 45.5 & 273 & 2707.25 \\
\hline SITE PREPARATION & & 2,850 & & 142.5 & 57.0 & 342.1 & 3,392 \\
\hline Site Preparation Subtotal & & 2,850 & & 143 & 57 & 342 & 3,392 \\
\hline \multicolumn{8}{|l|}{ BULKS } \\
\hline Piping (exclud. trestle) & & 12,000 & & 600.0 & 240.0 & 1440.0 & 14,280 \\
\hline Piling & & 0 & & 0.0 & 0.0 & 0.0 & 0 \\
\hline Insulation and Paint & & $\$ 7,981$ & & 399.1 & 159.6 & 957.8 & 9,498 \\
\hline Electrical/Instrumentation & & 9000 & & 450.0 & 180.0 & 1080.0 & 10,710 \\
\hline Bulks Subtotal & & 28,981 & & 1,449 & 580 & 3,478 & 34,488 \\
\hline REAL ESTATE & & 3,000 & & & & & 3,000 \\
\hline Real Estate Subtotal & & 3,000 & & & & & 3,000 \\
\hline \multicolumn{8}{|l|}{ OSBL INFRASTRUCTURE } \\
\hline \multicolumn{8}{|l|}{ Includes access roads, bldgs, hospitals, stores, bridges } \\
\hline OSBL Infrastructure Subtotal & & 0 & & & & & 0 \\
\hline UNADJUSTED GRAND TOTAL & 62,683 & 195,177 & 89,267 & 11,291 & 6,282 & 37,575 & 371,275 \\
\hline CONTINGENCY $12 \%$ OF THE TOTAL & & & & & & & 44,553 \\
\hline ADJUSTED GRAND TOTAL & & & & & & & 415,827 \\
\hline
\end{tabular}


ATLANTIC COAST LNG TERMINAL

PROFORMA ECONOMICS

Project Summary

\section{SUMMARY FACILITY ASSUMPTIONS}

\section{FINANCIAL ASSUMPTIONS}

\section{Facility Basis - Firm Service}

Cargos per Year

LNG Discharge per Ship, cubic meters LNG

LNG Btu content, Btu/scf

Storage Working Gas Volume, Bcf

Storage Base Gas Volume, Bcf

Pricing

Throughput Fee, \$/MmBtu

Other Revenue - \% of Terminal Throughput Rev.

Terminal Energy Use Charge, \% of throughput

Assumed Henry Hub Index for initial year

Gas Storage Net Revenue Realized \$MM/year

\section{Other Assumptions}

Base Gas Price (Delivered), \$/M

Base Gas Source ("Lease" or "Buy")

Total Operations Cost, \$M/Year

- Labor \& Maintenance, $\$ M / Y r$

- Electrical Demand Charge, \$M/Yr

Management Overhead, \$M/Year

Property Taxes (assumed amount), \$M/Yr

Storage Site Lease Fee, \$M/yr

$\%$ Revenue Stream to Inflation Protect, \%/yr

General Inflation Rate

Inflation applied to certain annual costs, $\% / y r$

Energy Use for Terminal ops., \% of throughput

Full storage cavern compression charge rate

$\%$ of throughput requiring compression at cavern

Project \& Technology Rights

Running Royalty, as \% of Henry Hub index

Project \& License Upfront Payment, \$MM
Facility Costs, \$

Marine Port Facilities

Terminal Utility System $\quad 28,288,700$

Storage Surface Facility $\quad 57,000,000$

Site Specific Misc $\quad 1,116,097$

Header Pipeline

Engineering \& Const. Mgmt.

Project Acquisition \& Tech. Rights $\quad 50,000$

50,000
$7,191,583$

$11,133,903$

$30,142,500$

$\begin{array}{rlr}0.0 \% & \text { Financing Fees } & 11,133,903 \\ 0.00 \% & \text { Contingency } & 30,142,500\end{array}$

$0.00 \%$

$\$ 3.50$

$\$ 0.0$

Total Facility Cost

$\mathbf{2 4 5 , 7 1 7 , 9 8 6}$

LNG Terminal Project Metrics

Load Factor (based on 240 cargos/yr max) $\quad 100 \%$

$\begin{array}{rlr}3.50 & \text { Reference Annual throughput, mcf/yr } & 182,263,008 \\ \text { buy } & \text { Annual LNG Offloaded, BCF/yr } & 182 \\ 2,499 & \text { Reference throughput, million mmBtu/yr } & 194,474,630\end{array}$

$\begin{array}{rlr}3.50 & \text { Reference Annual throughput, mcf/yr } & 182,263,008 \\ \text { buy } & \text { Annual LNG Offloaded, BCF/yr } & 182 \\ 2,499 & \text { Reference throughput, million mmBtu/yr } & 194,474,630\end{array}$

$\begin{array}{llr}2,499 & \text { Reference throughput, million mmBtu/yr } & 194,474,630 \\ 2,299 & \text { Daily equivalent amount (mcf/day) } & 506,286\end{array}$

200

Federal, \%/YR $\quad 35.0 \%$

State, $\% / Y R \quad 4.50 \%$

Blended Rate, \%/Yr. $\quad 37.93 \%$

Property, \%/YR, initial year/capital cost $\quad 1.63 \%$

Capital Gain Rate for Terminal Value $20 \%$

Depreciation

Depreciation (Straight-Line or Accel) Straight-Line

Depreciable Life, Years

20

Project Life, Years

20

$.00 \%$ based on mmBtu throughput
Financial Structure

Sr. Debt Percent of Capital

\% Capital

Jr. Debt Percent of Capital

$50.0 \%$

Equity Percent of Capital

Rate

Senior Debt Term

Junior Debt Term

Base Gas Lease Carrying Cost, \%/YR

FINANCIAL RESULTS

\begin{tabular}{|lr|}
\hline \multicolumn{1}{|l|}{ Cost of Capital } & \\
\hline Pretax WACC & $\mathbf{1 0 . 8 8 \%}$ \\
WACC & $\mathbf{9 . 6 0 \%}$ \\
Equity Return (assumed from above) & $\mathbf{1 5 . 0 \%}$ \\
& \\
Project Economics & $\mathbf{1 0 8 , 5 3 1}$ \\
Project NPV@Pretax WACC, \$M & $\mathbf{1 5 . 3 \%}$ \\
Project Pretax IRR & $\mathbf{6 9 , 9 5 9}$ \\
NPV @ WACC (tax-effected), \$M & $\mathbf{1 2 . 2 \%}$ \\
Project IRR (tax-effected) & \\
& $\mathbf{\$ 2 9 , 6 4 0}$ \\
Yr. 1 EBITDA \$M/year & $\mathbf{\$ 3 1 , 7 5 1}$ \\
Avg. EBITDA, Yrs 1-5, \$M/year & \\
Equity Returns, AFTER-Tax & $\mathbf{1 7 , 8 4 6}$ \\
\hline Equity NPV@ Assumed Equity Return, \$M & $\mathbf{1 6 . 7 \%}$ \\
Equity IRR (calculated) & \\
& Pre-tax \\
Debt Coverage & $\mathbf{3 . 6}$ \\
\hline Minimum EBITDA/Interest Coverage \\
Minimum EBITDA/Debt Service
\end{tabular}




\begin{tabular}{|c|c|c|c|c|c|c|c|}
\hline \multicolumn{8}{|c|}{ LNG Terminals Cost Comparison Equipment Summary Sheet } \\
\hline $\begin{array}{l}\text { Traditional Land Based Terminal } \\
\text { East Coast no Breakwater reqd. } \\
\text { Capacity - } 0.5 \text { Bcfd } \\
\qquad \text { Description }\end{array}$ & $\begin{array}{l}\text { Bare } \\
\text { Equipment } \\
\text { Cost }(\$ M) \\
\end{array}$ & $\begin{array}{l}\text { Steel } \\
\text { Concrete } \\
\text { I/E \& Piping } \\
\text { Cost (\$M) } \\
\end{array}$ & $\begin{array}{l}\text { Installed } \\
\text { Direct \& } \\
\text { Indirect } \\
\text { Cost (\$M) } \\
\end{array}$ & $\begin{array}{l}\text { Freight } \\
\text { Spares } \\
\text { Other } \\
\text { Cost }(\$ M) \\
\end{array}$ & $\begin{array}{c}\text { Taxes } \\
\text { Duties } \\
\text { Insurance } \\
\text { Cost }(\$ M) \\
\end{array}$ & $\begin{array}{c}\text { Contract } \\
\text { Engineering } \\
(12 \%) \\
\text { Cost }(\$ M) \\
\end{array}$ & $\begin{array}{l}\text { Total } \\
\text { Cost } \\
\text { Cost }(\$ M) \\
\end{array}$ \\
\hline LNG STORAGE TANK $2 \times(125,000 \mathrm{~m} 3) 5.0 \mathrm{Bcf}$ & $45,000.0$ & $19,800.0$ & $22,500.0$ & 990.0 & 846.0 & 5076.0 & 49,212 \\
\hline LNG Storage Tank Subtotal & & 19800 & 22500 & 990 & 846 & 5076 & 49,212 \\
\hline \multicolumn{8}{|l|}{ PROCESS VESSELS } \\
\hline Recondenser, 9'ID x 45', 304 SS & 142.0 & 85.9 & 172.2 & 15.7 & 8.1 & 48.0 & 472 \\
\hline BOG Compressor Knock Out Drum 70 m3 & 35.6 & 25.5 & 51.0 & 4.1 & 2.3 & 13.4 & 132 \\
\hline HP Fuel Gas Knock Out Drum, 3 m3 & 10.5 & 7.5 & 15.0 & 1.2 & 0.7 & 4.0 & 39 \\
\hline HP Flare Knock Out Drum, 50 m3 & 28.8 & 20.6 & 41.3 & 3.3 & 1.8 & 10.9 & 107 \\
\hline Service Water Storage Tank, $20 \mathrm{~m} 3$ & 12.2 & 8.1 & 16.1 & 1.4 & 0.7 & 4.4 & 43 \\
\hline Diesel Storage Tank, $50 \mathrm{~m} 3$ & 16.8 & 11.1 & 22.2 & 1.9 & 1.0 & 6.0 & 59 \\
\hline Foam Tank, $4 \mathrm{~m} 3$ & 6.5 & 4.3 & 8.6 & 0.7 & 0.4 & 2.3 & 23 \\
\hline Process Vessels Subtotal & 252.4 & 162.9 & 326.5 & 28.3 & 15.0 & 89.0 & 874.2 \\
\hline \multicolumn{8}{|l|}{ VAPORIZERS } \\
\hline Open Rack Vaporizers, 168 ton/hr (3 each) & 0.0 & 0.0 & 0.0 & 0.0 & 0.0 & 0.0 & 0 \\
\hline Submerged Combustion Vaporizers, 170 ton/hr ( 1 each) & 898.0 & 691.5 & $1,386.1$ & 106.4 & 60.0 & 357.1 & 3,499 \\
\hline Shell \& Tube & $1,100.0$ & 847.0 & $1,697.9$ & 130.4 & 73.6 & 437.4 & 4,286 \\
\hline Vaporizers Subtotal & 1,998 & 1,538 & 3,084 & 237 & 134 & 794 & 7,785 \\
\hline \multicolumn{8}{|l|}{ HEAT EXCHANGERS } \\
\hline Standby glycol/fuel gas heater $127 \mathrm{~kW}$ & $\$ 6$ & 4.03 & 8.07 & 0.7 & 0.4 & 2.2 & 21 \\
\hline HP knockout drum heater $20 \mathrm{~kW}$ & $\$ 1$ & 0.53 & 1.06 & 0.1 & 0.0 & 0.3 & 3 \\
\hline Gaseous N2 Vaporizer $35 \mathrm{~kW}$ & $\$ 1$ & 0.74 & 1.48 & 0.1 & 0.1 & 0.3 & 3 \\
\hline Gaseous N2 Vaporizer (Spare) 35 kW & $\$ 1$ & 0.74 & 1.48 & 0.1 & 0.1 & 0.3 & 3 \\
\hline Liquid N2 Pressurization vaporizer $35 \mathrm{~kW}$ & $\$ 1$ & 0.74 & 1.48 & 0.1 & 0.1 & 0.3 & 3 \\
\hline Liquid N2 Vaporizer $35 \mathrm{~kW}$ & $\$ 1$ & 0.74 & 1.48 & 0.1 & 0.1 & 0.3 & 3 \\
\hline Heat Exchangers Subtotal & 9.5 & 7.5 & 15.0 & 1.1 & 0.6 & 3.8 & 37.7 \\
\hline \multicolumn{8}{|l|}{ WASTE HEAT RECOVERY } \\
\hline Waste Heat Recovery Subtotal & 0 & 0 & 0 & 0 & 0 & 0 & 0 \\
\hline \multicolumn{8}{|l|}{ PUMPS } \\
\hline First stage sendout pump, 416 m3/hr (intank) & $\$ 640$ & 668.8 & 1340.6 & 84.6 & 53.4 & 317.9 & 3,105 \\
\hline Second stage sendout pump, $325 \mathrm{~m} 3 / \mathrm{hr}$ & $\$ 825$ & 862.1 & 1728.2 & 109.1 & 68.8 & 409.8 & 4,003 \\
\hline Seawater pump, $2187 \mathrm{~m} 3 / \mathrm{hr}$ & $\$ 452$ & 472.3 & 946.8 & 59.8 & 37.7 & 224.5 & 2,193 \\
\hline Sub combustion Vap. Overflow pump, 5hp & $\$ 15$ & 21.5 & 43.0 & 2.3 & 1.6 & 9.5 & 93 \\
\hline Process Area Sump Pump, $10 \mathrm{hp}, 5 \mathrm{~m} 3 / \mathrm{hr}$ & $\$ 7$ & 10.2 & 20.4 & 1.1 & 0.8 & 4.5 & 44 \\
\hline Service Water Pump, 5 hp, $57 \mathrm{m3} / \mathrm{hr}$ & $\$ 17$ & 24.9 & 49.9 & 2.6 & 1.9 & 11.1 & 108 \\
\hline Firewater Pumps & 203.70 & 213 & 426.7 & 26.9 & 17.0 & 101.2 & 988 \\
\hline Pumps Subtotal & $2,160.20$ & 2,273 & 4,556 & 286 & 181 & 1,079 & 10,534 \\
\hline \multicolumn{8}{|l|}{ COMPRESSORS } \\
\hline BOG Compressors & 800.00 & 440 & 882 & 86.0 & 42.9 & 254.6 & 2,506 \\
\hline Ship Vapor Return Blower & $1,000.00$ & 550 & 1102.5 & 107.5 & 53.7 & 318.3 & 3,132 \\
\hline Ship Unloading Compressor & $2,200.00$ & 440 & 2315.3 & 198.0 & 100.4 & 594.6 & 5,848 \\
\hline Compressors Subtotal & $4,000.00$ & 1,430 & 4,300 & 392 & 197 & 1,168 & 11,486 \\
\hline \multicolumn{8}{|l|}{ SEAWATER INTAKE SYSTEM (Incl Electrochlorination) } \\
\hline Electrochlorination Unit, $12,000 \mathrm{~m} 3 / \mathrm{hr}$ & 20 & 29 & 57.33 & 3.0 & 2.1 & 12.7 & 124 \\
\hline Seawater Intake Structure $(12,000 \mathrm{~m} 3 / \mathrm{hr}$ each $)$ & 1,100 & 1150 & 2304 & 145.5 & 91.7 & 546.4 & 5,337 \\
\hline Seawater Outfall Structure $(12,000 \mathrm{~m} 3 / \mathrm{hr}$ each) & 1,100 & 1755 & 3517 & 175.7 & 128.1 & 764.6 & 7,440 \\
\hline Seawater Intake Screens $(13,200 \mathrm{~m} 3 / \mathrm{hr}$ each $)$ & 500 & 1073 & 2150 & 93.6 & 74.7 & 446.7 & 4,337 \\
\hline Seawater Rotary Screens $(13,200 \mathrm{~m} 3 / \mathrm{hr}$ each $)$ & 500 & 1348 & 2701 & 107.4 & 91.3 & 545.8 & 5,293 \\
\hline Seawater Intake System Subtotal & 3,220 & 5,353 & 10,730 & 525 & 388 & 2,316 & 22,532 \\
\hline \multicolumn{8}{|l|}{ UTILITIES } \\
\hline HP Flare, $415,000 \mathrm{~kg} / \mathrm{hr}$ & 506.6 & 83.6 & 167.6 & 44.7 & 15.5 & 90.9 & 908.8 \\
\hline Electrical Switchgear \& Power Distrib ( $5 \%$ of FC) & & $1,908.1$ & & 95.4 & 38.2 & 229.0 & $2,270.6$ \\
\hline Emergency Generator - Diesel Driven, 500 kW & 230.0 & 63.3 & 126.8 & 21.6 & 8.5 & 50.4 & 500.5 \\
\hline Gas Turbine Generator & 0.0 & 0.0 & 0.0 & 0.0 & 0.0 & 0.0 & 0.0 \\
\hline Instrument air compressor and drier, $100 \mathrm{scfm}$ & 299.8 & 165.1 & 331.0 & 32.2 & 16.1 & 95.5 & 939.7 \\
\hline N2 Dewar for Terminal, Vac. insul. tank, $42 \mathrm{~m} 3$ & 78.0 & 60.1 & 120.4 & 9.2 & 5.2 & 31.0 & 303.9 \\
\hline Firewater Protection System (Foam Sys, dry powder, tanks) & 300.0 & 165.1 & 331.0 & 32.3 & 16.1 & 95.5 & 940.0 \\
\hline Utilities Subtotal & $1,414.4$ & $2,445.2$ & $1,076.7$ & 235.4 & 99.6 & 592.4 & $5,863.6$ \\
\hline \multicolumn{8}{|l|}{ MARINE FACILITIES - JETTY } \\
\hline Topworks (Road/150 meter Trestle/Pipeway) & & $9,000.0$ & 0.0 & 450.0 & 180.0 & $1,080.0$ & $10,710.0$ \\
\hline Cryogenic Piping (I/E, piping $w /$ insulation) & & $1,915.0$ & 0.0 & 95.8 & 38.3 & 229.8 & $2,278.9$ \\
\hline Berth (Mooring, Breasting Dolphins) & & $17,000.0$ & 0.0 & 850.0 & 340.0 & $2,040.0$ & $20,230.0$ \\
\hline Dredging & & 0.0 & 0.0 & 0.0 & 0.0 & 0.0 & 0.0 \\
\hline Marine Facilities - Jetty Subtotal & & $27,915.0$ & 0.0 & $1,395.8$ & 558.3 & $3,349.8$ & $33,218.9$ \\
\hline
\end{tabular}




\begin{tabular}{|c|c|c|c|c|c|c|c|}
\hline \multicolumn{8}{|l|}{ MARINE FACILITIES - UNLOADING } \\
\hline Unloading Arms & 0.0 & 0.0 & $1,470.0$ & 0.0 & 29.4 & 176.4 & $1,675.8$ \\
\hline Marine Facilities - Unloading Subtotal & 0.0 & 0.0 & $1,470.0$ & 0.0 & 29.4 & 176.4 & $1,675.8$ \\
\hline BREAKWATER & 0.0 & 0.0 & 0.0 & 0.0 & 0.0 & 0.0 & 0.0 \\
\hline Breakwater Subtotal & 0.0 & 0.0 & 0.0 & 0.0 & 0.0 & 0.0 & 0.0 \\
\hline \multicolumn{8}{|l|}{ NAVIGATIONAL AIDS (lighting and buoys) } \\
\hline \multicolumn{8}{|l|}{ Navigational Aids Subtotal } \\
\hline \multicolumn{8}{|l|}{ BUILDINGS } \\
\hline Administration Office/Control Center & & $1,400.0$ & & 70.0 & 28.0 & 168.0 & $1,666.0$ \\
\hline Compressor Building (Included in cost of compressors) & & 350.0 & & 17.5 & 7.0 & 42.0 & 416.5 \\
\hline Warehouse/Maintenance Building, 10,000 ft2 & & 525.0 & & 26.3 & 10.5 & 63.0 & 624.8 \\
\hline Buildings Subtotal & & $2,275.0$ & & 113.8 & 45.5 & 273.0 & $2,707.3$ \\
\hline SITE PREPARATION & & $2,850.5$ & & 142.5 & 57.0 & 342.1 & $3,392.0$ \\
\hline Site Preparation Subtotal & & $2,850.5$ & & 142.5 & 57.0 & 342.1 & $3,392.0$ \\
\hline \multicolumn{8}{|l|}{ BULKS } \\
\hline Piping (exclud. trestle) & & $12,000.0$ & & 600.0 & 240.0 & $1,440.0$ & $14,280.0$ \\
\hline Piling & & 0.0 & & 0.0 & 0.0 & 0.0 & 0.0 \\
\hline Insulation and Paint & & $5,342.7$ & & 267.1 & 106.9 & 641.1 & $6,357.8$ \\
\hline Electrical/Instrumentation & & $9,000.0$ & & 450.0 & 180.0 & $1,080.0$ & $10,710.0$ \\
\hline Bulks Subtotal & & $26,342.7$ & & $1,317.1$ & 526.9 & $3,161.1$ & $31,347.8$ \\
\hline REAL ESTATE & & 500.0 & & & & & 500.0 \\
\hline Real Estate Subtotal & & 500.0 & & & & & 500.0 \\
\hline \multicolumn{8}{|l|}{ OSBL INFRASTRUCTURE } \\
\hline \multicolumn{8}{|l|}{ Includes access roads, bldgs, hospitals, stores, bridges } \\
\hline OSBL Infrastructure Subtotal & & 0.0 & & & & & 0.0 \\
\hline UNADJUSTED GRAND TOTAL & 35,555 & 92,892 & 48,057 & 5,664 & 3,078 & 18,420 & 181,166 \\
\hline CONTINGENCY $12 \%$ OF THE TOTAL & & & & & & & 21,740 \\
\hline ADJUSTED GRAND TOTAL & & & & & & & 202,906 \\
\hline
\end{tabular}




\section{LNG ONSHORE TERMINAL WITH CAVERN STORAGE \\ PROFORMA ECONOMICS}

Project Summary

\section{SUMMARY FACILITY ASSUMPTIONS}

\section{FINANCIAL ASSUMPTIONS}

\section{Facility Basis - Firm Service}

Cargos per Year

LNG Discharge per Ship, cubic meters LNG

LNG Btu content, Btu/scf

Storage Working Gas Volume, Bcf

Storage Base Gas Volume, Bcf

Pricing

Throughput Fee, \$/MmBtu

Other Revenue - \% of Terminal Throughput Rev.

Terminal Energy Use Charge, \% of throughput

Assumed Henry Hub Index for initial year

Gas Storage Net Revenue Realized \$MM/year

\section{Other Assumptions}

Base Gas Price (Delivered), \$/Mcf

Base Gas Source ("Lease" or "Buy")

Total Operations Cost, \$M/Year

- Labor \& Maintenance, $\$ \mathrm{M} / \mathrm{Yr}$

- Electrical Demand Charge, \$M/Yr

Management Overhead, \$M/Year

Property Taxes (assumed amount), $\$ \mathrm{M} / \mathrm{Yr}$

Storage Site Lease Fee, $\$ M / y r$

$\%$ Revenue Stream to Inflation Protect, \%/yr

General Inflation Rate

Inflation applied to certain annual costs, $\% / \mathrm{yr}$

Energy Use for Terminal ops., \% of throughput

Full storage cavern compression charge rate

$\%$ of throughput requiring compression at cavern

Project \& Technology Rights

Running Royalty, as \% of Henry Hub index

Project \& License Upfront Payment, \$MM
Facility Costs, $\$$

LNG Process \& HP PIpeline

$47,118,345$

$51,374,800$

$28,288,700$

$\begin{array}{lr}\text { Terminal Utility System } & 108,000,000\end{array}$

$\begin{array}{lr}\text { Storage Surface Facility } & 108,00,000 \\ \text { Site Specific Misc } & 17,788,105\end{array}$

Header Pipeline

Engineering \& Const. Mgmt.

Project Acquisition \& Tech. Rights $\quad 50,000$

Owner Costs, Permits, Misc. 7,385,958

Financing Fees $\quad 15,154,197$
Contingency
Total Facility Cost
$\mathbf{3 1 , 2 4 2 , 5 0 0}$

LNG Terminal Project Metrics

Load Factor (based on 240 cargos/yr max) $\quad 98 \%$

Reference Annual throughput, mcf/yr $\quad 639,280,701$

Annual LNG Offloaded, BCF/yr 639

Reference throughput, million $\mathrm{mmBtu} / \mathrm{yr} \quad 682,112,508$

Daily equivalent amount (mcf/day) $\quad 1,775,780$

Tax Rates

Federal, \%/YR

$35.0 \%$

State, $\% / Y R$

Blended Rate, \%/Yr. $\quad 37.93 \%$

Property, \%/YR, initial year/capital cost $\quad 1.19 \%$

Capital Gain Rate for Terminal Value $\quad 20 \%$

Depreciation

Depreciation (Straight-Line or Accel) Straight-Line

Depreciable Life, Years

20

Project Life, Years

20

$0.00 \%$ based on mmBtu throughput
Financial Structure

Sr. Debt Percent of Capital

\% Capital

Jr. Debt Percent of Capital

$50.0 \%$

$0.0 \%$

$50.0 \%$

Rate

Equity Percent of Capital

$0.0 \%$

Senior Debt Term

Junior Debt Term

Base Gas Lease Carrying Cost, \%/YR

FINANCIAL RESULTS

\begin{tabular}{|lr|}
\hline & \\
Cost of Capital & \\
\hline Pretax WACC & $\mathbf{1 0 . 8 8 \%}$ \\
WACC & $\mathbf{9 . 6 0 \%}$ \\
Equity Return (assumed from above) & $\mathbf{1 5 . 0 \%}$ \\
& \\
Project Economics & $\mathbf{1 6 2 , 1 4 2}$ \\
\hline Project NPV@Pretax WACC, \$M & $\mathbf{1 5 . 7 \%}$ \\
Project Pretax IRR & $\mathbf{1 0 6 , 3 5 2}$ \\
NPV @ WACC (tax-effected), \$M & $\mathbf{1 2 . 5 \%}$ \\
Project IRR (tax-effected) & \\
& $\mathbf{\$ 4 1 , 6 1 8}$ \\
Yr. 1 EBITDA \$M/year & $\mathbf{\$ 4 4 , 5 7 6}$ \\
Avg. EBITDA, Yrs 1-5, \$M/year & \\
Equity Returns, AFTER-Tax & $\mathbf{3 1 , 0 0 6}$ \\
\hline Equity NPV@ Assumed Equity Return, \$M & $\mathbf{1 7 . 1 \%}$ \\
Equity IRR (calculated) & \\
\hline & Pre-tax \\
Debt Coverage & $\mathbf{3 . 7}$ \\
\hline Minimum EBITDA/Interest Coverage & $\mathbf{2 . 7}$ \\
\hline Minimum EBITDA/Debt Service &
\end{tabular}




\begin{tabular}{|c|c|c|c|c|c|c|c|}
\hline \multicolumn{8}{|c|}{ LNG Terminals Cost Comparison Equipment Summary Sheet } \\
\hline \multirow{3}{*}{$\begin{array}{l}\text { BIShop Process } \\
\text { Average capacity } 1.75 \text { Bcfd }\end{array}$} & & & Installed & Freight & Taxes & Contract & Total \\
\hline & Equipment & $\begin{array}{l}\text { Concrete } \\
\text { I/E \& Piping }\end{array}$ & $\begin{array}{l}\text { Direct \& } \\
\text { Indirect }\end{array}$ & $\begin{array}{l}\text { Spares } \\
\text { Other }\end{array}$ & $\begin{array}{l}\text { Duties } \\
\text { Insurance }\end{array}$ & $\begin{array}{l}\text { Engineering } \\
\qquad(12 \%)\end{array}$ & Cost \\
\hline & Cost (\$M) & Cost (\$M) & Cost (\$M) & Cost (\$M) & Cost (\$M) & Cost (\$M) & Cost (\$M) \\
\hline \multicolumn{2}{|l|}{ GLNG Storage Caverns: 6 ea x 2 BCF = 12 BCF $(608,000$ m3) } & 60,000 & & 3,000 & 1,200 & 3,600 & 67,800 \\
\hline \multicolumn{2}{|l|}{ Salt Cavern Storage 2 each at $15 \mathrm{BCF}$ total $30 \mathrm{BCF}$} & 60,000 & - & 3,000 & 1,200 & 3,600 & 67,800 \\
\hline \multicolumn{8}{|l|}{ PROCESS VESSELS } \\
\hline Recondenser, 9'ID x 45', 304 SS & 142.0 & 85.9 & 172.2 & 15.7 & 8.1 & 48 & 472 \\
\hline BOG Compressor Knock Out Drum 70 m3 & 35.6 & 25.5 & 51.0 & 4.1 & 2.3 & 13 & 132 \\
\hline HP Fuel Gas Knock Out Drum, 3 m3 & 10.5 & 7.5 & 15.0 & 1.2 & 0.7 & 4 & 39 \\
\hline HP Flare Knock Out Drum, 50 m3 & 28.8 & 20.6 & 41.3 & 3.3 & 1.8 & 11 & 107 \\
\hline Service Water Storage Tank, $20 \mathrm{~m} 3$ & 12.2 & 8.1 & 16.1 & 1.4 & 0.7 & 4 & 43 \\
\hline Diesel Storage Tank, $50 \mathrm{~m} 3$ & 16.8 & 11.1 & 22.2 & 1.9 & 1.0 & 6 & 59 \\
\hline Foam Tank, $4 \mathrm{~m} 3$ & 3.3 & 2.1 & 4.3 & 0.4 & 0.2 & 1 & 11 \\
\hline Process Vessels Subtotal & 249.2 & 160.7 & 322.2 & 28.0 & 14.8 & 87.9 & 862.7 \\
\hline VAPORIZERS & & & & & & & \\
\hline Open Rack Vaporizers, 168 ton/hr & 0 & 0 & 0 & 0.0 & 0.0 & - & 0 \\
\hline Submerged Combustion Vaporizers, 168 ton/hr & 0 & 0 & 0 & 0.0 & 0.0 & - & 0 \\
\hline Bishop Process & 6,020 & 3,973 & 7,964 & 680.3 & 362.8 & $1,077.5$ & 20,078 \\
\hline Vaporizers Subtotal & 6,020 & 3,973 & 7,964 & 680 & 363 & 1,077 & 20,078 \\
\hline HEAT EXCHANGERS & & & & & & & \\
\hline Standby glycol/fuel gas heater $127 \mathrm{~kW}$ & 6.1 & 4.03 & 8.1 & 0.7 & 0.4 & 2.2 & 21 \\
\hline HP knockout drum heater $20 \mathrm{~kW}$ & 0.8 & 0.53 & 1.1 & 0.1 & 0.0 & 0.3 & 3 \\
\hline Gaseous N2 Vaporizer 35 kW & 0.66 & 0.74 & 1.5 & 0.1 & 0.1 & 0.3 & 3 \\
\hline Gaseous N2 Vaporizer (Spare) 35 kW & 0.66 & 0.74 & 1.5 & 0.1 & 0.1 & 0.3 & 3 \\
\hline Liquid N2 Pressurization vaporizer $35 \mathrm{~kW}$ & 0.66 & 0.74 & 1.5 & 0.1 & 0.1 & 0.3 & 3 \\
\hline Liquid N2 Vaporizer $35 \mathrm{~kW}$ & 0.66 & 0.74 & 1.5 & 0.1 & 0.1 & 0.3 & 3 \\
\hline Heat Exchangers Subtotal & 9.5 & 7.5 & 15.0 & 1.1 & 0.6 & 3.8 & 37.7 \\
\hline WASTE HEAT RECOVERY & & & & & & & \\
\hline Waste Heat Recovery Subtotal & 0 & 0 & 0 & 0 & 0 & 0 & 0 \\
\hline PUMPS & & & & & & & \\
\hline First stage sendout pump, 416 m3/hr (intank) & 0.0 & 0.0 & 0.0 & 0.0 & 0.0 & 0.0 & 0 \\
\hline Second stage sendout pump, 28 each @270 m3/hr & 225.0 & 5386.5 & 1583.6 & 287.3 & 144.0 & 431.7 & 8,058 \\
\hline Seawater pump, $3160 \mathrm{~m} 3 / \mathrm{hr}$ & $2,100.0$ & 2194.5 & 527.9 & 277.7 & 97.7 & 289.3 & 5,487 \\
\hline Sub combustion Vap. Overflow pump, $5 \mathrm{hp}$ & 0.0 & 0.0 & 0.0 & 0.0 & 0.0 & 0.0 & 0 \\
\hline Process Area Sump Pump, $10 \mathrm{hp}, 5 \mathrm{~m} 3 / \mathrm{hr}$ & 0.0 & 0.0 & 0.0 & 0.0 & 0.0 & 0.0 & 0 \\
\hline Service Water Pump, 5 hp, 57 m3/hr & 3.6 & 0.0 & 17.4 & 0.3 & 0.4 & 2.5 & 24 \\
\hline Firewater Pumps & 203.7 & 213 & 426.7 & 26.9 & 17.0 & 101.2 & 988 \\
\hline Pumps Subtotal & $2,532.3$ & 7,794 & 2,556 & 592 & 259 & 825 & 14,558 \\
\hline COMPRESSORS & & & & & & & \\
\hline$\overline{\text { BOG Compressors }}$ & 800.0 & 264 & 529.2 & 77.2 & 32.3 & 191.2 & 1,894 \\
\hline Ship Vapor Return Unit w/Blower & $1,000.0$ & 330 & 661.5 & 96.5 & 40.4 & 239.0 & 2,367 \\
\hline Ship Unloading Compressor & 0.0 & 0 & 0.0 & 0.0 & 0.0 & 0.0 & 0 \\
\hline Compressors Subtotal & $1,800.0$ & 594 & 1,191 & 174 & 73 & 430 & 4,261 \\
\hline SEAWATER INTAKE SYSTEM (Incl Electrochlorination) & & & & & & & \\
\hline Electrochlorination Unit, $12,000 \mathrm{~m} 3 / \mathrm{hr}$ & 20 & 29 & 57.33 & 3.0 & 2.1 & 12.7 & 124 \\
\hline Seawater Intake Structure $(12,000 \mathrm{~m} 3 / \mathrm{hr}$ each) & 1,100 & 1150 & 2304 & 145.5 & 91.7 & 546.4 & 5,337 \\
\hline Seawater Outfall Structure $(12,000 \mathrm{~m} 3 / \mathrm{hr}$ each) & 1,100 & 1755 & 3517 & 175.7 & 128.1 & 764.6 & 7,440 \\
\hline Seawater Intake Screens $(13,200 \mathrm{~m} 3 / \mathrm{hr}$ each $)$ & 500 & 1073 & 2150 & 93.6 & 74.7 & 446.7 & 4,337 \\
\hline Seawater Rotary Screens $(13,200 \mathrm{~m} 3 / \mathrm{hr}$ each) & 500 & 1348 & 2701 & 107.4 & 91.3 & 545.8 & 5,293 \\
\hline Seawater Intake System Subtotal & 3,220 & 5,353 & 57.33 & 525 & 388 & 2,316 & 22,532 \\
\hline UTILITIES & & & & & & & \\
\hline HP Flare, $415,000 \mathrm{~kg} / \mathrm{hr}$ & 507 & 84 & 167.6 & 44.7 & 15.5 & 90.9 & 909 \\
\hline Electrical Switchgear \& Power Distrib ( $5 \%$ of FC) & & 3,618 & & 180.9 & 72.4 & 434.1 & 4,305 \\
\hline Emergency Generator - Diesel Driven, 500 kW & 230.0 & 63.3 & 126.8 & 21.6 & 8.5 & 50.4 & 501 \\
\hline Gas Turbine Generator, 22MW, GE LM2500 (back-up) & $11,000.0$ & $2,420.0$ & $4,851.0$ & $1,001.0$ & 372.0 & 2192.5 & 21,837 \\
\hline Instrument air compressor and drier, $100 \mathrm{scfm}$ & 299.8 & 82.4 & 165.3 & 28.1 & 11.1 & 65.7 & 652 \\
\hline N2 Dewar for Terminal, Vac. insul. tank, $42 \mathrm{~m} 3$ & 78.0 & 60.1 & 120.4 & 9.2 & 5.2 & 31.0 & 304 \\
\hline Firewater Protection System (Foam Sys, dry powder, tanks) & 300.0 & 198.0 & 396.9 & 33.9 & 18.1 & 107.4 & 1,054 \\
\hline Utilities Subtotal & $12,414.4$ & $6,525.1$ & $5,827.9$ & $1,319.4$ & 502.8 & $2,972.1$ & $29,561.7$ \\
\hline MARINE FACILITY - TRADITIONAL WHARF & & & & & & & \\
\hline Platform and topworks & & $4,500.0$ & 0.0 & 225.0 & 90.0 & 540.0 & $5,355.0$ \\
\hline Berth, walkways and dolphins & & $17,000.0$ & 0.0 & 850.0 & 340.0 & $2,040.0$ & $20,230.0$ \\
\hline & & 0.0 & 0.0 & 0.0 & 0.0 & 0.0 & 0.0 \\
\hline Dredging & & $1,400.0$ & 0.0 & 70.0 & 28.0 & 168.0 & $1,666.0$ \\
\hline Marine Facilities - Jetty Subtotal & & $22,900.0$ & 0.0 & $1,145.0$ & 458.0 & $2,748.0$ & $27,251.0$ \\
\hline
\end{tabular}




\begin{tabular}{|c|c|c|c|c|c|c|c|}
\hline \multicolumn{8}{|l|}{ UNLOADING ARMS } \\
\hline Arms: Unloading and Vapor Return & $1,960.0$ & 788.0 & $1,930.6$ & 196.2 & 94.7 & 561.4 & $5,531.0$ \\
\hline Marine Facilities - Unloading Subtotal & $1,960.0$ & 788.0 & $1,930.6$ & 196.2 & 94.7 & 561.4 & $5,531.0$ \\
\hline Piepline to Caverns 15 miles @ 1.5 mmUSD/mile & & 22,500 & & & & & 22,500 \\
\hline Pipeline Subtotal & & 22,500 & & & & & 22,500 \\
\hline \multicolumn{8}{|l|}{ NAVIGATIONAL AIDS (lighting and buoys) } \\
\hline \multicolumn{8}{|l|}{ Navigational Aids Subtotal } \\
\hline \multicolumn{8}{|l|}{ BUILDINGS } \\
\hline Administration Office/Control Center & & 850 & & 42.5 & 17.0 & 102.0 & 1,012 \\
\hline Compressor Building (Included in cost of compressors) & & 200 & & 10.0 & 4.0 & 24.0 & 238 \\
\hline Warehouse/Maintenance Building, 10,000 ft2 & & 525 & & 26.3 & 10.5 & 63.0 & 625 \\
\hline Buildings Subtotal & & 1,575 & & 78.75 & 31.5 & 189 & 1874.25 \\
\hline \multirow[t]{2}{*}{ SITE PREPARATION } & & 2,171 & & 108.5 & 43.4 & 260.5 & 2,583 \\
\hline & & 2,171 & & 109 & 43 & 260 & 2,583 \\
\hline \multicolumn{8}{|l|}{ BULKS } \\
\hline Piping (exclud. trestle) & & 19,853 & & 992.7 & 397.1 & 2382.4 & 23,625 \\
\hline Piling & & 0 & & 0.0 & 0.0 & 0.0 & 0 \\
\hline Insulation and Paint & & 9264.8 & & 463.2 & 185.3 & 1111.8 & 11,025 \\
\hline Electrical/Instrumentation & & 9000 & & 450.0 & 180.0 & 1080.0 & 10,710 \\
\hline Bulks Subtotal & & 38,118 & & 1,906 & 762 & 4,574 & 45,360 \\
\hline REAL ESTATE & & 750 & & & & & 750 \\
\hline Real Estate Subtotal & & 750 & & & & & 750 \\
\hline \multicolumn{8}{|l|}{ OSBL INFRASTRUCTURE } \\
\hline \multicolumn{8}{|l|}{ Includes access roads, bldgs, hospitals, stores, bridges } \\
\hline OSBL Infrastructure Subtotal & & 0 & & & & & 0 \\
\hline UNADJUSTED GRAND TOTAL & 28,205 & 173,209 & 25,200 & 9,754 & 4,191 & 19,645 & 265,541 \\
\hline CONTINGENCY $12 \%$ OF THE TOTAL & & & & & & & 31,865 \\
\hline ADJUSTED GRAND TOTAL & & & & & & & 297,406 \\
\hline
\end{tabular}




\section{LNG OFFSHORE TERMINAL WITH CAVERN STORAGE}

PROFORMA ECONOMICS

Project Summary

\section{SUMMARY FACILITY ASSUMPTIONS}

\section{Facility Basis - Firm Service}

Cargos per Year

LNG Discharge per Ship, cubic meters LNG

LNG Btu content, Btu/scf

Storage Working Gas Volume, Bcf

Storage Base Gas Volume, Bcf

Pricing

Throughput Fee, \$/MmBtu

Other Revenue - \% of Terminal Throughput Rev.

Terminal Energy Use Charge, \% of throughput

Assumed Henry Hub Index for initial year

Gas Storage Net Revenue Realized \$MM/year

\section{Other Assumptions}

Base Gas Price (Delivered), \$/Mcf

Base Gas Source ("Lease" or "Buy")

Total Operations Cost, \$M/Year

- Labor \& Maintenance, $\$ \mathrm{M} / \mathrm{Yr}$

- Electrical Demand Charge, \$M/Yr

Management Overhead, \$M/Year

Property Taxes (assumed amount), $\$ M / Y r$

Storage Site Lease Fee, $\$ M / y r$

$\%$ Revenue Stream to Inflation Protect, \%/yr

General Inflation Rate

Inflation applied to certain annual costs, $\% / \mathrm{yr}$

Energy Use for Terminal ops., \% of throughput

Full storage cavern compression charge rate

$\%$ of throughput requiring compression at cavern

Project \& Technology Rights

Running Royalty, as \% of Henry Hub index

Project \& License Upfront Payment, \$MM
Facility Costs, $\$$

$\begin{array}{lr}\text { Terminal Utility System } & 51,374,800\end{array}$

Storage Surface Facility $\quad 55,900,000$

Site Specific Misc $\quad-10,670,245$

Header Pipeline

Engineering \& Const. Mgmt.

Project Acquisition \& Tech. Rights $\quad 50,000$

Owner Costs, Permits, Misc. $\quad 7,653,250$

Financing Fees $\quad 15,156,957$

Contingency

Total Facility Cost $\quad 332,024,057$

LNG Terminal Project Metrics

Load Factor (based on 240 cargos/yr max) $\quad 98 \%$

Reference Annual throughput, mcf/yr $\quad 639,280,701$

Annual LNG Offloaded, BCF/yr 639

Reference throughput, million $\mathrm{mmBtu} / \mathrm{yr} \quad 682,112,508$

Daily equivalent amount (mcf/day) $\quad 1,775,780$

Tax Rates

200

360

4,000

500

$100 \%$

$3.0 \%$

$1.5 \%$

$0.35 \%$

$0.00 \%$

$0 \%$

$35.0 \%$

State, \%/YR $\quad 4.50 \%$

Blended Rate, $\% / Y r$. $\quad 37.93 \%$

Property, \%/YR, initial year/capital cost $\quad 1.20 \%$

Capital Gain Rate for Terminal Value $\quad 20 \%$

Depreciation

Depreciation (Straight-Line or Accel) Straight-Line

Depreciable Life, Years

Project Life, Years

20
20

$0.00 \%$ based on mmBtu throughput
FINANCIAL ASSUMPTIONS

Financial Structure

Sr. Debt Percent of Capital

\% Capital

Jr. Debt Percent of Capita

$50.0 \%$

Equity Percent of Capital

Rate

Senior Debt Term

Junior Debt Term

Base Gas Lease Carrying Cost, \%/YR

FINANCIAL RESULTS

\begin{tabular}{|lr|}
\hline & \\
Cost of Capital & $\mathbf{1 0 . 8 8 \%}$ \\
\hline Pretax WACC & $\mathbf{9 . 6 0 \%}$ \\
WACC & $\mathbf{1 5 . 0 \%}$ \\
Equity Return (assumed from above) & \\
& \\
Project Economics & $\mathbf{1 6 7 , 5 0 0}$ \\
\hline Project NPV@Pretax WACC, \$M & $\mathbf{1 5 . 9 \%}$ \\
Project Pretax IRR & $\mathbf{1 1 0 , 6 7 6}$ \\
NPV @ WACC (tax-effected), \$M & $\mathbf{1 2 . 7 \%}$ \\
Project IRR (tax-effected) & \\
& $\mathbf{\$ 4 1 , 8 2 1}$ \\
Yr. 1 EBITDA \$M/year & $\mathbf{\$ 4 4 , 7 9 2}$ \\
Avg. EBITDA, Yrs 1-5, \$M/year & \\
& $\mathbf{3 3 , 9 3 7}$ \\
Equity Returns, AFTER-Tax & $\mathbf{1 7 . 4 \%}$ \\
\hline Equity NPV@ Assumed Equity Return, \$M & \\
Equity IRR (calculated) & Pre-tax \\
Debt Coverage & $\mathbf{3 . 7}$ \\
\hline Minimum EBITDA/Interest Coverage & $\mathbf{2 . 7}$ \\
\hline Minimum EBITDA/Debt Service &
\end{tabular}




\begin{tabular}{|c|c|c|c|c|c|c|c|}
\hline $\begin{array}{l}\text { LNG Terminals Cost Comparison Equi } \\
\text { LNG Offshore Terminal with Salt Cavern Storage } \\
\text { Bishop Process } \\
\text { Average capacity } 1.75 \text { Bcfd }\end{array}$ & $\begin{array}{c}\text { pment S } \\
\text { Bare } \\
\text { Equipment } \\
\text { Cost (\$M) }\end{array}$ & $\begin{array}{c}\text { ammary S } \\
\text { Steel } \\
\text { Concrete } \\
\text { I/E \& Piping } \\
\text { Cost (\$M) } \\
\end{array}$ & $\begin{array}{l}\text { heet } \\
\text { Installed } \\
\text { Direct \& } \\
\text { Indirect } \\
\text { Cost (\$M) } \\
\end{array}$ & $\begin{array}{c}\text { Freight } \\
\text { Spares } \\
\text { Other } \\
\text { Cost }(\$ M) \\
\end{array}$ & $\begin{array}{c}\text { Taxes } \\
\text { Duties } \\
\text { Insurance } \\
\text { Cost }(\$ M)\end{array}$ & $\begin{array}{c}\text { Contract } \\
\text { Engineering } \\
(12 \%) \\
\text { Cost }(\$ M) \\
\end{array}$ & $\begin{array}{c}\text { Total } \\
\text { Cost } \\
\text { Cost }(\$ M)\end{array}$ \\
\hline $\begin{array}{r}\text { Salt Storage Caverns: } 6 \times 3.5 \text { BCF }=21 \text { BCF }(1,065,000 \mathrm{~m} 3) \\
\text { Salt Cavern Storage } 6 \text { each at } 3.5 \text { Bcf total } 21 \text { bcf }\end{array}$ & & $\begin{array}{l}20,000 \\
20,000\end{array}$ & $\begin{array}{l}30,000 \\
30,000\end{array}$ & $\begin{array}{l}1,000 \\
1,000\end{array}$ & $\begin{array}{l}1,000 \\
1,000\end{array}$ & $\begin{array}{l}6,000 \\
6,000\end{array}$ & $\begin{array}{l}58,000 \\
58,000\end{array}$ \\
\hline \multicolumn{8}{|l|}{ PROCESS VESSELS } \\
\hline Recondenser, 9'ID x 45', 304 SS & 142.0 & 85.9 & 172.2 & 15.7 & 8.1 & 48 & 472 \\
\hline BOG Compressor Knock Out Drum 70 m3 & 35.6 & 25.5 & 51.0 & 4.1 & 2.3 & 13 & 132 \\
\hline HP Fuel Gas Knock Out Drum, 3 m3 & 10.5 & 7.5 & 15.0 & 1.2 & 0.7 & 4 & 39 \\
\hline HP Flare Knock Out Drum, 50 m3 & 28.8 & 20.6 & 41.3 & 3.3 & 1.8 & 11 & 107 \\
\hline Service Water Storage Tank, $20 \mathrm{~m} 3$ & 12.2 & 8.1 & 16.1 & 1.4 & 0.7 & 4 & 43 \\
\hline Diesel Storage Tank, $50 \mathrm{~m} 3$ & 16.8 & 11.1 & 22.2 & 1.9 & 1.0 & 6 & 59 \\
\hline Foam Tank, $4 \mathrm{~m} 3$ & 3.3 & 2.1 & 4.3 & 0.4 & 0.2 & 1 & 11 \\
\hline Process Vessels Subtotal & 249.2 & 160.7 & 322.2 & 28.0 & 14.8 & 87.9 & 862.7 \\
\hline \multicolumn{8}{|l|}{ VAPORIZERS } \\
\hline Open Rack Vaporizers, 168 ton/hr & 0 & 0 & 0 & 0.0 & 0.0 & - & 0 \\
\hline Submerged Combustion Vaporizers, 168 ton/hr & 0 & 0 & 0 & 0.0 & 0.0 & - & 0 \\
\hline Bishop Process & 6,020 & 3,973 & 7,964 & 680.3 & 362.8 & $1,077.5$ & 20,078 \\
\hline Vaporizers Subtotal & 6,020 & 3,973 & 7,964 & 680 & 363 & 1,077 & 20,078 \\
\hline \multicolumn{8}{|l|}{ HEAT EXCHANGERS } \\
\hline Standby glycol/fuel gas heater $127 \mathrm{~kW}$ & 6.1 & 4.03 & 8.1 & 0.7 & 0.4 & 2.2 & 21 \\
\hline HP knockout drum heater $20 \mathrm{~kW}$ & 0.8 & 0.53 & 1.1 & 0.1 & 0.0 & 0.3 & 3 \\
\hline Gaseous N2 Vaporizer 35 kW & 0.66 & 0.74 & 1.5 & 0.1 & 0.1 & 0.3 & 3 \\
\hline Gaseous N2 Vaporizer (Spare) 35 kW & 0.66 & 0.74 & 1.5 & 0.1 & 0.1 & 0.3 & 3 \\
\hline Liquid N2 Pressurization vaporizer $35 \mathrm{~kW}$ & 0.66 & 0.74 & 1.5 & 0.1 & 0.1 & 0.3 & 3 \\
\hline Liquid N2 Vaporizer $35 \mathrm{~kW}$ & 0.66 & 0.74 & 1.5 & 0.1 & 0.1 & 0.3 & 3 \\
\hline Heat Exchangers Subtotal & 9.5 & 7.5 & 15.0 & 1.1 & 0.6 & 3.8 & 37.7 \\
\hline \multicolumn{8}{|l|}{ WASTE HEAT RECOVERY } \\
\hline Waste Heat Recovery Subtotal & 0 & 0 & 0 & 0 & 0 & 0 & 0 \\
\hline \multicolumn{8}{|l|}{ PUMPS } \\
\hline First stage sendout pump, 416 m3/hr (intank) & 0.0 & 0.0 & 0.0 & 0.0 & 0.0 & 0.0 & 0 \\
\hline Second stage sendout pump, 28 ea @ 270 m3/hr & $6,300.0$ & 6583.5 & 13196.9 & 833.2 & 525.4 & 1564.8 & 29,004 \\
\hline Seawater pump, $3160 \mathrm{~m} 3 / \mathrm{hr}$ & $2,100.0$ & 2194.5 & 4399.0 & 277.7 & 175.1 & 1043.2 & 10,190 \\
\hline Sub combustion Vap. Overflow pump, 5hp & 0.0 & 0.0 & 0.0 & 0.0 & 0.0 & 0.0 & 0 \\
\hline Process Area Sump Pump, $10 \mathrm{hp}, 5 \mathrm{~m} 3 / \mathrm{hr}$ & 0.0 & 0.0 & 0.0 & 0.0 & 0.0 & 0.0 & 0 \\
\hline Service Water Pump, 5 hp, $57 \mathrm{~m} 3 / \mathrm{hr}$ & 17.4 & 24.9 & 49.9 & 2.6 & 1.9 & 11.1 & 108 \\
\hline Firewater Pumps & 192.5 & 201 & 403.2 & 25.5 & 16.1 & 95.6 & 934 \\
\hline Pumps Subtotal & $8,609.9$ & 9,004 & 18,049 & 1,139 & 718 & 2,715 & 40,235 \\
\hline \multicolumn{8}{|l|}{ COMPRESSORS } \\
\hline BOG Compressors & 800.0 & 264 & 529.2 & 77.2 & 32.3 & 191.2 & 1,894 \\
\hline Ship Vapor Return Unit w/Blower & $1,000.0$ & 330 & 661.5 & 96.5 & 40.4 & 239.0 & 2,367 \\
\hline Ship Unloading Compressor & 0.0 & 0 & 0.0 & 0.0 & 0.0 & 0.0 & 0 \\
\hline Compressors Subtotal & $1,800.0$ & 594 & 1,191 & 174 & 73 & 430 & 4,261 \\
\hline \multicolumn{8}{|l|}{ SEAWATER INTAKE SYSTEM (Incl Electrochlorination) } \\
\hline Electrochlorination Unit, $12,000 \mathrm{~m} 3 / \mathrm{hr}$ & 20 & 29 & 57.33 & 3.0 & 2.1 & 6.4 & 117 \\
\hline Seawater Intake Structure $(12,000 \mathrm{~m} 3 / \mathrm{hr}$ each) & 0 & 0 & 0 & 0.0 & 0.0 & 0.0 & 0 \\
\hline Seawater Outfall Structure $(12,000 \mathrm{~m} 3 / \mathrm{hr}$ each) & 0 & 0 & 0 & 0.0 & 0.0 & 0.0 & 0 \\
\hline Seawater Intake Screens $(13,200 \mathrm{~m} 3 / \mathrm{hr}$ each $)$ & 250 & 69 & 56 & 23.4 & 7.7 & 22.5 & 429 \\
\hline Seawater Rotary Screens $(13,200 \mathrm{~m} 3 / \mathrm{hr}$ each $)$ & 250 & 69 & 56 & 23.4 & 7.7 & 22.5 & 429 \\
\hline Seawater Intake System Subtotal & 520 & 166 & 170 & 50 & 17 & 51 & 975 \\
\hline \multicolumn{8}{|l|}{ UTILITIES } \\
\hline HP Flare, $415,000 \mathrm{~kg} / \mathrm{hr}$ & 507 & 84 & 167.6 & 44.7 & 15.5 & 90.9 & 909 \\
\hline Electrical Switchgear \& Power Distrib ( $5 \%$ of FC) & & 3,001 & & 150.0 & 60.0 & 360.1 & 3,571 \\
\hline Emergency Generator - Diesel Driven, 500 kW & 115.0 & 31.6 & 63.4 & 10.8 & 4.3 & 25.2 & 250 \\
\hline Gas Turbine Generator, 32MW, GE LM2500+ & $11,000.0$ & $2,420.0$ & $4,851.0$ & $1,001.0$ & 372.0 & 2192.5 & 21,837 \\
\hline Instrument air compressor and drier, $100 \mathrm{scfm}$ & 299.8 & 82.4 & 165.3 & 28.1 & 11.1 & 65.7 & 652 \\
\hline N2 Dewar for Terminal, Vac. insul. tank, $42 \mathrm{~m} 3$ & 78.0 & 60.1 & 120.4 & 9.2 & 5.2 & 31.0 & 304 \\
\hline Firewater Protection System (Foam Sys, dry powder, tanks) & 300.0 & 198.0 & 396.9 & 33.9 & 18.1 & 107.4 & 1,054 \\
\hline Utilities Subtotal & $12,299.4$ & $5,876.7$ & $5,764.5$ & $1,277.8$ & 486.2 & $2,872.9$ & $28,577.5$ \\
\hline \multicolumn{8}{|l|}{ MARINE UNLOADING STRUCTURE } \\
\hline Platforms and Hex Bridge & & $50,000.0$ & 0.0 & $2,500.0$ & $1,000.0$ & $6,000.0$ & $59,500.0$ \\
\hline Cryogenic Piping (2 each 32" dia x L 1800 meters @ 1800 \$/m)) & & $6,480.0$ & 0.0 & 324.0 & 129.6 & 777.6 & $7,711.2$ \\
\hline Big Sweep Arm & & $5,000.0$ & 0.0 & 250.0 & 100.0 & 600.0 & $5,950.0$ \\
\hline & & 0.0 & 0.0 & 0.0 & 0.0 & 0.0 & 0.0 \\
\hline Marine Facilities - Subtotal & & $61,480.0$ & 0.0 & $3,074.0$ & $1,229.6$ & $7,377.6$ & $73,161.2$ \\
\hline
\end{tabular}




\begin{tabular}{|c|c|c|c|c|c|c|c|}
\hline \multicolumn{8}{|l|}{ MARINE UNLOADING ARMS } \\
\hline Arms: Unloading and Vapor Return & $1,500.0$ & 963.0 & $1,930.6$ & 168.2 & 88.8 & 527.2 & $5,177.8$ \\
\hline Marine Facilities - Unloading Subtotal & $1,500.0$ & 963.0 & $1,930.6$ & 168.2 & 88.8 & 527.2 & $5,177.8$ \\
\hline SUBSEA PIPELINE To Cavern (total 6 = I mile long) & & $1,120.0$ & 0.0 & 56.0 & 22.4 & 134.4 & $1,332.8$ \\
\hline To existing subsea infrastructure ( 5 miles to tie in & & $3,500.0$ & 0.0 & 175.0 & 70.0 & 420.0 & $4,165.0$ \\
\hline Pipeline Subtotal & & $4,620.0$ & 0.0 & 231.0 & 92.4 & 554.4 & $5,497.8$ \\
\hline \multicolumn{8}{|l|}{ NAVIGATIONAL AIDS (lighting and buoys) } \\
\hline \multicolumn{8}{|l|}{ MODULAR STRUCTURES } \\
\hline Administration Office/Control Center & & 500.0 & & 25.0 & 10.0 & 30.0 & 565.0 \\
\hline Compressor Building (Included in cost of compressors) & & 0.0 & & 0.0 & 0.0 & 0.0 & 0.0 \\
\hline Warehouse/Maintenance Building, 10,000 ft2 & & 0.0 & & 0.0 & 0.0 & 0.0 & 0.0 \\
\hline Buildings Subtotal & & 500.0 & & 25.0 & 10.0 & 30.0 & 565.0 \\
\hline SITE PREPARATION & & 0.0 & & 0.0 & 0.0 & 0.0 & 0.0 \\
\hline Site Preparation Subtotal & & 0.0 & & 0.0 & 0.0 & 0.0 & 0.0 \\
\hline \multicolumn{8}{|l|}{ BULKS } \\
\hline Piling & & 0 & & 0.0 & 0.0 & 0.0 & 0 \\
\hline Insulation and Paint & & 4201.4 & & 210.1 & 84.0 & 252.1 & 4,748 \\
\hline Electrical/Instrumentation & & 9000 & & 450.0 & 180.0 & 540.0 & 10,170 \\
\hline Bulks Subtotal & & 22,204 & & 1,110 & 444 & 1,332 & 25,091 \\
\hline REAL ESTATE & & 0 & & & & & 0 \\
\hline Real Estate Subtotal & & 0 & & & & & 0 \\
\hline \\
\hline OSBL Infrastructure Subtotal & & 0 & & & & & 0 \\
\hline UNADJUSTED GRAND TOTAL & 31,008 & 129,550 & 65,406 & 8,958 & 4,538 & 23,060 & 262,520 \\
\hline CONTINGENCY $12 \%$ OF THE TOTAL & & & & & & & 31,502 \\
\hline ADJUSTED GRAND TOTAL & & & & & & & 294,022 \\
\hline
\end{tabular}


Energy Bridge ${ }^{\circledR}$ LNG TERMINAL

PROFORMA ECONOMICS

Project Summary

\section{SUMMARY FACILITY ASSUMPTIONS}

\section{FINANCIAL ASSUMPTIONS}

\section{Facility Basis - Firm Service}

Cargos per Year

LNG Discharge per Ship, cubic meters LNG

LNG Btu content, Btu/scf

Storage Working Gas Volume, Bcf

Storage Base Gas Volume, Bcf

Pricing

Throughput Fee, \$/MmBtu

Other Revenue - \% of Terminal Throughput Rev.

Terminal Energy Use Charge, \% of throughput

Assumed Henry Hub Index for initial year

Gas Storage Net Revenue Realized \$MM/year

65
138,000
1067
16.00
7.30

\section{Other Assumptions}

Base Gas Price (Delivered), \$/Mcf

Base Gas Source ("Lease" or "Buy")

Total Operations Cost, $\$ M / Y e a r$

- Labor \& Maintenance, $\$ M / Y r$

- Electrical Demand Charge, \$M/Yr

Management Overhead, \$M/Year

Property Taxes (assumed amount), \$M/Yr

Storage Site Lease Fee, $\$ M / y r$

$\%$ Revenue Stream to Inflation Protect, \%/yr

General Inflation Rate

Inflation applied to certain annual costs, $\% / \mathrm{yr}$

Energy Use for Terminal ops., \% of throughput

Full storage cavern compression charge rate

$\%$ of throughput requiring compression at cavern

Project \& Technology Rights

Running Royalty, as \% of Henry Hub index

Project \& License Upfront Payment, \$MM

200

360

4,000

500

$100 \%$

$3.0 \%$

$1.5 \%$

$1.00 \%$

$0.00 \%$

$0 \%$
Facility Costs, $\$$

Marine Port Facilities

\begin{tabular}{ll}
$19,981,000$ \\
\hline
\end{tabular}

Storage Surfe

$175,000,000$

Site Specific Misc $\quad 3,640,466$

Header Pipeline

Engineering \& Const. Mgmt.

Project Acquisition \& Tech. Rights $\quad 50,000$

Owner Costs, Permits, Misc. 7,653,250

Financing Fees $\quad 13,421,313$

Total Facility Cost 292,730,563

LNG Terminal Project Metrics

Load Factor (based on 65 cargos/yr max) $\quad 100 \%$

Reference Annual throughput, mcf/yr 176,822,322

Annual LNG Offloaded, BCF/yr 177

Reference throughput, million mmBtu/yr $\quad 188,669,417$

Daily equivalent amount (mcf/day) 491,173

Tax Rates

$35.0 \%$

$4.50 \%$

Blended Rate, \%/Yr. $\quad 37.93 \%$

Property, \%/YR, initial year/capital cost $\quad 1.37 \%$

Capital Gain Rate for Terminal Value $20 \%$

Depreciation

Depreciation (Straight-Line or Accel) Straight-Line

Depreciable Life, Years

Project Life, Years

20
20

$0.00 \%$ based on mmBtu throughput
Financial Structure

Sr. Debt Percent of Capital

\% Capital

$50.0 \%$

Jr. Debt Percent of Capital

$0.0 \%$

$50.0 \%$

Rate

Equity Percent of Capital

20

Senior Debt Term

Junior Debt Term

Base Gas Lease Carrying Cost, \%/YR

FINANCIAL RESULTS

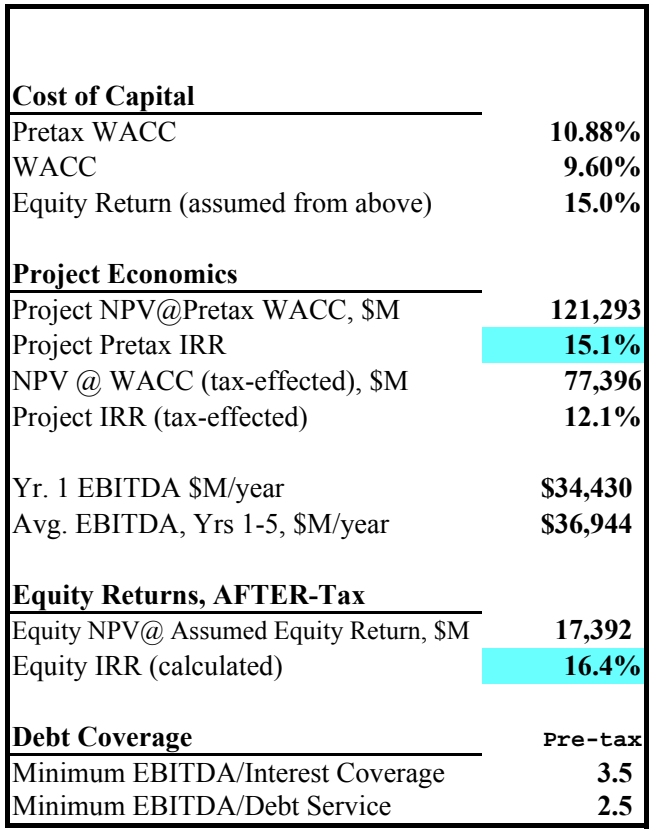




\begin{tabular}{|c|c|c|c|c|c|c|c|}
\hline \multicolumn{8}{|c|}{ LNG Terminals Cost Comparison Equipment Summary Sheet } \\
\hline \multirow{3}{*}{$\begin{array}{l}\text { Shipboard Regasification } \\
\text { Capacity } 0.48 \text { Bcfd }\end{array}$} & \multirow{3}{*}{$\begin{array}{c}\text { Bare } \\
\text { Equipment } \\
\text { Cost (\$M) }\end{array}$} & \multirow{3}{*}{$\begin{array}{l}\text { Steel } \\
\text { Concrete } \\
\text { I/E \& Piping } \\
\text { Cost (\$M) }\end{array}$} & \multirow{3}{*}{$\begin{array}{l}\text { Installed } \\
\text { Direct \& } \\
\text { Indirect } \\
\text { Cost (\$M) }\end{array}$} & \multirow{3}{*}{$\begin{array}{l}\text { Freight } \\
\text { Spares } \\
\text { Other } \\
\text { Cost }(\$ M) \\
\end{array}$} & \multirow{3}{*}{$\begin{array}{c}\text { Taxes } \\
\text { Duties } \\
\text { Insurance } \\
\text { Cost }(\$ M)\end{array}$} & \multirow{3}{*}{$\begin{array}{c}\text { Contract } \\
\text { Engineering } \\
(12 \%) \\
\text { Cost }(\$ M)\end{array}$} & \multirow{3}{*}{$\begin{array}{c}\text { Total } \\
\text { Cost } \\
\text { Cost (\$M) }\end{array}$} \\
\hline & & & & & & & \\
\hline & & & & & & & \\
\hline GLNG Storage Caverns: 2 ea $\times 3$ BCF $=6$ BCF $(304,400$ m3) & & - & - & - & - & - & - \\
\hline LNG Storage Tank Subtotal - NA - & & - & - & NA & - & - & - \\
\hline \multicolumn{8}{|l|}{ PROCESS VESSELS } \\
\hline Recondenser, 9'ID x 45', 304 SS & 0.0 & 0.0 & 0.0 & 0.0 & 0.0 & - & 0 \\
\hline BOG Compressor Knock Out Drum 70 m3 & 0.0 & 0.0 & 0.0 & 0.0 & 0.0 & - & 0 \\
\hline HP Fuel Gas Knock Out Drum, 3 m3 & 0.0 & 0.0 & 0.0 & 0.0 & 0.0 & - & 0 \\
\hline HP Flare Knock Out Drum, 50 m3 & 0.0 & 0.0 & 0.0 & 0.0 & 0.0 & - & 0 \\
\hline Service Water Storage Tank, $20 \mathrm{~m} 3$ & 0.0 & 0.0 & 0.0 & 0.0 & 0.0 & - & 0 \\
\hline Diesel Storage Tank, $50 \mathrm{~m} 3$ & 0.0 & 0.0 & 0.0 & 0.0 & 0.0 & - & 0 \\
\hline Foam Tank, $4 \mathrm{~m} 3$ & 0.0 & 0.0 & 0.0 & 0.0 & 0.0 & - & 0 \\
\hline Process Vessels Subtotal & 0.0 & 0.0 & 0.0 & 0.0 & 0.0 & 0.0 & 0.0 \\
\hline \multicolumn{8}{|l|}{ VAPORIZERS } \\
\hline Shell and TubeVaporizers, 168 ton/hr & 1,200 & 924 & 1,852 & 142.2 & 80.2 & 477 & 4,676 \\
\hline Submerged Combustion Vaporizers, $168 \mathrm{ton} / \mathrm{hr}$ & 0 & 0 & 0 & 0.0 & 0.0 & - & 0 \\
\hline Bishop Process & 0 & 0 & 0 & 0.0 & 0.0 & - & 0 \\
\hline Vaporizers Subtotal & 1,200 & 924 & 1,852 & 142 & 80 & 477 & 4,676 \\
\hline HEAT EXCHANGERS & & & & & & & \\
\hline Standby glycol/fuel gas heater $127 \mathrm{~kW}$ & 0 & 0.00 & 0.0 & 0.0 & 0.0 & - & 0 \\
\hline HP knockout drum heater $20 \mathrm{~kW}$ & 0 & 0.00 & 0.0 & 0.0 & 0.0 & - & 0 \\
\hline Gaseous N2 Vaporizer 35 kW & 0 & 0.00 & 0.0 & 0.0 & 0.0 & - & 0 \\
\hline Gaseous N2 Vaporizer (Spare) 35 kW & 0 & 0.00 & 0.0 & 0.0 & 0.0 & - & 0 \\
\hline Liquid N2 Pressurization vaporizer $35 \mathrm{~kW}$ & 0 & 0.00 & 0.0 & 0.0 & 0.0 & - & 0 \\
\hline Liquid N2 Vaporizer $35 \mathrm{~kW}$ & 0 & 0.00 & 0.0 & 0.0 & 0.0 & - & 0 \\
\hline Heat Exchangers Subtotal & 0.0 & 0.0 & 0.0 & 0.0 & 0.0 & 0.0 & 0.0 \\
\hline WASTE HEAT RECOVERY & & & & & & & \\
\hline Waste Heat Recovery Subtotal & 0 & 0 & 0 & 0 & 0 & 0 & $\mathrm{c}$ \\
\hline PUMPS & & & & & & & \\
\hline First stage sendout pump, 416 m3/hr (intank) & 0.0 & 0.0 & 0.0 & 0.0 & 0.0 & - & 0 \\
\hline Second stage sendout pump, $325 \mathrm{~m} 3 / \mathrm{hr}$ & $1,800.0$ & 1881.0 & 3770.6 & 238.1 & 150.1 & 894.2 & 8,734 \\
\hline Seawater pump, $2187 \mathrm{~m} 3 / \mathrm{hr}$ & 0.0 & 0.0 & 0.0 & 0.0 & 0.0 & - & 0 \\
\hline Sub combustion Vap. Overflow pump, 5hp & 0.0 & 0.0 & 0.0 & 0.0 & 0.0 & - & 0 \\
\hline Process Area Sump Pump, $10 \mathrm{hp}, 5 \mathrm{~m} 3 / \mathrm{hr}$ & 0.0 & 0.0 & 0.0 & 0.0 & 0.0 & - & 0 \\
\hline Service Water Pump, $5 \mathrm{hp}, 57 \mathrm{~m} 3 / \mathrm{hr}$ & 17.4 & 24.9 & 49.9 & 2.6 & 1.9 & 11.1 & 108 \\
\hline Firewater Pumps & 0.0 & 0 & 0.0 & 0.0 & 0.0 & - & 0 \\
\hline Pumps Subtotal & $1,817.4$ & 1,906 & 3,820 & 241 & 152 & 905 & 8,842 \\
\hline COMPRESSORS & & & & & & & \\
\hline BOG Compressors & 0.0 & 0 & 0 & 0.0 & 0.0 & - & 0 \\
\hline Ship Vapor Return Unit w/Blower & 0.0 & 0 & 0 & 0.0 & 0.0 & - & 0 \\
\hline Ship Unloading Compressor & 0.0 & 0 & 0.0 & 0.0 & 0.0 & - & 0 \\
\hline Compressors Subtotal & 0.0 & 0 & 0 & 0 & 0 & 0 & 0 \\
\hline SEAWATER INTAKE SYSTEM (Incl Electrochlorination) & & & & & & & \\
\hline Electrochlorination Unit, $12,000 \mathrm{m3} / \mathrm{hr}$ & 0 & 0 & 0 & 0.0 & 0.0 & - & 0 \\
\hline Seawater Intake Structure $(12,000 \mathrm{~m} 3 / \mathrm{hr}$ each) & 0 & 0 & 0 & 0.0 & 0.0 & - & 0 \\
\hline Seawater Outfall Structure $(12,000 \mathrm{~m} 3 / \mathrm{hr}$ each) & 0 & 0 & 0 & 0.0 & 0.0 & - & 0 \\
\hline Seawater Intake Screens $(13,200 \mathrm{~m} 3 / \mathrm{hr}$ each $)$ & 0 & 0 & 0 & 0.0 & 0.0 & - & 0 \\
\hline Seawater Rotary Screens $(13,200 \mathrm{~m} 3 / \mathrm{hr}$ each) & 0 & 0 & 0 & 0.0 & 0.0 & - & 0 \\
\hline Seawater Intake System Subtotal & 0 & 0 & 57.33 & 0 & 0 & 0 & 0 \\
\hline UTILITIES & & & & & & & \\
\hline HP Flare, $415,000 \mathrm{~kg} / \mathrm{hr}$ & 0 & 0 & 0.0 & 0.0 & 0.0 & - & 0 \\
\hline Electrical Switchgear \& Power Distrib ( $5 \%$ of FC) & & 429 & & 21.4 & 8.6 & 51.4 & 510 \\
\hline Emergency Generator - Diesel Driven, 500 kW & 0.0 & 0.0 & 0.0 & 0.0 & 0.0 & - & 0 \\
\hline Gas Turbine Generator, $22 \mathrm{MW}, \mathrm{GE}$ LM2500 & 0.0 & 0.0 & 0.0 & 0.0 & 0.0 & - & 0 \\
\hline Instrument air compressor and drier, $100 \mathrm{scfm}$ & 149.9 & 41.2 & 82.6 & 14.1 & 5.6 & 32.9 & 326 \\
\hline N2 Dewar for Terminal, Vac. insul. tank, $42 \mathrm{~m} 3$ & 78.0 & 60.1 & 120.4 & 9.2 & 5.2 & 31.0 & 304 \\
\hline Firewater Protection System (Foam Sys, dry powder, tanks) & 0.0 & 0.0 & 0.0 & 0.0 & 0.0 & - & 0 \\
\hline Utilities Subtotal & 227.9 & 530.0 & 203.0 & 44.7 & 19.4 & 115.3 & $1,140.3$ \\
\hline Offshore Platform and APL Subsea Installation & & & & & & & \\
\hline APL Buoy & & 12000 & & 600.0 & 240.0 & $1,440.0$ & 14,280 \\
\hline Pipeline to Plem 1 mile @ 2.3 mmUSD & & 2300 & & 115.0 & 46.0 & 276.0 & 2,737 \\
\hline Plem & & 0 & & 0.0 & 0.0 & - & 0 \\
\hline Turret, riser, moorings, and installation (EP supplied) & & 9000.0 & & 450.0 & 180.0 & $1,080.0$ & 10,710 \\
\hline Marine Facilities - Platform Subtotal & & 23300 & & 1165 & 466 & 2796 & 27727.0 \\
\hline
\end{tabular}




\begin{tabular}{|c|c|c|c|c|c|c|c|}
\hline \multicolumn{8}{|l|}{ MARINE FACILITIES - UNLOADING } \\
\hline Arms: Unloading and Vapor Return & $175,000.0$ & 0.0 & 0.0 & $14,000.0$ & $3,605.0$ & $10,500.0$ & $203,105.0$ \\
\hline Marine Facilities - Unloading Subtotal & $175,000.0$ & 0.0 & 0.0 & $14,000.0$ & $3,605.0$ & $10,500.0$ & $203,105.0$ \\
\hline SUBSEA PIPELINE To Cavern Platform (2 pipes 1 mile) & & 0.0 & & 0.0 & 0.0 & 0.0 & 0.0 \\
\hline To existing subsea infrastructure (11 miles) & & $2,000.0$ & & 100.0 & 40.0 & 240.0 & $2,380.0$ \\
\hline Pipeline Subtotal & & $2,000.0$ & & 100.0 & 40.0 & 240.0 & $2,380.0$ \\
\hline \multicolumn{8}{|l|}{ NAVIGATIONAL AIDS (lighting and buoys) } \\
\hline \multicolumn{8}{|l|}{ MODULAR STRUCTURES } \\
\hline Administration Office/Control Center & & 100 & & 5.0 & 2.0 & 12.0 & 119 \\
\hline Compressor Building (Included in cost of compressors) & & - & & 0.0 & 0.0 & - & 0 \\
\hline Warehouse/Maintenance Building, 10,000 ft2 & & - & & 0.0 & 0.0 & - & 0 \\
\hline Buildings Subtotal & & 100 & & 5 & 2 & 12 & 119 \\
\hline SITE PREPARATION & & 257 & & 12.9 & 5.1 & 30.9 & 306 \\
\hline Site Preparation Subtotal & & 257 & & 13 & 5 & 31 & 306 \\
\hline \multicolumn{8}{|l|}{ BULKS } \\
\hline Piping (exclud. trestle) & & 1,286 & & 64.3 & 25.7 & 154.3 & 1,531 \\
\hline Piling & & 0 & & 0.0 & 0.0 & 0.0 & 0 \\
\hline Insulation and Paint & & 600.2 & & 30.0 & 12.0 & 72.0 & 714 \\
\hline Electrical/Instrumentation & & 5000 & & 250.0 & 100.0 & 600.0 & 5,950 \\
\hline Bulks Subtotal & & 6,886 & & 344 & 138 & 826 & 8,195 \\
\hline REAL ESTATE & & 0.0 & & & & & 0 \\
\hline Real Estate Subtotal & & 0 & & & & & 0 \\
\hline \multicolumn{8}{|l|}{ OSBL INFRASTRUCTURE } \\
\hline \multicolumn{8}{|l|}{ Includes access roads, bldgs, hospitals, stores, bridges } \\
\hline OSBL Infrastructure Subtotal & & 0 & & & & & 0 \\
\hline UNADJUSTED GRAND TOTAL & 178,245 & 35,904 & 5,904 & 16,055 & 4,507 & 15,903 & 256,490 \\
\hline CONTINGENCY $12 \%$ OF THE TOTAL & & & & & & & 30,779 \\
\hline ADJUSTED GRAND TOTAL & & & & & & & 287,268 \\
\hline
\end{tabular}




\begin{tabular}{|l|l|l|l|}
\hline Customer: & $\begin{array}{l}\text { The United States Department of Energy } \\
\text { National Energy Technology Laboratory }\end{array}$ & $\begin{array}{l}\text { Date of Issue: } \\
24 / 04 / 2003\end{array}$ & \\
\hline $\begin{array}{l}\text { Document } \\
\text { Title: }\end{array}$ & Task 3 Doc 08: Matrix for Comparison of Five LNG Terminal Designs & $\begin{array}{l}\text { Doc \# \& Version: } \\
\text { Doc } 08 \text { r1.0 }\end{array}$ & Page 1 of 4 \\
\hline
\end{tabular}

\title{
Matrix for Comparison of Five LNG Terminal Designs
}

\author{
BY \\ Michael M. MCCALL \\ WILLIAM M. BISHOP \\ D. BRAXTON SCHERZ
}

\begin{tabular}{|c|c|c|c|c|c|c|c|c|}
\hline r 1.0 & For client review & 02/09/03 & BS & мм & & & & \\
\hline Version & Reason for Issue & $\begin{array}{l}\text { Issue } \\
\text { Date }\end{array}$ & Orig. & $\begin{array}{l}\text { Chk. } \\
\text { CGI }\end{array}$ & Appr. & $\begin{array}{l}\text { Chk. } \\
\text { NE }\end{array}$ & $\begin{array}{l}\text { Appr. } \\
\text { TTL }\end{array}$ & Review \\
\hline \multicolumn{2}{|c|}{$\begin{array}{l}\text { Document Title: } \\
\text { Matrix for Comparison of Five LNG Terminal } \\
\text { Designs }\end{array}$} & \multicolumn{7}{|c|}{ Document No: } \\
\hline
\end{tabular}




\begin{tabular}{|l|l|l|l|}
\hline Customer: & $\begin{array}{l}\text { The United States Department of Energy } \\
\text { National Energy Technology Laboratory }\end{array}$ & $\begin{array}{l}\text { Date of Issue: } \\
24 / 04 / 2003\end{array}$ & \\
\hline $\begin{array}{l}\text { Document } \\
\text { Title: }\end{array}$ & Task 3 Doc 08: Matrix for Comparison of Five LNG Terminal Designs & $\begin{array}{l}\text { Doc \# \& Version: } \\
\text { Doc } 08 \text { r1.0 }\end{array}$ & Page 2 of 4 \\
\hline
\end{tabular}

\section{TABLE OF CONTENTS}

1. MATRIX FOR COMPARISON PURPOSES... 


\begin{tabular}{|l|l|l|l|}
\hline Customer: & $\begin{array}{l}\text { The United States Department of Energy } \\
\text { National Energy Technology Laboratory }\end{array}$ & $\begin{array}{l}\text { Date of Issue: } \\
\mathbf{2 4 / 0 4 / 2 0 0 3}\end{array}$ \\
\hline $\begin{array}{l}\text { Document } \\
\text { Title: }\end{array}$ & Task 3 Doc 08: Matrix for Comparison of Five LNG Terminal Designs & $\begin{array}{l}\text { Doc \# \& Version: } \\
\text { Doc 08 r1.0 }\end{array}$ & Page 3 of 4 \\
\hline
\end{tabular}

\section{MATRIX FOR COMPARISON PURPOSES}

This matrix is based on a five tiered rating system with indicators depicting "Excellent to Acceptable" as follows:

$$
\begin{aligned}
& \Theta=\text { Excellent } \\
& =\text { = Very Good } \\
& =\text { Good } \\
& \bigoplus=\text { Fair } \\
& =\text { Acceptable }
\end{aligned}
$$

The first section of the matrix is based on the quantitative results of the factored analysis (see Doc 07 for Summary Table) discussed in prior sections and other calculated parameters. The quantitative analysis for the five terminals lends itself to a ranking whereby each terminal is uniquely rated "Acceptable through Excellent" unless the numerical results were equivalent. To better interpret the quantitative results of the matrix below, the

\begin{tabular}{|c|c|c|c|c|c|}
\hline Parameter & $\begin{array}{c}\text { Pacific } \\
\text { Coast }\end{array}$ & $\begin{array}{c}\text { Atlantic } \\
\text { Coast }\end{array}$ & $\begin{array}{c}\text { BPT } \\
\text { Onshore }\end{array}$ & $\begin{array}{c}\text { BPT } \\
\text { Offshore }\end{array}$ & $\begin{array}{l}\text { Energy } \\
\text { Bridge }\end{array}$ \\
\hline \multicolumn{6}{|l|}{ Quantitative } \\
\hline Annual Sendout & & $\bigoplus$ & 0 & 0 & \\
\hline TIC per Capacity & $\bigoplus$ & ) & c & (0) & \\
\hline \multicolumn{6}{|l|}{ OPEX per Capacity } \\
\hline \multicolumn{6}{|l|}{ Fuel Consumption } \\
\hline Service Fee & $\bigoplus$ & O & c & (2) & \\
\hline \multicolumn{6}{|l|}{ Qualitative } \\
\hline Security & $\bigoplus$ & $\bigoplus$ & 0 & 0 & ) \\
\hline \multicolumn{6}{|l|}{ Capacity } \\
\hline Economy & & (-) & 0 & 0 & ) \\
\hline Buyer Response & (0) & O & 0 & 8 & 0 \\
\hline
\end{tabular}
reader should refer to Table 4.3 in Doc 07 "LNG Terminal Cost Comparison."

All subjective parameters are based on a qualitative analysis and represent the experience of the Study Team and industry polling. Because the rankings in each parameter under the qualitative analysis are subjective, the five terminals may share a common ranking from time to time. 


\begin{tabular}{|l|l|l|l|}
\hline Customer: & $\begin{array}{l}\text { The United States Department of Energy } \\
\text { National Energy Technology Laboratory }\end{array}$ & $\begin{array}{l}\text { Date of Issue: } \\
24 / 04 / 2003\end{array}$ & \\
\hline $\begin{array}{l}\text { Document } \\
\text { Title: }\end{array}$ & Task 3 Doc 08: Matrix for Comparison of Five LNG Terminal Designs & $\begin{array}{l}\text { Doc \# \& Version: } \\
\text { Doc } 08 \text { r1.0 }\end{array}$ & Page 4 of 4 \\
\hline
\end{tabular}

\begin{tabular}{|c|c|c|c|c|c|}
\hline Netback to Seller & $\bigoplus$ & 0 & 0 & 0 & 0 \\
\hline Construction Time & 0 & 0 & 0 & 0 & 0 \\
\hline Permitting Complexity & 0 & 0 & 0 & 0 & 0 \\
\hline
\end{tabular}

